FACULDADE DE FILOSOFIA, LETRAS E CIÊNCIAS HUMANAS

DEPATAMENTO DE LETRAS MODERNAS

PROGRAMA DE PÓS-GRADUAÇÃO EM ESTUDOS LINGUÍSTICOS,

LITERÁRIOS E TRADUTOLÓGICOS EM FRANCÊS

\title{
A linguagem revelando o desenvolvimento do pesquisador na prática da Iniciação Científica
}

Thiago Jorge Ferreira Santos

\begin{abstract}
Dissertação apresentada no Programa de Pós-graduação em Estudos Linguísticos, Literários e Tradutológicos em Francês do Departamento de Letras Modernas da Faculdade de Filosofia, Letras e Ciências Humanas da Universidade de São Paulo, para obtenção do título de Mestre em Letras, Língua e Literatura Francesa.
\end{abstract}

Orientadora: Prof ${ }^{a}$. Dr ${ }^{a}$. Eliane Gouvêa Lousada

Versão corrigida

São Paulo 
Nome: FERREIRA-SANTOS, Thiago Jorge

Título:

Dissertação apresentada no Programa de Pós-graduação em Estudos Linguísticos, Literários e Tradutológicos em Francês do Departamento de Letras Modernas da Faculdade de Filosofia, Letras e Ciências Humanas da Universidade de São Paulo, para obtenção do título de Mestre em Letras, Língua e Literatura Francesa.

Aprovado em:

Banca Examinadora

Prof. Dr. Instituição:

Julgamento: Assinatura:

Prof. Dr. Instituição:

Julgamento: Assinatura:

Prof. Dr. Instituição:

Julgamento: Assinatura: 
Às pessoas cujas forças das ações me impulsionaram até aqui, com toda minha gratidão. 


\section{Agradeço de coração,}

Aos meus pais, Mario e Rosângela, por nunca terem interferido nas minhas escolhas de estudos e profissionais, e por terem viabilizado meus estudos em São Paulo sempre com muito estímulo.

A minha orientadora, Eliane Lousada, por praticamente ter me "tomado no colo" desde a graduação e ter a paciência de, aos poucos, me formar pesquisador. Pela sua confiança em mim e por sua dedicação à pesquisa científica séria.

A Luzia Bueno, pelo olhar atento e minucioso no relatório de qualificação, o que permitiu um avanço significativo na pesquisa.

A Adriana Zavaglia, por conter os excessos do meu trabalho, sempre de forma objetiva e sensível.

Aos meus irmãos, William e Samya, pelo incentivo.

A Camila, por partilhar dos momentos turbulentos da vida acadêmica e das outras vidas.

Às três participantes desta pesquisa, que tiveram a paciência de me fornecer os dados necessários para sua realização e responder aos meus questionamentos.

A Mariana Barioni, fiel amiga no âmbito pessoal e acadêmico, cujos conselhos sempre me mostram um novo olhar para as situações complicadas.

Aos colegas do grupo ALTER-AGE, com os quais tenho ótimas interlocuções teóricas em nossas reuniões e partilho momentos de alegria nos eventos acadêmicos em que juntos estamos: Simone Longhi, Marcos Menezes, Suélen Rocha, Priscila Melão, Flávia Fazion, Emily Silva, Ermelinda Barricelli, Renata Anez, Kamilla Crevelário, Naiara Duarte, Arthur Marra, Ana Paula Silva, Cinthia Bezerra, Aline Sumiya e Jaci Brasil

Ao Rodrigo Borgheti, Lucia Montagnani, Penha Tesche e Silvia Ferrari, por compreenderem que a participação em eventos científicos é de extrema importância para minha formação acadêmica.

A CAPES, pelo apoio financeiro, o qual me fez realizar este trabalho com maior dedicação.

Aos Docentes do curso de Letras da USP, os quais contribuíram para minha formação acadêmica, seja como pesquisador, seja como professor.

Aos meus amigos da USP, aos amigos professores e da vida, que tornam minha caminhada mais aprazível. 


\section{A linguagem revelando o desenvolvimento do pesquisador na prática da Iniciação Científica}

Esta pesquisa teve como objetivo compreender o processo da Iniciação Científica (IC) enquanto um dispositivo de formação do pesquisador na graduação, analisando especificamente o modo como os textos produzidos ao longo da IC podem revelar o desenvolvimento do aluno-pesquisador. Dentre as pesquisas já realizadas sobre a IC, observamos que elas não mostraram a relação entre o pensamento a linguagem nesse percurso formativo. Por isso, tivemos, como objetivos específicos, verificar quais as marcas textuais que nos permitem compreender essa prática científica e de formação por meio da relação entre a linguagem e o pensamento. Para tanto, partimos da teoria do Interacionismo Social (VIGOTSKI, 2001, 2007, 2009) e de estudos contemporâneos acerca da teoria vigotskiana (FRIEDRICH, 2012), sobretudo da noção de funções psicológicas superiores "linguagem" e "pensamento" e sua relação na formação dos conceitos científicos. Em seguida, baseamo-nos na corrente do Interacionismo sociodiscursivo (BRONCKART, 1999, 2006, 2008a, 2008b, 2008c, 2009, 2011), que é uma atualização contemporânea do Interacionismo social e que tem entre seus objetivos estudar o papel da linguagem no desenvolvimento humano e na construção de saberes, com base emVigotski e outros autores. Como dados de pesquisa coletamos os textos que, obrigatoriamente, os estudantes devem produzir no contexto da IC, na Faculdade de Filosofia, Letras e Ciências Humanas da Universidade de São Paulo. Assim, foram coletados projetos de pesquisa, relatórios finais, apresentações orais de pesquisa com os respectivos resumos de três estudantes do curso de Letras, na habilitação de Português/Francês. Esses dados foram analisados por meio dos níveis de análise textual e discursiva proposta por Bronckart (1999) e os resultados foram discutidos por meio dos sistemas linguageiros, assim como abordados por Bronckart (2008b) e Bota (2011), pelos quais toda produção linguageira sofre três tipos de restrições: social (incluem-se aqui os mecanismos enunciativos como as vozes e as modalizações), psicológica (restrições impostas pelo uso dos tipos de discurso) e lingüística (restrições impostas pelo uso dos conectores e da coesão verbal e nominal). Como resultado da pesquisa, encontramos uma dinâmica específica entre os tipos de discurso e o gênero textual produzido, pois, a cada etapa da pesquisa, os gêneros determinavam a escolha de determinado tipo de discurso. Também verificamos que a coesão nominal pode nos fornecer resultados importantes para a análise do posicionamento do autor empírico no texto, ou seja, a emergência de um posicionamento de pesquisador. Ademais, encontramos dois tipos de vozes no decorrer da Iniciação Científica: a voz do estudante e a voz do pesquisador. A primeira, identificada nos projetos de pesquisa, tem a função de organizar a pesquisa segundo uma ideia central advinda da experiência das estudantes enquanto graduandas em Letras, na habilitação de Português/Francês. A segunda voz, delimitada nos textos finais das pesquisas, o relatório final e a apresentação oral, é a voz do pesquisador, a qual busca a regularidade nos resultados das pesquisas e os nomeia, dando-lhes um contorno conceitual por meio de uma generalização.

Palavras-chave: Iniciação científica; pesquisador; linguagem. 


\section{The language revealing the researcher's development in the practice of "Scientific Initiation"}

This research aimed to understand the process of "Scientific Initiation" as an educational device in the undergraduate courses, analyzing specifically how the texts produced over the "Scientific Initiation" can reveal the development of student-researcher. Among the research already conducted on the "Scientific Initiation", we found that they did not show the relationship between language and thought. So we had, as specific objectives, to check which textual markers allow us to understand this scientific educational practice through the relationship between language and thought. The theories that underlie our study are the Social Interactionism (VIGOTSKI, 2001, 2007,2009 ) and the contemporary studies of Vigotskian theory (FRIEDRICH, 2012), especially the notion of higher mental functions "language" and "thought" and their relationship in the development of scientific concepts. We also rely on the Socio-Discursive Interactionism (BRONCKART, 1999, 2006, 2008a, 2008b, 2008c, 2009, 2011), which is a contemporary branch of social interactionism and which has among its objectives to study the role of language in human development and in the construction of knowledge, based on Vigotski and other authors. As research data,we collected texts that students must produce in the context of "Scientific Initiation" at the Faculty of Philosophy, Letters and Human Sciences, at the University of São Paulo. So we collected research projects, final reports and oral presentations with their abstracts of three students of Letters, students of Portuguese/French languages. These data were analyzed by levels of textual and discourse analysis proposed by Bronckart (1999) and the results were discussed through the language systems concept conceived by Bronckart (2008b) and Bota (2011), by which all language production suffers three types of constraints: social (they include the enunciative mechanisms such as voices and modalizations), psychological (restrictions imposed by use of the types of discourse) and linguistic (restrictions imposed by use of connectors and verbal and nominal cohesion). As a result of the research, we found a specific dynamic between the types of discourse and the produced genre, because in every stage of the research, the genres determined the choice of a particular type of discourse. We also found that the nominal cohesion can provide us with important results for the analysis of the empirical author positions in the text, so the emergence of a researcher position. Furthermore, we find two types of voices during the "scientific initiation": the voice of the students and the voice of the researcher. The first, identified in the projects, is used toto organize the research according to a central idea arising from the experience of students in the Undergraduate courses in Letters (Portuguese/ French). The second voice, found on the final texts of the research, the final report and the oral presentation, is the voice of the researcher, which seeks regularities in search results and names them, giving them a conceptual outline through a generalization.

Keywords: "Scientific Initiation”; researcher; language. 


\section{Le langage révélant le développement du chercheur dans la pratique "de l'Initiation scientifique"}

Cette recherche a pour objectif de comprendre le processus de L'“Initiation Scientifique" en tant qu'un dispositif de formation du chercheur au niveau de la licence, en analysant précisément comment les textes produits au cours de 1'"Initiation Scientifique" peuvent révéler le développement des étudiants-chercheurs. Parmi les recherches déjà menées sur "l'Initiation Scientifique", nous avons constaté qu'elles ne montrent pas le rapport entre la pensée et le langage dans cette formation. Nous avons donc eu pour objectif spécifique de vérifier ce que les marqueurs textuels nous permettent de comprendre sur cette formation scientifique et pratique à travers la relation entre langage et pensée. Pour ce faire, nous avons choisi, comme point de départ, la théorie de l'interactionnisme social (VIGOTSKI, 2001, 2007, 2009) et les études contemporaines de la théorie de Vigotski (FRIEDRICH, 2012), en particulier la notion de fonctions psychologiques supérieures "langage" et "pensée" et leursrapports dans la formation des concepts scientifiques. Ensuite, nous nous appuyons sur la théorie de l'Interactionnisme socio-discursif (BRONCKART, 1999, 2006, 2008a, 2008b, 2008c, 2009, 2011), qui est un courant contemporain de l'interactionnisme social et qui a parmi ses objectifs d'étudier le rôle de la langue dans le développement humain et dans la construction des savoirs, en se basant sur Vigotski et d'autres auteurs. Comme données de recherche, nous avons recueilli les textes que les étudiants doivent obligatoirement produire dans le cadre de "Initiation Scientifique", dans la Faculté de Philosophie, Lettres et Sciences Humaines de l'Université de São Paulo. Nous avons donc recueilli des projets de recherche, des rapports finaux, des présentations orales et leurs résumés de recherche produits partrois étudiantes de Lettres, de la licence Portugais/Français. Ces données ont été analysées par les niveaux d'analyse textuelle et discursive proposés par Bronckart (1999) et les résultats ont été examinés par le biais des systèmes langagiers traités par Bronckart (2008b) et Bota (2011), qui affirment que toute production langagière subit trois types de contraintes: sociales (qui comprennent les mécanismes énonciatifs comme les voix et les modalisations), psychologiques (restrictions imposées par l'utilisation des types de discours) et linguistiques (restrictions imposées par l'utilisation des connecteurs et de la cohésion verbale et nominale). Comme résultats, nous avons trouvé une dynamique spécifique entre les types de discours et le genre produit, parce qu'à chaque étape de la recherche, les genres déterminent le choix d'un type particulier de discours. Nous avons également constaté que la cohésion nominale peut nous fournir des résultats importants pour l'analyse le positionnement de l'auteur empirique dans le texte, c'est-à-dire, l'émergence d'un positionnement de chercheur. En outre, nous avons trouvé deux types de voix lors de l'Initiation scientifique: la voix de l'étudiant et la voix du chercheur. La première, identifiée dans des projets de recherche, organise la recherche en fonction d'une idée centrale découlant de l'expérience des sujets de recherche en tant qu'étudiantes de langue portugaise et française. La deuxième voix, que l'on retrouve sur le rapport final de recherche et la présentation orale, est la voix du chercheur, qui cherche la régularité dans les résultats de recherche et y attribue une nominalisation, en leur donnant un contour conceptuel à travers une généralisation.

Mots-clés: "Initiation Scientifique"; chercheur; langage. 


\section{LISTA DE QUADROS}

Quadro 1 - Pesquisas em Iniciação Científica de 1995 a 2013.

Quadro 2: Quadro de pesquisas sobre Iniciação Científica por área de pesquisa

Quadro 3 - As características e fases das sequências textuais (MACHADO, 2005, p. 246).

Quadro 4 - Duração das pesquisas de IC analisadas.

Quadro 5 - Primeira recolha dos dados escritos.

Quadro 6 - recolha dos dados orais.

Quadro 7 - Recolha geral dos dados da pesquisa.

Quadro 8 - Conteúdo temático esperado no gênero projeto de pesquisa.

Quadro 9- Conteúdo temático esperado no gênero resumo.

Quadro 10- Conteúdo temático esperado no gênero apresentação oral.

Quadro 11- Conteúdo temático esperado no gênero relatório.

Quadro 12 - Perguntas da pesquisa, textos de análise e categorias utilizadas.

Quadro 13: síntese das análises dos Planos globais do conteúdo temático dos resumos. ("X”= possui; "-" = não possui; "escrito" = possui em partes).

Quadro 14: Tipos de conexões entre as partes da apresentação oral (Estudante 1).

Quadro 15: Tipos de conexões entre as análises dos dados da pesquisa (Estudante 1).

Quadro 16: Tipos de conexões entre as partes da apresentação oral (Estudante 2).

Quadro 17: Tipos de conexões entre as análises dos dados da pesquisa (Estudante 2).

Quadro 18: Tipos de conexões entre as partes da apresentação oral (Estudante 3).

Quadro 19: Tipos de conexões entre as análises dos dados da pesquisa (Estudante 3).

Quadro 20: Plano global do relatório final de pesquisa (Estudante 1).

Quadro 21: Plano global do relatório final de pesquisa (Estudante 2).

Quadro 22: Plano global do relatório final de pesquisa (Estudante 3).

Quadro 23: índices textuais de desenvolvimento (Estudante 1).

Quadro 24: índices textuais de desenvolvimento (Estudante 2).

Quadro 25: índices textuais de desenvolvimento (Estudante 3).

Quadro 26: Papel dos gêneros textuais no desenvolvimento. 


\section{LISTA DE TABELAS}

Tabela 1- Quadro de pesquisas sobre Iniciação Científica por área de pesquisa.

Tabela 2 - Duração das pesquisas de IC analisadas.

Tabela 3 - Primeira recolha dos dados escritos.

Tabela 4 - recolha dos dados orais.

Tabela 5 - Recolha geral dos dados da pesquisa.

Tabela 6 - Data, horários e duração da filmagem. 


\section{LISTA DE FIGURAS}

Figura 1- As fases da produção verbal (SCHNEUWLY, 1989).

Figura 2- Relação entre o conceito cotidiano e científico (FRIEDRICH, 2013, p.100).

Figura 3- Os tipos de discurso (BRONCKART, 1999).

Figura 4 - da Cpq-FFLCH sobre a Iniciação Científica no site da Cpq-FFLCH.

Figura 5 - Folder de divulgação da Iniciação Científica da Área de Francês.

Figura 6 - Disposição dos participantes da pesquisa no momento da filmagem.

Figura 7 - Indicação da escrita do Projeto de Pesquisa no edital da IC.

Figura 8 - Indicação da escrita dos Relatórios de Pesquisa e da apresentação oral no edital da IC.

Figura 9 - Instruções para a escrita do Relatório de pesquisa no edital da IC.

Figura 10- Informações aos bolsistas FAPESP no site da Cpq-FFLCH.

Figura 11 - Indicações para a escrita do Projeto de Pesquisa no site da FAPESP.

Figura 12 - Sobre a escrita do Relatório de Pesquisa no site da FAPESP.

Figura 13 - Análise linguístico-discursiva segundo o ISD (BRONCKART, 1999).

Figura 14 - Os quatro tipos de discurso.

Figura 15 - Os sistemas da linguagem (BOTA, 2011).

Figura 16 - Normas de transcrição oral (NURC) 


\section{LISTA DE SIGLAS}

ALTER - Análise de Linguagem, Trabalho Educacional e suas relações

ALTER-AGE - Análise de Linguagem, Trabalho Educacional e suas relações Aprendizagem, Gêneros Textuais e Ensino

CAPES - Coordenação para Aperfeiçoamento do Pessoal de Nível Superior

Cpq - Comissão de Pesquisa

FFLCH - Faculdade de Filosofia, Letras e Ciências Humanas da USP

IC - Iniciação Científica

ISD - Interacionismo sociodiscursivo

TGI - Trabalho de Graduação Individual

USP - Universidade de São Paulo 


\section{Sumário \\ INTRODUÇÃOO}

1. Histórico da pesquisa: do projeto inicial ao projeto definitivo ............................................ 1

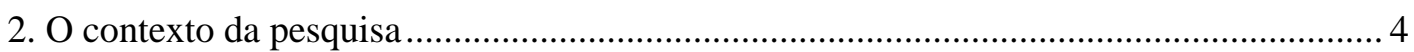

3. As pesquisas sobre Iniciação Científica no Brasil .............................................................. 4

3.1. Origem da Iniciação Científica no Brasil .................................................................... 5

3.2. Pesquisas já realizadas sobre a Iniciação Científica no Brasil.......................................... 6

3.3. A Iniciação Científica e a atividade de formação do universitário .................................. 10

3.4. A linguagem científica no processo da Iniciação Científica......................................... 14

3.5. Pesquisas sobre Iniciação Científica no curso de Letras .............................................. 16

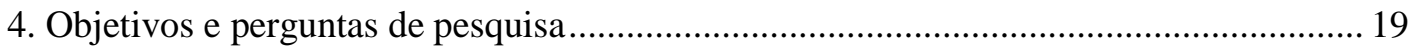

5. Organização geral da dissertação ................................................................................. 19

\section{Capítulo I - Pressupostos Teóricos}

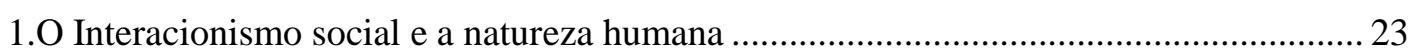

1.1 Métodos indiretos e e internalização das funções psicológicas superiores .................... 26

1.2 A relação pensamento e linguagem .......................................................................... 30

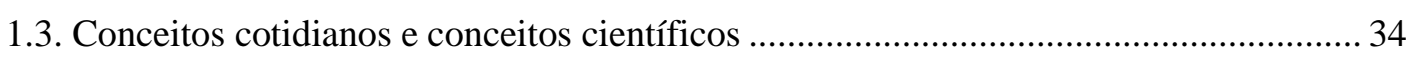

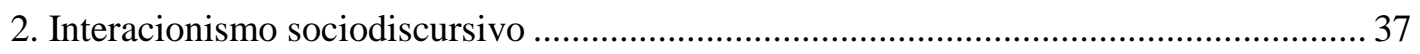

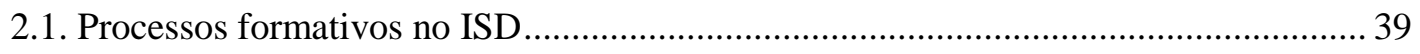

2.2. A linguagem como objeto de estudo no ISD .......................................................... 41

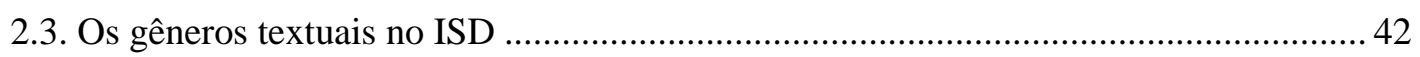

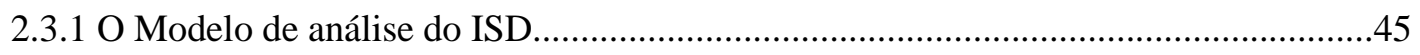

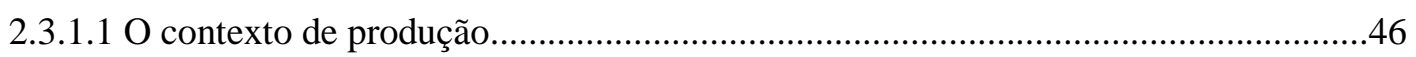

2.3.1.2 A infra-estrutura textual: o plano global do conteúdo temático............................... 48

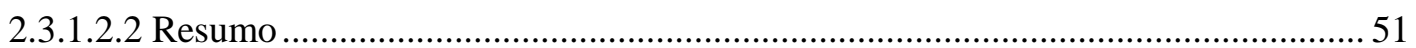

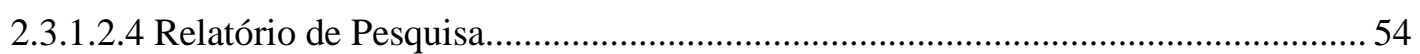

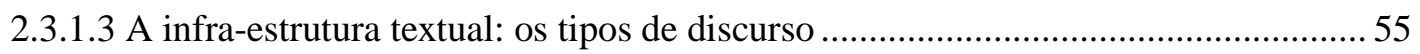

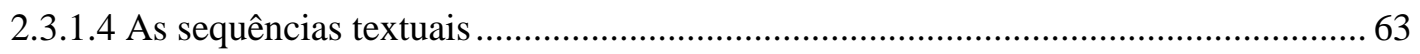

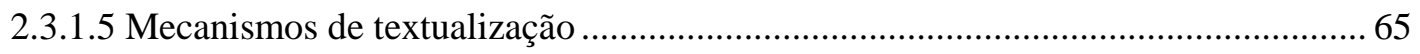

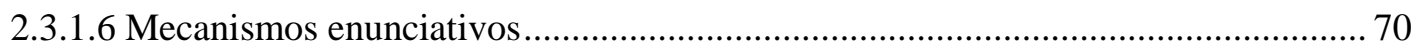

\section{Capitulo II - Metodologia}

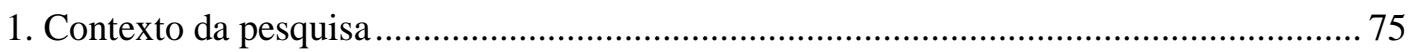

1.1. Iniciação Científica na Universidade de São Paulo ...................................................... 75

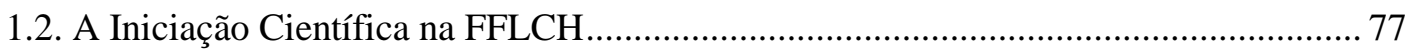

1.3. A Iniciação Científica da Área ELLTF ...................................................................... 78 
2.1 Estudante 1 (BT)

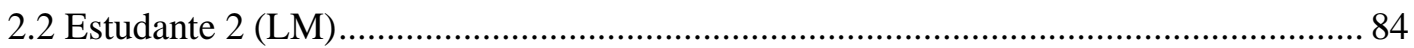

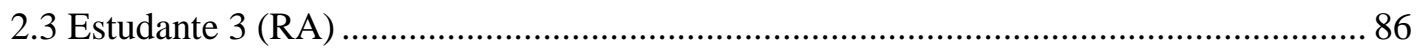

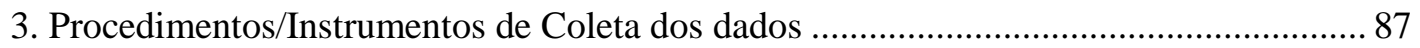

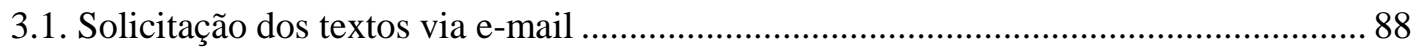

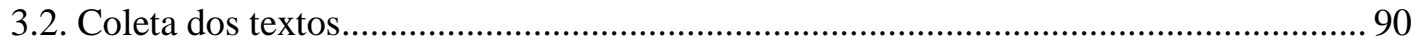

3.3. Filmagem das apresentações em 2013 ....................................................................... 91

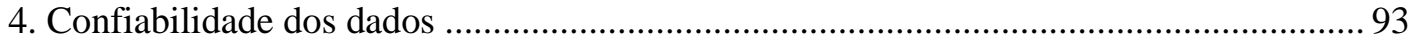

4.1. Validação em relação ao contexto de pesquisa............................................................... 93

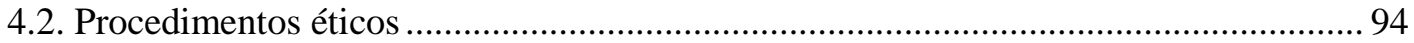

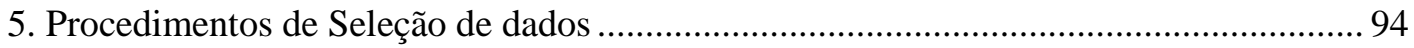

5.1. Os gêneros textuais exigidos no processo da Iniciação Científica ................................. 95

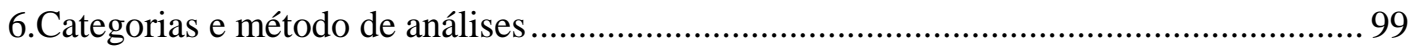

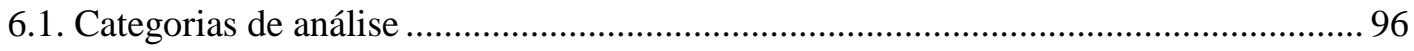

6.2. Categorias de análise e perguntas de pesquisa ............................................................. 104

\section{CAPítulo III - RESUltado dAS ANÁlises}

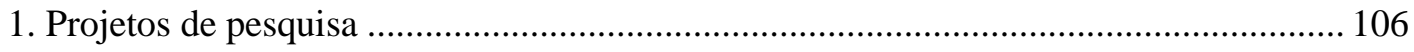

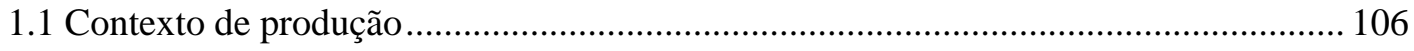

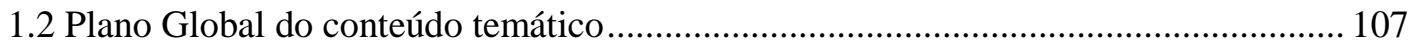

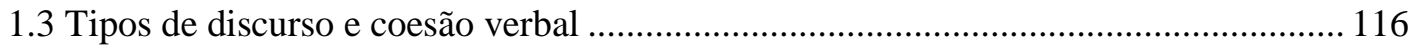

1.4 Mecanismos de textualização: conectores textuais........................................................ 123

1.5 Mecanismos de textualização: coesão nominal .......................................................... 128

1.6 Mecanismo enunciativos: vozes e modalizações......................................................... 133

1.7 Quadro sintético das análises dos projetos de pesquisa............................................... 142

2. Resumo para apresentação oral de pesquisa ................................................................. 144

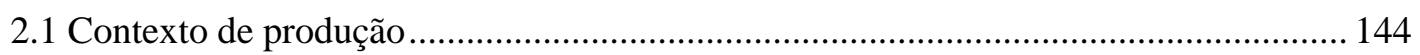

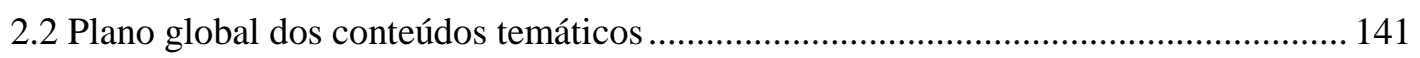

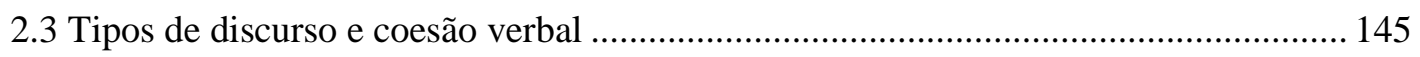

2.4 Mecanismos de textualização:conectores textuais........................................................ 151

2.5 Mecanismos de textualização: coesão nominal ............................................................ 153

2.6 Mecanismos enunciativos: vozes e modalizações .......................................................... 155

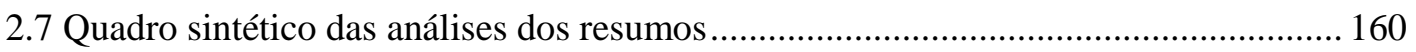

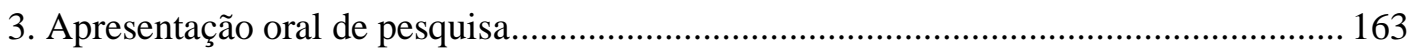




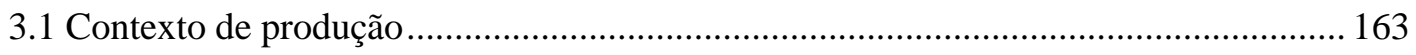

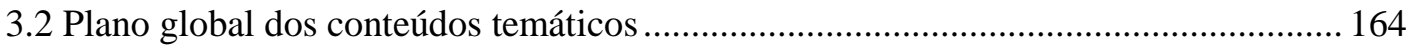

3.3 Tipos de discurso e coesão verbal ............................................................................ 169

3.4 Mecanismos de textualização: conectores textuais........................................................ 177

3.5 Mecanismos de textualização: coesão nominal .......................................................... 192

3.6 Mecanismos enunciativos: vozes e modalizações .......................................................... 196

3.7 Quadro sintético das análises das apresentações orais ............................................. 202

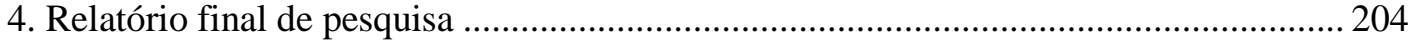

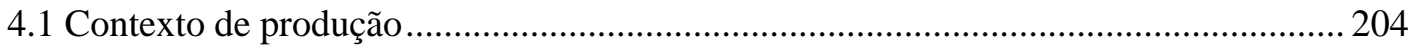

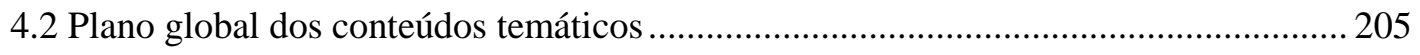

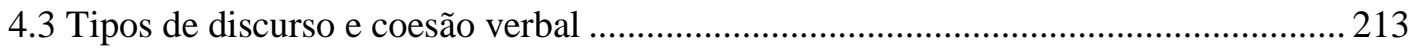

4.4 Mecanismos de textualização: conectores textuais....................................................... 226

4.5 Mecanismos de textualização: coesão nominal ........................................................... 228

4.6 Mecanismos enunciativos: vozes e modalizações ....................................................... 234

4.7 Quadro sintético das análises dos relatórios finais ...................................................... 241

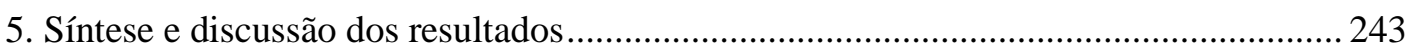

CONSIDERAÇÕES FINAIS...................................................................258

REFERÊNCIAS BIBLIOGRÁFICAS...................................................264

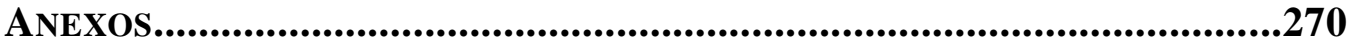




\section{Introdução}

Tudo aqui! Quer me revelar [...] O que eu não digo, o que eu afirmo [...] Tudo aqui! Quer me revelar

Unhas roídas Ausências, visitas [...] (Me revelar - Zélia Duncan)

Para melhor expormos o percurso de nossa pesquisa, apresentaremos primeiramente o histórico que nos levou de um projeto inicial a um projeto final, salientando a delimitação dos nossos objetivos de pesquisa. Depois, faremos uma reflexão acerca das pesquisas que tiveram a Iniciação Científica como foco de investigação, buscando posicionar a nossa nesse conjunto. Finalmente, detalharemos nossas perguntas pesquisa e a organização estabelecida para esta dissertação.

\section{Histórico da pesquisa: do projeto inicial ao projeto definitivo}

O objetivo amplo desta pesquisa é investigar o desenvolvimento ${ }^{1}$ do aluno enquanto pesquisador durante o processo de Iniciação Científica por meio da análise das relações entre o uso da linguagem e a apropriação dos saberes. Desse modo, esta seção tem por objetivo apresentar como esta pesquisa se constituiu, desde sua primeira ideia, ainda na graduação, buscando mostrar as mudanças ocorridas no projeto inicial, sobretudo quanto aos nossos objetivos de pesquisa. Consideramos ${ }^{2}$ importante o relato que faremos, pois o percurso exposto muito nos permite compreender os procedimentos adotados, os quais descreveremos detalhadamente nas partes desta dissertação.

Durante a graduação em Letras desenvolvi três projetos de Iniciação Científica no período de 2009 a 2012 orientados pela Profa. Dra. Eliane Gouvêa Lousada. Nesse período, foi necessário que eu me apropriasse de várias práticas de pesquisa que,

\footnotetext{
$1 \mathrm{O}$ conceito de desenvolvimento que estamos utilizando advem da teoria do Interacionismo social de Vigotski e seu grupo, desenvolvida no início do século XX. Entre as pesquisas do grupo, destacavam-se as aquelas acerca do desenvolvimento filogenético (da espécie), ontogenético (da espécie humana) e também microgenético, pelo qual se analisa aspectos desenvolvimentais do homem durante a execução de uma atividade, em um menor período de tempo. Nossa pesquisa se situa na perspectiva microgenética, pois verifica o desenvolvimento dos estudantes de Iniciação Científica durante a axecução da pesquisa.

${ }^{2} \mathrm{~A}$ partir desta seção, estabelecemos uma diferença no uso de dois pronomes pessoais: a primeira pessoa do plural, quando se trata do pesquisador que está escrevendo e apresentando esta pesquisa: trata-se do pronome nós; a primeira pessoa do singular, quando se trata do autor enquanto estudante da graduação em Letras, desenvolvendo pesquisa em nível de Iniciação Científica.
} 
enquanto aluno da graduação, eu não realizaria nem por uma exigência curricular, nem pelos dispositivos de avaliação das disciplinas do Bacharelado ou da Licenciatura em Letras. Dentre essas práticas, posso citar as minhas participações em eventos científicos tanto nacionais (em São Paulo, Rio de Janeiro, São Carlos, Bauru), quanto internacional (Canadá, Suiça); em grupo de pesquisa (ALTER-AGE); na escrita de artigos para revistas científicas avaliadas por Qualis-CAPES; participação como membro do corpo editorial de revista científica. Ademais, ressalto que, durante o período da IC, eu obtive duas bolsas, uma concedida pelo Conselho Nacional de Desenvolvimento Científico e Tecnológico e outra pela FFLCH-USP, que foram minhas primeiras remunerações mensais.

Todas as práticas elencadas acima foram realizadas por mim durante o período das pesquisas em IC, pelas quais eu dispensava grande parte do tempo da minha rotina para desenvolver. Assim, como projeto inicial de mestrado, eu objetivava investigar o "trabalho do aluno em IC", buscando discutir os textos prescritivos que regulam essa prática de pesquisa e também analisar os textos produzidos pelos estudantes no processo completo da pesquisa.

Após o término da última Iniciação Científica, a minha participação em dois eventos científicos foi importante para eu objetivar melhor as perguntas de pesquisa: $\mathrm{O} 4^{\circ}$ Encontro Internacional do Interacionismo sociodiscurso, ocorrido na Universidade de Genebra (Suíça), no mês de julho de 2013; e o Colóquio Internacional "Analisar o Trabalho Educacional", ocorrido na Universidade de São Paulo (São Paulo), no mês de novembro do mesmo ano.

Em minha participação no $4^{\circ}$ Encontro Internacional do Interacionismo sociodiscursivo (ISD) fui apresentar os resultados de duas pesquisas de Iniciação Científica desenvolvidas por mim entre os anos de 2009-2010 e 2011-2012. Nessa ocasião, tive conhecimento da tese de Bota (2011), orientada pelo Prof. Dr. Jean-Paul Bronckart, intitulada Savoirs, textes et apprentissages en milieu universitaire. Pour une analyse sociodiscursive de travaux de validation pour les cours, que foi desenvolvida dentro do ISD e na qual o autor discutiu o conceito de aprendizagem epistêmica, o qual relacionava a produção dos gêneros textuais e o uso da linguagem com a apropriação e transmissão dos saberes dentro do contexto universitário. O estudo de Bota (2011) foi essencial para a consolidação e compreensão do meu objetivo de pesquisa, já que me 
possibilitou um olhar analítico para a reflexão do processo da Iniciação Científica como um espaço de formação em que ocorre a apropriação e transmissão de saberes científicos dentro do contexto universitário.

Como eu disse, dois foram os eventos cujas discussões foram essenciais para a delimitação do objetivo desta pesquisa. Já tendo discorrido sobre o primeiro, o segundo evento que participei e que foi importante para delimitação dos objetivos desta pesquisa foi o "Colóquio Internacional Analisar o Trabalho Educacional”, promovido pela Área de Estudos Linguísticos, Literários e Tradutológicos em francês da FFLCH-USP. Nesta oportunidade, apresentei o pôster "A aprendizagem do gênero da atividade profissional do pesquisador por alunos em Iniciação Científica", no qual mostrei minhas análises preliminares dos dados da pesquisa, evidenciando que a apropriação dos gêneros textuais (mais especificamente do gênero textual projeto de pesquisa) faz parte do gênero da atividade profissional do pesquisador. Embora as discussões no evento tenham sido muito profícuas, ficou evidente que o meu objetivo de pesquisa não seria viável de ser desenvolvidos dentro das Ciências do Trabalho, pois o gênero da atividade do pesquisador no Brasil é atrelado à atuação no ensino superior ${ }^{3}$. Logo, os textos que regulam essas práticas estão atrelados à vinculação à atividade de ensino superior. Ora, os estudantes de IC não desempenham todas as funções de um pesquisador já formado e, menos ainda, atividade de ensino superior, por isso compreender o trabalho dos estudantes enquanto pesquisadores seria necessário considerarmos que há um "métier" de pesquisador na Iniciação Científica, afirmação não muito clara no contexto brasileiro.

Após minha experiência nos dois eventos citados, tirei duas conclusões que contribuíram para a delimitação do objetivo geral desta pesquisa:

I. Meu objetivo de pesquisa poderia ser melhor desenvolvido na discussão sobre o uso da linguagem dentro do percurso completo da IC.

II. Embora os conceitos advindos das Ciências do Trabalho sejam importantes, eles não permitiriam desenvolver o nosso objetivo de forma a investigar a relação da linguagem e a construção dos saberes no percurso da IC, que não poderia ser

\footnotetext{
${ }^{3}$ Outros países como a França e o Canadá possuem outras regulamentações quanto ao métier de pesquisador. Na França, por exemplo, há o Centre National de la Recherche Scientifique (CNRS), onde são desenvolvidos estudos em várias áreas do saber por pesquisadores cujas funções não incluem atividades de docência, senão de pesquisa científica. Já no contexto canadense, desde 2000 , há um programa de pesquisa criado pelo governo canadense, chamado de Chaires de recherche du Canada, através do qual são selecionados pesquisadores de diversas áreas do saber, a fim de desenvolverem pesquisas que visam descobrir novos conhecimentos e também melhorar a competitividade do país no âmbito da pesquisa científica internacional.
} 
considerada uma prática profissional e, por isso, teríamos que discutir essa questão não prevista nos nossos objetivos.

\section{2. $O$ contexto da pesquisa}

Nossa pesquisa tem como contexto mais amplo a Universidade de São Paulo, instituição de ensino superior brasileira, considerada grande produtora de conhecimento científico tanto no âmbito nacional, quanto internacional. De forma mais específica, nossa pesquisa ocorreu na Faculdade de Filosofia, Letras e Ciências Humanas da USP (FFLCH-USP), particularmente na Área de Estudos Linguísticos, Literários e Tradutológicos em francês do Departamento de Letras Modernas do curso de Letras da FFLCH.

Para o nosso estudo, contamos com a participação de três estudantes, graduandas em Letras e pesquisadoras, pela primeira vez, em nível de Iniciação Científica.

Nossos dados compreenderam as produções textuais realizadas pelas estudantes durante o processo completo da Iniciação Científica e que são exigidas formalmente pela Comissão de Pesquisa da FFLCH, por isso coletamos dados escritos (projetos de pesquisa, resumos e relatórios) e dados orais (filmagem da apresentação oral de pesquisa). Esses dados foram coletados durante os anos de 2013 e 2014.

Os textos foram analisados tendo em vista os pressupostos teóricos desenvolvidos por Vigotski (1999, 2001, 2007, 2009) no âmbito da corrente do Interacionismo social (IS) e também da atualização e perspectivas dessas pesquisas proposta pela corrente do Interacionismo sociodiscursivo (BRONCKART, 1999, 2006, 2008). Ambas as correntes teóricas serão melhores abordadas no nosso capítulo de Fundamentação teórica.

A seguir, apresentaremos um panorama das pesquisas em IC no Brasil para, em seguida, mostrar os objetivos e as perguntas que guiaram a realização deste estudo.

\section{As pesquisas sobre a Iniciação Científica no Brasil}

Nesta seção, discutiremos as pesquisas sobre a Iniciação Científica desenvolvidas no Brasil. Para isso, primeiramente, trataremos a origem da IC no país para, depois, 
descreveremos algumas das características desses trabalhos. Em seguida, abordaremos alguns aspectos importantes das pesquisas encontradas e que se relacionam com os nossos interesses de trabalho para, finalmente, discutirmos os estudos que tiveram o curso de Letras como espaço de investigação.

\subsection{Origem da Iniciação Científica no Brasil}

A preocupação com o desenvolvimento da pesquisa científica no Brasil teve como causa o momento estruturante em que a atividade econômica brasileira se encontrava na segunda metade do séc. XX frente aos países desenvolvidos da Europa e da América do Norte, os quais tinham uma atividade industrial já sistematizada, bem como vasta experiência na regulação das atividades científicas (MUNIZ-OLIVEIRA, 2011, p.28). Ao traçar um panorama da industrialização no Brasil, Versiani e Suzigan (1990) afirmam que o período de 1950 a 1979 foi importante para a economia do país, visto que ocorreram importantes experiências de planejamento de desenvolvimento industrial, como o Plano de Metas (1956-1960) e II Plano Nacional de Desenvolvimento, o PND (1975-1979), a criação da PETROBRAS e do Banco Nacional de Desenvolvimento Econômico (BNDS). Também se verifica nesse período um alto investimento do capital do Estado, privado e estrangeiro em infra-estrutura, interferência direta do Estado no setor econômico, além da criação de um sistema de protecionismo à industria e ao mercado interno (VERSIANI, SUZIGAN, 1990).

Em conseqüência desse contexto da atividade econômica brasileira, houve a necessidade de pessoal qualificado e especializado para trabalhar nas indústrias e modernizá-la por meio da criação tecnológica, o que impulsionou, por conseguinte, uma política de desenvolvimento científico com a criação da "Campanha de Aperfeiçoamento de Pessoal de Nível Superior”, a CAPES, com o Decreto n. 29.741/51 (BRASIL, 1951) em 1951 que, mais tarde, passou a se chamar "Coordenação de Aperfeiçoamento de Pessoal de Nível Superior (MUNIZ-OLIVEIRA, 2011). A partir da promulgação do Decreto houve uma expansão dos cursos de Pós-graduação no Brasil e uma busca de intercâmbio com os "países centrais" detentores de experiência no desenvolvimento científico e tecnológico, por isso a regulamentação da pesquisa no Brasil tem formatos parecidos com aqueles de países desenvolvidos e experientes nas atividades científicas, 
por exemplo o Parecer n.977/65, baseado no modelo norte-americano, e que define o artigo 69 da Lei de Diretrizes e Bases de 1961, distinguindo as três categorias de curso superior: a graduação; a pós-graduação; e especialização, aperfeiçoamento e extensão (MUNIZ-OLIVEIRA, 2011).

Nesse panorama de regulamentação da atividade científica e incentivo à pesquisa no Brasil é criado, de acordo com Massi e Queiroz (2010), também em 1951, o Conselho Nacional de Desenvolvimento Científico e Tecnológico (CNPq), por meio do qual houve o início do financiamento das pesquisas em nível de Iniciação Científica, através da concessão de bolsas anuais de fomento à pesquisa na graduação ${ }^{4}$. A atividade de pesquisa-ensino foi regulamentada na Lei da Reforma Universitária de 1968 (Art. $2^{\circ}$, da Lei n. 5.540, de 28/11/1968) e mais tarde na Constituição de 1988 e, consequentemente, na nova Lei de Diretrizes e Bases da Educação Nacional (Lei n. 9.394, de 20/12/1996) ${ }^{5}$.

No Brasil, até o final dos anos 1980, as bolsas de Iniciação Científica eram solicitadas pelos pesquisadores que escolhiam os alunos aos quais as bolsas seriam concedidas (MASSI, QUEIROZ, 2010). A partir de 1988, porém, as bolsas passaram a ser concedidas às Instituições de Ensino Superior, as quais deveriam gerenciar todo o processo de solicitação e concessão dos auxílios, bem como promover um encontro anual no qual as pesquisas seriam partilhadas e discutidas por meio da apresentação de pôsteres ou apresentações orais ${ }^{6}($ MASSI, QUEIROZ, 2010).

Segundo Zakon (1989, p.876), são vários os efeitos do processo da Iniciação Científica, entre eles ser o primeiro passo para uma carreira de pesquisador que atuará na universidade ou em alguma empresa que faça pesquisa, desenvolvimento da curiosidade de investigação científica do estudante, o enfrentamento desafios e dificuldades de pesquisa, entre outros. Aliás, as conseqüências, sejam positivas ou negativas do processo da Iniciação Científica, já foram objetos de muitas teses, dissertações, artigos científicos, em vários contextos universitários brasileiros, enfocando variados cursos de graduação.

\footnotetext{
${ }^{4} \mathrm{Na}$ verdade, nas décadas de 30 e 40, já havia atividade de pesquisa nos cursos de graduação, porém elas não eram respaldadas por documentos oficiais e muitas vezes não eram financiadas (MASSI, QUEIROZ, 2010).

${ }^{5} \mathrm{O}$ incentivo ao desenvolvimento científico se deu também no nível estadual, como por exemplo, com a criação da Fundação de Amparo à Pesquisa do Estado de São Paulo (FAPESP), em 1960 (Lei Orgânica 5.918, de 18 de outubro de 1960), e começou a funcionar efetivamente em 1962 (Decreto 40.132, de 23 de maio de 1962).

${ }^{6} \mathrm{Na}$ Universidade de São Paulo há as Comissões de Pesquisa das Faculdades e Institutos, que gerenciam os trâmites da Iniciação Científica. Além disso, a USP promove anualmente o Simpósio Internacional de Iniciação Científica da USP (SIICUSP).
} 


\subsection{Pesquisas realizadas sobre a Iniciação Científica}

Para a realização do levantamento das pesquisas de 1990 a 2004, estudadas por Massi (2008) e que tiveram a Iniciação Científica como objeto de análise. Dando continuidade ao estudo da pesquisadora, fizemos o levantamento das pesquisas de IC no período de 2005 a 2013 através da Biblioteca Digital Brasileira de Teses e Dissertações (BDTD) por meio da palavra de busca "Iniciação Científica".

Em nossa busca, encontramos registradas na BDTD as pesquisas já localizadas por Massi (2008) e outras que tinham como foco de investigação a Iniciação Científica Júnior realizada por alunos de Ensino Médio; outros trabalhos tratavam da relação entre a Iniciação Científica e a formação de professores; um outro grupo de pesquisas se referiam a IC somente como espaço no qual os dados foram coletados, porém sem considerar a IC como uma prática específica no meio universitário.

No conjunto das duas buscas, a de Massi (2008) e a nossa própria, mostramos abaixo a tabela que tiveram a Iniciação Científica com objeto de investigação científica:

\begin{tabular}{|c|c|c|c|}
\hline Área de pesquisa & Autor & Ano & $\begin{array}{c}\text { Curso de Graduação } \\
\text { investigado }\end{array}$ \\
\hline \multicolumn{4}{|l|}{ Teses } \\
\hline Educação & OAIGEN, E. R. & 1995 & Geral \\
\hline Educação & BARIANI, I. C. D. & 1998 & $\begin{array}{l}\text { Biologia, Psicologia, } \\
\text { Arquitetura, Urbanismo }\end{array}$ \\
\hline Comunicação & FARIA, A. V. & 2000 & Comunicação Social \\
\hline Educação & BREGLIA, V. L. A. & 2002 & $\begin{array}{l}\text { Psicologia, Economia, } \\
\text { Física }\end{array}$ \\
\hline Educação & CABERLON, V. I. & 2003 & Geral \\
\hline Educação & MELO, G. F. A. & 2003 & Matemática \\
\hline Saúde da Mulher & GORGENS, J. B. & 2007 & Medicina \\
\hline Educação & PIRES, R. C. M. & 2008 & Geral \\
\hline Educação & SANTOS, S. A. & 2013 & Geral \\
\hline \multicolumn{4}{|l|}{ Dissertações } \\
\hline Educação & OAIGEN, E. R. & 1990 & Geral \\
\hline Psicologia & BETTOI, S. M. & 1995 & Psicologia \\
\hline Química Biológica & AGUIAR, L. C. C. & 1997 & Ciências Biológicas \\
\hline Educação & MALDONADO, L. A. & 1998 & Nutrição \\
\hline Psicologia da Educação & CHICARELLE, R. J. & 1998 & Pedagogia \\
\hline Desenvolvimento Sustentável & NEDER, R. T. & 2001 & Geral \\
\hline Educação & PIRES, R. C. M. & 2002 & Geral \\
\hline
\end{tabular}




\begin{tabular}{|l|l|l|l|}
\hline Sociologia & CARVALHO, A. G. & 2002 & Geral \\
\hline Educação & ALMA, J. M. & 2003 & Medicina e Enfermagem \\
\hline Educação & FIOR, C. A. & 2003 & Geral \\
\hline Educação & BRIDI, J. C. A. & 2004 & Geral \\
\hline Controladoria e Contabilidade Estratégica & SOUZA, M. B. & 2005 & Ciências Contábeis \\
\hline Educação & KIRSCH, D. B. & 2007 & Pedagogia \\
\hline Educação & EUFRÁSIO, D. A. & 2007 & Letras \\
\hline Ciências & MASSI, L. & 2008 & Química \\
\hline Educação & RIBEIRO, M. A. de O. & 2010 & Letras \\
\hline Educação & OLIVEIRA, K. G. & 2013 & Letras \\
\hline
\end{tabular}

Quadro 1: Pesquisas em Iniciação Científica de 1990 a 2013

Na tabela abaixo, quantificamos os trabalhos encontrados segundo a área de pesquisa na qual foram desenvolvidos.

\begin{tabular}{l|c}
\hline Áres de pesquisa & Quantidade \\
\hline Ciências & 1 \\
\hline Comunicação & 1 \\
\hline Controladoria e Contabilidade Estratégica & 1 \\
\hline Desenvolvimento Sustentável & 1 \\
\hline Educação & 17 \\
\hline Psicologia & 1 \\
\hline Psicologia da Educação & 1 \\
\hline Química Biológica & 1 \\
\hline Saúde da Mulher & 1 \\
\hline Sociologia & 1 \\
\hline
\end{tabular}

Quadro 1: Quadro de pesquisas sobre Iniciação Científica por área de pesquisa

Através do levantamento bibliográfico de dissertações e teses registradas de 1995 a 2004, Massi (2008) identificou três tipos distintos de contribuições no conjunto de pesquisas quanto às contribuições da IC nos trabalhos verificados:

- Avaliação da Iniciação Científica como atividade de formação do universitário:

$\checkmark$ Desempenho da graduação

Desenvolvimento pessoal e socialização profissional

- Avaliação do PIBIC com relação aos objetivos almejados pelo Programa. 
- Caracterização de algumas particularidades do desenvolvimento da Iniciação Científica:

$\checkmark$ Natureza das atividades desenvolvidas pelos graduandos e a sua motivação para a pesquisa

$\checkmark$ Os critérios adotados para a seleção de orientadores e bolsistas

As expectativas, decepções e dificuldades vivenciadas pelos bolsistas durante a IC.

Nas pesquisas encontradas, notamos que muitos trabalhos aludem à questão do "domínio da linguagem científica" e também a "melhoria da escrita científica" como um aspecto positivo a ser considerado no processo da IC. Analisando as pesquisas encontradas por Massi (2008), sugerimos acréscimos à divisão realizada acima, tanto com relação aos benefícios da IC quanto ao "aprimoramento das capacidades de comunicação nas modalidades oral e escrita" e na "linguagem científica no processo da Iniciação Científica" como mostraremos na seção seguinte. Os nossos acréscimos em relação às pesquisas encontradas por Massi (2008) são dois (em negrito):

- Avaliação da Iniciação Científica como atividade de formação do universitário:

$\checkmark$ Desempenho da graduação

$\checkmark$ Desenvolvimento pessoal e socialização profissional

\section{$\checkmark$ Aprimoramento das capacidades de comunicação nas modalidades oral e escrita}

\section{$\checkmark$ A linguagem científica no processo de Iniciação Científica}

- Avaliação do PIBIC com relação ao objetivo almejados pelo Programa.

- Caracterização de algumas particularidades do desenvolvimento da Iniciação Científica:

$\checkmark \quad$ Natureza das atividades desenvolvidas pelos graduandos e a sua motivação para a pesquisa 
$\checkmark$ Os critérios adotados para a seleção de orientadores e bolsistas

As expectativas, decepções e dificuldades vivenciadas pelos bolsistas durante a IC.

Aproveitaremos também para discutir os resultados das pesquisas desenvolvidas, sobretudo da área de Educação entre os anos de 2005 e 2013 levantadas por nós. Dentre as três contribuições destacadas acima, na próxima seção, discorremos sobre a primeira delas: "Avaliação ${ }^{7}$ da Iniciação Científica com atividade de formação do universitário", pois é o que mais se adequa aos objetivos de nossa pesquisa.

\title{
3.3. A Iniciação Científica e a atividade de formação do universitário
}

As pesquisas analisadas no trabalho de Massi (2008) traziam a discussão, muito recorrente no ensino superior brasileiro, da separação entre teoria e prática, ou seja, o ensino na graduação e na pós-graduação, entendendo que este seria um espaço de investigação científica e aquele um espaço de reprodução das pesquisas realizadas. Nesse sentido, o espaço da sala de aula e o espaço da pesquisa são claramente distintos, logo a sala de aula não é vista como um local onde se poderia também produzir conhecimento, assim como explica Breglia (2013, pag. 11):

\begin{abstract}
Entre os resultados sugeridos pelo campo empírico, chamou especial atenção o fato de alguns professores estabelecerem uma diferença entre o espaço da sala de aula e o espaço da pesquisa, o que indica que ainda permanece uma visão tão antiga quanto distorcida: a graduação continua ocupando no sistema de ensino superior, um espaço de reprodução e não de produção de conhecimentos. $\mathrm{O}$ espaço da pesquisa é muito mais valorizado e altera o comportamento dos professores na elaboração das rotinas, na relação com os alunos, no investimento que é feito. Ficou claro que a sala de aula não é vista como um espaço de trabalhar o conhecimento com o objetivo de criar nos alunos um espírito de investigação.
\end{abstract}

A causa desse problema, segundo a autora, é a própria tradição do sistema superior brasileiro que, ao ser implantado, privilegiou um ensino de graduação cujo objetivo era a formação profissionalizante imediatista e utilitarista, gerando uma hierarquização dual entre graduação e pós-graduação, com hegemonia da segunda. É

\footnotetext{
${ }^{7} \mathrm{O}$ termo "avaliação" neste caso se refere aos dados coletados nas pesquisas sobre IC que são, majoritariamente, provenientes de entrevista ou questionários com graduando ou egressos de cursos de graduação. Nesses dados, os participantes avaliam a prática da IC tendo vista a experiência que tiveram durante o seu exercício.
} 
nesse contexto que surgem as iniciativas de aliar o ensino da graduação com o ensino da pós-graduação, a prática e a pesquisa por meio da Iniciação Científica que, como já informamos, foi criada em 1951, logo após a criação do CNPq.

Ao estudar a relação da IC em disciplinas de cursos de Ciências Contábeis de Instituições de Ensino Superior da cidade de São Paulo, Souza (2005) conclui que as atividades e conteúdos de Iniciação Científica podem estimular o desenvolvimento do pensamento crítico, além de ser percebida como uma competência profissional para uma atuação eficaz no mercado de trabalho, e efetivamente estimuladora para a competência profissional e o desempenho acadêmico dos alunos.

Nesse mesmo sentido, como constatado em nosso levantamento, muitos outros trabalhos evidenciam os benefícios da prática de pesquisa na graduação em outros cursos de ensino de superior investigados. Assim, é constatado por Kirsch (2007), após realizar entrevistas como dez graduandas egressas do curso de Pedagogia da Universidade Federal de Santa Maria, que a prática de IC revaloriza o espaço da sala de aula, tornando-o um lugar de construção do conhecimento (KIRSCH, 2007, p.85).

As pesquisas ainda apontam que os benefícios da IC na graduação podem ser percebidos também no desempenho dos alunos nas disciplinas do curso, por meio de um maior rendimento em sala de aula. No processo de IC os estudantes adquirem um novo referencial crítico e por isso não se tornam tão passivos nas aulas, posto que conseguem participar das discussões de forma efetiva e com maior qualidade, trazendo muitas vezes para a sala de aula dados e resultados de pesquisas realizadas. Ademais, os fatores da IC que melhoram o desempenho dos alunos na graduação são:

[...] garante maior embasamento teórico; garante mais prática em laboratório; maior contextualização do conteúdo, ensina a organizar e a desenvolver projetos; permite formação de hábitos de estudo; desenvolve a iniciativa de buscar o que não se base em diversas fontes; permite o aumento da responsabilidade e o crescimento pessoal; aumenta a possibilidade de diálogo com pessoas mais experientes (AGUIAR, 1997 p.84).

Como apontado nas dezesseis entrevistas coletadas por Fior (2003, p.77) com graduandos de diversos cursos da UNICAMP e também por Bridi (2004, p.52), a IC permite um contato mais próximo com professores, não somente no espaço restrito das discussões a respeito do projeto de pesquisa, mas também no que se refere às trocas de experiências pessoais entre ambos, no aconselhamento dos professores sobre as decisões 
futuras dos estudantes e uma maior afinidade até mesmo no âmbito mais pessoal. As autoras também salientam o desenvolvimento de um raciocínio mais crítico por parte dos alunos para sintetizar informações e aproximar pensamentos de diferentes pontos de vista, benefício esse levantado por Souza (2005) quando este afirma que a IC desenvolve o "pensamento crítico" dos estudantes.

Após analisar as respostas de questionários respondidos por 78 graduandos de cursos de Humanas, Exatas, Biológicas e Artes da UNICAMP, que desenvolviam pesquisas em IC, Bridi (2004) separa os benefícios da IC em três: os benefícios acadêmicos, pessoais e profissionais. Assim, o desenvolvimento do pensamento mais reflexivo foi inserido nos benefícios acadêmicos, dado que os estudantes percebem que começam a se especializar em um assunto particular, tendo nesse processo contato com outros trabalhos científicos que permitem uma abordagem mais crítica em relação aos saberes do curso. É por meio do entrosamento com as pesquisas de uma dada área que os estudantes traçam seus perfis profissionais e muitos decidem os setores de trabalho que mais lhes agradam, além de ser um momento no qual os alunos são melhores direcionados para a pós-graduação.

Nesse sentido, a IC pode contribuir para a autonomia e maturidade dos estudantes, pois cobra que o aluno possa organizar tanto as tarefas da graduação quanto as atividade da pesquisa de acordo com o cronograma traçado, para que nem as disciplinas do curso e nem a pesquisa fiquem prejudicadas em termos de qualidade de trabalho. Ademais, o percurso da IC desenvolve uma autonomia nos alunos, visto que eles devem participar de eventos científicos para apresentar seus trabalhos de pesquisa e, nessas ocasiões, saber explicar e defender os procedimentos utilizados. Isso foi constatado de modo mais latente na pesquisa de Pires (2008), na qual foram entrevistados 127 egressos de diversos cursos da Universidade do Estado da Bahia que realizaram pesquisas na graduação.

Ainda nessa perspectiva, Bazin (1982, p.82) sustenta que de fato a IC é um momento de ganho de autonomia, a partir da ruptura dos hábitos praticados no Ensino Médio, no qual os estudantes são passivos durante a transmissão do conhecimento, pois não estão lá para desenvolver o pensamento crítico, mas somente para passar pelo vestibular e ingressar em uma Universidade, onde, muitas vezes, são preservados os mesmo hábitos da escola. Desse modo, a IC torna-se um momento de busca de respostas e 
investigações científicas levadas a cabo pelos estudantes com a ajuda de um orientador, mas desenvolvidas em grande parte pelas descobertas dos próprios alunos.

O pensamento crítico reflexivo, a autonomia e a maturidade adquiridos pelos alunos durante a pesquisa de IC podem influenciar também em uma maior consciência no âmbito profissional existente, servindo como forma de o estudante direcionar seu percurso profissional, além de ser um espaço de socialização profissional. Nas entrevistas realizadas por Bridi (2004, p.53), verificou-se que os alunos consideram que a IC amplia o conhecimento de uma área profissional, é uma oportunidade de iniciação na carreira acadêmica, de direcionamento na carreira profissional, bem como uma ocasião de ampliação dos contatos profissionais e de trabalho em grupo. A participação em eventos acadêmicos para a apresentação das pesquisas de IC, por exemplo, proporciona aos alunos um conhecimento de outros trabalhos realizados em outras Instituições de Ensino Superior e também uma oportunidade de conhecer pesquisadores de outros lugares, ampliando os contatos. Para Kirsch (2007, p.81), a comunicação científica estimulada através da participação dos estudantes em eventos da área colabora "para os alunos manterem-se atualizados, divulgarem as produções de suas pesquisas, ampliando a capacidade escrita e oral de elaboração própria, trocar com os demais investigadores da área".

Como discorreremos a seguir, tanto o levantamento das pesquisas feito por Massi (2008), quanto o nosso próprio, acima exposto, apontam que a IC também é um espaço de aprimoramento de capacidades de comunicação, seja na modalidade oral ou escrita. Assim, segundo Massi (2008):

[...] a iniciação científica possibilita a apreciação pelo pesquisar, a superação das dificuldades na leitura dos textos acadêmicos, contribui para a melhora da escrita do estudante, aumenta o conhecimento técnico e científico, além de favorecer o rendimento acadêmico.

Nas pesquisas analisadas é recorrente as falas dos alunos reforçando os benefícios da IC para o tratamento com o texto, como podemos conferir no trabalho de Bridi (2004): "aprendi muitas coisas como escrever melhor, fazer uma pesquisa bibliográfica, debater com autores, sistematizar leituras na forma de textos. A IC é uma verdadeira escola”.

$\mathrm{Na}$ contramão dos vários benefícios gerados pela atividade de IC, destacam-se também em nosso levantamento alguns aspectos negativos provenientes das atividades de 
pesquisas na graduação constatados por Santos (2013) em sua pesquisa realizada em uma grande IES pública do estado do Paraná. Os apontamentos de Santos (2013), baseados em depoimentos tanto de alunos de IC quanto de professores, evidenciam que o modo e o gerenciamento da pesquisa científica como um todo no Brasil atualmente e, também na IC, vem causando afeitos negativos que não permitem uma experiência benéfica para os estudantes no contexto da pesquisa.

Nas pesquisas acima discutidas foram usados dados predominantemente resultantes de questionários ou entrevistas com estudantes de gradução ou egressos que participaram de um programa de IC. Entretanto, chama-nos atenção o fato de as pesquisas não analisarem os próprios textos produzidos durante a prática da pesquisa, buscando verificar se, por meio deles, é possível compreendermos essa prática de pesquisa realizada em contexto universitário. Além disso, constatamos nessas pesquisas aspectos positivos e negativos. Dentre os aspectos positivos, sobressai-se o aprimoramento das capacidades de linguagem, sobretudo da linguagem escrita, já que, nas pesquisas, os estudantes devem escrever projetos e relatórios. No entanto, encontramos somente uma em que a apropriação da linguagem científica é objeto de estudo aprofundado, como veremos na próxima seção.

\subsection{A linguagem científica no processo de Iniciação Científica}

No levantamento que fizemos das pesquisas realizadas entre 2005 e 2013, encontramos a pesquisa de Massi (2008), intitulada "Contribuições da Iniciação Científica na apropriação da linguagem científica por alunos de graduação em Química" defendida no Instituto de Química da Universidade de São Paulo (São Carlos). O título da pesquisa nos chamou atenção e, por isso, buscamos analisá-la para verificar as semelhanças e diferenças quanto a nossa.

$\mathrm{Na}$ seção de Introdução, mais especificamente na seção dos objetivos, encontramos um parágrafo (MASSI, 2008, pag. 78) que resumiu a pesquisa realizada:

Nessa perspectiva, nosso estudo teve como objetivo investigar se as atividades desenvolvidas na IC são relevantes para a apropriação da 
linguagem científica pelos estudantes e como se dá essa apropriação. Para tanto acompanhamos, no intervalo de um ano, dois graduandos que realizaram IC em laboratórios de pesquisa na área de Química e coletamos dados referentes às suas produções científicas escritas e orais. As análises dos dados obtidos foram realizadas tomando como base o referencial teórico da Análise do Discurso de linha francesa, como divulgada por Orlandi (1986, 1996a, 1996b, 2000, 2003a), quanto à tipologia dos discursos e à noção de autoria; e da Sociologia e Antropologia da Ciência, especificamente os Estudos Etnográficos de Laboratório como aqueles desenvolvidos por Latour e Woolgar (1997).

A pesquisa nos chamou atenção pelos seguintes motivos:

i. Por analisar dados referentes ao processo da IC em um período de tempo;

ii. Preocupar-se com a apropriação da linguagem científica;

iii. Coletar tanto dados orais quanto dados escritos;

iv. Utilizar uma teoria da Análise do Discurso.

Na leitura mais aprofundada desta pesquisa, notamos as diferenças entre ela e a nossa. Primeiramente, o processo investigado na pesquisa de Massi (2008) ocorreu dentro do curso de Química, diferentemente do nosso caso em que estamos investigando saberes do curso de Letras. Nesse sentido, a problematização da relação entre o uso da linguagem e a transmissão de saberes não é alvo das preocupações na pesquisa de Massi (2008), ao passo que é essa relação que nos permitirá analisar os dados coletados. Segundo Vigotski (2006), a relação entre questões psicológicas e linguageiras propicia a formação de uma "generalização", noção importante para a nossa pesquisa. Assim, a questão da transmissão dos saberes por parte dos estudantes fica subjacente nos resultados de Massi (2008).

No que concerne aos aportes teóricos, utilizaremos os pressupostos do Interacionimo social e do Interacionismo sociodiscursivo que, embora não seja uma teoria de Análise do Discurso (AD), possui um programa de pesquisas com objetivos os quais são desenvolvidos também por meio de aportes da AD.

No tocante aos dados analisados pela pesquisadora, embora haja uma preocupação com dados tanto da modalidade oral quanto da modalidade escrita, os textos recolhidos para a pesquisa de Massi (2008) foram: gravação e transcrição de diálogos 
travados entre o orientando e a orientadora, entrevistas abertas com os orientandos e orientadores, cadernos de laboratório, material bibliográfico consultado, resumo e pôsteres apresentados por alunos em Congressos de IC, além de gravação em vídeo das apresentações dos pôsteres. Todavia, em nossa pesquisa, selecionamos os textos que, obrigatoriamente, os estudantes devem produzir como exigência do dispositivo formativo do Programa de Iniciação Científica da USP. Assim, embora tenhamos feito um recorte nos nossos dados, consideramos importante o projeto de pesquisa, os relatórios de pesquisa, além da apresentação oral ao final do processo. Ademais, posto que nosso contexto de pesquisa é a Faculdade de Letras, não temos cadernos de laboratório em nossos dados e nem seria viável para o nosso objetivo de pesquisa, já que esses cadernos não são exigidos pelo Programa de Iniciação Científica da USP.

\subsection{Pesquisas sobre Iniciação Científica no curso de Letras}

Em nosso levantamento, diferentemente do realizado por Massi (2008), encontramos três dissertações que abordavam a Iniciação Científica no curso de Letras, sendo que todas elas foram desenvolvidas no Programa de Pós-graduação em Educação da Faculdade de Educação da Universidade de São Paulo, duas delas, inclusive, orientadas pela mesma docente. Depois dessa descoberta, analisamos cuidadosamente os três trabalhos encontrados que podem ser consultados na Biblioteca Digital de teses e dissertações da USP.

A primeira dissertação, de Eufrásio (2007), intitulada “Traços das formações discursivas do dogma e da investigação em relatórios de pesquisa e de estágio. Reflexão sobre o papel da pesquisa na formação docente" objetivava analisar tanto o relatório de Iniciação Científica quanto relatórios de estágio de alunos de Letras, a fim de compreender como o conhecimento enquanto pesquisador influencia na prática didática e na formação do professor de língua portuguesa. Os relatórios foram escritos em dois contextos diferentes e os três informantes da pesquisa tinham dois papéis sociais diferentes: o contexto da Iniciação Científica, no qual eles atuavam como iniciantes na pesquisa científica, e também no contexto de uma disciplina da Licenciatura em Letras que eles cursaram enquanto graduandos do curso de Letras. 
O conceito central da pesquisa são as "formações discursivas" de Michel Foucault, entendido na pesquisa em questão como "objetos, tipos de enunciados, os conceitos, as escolhas temáticas que tenham uma ordem, correlações posições e funcionamentos, transformações" (EUFRÁSIO, 2007).

Como resultado dos dados, a autora concluiu que o trabalho de pesquisa é uma prática fundamental na formação do profissional em Letras, mais do que isso a autora considera que a pesquisa deva ser um instrumento de formação e por isso poderia ser inserido de forma sistemática na formação do professor de Língua Portuguesa. Ademais, conclui-se que a prática de pesquisa na formação docente proporciona aos alunos intervenções críticas na sua relação com o conhecimento.

Em nossa pesquisa, todavia, não teremos como objetivo a relação entre a influência da experiência de pesquisador ${ }^{8}$ na formação enquanto professor, mas o percurso completo do aluno graduando em Letras na IC, no qual não somente o relatório de pesquisa é produzido, mas outros gêneros textuais pelos quais o saber apropriado é transmitido pelos alunos.

A segunda dissertação que analisamos, defendida em 2010, intitulada "O discurso universitário materializado: aprendendo a escrever o texto acadêmico" (RIBEIRO, 2010) tinha como objetivo comparar o modo como uma mesma informante da área de Letras redigiu o embasamento teórico do seu trabalho, a metodologia adotada e a seção dedicada à análise de dados, em três textos diferentes: o relatório de Iniciação Científica, a dissertação de mestrado e a tese de doutorado, objetivando mostrar as transformações nas maneiras de o pesquisador lidar com seus pressupostos teóricos, a metodologia utilizada e os procedimentos de análise.

A pesquisa partiu do pressuposto de que, para ser bem sucedido, o pesquisador, nos mais diversos níveis, deve aprender a escrever nos moldes da comunidade discursiva onde se realiza a formação, e, além disso, precisa aprender também a transmitir "os seus impasses lógicos" por escrito. Logo, percebemos que a análise do trabalho não é a duração da Iniciação Científica como um todo.

\footnotetext{
${ }^{8}$ Ademais, questionamos a denominação dos alunos enquanto pesquisadores na atividade de Iniciação Científica, posto que o esse métier tem particularidades de uso na esfera do trabalho e científica no Brasil.
} 
O conceito central usado na pesquisa foi o esquema das "formações imaginárias" da Análise do Discurso de Pêcheux, entendido como as imagens ou representações dos lugares que cada interlocutor atribui a si e ao outro.

Nas considerações finais do trabalho, a autora busca resumir o resultado das suas análises, mostrando que no relatório final de pesquisa da IC realizada pela informante não havia ainda uma articulação teórica coerente, mas desarticulada e funcionando como um discurso comum, pois no corpo do relatório não havia qualquer referência direta a um autor, teoria ou conceito. Já na redação de sua dissertação de mestrado a mesma informa conseguiu se inserir no discurso universitário, pois dedicou dois capítulos de seu texto para o embasamento teórico. O mesmo ocorreu na redação da metodologia descrita no relatório de IC e na dissertação, em que, neste, a informante se apropriara de um método consolidado no meio científico e soube justificá-lo, porém, naquele, ela ainda não sabia separar os objetos empíricos dos objetos da pesquisa.

Na pesquisa que aqui propomos, contudo, não somente analisaremos o relatório final de pesquisa, mas, também, os outros gêneros textuais que, necessariamente, os estudantes devem produzir no âmbito da pesquisa em IC.

A terceira dissertação, de 2013, que tinha como título "A leitura do outro e a modalidade linguística: impactos no percurso de formação de um jovem pesquisador" (OLIVEIRA, 2013) objetivou analisar a influência de terceiros (orientador e representantes de órgãos de fomento) na mudança e reescrita dos relatórios de pesquisa redigidos por uma única informante que desenvolveu, no período de março de 2007 a março de 2009, uma pesquisa em Iniciação Científica. A pergunta do trabalho foi: “em que medida é possível correlacionar as intervenções feitas por terceiros na utilização da modalidade linguística por uma pesquisadora em formação em versões do seu relatório de Iniciação Científica? A hipótese da autora é de que os alunos modificam os seus textos após os comentários de terceiros de acordo com a imagem que eles têm da comunidade científica na qual estão inseridos.

Para responder a sua pergunta de pesquisa, a autora do trabalho utilizou o conceito de "formações imaginárias" de Pêcheux, a noção de "auditório" de Chaim Perelman e a classificação de modalização de Pottier. Através da pergunta de pesquisa, podemos notar uma preocupação com a formação do pesquisador, mas não encontramos ao longo da dissertação nenhuma definição do conceito de "formação", pois a autora a esse respeito 
parte de uma premissa: “Advogamos em favor de que essa formação [de um aluno de ensino superior] vá além da exposição de conceitos ou autores consagrados em uma determinada área. Trata-se de uma formação que vise a uma filiação teórica e um engajamento de produção de conhecimento de forma a não deixar de lado a missão primeira da universidade: ensino, pesquisa e extensão" (OLIVEIRA, 2013).

Como conclusão do estudo realizado, constatou-se que os ajustes textuais no texto escrito têm relação com a imagem criada pelo pesquisador em formação a respeito da comunidade acadêmica em que ele está inserido. Em contraste, nossa pesquisa considerará também os textos orais, uma vez que, no âmbito da IC, os alunos devem obrigatoriamente realizar apresentações orais de pesquisa, que também fazem parte do processo da IC. Em nossa pesquisa, a noção de "formação" 9 do Interacionismo sociodiscursivo será importante para se compreender os nossos objetivos e os nossos procedimentos metodológicos.

\section{Objetivos e perguntas de pesquisa}

Partindo do histórico de nossos estudos e, também, do levantamento de pesquisas que já foram realizadas sobre a IC, procuramos formular um objetivo geral e algumas perguntas mais específicas da pesquisa.

Assim, o objetivo amplo desta pesquisa é investigar o desenvolvimento do aluno enquanto pesquisador durante o processo de Iniciação Científica por meio da análise das relações entre o uso da linguagem e a apropriação dos saberes. Assim, analizaremos textos produzidos por estudantes de IC durante o processo da pesquisa e que são exigidos por este dispositivo de formação na Universidade de São Paulo. Para atingir nossos objetivos, formulamos três perguntas de pesquisa as quais buscamos responder ao longo do estudo realizado:

1) Houve desenvolvimento dos alunos particpantes da pesquisa durante o processo de IC?

\footnotetext{
${ }^{9}$ O conceito de "formação" que utilizaremos na pesquisa será explicado na seção 2.1 do capítulo I.
} 
2) Quais marcas linguístico-discursivas presentes nos textos produzidos durante o processo de IC (projeto de pesquisa, resumo para apresentação, apresentação oral de pesquisa e relatório final) permitem depreender esse desenvolvimento?

3) Qual o papel dos gêneros textuais produzidos durante o processo da IC nesse desenvolvimento?

Após realizarmos o quadro geral desta pesquisa quanto ao contexto e aos objetivos, passaremos à apresentação do modo pelo qual esta dissertação foi organizada.

\section{Organização geral da dissertação}

Este relatório está dividido em três capítulos, começando pela introdução, seguida pelos seguintes conteúdos:

\section{Capítulo I: Pressupostos teóricos}

Neste capítulo, primeiramente discorreremos sobre a corrente epistemológica do Interacionismo social tal como desenvolvida por Vigotski, que desenvolveu o conceito de funções psicológicas superiores. Entre essas funções destacamos a linguagem que, juntamente com o pensamento, permitem níveis de generalizações por meio da palavra na formação dos conceitos.

Em seguida, trataremos especificamente do Interacionismo sociodiscursivo, proposto por Bronckart (1999) que é um prolongamento das questões de pesquisa iniciadas pelo Interacionismo social, sobretudo a validação do papel da linguagem como reguladora das interações humanas. Decorrente disso, o estudo do tex to torna-se essencial para a compreensão das interações humanas ocorridas sempre dentro de um dispositivo de formação seja ele mais formal (como a formação oferecida pelas escolas), seja outro tipo de formação que não ocorre no espaço escolar, mas nas mais diversas atividades humanas. Para complementar os estudos do ISD na análise, utilizaremos os conceitos de modalização autonímica (AUTHIER-REVUZ, p.1999), valor autonímico e ilhas textuais (MAINGUENEAU, p.2005). 


\section{Capítulo II: Metodologia de pesquisa}

Este capítulo é composto por seis seções, nas quais descreveremos o nosso contexto de pesquisa, depois os participantes de estudo; em seguida, mostraremos os procedimentos e instrumentos metodológicos que utilizamos para a coleta dos dados e a sua validade para a nossa pesquisa. Posteriormente, descreveremos os procedimentos de seleção dos textos que coletamos para a pesquisa, para, finalmente, apresentar os procedimentos de análise dos textos.

\section{Capítulo III: Análise dos dados}

Para a análise dos textos de uma participante de nossa pesquisa, utilizaremos as categorias analíticas do Interacionismo sociodiscursivo desde o projeto de pesquisa escrito até os últimos textos produzidos, seja o relatório, seja a apresentação oral de pesquisa. Com isso, buscamos compreender o modo como a linguagem foi utilizada durante o processo da Iniciação Científica e, para tanto, o método de análise do ISD será importante, dado que ele tem como preocupação tantos os aspectos contextuais do texto produzido, quanto os aspectos da macro e da microestrutura textual.

\section{Síntese dos resultados e discussão}

Retomando nossas perguntas de pesquisa, faremos uma sistematização sintética dos resultados encontrados, objetivando facilitar a compreensão das discussões que empreenderemos. Para a discussão dos resultados, utilizaremos a noção de sistemas da linguagem proposta por Bota (2011). 


\section{Considerações Finais}

Exporemos nossas considerações finais, buscando apontar as nossas contribuições para pesquisas futuras e as limitações do estudo que realizamos. 


\section{Capítulo II - Pressupostos teóricos}

Nosso capítulo teórico será divido em duas partes complementares. A primeira trará as considerações da teoria vigotskiana sobre a relação pensamento e linguagem, e como ela forma os conceitos cotidianos e científicos. Para chegarmos a essa ideia, faremos uma exposição das reflexões Vigotski acerca do gênero humano e do processo de produção dos instrumentos psicológicos.

Na segunda parte, abordaremos a teoria do Interacionismo Sociodiscursivo (ISD), baseada nos princípios fundadores do Interacionismo Social, pela qual compreenderemos o papel da linguagem nos processos formativos e na construção dos conhecimentos humanos. Para isso, mostraremos, em primeiro lugar, os pressupostos dessa teoria e o seu método de análise textual/discursivo.

\section{O Interacionismo social e a natureza humana}

O Interacionismo desenvolvido, sobretudo por Vigotski, Leontiev e Luria, deve ser entendido dentro do contexto histórico no qual ela se desenvolveu e o qual propiciou a criação desse arcabouço teórico muito diversificado, que possibilitou reflexões em muitos campos do conhecimento como na psicologia, biologia, defectologia e pedagogia (TULESKI, 2008).

Esse contexto ao qual a autora se refere é o período da Revolução Russa (1917), no qual pela primeira vez na história da humanidade se realizava "uma experiência de fazer-se conscientemente comunista" (TULESKI, 2008, p.137). Foi participando ativamente dessa experiência, sobretudo da psicologia, que Vigotski desenvolveu o conceito histórico da natureza humana, a partir do qual seria possível pensar uma sociedade na qual os indivíduos pudessem se apropriar do conhecimento, das capacidades, dos instrumentos e signos criados pelo gênero humano, a fim de se auto-regularem e controlarem o próprio comportamento.

Assumindo essa perspectiva, Leontiev (2005, p. 90) demonstrava o modo como o ser humano adquire seu desenvolvimento mental através da apropriação da experiência da sua espécie. Dentro desse raciocínio, o autor traça primeiramente um paralelo entre o 
desenvolvimento do homem em relação àquele encontrado nos animais. Para ilustrar essas pesquisas, muitos estudos do grupo de Vigotski centraram-se em pesquisas de campo com crianças, a fim de compreender como ocorre esse desenvolvimento.

Para os estudiosos do grupo de Vigotski, toda criança, ao nascer, encontra-se em um ambiente onde existem leis biológicas da própria espécie, mas também leis sociais, que diferenciam o gênero humano de todos os outros animais. Por leis biológicas, Leontiev (2005) designa todos os processos que foram adquiridos durante os muitos anos da evolução de uma determinada espécie, ou seja, a experiência filogenética que os seres herdam ao nascerem em um tempo situado dessa evolução. Os animais, por exemplo, além dessa experiência adquirida, também desenvolvem comportamentos devido à própria necessidade de adaptação ao ambiente.

O gênero humano, ao contrário, que também herda aspectos da experiência filogenética, é influenciado igualmente pela experiência histórico-social da espécie humana, dentro da qual agem as leis sociais. De acordo Leontiev (2005, p. 91), bem como para Vigotski, essa experiência social surgiu devido à atividade produtiva do homem, ou seja, através do seu trabalho. Por meio de sua atividade produtiva o homem construiu "produtos" tanto mentais quanto materiais que foram se modificando ao longo do desenvolvimento humano (a ontogênese), como nos exemplifica o autor (LEONTIEV, 2005, p. 92):

Qualquer objeto criado pelo homem - desde o mais simples utensílio à moderníssima máquina calculadora eletrônica - realiza tanto a experiência histórica do gênero humano como as capacidades intelectuais formadas nesta experiência. O mesmo pode comprovar-se com maior clareza na linguagem, na ciência, nas obras de arte.

Nesse sentido, o desenvolvimento mental da criança se inicia em um mundo humanizado, quer dizer, um espaço objetivo criado pelo homem, com alimentos, vestuário, a linguagem, os conceitos e as ideias. Assim, ao se relacionar com os fenômenos naturais, por exemplo, a criança percebe que estes já foram condicionados pelo homem, como nas roupas que a protegem do frio ou mesmo a luz artificial que dissipa a escuridão da noite, entre outros possíveis exemplos. 
Todavia, esse processo de humanização do ser humano é muito complexo, pois a apropriação das conquistas humanas é diferente de um indivíduo para outro. Logo, a questão central é saber como as crianças se apropriam dos objetos e fenômenos que as circundam, mais especificamente, como acorre a apropriação e a transmissão dos saberes?

Diferentemente dos animais, que passam por uma adaptação biológica pelas exigências do ambiente, os humanos passam por um processo de apropriação muito diferente, explicado por Leontiev (2005, p. 93) da seguinte forma:

É um processo que tem como consequência a reprodução no indivíduo de qualidades, capacidades e características humanas de comportamento. Em outras palavras, é um processo por meio do qual se produz na criança o que nos animais se consegue mediante a ação da hereditariedade; a transmissão para o indivíduo das conquistas do desenvolvimento da espécie.

As conquistas da espécie humana possibilitadoras do seu desenvolvimento são chamadas, dentro da teoria histórico-cultural de Vigotski, de funções psicológicas superiores, que são capacidades não inatas nos seres humanos desenvolvidas no processo da ontogênese. Nas obras de Vigotski (2001a, 2001b, 2007), podemos encontrar trabalhos experimentais desenvolvidos por ele a respeito das funções, como, por exemplo, no livro "Psicologia pedagógica" sobre a atenção, a memória, o comportamento emocional e o pensamento; e também em sua obra "A construção do pensamento e da linguagem", na qual há capítulos sobre a formação dos conceitos e a linguagem.

A apropriação das funções psicológicas superiores pelos diferentes indivíduos tem início a partir do momento em que é empreendida uma atividade adequada ao conteúdo no objeto ou no fenômeno dado. Assim, ao assimilar algum instrumento com precisão, a criança necessitará fazer corresponder a esse uso certas ações e operações motoras e mentais, que são formadas na criança pelas relações com o mundo circundante e pelas suas relações com as pessoas, através da linguagem. Notamos, desse modo, a importância da linguagem frente às outras funções superiores e sobre ela discorremos nas próximas páginas com maiores detalhes (LEONTIEV, 2005, p.94). 
Na espécie humana, especificamente, todo o processo de apropriação das funções psicológicas superiores é possível por meio do uso da linguagem, das trocas verbais entre os indivíduos no processo de uma atividade. Sobre essa questão, discorreremos quando tratarmos do Interacionismo Sociodiscursivo. De acordo com Tuleski (2008, p.145):

\begin{abstract}
A aquisição da linguagem, a partir da interação com os membros adultos de seu meio social, permite uma superação qualitativa dos fatores biológicos existentes em cada função psicológica, isto é, a percepção, a memória, a imaginação etc., enfim, todas as funções se redimensionam a partir dos significados que a linguagem oferece à realidade.
\end{abstract}

Por essa peculiaridade da linguagem dentre as funções psicológicas superiores, ela deve ser compreendida e explicada com maiores detalhes, tarefa esta que realizaremos ainda neste capítulo. Antes disso, porém, discorremos com maiores detalhes a respeito da internalização das funções humanas superiores segundo a perspectiva de Vigotski (2007) e seu grupo.

\title{
1.1 Métodos indiretos e a internalização das funções psicológicas superiores
}

Ao construir o estado da arte das correntes em psicologia das três primeiras décadas do século XX, Vigotski criticava tanto a psicologia introspectiva, quanto a psicologia do comportamento, pois elas utilizavam métodos diretos de pesquisa, quer dizer, usavam procedimentos que afirmavam que só seria possível estudar o que nos é dado pela experiência imediata (FRIEDRICH, 2012). Logo, a experiência era considerada como a única fonte e o limite natural do saber científico, por isso Vigotski criticou radicalmente o uso do método direto em psicologia (FRIEDRICH, 2012).

Buscando se contrapor a essas correntes que utilizam métodos diretos, Vigotski propôs o conceito de instrumento psicológico. Os instrumentos psicológicos têm por finalidade auxiliar o desempenho dos fenômenos psíquicos necessários para a realização de uma tarefa, sendo o objeto de sua ação não o meio natural, mas a atividade psíquica do sujeito que o utiliza (FRIEDRICH, 2012). Por meio do uso e da criação de instrumentos 
psicológicos, os homens intervêm de maneira artificial (indireta) sobre os fenômenos psíquicos, transformando-se, ao mesmo tempo, em objeto sobre o qual o instrumento age. Para Vigotski, de acordo com Friedrich (2012), o desenvolvimento ocorre na transformação operada pelo instrumento psicológico.

Nesse sentido, segundo Friedrich (2012), o psicólogo russo entendia que as pesquisas em psicologia deveriam utilizar métodos de caráter indireto, como no caso dos métodos interpretativos e reconstrutivos utilizados nas ciências históricas. Por exemplo, um historiador, um geólogo e um filólogo estudam o passado da humanidade e da terra, ou ainda das línguas antigas, de um modo indireto, com o auxílio de traços, pistas com os quais o pesquisador vai formular um conhecimento do passado, interpretando-o e reconstituindo-o. Vigotski (1927[1999] apud FRIEDRICH, 2012) entendia que o uso do método indireto não nos afasta da verdade, mas, muito pelo contrário, aproxima-nos dela, pois uma interpretação ou uma reconstrução de um fato se realiza sempre por intermédio de um conhecimento já existente que mediatiza, seja diretamente, enquanto conhecimento, seja sob a forma de um construto, a produção do conhecimento do fato em questão.

Para o pesquisador russo, os signos semióticos também podem funcionar como instrumento psicológico. Vigotski (2007) nomeia "signalização" a criação de signos para mediar uma dada atividade, sendo que o uso dos signos orienta o comportamento humano para o interior do indivíduo. Como nos explica Vigotski (2007, p.55):

\begin{abstract}
A função do instrumento é servir como um condutor da influência humana sobre o objeto da atividade; ele é orientado externamente; deve necessariamente levar a mudanças nos objetos. Constitui um meio pelo qual a atividade humana externa é dirigida para o controle e domínio da natureza. O signo, por outro lado, não modifica em nada o objeto da operação psicológica. Constitui um meio da atividade interna dirigido para o controle do próprio indivíduo; o signo é orientado internamente.
\end{abstract}

Na citação de Vigotski (2007) acima, distinguem-se os instrumentos físicos e psicológicos. Dentre esses últimos, incluem-se os signos semióticos, os quais estabelecem uma relação indireta entre o sujeito e a tarefa, na medida em que cada signo é dotado de um valor particular dado tanto pelo uso social quanto pelo uso individual que se faz dele. Embora Vigotski (2007) nomeie com o termo "instrumentos" tanto os físicos quanto os psicológicos, podemos estabelecer uma diferenciação entre eles, pois: 
A simples utilização de instrumentos não caracteriza a atividade especificamente humana, dado que os animais também usam instrumentos. Mas é a produção, enquanto trabalho material e simbólico, significativo, enquanto atividade prática e cognitiva, que distingue e instaura a dimensão histórica e cultural. (SMOLKA, 1995).

Ou ainda, nos dizeres de Oliveira:

[...] os instrumentos simbólicos estabelecem uma forma diferente de relação entre o sujeito e o objeto, na medida em que eles criam o objeto na interação social e não são simples meios pré-determinados de significação (OLIVEIRA, 1995)

Como exemplo do uso dos signos, Vigotski (2007) menciona o "apontar o dedo" da criança. Quando esta quer estabelecer uma relação direta como algum objeto, porém não consegue alcançá-lo, ela começa a apontar para este objeto. Quando o adulto se dá conta do gesto de apontar e a ajuda, o gesto ganha um novo significado, ou seja, de influenciar indiretamente a ação de outrem. Assim, o gesto que, primeiramente, era orientado para o objeto passa a ser orientado para estabelecer relações, o movimento de pegar transforma-se no ato de apontar.

O processo que acabamos de explicar pode ser compreendido da seguinte forma (VIGOTSKI, 2007, p.57).

a) Uma operação que inicialmente representa uma atividade externa (indireta) é reconstruída e começa a ocorrer internamente.

b) Um processo interpessoal é transformado num processo intrapessoal.

c) A transformação de um processo interpessoal num processo intrapessoal é o resultado de uma longa série de eventos ocorridos ao longo do desenvolvimento.

Assumindo essa análise dos processos na apropriação das funções psicológicas superiores, Vigotski se opõe às abordagens em Psicologia que analisam a internalização das funções por meio de métodos diretos, especialmente pelo método de estímulo-resposta, nos quais o sujeito é confrontado com algum tipo de situação-estímulo para influenciá-lo a determinada maneira buscando analisar as respostas (VIGOTSKI, 
2007, p.59). Por meio do método estímulo-resposta é somente possível registrar as várias respostas dadas aos estímulos em diversos estágios de desenvolvimento humano. Portanto, os métodos diretos não são adequados para o estudo da internalização das funções psicológicas superiores.

Assumindo a perspectiva marxista, o psicólogo russo entende que as relações dos homens com a natureza não se dão unidirecionalmente (como nos métodos diretos), mas de forma mediada, pela qual o homem transforma a natureza para a sua existência. Segundo Vigotski (2007, p.63), o método indireto, na análise das funções psicológicas superiores, tem alguns princípios:

- Analisar processos, e não objetos: para Vigotski (2007) muitos métodos em psicologia não consideravam a dimensão temporal na análise dos objetos de pesquisa, porém tratavam-nos como fixos e imutáveis. Logo, essas abordagens não eram desenvolvidas dentro da psicologia do desenvolvimento, caso contrário, teriam em consideração o fato de que o pensamento, por exemplo, sofre mudanças "a olho nu", sejam transformações rápidas, sejam mudanças que podem durar semanas. Para analisar os processos, o método proposto propõe a criação de um processo artificial para o desenvolvimento psicológico, buscando reconstruir os estágios finais do processo desde os estágios iniciais.

- Explicação versus descrição: nas perspectivas que utilizam métodos diretos não encontramos explicações dos objetos usados nos experimentos, mas somente uma descrição de suas respostas. Ao considerar os processos e não os objetos isoladamente, entende-se que é necessária a explicação dinâmico-causal dos estágios dos processos psicológicos e de suas manifestações externas.

Depois de termos tratado da perspectiva de Vigotski (2007) na internacionalização das funções psicológicas superiores por meio dos métodos indiretos, discorremos a seguir sobre a relação entre duas importantes funções humanas superiores estudadas pelos estudiosos interacionistas russos: o pensamento e a linguagem. 


\subsection{A relação pensamento e linguagem}

Para estudar o pensamento, Vigotski (2001) expõe a relação existente entre este e sua natureza motora, visto que o pensamento pode ser caracterizado pelo: retardamento ou suspensão dos movimentos externos, pelo aumento da tensão interna das correntes nervosas, bem como pelo surgimento de uma solução.

Ademais, o pensamento funciona como um organizador prévio de algum comportamento, pois as reações internas do pensamento primeiro adaptam e preparam o organismo para, depois, as reações externas realizarem o que foi antecipadamente estabelecido e preparado no pensamento. Essa função do pensamento acontece quando falamos sozinhos e organizamos o nosso comportamento dentro de nós mesmos e em relação ao comportamento de outras pessoas, o que revela a natureza social do pensamento e como ele modela nossa personalidade para o convívio social.

O papel organizador do pensamento não nos permite caracterizá-lo como livre no sentido de que o indivíduo possui autocontrole sobre ele, ou seja, não é pelo fato do homem primeiro pensar e depois executar na prática o pensamento que há uma autonomia com relação a esse processo. Na verdade, isso é uma ilusão, pois se cria a impressão de que a vontade ou desejo e o esforço volitivo livre são absolutamente autônomos.

Nesse sentido, Vigotski (2001) afirma que todo ato volitivo pressupõe necessariamente a existência de certos desejos e aspirações relacionadas, primeiramente, com a concepção do objetivo final a que aspiramos e, posteriormente, com a concepção das atitudes e ações que são necessárias da nossa parte para a realização do nosso objetivo. Quando nos deparamos com uma situação em que podemos escolher livremente entre muitas possibilidades por nosso próprio arbítrio, acreditamos plenamente que somos livres em nossas escolhas. Nessa situação, segundo Vigotski (2001), estamos diante de uma ausência de liberdade, já que a força dos motivos gerará a criação de alguns estímulos internos que lutam pelo campo motor geral com a força espontânea dos processos nervosos. O desfecho da escolha será pautado: por um lado, pela força relativa das partes em luta e, por outro, pelo clima de luta que se forma como decorrência de equilíbrio geral de forças dentro do organismo.

Dessa forma, Vigotski (2001) entende que o pensamento só surge na base instintiva e emocional, sendo orientado precisamente pelas forças, sobretudo da base 
emocional, pois o fluxo das ideias não está subordinado às leis mecânicas da associação e nem às leis lógicas da veracidade, mas às leis psicológicas da emoção. Assim, o pensamento sempre surge de dificuldades.

Como explicamos acima, a apropriação das funções psicológicas superiores para o gênero humano segue uma lógica "do exterior para o interior" do sujeito. Desse modo, a produção verbal passa por um processo interno (semântico) e um externo (fonético) para a sua realização, portanto há uma lógica interna e uma lógica externa pela qual o pensamento sofrerá, necessariamente, uma modificação de sentido ao ser “encarnado" em palavras. O processo de passagem pode ser entendido pelo esquema abaixo (SCHNEUWLY, 1989):

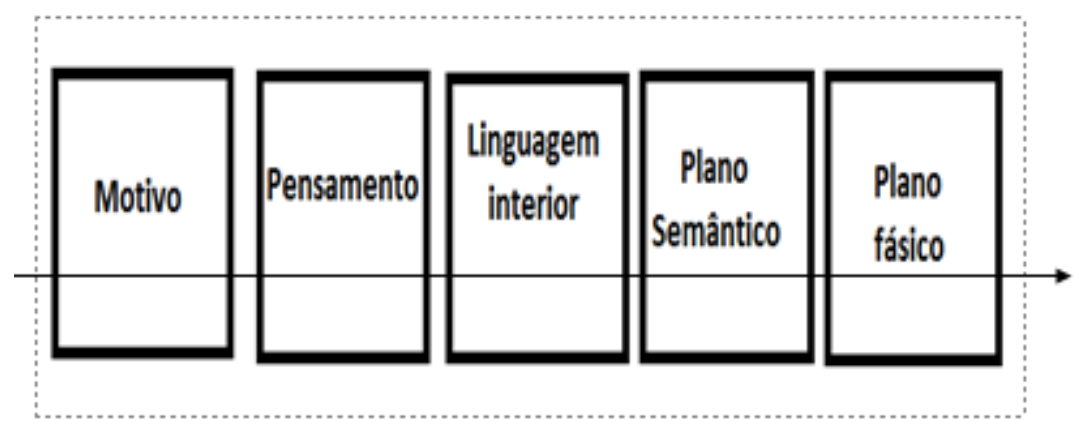

Figura 1: As fases da produção verbal (SCHNEUWLY, 1989)

A primeira fase do esquema é, como esboça Vigotski (2009), o “motivo". Já expusemos acima que o pensamento para Vigotski tem seu início em uma esfera motivante que engloba nossos impulsos, nossas necessidades e interesses, além dos nossos afetos e emoções. É a partir dessa esfera que podemos entender a causa do aparecimento do pensamento.

A fase seguinte é a do pensamento, na qual há uma união e relação com uma função específica, para resolver um certo problema. Nos escritos de Vigotski (2009), discute-se prioritariamente a relação do pensamento com a linguagem e não propriamente essas duas funções psicológicas superiores isoladamente. Nesse sentido, o autor somente diferencia o pensamento da linguagem, ao explicar que esta é composta por palavras isoladas, e aquele não. Com isso, ele objetivava explicar a sequencialização do pensamento. Exemplificando essa característica do pensamento, o autor faz a hipótese de que, se queremos transmitir a ideia: hoje eu vi um garoto correr na rua vestido de blusa 
azul e descalço, não vemos separadamente o garoto, sua blusa, a cor azul que a roupa tem, a ausência de sapatos, o fato que ele corre, mas sim todo o conjunto.

É por isso que o autor entende que todo pensamento tem uma sequencialização que é desenvolvida sucessivamente na linguagem. No entanto, não há uma coincidência imediata entre os dois, pois uma mesma frase, mesmo com uma mesma estrutura sintática, pode conter sentidos diferentes se tivermos em conta as causas de sua produção, ou seja, o motivo ou a intenção que define a direção do pensamento.

De tudo posto, ainda nos resta compreender o pensamento em sua união com a linguagem, já que:

\begin{abstract}
A união do pensamento com a linguagem redimensiona todas as funções psicológicas, fazendo-as passar para o domínio do próprio indivíduo [...] A linguagem, para Vygotski, e sua ligação com o pensamento alteram inclusive a forma do conteúdo da imaginação, dos sentidos e da vontade. (TULESKI, 2008, p.147)
\end{abstract}

Dada a importância da relação entre o pensamento e a linguagem para o desenvolvimento humano, de acordo com a teoria interacionista de Vigotski (2009), trataremos dessa questão na seção a seguir. Para isso, como veremos, utilizaremos algumas considerações de Saussure (2002) e de Bronckart (2010) sobre a questão.

Para Vigotski (2009, pág.130), a junção do pensamento com a linguagem aparece mais ou menos na idade de dois anos, sendo que, nesse momento ocorre a etapa mais importante do desenvolvimento do pensamento, pois "[as crianças] despertam a consciência obscura do significado da linguagem e a vontade de dominá-lo, sendo nessa época que a criança faz a maior descoberta de sua vida, a de que cada coisa tem o seu nome" (VIGOTSKI, 2009). Ao perguntar "Como isso se chama?" a criança mostra uma necessidade da palavra e procura ativamente assimilar o signo pertencente ao objeto, signo esse que lhe serve para nomear e comunicar, o que permite à criança, descobrir a função simbólica da linguagem.

Para estudar a relação entre linguagem e pensamento, Vigotski (2009) escolheu o significado $^{10}$ da palavra como a unidade que reflete a unidade do pensamento e da

\footnotetext{
${ }^{10}$ Vigotski (2009) usa o termo "generalização da palavra" como sinônimo de "significado da palavra".
} 
linguagem. O significado é tanto um fenômeno do discurso, quanto o ato mais autêntico do pensamento:

Assim, o significado da palavra é, ao mesmo tempo, um fenômeno do
discurso e intelectual, mas isto não significa a sua filiação puramente
externa de dois campos da vida psíquica. O significado da palavra só é
um fenômeno de pensamento na medida em que o pensamento está
relacionado à palavra e nela materializado, e vice-versa: é um
fenômeno de discurso apenas na medida em que o discurso está
vinculado ao pensamento e focalizado por sua luz. É um fenômeno do
pensamento discursivo ou da palavra consciente, é a unidade da
palavra com o pensamento (VIGOTSKI, 2009).

O que grifamos acima é uma das teses mais importantes da teoria do desenvolvimento de Vigotski (2009). No entanto, para o psicólogo russo, o mais importante das suas pesquisas foi a descoberta de que o significado das palavras se desenvolve, sendo esta uma condição necessária de toda palavra. $\mathrm{O}$ vínculo associativo entre a palavra e o significado pode sofrer várias mudanças, como a expansão ou restrição do significado. Assim, o desenvolvimento histórico da palavra modificava o seu conteúdo concreto e o seu próprio caráter da representação e da generalização da realidade (VIGOTSKI, 2009).

Sobre o desenvolvimento histórico do signo, Saussure também entende que ele tem uma referência na mente humana (significante) e outra na sociedade (significado). Para Saussure (2002, p.249), a palavra não é estabelecida pela relação entre ideia e som, pois o valor da palavra não está nessa relação e seria ilusão dizer que a ideia que se liga a uma palavra está representada nas unidades da língua. Nesse mesmo sentido, Bronckart (2010) entende que o signo, tal como concebido por Saussure, revela uma propriedade radical que eles têm, ou seja, das cristalizações psíquicas de unidades da interação social e sua interiorização, geradora da socialização do psiquismo. No mesmo modo, segundo Bronckart (2010), essa propriedade da palavra constitui a propriedade primeira do funcionamento psicológico humano.

O desenvolvimento do psiquismo é socialogizado e assim interiorizado pelo indivíduo, sendo essa a propriedade primeira do funcionamento psicológico humano. Por exemplo, ao se apropriar de uma língua é iniciado um processo de valoração dos signos linguísticos, de modo que cada um terá um valor particular de uso atribuído por uma certa comunidade linguística (VIGOTSKI, 2009). Segundo Vigotski (2009, p.12), uma língua, 
para ser comunicável, deve ser inserida em um acordo tácito pela sociedade. Esse "acordo tácito", para Saussure (2002), pode ser explicado da seguinte forma:

Seja qual for a sua natureza mais particular, a língua, como os outros tipos de signos, é, antes de tudo, um sistema de valores, e é isso que estabelece seu lugar no fenômeno. Com efeito, toda a espécie de valor, mesmo usando elementos muito diferentes, só se baseia no meio social e na força social. É a coletividade que cria o valor, o que significa que ele não exista antes e fora dela, nem em seus elementos decompostos e nem nos indivíduos.

Como podemos perceber há várias semelhanças entre os escritos de Vigotski e Saussure, na medida em que eles colocam em evidência o papel do "social" na constituição da palavra, tendo ela também um correlato no psíquico, uma imagem mental. $\mathrm{Na}$ relação entre o uso da palavra e o correlato psíquico podem ser produzidos tanto conceitos cotidianos quanto conceito científico, sobre os quais discorreremos a seguir.

\subsection{Conceitos cotidianos e conceitos científicos}

Ao eleger a palavra como a unidade de análise da relação entre o pensamento e a linguagem, como já indicamos, Vigotski (2009) diferencia o conceito cotidiano do conceito científico.

De acordo com o autor (Vigotski, 2009), os conceitos cotidianos são aqueles que utilizamos nas nossas atividades práticas e nas interações sociais imediatas, nas quais não há um pensamento com grau elevado de generalização. Em contrapartida, se utilizado em uma atividade cujas práticas são mais complexas no nível do pensamento abstrato, o conceito ganha um grau maior de generalização, pois catalisa índices de significação mais específicos, como ocorre, por exemplo, nas práticas da esfera científica cujas interações se estruturam em torno, não de conceitos cotidianos, mas de conceitos científicos. Esses conceitos não se restringem somente à esfera científica, mas em outras atividades como na esfera política ou econômica. Nas eleições presidenciais de 2014, por exemplo, a alta inflação da economia do país fez com que os eleitores usassem esse termo demasiadamente nas redes sociais. Na maioria das vezes, a palavra "inflação" foi tida 
como um conceito cotidiano, pois, se tratado como um conceito científico, o uso do termo demandaria uma discussão dentro das práticas econômicas, nas quais deveriam ser considerados índices de generalização como: a relação entre o consumo e oferta do setor industrial, a produtividade das indústrias, a taxa de emprego da população, a política fiscal assumida pelo governo, a infra-estrutura oferecida pelo governo e o nível de qualificação dos empregos, entre outros.

No entanto, posto que a finalidade da esfera científica é a produção do conhecimento, os conceitos científicos fazem parte das várias práticas próprias a essa esfera. Caso tenhamos em conta o campo de saber da filosofia, por exemplo, podemos encontrar em um mesmo conceito como o de "Ética" significações totalmente diferentes a depender da abordagem escolhida. No campo dos saberes da área de Letras e Linguística também podemos citar exemplos nesse sentido, como o conceito de "gêneros textuais", que pode variar dependendo da perspectiva adotada, seja interacionista (Bronckart, 1999; Volochinov,1929) ou sóciorretórica (Swales, 1990), entre outras possíveis.

Nessas situações mais formais, onde há a discussão ou produção dos conceitos científicos (esfera científica), os valores desses conceitos não são apropriados de forma espontânea, mas devem ser transmitidos em situações formais de ensino-aprendizagem (FRIEDRICH, 2013, p. 99). Diferentemente dos conceitos cotidianos, que se originam de um confronto espontâneo com uma situação concreta, os conceitos científicos envolvem, desde o início de sua origem, uma atitude mediada em relação ao seu objeto (OLIVEIRA, 1992, p.31).

Justamente pelo fato de os conceitos científicos não estabelecerem uma relação direta com o mundo, eles são, segundo Friedrich (2013), generalizações de segunda ordem, pois sempre se realizam por intermédio de outro conceito, logo eles são "generalizações das generalizações". Disso depreendem-se duas ideias: 1) os conceitos científicos sempre se apóiam nos conceitos cotidianos, não podendo ser originados sem eles; 2) um conceito científico existe sempre no interior de um sistema de conceitos. Ilustrando o que dissemos, vejamos o esquema abaixo, proposto porFriedrich (2013, p.100):

\section{Conceito científico $\square$ Conceito cotidiano $\square$ mundo}


Figura 6: Relação entre o conceito cotidiano e científico

As duas ideias acima mencionadas podem ser compreendidas da seguinte forma:

1) Se os conceitos científicos pudessem ser originados sem a mediação dos conceitos cotidianos, seria perdido o primado monista da teoria histórico-cultural de Vigotski, que afirma que há uma relação em paralelo entre os fenômenos psíquicos (as ideias) e os fenômenos físicos (corpos e objetos). Por isso, um conceito científico sempre será mediado pelo conhecimento advindo da experiência prática imediata e, decorrente dela, outras relações serão estabelecidas para a formação de um conceito científico.

2) Os conceitos científicos sempre estão incluídos em um sistema de interrelações que, inevitavelmente, pressupõem a relação com outros conceitos científicos, com os quais compartilham algumas dessas relações. Exemplificando essa afirmação, é possível mencionarmos as teorias científicas, como, por exemplo, a teoria do Interacionismo sociodiscursivo. O conceito de "gêneros textuais" não pode ser completamente entendido nessa vertente teórica sem termos em conta o conceito de "atividade de linguagem" e, por conseguinte, o conceito de "atividade humana" do interacionismo social (LEONTIEV, 2012). Portanto, um conceito científico só pode ser compreendido dentro do sistema conceitual do qual ele faz parte.

A formação dos conceitos científicos é uma função psicológica superior conquistada pelo gênero humano possibilitada, sobretudo, pelo uso da linguagem. Assim, a palavra ocupa um papel decisivo na formação do verdadeiro conceito, pois:

É precisamente com ele que a criança [e também no adulto] orienta arbitrariamente a sua atenção para determinados atributos, com a palavra ela os sintetiza, simboliza o conceito abstrato e opera com ele como lei suprema entre todas aquelas criadas pelo pensamento humano (VIGOTSKI, 2009, p.226).

O conceito científico possui um nível de complexidade maior, já que denota uma generalização e abstração maior da realidade, logo uma relação mais "sofisticada" entre o pensamento e a linguagem. 
Durante toda essa primeira seção, mostramos as considerações metodológicas definidas por Vigotski e seu grupo, a fim de mostrar a especificidade do humano na criação de instrumentos e alguns aspectos para a compreensão do pensamento, bem como a apropriação das funções psicológicas superiores, entre elas a formação do conceito cotidiano e científico na relação entre pensamento e da linguagem e a função desta como instrumento nesse processo. Todavia, cabe lembrar que Vigotski foi um estudioso, sobretudo da área do desenvolvimento, embora seus interesses de pesquisa se espraiem em outras áreas científicas e suas teorias tenham um alcance bastante abrangente, até mesmo porque ele contestava a divisão entre as ciências humanas; no entanto, ele não era um especialista na análise textual. Desse modo, discorreremos a seguir sobre a perspectiva do Interacionismo Sociodiscursivo, a fim de compreendermos dois aspectos: i) o uso da linguagem nas práticas discursivas para a construção dos conhecimentos; ii) como a apropriação da linguagem se relaciona com os processos de formação.

\section{O Interacionismo sociodiscursivo}

O Interacionismo sociodiscursivo é uma vertente teórica iniciada na segunda metade do séc. XX e em continuidade até os dias de hoje que surgiu como uma atualização das questões de pesquisa iniciadas pelo Interacionismo social, corrente científica da primeira metade do séc. XX, cujo desenvolvimento ocorreu em alguns países como França, Estados Unidos, Alemanha e Rússia. Em cada um desses países onde o IS foi desenvolvido, é possível citar um pesquisador de referência como, Wallon, na França, Dewey e Mead, nos EUA, Buhler, na Alemanha. No entanto, foi sobretudo por meio dos estudiosos russos, como Vigotski, Leontiev e Luria, entre outros membros desse grupo, que o ISD retomou e atualizou a agenda de pesquisas discutidas e iniciadas por eles.

Devido a essa filiação teórica, o ISD assume, no nível epistemológico, alguns pressupostos importantes nos quais a teoria se apoia para discutir suas questões de pesquisa. Segundo Bronckart (2006), esses pressupostos são: a adesão ao monismo spinozano, do qual se entende que aquilo que existe é o resultado da matéria em constante mudança, sendo que os componentes físicos (observáveis no espaço) e psíquicos (relativos à mente e observáveis somente pelos seus efeitos), embora tendo manifestações 
diferentes, possuem a mesma natureza e, logo, relacionam-se em paralelo. Assim, a cada ponto do pensamento corresponde um ponto da extensão (do físico) e a cada ponto da extensão corresponde a um ponto do pensamento, portanto há um paralelismo psico-físico nos modos materiais compostos por esses dois atributos constitutivos dos seres humanos.

Em decorrência dessa primeira adesão epistemológica, o ISD se opõe ao cartesianismo dualista de Descartes, no qual a mente não tem relação com o componente físico, mas o controla. De acordo com Fristalon e Mewuly-Bonte (2006, p.3):

\begin{abstract}
Por sua posição monista e spinozista, Jean-Paul Bronckart se opõe a uma concepção dualista do ser humano que privilegia a concepção de um sujeito cujas propriedades cognitivas primam sobre as outras propriedades de ser humano (linguageiras, afetivas, sociais, etc.). Contestando a "preeminência do sujeito cognitivo", e se opondo ao dualismo cartesiano e a uma concepção do sujeito como ser cognitivo, Jean-Paul Bronckart contesta também o fracionamento da psicologia. Ele se inscreve também em uma dupla contestação do sujeito cognitivo e da atomização das capacidades humanas. (Tradução nossa)
\end{abstract}

Ao assumir a posição monista, o ISD rejeita o primado da Física de Newton, o qual postulava a estabilidade e a finitude dos mecanismos de organização do universo, entendendo que a Natureza possui propriedades estáveis eternas, logo "Nada se perde, nada se cria, tudo se transforma". Em contraste, o ISD defende que a história - a flecha do tempo - nos mostra uma conclusão contrária, ou seja, não há determinação tão categórica e previsível como apontava Newton (BRONCKART, 2006).

Decorrente disso, o ISD também se coloca contra o fracionamento das Ciências Humanas/Sociais por considerar que o Homem não pode ser analisado em sua complexidade se o isolarmos em um conjunto de práticas somente econômicas, ou sociais, ou linguísticas. Portanto, o ISD não adota epistemologia positivista de Comte, que previa a catalogação e separação das ciências para descrevê-las separadamente por suas leis próprias.

Pela aceitação a todos esses princípios, a corrente do Interacionismo sociodiscursivo busca a compreensão de uma Ciência do Humano, a partir da qual os seres humanos seriam compreendidos em sua complexidade, nas suas mais diversas práticas adquiridas e criadas ao longo dos anos de sua evolução, e por meio das quais, é constituído o psiquismo humano (BRONCKART, 2008). Ao nos referirmos às práticas, estamos pensando em práticas coletivas, acordadas entre os membros que as executam 
em interação. Mais especificamente, o ISD visa a mostrar o papel central da linguagem como criadora e mediadora dessas práticas quer sejam econômicas, políticas, sociais, entre outras, daí o nome Interacionismo sociodiscursivo. Nas palavras de Bronckart (2006):

A especificidade do ISD é a de postular que o problema da linguagem é absolutamente central, visando demonstrar que as práticas de linguagem situadas são instrumentos do desenvolvimento humano, tanto em relação aos conhecimentos e aos saberes quanto em relação às capacidades do agir e da identidade das pessoas.

Ao delimitar seu campo de investigação científica, o ISD assume os seguintes princípios sobre o "Gênero humano": a) diferentemente das outras espécies, a espécie humana é dotada de capacidades novas permitindo a organização de atividades coletivas mais organizadas e complexas; b) justamente pela complexidade das relações humanas, foi necessária a criação de mecanismos de cooperação por meio da emergência de atividades de linguagem, a fim de regular e avaliar as relações; c) as unidades semióticas produzidas por essa atividade de linguagem são partilhadas pela coletividade; d) a apropriação e interiorização dessas unidades semióticas são transformadoras do psiquismo individual, tornando possível a constituição dos mundos das obras e da cultura, por meio do qual ocorre a passagem do homem da ordem biológica para a ordem histórico-social (BRONCKART, 2008).

Assumindo essas quatro teses e buscando desenvolver uma Ciência do Humano, o ISD objetiva estudar as "mediações formativas" pelas quais os pré-construídos humanos são apresentados aos novos membros do grupo com a função de lhes transmitir os "adquiridos coletivos" e permitir-lhes o desenvolvimento de suas capacidades. A seguir, trataremos de forma mais detalhada os processos de formação no ISD.

\subsection{Processos formativos no ISD}

Em consequência dos pressupostos nos quais se baseia, um dos interesses de pesquisa do ISD é a análise dos processos de mediação e de formação, posto que os saberes organizados dentro das práticas humanas precisam ser apropriados pelos novos 
indivíduos que começam a executá-las, para que se tornem autônomos. Desse modo, o ISD distingue três processos de formação possíveis como objeto de análise (BRONCKART, 2008, p.114):

- Os processos de educação informal: nos quais os indivíduos integram os recém-chegados no conjunto de pré-construídos coletivos, desenvolvendo atividades conjuntas e mostrando as normas e os valores sociais, bem como os aspectos dos conhecimentos dos mundos formais, quando lhes são fornecidos comentários verbais sobre essas atividades.

- Os processos de educação formal: os processos desenvolvidos especificamente no meio escolar.

- Os processos de transação social: que se desenvolvem nas interações cotidianas entre as pessoas já dotadas de pensamento consciente, na forma de avaliações muitas vezes linguageiras, que contribuem para a manutenção das interações, mesmo que conflituosas, e para a reinterpretação que podem fazer evoluir as práticas e os conhecimentos de cada indivíduo a respeito dos pré-construídos coletivos.

Assim, dentro de cada um desses três processos de formação podem ocorrer vários "sistemas formativos", definidos por Bronckart, Bulea e Bota (2006, p.51) como:

toutes les activités (formelle ou informelle, «scolaires» ou non) visant à la transmission des acquis collectifs, c'est-à-dire les démarches d'intervention délibérée visant au développement des personnes, qui à la fois mettent à disposition de ces dernières certains aspects des préconstruits sociohistoriques («versant instruction»), et fournissent les instruments leur permettant de contribuer de manière originale á la transformation permanente de ces mêmes précontruits (versant «éducation»). ${ }^{11}$

Para o ISD, não foi somente a emergência das práticas de linguagem que causaram a "revolução da espécie humana", mas também a criação dos sistemas formativos, pois é por meio deles que a espécie encaminha aquilo que é pensado para a

\footnotetext{
${ }^{11}$ Nós qualificamos de « sistemas formativos » todas as atividades (formal ou informal, "escolar" ou não) visando à transmissão dos adquiridos coletivos, quer dizer os procedimentos de intervenção deliberados visando ao desenvolvimento das pessoas, que por sua vez colocam à disposição desses últimos certos aspectos dos pré-construídos sociohistóricos ("versão instrução"), e fornecendo os instrumentos que permitem a eles de contribuir de maneira original na transformação permanente desses mesmos pré-construídos ("versão educação").
} 
sua própria continuação, logo existe uma "intencionalidade social" para a criação de sistemas formativos, dado que eles orientam o desenvolvimento (BRONCKART, BULEA, BOTA, 2006). Nesse sentido, o ISD questiona os sistemas ditos auto-formativos, a partir dos quais o indivíduo pode exercer um controle sobre a sua própria atividade e também mensurar aquilo que será aprendido ou não, ou seja, controlar as relações cognitivas. Por conseguinte, aceitar os sistemas formativos "auto" é rejeitar o papel dos pré-construídos criados pelas coletividades ao longo da história, além de excluir o papel central das práticas de linguagem no processo de formação e na relação com o pensamento.

Diferentemente do que postulam as abordagens cognitivistas a respeito dos sistemas de formação, as quais defendem que os níveis cognitivos explicam as capacidades de aprendizagem e das capacidades sociais, linguageiras e afetivas, o ISD defende o papel preponderante da linguagem nesses processos, entendendo que: i) é pela interiorização das quatro propriedades dos signos da linguagem postuladas por Saussure (seu caráter imotivado, radicalmente arbitrário, discreto e ativo) que a construção das unidades representativas do psiquismo humano se torna possível; ii) é a interiorização das relações predicativas entre as frases que articula as unidades representativas em um sistema de pensamento; iii) é a apropriação dos tipos de discurso (sobre os quais discorremos mais à frente) que permite o desenvolvimento dos diferentes tipos de raciocínios: do senso prático, os causais-temporais, e os raciocínios lógicos ou semi-lógicos (BRONCKART, BULEA, BOTA, 2006).

Por meio dos sistemas formativos, a consciência humana se torna, além de histórico-cultural, também semiótica.Segundo Bronckart (2003, p. 56), o ISD entende que a consciência e as funções psíquicas superiores do homem (sobretudo o pensamento e a linguagem) são o produto da apropriação e, posteriormente, da interiorização das propriedades das diferentes formações sociais nas quais todo ser humano se encontra necessariamente inserido. Esse processo de interiorização, por sua vez, realiza-se no quadro estrutural que constitui a ação humana e por um meio, que é o das produções semióticas, sejam os textos verbais orais ou escritos. 


\subsection{A linguagem como objeto de estudo no ISD}

Até aqui, podemos perceber claramente a importância dada pelo ISD ao papel preponderante da linguagem nas práticas humanas.

Desse modo, para se realizar uma pesquisa que tome o ISD como base teórica, é preciso situar o estudo dentro do percurso investigativo da teoria, especialmente na abordagem dada ao conceito e papel da linguagem. Justamente por isso, nos deteremos mais nessa questão nas próximas seções, buscando compreender de forma mais clara a discussão da linguagem no desenvolvimento e na sua relação com o pensamento humano na perspectiva do ISD. Além disso, trataremos da proposta metodológica do ISD na construção de um modelo de análise textual e discursiva das produções de linguagem situadas.

\subsection{Os gêneros textuais no ISD}

Dentro de cada formação social, há textos (orais ou escritos), que são os correspondes empíricos de uma ação de linguagem e são produzidos com os recursos de uma língua natural. Sendo produtos de uma ação linguageira, as características composicionais dos textos dependem das propriedades das situações de interação, da atividade que os gerou e também das condições sócio-históricas de sua produção (BRONCKART, 2008, p.113). Na medida em que cada texto se inscreve em um conjunto de textos, ele pertence a um gênero textual.

Dito de outra forma, os gêneros textuais no ISD são considerados os produtos empíricos da ação de linguagem mediada por uma língua natural. Isso não quer dizer que, para o ISD, as estruturas linguísticas sejam a verdadeira expressão do pensamento consciente (intenções, razões e fins para agir), mas, seguindo uma corrente filosófica que remonta a Humboldt, Saussure e Volochinov, a linguagem é uma forma de agir no mundo.

Para compreendermos melhor a noção de gêneros textuais na perspectiva do Interacionismo sociodiscursivo é necessário, antes de tudo, definir o conceito de texto tal como entendido por esta vertente teórica.

O texto é uma unidade comunicativa, produto empírico de uma atividade de linguagem, por isso todo o texto tem uma motivação para a sua produção. Além do uso 
comunicativo que fazemos da linguagem, a utilização da faculdade de linguagem também é pragmática, no sentido de sempre estabelecer relação com a situação de produção na qual o texto será produzido (BRONCKART, 1999). Corroborando com essa questão, para o ISD, o texto é considerado a materialização de uma ação de linguagem constituída por determinadas operações que já existem historicamente no ambiente sociossemiótico, e o ser humano, no seu desenvolvimento, no decorrer da história, apropria-se delas. (LOUSADA; BARRICELLI; OLIVEIRA, 2011)

$\mathrm{Na}$ verdade, não temos acesso à atividade de linguagem, senão através das práticas verbais pelas quais podemos compreendê-la, ou seja, os textos convencionalizados para as várias situações de comunicação (BRONCKART, 1999)

Para o ISD, na medida em que cada texto tem características particulares, eles pertencem a um gênero textual, que não esgota de forma alguma o estilo particular de cada texto, visto que este é resultado de uma ação de linguagem em uma situação de comunicação determinada (LOUSADA, ROCHA, 2014).

Os gêneros textuais, posto que são resultados da atividade humana, são de número infinito e por isso não são fáceis de serem classificados, tanto que Bronckart (1999) os define como uma nebulosa, na qual a exata identificação dos gêneros é impossível de se obter. Muitos estudiosos já procederam a uma divisão de gêneros, desde Aristóteles como os gêneros do discurso judiciário, epidítico e demonstrativo; os gêneros épico, lírico e dramático de Diomedes a Goethe; as tipologias textuais de Vietor e Petitjean. Para Bronckart (2003, p.51), as diversas nomenclaturas de "gêneros", "tipos" e ainda "modo" definem vários critérios de separação, o que gera classificações muito diferentes.

$\mathrm{Na}$ perspectiva do ISD, os gêneros textuais se modificam na medida em que as práticas humanas sofrem mudanças. Apropriar-se dos gêneros textuais, portanto, é dominar as práticas humanas numa determinada esfera e participando de forma consciente das interações sociais. A aprendizagem dos gêneros é uma forma de socialização do indivíduo, que se torna um ser social, uma vez que poderá participar de forma eficaz das atividades humanas (MACHADO, 2005).

Nesse sentido, podemos entender o modo pelo qual o ISD entende o desenvolvimento humano por meio da aprendizagem dos gêneros textuais, que permitem ao indivíduo a participação efetiva nas interações sociais. Ao tratar dessa questão, Bronckart (2006) designa como uma aprendizagem social a apropriação dos gêneros 
textuais pelos indivíduos, entendendo os gêneros como instrumentos (no sentido vigotskiano) para o desenvolvimento.

No sentido de que todo texto envolve a mobilização de operações relativas ao contexto de produção e as aspectos linguístico-discursivos (DOLZ, GAGNON, VUILET, 2011), o domínio dessas operações por parte dos alunos na produção textual, permite-lhe o desenvolvimento de capacidades transferíveis para outros gêneros textuais (LOUSADA; BARRICELLI; OLIVEIRA, 2011).

Apropriando-se dessas operações, que compreendem o domínio contextual e linguístico-discursivo de um texto, aprende-se a gerenciar as indexações sociais de que cada gênero é portador, o que lhes permite o entendimento da rede de significações cristalizadas nos modelos preexistentes. A noção de indexação significa que o conhecimento de um gênero textual, no sentido dado pelo ISD, não se limita ao conhecimento das características linguísticas dos textos, mas também da situação de atividade de linguagem em que ele pode ser utilizado (indexação referencial), o tipo de mídia na qual ele pode ser produzido (indexação comunicacional) e o valor social atribuído ao gênero textual, ou seja, o seu "grau de nobreza” (BRONCKART, 2011).

Nas práticas da esfera científica, é necessária a compreensão da indexação referencial dos textos, pois uma pesquisa científica deve ser planejada, relatada, sintetizada e apresentada oralmente. Dessa forma, podemos dizer que a prática científica mobiliza diversos textos como, por exemplo, o artigo científico e as resenhas, entre outros. No entanto, os alunos futuros pesquisadores inscritos no Programa de Iniciação Científica da USP devem produzir alguns gêneros textuais específicos para o cumprimento dos requisitos exigidos pela Comissão de Pesquisa da Faculdade de Letras. Assim, é por meio desse percurso de práticas de linguagem que o estudante tem acesso à atividade de fazer uma pesquisa científica.

Em outras palavras, considerando a IC como uma prática particular dentro do meio universitário, na qual há uma atividade científica específica, a saber, desenvolver pela primeira vez um estudo científico, deve-se observar que algumas ações de linguagem são essenciais para a realização da pesquisa (LOUSADA; SANTOS, 2014). Primeiramente, o estudante precisará escrever um projeto com resumo. Posteriormente, ele deverá relatar o desenvolvimento de seu projeto, mostrando seus dados já obtidos, logo, ele necessitará apresentar um relatório. Finalmente, esse aluno precisará apresentar 
os seus resultados de pesquisa à comunidade científica, devendo elaborar uma apresentação oral.

Como dissemos, as práticas de linguagem são moldadas por um determinado gênero textual, mas não somente por ele, pois as características linguísticas de um texto não permitem compreender o seu verdadeiro sentido na atividade comunicativa. Os aspectos linguístico-textuais também atribuem significação ao texto, logo se faz necessário um método a partir do qual seja possível realizar a descrição linguística que será articulada com outros aspectos do enunciado dos quais podemos compreender melhor o tema em questão. Nesse sentido, o ISD, após muitas pesquisas, elaborou um método de análise textual que será explicado a seguir.

\subsubsection{O modelo de análise do ISD}

O método de análise do ISD tem como primeira preocupação o levantamento das questões contextuais nas quais a ação de linguagem está sendo efetuada. Para isso, analisa-se a esfera da atividade humana e o contexto social mais amplo e específico, demarcando quais os papéis sociais do enunciador e do destinatário da ação de linguagem, além do local social da interação e de seu objetivo. Apenas após essa reflexão, parte-se para análise propriamente textual, desde a macroestrutura até a microestrutura do texto.

Nessa perspectiva, o produtor de um texto deve tomar decisões na execução da

produção textual, pensando em estratégias para melhor desempenhar a ação comunicativa de linguagem pretendida. Primeiramente, o produtor do texto deverá ter em vista o quadro contextual, devendo refletir na situação de ação de linguagem em que ele está inscrito, no contexto de produção e no conjunto de informações, conhecimentos que quer apresentar, ou seja, o "assunto" que o agente produtor quer produzir. Depois, analisa-se a macroestrutura textual por meio da descrição do plano global do global dos conteúdos temáticos do texto, os tipos de discurso e as sequências textuais. Esses três elementos de análise fazem parte da infraestrutura do texto. Em seguida, analisamos a microestrutura do texto por meio dos mecanismos de textualização e os mecanismos enunciativos. É para a explanação desses diferentes níveis de análise que se voltam as próximas seções. 


\subsubsection{O contexto de produção}

O método de análise do ISD tem como primeira preocupação o levantamento das questões contextuais nas quais a ação de linguagem está sendo efetuada. Para isso, analisa-se a esfera da atividade humana e o contexto social mais amplo e específico, demarcando quais os papéis sociais do enunciador e do destinatário da ação de linguagem. Para Bronckart (1999), em uma situação de linguagem, deve-se levar em conta as propriedades dos mundos formais (tais como propostos por Habermas, 1987: físico, social e subjetivo) que exercem influência sobre a produção textual. Os mundos são representações sociais que são percebidas por um conjunto de indivíduos ou por um indivíduo particular. Assim, o produtor do texto deverá mobilizar algumas representações sobre esses mundos em dois parâmetros: o contexto de produção e o conteúdo temático do texto que ele quer produzir. Ao pensar sobre o contexto de produção, o agente produtor refletirá sobre o mundo físico de produção, compreendido pelo:

a) lugar físico de produção, ou seja, o local onde o texto é produzido;

b) momento de produção, ou a duração temporal na qual o texto foi escrito;

c) emissor, ou a pessoa que fisicamente produziu o texto;

d) receptor, ou a pessoa que fisicamente recebe o texto.

Além das reflexões acerca do mundo físico, o produtor deverá também refletir sobre o mundo social e subjetivo, portanto, sobre o contexto sociossubjetivo, entendido da seguinte forma:

a) lugar social: em que ambiente de interação o texto é produzido;

b) posição social do produtor: o papel social desempenhado na interação (professor, jornalista, patrão), que lhe dá o estatuto de enunciador;

c) posição social do receptor, que lhe dá o estatuto de destinatário;

d) objetivo da interação.

Em seguida, o agente produtor do texto, a partir do seu conhecimento pessoal (e parcial), escolherá um modelo de gênero textual que mais se adapte à situação de 
comunicação em que está inserido, devendo escolhê-lo não somente pelas suas características linguísticas, mas também pelas etiquetagens sociais que possuem, ou seja, as indexações sociais atribuídas a ele.

Primeiramente, o produtor do texto deverá ter em vista o quadro contextual (acima descrito), ou seja, ele deverá refletir sobre a situação de ação de linguagem em que ele está inscrito, no contexto de produção e no "assunto", isto é, o conteúdo temático que o agente produtor quer produzir, de acordo com os parâmetros dos mundos físico e sociossubjetivo. Após essa primeira reflexão, o produtor do texto deve escolher um gênero textual para, a seguir, articular o plano geral do texto, os tipos de discurso que serão organizados através das sequências e/ou outros tipos de planificação (BRONCKART, 1999). A reflexão sobre cotexto, que compreende o quadro das escolhas referentes aos tipos de discurso e às sequências textuais, é chamado por Bronckart (1999, p.119) de infraestrutura geral de um texto, formando, segundo o autor, juntamente com os mecanismos de textualização e os mecanismos enunciativos, a arquitetura textual, isto é, três camadas superpostas que configuram a organização dos textos. A infraestrutura textual é composta pelo plano global dos conteúdos temáticos, tipos de discurso e sequências. Já os mecanismos de textualização englobam a coesão verbal, nominal e as conexões. Finalmente, os mecanismos enunciativos compreendem as vozes e as modalizações.

Nas próximas seções, apresentaremos os níveis de análise da arquitetura textual, ilustrando-os com exemplos.

\subsubsection{A infra-estrutura textual: o plano global dos conteúdos temáticos}

O plano global dos conteúdos temáticos pode ser definido como a organização dos conteúdos que se tornam visíveis no processo de leitura e que podem ser codificados em um resumo (BRONCKART, 1999, p. 120).

Para exemplificarmos a análise do plano do global do conteúdo temático, vamos utilizar a descrição dos quatro gêneros textuais (projeto de pesquisa, seguido do resumo, do relatório de pesquisa e da apresentação oral de pesquisa) que os estudantes de Iniciação Científica, participantes da nossa pesquisa, têm que produzir no âmbito do 
processo de pesquisa. Para isso, descreveremos primeiramente os aspectos mais importantes de cada gênero, como seu espaço de circulação e de produção, bem como apontamentos sobre seu contexto de produção; em seguida, utilizaremos estudos de pesquisadores que trabalham com gêneros textuais da esfera científica/acadêmica para apresentar os planos globais dos conteúdos temáticos de cada gênero.

\subsection{Projeto de pesquisa}

Como justifica Leitão (2012, p.18), o gênero textual projeto de pesquisa é de grande importância no âmbito acadêmico, pois, além de ser exigido em processos seletivos de Pós-graduação, como Doutorado, Mestrado e, em alguns casos, Especialização, o projeto de pesquisa vem adquirindo grande importância, também, no ambiente escolar, por ser um instrumento de ensino e aprendizagem. Bem como esses usos, o projeto de pesquisa é, geralmente, o primeiro gênero textual da esfera científica em que o aluno graduando realiza Iniciação Científica tem contato. Em um estudo sobre as primeiras versões de projetos de pesquisa redigidos por estudantes de Iniciação Científica, verificamos (LOUSADA; SANTOS, 2014) que esses textos deixam entrever as motivações dos alunos para a proposição do projeto, atreladas a uma dificuldade encontrada em meio universitário ou em um interesse despertado pelas disciplinas curriculares do curso de graduação no qual estão inscritos. Trata-se, portanto, do que chamamos de motivações próprias da "esfera universitária".

Desse modo, estamos compreendendo a esfera universitária como um conjunto de práticas executadas pelos estudantes universitários no âmbito da graduação, como aprender os conceitos das disciplinas curriculares do curso, produzir trabalhos finais de disciplinas, fichamentos, por exemplo. Por outro lado, entendemos a esfera científica (ou acadêmica) como os conjuntos das práticas que envolvem a produção e divulgação de saberes por meio dos gêneros textuais próprios dessa esfera, tais como: resumo para congresso, projeto de pesquisa, relatório de pesquisa, apresentação oral, dissertação, tese, artigo científico, entre outros.

No mesmo estudo, observamos (LOUSADA; SANTOS, 2014) que os estudantes, no momento em que se propõem a realizar a IC, não conhecem o gênero textual projeto de 
pesquisa, já que, em nossas análises, constatamos que muitas partes que compõem esse gênero foram esquecidas ou desenvolvidas de forma inadequada.

Para apresentar e ilustrar o plano global do conteúdo temático do gênero textual projeto de pesquisa, utilizamos os estudos de Machado, Lousada, Abreu-Tardelli (2005) e Motta-Roth, Hendges (2010). Segundo os dois estudos citados, o projeto de pesquisa deve conter as seguintes partes:

- Identificação ou dados do projeto: nessa seção os dados mais importantes são o título da pesquisa (que deve expressar com precisão o tema ou problema que o projeto se ocupa); área de pesquisa; autor e orientador; instituição.

- Problemas, hipóteses e perguntas: apresentação do problema de pesquisa ou a pergunta à qual o pesquisador quer responder.

- Justificativa: aqui se deve mostrar a relevância e originalidade do projeto, ressaltando sua inovação. Essa seção é altamente argumentativa, pois tem de levar o leitor a ficar convencido da importância da pesquisa (MOTTA-ROTH, HENDGES, 2010, p.56).

- Objetivo geral e objetivo específico: de acordo com Machado, Lousada, Abreu-Tardelli (2005, p.84), o objeto que será tratado deve ser explicitado logo no início da introdução, sendo acompanhado de um relato dos percursos seguidos para a delimitação do assunto. O objetivo geral é o que se espera vir a conseguir com a realização da pesquisa. O objetivo específico esclarece o conteúdo do objetivo geral, sendo expresso por itens separados ( $a$ e $b$, por exemplo).

- Síntese da literatura relevante: apresentar uma síntese dos textos lidos, mostrando os conceitos centrais relevantes para a pesquisa. Para Motta-Roth, Hendges $(2010$, p.57) a pesquisa científica é um trabalho comunitário de uma dada comunidade científica com seus objetos de estudo, raciocínios, ferramental teórico.

- Metodologia: explicitação dos procedimentos adotados e a natureza dos dados obtidos. Além disso, há a descrição dos participantes da pesquisa e os procedimentos de coleta dos dados. 
- Resultados/impactos esperados: essa seção é uma das mais argumentativas, pois se pretende convencer o leitor de que os resultados esperados serão importantes e úteis.

- Cronograma: é a divisão temporal das etapas da pesquisa dentro do prazo de vigência do trabalho como um todo.

- Orçamento: explicitação das fontes financiadores da pesquisa, caso houver.

- Bibliografia: ao final do projeto de pesquisa, todas as referências citadas ao longo do trabalho (especialmente aquelas da seção da revisão da literatura) devem ser indicadas e listadas em ordem alfabética.

Após termos apresentado o plano global dos conteúdos temáticos dos projetos de pesquisa, passemos para o plano global dos resumos para apresentação em congresso.

\subsection{Resumo}

De acordo com Motta-Roth, Hendges (2010, p.151), o gênero textual resumo tem grande circulação nos meios científicos, pois é amplamente utilizado nos eventos, como seminários e congressos, para os quais os participantes devem enviar uma proposta de comunicação, ou seja, um texto que reúna as principais informações de um trabalho de pesquisa, sempre mais longo. A aceitação do resumo é pré-requisito para a participação em eventos e também nas ocasiões de apresentação da pesquisa. Assim, o resumo deve conter uma organização textual que convença tanto aos avaliadores desses textos para a participação nos eventos científicos, quanto aos demais participantes do evento, instigando-lhes a se interessar pelo trabalho.

Além disso, encontramos também os resumos presentes nos artigos científicos, que diferem um pouco dos resumos para congresso. De qualquer forma, os resumos são de "extrema importância", visto que é crescente o número de publicações de artigos científicos, $\operatorname{logo}$ os resumos são uma útil fonte de informação que ajudam no acesso àqueles artigos mais interessantes para os leitores. Assim, os resumos funcionam como textos importantes na divulgação científica. 
A organização textual dos resumos é semelhante a do artigo científico, porém para a produção de resumos é necessário o uso do recurso textual da sumarização. Segundo Machado (2005, p. 140), a sumarização é uma redução de informação semântica, na qual são retidos somente os dados básicos de um texto, em que alguns são apagados ou substituídos por meio de generalizações (o produtor do texto reúne várias informações por meio de uma nominalização geral) e novas construções (pressupostas no texto resumido). Desse modo, o resumo é composto pela seguinte organização esquemática (MOTTA-ROTH, HENDGES, 2010, p.155):

- Situar a pesquisa: por meio da contra-argumentação de pesquisas prévias, indicando as lacunas desses trabalhos.

- Apresentar a pesquisa: apresentação dos principais objetivos e levantamento hipóteses.

- Descrever a metodologia: descrição tanto do método de análise quanto do método de coleta dos dados.

- Sumarizar os resultados: sintetizar os principais resultados aos quais a pesquisa chegou.

- Discutir a pesquisa: elaboração conclusões, recomendação de futuras aplicações.

Vejamos, agora, o plano global dos conteúdos temáticos do gênero apresentação oral de pesquisa:

\subsection{Apresentação oral de pesquisa}

O gênero textual apresentação oral de pesquisa muitas vezes não é privilegiado nos estudos científicos sobre as práticas de linguagem na universidade, visto que há, em maior escala, trabalhos a respeito da escrita em meio universitário, como projetos de pesquisas, resumos e artigos científicos; em comparação a esses trabalhos poucas são as 
pesquisas que têm as práticas científicas orais como foco. Quando trabalhados, os gêneros textuais orais não são entendidos como tal e por isso não são considerados por meio de suas características específicas (LOUSADA, ROCHA, GUIMARÃES-SANTOS, 2015). No caso da prática da Iniciação Científica, o gênero textual apresentação oral deve ser apropriado pelos estudantes muitas vezes de forma prescritiva a partir do momento que iniciam suas primeiras pesquisas científicas, por isso ele deve estudado dentro desse contexto específico.

Ao estudar a situação comunicativa de uso do seminário escolar, Chaves (2008, p.73) a compara com um triângulo escaleno em que há três interlocutores com participações diferentes que são o auditório, o qual acompanhará a exposição realizada, buscando aprender um conteúdo novo, o expositor, aquele irá transmitir informações a esse público, buscando explicar o seu objeto de explanação e, por fim, o professor, que tem a função de avaliar a explanação do conteúdo, posto que, nessa situação de comunicação, ele quem detém o maior conhecimento. Assim, tendo consciência dessa assimetria situacional, o expositor não pode perder de vista os interlocutores que avaliarão a performance oral realizada, mostrando um domínio do objeto exposto.

No caso do gênero textual apresentação oral de pesquisa em nosso contexto de estudo, também podemos usar a mesma comparação, pois há três interlocutores envolvidos na atividade de linguagem: a estudante/pesquisadora em IC; pesquisadores experientes (seja o orientador como ouvinte participando do debate, seja implicitamente pela orientação realizada e também do professor universitário que comenta a apresentação) e, também, os ouvintes.

Os apontamentos de Chaves (2008) encaixam-se na situação comunicativa proposta por Dolz et al (2004) em suas pesquisas sobre o gênero textual apresentação oral. Segundo os autores, essa situação comunicativa apresenta três dimensões que devem ser consideradas ao se tratar da exposição oral, sendo elas a situação comunicativa, a situação da organização interna da exposição, a situação das características linguísticas. Na situação comunicativa, além das características já elencadas, Dolz et al (2004) nomeiam o expositor como um "especialista” no assunto, o qual é detentor de um conhecimento específico maior do que o público, porém não maior do que o domínio que o avaliador tem do assunto exposto. De todo modo, o papel de especialista garante ao 
expositor uma autoridade perante o auditório, quando este transmite uma sensação de segurança daquilo que está sendo explanado.

O momento de investidura do papel de especialista por parte do expositor acontece na primeira etapa do processo de produção de uma apresentação oral, o chamado momento "pré-expositivo", dividido em dois outros momentos: a preparação do conteúdo e o planejamento/organização da exposição oral. A segunda etapa é aquela da "exposição propriamente dita"; já a terceira é a chamada etapa "pós-expositiva", na qual ocorrerá a avaliação do foi exposto tanto por parte dos professores/mediador/avaliador quanto do público ouvinte, além das contra-argumentações dos expositores às perguntas formuladas.

É na fase pré-expositiva que a apresentação oral será planejada e o conteúdo a ser exposto ganhará uma coerência por meio de pesquisas nas fontes pertinentes. Nesse momento, portanto, ocorrerá o levantamento das referências bibliográficas da exposição oral. Após esse momento, uma hierarquização das informações recolhidas será necessária, haja vista a necessidade do estabelecimento de uma coerência para a exposição, que garantirá a sua clareza. Depois, é possível elaborar um roteiro da apresentação oral. O próximo passo é a ordenação das partes da exposição que, de acordo com Dolz et al (2004), tem as seguintes fases:

- Abertura: fase em que o expositor assumirá o seu papel de especialista e terá direito ao turno de fala, ao contrário do público que passará a escutar a exposição não podendo tomar a palavras por vontade própria. A fase de abertura pode ser gerida por alguém que organizará esses papéis, podendo ser o professor/mediador.

- Introdução ao tema: apresentação e delimitação do conteúdo referencial (o objetivo) a ser veiculado durante o seminário.

- Apresentação do plano da exposição: os passos da apresentação serão explicitados ao auditório que terá um roteiro do assunto do seminário;

- Desenvolvimento do tema: o expositor deve gerir de forma clara a progressão do conteúdo temático, buscando marcar as passagens entre os itens expostos no roteiro, além de marcar, linguisticamente, a mudança de turno entre os membros do grupo, caso haja mais de um expositor. 
- Recapitulação e síntese: retomada dos argumentos que sustentarão a conclusão, garantido o cumprimento do roteiro para o público e sinalizando o término da exposição.

- Conclusão: momento do fechamento da exposição, no qual o expositor vai apresentar sua conclusão sobre o assunto, resultado da sua pesquisa, ou vai corroborar a conclusão trazendo uma voz de autoridade a partir da qual a suas considerações têm validade. Ainda, o expositor pode fechar o assunto exposto ou deixá-lo em aberto para desenvolvimentos futuros, o que é mais recomendável.

- Encerramento: o expositor encerra a apresentação, agradecendo a atenção e abrindo o espaço para perguntas.

Passemos, a seguir, para o plano global dos conteúdos temáticos do gênero relatório final de pesquisa.

\subsection{Relatório final de pesquisa}

De acordo com Silva e Silva (2010), a dinâmica funcional do gênero textual relatório de pesquisa é bastante significativa no meio acadêmico. Geralmente, os relatórios são requisitados pelas agências financiadoras de pesquisas, a fim de regular e acompanhar as pesquisas científicas por elas financiadas. No caso dos relatórios de pesquisa parciais, eles têm a função de compartilhar o trabalho com outros estudiosos da área para que contribuam com o estudo realizado. Ambos os relatórios de pesquisa, seja parcial seja final, abrem portas para o diálogo e a troca de experiências e de conhecimento, bem como servem para a manutenção do rigor administrativo das agências de fomento.

O relatório de pesquisa tem o propósito de mostrar o processo da investigação científica, já os artigos têm a função de apresentar um conhecimento científico mais sistematizado e estabilizado; a monografia, por sua vez, tem como finalidade expor com 
maiores detalhes um objeto de pesquisa por meio das perguntas de pesquisa e as respostas encontradas a elas (SILVA, SILVA, 2010).

O gênero textual relatório de pesquisa, tendo como finalidade relatar o processo de uma pesquisa científica, é composto pelas seguintes partes (RODRIGUES, 2008):

- Introduzir o estudo

- Revisar literatura

- Descrever a metodologia

- Apresentar e discutir dados

- Concluir o relato

Após termos apresentado os gêneros necessários no processo de IC e seus respectivos planos globais, veremos, em seguida, o segundo nível de análise da infra-estrutura geral do texto.

\subsubsection{A infra-estrutura textual: Os tipos de discurso}

Considerando as muitas classificações dadas para divisão dos gêneros e analisando um grande corpus de textos para a construção do modelo de análise textual, os pesquisadores do ISD perceberam que vários gêneros textuais possuíam macro-estruturas textuais que se repetiam em um ou outro gênero, mas que eram de número finito. A partir desse momento, buscou-se verificar qual seria a relação entre essas estruturas regulares e os gêneros textuais. Para isso, Bronckart (1999) retoma os estudos de Genette (1979), obra na qual o autor francês faz uma discussão das várias classificações de gêneros já realizadas partindo da divisão aristotélica. Como conclusão desse estudo, Genette (1979) afirma que, de fato, os critérios de classificação para os gêneros são muitos diversos e heterogêneos, sendo necessários critérios mais estáveis, como os "modos" ou "atitudes de locução":

Os modos de enunciação poder ser qualificados de "forma naturais", pelo menos no sentido em que falamos de "línguas naturais": deixando-se de lado qualquer intenção literária, o usuário da língua 
deve constantemente, mesmo, ou sobretudo, se inconscientemente, escolher entre atitudes de locução, tais como discurso e história (no sentido benvenistiano), citação literal e sentido indireto etc. Os gêneros são categorias propriamente literárias, ao passo que os modos são categorias dependentes da linguística (GENETTE, 1979).

No sentido de classificar os "modos" ou "atitudes de locução", outros estudos podem ser considerados como, por exemplo, distinção entre Discurso e História de Benveniste (1976), a divisão entre mundo narrado e mundo comentado de Weinrich (1973) e os três planos enunciativos de Simonin-Grumbach (1975). Todos esses trabalhos, à guisa do que foi nomeado por Genette de "modos" ou "atitudes de locução", descreviam atitudes gerais de locução atestáveis nas línguas naturais por meio de configurações de unidades e processos linguísticos relativamente estáveis. No ISD, esses "modos" são chamados de "tipos de discurso". A noção de tipos de discurso foi construída pelo ISD a partir dos estudos já existentes desenvolvidos por Weinrich (1973) e Benveniste (1976).

Segundo Weinrich (1973), há duas possibilidades que o autor denomina como “atitudes de elocução". O enunciador pode tanto estar em uma situação de tensão, na qual ele e seu enunciatário estão engajados no processo locucional, quanto pode se situar em uma situação cuja atitude é de relaxamento e distensão. Para Weinrich (1973), a primeira atitude é a criada pelo mundo comentativo e a segunda, aquela mais relaxada, deriva do mundo narrativo. De acordo com o autor:

En employant les temps commentatifs, je fais savoir à mon interlocuteur que le texte mérite de sa part une attention vigilante [Gespanntheit]. Par les temps du récit, au contraire, je l'avertis qu'une autre écoute, plus détachée [Entspannheit], est possible. C'est cette opposition entre le groupe des temps du monde raconté et celui des temps du monde commenté que je caractériserai globalement comme attitude de locution. (WEINRICH, 1973, p.30) ${ }^{12}$

\footnotetext{
${ }^{12}$ Empregando os tempos comentativos, eu faço saber a meu interlocutor que o texto merece de sua parte uma atenção vigilante. Pelos tempos do narrar, ao contrário, eu o advirto que outra atenção de escuta, mais relaxada, é possível. Esta oposição entre os grupos dos tempos do mundo narrar e aquele dos tempos do mundo do comentar que eu caracterizaria globalmente como atitude de locução.
} 
Por meio da citação acima, entendemos que o mundo comentado gera sempre uma tensão, portanto uma dramaticidade, posto que o enunciador, diante do enunciatário, espera uma reação que ele muitas vezes não sabe qual será. Assim, ao comentar, o enunciador se encontra comprometido com a situação comunicativa, o que gera a tensão, o conflito. Em oposição, o mundo do narrar cria uma situação de comunicação mais relaxada, visto que o enunciador tem o monopólio da fala e o enunciatário é um ouvinte somente, logo não se cria uma situação tensionada. Estudando os tempos verbais dos dois mundos na língua francesa, Weinrich (1973) mostrou que, no mundo comentado, os tempos encontrados foram presente do indicativo, pretérito perfeito composto e futuro do presente composto; já no mundo do narrar, os tempos verbais encontrados foram o pretérito perfeito simples do indicativo, pretérito imperfeito e futuro do pretérito.

Objetivando estudar os valores do sistema verbal no sistema da língua, Benveniste (1976, p. 262), do mesmo modo que o linguista alemão, também classificou os tempos verbais de acordo com os posicionamentos enunciativos. Sendo assim, Benveniste (1976, p.262) os separa em dois planos da enunciação: o plano da história e o plano do discurso.

No plano da história, as ações são arroladas no passado sem nenhuma intervenção do produtor da enunciação, de modo que ele fica ausente nesse processo, não dizendo em nenhum momento "eu" nem "tu" e nem "aqui" e "agora", mas usando formas que remetem à terceira pessoa do discurso, o "ele". Assim, fazem parte desse plano os tempos do passado, como o pretérito perfeito, imperfeito e mais-que-perfeito. A forma do presente pode aparecer somente contento um valor de "presente intemporal" ou o "presente de definição". O enunciador fica isento de tecer reflexões ou comparações, ficando o mais fiel possível ao seu propósito de narrador dos acontecimentos, que parecerem narrar-se a si mesmo.

Em oposição, Benveniste (1976, p.267) define o plano do discurso, no qual há a participação ativa do enunciador no processo da enunciação. Na sua essência, para o linguista francês, o plano do discurso é caracterizado por toda enunciação que suponha um locutor e um ouvinte e, no primeiro, a intenção de influenciar, de algum modo, o outro. As práticas de linguagem orais, das mais variadas formas, geralmente são constituídas pelo plano do discurso, pois exige para a sua construção a implicação do locutor na organização do conteúdo, porém o plano do discurso pode ocorrer tanto nas formas escritas quanto nas formas orais do discurso. 
No plano do discurso são utilizadas formas de primeira, segunda ou terceira pessoas verbais, além do uso de uma grande variedade de tempos verbais, e não majoritariamente os tempos do passado como no plano da história. Em síntese, Benveniste (1976, p.270) propõe a seguinte delimitação:

- Na enunciação histórica: admitem-se (em formas de terceira pessoa): o imperfeito, o mais-que-perfeito e o prospectivo; excluem-se: o presente, o perfeito, o futuro (simples e composto).

- Na enunciação de discurso: admitem-se todos os tempos em todas as formas; excluem-se o aoristo (simples e composto).

Bronckart (1999) parte desses etudos e propõe, no cruzamento das características dos dois mundos discursivos de Weinrich, do NARRAR e do EXPOR, e também das duas formas de enunciação de Benveniste, do Discurso e da História, a definição de quatro tipos de discursos: o NARRAR implicado e o NARRAR autônomo; e EXPOR implicado e o EXPOR autônomo.

Quando dizemos no ISD que o texto é IMPLICADO, estamos dizendo que ele implica os parâmetros de ação de linguagem, com referências dêiticas a esses parâmetros, integrados ao conteúdo temático, sendo que, para compreendermos este texto, devemos estudar as suas condições de produção. Quando o texto possui uma relação de independência com os parâmetros de ação de linguagem, ele é AUTÔNOMO destes parâmetros e sua compreensão não requer que saibamos suas condições de produção.

Tendo estes dois subconjuntos (NARRAR e EXPOR/ IMPLICADO e AUTÔNOMO) em vista, podemos definir os quatro tipos de discurso segundo Bronckart (1999):

\begin{tabular}{|c|c|c|c|}
\hline & & Coordenadas ge & ais dos mundos \\
\hline & & Conjunção & Disjunção \\
\hline & & EXPOR & $N A R R A R$ \\
\hline $\begin{array}{l}\text { Relação ao ato de } \\
\text { produção }\end{array}$ & Implicação & $\begin{array}{l}\text { Discurso } \\
\text { interativo }\end{array}$ & Relato interativo \\
\hline & Autonomia & Discurso teórico & Narração \\
\hline
\end{tabular}


Figura 3: Os tipos de discurso (BRONCKART, 1999)

Cada um dos tipos de discurso tem características linguísticas estáveis como mostraremos abaixo, por meiode exemplos dos nossos dados de pesquisa.

O primeiro exemplo é o do discurso interativo, como vemos abaixo:

\section{Discurso interativo (Mundo do EXPOR implicado):}

Mediadora: Você poderia explicar como você procede para isso...como você....ahn....ahn...fez então...como você procedeu para chegar ao que você...enfim.

Apresentadora: Nos comentários?

Mediadora: Nos seus próprios comentários.

Apresentadora: Éh...éh...sobretudo depois da leitura teórica sobretudo do Chevrel...que ele foca bastante na recepção de literatura...na França...eu me lembro que no texto ele coloca alguma perguntas pra pautar a recepção dessa literatura...então era..."Em que contexto o texto foi publicado?"...éh:......"Quando foi publicado?...”'Em que editora foi publicado?"...então...então todas...todo o contexto em que se publicou essa tradução...foi mais ou menos o que me baseou para realizar os comentários...que são bem...não são comentários profundos...foi...foram comentários breves sobre aquilo que a gente conseguiu levantar...eh foi um pouco baseado nessas perguntas...em que contexto...em que editora foi publicado...em que época...não sei se eu respondi a pergunta.

O efeito do discurso interativo é a criação de um diálogo com trocas de turnos conversacionais entre dois participantes ou mais, porém também é possível que tenhamos um falar consigo mesmo. Como lemos no exemplo acima, sobretudo nos pequenos trechos sublinhados, percebemos que o assunto é co-construído na situação em que os falantes se encontram, por isso é sempre uma situação que tende ao não-planejamento; mesmo que tenhamos nos preparado e regulado toda a nossa fala, o não previsto estará presente na situação de comunicação, por isso a língua falada apresenta uma tendência ao não planejado, ou, ainda, com base nas ideias de Ochs, a língua falada é planejada localmente, isto é, constitui uma atividade de administração passa a passo (RODRIGUES, 2003, p.23). Devido à implicação dos falantes na realização do discurso, que é quase concomitante com o eixo temporal, é possível verificarmos as unidades dêiticas durante as trocas entre os interlocutores (eu, você) que remetem diretamente aos protagonistas da interação verbal, além dos marcadores próprios de uma conversação 
como as hesitações (ahn), reformulações (foi...foram comentários breves)e os termos que evidenciam a presença dos outros interlocutores na situação (gente). Ainda segundo Bronckart (1999), os tempos verbais de base para o discurso interativo sãoo presente e o pretérito perfeito, além do futuro recente.

O próximo exemplo é o do discurso teórico, como vemos abaixo:

\section{Discurso teórico (Mundo do EXPOR autônomo):}

Assim, por sua vasta aplicação na didática das línguas, os gêneros textuais têm sido amplamente abordados. Dentre os trabalhos desenvolvidos na área, destacam-se os de Schneuwly \& Dolz (2004). Para ambos, todo gênero é constituído de diversos elementos que representam os objetos de ensino gradativo que devem ser aplicados pelo professor a fim de que o aprendiz desenvolva suas capacidades de linguagem e, mais que apreender uma modalidade de texto, possa expandir os novos savoir-faire para diversas realizações comunicativas que partilhem elementos constitutivos em comum. Assim, no processo de aprendizagem, faz-se necessário compreender quais conteúdos são dizíveis em determinado gênero, assim como entender qual é sua estrutura comunicativa particular, formada por um conjunto de unidades linguísticas, de sequências textuais e pelos tipos de discurso que constroem o texto.

O trecho acima faz parte da introdução de um projeto de pesquisa dos nossos dados de análise. Podemos perceber pela leitura que todo o trecho é conectado de forma lógica por meio de conectores como "Assim" e por meio de retomadas "Dentre os trabalhos desenvolvidos na área" e "Para ambos" os quais asseguram a progressão lógica das informações do texto. Diferentemente do exemplo anterior, não identificamos o produtor do texto de forma explícita no texto, ou seja, ele não está implicado no conteúdo temático que está textualizando, ao contrário, nota-se uma autonomia com relação aos parâmetros de produção do texto. Além disso, não notamos nenhuma unidade linguística referente ao tempo e o espaço de produção desse trecho, sendo que, na verdade, não precisaríamos dessas informações para compreender o conteúdo que ele transmite, logo a situação de produção neste trecho não é essencial para a sua codificação. Ademais, nos excertos de discurso teórico, de acordo com Bronckart (1999), temos os mesmos tempos verbais explorados no discurso interativo, exceto o uso do tempo futuro, presença de inúmeros organizadores lógico-argumentativos, grande número de modalizações lógicas e de anáforas nominais.

De acordo com Bronckart (1999, p.191), o discurso teórico comporta graus maiores ou menores de autonomia pelos quais é possível identificarmos a voz do autor 
empírico do texto por meio dos seus posicionamentos e interpretações acerca do conteúdo temático.

Em seguida, veremos trechos do relato interativo, extraídos das apresentações orais das três estudantes, participantes da nossa pesquisa:

\section{Relato interativo (Mundo do NARRAR implicado)}

éh...eu percebi duas coisas...primeiro que existe um mística com relação ao país tropical...o Brasil...e depois que/ existe uma relação muito direta feita constantemente com a Literatura portuguesa...por causa da relação da língua mesmo...entre outras razões [...] (Estudante 1)

Ahn...o que eu fiz, né? Não sei se deu pra ver nos slides anteriores...mas eu fiz essa experiência agora no primeiro semestre com uma turma do Centro de Língua [...] (Estudante 2)

nós verificamos que os alunos tiveram um apropriação satisfatória das capacidades esperadas...persistiram alguns problemas isolados relacionados às capacidades linguístico-discursivas..ah:....relacionados à coesão verbal e a coesão nominal...nas produções dos alunos GS e RG [...] (Estudante 3)

No excerto acima, podemos notar que o conteúdo temático é deslocado para outro tempo - tempo passado nesse caso - com objetivo de expor aos ouvintes informações sobre a pesquisa realizada. Por isso, há predominantemente o uso do tempo passado, no qual o produtor do texto se implica de forma explícita como podemos perceber nas conjugações verbais e no uso dos pronomes como "nosso", que mostram tanto a participação da estudante no processo da pesquisa quanto de sua orientadora. Segundo Bronckart (1999, p.175), o relato interativo é, em princípio monologado, podendo ser desenvolvido tanto em uma interação real ou no quadro de um gênero textual escrito como o romance, por exemplo. Esse tipo de discurso se caracteriza por explorar um sistema de tempos verbais da historia, nos termos benvenistianos, ou no tempo narrativo, de acordo com Weinrich, logo há o predomínio do pretérito perfeito, imperfeito, aos quais, às vezes, podem estar associados com pretérito mais que perfeito, com o futuro do presente e futuro do pretérito. Ademais, o relato interativo apresenta a presença de pronomes pessoais seja primeira ou de segunda pessoa do singular ou plural, uma grande quantidade de organizadores temporais, de pronomes que explicitam a implicação do agente produtor no texto, de anáforas pronominais e nominais. 
Finalmente, veremos um exemplo do tipo de discurso narração, extraído do relatório final de pesquisa da Estudante 1:

\section{Narração (Mundo do NARRAR autônomo)}

Assim, a leitura de Hans Robert Jauss e Wolfgang Iser foi essencial à introdução do tema, já que ambos são responsáveis pela noção de "estética da recepção". Além desses, incorporaram-se à nossa base teórica: Regina Zilberman e Paul Zumthor, que ajudaram na compreensão da teoria defendida por Jauss e Iser; John Milton, que garantiu a compreensão do funcionamento do mercado editorial envolvendo a tradução; e Yves Chevrel, que adicionou à teoria da recepção a ideia de "horizonte de espera

No trecho acima notamos que há um deslocamento da ação de linguagem para um outro tempo e um outro espaço autônomo com relação a situação de produção, sem a implicação da produtora do tex to no processo narrativo ao contar as ações. Assim como o relato interativo, os tempos verbais do passado são os mais explorados, além da explícita presença dos organizadores temporais e espaciais, presença de anáforas pronominais, mas também anáforas nominais por substituição lexical. Além disso, verifica-se a ausência de pronomes pessoais seja primeira ou de segunda pessoa do singular ou plural.

Os quatro tipos de discurso que explicamos acima podem ser fusionados em alguns trechos, gerando segmentos mistos (BRONCKART, 1999, p. 187). Desse modo, podemos encontrar, entre outros:

- Tipo misto interativo-teórico: Trata-se de segmentos que aparecem principalmente no quadro de exposições orais (intervenções científicas, pedagógicas, políticas) e também de segmentos incluídos em textos escritos (editoriais brochuras de propagandas). Nesses textos, encontramos pronomes de primeira pessoa, que marcam a implicação no texto, típicos do discurso interativo; e também conectores lógico-argumentativos, bem como modalizações lógicas e retomas anafóricas, características típicas do discurso teórico.

- Tipo misto narrativo-teórico: Encontrado em trechos de monografias científicas e em obras históricas, alguns segmentos abordam acontecimentos históricos, ao mesmo tempo em que expõem os detalhes da situação ou de um problema técnico. Por isso, encontramos organizadores temporais (narração) e organizadores lógico-argumentativos e grande densidade sintagmática (discurso teórico). 


\subsubsection{As Sequências textuais}

Com relação às sequências textuais, Bronckart (1999) retoma e reformula o conceito de sequência textual de Adam (1992), classificadas em cinco tipos, ao passo que, para Bronckart (1999), as sequências se distribuem em seis tipos, pois além da sequência argumentativa, dialogal, descritiva, explicativa e narrativa, ele inclui a sequência injuntiva.

Para Bronckart (1999), as sequências textuais estão a serviço dos tipos de discurso e é em seu interior que podem ser observadas. Segundo o autor (BRONCKART, p. 251), as sequências são:

Baseadas em operações de caráter dialógico, organizam uma parte ou a totalidade dos enunciados que pertencem a um tipo, de acordo com um plano linguisticamente marcado, que se sobrepõe à linearidade primeira de todo segmento textual. Esse plano comporta um número $\mathrm{n}$ de fases (ou de "pacotes" de enunciados), explicitamente delimitados e, portanto, identificáveis, que se sucedem na ordem requerida pelo objetivo especifico buscado pelo agente-produtor, tendo em vista seus destinatários.

Como fizemos para os tipos de discurso, apresentaremos as características próprias das sequências textuais em diferentes níveis, segundo Machado (2005):

- no nível semântico-pragmático, as sequências são modos do agente produtor do texto (re)construir, no mundo discursivo, os elementos do mundo ordinário, tendo em vista seus destinatários e os efeitos pretendidos.

- no nível morfossintático, elas se caracterizam por apresentar um número de fases, marcadas por unidades linguísticas.

- no nível psicológico, elas implicam operações discursivas desenvolvidas pelo produtor para organizar os conteúdos.

- no nível teórico, as sequências não são modelos imutáveis, mas sim construtos teóricos derivados de análises.

- no nível de sua relação com os tipos de discurso, elas são determinadas pelos tipos de discurso,sendo que em cada um dos tipos de discurso há o predomínio de determinadas sequências. 
Segundo Bronckart, (1999), as sequências textuais podem ser descritas em fases, com suas características, como vemos no quadro a seguir, proposto por Machado (2005, p. 246):

\begin{tabular}{|c|c|c|}
\hline SEQUÊNCIAS & $\begin{array}{l}\text { REPRESENTAÇÕES DOS } \\
\text { EFEITOS PRETENDIDOS }\end{array}$ & FASES \\
\hline Descritiva & $\begin{array}{l}\text { Fazer o destinatário ver em } \\
\text { pormenor elementos de um objeto } \\
\text { de discurso, conforme a } \\
\text { orientação dada a seu olhar pelo } \\
\text { produtor }\end{array}$ & $\begin{array}{l}\text { Ancoragem } \\
\text { Aspectualidade } \\
\text { Relacionamento } \\
\text { Reformulação }\end{array}$ \\
\hline Explicativa & $\begin{array}{l}\text { Fazer o destinatário compreender } \\
\text { um objeto de discurso, visto pelo } \\
\text { produtor como incontestável, mas } \\
\text { também como de difícil } \\
\text { compreensão para o destinatário }\end{array}$ & $\begin{array}{l}\text { Constatação inicial } \\
\text { Problematização } \\
\text { Resolução } \\
\text { Conclusão/ avaliação }\end{array}$ \\
\hline Argumentativa & $\begin{array}{l}\text { Convencer o destinatário da } \\
\text { validade de posicionamento do } \\
\text { produtor diante de um objeto de } \\
\text { discurso visto como contestável } \\
\text { (pelo produtor e/ou pelo } \\
\text { destinatário. }\end{array}$ & $\begin{array}{l}\text { Estabelecimento de: } \\
\qquad \begin{array}{l}\Rightarrow \text { premissas } \\
\Rightarrow \text { suporte argumentativo } \\
\Rightarrow \text { contra-argumento } \\
\Rightarrow \text { conclusão }\end{array}\end{array}$ \\
\hline Narrativa & $\begin{array}{l}\text { Manter a atenção do destinatário, } \\
\text { por meio da construção de } \\
\text { suspense, criado pelo } \\
\text { estabelecimento de uma tensão e } \\
\text { subsequente resolução. }\end{array}$ & $\begin{array}{l}\text { Apresentação de: } \\
\qquad \begin{array}{l}\Rightarrow \text { situação inicial } \\
\Rightarrow \text { complicação } \\
\Rightarrow \text { ações desencadeadas } \\
\Rightarrow \text { resolução } \\
\Rightarrow \text { situação final }\end{array}\end{array}$ \\
\hline Injuntiva & $\begin{array}{l}\text { Fazer o destinatário agir de certo } \\
\text { modo ou em determinada direção }\end{array}$ & $\begin{array}{l}\text { Enumeração de ações } \\
\text { temporariamente subsequentes }\end{array}$ \\
\hline Dialogal & $\begin{array}{l}\text { Fazer o destinatário manter-se na } \\
\text { interação proposta. }\end{array}$ & $\begin{array}{l}\text { Abertura } \\
\text { Operações transacionais } \\
\text { Fechamento }\end{array}$ \\
\hline
\end{tabular}

QUADRO 1 - As características e fases das sequências textuais (MACHADO, 2005, p.246) 
Além das seis sequências textuais retomadas por Bronckart (1999) a partir dos estudos de Adam (1992), são concebidas duas outras formas de sequências ou de planificações textuais chamadas de script e esquematização.

O script, segundo Bronckart (1999), é uma forma de planificação textual da ordem do NARRAR considerada como o "grau zero" da narrativa, ou seja, é uma forma de organização textual em que as ações são encadeamos de forma causal/temporal não por meio de um agente complicador ou de uma tensão característicos da sequência narrativa canônica. No relatório final, a estudante-pesquisadora utiliza o script para relatar as ações da pesquisa no que tange às leituras teóricas realizadas, à metodologia seguida, aos resultados levantados e também às dificuldades encontradas no processo da pesquisa. A esquematização por sua vez, é o "grau neutro" da ordem do EXPOR, quer dizer, é o segmento que tem a função puramente informativa, diferentemente das sequências explicativas e argumentativas, nas quais o objeto de discurso é tido como problemático ou contestável e, por isso, deve ser explicado e argumentado.

Não nos atardaremos na explanação das sequências textuais, pois, em nossas análises, optamos por não dar destaque para essa categoria de análise, já que, apesar de termos identificado o uso de sequências do tipo script, explicativa, dialogal e argumentativa em nossos dados, decidimos priorizar outras categorias mais pertinentes para mostrar o desenvolvimento do estudante e futuro pesquisador durante o processo de IC.

\subsubsection{Mecanismos de Textualização}

Conforme Bronckart (1999), a segunda camada do folhado textual refere-se aos mecanismos de textualização, que são séries isotópicas que contribuem para uma coerência temática, articulada pelo destinatário em grandes articulações hierárquicas, lógicas e/ou temporais do texto. Distinguimos três mecanismos de textualização: conexão, coesão nominal e coesão verbal.

Os mecanismos de conexão servem para articular a progressão temática por meio de organizadores textuais. Esses organizadores podem marcar a transição entre tipos de 
discurso ou entre tipos de sequência ou outra forma de planificação, podendo, também, articular frases.

Quando os conectores assinalam a transição entre tipos de discurso, assumem a função de segmentação e quando assinalam a transição entre tipos de sequências, têm função de demarcação ou balizamento. Os conectores ainda podem "explicitar as modalidades de integração das frases sintáticas à estrutura que constituiu a fase uma sequência ou outra forma de planificação (Bronckart, pág.264), tendo assim, função de empacotamento. Por último, osmecanismos de conexão podem articular duas frases sintáticas em uma só frase, exercendo a função de ligação (coordenação) ou de encaixamento (subordinação).

De acordo com Bronckart (1999, p.266), podem assumir a função de conectores:

- Advérbios e locuções adverbiais: de fato; depois; além de; ontem; então etc.

- Sintagmas preposicionais: depois de três dias; sintagmas construídos com a preposição “para”, por exemplo, entre outros.

- Conjunções de coordenação: e; ou; nem; mas etc.

- Conjunções subordinação: antes que; desde que; porque, entre outras.

Além desses conectores, também são marcas de conexão os sintagmas nominais, pois organizam o texto em conectores sintagmáticos, sendo, portanto, chamados de organizadores textuais (BRONCKART, 1999, p. 267).

Os mecanismos de coesão nominal tanto podem introduzir temas e/ou personagens, quanto assegurar sua retomada ou substituição no desenvolvimento do texto, fazendo com que o produtor do texto organize as informações novas e as já fornecidas por meio de cadeias referenciais formada por expressões nominais e pronominais. Segundo constata Lousada (2010, p. 9), as cadeias nominais podem expressar o ponto de vista do enunciador do texto por meio das escolhas de termos que substituem os referentes. Desse modo, a autora propõe uma análise dos termos usados na coesão nominal atrelada a uma análise dos mecanismos enunciativos, pois denotam traços da posição enunciativa do produtor do texto em relação ao conteúdo temático.

Para a coesão verbal, Bronckart (1999) propõe três parâmetros para sua análise: os processos, vinculados à aspectualidade, os eixos de referência, vinculados à 
temporalidade, e a duração psicológica associada ao ato de produção. Para a análise desses parâmetros, faremos como Bronckart propõe (2006, 2008), ou seja, aliar a coesão verbal aos tipos de discurso.

\subsubsection{Mecanismos enunciativos}

Os mecanismos enunciativos oferecem grande contribuição para o estabelecimento da coerência interativa, pragmática ou configuracional do texto e também orientam o destinatário na interpretação do conteúdo temático dos mesmos. Para Bronckart (1999, p.319), os mecanismos enunciativos:

[...] contribuem para a coerência pragmática do texto, explicitando, de um lado, as diversas avaliações (julgamento, opiniões, sentimentos) que podem ser formuladas a respeito de um ou outro aspecto do conteúdo temático e, de outro, as próprias fontes dessas avaliações: quais são as instâncias que as assumem ou que se "responsabilizam" por elas?

Qualquer texto, seja oral ou escrito, é, como já dissemos, um mediador de uma ação de linguagem, sendo este texto decorrente do acionamento de um conjunto de representações interiorizadas pelo sujeito. Disso concluímos, num primeiro momento ${ }^{13}$, que, do ponto de vista comportamental e mental, o organismo humano é o próprio autor, ou seja, aquele que está na origem do texto.

Deparando-se com uma dada situação de linguagem, o autor mobiliza suas representações a respeito do contexto físico e social, bem como seus próprios motivos e intenções que justifiquem sua intervenção. No entanto, essas representações de um agente particular estão em interação com as representações dos outros e, "mesmo quando são alvo de uma reorganização singular, resultante da dimensão experimental própria de cada pessoa, continuam portando os traços dessa alteridade constitutiva" (Bronckart, 1999, p.321). Segundo esse ponto de vista, as noções, opiniões e os valores do agente-produtor

\footnotetext{
13 Utilizamos o conector «num primeiro momento », pois sabemos que o autor do texto pode assumir diferentes papéis sociais, mudando assim sua posição enunciativa.
} 
do texto são sempre interativos, uma vez que se integram às representações dos outros, tendo que confrontá-las e negociá-las.

Ao ser semiotizada pelo autor, a ação de linguagem é colocada em interface com o que Bronckart (1999, p.322) denomina de espaço mental coletivo, no qual os conhecimentos dos autores sobre o gênero textual escolhido se colocam em interface com os conhecimentos precedentes do gênero textual em uso, tanto em seus aspectos estruturais (propriedade linguísticas) quanto funcionais (indexação em determinadas situações de ação). Essas outras representações têm sede no próprio autor de tal maneira que o espaço mental coletivo é resultado do confronto das representações pessoais do autor com a dos outros.

A transferência de responsabilidade do que está sendo enunciado, portanto, não é somente do autor, mas de outras instâncias do espaço mental coletivo, sendo esta uma “consequência necessária e inelutável de todo e qualquer funcionamento de um sistema semiótico" (Bronckart, p. 323).

Em todo texto, as vozes se responsabilizam pelo que é enunciado e podem ser reagrupadas em três subconjuntos: voz do autor empírico, vozes dos personagens e vozes sociais.

De acordo com Leite (2009, p. 42), a voz do autor empírico é procedente da pessoa que está na origem da produção textual e que intervém nesta produção para tecer comentários, esboçar opiniões, avaliar alguns aspectos do que é enunciado.

As vozes dos personagens são as vozes que procedem dos seres humanos (herois presentes em relatos, narrações e interlocutores implicados em um discurso interativo dialogado), ou entidades humanizadas (por exemplo, os animais em cena em certos contos), implicados nos acontecimentos ou ações constitutivas do conteúdo temático do texto.

Por fim, as vozes sociais são vozes de outros personagens, grupos ou instituições sociais, que não intervêm como agentes no percurso temático do texto, mas são mencionadas como instâncias externas de avaliação de aspectos do conteúdo textual.

As vozes semiotizadas no texto, ao se posicionarem sobre um determinado assunto, utilizam modalizações que evidenciam o ponto de vista assumido. As modalizações são as avaliações dos enunciadores a respeito do conteúdo temático sobre o 
qual está fazendo referência e que orienta o destinatário na interpretação do assunto. As modalizações no ISD são divididas em:

- Modalizações lógicas: consistem em avaliações apoiadas em critérios ou conhecimentos do ponto de vista das suas condições de verdade, como fatos atestados ou certos, possíveis, prováveis, eventuais, necessários. Algumas expressões que podem introduzir uma avaliação lógica são: é evidente, é necessário, é possível.

- Modalizações deônticas: são as avaliações apoiadas em critérios de deveres, regras e normas, apresentando elementos do conteúdo como sendo do domínio do direito e da obrigação social. Podem ser expressas pelos verbos "poder", “dever", "ter que" etc.

- Modalizações apreciativas: elas são apoiadas em critérios subjetivos, podendo apresentar os fatos do ponto de vista dos efeitos afetivos, como, por exemplo: feliz, estranho, benéfico, entre outros.

- Modalizações pragmáticas: explicitam a responsabilidade das ações dos agentes envolvidos e responsáveis pelos atos executados, atribuindo intenções e razões para essas ações. São exemplos de unidades linguísticas que exercem a função modalizadora pragmática: verbos no pretérito (quis, pretendeu, pudesse).

Para complementarmos a análise das vozes, utilizaremos os estudos de Maingueneau (2008) e de Authier-Revuz (1999) acerca dos itens linguísticos identificadores da polifonia. Os estudos dos linguistas franceses são compatíveis com os pressupostos do ISD, sobretudo no que concerne ao papel do contexto na explicação da utilização dos recursos linguístico-discursivos.

O que se quer dizer é que, fora de contexto, não podemos falar realmente do sentido de um enunciado, mas, na melhor das hipóteses, de coerções para que um sentido, seja atribuído à sequência verbal proferida em uma situação particular, para que torne um verdadeiro enunciado, assumindo em um lugar e em um momento específicos, por um sujeito que se dirige numa determinada perspectiva, a um ou vários sujeitos (MAINGUENEAU, 2008, P. 20). 
De acordo com a citação acima, o enunciador sempre produz enunciados situados em um lugar e em momentos específicos, dirigindo-se a um determinado auditório particular. Nessa situação, ele pode se investir de vários papéis sociais, participando sempre de um contrato comunicativo mediado por um gênero textual (MAINGUENEAU, 2008, P. 69). Todavia, um texto não é composto por uma única voz, pois esta pode convocar outras para construir o enunciado, sendo que essa polifonia pode ser verificada por meio de marcas linguístico-discursivas.

Tanto no discurso direto quanto no indireto, podemos encontrar algumas categorias que nos indicam a polifonia textual. No discurso indireto, podemos encontrar ilhas textuais ou enunciativas, que são palavras ou fragmentos atribuídos ao enunciador citado pelo enunciador citante, o qual, ao mesmo tempo, utiliza e menciona, emprega e cita. Assim, cria-se um trecho com característica de discurso direto, porém encaixado perfeitamente à sintaxe do enunciado em discurso indireto. As aspas são caracterizadoras das ilhas textuais (MAINGUENEAU, 2008, P. 151).

Paralelamente ao uso das aspas, há outro recurso que identifica as vozes no texto, chamado de modalização autonímica. A modalização autonímica foi proposta por Authier-Revuz (1999, p.14) e, segundo a autora, tem a função de remeter a um discurso X um outro em seguida, um discurso Y.

Maingueneau apoia-se em Authier-Revuz (1999) e afirma que, ao utilizar palavras ou expressões com valor autonímico, o enunciador se refere aos signos em si mesmos, opondo-se ao uso corrente em que as palavras se referem às realidades externas à linguagem. Por meio desse recurso, empregam-se as palavras não aspeadas, pelas quais o enunciador desdobra, de uma certa maneira, seu discurso para comentar sua fala enquanto está sendo produzida (MAINGUENEAU, 2008, P. 158). Segundo o autor, a modalização autonímica se manifesta em uma grande variedade de categorias e construções, como, "de uma certa forma", "se eu posso dizer", “ou melhor", “isto é”, entre muitas outras. Esses comentários do enunciador sobre sua própria enunciação são denominados, por Authier-Revuz (1999), de "não-coincidências do dizer". 


\subsection{A arquitetura textual e as restrições da linguagem}

Depois de expostas todas as categorias que utilizaremos nas nossas análises, discutiremos abaixo o modo como iremos organizá-las na seção de síntese e discussão dos resultados, sobretudo para problematizarmos a nossa terceira pergunta de pesquisa.

Em 2008, Bronckart propõe um reagrupamento das camadas da arquitetura textual, rearranjando-as em categorias maiores. Nessa perspectiva, as camadas foram distribuídas em três restrições da linguagem que, segundo o autor, influenciam toda produção verbal de linguagem: a restrição social, restrição psicológica e restrição linguística. Todo texto, pertencente a um gênero textual, guarda os traços da hierarquia particular ou das relações de dominância entre essas três restrições da linguagem.

$\mathrm{Na}$ restrição social, todo ato expressivo verbal é dotado de sentido através da situação de comunicação, o que, consequentemente, forçará a produção verbal a se moldar na forma de um gênero textual adequado à situação. Assim, não é possível apresentar uma receita de cozinha no dia da defesa do mestrado, pois a situação exige que primeiramente se tenha pronta uma dissertação e se saiba discuti-la dentro de uma arguição. Dentro dessa situação, não é possível divagar sobre quais assuntos quisermos, dado que defenderemos o assunto desenvolvido na pesquisa. Portanto, toda ação de linguagem está dentro de uma prática social.

Além disso, cada gênero textual organiza de forma particular o conteúdo temático da produção de linguagem, na qual são articulados os conteúdos temáticos que mostram as motivações sociais para serem tratados.

Até os mecanismos enunciativos estabelecem uma dependência com gênero textual usado, na medida em que as vozes e modalizações se relacionam aos papéis sociais previstos em toda situação de linguagem.

Uma última restrição imposta pelo gênero textual é o fato de que eles organizam a mobilização dos tipos de discurso e sua disposição dentro do texto. No entanto, Bronckart (2008b, p.89) afirma que estudos são necessários para se verificar se os tipos de discurso, eles mesmos, podem ser vistos como entidades que escapam às restrições do gênero textual e da atividade social, pois as propriedades linguísticas que compõem os tipos são atestáveis em qualquer gênero textual dentro do qual aparece. 
$\mathrm{Na}$ restrição psicológica, atenta-se para o uso dos tipos de discurso, enquanto produtos das operações psico-linguageiras que consistem, por um lado, no estabelecimento das coordenadas temporais que organizam as ações semiotizados e, do outro lado, clarificam as relações de autonomia ou implicação no texto.

Já as restrições linguísticas impõem duas restrições. A primeira se refere às modalidades que marcam os tipos de discurso e os efeitos possíveis dentro do uso de cada um deles. Na língua francesa, por exemplo, o passé composé é usado no relato interativo, e o passé simple na narração, mas isso pode mudar de uma língua para outra. A segunda restrição é a imposta pelos mecanismos de textualização, visto que todas as línguas, de uma forma ou outra, apresentam processos de conexão e coesão nominal, além de operações sintáticas particulares.

Utilizando esse reagrupamento proposto por Bronckart (2008b), Bota (2011) defendeu uma tese, intitulada Savoirs, textes et apprentissages en milieu universitaire. Pour une analyse sociodiscursive de travaux de validation pour les cours, na qual ele analisou não somente um único texto, buscando compreender o papel das restrições para a construção do sentido, porém foram analisados vários textos produzidos dentro de um dispositivo de formação universitário da Universidade de Genebra. Dentro desse contexto de pesquisa, Bota (2011) constatou que as restrições da linguagem de Bronckart (2008b) atuavam conjuntamente nas produções textuais, mas de forma hierarquizada, por isso ele as denominou de "sistemas da linguagem". Segundo autor:

le raisonnement, en tant que processus interprétatif spécifique réalisé dans le cadre d'un genre de texte, constitue une hiérarchie particulière entre les systèmes à intérieur de la hiérarchie "prévue par le genre" (BOTA, 2011, p.193) $)^{14}$.

Ademais, os três sistemas restringem a construção do pensamento nas produções verbais. Diante dessas constatações, Bota (2011) propõe alguns princípios que definem o conceito de raciocínio na perspectiva interacionista sociodiscursiva:

D'une manière générale, dans cette perspective, les différentes sortes de raisonnements peuvent être considérés comme un sous-ensemble particulier des processus d'interprétation qui se réalisent à

$14[\ldots]$ o raciocínio, enquanto processo interpretativo específico realizado no gênero textual, constitue uma hierarquia particular entre os sistemas no interior da hierarquia « prevista pelo gênero. 
l'intersection de ces trois systèmes et qui sont donc redevables des rapports et des interaction spécifiques entre les ingrédients sémiologiques, psychologiques et sociaux.(BOTA, 2011) $)^{15}$

A partir dessas considerações, é possível estabelecer, de acordo com Bota (2011), um conjunto de princípios sobre os raciocínios enquanto processos ao mesmo tempo processos mentais e linguageiros:

a) os raciocínios nos mais diversos gêneros textuais são constituídos necessariamente pela conjunção no processo interpretativo dos três sistemas: psicológico, social e linguageiro.

b) o texto é a unidade de significação, pois é o produto empírico de uma atividade de linguagem, logo é o espaço no qual se encontram as interações explícitas, entre as operações semiológicas, os processos de abstração e de generalização, além dos valores sociais veiculados pelas atividades humanas.

c) É no nível do texto, enquanto unidade da comunicação, que os processos de abstração e generalização são possíveis, mais especificamente a partir da organização discursiva de um texto e da produção dos mundos discursivos. Assim, é a partir dos estágios maiores da textualidade (dos tipos de discurso) que pode ocorrer a interação entre os signos e os processos de abstração e a generalização.

d) O raciocínio, entendido como modalidade do processo interpretativo, estabelece uma hierarquia ou uma dominância entre os sistemas. A produção textual, quando influenciada mais pela intervenção de um dos sistemas, não visa somente favorecer a intervenção dos processos de abstração e generalização, mas visa mais particularmente conceder um lugar de dominância, ou seja, o raciocínio explora certos mecanismos semiológicos como recursos de um processo de abstração e de generalização.

e) os conceitos, portanto, são considerados como o produto semio-lógico ou semio-cognitivo derivado de um raciocínio pela condensação dos processos de abstração e de generalização na entidade semiológica. Decorrente disso, os conceitos não podem

\footnotetext{
${ }^{15}$ De uma maneira mais geral, nesta perspectiva, os diferentes tipos de raciocínios podem ser considerados como conjuntos particulares submetidos aos processos de interpretação que se realizam na intersecção desses três tipos de sistemas e que são devedores das relações e das interações específicas entre os ingredientes semiológicos, psicológicos e sociais
} 
ser produzidos de forma independente das unidades de uma língua natural, assim como afirmava Vigotski, segundo o qual les concepts sont une forme spéciale de signe, un cas spécial d'emploi fonctionnel du mot. Em suma, un raisonnement est le processus même qui crée un concept ou qui produit les rapports de généralités définitoires d'un concept (BOTA, 2011, p.195) ${ }^{16}$.

16 os conceitos são uma forma especial de signo, um caso especial de emprego funcional da palavra. Em suma, um raciocínio é o processo mesmo que cria um conceito ou que produz as relações de generalidades definitórias de um conceito. 


\section{CAPÍTULO III - Metodologia da pesquisa}

Dado que a nossa pesquisa tem o objetivo de pesquisar o modo como os textos produzidos ao longo da Iniciação Científica permitem compreender o desenvolvimento do aluno-pesquisador, neste capítulo buscaremos descrever esses textos coletados para a pesquisa e os nossos métodos de análise. Para tal, iniciaremos esta parte detalhando o contexto da pesquisa, destacando a Iniciação Científica dentro do contexto universitário da Universidade de São Paulo, e, em seguida, a Faculdade de Filosofia, Letras e Ciências Humanas da USP e a Área de Estudos Linguísticos, Literários e Tradutológicos em francês. Depois, descreveremos os nossos participantes de pesquisa, pois consideramos relevante mostrar o percurso acadêmico que seguiram até o momento em que os dados foram coletados. Posteriormente, mostraremos as condições estabelecidas para a produção dos textos, segundo a Comissão de Pesquisa da FFLCH e a FAPESP. Para finalizar, descreveremos o nosso método de análise.

\section{Contexto da Pesquisa}

Nesta seção, descreveremos o nosso contexto de pesquisa mais geral e específico, iniciando pela descrição da Universidade de São Paulo, depois da Faculdade de Filosofia, Letras e Ciências Humanas para, finalmente, centrarmos na Área de Estudos Linguísticos, Literários e Tradutológicos em francês, explicando o processo de Iniciação Científica nesse contexto e também a importância deles para esta pesquisa. Em seguida, apresentaremos os participantes deste estudo, buscando mostrar os seus interesses por meio do percurso acadêmico que traçaram durante a graduação em Letras. 


\subsection{Iniciação Científica na Universidade de São Paulo}

Nosso contexto mais geral de pesquisa é a Universidade de São Paulo, uma Instituição de Ensino Superior brasileira criada em 1934 e com localização central na cidade de São Paulo, mas tendo outros sete campi situados em diversas cidades do estado, como Bauru, Lorena, Piracicaba, Pirassununga, Ribeirão Preto, São Carlos e Santos, cidades que juntas agrupam 42 unidades de ensino e pesquisa, além de 300 cursos de graduação, 222 programas de pós-graduação (mestrado e doutorado). A comunidade USP é composta por 94.875 mil estudantes, divididos em 59 mil estudantes na graduação e 30 mil estudantes de pós-graduação, somando-se a esse montante os alunos de programas de especialização e de extensão universitária. A USP ainda conta com mais de 6.000 professores e cerca de 17.100 funcionários ${ }^{17}$. Do ponto de vista de sua organização administrativa, a USP é gerida pela Reitoria Central e, ligadas a ela, as Pró-reitorias de Pós-graduação, Graduação, Extensão Universitária, e Pesquisa. Dentre elas, a Pró-reitoria de Pesquisa (PRP) tem a função de normatizar e viabilizar as práticas de pesquisa científica na Universidade através de lançamento de editais, Programas especiais de pesquisa e Núcleos de Apoio à Pesquisa (NAPs). Entre os Programas administrados pela PRP, destacamos o Programa de Iniciação Científica que, segundo informado no site da Pró-reitoria, visa a:

promover desenvolvimento da Pesquisa da Instituição, diante do encaminhamento de alunos de graduação para a descoberta científica, e convivência com procedimento e a metodologia adotada em ciência e em tecnologia. O princípio que deve reger as atividades de Iniciação Científica é dirigido prioritariamente ao beneficio dos alunos, que tem no Programa a oportunidade de complementar sua formação acadêmica, aprimorando seu conhecimento e preparo para a vida profissional.

A fim de que os alunos da graduação possam participar do Programa de Iniciação Científica, a PRP divulga anualmente um edital contendo os procedimentos necessários para a efetiva inscrição e permanência no Programa.

17 Dados do Anuário Estatístico da USP de 2014. 
Como já informamos, a USP conta com 42 Unidades de Ensino e Pesquisa, cuja maioria oferece aos graduandos a oportunidade de desenvolverem pesquisa em nível de IC, que é gerida dentro das unidades por meio das Comissões de Pesquisa. Como nosso contexto de pesquisa é a IC que se desenvolve na Faculdade de Letras, pertencente à FFLCH, optamos por caracterizar apenas essa unidade da USP.

\subsection{A Iniciação Científica na FFLCH}

Todos os trâmites burocráticos da pesquisa em Iniciação Científica são geridos pela Comissão de Pesquisa da FFLCH (Cpq) que articula o Programa de Iniciação Científica da PRP dentro da unidade. Ao entrarmos no site da Cpq, encontramos uma aba destinada especificamente às informações sobre a IC assim como visualizamos a seguir:

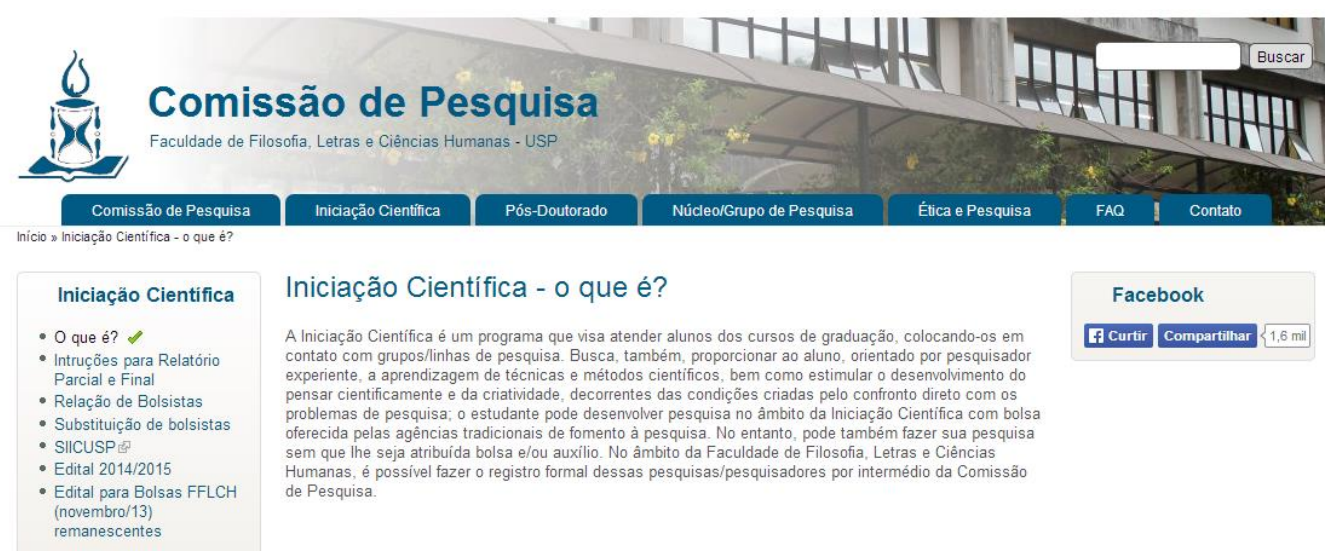

Figura 4 - da Cpq-FFLCH sobre a Iniciação Científica no site da Cpq-FFLCH

Segundo o Regimento da Comissão, é de competência da Cpq: "Estimular a pesquisa na FFLCH, nas diversas áreas do conhecimento, bem como o desenvolvimento de projetos interdisciplinares, desde a iniciação científica até o pós-doutoramento e, para tanto, promover diagnósticos e a identificação de carências e facilidades". ${ }^{18}$

A primeira informação neste espaço do site refere-se ao conceito de IC:

${ }^{18} \mathrm{O}$ Regimento da Cpq pode ser consultado em http://pesquisa.fflch.usp.br/node/8. 


\begin{abstract}
"A Iniciação Científica é um programa que visa atender alunos dos cursos de graduação, colocando-os em contato com grupos/linhas de pesquisa. Busca, também, proporcionar ao aluno, orientado por pesquisador experiente, a aprendizagem de técnicas e métodos científicos, bem como estimular o desenvolvimento do pensar cientificamente e da criatividade, decorrentes das condições criadas pelo confronto direto com os problemas de pesquisa; o estudante pode desenvolver pesquisa no âmbito da Iniciação Científica com bolsa oferecida pelas agências tradicionais de fomento à pesquisa. No entanto, pode também fazer sua pesquisa sem que lhe seja atribuída bolsa e/ou auxílio. No âmbito da Faculdade de Filosofia, Letras e Ciências Humanas, é possível fazer o registro formal dessas pesquisas/pesquisadores por intermédio da Comissão de Pesquisa." 19 (Grifos nossos)
\end{abstract}

A Cpq é a instância que estabelece as datas da inscrição dos projetos, da apresentação dos relatórios, além de fazer a distribuição das bolsas e todos os trâmites burocráticos da pesquisa de IC. Por meio de um edital semestral a Cpq estabelece as normas necessárias para a inscrição e gestão de todo o processo da pesquisa, como, por exemplo, instruções para a escrita do primeiro gênero textual, o projeto de pesquisa, a ser produzido pelos alunos nesse contexto e que é pré-requisito para a inscrição no Programa de IC.

Por meio do edital de IC, a Cpq fornece diretrizes para a escrita do projeto de pesquisa, que deve conter: introdução, objetivo, metodologia e referências entre outros dados essenciais para a efetiva inscrição no processo de pesquisa.

\title{
1.3.A Iniciação Científica da Área de Estudos Linguísticos, Literários e Tradutológicos em Francês
}

Nossa pesquisa é realizada no contexto universitário do curso de Letras da Faculdade de Filosofia, Letras e Ciências Humanas (FFLCH) da Universidade de São Paulo, que compreende cinco departamentos de ensino: Departamento de Letras Clássicas e Vernáculas, Departamento de Letras Modernas, Departamento de Linguística, Departamento de Letras Orientais e o Departamento de Teoria Literária e Literatura Comparada. Mais especificamente, nossa pesquisa está sendo realizada na Área de

\footnotetext{
${ }^{19}$ Informação encontrada emhttp://pesquisa.fflch.usp.br/node/20
} 
Estudos Linguísticos, Literários e Tradutológicos em francês do Departamento de Letras Modernas.

Segundo dados do Departamento de Letras Modernas, a Iniciação Científica é concebida como:

[...] um processo formativo, cuja eficiência está assentada na garantia de uma orientação segura e individualizada por parte de um docente-pesquisador experiente e qualificado. A iniciação científica é uma prática mais intensiva da busca e construção do conhecimento. A IC é, antes de mais nada, um tempo de formação das habilidades básicas indispensáveis ao pesquisador: capacidade de manuseio da informação científica acumulada nas bibliotecas e nos bancos de dados; boa redação e apresentação de textos científicos em português e línguas estrangeiras; aptidão para transformar vagas intenções ou intuições em problemas a serem estudados; habilidade para seleção adequada da informação; capacidade de estabelecimento de hipóteses; aperfeiçoamento do espírito crítico, seja para criticar, seja para aceitar críticas; busca e consolidação de conhecimentos necessários à complementação da formação. $\underline{\mathrm{O} \text { aluno aprende aí a preparar um }}$ projeto de pesquisa, um relatório, etc. A IC assegura ao estudante um processo de amadurecimento e de diferenciação individual, de tal modo que ele seja capaz de, inclusive, buscar as fontes do conhecimento que não domina.(Sublinhados nossos) $)^{20}$

No mesmo site do DLM, encontramos o espaço da Área de Estudos Linguísticos, Literários e Tradutológicos em francês (ELLTF) que conceitua a Iniciação Científica como: "um programa que visa atender alunos dos cursos de graduação, colocando-os em contato com grupos/linhas de pesquisa. Busca, também, proporcionar ao aluno, orientado por pesquisador experiente, a aprendizagem de técnicas e métodos científicos." Além dessa informação, são fornecidos outros dados relativos ao desenvolvimento da IC na Área, como as modalidades, requisitos, compromissos, documentos exigidos, inscrição e tipos de bolsas. Como forma de melhor divulgar a IC dentro da Faculdade, a Área de ELLTF criou um folder com informações relativas a essa modalidade de pesquisa, como podemos ver abaixo:

\footnotetext{
${ }^{20}$ Informações encontradas no site do Departamento de Letras Modernas: $\underline{\text { http://dlm.fflch.usp.br/node/859. }}$
} 

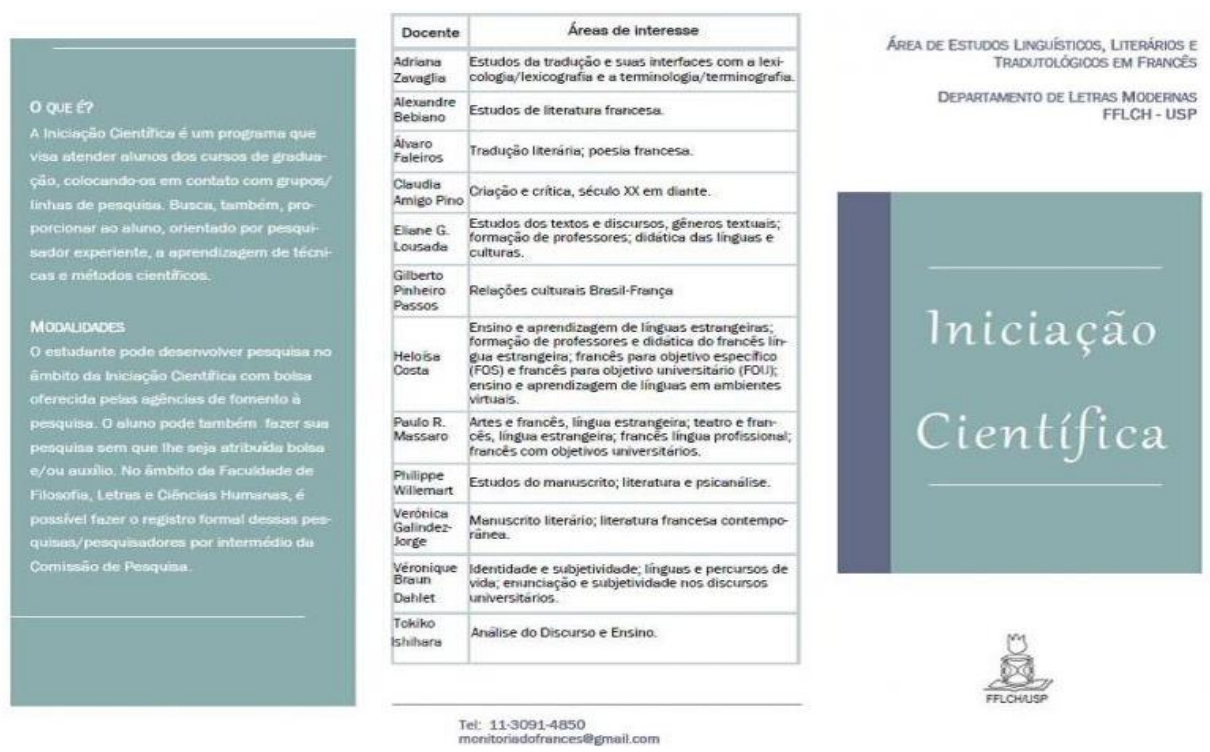

Figura 5 - Folder de divulgação da Iniciação Científica da Área de Francês

Dentro da Área de ELLTF são desenvolvidos trabalhos nas seguintes linhas: Escrita Literária; Relações França-Brasil; Problemas Críticos de Literatura Francesa; A tradução entre línguas e práticas; Literaturas em tradução etc. A linha de pesquisa em Estudos Linguísticos e Didáticos (no qual a nossa pesquisa de Mestrado está inserida) é composto pelos projetos de pesquisa: Estudos das Línguas, Culturas e Textos; Didática do Francês Língua Estrangeira em Perspectiva; Ensino de Francês para a Comunidade; Ensino do francês com objetivos específicos Na graduação, ao realizar uma pesquisa de Iniciação Científica, os estudantes iniciam o contato com os procedimentos teóricos e metodológicos em uma dessas linhas de pesquisa, orientados por um professor-pesquisadorda área de ELLTF, que o orienta a partirdas teorias que utiliza em suas investigações científicas.

A Área em Estudos Linguísticos, Literários e Tradutológicos em francês, por meio da coordenação do seu Programa de Pós-graduação, realiza, anualmente, desde 2009, o Encontro de Pesquisas do Francês, evento no qual os estudantes de Mestrado e Doutorado são convidados a enviarem resumos de suas respectivas pesquisas para serem apresentadas durante as várias seções de comunicação oral. Nesse contexto, tanto pós-graduandos, quanto os estudantes em IC, são também convidados a apresentarem suas pesquisas, a fim de terem seus trabalhos comentados pelo público ouvinte e, sobretudo, por um pesquisador do Programa previamente convidado para mediar a seção de comunicação. 
Durante as seis edições do Encontro, há grande participação dos alunos de IC que procuram no evento um momento de apresentação de seus trabalhos, que podem estar em nível inicial de desenvolvimento ou não, para que sejam comentados e debatidos, bem como para obter apontamentos de novas maneiras de conduzir a pesquisa realizada.

Visto que o objetivo de nossa pesquisa consiste em estudar o processo completo da Iniciação Científica, o contexto das pesquisas de Iniciação Científica desenvolvidas pela Área de Estudos Línguísticos, Literários e Tradutológicos em francês, onde ocorre o "Encontro de Pesquisas", foi importante, pois é uma exigência da Comissão de Pesquisa da FFLCH que, no início ou ao final do processo da pesquisa em IC, os alunos apresentem seus trabalhos em um evento científico (é necessária somente uma apresentação). Na verdade, essa exigência é imposta, primeiramente, pelo CNPq aos seus alunos bolsistas, no entanto a USP estende essa indicação tanto aos alunos que recebem bolsa quanto aos não bolsistas. Com esse intuito, a Universidade de São Paulo organiza anualmente o Simpósio Internacional de Iniciação Científica da USP (SIICUSP), evento em que os estudantes devem apresentar os seus trabalhos de pesquisa.

\section{Participantes: estudantes de Iniciação Científica}

Nesta seção, apresentaremos os participantes da pesquisa, fornecendo informações sobre cada um deles.

Os participantes deste estudo são alunos graduandos da habilitação em Língua Francesa da Área em Estudos Línguísticos, Literários e Tradutológicos em francês da Faculdade de Filosofia, Letras e Ciências Humanas da Universidade de São Paulo, que desenvolveram suas pesquisas de Iniciação Científica, cumprindo todos os pré-requisitos burocráticos exigidos pela Comissão de Pesquisa da FFLCH. Para escolher os alunos que participariam de nossa pesquisa, elaboramos os seguintes critérios:

I. Ser estudante do curso de Letras na FFLCH-USP na habilitação em francês e realizar pesquisa em Iniciação Científica orientado por professores-pesquisadores da Área de Estudos Linguísticos, Literários e Tradutológicos em francês da FFLCH. 
II. Realizar pela primeira vez pesquisa em nível de IC na área de Letras e Linguística, pois, já que o objetivo de pesquisar o modo como os textos produzidos ao longo da Iniciação Científica permitem compreender o desenvolvimento do aluno-pesquisador, os estudantes que já tivessem realizado uma pesquisa científica na graduação estariam em um outro momento de formação.

III. Realizar pesquisa mais próxima ao eixo de Estudos Linguísticos, uma vez que esta pesquisa é desenvolvida na linha de pesquisa em Estudos Linguísticos e Didáticos, e, por isso, a nossa proximidade na abordagem dos dados seria mais facilitada do que se comparada a saberes advindos dos Estudos Literários, por exemplo. Portanto, eliminamos os alunos da área de Estudos Literários, guardando os de Estudos Linguísticos e Tradutológicos.

IV. Apresentar a pesquisa no final de seu desenvolvimento no V Encontro de Pesquisas do Francês. Como já salientamos, é uma exigência da Comissão de Pesquisa da FFLCH que os estudantes que realizam pesquisas em IC apresentem oralmente suas pesquisas ao menos uma vez.

V. Ser orientado por professores-pesquisadores diferentes, para podermos ter uma variedade de pesquisas, com objetivos e desenvolvimentos diferentes.

VI. Estar disposto a disponibilizar seus textos acadêmicos, bem como as suas versões, para o bom desenvolvimento de nossa pesquisa.

Seguindo os critérios acima e limitando nossa coleta aos anos 2011 e 2013, selecionamos apenas três alunos de IC e, consequentemente, recolhemos seus textos para compor nossos dados. Como mencionamos na Introdução, outras pesquisas sobre a IC procuraram fazer estudos mais abrangentes, envolvendo grande quantidade de alunos. No entanto, em nosso caso, optamos por fazer uma análise qualitativa, restringindo o número de participantes, pois nosso objetivo é acompanhar o desenvolvimento dos alunos no processo de IC.

A seguir, descrevemos os quatro estudantes participantes da nossa pesquisa, os quais nomearemos por Estudante 1 (BT), Estudante 2 (LM), Estudante 3 (RA). 


\subsection{Estudante 1 (BT)}

Iniciou seus estudos no curso de Letras na Universidade de São Paulo em 2008, tendo cumprido durante este ano as disciplinas obrigatórias básicas do primeiro ano do curso. Em 2009, foi ranqueada em posição suficiente para entrar na habilitação de francês, na qual iniciou seus estudos em Língua e Literatura Francesa. BT já tinha conhecimento avançado de Língua Francesa, visto que ela passara por um exame de proficiência avançado aplicado por uma renomada escola de ensino de francês. No ano seguinte, em 2010, BT escolhe entre as disciplinas optativas do curso - aquelas em que estudantes podem escolher livremente e conduzir de forma mais específica a sua formação - a disciplina "Introdução aos Estudos Tradutológicos", cujo objetivo é o estudo histórico e teórico dos estudos da tradução. Embora essa disciplina seja oferecida por professores das habilitações de italiano e alemão, BT escolhera a turma da sua futura orientadora de Iniciação Científica, cuja especialidade é a tradução em língua francesa.

Tendo obtido um excelente aproveitamento nessa disciplina, BT matriculou-se em uma outra, chamada "Introdução à Prática de Tradução do Francês" também ministrada pela sua futura orientadora. Percebe-se, assim, um interesse pela estudante a respeito do campo de saberes dos estudos tradutológicos e mais especificamente associado à língua francesa, visto que o objetivo da segunda disciplina é "levar o aluno, pela tradução de textos, a ampliar e aprimorar seu domínio da língua e cultura estrangeira, e a adquirir os elementos básicos necessários a uma prática" ${ }^{21}$.

O interesse de BT pela tradução, mais especificamente a prática de tradução em língua francesa, pode ser constatado na terceira disciplina em que ela se matriculou, “Análise Contrastiva do francês", cujo objetivo é propor uma reflexão entre teoria e prática da tradução por meio da análise do sistema linguístico da língua francesa para a compreensão dos procedimentos de tradução; esta disciplina também ministrada por sua orientadora.

Por fim, destacamos os eventos sobre tradução nos quais a BT participou como o evento “Transfusão: II Encontro de Tradutores Casa Guilherme de Almeida”.

\footnotetext{
${ }^{21}$ Os dados sobre os objetivos das disciplinas foram retirados das Ementas dos cursos, disponibilizadas no sistema da Graduação da USP, o Júpiterweb: https://uspdigital.usp.br/jupiterweb/
} 
Paralelamente a essas disciplinas optativas sobre estudos da tradução, a BT também se matriculou em disciplinas sobre estudos literários. Em 2010, ela se matriculara em "Introdução aos Estudos Comparados de Literatura de Língua Portuguesa", "Literatura Infantil e Juvenil: Linguagens do Imaginário”, em 2011; “Teoria Literária" e "Escrita e estilo em estudos literários".

No segundo semestre de 2012, a estudante iniciou contato com a sua orientadora para realização de um projeto de pesquisa sobre a tradução da poesia de Carlos Drummond de Andrade na França. A orientadora desenvolve pesquisas na área de Tradução, considerando suas interfaces com a Linguística (enunciativa e de corpus), a Lexicologia/Lexicografia bilíngue, a Terminologia/Terminografia bilíngue e a Literatura. Além disso, é autora de inúmeras publicações entre elas artigos, livros e capítulos de livros nas áreas de Estudos Tradutológicos, muitas delas em interface com os Estudos Literários.

Em 2013, BT terminou seus estudos no curso de Letras e hoje ela é bacharela em Letras (Língua Portuguesa e Língua Francesa) e licenciada em Letras (Língua Portuguesa).

\subsection{Estudante 2 (LM)}

Assim como BT, entrou no curso de Letras no ano de 2008 e na habilitação em Língua Francesa, em 2009. Desde 2012, é monitora no Centro de Línguas da FFLCH, onde ministra o curso de extensão "Práticas de Leitura em Francês", que tem o objetivo de desenvolver a habilidade de leitura em língua francesa, levando o aluno à compreensão de textos de sua área acadêmica e/ou profissional e à seleção de informações de acordo com o objetivo de leitura estabelecido. A partir do mesmo ano, a estudante iniciou sua pesquisa em Iniciação Científica, intitulada "Desenvolvimento de competências leitoras em francês pela abordagem da intercompreensão nos cursos de Práticas de Leitura do Centro de Línguas da FFLCH”, na qual estudou a intercompreensão nas línguas românicas, analisando os pressupostos metodológicos que orientam as atividades propostas para os módulos iniciais do Curso Práticas de Leitura em Francês e a articulação com os conceitos de intercompreensão, por meio da aplicação de atividades de leitura em diferentes línguas românicas. 
A pesquisa foi orientada por uma pesquisadora especialista em didática das línguas estrangeiras, enfocando ensino do francês com fins específicos e universitários, bem como as tecnologias da informação e da comunicação para o ensino de línguas em ambientes virtuais de aprendizagem. Soma-se a essas questões abordadas em suas pesquisas, a questão da intercompreensão das línguas românicas no ensino-aprendizagem do francês língua estrangeira. Essa outra preocupação das suas pesquisas pode ser constatada nos textos científicos publicados, "Français instrumental au Centre de Langues de 1'Université de Sao Paulo et intercompréhension: voies possibles pour une refonte de la programmation des cours"; e nos eventos que já organizou sobre intercompreensão, como a ''I Jornada de Estudos em Letras Modernas: A Intercompreensão em línguas românicas", em 2012.

Em 2013, LM, após apresentar a sua pesquisa no SIICUSP, recebeu menção honrosa pelo trabalho realizado.

Com relação às disciplinas optativas cursadas, LM escolheu ora disciplinas de cunho teórico como "Tópicos em Teoria do texto", sobretudo aquelas em que os textos literários são objeto de análise como "Introdução aos Estudos Comparados de Literatura e Língua Portuguesa", “Teoria Literária", "Literatura Infantil e Juvenil: Linguagens do Imaginário", "Literaturas de Expressão Francesa" e "Literatura Comparada"; ora disciplinas em que o ensino de língua é estudado, como "Leitura e Produção de textos" e “Introdução aos Estudos do Português para Falantes de Outras Línguas". Portanto, constatamos que há grande interesse de LM pelo ensino de línguas e estudos do texto.

Além disso, participou de eventos científicos sobre a intercompreensão, como a "I Jornada de Estudos das Línguas Modernas", apresentando o trabalho "Estratégias de intercompreensão para o desenvolvimento de competências leitoras em francês" e o “Colloque Intercompréhension: compétences plurielles, corpus, intégration", evento no qual apresentou a comunicação "Français instrumental au Centre de Langues de l'Université de Sao Paulo et intercompréhension: voies possibles pour une refonte de la programmation des cours", ambas em 2012. Em 2013, participou do "I Colóquio Internacional de Intercompreensão de Natal”, onde apresentou a comunicação "Sensibiliser et former des professeurs de langues étrangères par l'intercompréhension: l'expérience de l'Université de Sao Paulo". 


\subsection{Estudante 3 (RA)}

A estudante começou o seu percurso no curso de Letras no ano de 2011 e, em 2012, iniciou seus estudos na habilitação em Língua Portuguesa e Língua Francesa.

No tocante às disciplinas optativas, a Aluna 3 ainda não tinha se matriculado em nenhuma tendo cumprido até o momento somente as disciplinas obrigatórias das duas habilitações, como as disciplinas "Francês 1", "Francês 2", "Francês 3" e "Francês 4", nas quais obteve excelente aproveitamento.

No ano de 2012, RA foi inscrita no Programa de Iniciação Científica da FFLCH, com o projeto "Produção escrita de FLE em foco: um estudo sobre o desenvolvimento das capacidades de linguagem por meio das atividades linguageiras relatar e expor", cujo objetivo era o estudo da produção escrita de alunos universitários implicados no aprendizado do francês como língua estrangeira, mais especificamente a escrita como instrumento de desenvolvimento das capacidades de linguagem. O estudo visou à reflexão sobre atividades de produção escrita de gêneros textuais que contribuam para o desenvolvimento dos alunos.

A orientadora de RA tem experiência nas áreas de desenvolvimento e formação de professores, elaboração de material didático baseado na noção de gênero textual e análise de textos e discursos. As suas pesquisas estão ligadas ao uso dos gêneros textuais na aprendizagem de língua materna e estrangeira (francês e inglês), à elaboração de material didático baseado no conceito de gênero textual, ao desenvolvimento de professores na perspectiva das ciências do trabalho e à análise dos discursos. Além disso, a orientadora da Estudante 3 tem diversas publicações na área de ensino e aprendizagem de línguas por meio do conceito de gêneros textuais, como "Gêneros textuais em foco: instrumentos para o desenvolvimento de alunos e professores" (2011); “A apropriação de gêneros textuais pelo professor: em direção ao desenvolvimento pessoal e à evolução do métier" (2010); "Produção Escrita em Francês como Segunda Língua: uma experiência baseada em gêneros textuais" (2009); "Utiliser les genres textuels dans une perspective actionnelle" (2009); além de orientações em nível de Mestrado e Iniciação Científica sobre essa temática.

Verifica-se um interesse pelo estudo do ensino e aprendizagem do Francês Língua Estrangeira, visto que RA participou de alguns eventos científicos sobre o assunto como 
“I Encontro sobre Ensino-aprendizagem do Centro de Línguas da FFLCH/USP”, no qual apresentou a comunicação "Desenvolvimento de capacidades de linguagem em atividades de produção escrita"; e participou dos eventos "V Journée de Formation: L'interculturel en action" e "VI Journée de Formation: L'évaluation dans les processus d'apprentissage", ambas ocorridas em 2012. No ano de 2013, ela participou da "VIII Journée de Formation: De l'écrit à l'oral'.

Desde 2012, é membro do grupo ALTER-AGE (Análise de Linguagem, Trabalho e suas Relações - Aprendizagem, Gêneros Textuais e Ensino).

As participantes acima descritas, tendo cumprido todas as exigências da IC, estavam em momentos distintos das suas pesquisas, sendo que as três estavam no término do desse processo, como pode ser melhor compreendido pela tabela a seguir:

\begin{tabular}{l|c|c|c} 
& Estudante 1 & Estudante 2 & Estudante 3 \\
\hline Início & set/12 & out/12 & ago/12 \\
\hline Término & jun/13 & nov/13 & jan/14 \\
\hline Duração & 9 meses & 12 meses & 6 meses \\
\hline
\end{tabular}

Tabela 2 - Duração das pesquisas de IC analisadas

\section{Procedimentos e Instrumentos de Coleta de dados}

Nesta seção, apresentaremos os procedimentos de solicitação de coleta dos dados, indicando os instrumentos utilizados para coletá-los e o tempo em que os dados foram obtidos. Os procedimentos foram:

3.1.) solicitação dos textos via e-mail

3.2.) aceite dos participantes e coleta dos textos: recebimentos dos textos solicitados 3.3.) realização das filmagens 


\subsection{Solicitação dos textos via e-mail}

A troca de e-mails se deu entre o pesquisador/orientadoras e pesquisador/estudantes.

Nosso primeiro contato para a coleta dos dados foi realizado com as três orientadoras envolvidas na pesquisa, pois era necessário lhes explicar o nosso objetivo de pesquisa, intentando buscar uma possível "ponte" entre o pesquisador e estudantes durante a realização do estudo. Tivemos êxito nesse procedimento, pois as professoras se mostraram muito solícitas e autorizam o contato com seus respectivos orientandos.

Os e-mails foram essenciais para a interlocução entre o pesquisador e os participantes da pesquisa, visto que a carregada rotina dos estudantes os impediria de participar de reuniões ou encontros presenciais para a entrega dos textos escritos. Os participantes da nossa pesquisa estavam no final da graduação em Letras e, por isso, alguns estavam realizando os estágios finais exigidos na Licenciatura em Letras ou tinham compromissos profissionais, em escolas de idiomas.

Tivemos cuidado na redação dos e-mails de pesquisa, buscando sempre justificar aos participantes o porquê do pedido dos textos escritos, segundo as etapas da pesquisa, a fim de que eles se sentissem realmente como participantes do estudo em realização.

Assim, iniciamos a coleta dos nossos dados no dia 22/08/2013 com o envio de um e-mail, preparado por mim e previamente lido pela orientadora desta pesquisa, aos docentes da Área de Estudos Linguísticos, Literários e Tradutológicos em francês, mais especificamente a oito professores das sub-áreas de Língua e Tradução, orientadores dos estudantes selecionados como participantes da nossa pesquisa. Abaixo, reproduzimos o e-mail:

Prezada Profa,

Em minha pesquisa de mestrado, sob orientação da Profa. Eliane Lousada, estou analisando alguns textos pertencentes a gêneros da esfera acadêmica e produzidos por alunos em Iniciação Científica. Visto que estou delimitando o corpus da pesquisa, gostaria de pedir seu consentimento para entrar em contato com os alunos de IC, [nomes dos dois estudantes], a fim de lhes perguntar se há interesse em participar da pesquisa, cedendo alguns textos escritos, como o projeto de pesquisa. Além disso, trabalharemos com textos orais em nossa pesquisa, por isso vou solicitar-lhes também a permissão para a filmagem de suas apresentações no V Encontro de Pesquisas do Francês. Em todos os procedimentos de nossa pesquisa que envolvam questões de imagem e identidade, 
utilizaremos um "termo de consentimento livre e esclarecido", que será explicado aos alunos antes da coleta dos dados.

Certo de sua ajuda, aguardo uma resposta.

Respeitosamente,

Thiago

Após o envio, recebemos no decorrer dos dias as repostas positivas das três docentes, orientadoras das três estudantes que participaram da nossa pesquisa, autorizando-nos a entrar em contato com seus orientandos para lhes solicitar ajuda durante a nossa pesquisa. As professoras, inclusive, muito gentilmente nos enviaram os textos dos alunos orientandos, até mesmo materiais de outros orientandos que, segundo elas, poderiam ajudar na pesquisa, como lido no e-mail a seguir:

Querido Thiago,

Desculpe a demora, mas aí estão as respostas e vc já deve ter recebido o monte de emails que encaminhei. Ainda tem o [nome de um outro estudante de IC orientado pela Profa.]. Vc quer tb os dados dele?

Acho que seria mais interessante você mandar esse questionário para os próprios alunos. Acho que eles terão todas as versões registradas, às vezes o orientador não registra tudo. Estou à disposição.

Consideramos importante o estabelecimento do contato com as professoras para que, primeiro, elas pudessem nos ajudar no contato e incentivo na participação dos seus orientandos; após esse primeiro procedimento, explicamos aos estudantes que as suas respectivas orientadoras estavam apoiando a participação deles em nossa pesquisa. Isso pode ser constatado no e-mail abaixo que fora enviado a todos os estudantes participantes do nosso estudo.

Prezado [nome do estudante], tudo bem?

Meu nome é Thiago Jorge Ferreira Santos, sou aluno de mestrado do francês, orientando da Profa. Eliane Lousada. Em minha pesquisa de mestrado, estou analisando alguns textos pertencentes a gêneros textuais da esfera acadêmica e produzidos por alunos em Iniciação Científica da área de francês. Visto que estou delimitando o corpus da pesquisa, gostaria de pedir sua ajuda para ser um dos participantes da minha pesquisa, 
juntamente com outros alunos da área. A ajuda é simples, e consiste em ceder os textos escritos, como o projeto de pesquisa e outros que ainda serão escritos futuramente, como os relatórios. Além disso, trabalharemos com textos orais em nossa pesquisa, por isso preciso da sua permissão para a filmagem da sua apresentação no $V$ Encontro de Pesquisas do Francês, na sexta-feira. Em todos os procedimentos de nossa pesquisa que envolvam questões de imagem e identidade, utilizaremos um "termo de consentimento livre e esclarecido", que vou explicar a você como funciona, assim que obtiver sua resposta.

Já entrei em contato com a sua orientadora e ela permitiu que eu entrasse em contato contigo, além de ter achado boa a ideia de você participar. Em seguida, envio a resposta da sua orientadora frente a minha solicitação.

Aguardo sua resposta,

Att,

Como é possível ler no e-mail acima, solicitamos tanto os textos escritos (projetos de pesquisa, resumos e relatórios de pesquisa) quanto a permissão para a filmagem da apresentação no V Encontro de Pesquisas do Francês que, como já informamos, foi realizado nos dias 29 e 30 de agosto de 2013 na FFLCH-USP.

\subsection{Coleta dos textos}

A coleta dos dados escritos foi sendo feita à medida que os alunos já tinham cumprido as exigências de datas para a entrega dos textos da pesquisa. Assim, no mês de agosto/2013, quando enviamos o e-mail acima aos orientadores, tínhamos os seguintes textos escritos enviados pelos próprios estudantes:

\begin{tabular}{l|c|c|c} 
& Estudante 1 & Estudante 2 & Estudante 3 \\
\begin{tabular}{l|c|c} 
Projeto de \\
pesquisa
\end{tabular} & $\checkmark$ & $\checkmark$ & $\checkmark$ \\
\hline $\begin{array}{l}\text { Relatório final de } \\
\text { pesquisa }\end{array}$ & $\checkmark$ & $\odot$ & $\diamond$ \\
\hline & & & \\
\hline
\end{tabular}

Após o V Encontro de Pesquisa em francês, tivemos, além dos textos escritos, os seguintes dados orais: 


\begin{tabular}{l|c|c|c} 
& Estudante 1 & Estudante 2 & Estudante 3 \\
\hline $\begin{array}{l}\text { Projeto de } \\
\text { pesquisa }\end{array}$ & $\checkmark$ & $\checkmark$ & $\checkmark$ \\
\hline $\begin{array}{l}\text { Resumo da } \\
\text { apresentação } \\
\text { oral }\end{array}$ & $\checkmark$ & $\checkmark$ & $\checkmark$ \\
\hline $\begin{array}{l}\text { Apresentação } \\
\text { oral de pesquisa }\end{array}$ & $\checkmark$ & $\checkmark$ & $\checkmark$ \\
\hline $\begin{array}{l}\text { Relatório final de } \\
\text { pesquisa }\end{array}$ & $\checkmark$ & $Q$ & $\otimes$ \\
\hline
\end{tabular}

Tabela 4 - recolha dos dados orais

Como podemos perceber na tabela acima, até o evento não tínhamos o relatório final da Estudante 2, pois o término da sua pesquisa e a entrega do relatório estava previstos para Nov/2013. Assim, LM nos enviou o seu relatório final no mês de Dez/2013 e também uma outra versão ainda não comentada pela orientadora. Em Jan/14, foi coletado o relatório final da Estudante 3.

\subsection{Filmagem das apresentações em $2013^{22}$}

Em relação à parte técnica das filmagens, preocupamo-nos em utilizar um aparelho de filmagem que fosse de grande qualidade de áudio, embora o vídeo propriamente não fosse objeto de nossas análises, senão os dados orais obtidos a partir deles. No levantamento realizado por Massi (2008) sobre pesquisas que tiveram a IC como foco de 1998 a 2004 e o nosso próprio de 2005 a 2013, descritos na Introdução, não foram encontrados estudos que tivessem procedido em filmagens de apresentações orais e a posterior transcrição de apresentações orais produzidas pelos estudantes.

De nossa parte, era essencial que garantíssemos a melhor qualidade possível de áudio, a fim de obtermos bons dados orais para a posterior transcrição. Assim, foi-nos disponibilizada uma câmera digital de alta qualidade pela coordenação dos cursos extracurriculares de francês que utilizam esse equipamento para pesquisas em formação de professores de língua francesa.

\footnotetext{
${ }^{22}$ Para obtermos as trasncrições das apresentações, necessitamos primeiramente de filmá-las, por isso consideramos importante descrevermos os procedimentos das filmagens.
} 
Decidimos também que o pesquisador filmaria as apresentações orais, pois, no momento anterior à apresentação, ele daria explicações básicas aos estudantes com relação à pesquisa e aos objetivos com a filmagem. Além disso, ressaltamos que os estudantes não tinham experiência em apresentar oralmente as suas pesquisas diante de um público e de um pesquisador experiente, logo concluímos que, se uma outra pessoa fizesse as filmagens, poderia inibir a desenvoltura dos estudantes que estavam em uma situação de tensão.

As apresentações foram filmadas no dia 30 de agosto de 2013, na sexta-feira em que ocorreu o V Encontro de Pesquisas do francês. Cada apresentação, assim como indicado pela Comissão Organizadora dos eventos, poderia ser apresentada em até 15 minutos, sendo que o mediador da sessão escolheria se a discussão seria feita logo após cada apresentação ou nos 20 minutos finais da sessão. Abaixo, descrevemos melhor esses dados:

\begin{tabular}{c|c|c|c} 
& $\begin{array}{c}\text { Data da } \\
\text { fimagem }\end{array}$ & $\begin{array}{c}\text { Horário da } \\
\text { sessão }\end{array}$ & Tempo de filmagem \\
\hline Estudante 1 & $30 / 08 / 2013$ & $11 \mathrm{~h}-12 \mathrm{~h} 30$ & $13^{\prime} 42^{\prime \prime}$ \\
\hline Estudante 2 & $30 / 08 / 2013$ & $17 \mathrm{~h}-18 \mathrm{~h} 30$ & $20^{\prime}$ \\
\hline Estudante 3 & $30 / 08 / 2013$ & $17 \mathrm{~h}-18 \mathrm{~h} 30$ & $16^{\prime} 10^{\prime \prime}$ \\
\hline
\end{tabular}

Tabela 6 - Data, horários e duração da filmagem

O responsável pelas filmagens posicionou-se de modo a focalizar a tela do datashow e as apresentadoras, estes posicionados ao lado da mesa do professor. Durante as filmagens, é possível visualizar outros participantes da sessão de comunicação, sobretudo os pesquisadores-mediadores, que se sentaram à frente, na posição em destaque aposta aos apresentadores, como vemos no posicionamento do desenho da sala de aula abaixo ${ }^{23}$ :

${ }^{23}$ Desenho baseado em Lousada (2006). 


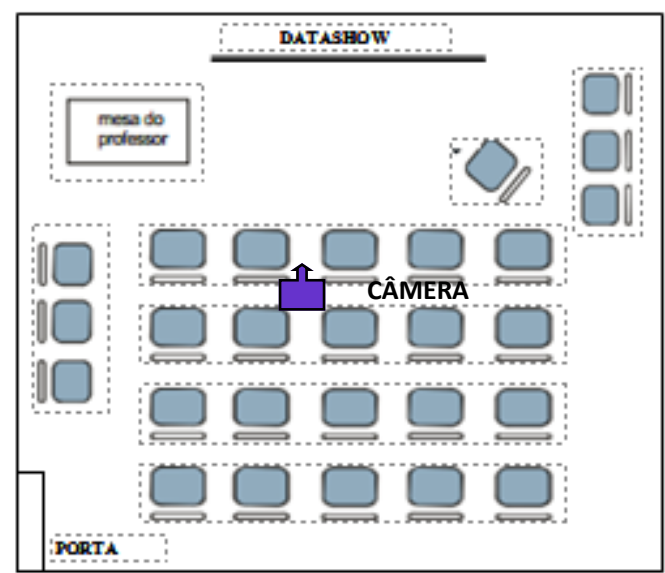

Figura 6: Disposição dos participantes da pesquisa no momento da filmagem.

\section{4) Confiabilidade dos dados}

Abaixo, buscararemos explicar a validação dos dados em relação ao contexto de pesquisa e os procedimentos éticos adotados.

\section{1) Validação em relação ao contexto de pesquisa}

Mesmo pelo fato de o pesquisador já ter sido estudante de IC no mesmo contexto de pesquisa, podemos afirmar que isso não invalida a pesquisa realizada. Durante o processo da IC, os estudantes não analisam empiricamente os próprios textos produzidos durante a pesquisa, por isso acreditamos que não há por parte dos estudantes no momento de desenvolvimento de uma primeira pesquisa científica uma consciência do percurso iniciado na redação do projeto de pesquisa. Enquanto ex-orientando de IC no mesmo contexto, eu cumpria as etapas e o cronograma da pesquisa sem uma análise mais criteriosa desse percurso e, na verdade, seria muito difícil fazê-lo, dado que os próprios gêneros textuais exigidos na pesquisa científica estão sendo apropriados pelos estudantes que nunca outrora escreveram projetos e relatórios de pesquisa e nem fizeram uma apresentação oral de pesquisa.

Ademais, os estudantes e seus orientadores não realizam filmagens das apresentações orais de pesquisa para uma posterior análise do processo de IC buscando relações entre a apropriação dos saberes e o uso da linguagem. 
Em suma, o fato de o pesquisador conhecer o contexto de pesquisa foi importante para que os orientadores fossem mais solícitos quanto ao pedido de ajuda na interlocução com os estudantes, uma vez que eles sabiam que a pesquisa seria realizada com seriedade e cientificidade. Nesse sentido, tivemos o total consentimento dos pesquisadores-mediadores das sessões de comunicação que também são docentes da Área em Estudos Linguísticos, Literários e Tradutológicos em francês da FFLCH-USP, para efetuarmos as filmagens nas sessões que eles coordenaram durante o V Encontro de Pesquisas do Francês.

\subsection{Procedimentos éticos}

Como já explicado, foi pedido primeiramente o consentimento das orientadoras, depois dos estudantes e dos pesquisadores-mediadores das sessões em que os graduandos se apresentaram no V e VI Encontro de Pesquisas do Francês, além dos outros alunos por intermédio dos pesquisadores que mediaram as sessões de comunicação, ainda que não utilizássemos as imagens e nem os dados orais desses alunos.

A Universidade de São Paulo não conta com uma Comissão de Ética para a Área de Ciências Humanas, de modo que, embora fosse de nossa vontade, não tivemos que entregar nenhum documento referente à pesquisa para a Universidade. Entretanto, intentando realizar a pesquisa de modo mais seguro e confiável, utilizamos o "termo de consentimento livre e esclarecido" que foi assinado pelas três estudantes que filmamos, logo temos a suas autorizações para trabalharmos tanto com as imagens quanto com os dados orais. Esses documentos estão de posse do pesquisador.

\section{5) Procedimentos de Seleção de dados}

Nesta seção, exporemos os critérios que escolhemos para a seleção dos dados coletados, com relação à seleção dos gêneros textuais que analisaremos e a prescrição da Comissão de Pesquisa da FFLCH e da FAPESP quanto à produção dos textos para a pesquisa. 


\subsection{Os gêneros textuais exigidos no processo de Iniciação Científica}

Como objetivamos nesta pesquisa estudar a IC enquanto uma prática que prepara para a participação na esfera científica, selecionamos os textos pertencentes a alguns gêneros textuais que são produzidos nesse contexto. Especificamente no nosso caso, a IC é regulada burocraticamente pela Comissão de Pesquisa (Cpq) da FFLCH-USP, particularmente por meio do Programa de Iniciação Científica, onde são estabelecidas as regras para a inscrição da IC e as datas de entrega dos textos, informações divulgadas no site da Cpq. Por meio de um edital, são topicalizados os procedimentos necessários para a inscrição na IC e também os deveres dos orientandos e orientadores durante a inscrição no Programa. Dentre esses deveres incluem-se os textos que devem ser entregues. Abaixo, mostraremos a exigência do primeiro texto solicitado aos estudantes para a inscrição:

I. Histórico Escolar completo e atualizado do aluno incluindo as reprovações, se houver;

II. No caso de reprovações no histórico, anexar justificativa;

III. Currículo Lattes do aluno;

IV. Cópia do termo de outorga dos itens preenchidos em Indicadores de Atividade de Pesquisa constante no questionário do Sistema, nas questões referentes a projetos de pesquisa Temático, Milênio, Individual etc. Para serem válidos, os indicadores devem estar vigentes em 30 de junho de 2013;

V. Projeto Resumido de Pesquisa (máximo de 3 páginas, excluindo-se a capa e contendo: Introdução, Objetivo, Metodologia e Referências). O projeto pode ser individual do aluno ou, se pertencer a um projeto maior, tipo temático, o orientador deverá definir exatamente a atividade a ser desenvolvida pelo aluno;

VI. Atualização de todos os dados pessoais do aluno no Sistema Júpiter;

VII. No caso de pedido de renovação, deverá ser anexado o relatório parcial;

VIII. Todos os arquivos devem ser anexados pelo orientador no sistema Atena em "PDF".

Figura 7 - Indicação da escrita do Projeto de Pesquisa no edital da IC

O mesmo edital explicita aos alunos os dois outros gêneros textuais (relatório de pesquisa e a apresentação oral de pesquisa) que eles se comprometem a entregar nos prazos estabelecidos: 


\subsection{Compromissos}

I. No momento da atribuição da bolsa de Iniciação Científica, não estar recebendo bolsa de outros programas do CNPq, da USP ou de outras agências de fomento;

II. Apresentar sua produção científica, sob a forma de pôster ou apresentação oral, no Simpósio Internacional de Iniciação Científica - SIICUSP:

III. Nas publicaçôes e trabalhos apresentados, fazer referência à condição de bolsista do CNPq, Institucional ou Santander;

IV. Apresentar relatório de atividades, parcial (após 6 meses de Bolsa) e final (após 12 meses de Bolsa);

V. Devolver ao CNPq, ou à Pró-Reitoria de Pesquisa, ou ao Santander, em valores atualizados, a(s) mensalidade(s) recebida(s) indevidamente, caso os requisitos e compromissos estabelecidos na $\mathrm{RN} 017 / 2006 \mathrm{CNPq}$ e acima não sejam cumpridos.

Figura 8: Indicação da escrita dos Relatórios de Pesquisa e da apresentação oral no edital da IC

A respeito do relatório final, o edital estipula qual o formato que esses textos devem ser entregues:
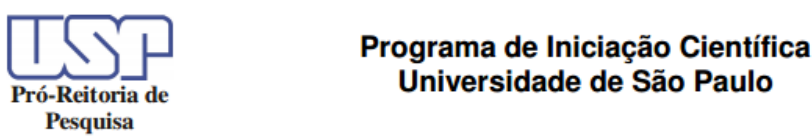

11. Relatórios

I. Os relatórios parcial e final devem contemplar:

- Introdução;

- Objetivos;

- Metodologia;

- Resultados parciais ou finais;

- Análises;

- Conclusões parciais ou finais;

- Referências;

- Avaliação do Orientador.

Figura 9 - Instruções para a escrita do Relatório de pesquisa no edital da IC

Diante dessas exigências impostas pelo edital, selecionamos inicialmente para a nossa pesquisa os textos que seguiram essas diretrizes e a todas as demais exigências burocráticas do Programa de Iniciação Científica da USP: projeto de pesquisa, resumo para a apresentação oral, a apresentação oral propriamente e o relatório final de pesquisa.

A participante BT não estava inscrita no Programa de Iniciação Científica da USP, posto que era bolsista da Fundação de Amparo à Pesquisado do Estado de São Paulo 
(FAPESP) e, por isso, não é necessária a inscrição formal na Universidade, senão na agência de fomento, como explicado no site da Cpq:

\section{FAPESP}

As bolsas de Iniciação Científica devem ser propostas pelo orientador diretamente à entidade. A solicitação deve ser encaminhada em formulário próprio em qualquer época do ano. O prazo de análise é de aproximadamente 75 dias. Todas as informações acerca dessa modalidade de bolsa podem ser obtidas no endereço http://www.fapesp.br

Figura 10: Informações aos bolsistas FAPESP no site da Cpq-FFLCH

Assim, fomos verificar se, igualmente à Cpq, a FAPESP fornece informações a respeito dos textos que os estudantes devem entregar durante o desenvolvimento da pesquisa. No site da instituição encontramos as seguintes informações:

a) Quanto ao projeto de pesquisa: ${ }^{24}$

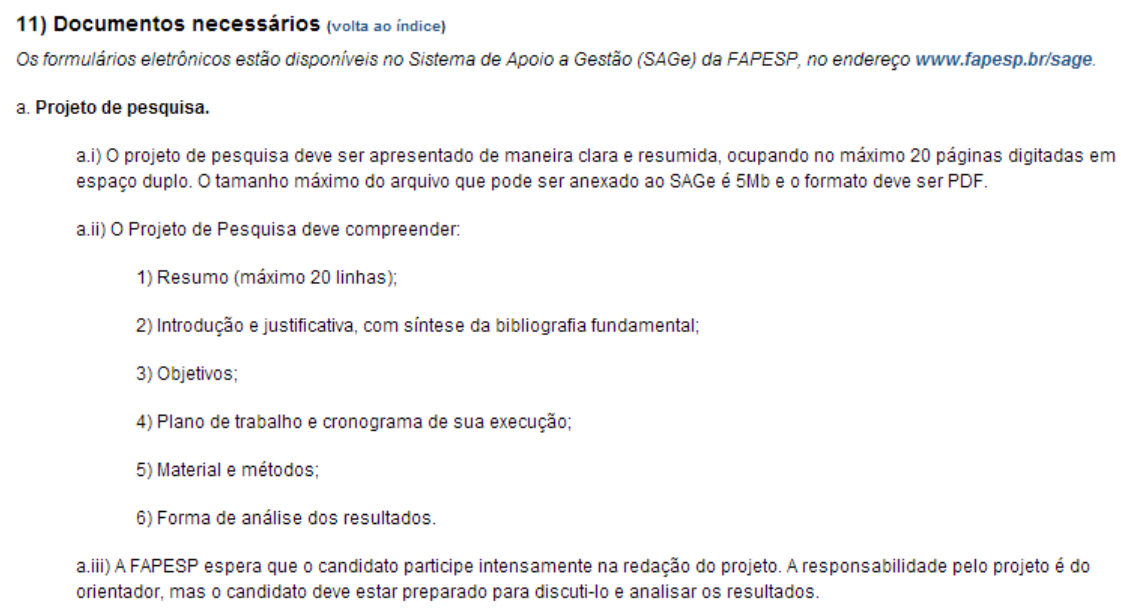

Figura 11 - Indicações para a escrita do Projeto de Pesquisa no site da FAPESP

b) Quanto ao relatório final ${ }^{25}$ :

\section{5) Relatórios (volta ao índice)}

Devem ser elaborados dois relatórios científicos durante a vigência da bolsa, sendo um Relatório Científico de Progresso no sexto mês e um Relatório Científico Final, no décimo dia do mês subseqüente ao término.

${ }^{24} \mathrm{http}: / /$ www.fapesp.br/248

${ }^{25} \mathrm{http}: / /$ www.fapesp.br/248\#258 
Figura 12 - Sobre a escrita do Relatório de Pesquisa no site da FAPESP

Logo, percebemos que as exigências tanto da Cpq-FFLCH quanto da FAPESP são parecidas em relação às diretrizes sobre os textos escritos a serem produzidos pelos estudantes no decorrer da pesquisa.

c) Quanto à apresentação oral: a FAPESP não exige que os bolsistas apresentem oralmente as suas pesquisas em um evento científico, embora lhes disponibilize uma reserva técnica pela qual eles podem, se quiserem, usá-la para arcar custos na participação em eventos acadêmicos. Por esse motivo, procuramos verificar em qual outro evento a aluna BT apresentaria oralmente sua pesquisa, já que a Estudante 1 não precisaria apresentar sua pesquisa no SIICUSP como exigência da Universidade de São Paulo. Foi assim que escolhemos o Encontro de Pesquisas do Francês como local para a filmagem das apresentações orais, já que, em princípio, todos os alunos apresentariam suas pesquisas nesse Encontro.

Percebemos, portanto, as semelhanças entre as exigências do Programa de Iniciação Científica da USP e aquelas da FAPESP, sendo que a única diferença está na exigência da apresentação oral, solicitada pela USP, mas não pela agência de fomento, de modo que adequamos essa diferença pela escolha da coleta da apresentação oral durante o Encontro de Pesquisas do Francês, evento em que todos os participantes fariam comunicação oral, já que todos são orientados por pesquisadores da Área de Estudos Linguísticos, Literários e Tradutológicos em francês, em lugar do SIICUSP.

Como já enfatizamos na introdução desta pesquisa, mesmo que IC já tenha sido estudada vários cursos de ensino superior, em diversas pesquisas científicas, não encontramos pesquisas que tivessem a preocupação em considerar todo o percurso da IC, enfocando a questão do desenvolvimento do aluno-pesquisador.

\section{Categorias e método de análise dos dados}

Como mencionamos em nossa Fundamentação teórica, a base epistemológica da nossa pesquisa advém do Interacionismo sociodiscursivo, sobretudo os conceitos de 
atividade de linguagem e gêneros textuais. Dessa vertente teórica também utilizamos o método de análise textual e discursiva proposta por Bronckart (1999). Dentre os elementos do folhado textual, consideramos importantes os conceitos de contexto de produção, tipos de discurso, mecanismos de textualização e enunciativos.

\subsection{Categorias de análise}

A partir de Bronckart (1999), primeiramente, o produtor do texto deverá ter em vista o quadro contextual, devendo refletir na situação de ação de linguagem em que ele está inscrito, no contexto de produção e no conjunto de informações, conhecimentos que quer apresentar, ou seja, o "assunto" que o agente produtor quer produzir. Depois, analisa-se a macro-estrutura textual por meio da descrição do plano global do conteúdo temático do texto e os tipos de discurso. Esses três elementos de análise fazem parte da infra-estrutura do texto. Em seguida, analisamos a micro-estrutura do texto por meio dos mecanismos de textualização (que confere coerência temática ao texto) e os mecanismos enunciativos (que confere coerência pragmática ao texto).

Assim, teríamos a seguinte categorização:

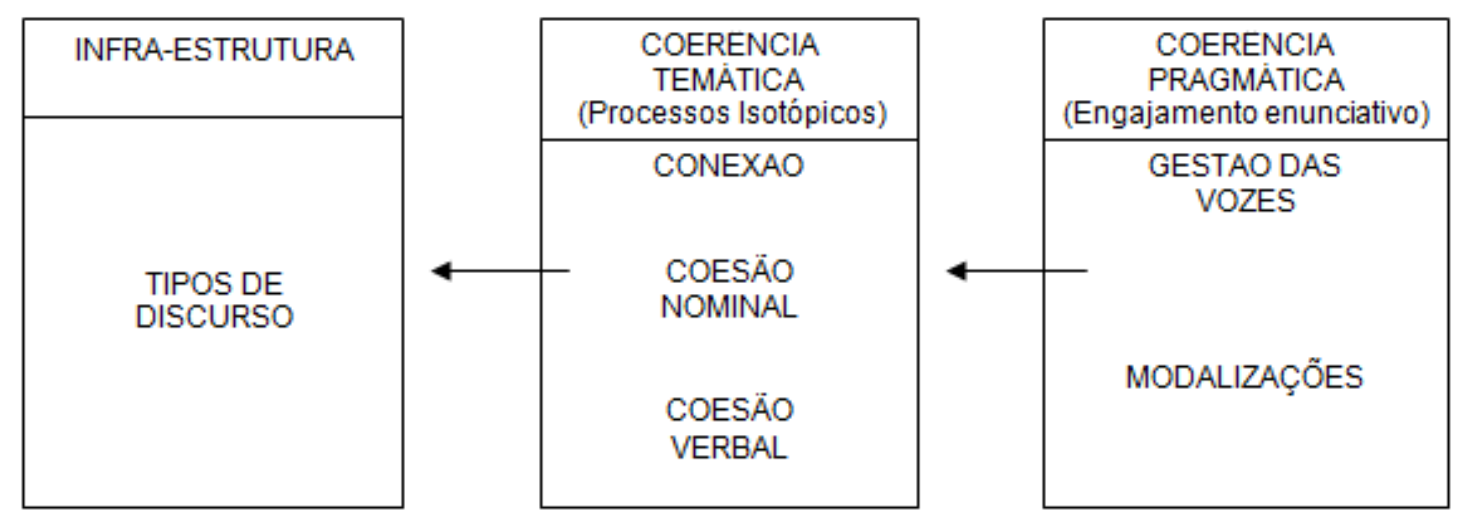

Figura 13 - Análise linguístico-discursiva segundo o ISD (BRONCKART, 2006).

A análise textual e discursiva proposta pelo ISD deve ser iniciada pelo contexto de produção, pois todo texto é oriundo de uma prática social, na qual os indivíduos se organizam para o desenvolvimento de ações tendo em vista uma finalidade. Assim, analisa-se a esfera da atividade humana e o contexto social mais amplo e específico, 
demarcando quais os papéis sociais do enunciador e do destinatário da ação de linguagem, bem como o momento temporal em que o texto foi produzido.

As práticas sociais são mediadas pelo uso de determinado gênero textual, os quais contêm certa estabilidade estrutural; de modo que os textos são organizados de acordo com o conteúdo temático mobilizado. No caso da Iniciação Científica, tal como desenvolvida em nosso contexto de pesquisa, os estudantes devem produzir textos de quatro gêneros textuais diferentes: o projeto de pesquisa, o resumo e a apresentação oral de pesquisa e relatório final. Nesses gêneros, os estudantes devem organizar os conteúdos temáticos da pesquisa. Abaixo, descreveremos os passos que seguiremos para a análise dos textos:

a) Analisaremos a organização textual dos gêneros exigidos na Iniciação Científica e os conteúdos temáticos veiculados por eles, procurando comparar a organização textual e os conteúdos temáticos segundo o que é estabelecido por outros autores sobre os conteúdos temáticos esperados nesses gêneros. Desse modo, estaremos iniciando a nossa análise da infraestrutura geral dos textos por meio do cotejo entre os gêneros textuais produzidos e os conteúdos temáticos veiculados pelas três estudantes ao longo da IC e o que especialistas dizem sobre os conteúdos que devem ser veiculados nesses gêneros. A seguir, descreveremos a organização estrutural esperada dos quatro gêneros textuais a partir de estudos científicos sobre gêneros acadêmicos.

\section{Gênero 1: Projeto de pesquisa}

Conteúdos temáticos identificados a partir dos estudos de: MACHADO, LOUSADA, ABREU-TARDELLI, 2005; MOTTA-ROTH, HENDGES, 2010

- Problemas, hipóteses e perguntas

- Justificativa

- Objetivo geral e objetivo específico

- Síntese da literatura relevante

- Metodologia

- Resultados/impactos esperados

- Cronograma

- Orçamento

- Bibliografia

Quadro 8: Conteúdo temático esperado no gênero projeto de pesquisa

\section{Gênero 2: Resumo}

Conteúdos temáticos identificados a partir dos estudos de: MACHADO, LOUSADA, ABREU-TARDELLI, 2004; MOTTA-ROTH, HENDGES, 2010 
- Apresentar a pesquisa

- Descrever a metodologia

- Sumarizar os resultados

- Discutir a pesquisa

Quadro 9: Conteúdo temático esperado no gênero resumo

\section{Gênero 3: Apresentação oral de pesquisa}

Conteúdos temáticos identificados a partir dos estudos de: DOLZ, SCHNEUWLY, 2004

Fase pré-expositiva

Hierarquização das informações

Ordenação das fases da exposição:

- Abertura

- Tomada de palavra

- Apresentação do plano da exposição

- Desenvolvimento do tema

- Recapitulação e síntese

- Conclusão

- Encerramento

Quadro 10: Conteúdo temático esperado no gênero apresentação oral

\section{Gênero 4: Relatório de pesquisa}

Conteúdos temáticos identificados a partir dos estudos de: RODRIGUES, 2008; SILVA, SILVA, 2010

- Introduzir o estudo

- Revisar literatura

- Descrever a metodologia

- Apresentar e discutir dados

- Concluir o relatório

Quadro 11: Conteúdo temático esperado no gênero relatório

b) Após as análises do contexto de produção e do plano global dos conteúdos temáticos, passaremos a analisar os quatro tipos de discurso, assim como definidos por Bronckart (1999): 


\begin{tabular}{|c|c|c|c|}
\hline & & \multicolumn{2}{|c|}{ Coordenadas gerais dos mundos } \\
\hline & & $\begin{array}{c}\text { Conjunção } \\
\text { EXPOR }\end{array}$ & $\begin{array}{l}\text { Disjunção } \\
\text { NARRAR }\end{array}$ \\
\hline \multirow{2}{*}{$\begin{array}{l}\text { Relação ao ato de } \\
\text { produção }\end{array}$} & Implicação & Discurso interativo & Relato interativo \\
\hline & Autonomia & Discurso teórico & Narração \\
\hline
\end{tabular}

Figura 14 - Os quatro tipos de discurso

$\mathrm{Na}$ análise dos tipos de discurso, consideraremos os sentidos atribuídos aos momentos de conjunção e disjunção da linguagem (Weinrich, 1983), e também a passagem de um tipo de discurso para outro, objetivando buscar índices que possam nos auxiliar na reflexão acerca do desenvolvimento do aluno-pesquisador.

c) Inciaremos nossas análises dos mecanismos de textualização, verificando a organização do fluxo informacional de um texto. Assim, os aspectos relevantes nesse sistema para Bronckart (1999), e que serão utilizados em nossas análises, são:

\section{- Conexão}

Para analisarmos os elementos de conexão dos textos escritos (projeto de pesquisa, resumo para apresentação oral e relatório de pesquisa), utilizaremos os estudos de Bronckart (1999), buscando relacionar a construção dos períodos e o momento da pesquisa na duração da IC, para relacionarmos posteriormente com o desenvolvimento do aluno-pesquisador. Já para a análise dos mecanismos de conexão do texto oral (apresentação oral de pesquisa), consideramos os estudos de Rodrigues (2003) na identificação dos marcadores conversacionais e das hesitações, que marcam a mudança tópica do texto.

\section{- Coesão nominal}

Nas análises da coesão nominal, analisaremos, assim como já feito por Lousada (2010), a construção das cadeias nominais, sobretudo aquelas que contêm sintagmas nominais, 
objetivando buscar os poscionamentos das estudantes que, na nossa pesquisa, podem ser índices que nos apontem para um possível desenvolvimento do aluno-pesquisador.

- Coesão verbal articulada

Será analisada juntamente com os tipos de discurso, assim como proposto por Bronckart (2008b), ou seja, junto com item b).

d) Depois, passaremos para os mecanismos enunciativos, analisando o estatuto dialógico dos textos por meio das vozes e modalizações. Nas análises das vozes, buscaremos identificar a voz do estudante e a voz do pesquisador, bem como a passagem da primeira para a segunda. Para isso, consideraremos:

- O uso de alguns tipos de discurso (BRONCKART, 1999) em partes específicas dos gêneros produzidos.

- O emprego autonímico de algumas palavras (AUTHIER-REVUZ, 1999;

MAINGUENEAU, 2008).

- O discurso direto ou indireto (MAINGUENEAU, 2008)

- As ilhas textuais (MAINGUENEAU, 2008).

Já nas análises das modalizações, buscaremos identicar as quatro modalizações propostas do Bronckart (1999):

- Modalização lógica

- Modalização apreciativa

- Modalização deôntica

- Modalização pragmática

Sendo além desses quatro tipos de modalização, utilizaremos também como categoria para a análise dos mecanismos enunciativos a noção de modalização 
autonímica proposta por Authier-Revuz (1999) e retomada por Maingueneau (2008). Os modalizadores encontrados serão analisados, buscando identificar quais as vozes responsáveis pelas avaliações expressas por eles.

Através das categorias dos mecanismos enunciativos, poderemos ver, ao longo das análises dos gêneros produzidos, como o aluno se torna pesquisador. Porém, essa mudança de aluno para pesquisador também poderá ser observada, de maneira mais sutil, por meio das outras categorias de análise, como os tipos de discurso e a coesão nominal.

\subsection{Categorias de análise e perguntas de pesquisa}

Como indicamos na introdução, formulamos três questões de pesquisa a que buscaremos responder ao longo desta dissertação.

1) Houve desenvolvimento dos alunos particpantes da pesquisa durante o processo de IC?

2) Quais marcas linguístico-discursivas presentes nos textos produzidos durante o processo de IC (projeto de pesquisa, resumo para apresentação, apresentação oral de pesquisa e relatório final) permitem depreender esse desenvolvimento?

3) Qual o papel dos gêneros textuais produzidos durante o processo da IC nesse desenvolvimento?

Para melhor explicar os textos que utilizaremos para nossas análises e as categorias de que nos serviremos, propomos o quadro abaixo: 


\begin{tabular}{|c|c|c|}
\hline $\begin{array}{l}\text { Perguntas de pesquisa } \\
\text { 1) Houve desenvolvimento } \\
\text { dos alunos participantes da } \\
\text { pesquisa durante o processo } \\
\text { de IC? }\end{array}$ & $\begin{array}{l}\text { Textos analisados } \\
\text { - Projeto de pesquisa } \\
\text { - Relatório final de } \\
\text { pesquisa } \\
\text { - Resumo para } \\
\text { apresentação oral } \\
\text { - Apresentação oral de } \\
\text { pesquisa }\end{array}$ & $\begin{array}{l}\text { Categorias de análise } \\
\text { a) organização dos conteúdos } \\
\text { temáticos } \\
\text { b) tipos de discurso } \\
\text { c) conexão, coesão nominal e } \\
\text { verbal } \\
\text { d) vozes e modalizações } \\
\text { Após essas análises, } \\
\text { buscaremos relacioná-las com } \\
\text { a noção de conceito científico } \\
\text { (VIGOTSKI, 2009) e de } \\
\text { instrumento psicológico } \\
\text { (FRIEDRICH, 2012). }\end{array}$ \\
\hline $\begin{array}{l}\text { 2) Quais marcas } \\
\text { linguístico-discursivas } \\
\text { presentes nos textos } \\
\text { produzidos durante o processo } \\
\text { de IC (projeto de pesquisa, } \\
\text { resumo para apresentação, } \\
\text { apresentação oral de pesquisa } \\
\text { e relatório final) permitem } \\
\text { depreender } \\
\text { desenvolvimento? }\end{array}$ & $\begin{array}{l}\text { - Projeto de pesquisa } \\
\text { - Relatório final de } \\
\text { pesquisa } \\
\text { - Resumo para } \\
\text { apresentação oral } \\
\text { - Apresentação oral de } \\
\text { pesquisa }\end{array}$ & $\begin{array}{l}\text { a) organização dos conteúdos } \\
\text { temáticos } \\
\text { b) tipos de discurso } \\
\text { c) conexão, coesão nominal e } \\
\text { verbal } \\
\text { d) vozes e modalizações }\end{array}$ \\
\hline $\begin{array}{l}\text { 3) Qual o papel dos gêneros } \\
\text { textuais produzidos durante o } \\
\text { processo da IC nesse } \\
\text { desenvolvimento? }\end{array}$ & $\begin{array}{l}\text { - Projeto de pesquisa } \\
\text { - Relatório final de } \\
\text { pesquisa } \\
\text { - Resumo para } \\
\text { apresentação oral } \\
\text { - Apresentação oral de } \\
\text { pesquisa }\end{array}$ & $\begin{array}{l}\text { a) organização dos conteúdos } \\
\text { temáticos } \\
\text { b) tipos de discurso } \\
\text { c) conexão, coesão nominal e } \\
\text { verbal } \\
\text { d) vozes e modalizações } \\
\text { Discutiremos essa pergunta } \\
\text { utizando a noção de restrição } \\
\text { sistema da linguagem } \\
\text { (BRONCKART, 2008b; } \\
\text { BOTA, 2011). }\end{array}$ \\
\hline
\end{tabular}

Quadro 12: Perguntas da pesquisa, textos de análise e categorias utilizadas 


\section{Resultados das análises}

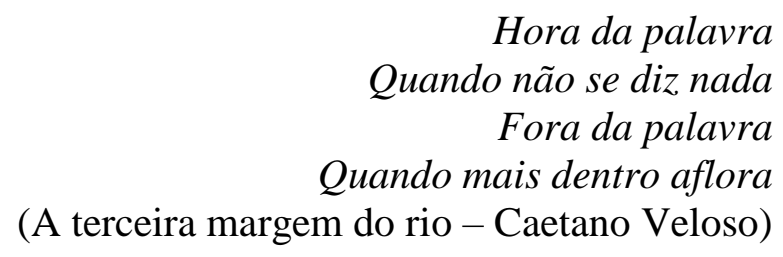

\section{Projeto de Pesquisa}

Como apresentado no capítulo anterior, iniciaremos nossas análises dos projetos de pesquisa por meio do contexto de produção textual e, em seguida, do plano glabal do conteúdo temático e dos tipos de discurso associados à coesão verbal. Depois, analisaremos os mecanismos de textuzaliação por meio das conexões encontradas e da coesão nominal criada nos textos. Por último, mostraremos nossos resultados quanto às análises das vozes e das modalizações.

\subsection{Contexto de produção dos projetos de pesquisa}

Os projetos de pesquisa foram produzidos tendo como lugar social a Faculdade de Filosofia, Letras e Ciências Humanas da USP, que tem um Programa de Iniciação Científica (IC), gerido pela Comissão de Pesquisa (Cpq/FFLCH), instância que estabelece as datas da inscrição dos projetos, da apresentação dos relatórios, além de fazer a distribuição das bolsas e todos os trâmites burocráticos da pesquisa de IC.

Para a escrita do projeto de pesquisa, os alunos têm instruções sobre a sua estrutura composicional, contidas no edital de inscrição.

Os projetos que analisamos foram produzidos por alunas da graduação em Letras da FFLCH/USP, mais especificamente alunas do Bacharelado em Língua Francesa e Língua Portuguesa. Essas alunas são interessadas, sobretudo, nas questões relativas ao ensino do Francês Língua Estrangeira (FLE) e na análise de textos, seja literário ou de tradução. As estudantes tinham versões dos projetos de pesquisa mas, quando da sua primeira versão, elas nunca tiveram contato com essa prática textual. 
Os destinatários primeiros dos projetos analisados foram as orintadoras, professoras doutoras. Os alunos ajustaram os projetos, que foram padronizados de acordo com as instruções da Cpq/FFLCH. Após algumas versões, os projetos foram submetidos à avaliação pela Cpq.

O projeto de pesquisa, como explicamos acima, é pré-requisito para a inscrição formal do aluno no Programa de Iniciação Científica da USP, a fim de desenvolver um estudo científico e, ao final, receber um certificado de conclusão da pesquisa, caso essa seja aprovada pelas orientadoras. Além disso, o projeto é essencial para pleitear uma bolsa de pesquisa do CNPq, da FFLCH ou da Reitoria da USP.

\subsection{Plano global do conteúdo temático}

Ao entrar na graduação, os estudantes empreendem uma aprendizagem de saberes através das disciplinas curriculares (BREGLIA, 2013). Nesse espaço, a Iniciação Científica pode ser a primeira experiência de atividade científica do estudante universitário, podendo ser um diferencial positivo para o aluno nos âmbitos acadêmico, pessoal e profissional (BRIDI, 2004). Porém, ao se analisar o processo de IC, quais seriam as peculiaridades da entrada dos estudantes nessa atividade?

Por meio das nossas análises dos planos globais dos conteúdos temáticos dos projetos de pesquisa, constatamos que, em todos eles, há uma ideia central pela qual são produzidos. Por meio das análises, percebemos que essa ideia central revela a relação que há entre a esfera universitária e a esfera científica no início de uma primeira pesquisa, ou seja, é a experiência em meio universitário que propiciará a motivação para a formulação de um projeto. Em nossos pressupostos teóricos, mostramos que na teoria vigotskiana, todo conceito, seja ele cotidiano ou científico, apóia-se em uma experiência prática no mundo (FRIEDRICH, 2013, p. 100); assim, a pesquisa de IC é motivada pela experiência do estudante em meio universitário. Realizando um estudo por meio de análises das primeiras versões de projetos escritos por estudantes de Iniciação Científica, na área de Letras e Linguística, verificamos (LOUSADA; SANTOS, 2014) que a motivação da pesquisa em IC advém de uma dificuldade que os estudantes encontram durante a graduação ou de um interesse particular despertado nas disciplinas curriculares do curso. Como já explicamos na Fundamentação teórica, todo pensamento tem como origem uma 
motivação, que engloba nossos impulsos, necessidades, e interesses (Vigotski, 2009). Também Schneuwly (1989), como mostramos na figura 5, aponta a esfera motivante e emocional como a primeira fase de qualquer pensamento. Justamente, como analisaremos a seguir, em nossas análises dos planos globais dos conteúdos temáticos dos três projetos de pesquisa encontramos esses mesmos resultados que se aproximam da posição de Vigotski (2009).

\section{Estudante 1}

Objetivaremos evidenciar as ideias centrais construídas textualmente pela estudante no seu projeto de pesquisa. Essas ideias se referem ao fato de Carlos Drummond de Andrade abordar temas brasileiros, que tocam à cultura brasileira, mas que, por suas abrangências, podem ser discutidos e pensados em outras culturas. Assim, mostraremos como essas duas ideias estão desenvolvidas durante as seções do projeto de pesquisa.

$\mathrm{Na}$ seção introdutória, cuja função é, de acordo com Machado, Lousada, Abreu-Tardelli (2005) e Motta-Roth, Hendges (2010), situar o leitor na temática da pesquisa, há algumas considerações feitas pela Estudante 1 a respeito do modo como a poesia de Drummond pode ser interpretada se aproximada das questões vividas no Brasil na primeira metade do século XX. Como exposto no excerto abaixo, entre os acontecimentos importantes do país naquela época, a estudante destaca a influência das propostas da Semana de Arte Moderna que foi assimilada pelo poeta mineiro, no que tange às métricas escolhidas por ele para suas poesias e aos conteúdos dos seus textos poéticos, que demonstram as preocupações sociais do Brasil naquela época. Vejamos um excerto da Introdução do projeto de pesquisa:

(1) No que se refere ao Brasil, a ditadura que se inicia em 1964 também é fator importante em sua poesia. Quanto às características estéticas do poeta, a grande influência modernista oriunda do Movimento de 1922 faz-se notar nos versos escritos por Drummond - em sua grande maioria, não são compostos em métrica pré-definida, sendo alguns poemas definidos como "poemas em prosa", ou "prosa poética", típicos do movimento que rompeu com as regras clássicas da literatura. Além disso, são evidentes as suas preocupações sociais, sobretudo em relação a seu próprio país. Essas preocupações, que parecem ser um dos grandes motores de sua escrita, podem ser reconhecidas na leitura de diversos poemas, dentre os quais "Morte do Leiteiro" 
(DRUMMOND, 2009, 178) e "A flor e a náusea" (DRUMMOND, 2009, p. 36) (PP1) ${ }^{26}$.

Mesmo que os poemas de Drummond tenham como referência os aspectos vividos particularmente no Brasil, na primeira metade do século passado, a estudante enfatiza que a poesia desse escritor ultrapassa as fronteiras nacionais, pois os seus textos poéticos contêm uma abordagem tão profunda do universo humano e questionamentos universais que podem ser lidos em diversas perspectivas, com outros vieses, como vemos abaixo:

(2) Contudo, não é possível cristalizá-la dessa maneira, porque a matéria de que trata a poesia de Drummond é demasiado profunda e vai além das sólidas questões históricas e sociais, percorrendo, além do universo material propriamente dito, o difuso e instável universo humano. De modo que uma das maiores preocupações em torno da obra de Drummond relaciona-se aos aspectos coletivos e individuais que constituem seus poemas. Dessa forma, sua leitura proporciona a exploração de vieses diversos, permite a visita concomitante ao modesto e ao sublime, em uma composição entremeada de vocabulário simples e regional, questões intelectuais e filosóficas, temas cotidianos e questionamentos universais.

É o interesse pelo estudo da poesia de Drummond, que é grandemente marcada pelo cotidiano brasileiro do século XX, por outras culturas, que levou a estudante a delinear o objetivo da sua pesquisa de Iniciação Científica. $\mathrm{Na}$ introdução do projeto, o objetivo não tinha grandes especificações, como constatamos no final da Introdução:

(3) Naturalmente, tamanha recepção nacional à obra de um artista repercute internacionalmente, atingindo e interessando leitores em outros lugares, de culturas diferentes. Na pesquisa que aqui se apresenta, o objetivo é levantar e compreender a recepção dos poemas de Drummond em língua francesa, mais particularmente na França. (PP1)

Após essa primeira parte do projeto de pesquisa, a estudante inicia a seção de Fundamentação teórica, destacando a dificuldade da tradução poética no que concerne aos aspectos linguísticos da poesia. Para abordar essa dificuldade, ela se apoia em estudiosos dos Estudos Tradutológicos:

(4) Segundo Azenha Jr. (1999, p. 28), "a linguagem deve ser vista aqui como elemento integrante de uma cultura, como uma de suas formas de manifestação mais poderosas".

${ }^{26}$ PP1: Projeto de Pesquisa da Estudante 1

PP2: Projeto de Pesquisa da Estudante 2

PP3: Projeto de Pesquisa da Estudante 3 
do conhecimento linguístico, já que "a mensagem de um poema é muitas vezes implícita e conotativa ao invés de explícita e denotativa, originando diferentes leituras e múltiplas interpretações" (cf. CONNOLLY, 1998, 170, tradução nossa) (PP1).

Esse embasamento teórico permite à produtora do texto sustentar as suas considerações da Introdução, pois lá ela apontou que a poesia drummondiana tem características tanto regionais do estado onde o poeta nasceu e cresceu (Minas Gerais), quanto aspectos históricos do Brasil. Por essa particularidade, a poesia de Drummond "utiliza um vocabulário regional, imagens de seu cotidiano", o que torna complicada a compreensão da sua poesia pelos brasileiros e, ainda mais, para um tradutor de uma outra língua, porque "impõe ao tradutor um percurso que atravessa a língua original e a língua alvo, os contextos históricos dos quais surge e nos quais se pretende disseminá-la e, sobretudo, as referências culturais de cada um desses espaços.” Portanto, segundo a Estudante 1, a tradução influencia a compreensão dos leitores, que, no caso da pesquisa, são os leitores franceses da poesia deDrummond.

Em seguida, na Justificativa do projeto, a produtora do texto novamente destaca, primeiramente, o aspecto de brasilidade que a poesia do escritor brasileiro comporta e, depois afirma, mais uma vez, que as questões da sua poética têm uma dimensão mundial e abordam aspectos relativos à realidade humana:

(5) A obra de Carlos Drummond de Andrade tem suas raízes, evidentemente, fincadas em solo brasileiro. Sua poesia, entretanto, retrata grande parte do século XX (cf. LUCCHESI, 2009, p. 12), passa por importantes eventos em dimensão mundial e aborda aspectos relativos à realidade humana - ao percorrer os poemas de Drummond, nota-se um crescendo de matéria, que se inicia nos elementos mais humildes e que se abre a grandes reflexões. (PP1)

Desse modo, torna-se proveitoso, segundo ela, estudar a recepção de uma poesia tão complexa como a de Drummond por uma outra cultura, por um outro povo com um contexto histórico e social diferentes daqueles dos quais a poesia foi produzida. No caso da proposta do projeto apresentado, trata-se do contexto de recepção dos franceses.

Por meio das justificativas, a estudante argumenta a favor do seu objetivo de pesquisa: 
(6) Por isso, mostra-se de grande valor o levantamento sobre a recepção da poesia de Drummond em um país que difere em diversos aspectos da nação em que foi escrita sua obra. Esta, cujos valores possuem grandes proporções, merece atenção não só dos falantes do português, mas de leitores interessados em uma literatura de alta qualidade, que expressa algo além dos sentimentos do poeta, atingindo patamares filosóficos e existenciais. (PP1)

Depois, a Estudante 1 utiliza mais um argumento que justifica a pesquisa. Esse argumento também tem relação com a ideia central que a produtora do texto utilizou durante as seções anteriores do seu projeto de pesquisa, a saber, o fato da poesia de Drummond dialogar com questões brasileiras do século XX e também com temas que tocam outras culturas; assim o interesse da recepção da poesia drummondiana na França pode contribuir para um estudo que analise a compreensão da cultura brasileira pela cultura francesa:

(7) O levantamento acerca da recepção dos poemas de Carlos Drummond de Andrade na França pode trazer grandes benefícios no que se refere aos estudos relacionados à cultura, porque estabelece um paralelo entre dois diferentes universos culturais, possibilitando assim o confronto comparativo entre ambos. (PP1)

No tocante aos Materiais e Métodos da pesquisa, o critério de escolha dos procedimentos metodológicos partiu da mesma ideia central usada para apresentar a temática na Introdução etambém usada para justificar a pesquisa. Assim, a internet foi o suporte para coletar dados em ambas as línguas, português e francês, entre eles textos teóricos sobre recepção e tradução cultural, a obra do poeta mineiro, prefácios escritos.

Tendo realizado todos os levantamentos propostos pela estudante no seus objetivos de pesquisa, ela realizaria um comentário sobre a obra de Carlos Drummond de Andrade traduzida na França.

\section{Estudante 2}

A ideia central que guia o projeto de pesquisa da Estudante 2 se refere ao fato de que não há dentro da didática das línguas uma reflexão a respeito do desenvolvimento da competência de leitura por meio do conceito de intercompreensão. Assim, desde o resumo do projeto, podemos verificar como a ideia central guiará o objetivo da pesquisa: 
atividades propostas para os módulos iniciais do Curso Práticas de Leitura em Francês e a articulação com os conceitos de intercompreensão (daqui em diante, IC), por meio da aplicação de atividades de leitura em diferentes línguas românicas. (PP2)

Ora, se o objetivo da pesquisa é a discussão dos pressupostos metodológicos que orientam a elaboração de um curso de leitura em língua francesa e que contenha atividades de intercompreensão, levantamos a hipótese de que esse método seria elaborado e posteriormente aplicado como parte da pesquisa de IC.

Ainda no resumo do projeto, é possível compreendermos que a reflexão acerca da intercompreensão para o desenvolvimento da competência de leitura era escassa tanto no contexto universitário em que a pesquisa foi realizada (a Universidade de São Paulo), quanto no contexto mais específico (Centro de Línguas da FFLCH-USP), ou seja, a estudante não elaborou um estado da arte a partir de outros estudos sobre o mesmo assunto para justificar a pesquisa, mas tentou abordá-lo de forma sucinta a partir do seu conhecimento do contexto local enquanto estudante de Letras.

(9) A concepção, aplicação, análise dos resultados e avaliação de atividades em IC no contexto citado permitirá a reformulação conceitual e metodológica dos cursos de leitura em língua estrangeira do Centro de Línguas, numa perspectiva de construção de uma política linguística de IC na Universidade de São Paulo, principalmente no que se refere aos programas de cursos, metodologia utilizada, níveis de progressão em leitura e formação de professores. (PP2)

$\mathrm{Na}$ introdução do projeto, a ideia central está no cerne desta seção, pois a produtora do texto cria um raciocínio para mostrar a ausência de reflexão e de pesquisas no tocante ao tema da intercompreensão para o desenvolvimento da competência leitora plurilíngue. Primeiramente, ela enfatiza algumas pesquisas na área de ensino de leitura em língua estrangeira as quais possibilitaram a compreensão das estratégias de leitura para a formação do leitor em uma única língua estrangeira:

(10) Pesquisas na área do ensino de leitura em língua estrangeira permitiram a reflexão sobre as competências e estratégias a serem desenvolvidas para a compreensão de textos, visando a formação progressiva do leitor na língua alvo (Giasson, 1990; Jouve, 1993; Pietraróia, 1997; Chartier, 1998). (PP2) 
A pergunta que se coloca ao leitor após isso é: mas não há pesquisas que tratem sobre o desenvolvimento da competência de leitura por meio de atividades de intercompreensão? Justamente é essa a questão trazida para discussão: "Mais recentemente, no contexto da didática das línguas a noção de plurilinguismo, a formação pela intercompreensão de línguas românicas têm se mostrado como fundamental no contexto de desenvolvimento de competências de leitura."

Ao final da introdução, mais uma vez, a ideia central é reforçada:

(11) Por meio das atividades de leitura pela intercompreensão no Curso de Práticas de Leitura em francês pretendemos propiciar uma reflexão sobre a "desconstrução" do horizonte de expectativa inicial (com foco na língua francesa), para uma "reconstrução" de competências de leitura em contextos plurilíngues. (PP2)

Se a pesquisa de IC propiciará uma reflexão acerca do desenvolvimento da competência de leitura por meio de atividades de intercompreensão, compreende-se que, do ponto de vista da Estudante 2, essa reflexão foi pouco realizada dentro dos estudos em Didática das Línguas e, por isso, carece de mais estudos.

Além dessas considerações encontradas na seção de introdução, a ideia central também aparece nos objetivos da pesquisa, explicitadas na seção correspondente:

(12) a)Analisar em que medida as estratégias de leitura trabalhadas nos cursos do CL são equivalentes às utilizadas nos contextos de intercompreensão, como o Galanet.

b) Identificar os procedimentos cognitivos e metacognitivos ativados nos processos de construção de sentido dos textos durante as aulas de PLF.

c) Aplicar, analisar e avaliar a realização das atividades pela intercompreensão no contexto do ensino da leitura em língua francesa dos cursos do CL

d) Contribuir para a reformulação dos programas de PLF e para a formação de professores do Centro de Línguas pela intercompreensão de línguas românicas. (PP2)

Os objetivos são indicadores de que é por meio da ideia central que a estudante ficou motivada a desenvolver a pesquisa na área específica da Didática das Línguas. O quarto objetivo reforça isso, já que a pesquisa visará a reformular os programas do curso Práticas de Leitura em Francês do Centro de Línguas, ou seja, não há pesquisas anteriores pelas quais essa reformulação já pudesse ter sido realizada.

Também na seção de metodologia, a ideia da escassez de estudos e de uma 
metodologia a respeito do desenvolvimento da competência de leitura em diversas línguas também é tratada:

(13) A segunda parte do projeto consiste na concepção, aplicação e avaliação de atividades envolvendo as línguas românicas em uma turma de Práticas de Leitura em Francês, durante o módulo inicial do curso. Desta forma, serão coletados dados a partir da observação do desempenho da turma em cada uma das atividades propostas. (PP2)

Portanto, identificamos que o raciocínio seguido no projeto de pesquisa e identificável nas diversas seções desse gênero textual teve como elemento condutor uma ideia central, pela qual a Estudante 2 projetou a sua pesquisa de Inicição Científica a partir da sua experiência enquanto graduanda, no contexto da Universidade de São Paulo. Mais a frente, em nossas análises das vozes, voltaremos nessa discussão.

\section{Estudante 3}

A ideia central que encontramos no projeto de RA se refere ao papel da produção escrita no desenvolvimento das capacidades de linguagem, a fim de possibilitar ao estudante a expansão do seu "savoir-faire" e, assim, ser capaz de participar de diversas realizações comunicativas. Essa ideia central é desenvolvida e apresentada já no resumo do projeto de pesquisa:

\section{(14) RESUMO}

O presente projeto tem por objetivo o estudo da produção escrita de alunos universitários implicados no aprendizado do francês como língua estrangeira, tendo em vista o lugar privilegiado da escrita como instrumento de desenvolvimento das capacidades de linguagem e, portanto, da comunicação em si mesma. (PP3)

Durante o projeto, RA apresenta a ideia do desenvolvimento do "savoir-faire" por meio da produção escrita, registrando essa ideia nas diversas seções do texto, seja na introdução, seja na construção do raciocínio na Fundamentação teórica ou na seção dos objetivos. A seção de introdução, por exemplo, é iniciada pelo mesmo período com o qual o resumo foi iniciado, o que mostra como essa ideia é importante para a compreensão da pesquisa: 
(15) Introdução

O presente projeto tem por objetivo o estudo da produção escrita de alunos universitários implicados no aprendizado do francês como língua estrangeira, tendo em vista o lugar privilegiado da escrita como instrumento de desenvolvimento das capacidades de linguagem e, portanto, da comunicação em si mesma. (PP3)

No excerto anterior, a estudante considera a escrita importante para o desenvolvimento das capacidades de linguagem na compreensão da comunicação. Logo, em seguida, na Fundamentação teórica, essa mesma ideia central é trazida novamente na discussão dos pressupostos teóricos da pesquisa, ou seja, os textos teóricos são lidos sob a perspectiva contida da ideia central do trabalho:

(16) Fundamentação teórica

[...] todo gênero é constituído de diversos elementos que representam os objetos de ensino gradativo que devem ser aplicados pelo professor a fim de que o aprendiz desenvolva suas capacidades de linguagem e, mais que apreender uma modalidade de texto, possa expandir os novos savoir-faire para diversas realizações comunicativas que partilhem elementos constitutivos em comum. (PP3)

Nessa retomada da ideia central, acrescenta-se que as capacidades de linguagem são transferíveis para a produção de outros gêneros textuais. Assim, a ideia central geral através da qual a estudante guia a produção do projeto de pesquisa é a seguinte:

(17) Na seção dos objetivos

Esse objetivo de pesquisa está atrelado a uma reflexão de âmbito educacional, pois pretendemos contribuir para a reflexão sobre instrumentos de aprendizagem da produção escrita que promovam o deslocamento do aprendiz da posição passiva de receptor de conhecimento para actante da própria compreensão e realização dos diferentes gêneros textuais. (PP3)

A ideia central possibilita à produtora do texto a construção de um raciocínio lógico entre as seções que estruturam o projeto de pesquisa. Assim, é possível encontrarmos uma relação lógica entre as partes através do projeto. 


\subsection{Tipos de discurso e coesão verbal}

Nos projetos de pesquisa, encontramos o tipo de discurso teórico, pois se buscou nesses textos construir um raciocínio lógico acerca da pesquisa que foi realizada. Assim, constatamos uma relação existente entre nossas análises do plano global e do tipo de discurso teórico, uma vez que é possível identificar o raciocínio lógico realizado pelas estudantes que evidencia a ideia central de cada projeto de pesquisa. Essa constatação pode ser percebida nas principais seções que compõem o texto, como na introdução, justificativa, Fundamentação teórica e, também, na metodologia. Assim, a textualidade nos faz encontrar a ideia central durante a escrita de todo o projeto, sendo uma guia para a concepção da pesquisa de Iniciação Científica. Embora seja criado um raciocínio lógico, a autonomia do discurso teórico, segundo Bronckart (1999, p.191), tem diferentes graus, maiores ou menores, não podendo ser atingida verdadeiramente, assim como expusemos em nossa Fundamentação teórica. Desse modo, é possível identificarmos o autor empírico do texto no discurso teórico por meio dos seus posicionamentos e interpretações do conteúdo temático (BRONCKART, 1999, p.191). Nos segmentos de discurso teórico dos três projetos encontramos uma menor autonomia, como analisaremos na coesão nominal e nas vozes e modalizações.

Abaixo, evidenciaremos as nossas análises do tipo de discurso teórico, mostrando a sua funcionalidade nos projetos analisados:

\section{Estudante 1}

Neste projeto de pesquisa encontramos, sobretudo, o tipo de discurso teórico, pois verificamos, já na Introdução, a construção de um mundo discursivo conjunto e autônomo através do uso do presente do indicativo e pela ausência total de formas do tempo futuro:

(18) Muitas são as linhas e entrelinhas que compõem a obra de Carlos Drummond de Andrade, escritor brasileiro nascido em 1902 no Estado de Minas Gerais. É a partir de uma pacata cidade interiorana, chamada Itabira, que surge uma das grandes obras poéticas da história do país. (PP1)

(19) Esta, cujos valores possuem grandes proporções, merece atenção não só dos falantes do português, mas de leitores interessados em uma literatura de alta qualidade, que expressa algo 
além dos sentimentos do poeta, atingindo patamares filosóficos e existenciais. (PP1)

Ademais, ainda há grande utilização de conectores lógicos como:

(20) Por isso, mostra-se de grande valor o levantamento sobre a recepção da poesia de Drummond em um país que difere em diversos aspectos da nação em que foi escrita sua obra. (Pág.8)

A busca inicial é, portanto, mais física, ou seja, exige pesquisa em bibliotecas e livrarias nacionais e francesas, além de editoras que tenham publicado as traduções de Carlos Drummond de Andrade. (PP1)

Outra característica que marca o tipo de discurso teórico é a ausência de pronomes e verbos na primeira e segunda pessoa do singular, como constatado nos excertos abaixo:

(21) A obra de Carlos Drummond de Andrade tem suas raízes, evidentemente, fincadas em solo brasileiro (pág. 7).

Seguindo, assim, as proporções de sua essência, a poesia drummondiana deve ser expandida, irradiada, vista por mais olhos e, para tanto, a tradução mostra-se elemento essencial. (PP1)

Embora no discurso teórico não seja comum encontrar nomes próprios (BRONCKART, 1999, pág. 172), durante todo o projeto de pesquisa o nome de Carlos Drummond de Andrade foi citado nas principais seções do texto, desde a Introdução até a descrição das etapas da pesquisa. Esse uso acorreu por dois motivos: primeiramente, porque a pesquisa teve como foco o levantamento de textos referentes ao poeta mineiro, buscando estudar a recepção de sua poesia na França; o segundo motivo se refere ao fato da autora do projeto de pesquisa discorrer ao longo do texto sobre as características da poesia de Drummond, enfatizando, sobremaneira, um aspecto importante da sua poética, a saber, a brasilidade das suas poesias que permite a abordagem também de questões universais e não somente relacionadas ao Brasil e aos brasileiros.

Nesse sentido, buscamos encontrar qual o raciocínio criado pelo mundo discursivo na Introdução para identificarmos qual a ideia principal que a produtora do projeto buscou desenvolver nesta seção. Assim, pudemos encontrar que, no final da Introdução, há uma síntese dos dados selecionamos para apresentar o seu objetivo de pesquisa: 
(22) Dessa forma, sua leitura proporciona a exploração de vieses diversos, permite a visita concomitante ao modesto e ao sublime, em uma composição entremeada de vocabulário simples e regional, questões intelectuais e filosóficas, temas cotidianos e questionamentos universais. (PP1)

Para que a produtora do texto tenha chegado nessa síntese, ela se valeu de citações tanto do próprio Carlos Drummond de Andrade quanto de Marco Lucchesi, estudioso da obra do poeta mineiro. Dessas citações, ela destacou a ideia de que a poesia de Drummond contém como referência a situação brasileira da primeira metade do século $\mathrm{XX}$, porém trata de questões universais e não somente restritas ao contexto brasileiro, logo "Com tais informações, pode-se pressupor um caráter concreto nos versos do poeta, já que fatos verídicos e acontecimentos de proporções nacionais e mundiais permeiam sua obra."

Do mesmo modo, na seção de Fundamentação teórica, a estudante se vale da mesma ideia desenvolvida na Introdução, a fim de selecionar os autores os quais ela utilizará para estudar os aspectos da recepção da obra de Drummond. Assim, ela cita alguns estudiosos sobre Tradução que enfatizam a dificuldade no ato tradutório poético:

(23) A tradução de uma poesia composta de tão notáveis e complexos elementos tal como a de Drummond torna-se um processo delicado e exige critérios outros que a simples relação direta entre palavras, porque tange não só à linguística das línguas em questão, mas aos componentes culturais de cada uma delas. Segundo Azenha Jr. (1999, p.28) (PP1)

Após esse desenvolvimento, a produtora do texto, mais uma vez, mostra a peculiaridade da poesia de Drummond:

(24) Podem tornar-se ilusoriamente dubitáveis, desse modo, as possibilidades da tradução de um poeta que, ao mesmo tempo em que se questiona filosoficamente sobre o mundo em que vive, utiliza um vocabulário regional, imagens de seu cotidiano e referências à sua origem interiorana. É tarefa árdua a representação de tal obra em outra língua que não o português brasileiro, porque impõe ao tradutor um percurso que atravessa a língua original e a língua alvo, os contextos históricos dos quais surge e nos quais se pretende disseminá-la e, sobretudo, as referências culturais de cada um desses espaços. (PP1)

É por meio dessa ideia central, criada por meio de um raciocínio lógico (fortes marcas de discurso teórico: conjunção da ação de linguagem com certa autonomia quanto 
às ações do mundo ordinário, presença de coesão verbal no presente do indicativo e conectores lógicos), que a estudante vai argumentar em favor da sua pesquisa, encaminhando o leitor para a seção de Justificativa: "Tais referências transformam a tradução da obra de Drummond em trabalho merecedor de aguda atenção, já que estenderá a obra a outros horizontes, e atingirá outros leitores, aqueles que receberão a versão traduzida."

Nossa linha de raciocínio se justifica, pois a própria produtora do texto deixa entrever que a reflexão desenvolvida na Introdução é a principal motivação para a sua pesquisa: “[...] esses aspectos [referentes às dificuldades da tradução poética] ganham, portanto, ainda mais complexidade quando se trata dos poemas de Carlos Drummond de Andrade, pelas diversas razões já expostas (cf. Introdução).”

$\mathrm{Na}$ seção de Justificativa propriamente, a estudante segue a mesma linha de raciocínio, ou seja, inicia a seção criando um mundo discursivo conjunto e autônomo por meio da ideia desenvolvida na Introdução, mostrando que a poesia de Drummond, embora tenha como motor as questões do Brasil da época, contém também "aspectos relativos à realidade humana" e "grandes reflexões". Esse raciocínio levará à seguinte síntese: "Por isso, mostra-se de grande valor o levantamento sobre a recepção da poesia de Drummond em um país que difere em diversos aspectos da nação em que foi escrita sua obra."

O raciocínio criado pelo discurso teórico desde a Introdução pode ser identificado também na seção de Materiais e Métodos, na qual é retomada a ideia central do projeto e que foi o critério principal para a seleção dos dados da pesquisa e também para a escolha dos procedimentos metodológicos, como podemos ler no último parágrafo da seção:

(25) Do mesmo modo, a pesquisa que aqui se propõe buscará, com o auxílio de todos os materiais enumerados acima, encontrar e reunir materiais que possibilitem o levantamento da recepção da obra de um poeta importante à literatura e à cultura brasileiras como Carlos Drummond de Andrade, que, aliás, como já referido (cf. Justificativa), muito se interessava pela França, buscando por muito tempo inspiração em sua cultura e em sua língua. (PP1)

Ao indicar textualmente a referência feita na seção de Justificativa, a produtora do texto, além de evidenciar um raciocínio lógico-formal construído na redação do projeto, retoma a ideia da pluralidade da poética de Drummond permitindo assim a abertura de 
uma lacuna, a qual a pesquisa proposta irá preencher.

\section{Estudante 2}

A ideia central do projeto de pesquisa é desenvolvida durante as seções do texto, por meio do tipo de discurso teórico, criando um raciocínio lógico. Na seção introdutória do projeto, encontramos um excerto que evidencia esse tipo de discurso:

(26) Mais recentemente, no contexto da didática das línguas a noção de plurilinguismo, a formação pela intercompreensão de línguas românicas têm se mostrado como fundamental no contexto de desenvolvimento de competências de leitura. Partindo do princípio de que num contexto plurilíngue as línguas "se inter-relacionam e interagem", a abordagem pela intercompreensão desenvolve a compreensão escrita de falantes de diferentes línguas, cada um interagindo em sua língua materna. (PP2)

Como é possível observamos no fragmento acima, a sua construção é baseada na conjunção e certa autonomia da ação de linguagem através da utilização do presente do indicativo. A conjunção foi utilizada nesse excerto, pois a estudante situou os estudos sobre a noção de plurilinguismo e de intercompreensão nos estudos em didática das línguas estrangeiras, a fim de colocar a ideia central do seu projeto em evidência, justificando a sua necessidade. Em seguida, o raciocínio lógico tem continuidade através do paralelo feito entre o que indicam os estudos atuais sobre intercompreensão e o contexto em que a pesquisa foi realizada: "a intercompreensão se dá entre línguas românicas - espanhol, francês, italiano, português e romeno - valendo-se sempre das proximidades linguísticas trazidas pela "raiz latina" comum a todas elas".

A ideia central também é ressaltada na seção de justificativa, na qual a estudante afirma que, devido a sua experiência enquanto professora/monitora do Centro de Línguas da USP, do curso de Leitura em francês, e também devido a sua experiência na participação, durante o curso de Letras, em uma sessão da plataforma Galanet ${ }^{27}$, estudará o ensino de leitura em francês:

(27) Baseando-nos nesses estudos, na qualidade de professora dos Cursos de Práticas de Leitura

27 O Projeto "Galanet: galáxia em rede" é uma plataforma digital que tem por objetivo estimular a intercompreensão entre os romanófonos, ou seja, os falantes de português, francês, italiano, espanhol e romeno. 
em Francês do Centro de Línguas da FFLCH e na experiência como aluna participante de uma sessão Galanet [...] foi possível estabelecer comparações entre o ensino da leitura e os novos caminhos metodológicos trazidos pelas políticas de plurilinguismo e intercompreensão. (PP2)

Justamente pelo fato da estudante ser monitora do Centro de Línguas, nos cursos de leitura em língua francesa, que ela detectou a necessidade do estudo da intercompreensão no ensino/aprendizagem do processo de leitura em francês. No mais, também foi por meio da participação em uma plataforma de intercompreensão em línguas românicas que a estudante percebeu a importância do ensino da leitura em um contexto parecido. Assim sendo, a ideia central do projeto foi também é ressaltada para justificar a pesquisa.

Igualmente ao que destacamos nos outros projetos, notamos que a ideia central do projeto advém da experiência da estudante enquanto aluna do curso de Letras. É a partir da vivência da aluna na condição de estudante no ensino superior que surgirá a necessidade da pesquisa, como constatado no excerto anterior. No fragmento acima, notamos que, embora a estudante tenha se colocado na posição de professora, ela ocupa essa lugar, posto que ela é estudante da graduação em Letras, na habilitação de francês e se tornou professora/monitora do Centro de Língua enquanto graduanda. Além do mais, podemos verificar que a experiência obtida ao participar de uma interação via plataforma Galanet (interação com estudantes de línguas em de diversos países) ocorreu, já que ela era aluna da graduação em Letras (língua francesa). Portanto, a necessidade em se realizar uma pesquisa científica é oriunda das experiências passadas na graduação e do modo como elas criam questões de interesse científico.

\section{Estudante 3}

A ideia central foi construída por meio da construção de um raciocínio lógico, logo por meio do discurso teórico. Assim, a disjunção e autonomia da ação de linguagem mostram o desenvolvimento da ideia central ao longo das seções do projeto de pesquisa:

(28) Na Fundamentação teórica:

Assim, se ressaltamos a definição de Bakhtin para os gêneros discursivos, temos que estes são 
realizações comunicativas através de formas mais ou menos estáveis de enunciados, ou seja, fundados por convenções sociais. Logo, podemos considerar os gêneros um instrumento importante no processo de ensino da língua, em que a apropriação das capacidades de linguagem passa, forçosamente, pela comunicação. (PP3)

Por meio dessa construção, RA enfatiza que as produções escritas devem ser organizadas em gêneros textuais para o desenvolvimento das capacidades de linguagem e do savoir-faire, já que os gêneros conferem uma certa estabilidade aos textos de acordo com as "convenções sociais". Nesse excerto, encontramos a autonomia e conjunção da linguagem, nas conjugações "temos" e "podemos"; nos conectores lógicos "Assim" e "Logo"; no modalizador lógico "forçosamente". Em seguida, a estudante define a concepção de gênero textual segundo a teoria do Interacionismo Sociodiscursivo a partir da noção de texto tal como apresentado por essa corrente teórica:

(29)Assim, todo texto insere-se em determinado quadro situacional, que lhe ditará as especificidades, conforme as condições de interação a que estará submetido. Dessa maneira, conclui-se que todo texto está vinculado a algum gênero, ou seja, a algum formato historicamente convencionado, que, no entanto, não exclui seu caráter permanentemente passível de mudanças. (PP3)

O uso do presente do indicativo dos verbos "inserir" e "estar"; os conectores lógicos "Assim", "conforme" e "no entanto" marcam o discurso teórico. Posteriormente, RA relacionou o conceito de gêneros textuais para o ISD na discussão sobre o ensino de línguas, através do conceito de capacidades de linguagem:

(30) Para ambos, todo gênero é constituído de diversos elementos que representam os objetos de ensino gradativo que devem ser aplicados pelo professor a fim de que o aprendiz desenvolva suas capacidades de linguagem e, mais que apreender uma modalidade de texto, possa expandir os novos savoir-faire para diversas realizações comunicativas que partilhem elementos constitutivos em comum. (PP3)

De acordo com a estudante, é por meio do desenvolvimento das capacidades de linguagem que é possível o desenvolvimento de uma competência pela qual o aluno de língua estrangeira poderá transpor os conhecimentos linguageiros em outras situações de comunicação, e através de outros gêneros textuais. O raciocínio lógico é expresso aqui 
pela anáfora "Para ambos"; pela conjugação "representam" e pelo conector "a fim de que".

Continuando o raciocínio (expresso no tempo verbal presente "remetem"; na anáfora "Tais ferramentas" e no conector lógico "bem como") RA remete o conceito de gêneros textuais à noção de "ferramenta" segundo a teoria vigotskiniana:

(31) Ainda nos estudos de Schneuwly \& Dolz (2004), os autores remetem à noção vigotskiniana de ferramenta, que seria o meio pelo qual o homem pode operar modificações desejadas no objeto em seu processo de trabalho. Tais ferramentas seriam intermediações indispensáveis na relação do homem e objeto, bem como no contato entre o homem e os outros. É a ferramenta que guia o comportamento do indivíduo, adequando-o aos diversos contextos cotidianos. (PP3)

É por meio dessa relação que a estudante nos fará compreender que os gêneros textuais são ferramentas que guiam o comportamento nas mais diversas situações de comunicação. Finalizando o raciocínio lógico criado por RA, ela expõe o modo de desenvolvimento das capacidades de linguagem por meio da aplicação de uma sequência didática:

(32) As SD, por sua vez, propostas por Schneuwly \& Dolz (2004), são a sistematização de atividades didáticas organizadas em torno do gênero trabalhado. Quatro etapas se distinguem: a apresentação do gênero; uma produção inicial para identificação das dificuldades; atividades (módulos) que possam reparar os problemas detectados; produção final. (PP3)

Como é possível verificarmos, o raciocínio lógico criado pelo tipo de discurso teórico é construído pelos conectores lógicos, como podemos destacar em diversos excertos do projeto de pesquisa.

\subsection{Mecanismos de textualização: conectores textuais}

Os mecanismos de conexão explicitam as relações existentes entre os diferentes níveis de organização de um texto, sendo os organizadores lógicos mais frequentes no tipo de discurso teórico (BRONCKART, 1999, p.264).

Os conectores textuais dos projetos de pesquisa permitem a construção, na macro ou na micro-estrutura dos textos, da construção da ideia central da qual discorremos em nossas análises dos planos globais dos projetos. Em cada um deles, encontramos uma 
dinâmica particular de construção, cujo objetivo principal é explicitar essa ideia central durante as partes próprias de um projeto de pesquisa, seja na introdução, seja nos objetivos ou até mesmo na metodologia.

Desse modo, as análises dos conectores textuais certificam que há de fato uma ideia central nos projetos de pesquisa, ou seja, há uma percepção motivadora da realização das pesquisas, sendo esta advinda das experiências dos estudantes de graduação no contexto universitário.

A seguir, mostraremos como os conectores textuais nos permitem entrever de forma clara a ideia central que guia a escrita dos projetos de pesquisas dos três estudantes.

\section{Estudante 1}

Através do uso específico de alguns conectores utilizados durante o projeto de pesquisa, podemos verificar como que a ideia central da pesquisa foi construída. Os conectores nos permitem compreender no nível da marcro e da micro-estrutura textual que, apesar da poesia de Drummond ter como motivação a cultura brasileira, ela também aborda questões universais e que podem ser discutidas por leitores que não conhecem ou que não tenham essa cultura enquanto referência. Os conectores nos permitem analisar essa questão por meio de conexões de adição e depois de oposição ou somente de oposição, como podemos perceber nos exemplos abaixo:

(33) Na Introdução:

A grande repercussão de sua obra no contexto brasileiro explica-se por aspectos linguísticos, históricos (cf. LUCCHESI, 2009) sociais e também estéticos [...] Além disso, a agitação do contexto histórico em que se deu a escrita da obra drummondiana é evidente em diversos poemas [...] Além disso, são evidentes as suas preocupações sociais, sobretudo em relação a seu próprio país [...] Contudo, não é possível cristalizá-la dessa maneira, porque a matéria de que trata a poesia de Drummond é demasiado profunda e vai além das sólidas questões históricas e sociais, percorrendo, além do universo material propriamente dito, o difuso e instável universo humano (PP1)

No excerto acima, encontrado na seção de Introdução, podemos, primeiramente, perceber no início a ideia central do parágrafo que posteriormente será desenvolvida por 
um mesmo conector lógico de adição, "além disso". Depois, essas informações são opostas pelo conector "Contudo" a uma outra característica da poesia de Drummond, ou seja, de que sua poesia transcende o contexto brasileiro e por isso pode ser lida por outras culturas. Esse mesmo mecanismo de uso dos conectores aparece na seção de Justificativa:

(34) A obra de Carlos Drummond de Andrade tem suas raízes, evidentemente, fincadas em solo brasileiro. Sua poesia, entretanto, retrata grande parte do século XX (cf. LUCCHESI, 2009, p. 12), passa por importantes eventos em dimensão mundial e aborda aspectos relativos à realidade humana - ao percorrer os poemas de Drummond, nota-se um crescendo de matéria, que se inicia nos elementos mais humildes e que se abre a grandes reflexões. (PP1)

Seguindo o mesmo raciocínio criado pelo uso do conector "Contudo", a conexão estabelecida pela conjunção "entretanto" também teve como finalidade acrescentar à poesia de Drummond outros aspectos abrangidos por ela, como eventos do século $\mathrm{XX}$ que tocam não somente ao Brasil, mas também questões de ordem e interesse mundiais. Portanto, é possível compreendermos que o eixo do raciocínio da produtora do texto é, primeiramente, a característica brasileira que está presente na poesia de Drummond, como também questões que ultrapassam as fronteiras históricas e sociais do Brasil e que por isso podem ser tratadas de outras perspectivas, inclusive sobre à luz da cultura francesa. No excerto a seguir, podemos identificar o conector "porém" que possui o mesmo valor que os outros de oposição, "Contudo" e "entretanto":

(35) É, portanto, de grande proveito o estudo de sua obra pura, daquilo que, deixado pelo poeta, perpetua-se ao longo da história literária. Ainda mais proveitoso, porém, pode ser o aprofundamento daquilo que se propaga e se multiplica a partir de tal obra - o impacto que ela causa, o modo como atinge o público em outra época, em outra sociedade, em outra cultura e, mais especificamente no caso do presente projeto, o modo como é lida a tradução da poesia drummondiana, essencialmente brasileira, no contexto sociocultural francês. (PP1)

Como conclusão da ideia desenvolvida no excerto anterior, marcada por meio do conector "portanto", a estudante mostra a importância da poesia de Drummond na história literária. Depois, opondo-se a essa conclusão global, por meio da conjunção "porém", a estudante restringe a ideia da conclusão para argumentar a favor do seu objetivo de pesquisa, visto que estudar a recepção da poesia de Drummond, 
“essencialmente brasileira", por um outro público decultura diferente, como a francesa, por exemplo, seria de grande proveito.

\section{Estudante 2}

$\mathrm{Na}$ introdução do projeto de pesquisa, encontramos conectores temporais, que marcam as pesquisas sobre a competência de leitura em língua estrangeira:

(36) O ensino instrumental de línguas estrangeiras surgiu e se desenvolveu na América Latina, a partir de 1970 [...] Mais recentemente, no contexto da didática das línguas a noção de plurilinguismo, a formação pela intercompreensão de línguas românicas têm se mostrado como fundamental no contexto de desenvolvimento de competências de leitura. (PP2)

No excerto acima, os conectores de tempo são expressos por “a partir de 1970" e "Mais recentemente", os quais buscam apresentar uma síntese das pesquisas sobre leitura em língua estrangeira. $\mathrm{O}$ segundo conector tem a função de aproximar o leitor da temática principal da pesquisa que, embora seja "fundamental no contexto de desenvolvimento de competências de leitura", ainda não é abordada no contexto mais geral da pesquisa (Universidade de São Paulo) e nem no contexto mais específico (Centro de Línguas da FFLCH-USP):

(37) Por meio da análise dos pontos convergentes entre o ensino da leitura em francês nos cursos de Práticas de leitura do CL-USP e as teorias de IC entre línguas românicas e visando contribuir para a reformulação conceitual e metodológica dos cursos de leitura em língua estrangeira do Centro de Línguas $[\ldots](\mathrm{PP} 2)$

Como já mostramos em nossas análises do plano global do conteúdo temático da pesquisa da Estudante 2, a ideia central que ela desenvolve se refere à falta de uma reflexão metodológica no âmbito do seu contexto de pesquisa acerca do desenvolvimento da competência de leitura por meio de atividades de intercompreensão. Podemos constatar por meio da oração coordenada aditiva sublinhada no excerto acima da seção de objetivos, expressa pelo conector de adição "e", que a pesquisa objetivou reformular os cursos de leitura em língua estrangeira no Centro de Línguas. 
Na seção de metodologia, igualmente, é por meio da ideia central que a estudante elabora as etapas da sua pesquisa:

(38)A primeira parte da pesquisa partirá de um levantamento teórico dos pressupostos que orientam as atividades de leitura em francês realizadas nos cursos de Práticas de Leitura em Francês da USP (PLF-USP) [...]). A segunda parte do projeto consiste na concepção, aplicação e avaliação de atividades envolvendo as línguas românicas em uma turma de Práticas de Leitura em Francês, durante o módulo inicial do curso. (PP2)

Através do primeiro conector organizacional de sequenciação, "A primeira parte da pesquisa", a estudante planejou realizar um estudo do conceito central da pesquisa, a intercompreensão, buscando subsídios para elaborar atividades de leitura. Já o segundo conector textual, "A segunda parte do projeto", seria a fase da elaboração efetiva das atividades de intercompreensão, posto que não há trabalhos científicos suficientes dessa área nos quais a estudante pudesse se basear para construir a metodologia da sua pesquisa.

\section{Estudante 3}

Assim como já analisamos nos projetos de pesquisa anteriores, neste também encontramos conectores textuais que explicitam e constroem, nas diversas seções do projeto, a ideia central da pesquisa. $\mathrm{Na}$ introdução do projeto da Estudante 3, encontramos os seguintes conectores:

(39) Sob esta perspectiva, a língua não é vista como mero conhecimento passivo de aceitação, mas como ocorrência ativa e real, ou seja, não se insere como informações a serem acumuladas, mas sim como savoir-faire a ser desenvolvido. (PP3)

No excerto acima, as duas ocorrências do conector "mas", pelos quais são construídas orações coordenadas opositivas, têm a função de constatar, primeiramente, que a pesquisa assume o conceito de que a língua não pode ser analisada fora contexto para o qual ela foi ativada e realizada. Segundamente, a língua não pode ser entendida 
como um conjunto de conhecimentos passivos, porém como uma capacidade a ser desenvolvida.

A língua enquanto ocorrência ativa e real se organiza por meio dos gêneros textuais, por isso estes devem ser trabalhados para o desenvolvimento das capacidades de linguagem e a expansão do savoir-faire:

(40) [...] todo gênero é constituído de diversos elementos que representam os objetos de ensino gradativo que devem ser aplicados pelo professor a fim de que o aprendiz desenvolva suas

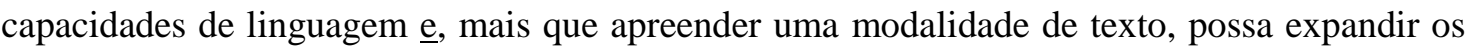
novos savoir-faire para diversas realizações comunicativas que partilhem elementos constitutivos em comum. (PP3)

No excerto acima, encontramos o conector "a fim de que" e o conector "e". O primeiro tem a função de sustentar a ideia de que a língua é usada efetivamente nos gêneros textuais, devendo ser trabalhada em sala de aula para o desenvolvimento das capacidades de linguagem. O segundo conector, por sua vez, adiciona a informação de que esse trabalho com a língua ativa na sala de aula propicia a expansão do savoir-faire dos estudantes.

Na seção de objetivos, a ideia central também é reforçada:

(41) Esse objetivo de pesquisa está atrelado a uma reflexão de âmbito educacional, pois pretendemos contribuir para a reflexão sobre instrumentos de aprendizagem da produção escrita que promovam o deslocamento do aprendiz da posição passiva de receptor de conhecimento para actante da própria compreensão e realização dos diferentes gêneros textuais. (PP3)

O conector explicativo "pois" reforça a ideia central, ou seja, a produção escrita pode promover o desenvolvimento das capacidades de linguagem, pelas quais os estudantes sairão de uma posição passiva de receptor de conhecimento para um uso consciente e ativo da comunicação por meio da realizadas de diferentes gêneros textuais. 


\subsection{Mecanismos de textualização: coesão nominal}

No tocante à coesão nominal, identificamos usos de anáforas textuais e expressões nominais que, segundo Bronckart (1999, p.173), são típicos do tipo de discurso teórico. As expressões nominais, por sua vez, são mais frequentes no discurso teórico e são geralmente associadas às relações complexas de co-referência (BRONCKART, 1999, p. 271). As cadeias nominais nos projetos de pesquisa têm a função de mostrar o desenvolvimento das ideias centrais encontradas nos projetos de pesquisa. Cada um dos projetos explicita uma construção nominal pela qual entrevemos os posicionamentos das estudantes e suas formas de compreender a pesquisa que iniciaram. Desse modo, como apontado por Lousada (2010, p.5), a coesão nominal pode expressar um posicionamento subjetivo por meio das escolhas lexicais utilizadas na cadeia nominal. Nas nossas análises, pudemos indentificar a subjetividade das estudantes quanto à ideia central de cada um dos projetos de pesquisa por meio das cadeias anafóricas e dos sintagmas nominais.

Abaixo, mostraremos como essas constatações referentes à coesão nominal nos três projetos analisado:

\section{Estudante 1}

Como já discorremos no tópico anterior, durante o projeto de pesquisa encontramos várias retomadas anafóricas com o próprio nome do poeta, Carlos Drummond de Andrade. Especificamente, encontramos 17 recorrências desse termo. Além do mais, encontramos várias recorrências de retomada deste mesmo referente: 23 ocorrência de "Drummond"; 12 de "poeta" e 7 de "poeta brasileiro".

Dentre os termos nominais utilizados para retomar o referente da figura do poeta, a produtora do texto se vale, sobretudo, do seu nome completo ou somente do sobrenome. Este último é usado no projeto de pesquisa para se referir ao autor enquanto um escritor conhecido por conter uma vasta obra poética. No mais, ela utiliza o termo "poeta" e também um outro mais qualificativo desse último, o termo "poeta brasileiro", que é associado sempre a algum termo referente à cultura francesa. Abaixo, 
selecionamos vários excertos em que essa forma coesiva aparece no projeto de pesquisa, buscando compreender a sua função:

(42) Desse modo, a tradução influencia na compreensão de leitores específicos - no caso de nossa pesquisa, os franceses - da obra do poeta brasileiro, e no modo como se expande sua obra literária em países que, como a França, o influenciaram e inspiraram. (PP1)

Quanto à crítica em francês sobre o poeta brasileiro, uma primeira busca detectou uma reunião de textos brasileiros traduzidos para a língua francesa. (PP1)

Há, aliás, uma relação intensa do poeta brasileiro em relação à França e à língua francesa. (pág.7) em seus mais variados aspectos, quando se confronta com ela a cultura francesa, ou seja, pelo modo como esta última lê o poeta brasileiro. (PP1)

Também servirão de apoio os prefácios de antologias publicadas tanto em português brasileiro quanto em francês, além de textos críticos sobre a obra do poeta brasileiro e sua recepção em outras culturas. (PP1)

Nos fragmentos acima, além de destacarmos os excertos em que a expressão "poeta brasileiro" aparece, sublinhamos também sempre um referente que retoma a diferença entre o universo poético de Drummond, marcadamente influenciado pelas questões históricas e sociais do seu país, e a cultura francesa. Logo, percebemos que nos excertos em que a figura do poeta é retomada como "poeta brasileiro" destaca-se tanto a influência da cultura brasileira nas suas poesias, quanto marca a diferença entre a cultura brasileira e a francesa. Com isso, portanto, podemos compreender o modo como a produtora do texto avalia a poesia de Drummond como tendo fortíssimas características inerentes ao Brasil e ao povo brasileiro.

Entretanto, quando o termo "poeta" é usado, não encontramos essa dualidade entre duas culturas díspares e nem a ênfase nas características da cultura brasileira que podem ser encontradas na poesia de Drummond:

(43) outros críticos literários da obra do poeta e outros teóricos que trabalham a questão da recepção cultural de tradução deverão se reunir aos autores aqui apresentados, de modo a acrescentar à pesquisa um embasamento teórico que possibilitará o levantamento proposto neste projeto. (PP1)

É, portanto, de grande proveito o estudo de sua obra pura, daquilo que, deixado pelo poeta, perpetua-se ao longo da história literária. (PP1)

Esta, cujos valores possuem grandes proporções, merece atenção não só dos falantes do português, mas de leitores interessados em uma literatura de alta qualidade, que expressa algo 
além dos sentimentos do poeta, atingindo patamares filosóficos e existenciais. (PP1)

Diferentemente dos excertos anteriores, nestes e nos outros em que o termo "poeta" é encontrado, não identificamos no mesmo período nenhum índice textualque remetesse à cultura francesa e nem uma ênfase nos aspectos da influência da cultura brasileira nas poesias de Drummond. O termo "poeta", assim, é usado para se referir ao escritor brasileiro de forma geral e sua importância ou para registrar a abrangência das questões abordadas na poética de Carlos Drummond de Andrade.

Na seção de Fundamentação teórica, a produtora do texto demonstra a dificuldade da tradução poética, pois exige um conhecimento apurado da língua em que a poesia foi escrita, bem como dos elementos sociais e históricos que serviram de referência para o conteúdo dos textos poéticos:

(44) Além disso, sabe-se que é grande a discussão acerca da dificuldade da tradução poética, que exige do tradutor muito além do conhecimento linguístico. (PP1)

A tradução de uma poesia composta de tão notáveis e complexos elementos tal como a de Drummond torna-se um processo delicado. (PP1)

A palavra "tradução" dos dois excertos anteriores foi retomada no excerto a seguir pela expressão "tarefa árdua",indicadora de que o estudo da poesia de Drummond tal como recebida pelos franceses não é simples, posto que os textos poéticos do escritor contêm referências nacionais bem marcadas:

(45) É tarefa árdua a representação de tal obra em outra língua que não o português brasileiro. (PP1)

A retomada pela forma "tarefa árdua" advém da experiência da estudante de Letras enquanto leitora da poesia de Drummond que, nessa prática, encontra dificuldades nos textos poéticos do escritor, visto que eles abordam complexas questões. Pela dificuldade encontrada pela estudante nas poesias de Carlos Drummond de Andrade é que fazem deste escritor "um artista": 
(46) Naturalmente, tamanha recepção nacional à obra de um artista repercute internacionalmente, atingindo e interessando leitores em outros lugares, de culturas diferentes. (PP1)

Este excerto faz parte do último parágrafo da Introdução, no qual foi apresentado em linhas gerais o objetivo da pesquisa que, pelo uso do termo "artisita", constatamos que surge a partir da experiência da estudante enquanto leitora do poeta mineiro e admiradora de sua poesia.

\section{Estudante 2}

No projeto de pesquisa da Estudante 2, a coesão nominal referente ao objetivo da pesquisa revela a ideia central por meio da seguinte cadeia nominal:

(47) \{a reformulação conceitual e metodológica; uma reflexão sobre a "desconstrução" do horizonte de expectativa inicial (com foco na língua francesa), para uma "reconstrução" de competências de leitura em contextos plurilíngues; uma real implantação de políticas de plurilinguismo e intercompreensão (PP2)

A primeira expressão nominal foi encontrada no resumo do projeto de pesquisa, mais especificamente no seguinte excerto: "a reformulação conceitual e metodológica dos cursos de leitura em língua estrangeira do Centro de Línguas”. Como é possível perceber, ao nomear como "a reformulação conceitual e metodológica", a estudante se posiciona no sentido de que os cursos de língua estrangeira, mais precisamente no Centro de Línguas da FFLCH-USP, necessitam de uma mudança no que tange ao seu objetivo e também quanto a sua metodologia, que desconsidera o ensino de leitura em francês desvinculado do conceito de intercompreensão.

Para isso, segundo a estudante, é necessária a "desconstrução" do modelo atual de ensino de leitura para uma "reconstrução" de novas metodologias que abordem a questão do ensino de leitura em contextos plurilíngues.

Por último, e somente após essa reflexão conceitual e metodológica, visando à reconstrução de um novo modelo de ensino de leitura, que se alcançará "a reformulação 
conceitual e metodológica dos cursos de leitura em língua estrangeira do Centro de Línguas", assim como expresso na seção dos objetivos da pesquisa.

\section{Estudante 3}

No projeto de pesquisa produzido por RA, encontramos uma cadeia nominal cujo referente é a ideia de gêneros textuais, que é retomada durante o projeto e pela qual podemos perceber o desenvolvimento da ideia central do texto:

(48) Assim, se ressaltamos a definição de Bakhtin para os gêneros discursivos, temos que estes são realizações comunicativas através de formas mais ou menos estáveis de enunciados, ou seja, fundados por convenções sociais. (PP3)

Dessa maneira, conclui-se que todo texto está vinculado a algum gênero, ou seja, a algum formato historicamente convencionado, que, no entanto, não exclui seu caráter permanentemente passível de mudanças. (PP3)

Se entendemos os gêneros como ferramentas, trabalhamos, então, com a construção e transformação das relações entre sujeito-objeto e sujeito-sujeito, ultrapassando o ensino-aprendizagem e promovendo o desenvolvimento do aprendiz enquanto sujeito no mundo. (PP3)

Assim, a cadeia nominal é composta pelos seguintes termos coesivos: \{gêneros discursivos, realizações comunicativas, formato historicamente convencionado, gêneros textuais, ferramenta\}.

Ao nomear os gêneros textuais enquanto ferramentas no sentido atribuído ao termo para Vigotski, RA reforça a ideia central do projeto de pesquisa, a qual entende que os gêneros textuais podem ser apropriados pelos alunos no processo da produção textual escrita, dentro de uma sequência didática. A partir dessa apropriação, os gêneros se tornam ferramentas pelas quais os estudantes podem participar ativamente em contextos comunicativos. 


\subsection{Mecanismos enunciativos: vozes e modalizações}

Os mecanismos enunciativos também relevam no nível da textualidade o imbricamento entre a esfera universitária e a esfera científica no processo da Iniciação Científica, mais notadamente no projeto, primeiro gênero textual necessário para o desenvolvimento das pesquisas. Nesse gênero textual, identificamos uma instância enunciativa a qual denominamos de voz do estudante. É por meio dela que as avaliações são emitidas e as estudantes se posicionam frente às informações do conteúdo temático que desenvolveram. Através dela, também, podemos perceber que há uma motivação para o desenvolvimento da pesquisa, que surge da própria experiência das três estudantes enquanto alunas de graduação, na esfera universitária.

Assim, encontramos modalizações lógicas e apreciativas (BRONCKART, 1999) e índices de inserção de vozes, como as modalizações autonímicas (AUTHIER-REVUZ, 1999; MAINGUENEAU, 2005), bem como ilhas enunciativas (MAINGUENEAU, 2005), sobretudo no projeto da Estudante 2. As avaliações são mais claramente identificáveis como sendo expressas pelas estudantes quanto à temática da pesquisa e a sua pertinência. Mesmo que os projetos tenham predominância do discurso teórico, ou seja, há uma tendência à autonomia do agente produtor do texto em relação aos parâmetros da situação de ação de linguagem, encontramos índices que nos permitem nomear a voz do estudante.

Além da voz da estudante, encontramos a voz da ciência materializada, sobretudo na seção de Fundamentação teórica dos projetos de pesquisa, notadamente nas citações diretas e indiretas de especilistas. As reformulações dos dizeres teóricos nos permitem identificar a voz do estudante por meio das modalizações autonímicas. Em trabalho realizado utilizando projetos de pesquisa escritos por alunos de IC, Lousada e Santos (2014) mostraram que os conceitos necessários para o desenvolvimento da pesquisa, nesse momento, ainda estão sendo apropriados pelos estudantes, pois constataram que as relações lógicas estabelecidas entre os conceitos selecionados para o estudo contêm raciocínios não formais. 


\section{Estudante 1}

Iniciaremos pela análise das modalizações autonímicas, que, no projeto da Estudante 1, revelam a voz do estudante por meio de algumas construções nas quais aparecem a palavras "modo":

(49) De modo que uma das maiores preocupações em torno da obra de Drummond relaciona-se aos aspectos coletivos e individuais que constituem seus poemas. (PP1)

Podem tornar-se ilusoriamente dubitáveis, desse modo, as possibilidades da tradução de um poeta que, ao mesmo tempo em que se questiona filosoficamente sobre o mundo em que vive, utiliza um vocabulário regional, imagens de seu cotidiano e referências à sua origem interiorana. (PP1)

Desse modo, a tradução influencia na compreensão de leitores específicos - no caso de nossa pesquisa, os franceses - da obra do poeta brasileiro, e no modo como se expande sua obra literária em países que, como a França, o influenciaram e inspiraram. (PP1)

Nas expressões construídas com a palavra "modo", encontra-se um comentário da Estudante 1 acerca daquilo que ela expõe, o que evidencia a voz do estudante por meio dessas modalizações autonímicas. Podemos constatar nos três primeiros excertos acima que as expressões autonímicas têm a função de fornecer comentários conclusivos os quais encaminham o leitor para a ideia central construída no projeto de pesquisa.

A respeito das modalizações lógicas e apreciativas encontradas, buscamos situá-las no conteúdo temático do projeto, procurando compreender o seu uso pela produtora do texto. Na seção dedicada à Justificativa da pesquisa, encontramos a seguinte modalização lógica:

(50) A obra de Carlos Drummond de Andrade tem suas raízes, evidentemente, fincadas em solo brasileiro. (PP1)

No excerto acima, encontrado na argumentação utilizada para a valorização do objetivo da pesquisa proposta, a produtora do texto utiliza algumas modalizações lógicas que evidenciam a peculiaridade da poesia de Drummond, que, segundo ela, é marcada 
pelos valores do Brasil do século passado. A modalização "evidentemente" é oriunda dos dados fornecidos na Justificativa sobre a abrangência da obra do poeta mineiro, e também da experiência da estudante enquanto leitora da poesia do escritor brasileiro. Assim, torna-se possível afirmar de forma tão categórica as características da obra do poeta. Abaixo, por meio da modalização "essencialmente", a característica "brasileira" da obra de Drummond também é afirmada:

(51) o impacto que ela causa, o modo como atinge o público em outra época, em outra sociedade, em outra cultura e, mais especificamente no caso do presente projeto, o modo como é lida a tradução da poesia drummondiana, essencialmente brasileira, no contexto sociocultural francês. (PP1)

As avaliações lógicas feitas pela Estudante 1 dão ensejo para que a importância da obra de Carlos Drummond de Andrade deva ser estudada, dado que pode contribuir para os estudos sobre cultura. No excerto seguinte, encontraremos a modalização "Naturalmente", a qual permite à aluna validar e propor o objetivo na sua pesquisa na seção de Introdução:

(52) Naturalmente, tamanha recepção nacional à obra de um artista repercute internacionalmente, atingindo e interessando leitores em outros lugares, de culturas diferentes. Na pesquisa que aqui se apresenta, propõe-se levantar textos relacionados à recepção dos poemas de Drummond em língua francesa, mais particularmente na França. (PP1)

Do mesmo modo, a modalização "certamente", no excerto a seguir, que concluiu a seção de Justificativa, assevera a importância do estudo de uma obra tão complexa quanto a de Drummond:

(53) Sendo assim, certamente pode-se conhecer mais profundamente a cultura brasileira - tanto do século XX quanto do século XXI, séculos que englobam a existência da poesia drummondiana. (PP1)

Durante o projeto de pesquisa, encontramos também algumas modalizações apreciativas da produtora do texto com relação tanto ao poeta brasileiro, quanto a sua obra. No excerto abaixo, podemos ler a apreciação por meio da nomeação "um dos maiores poetas que o Brasil já teve", o que evidencia a importância de Drummond na 
literatura brasileira, segundo a avaliação da estudante:

(54) É justificável, portanto, a grande difusão da obra de Carlos Drummond de Andrade, considerado por muitos um dos maiores poetas que o Brasil já teve. (PP1)

A avaliação também foi dirigida à obra do poeta mineiro, pois é por isso que ela deve ser estudada, logo o levantamento proposto na pesquisa tem validade devido ao grande valor dado pela produtora do texto ao trabalho literário de Drummond. Isso pode ser constatado na avaliação sublinhada abaixo:

(55) Por isso, mostra-se de grande valor o levantamento sobre a recepção da poesia de Drummond em um país que difere em diversos aspectos da nação em que foi escrita sua obra. (PP1)

É por meio da análise das modalizações do projeto de pesquisa que se torna possível identificarmos a principal voz presente no texto, responsável por todas as avaliações que destacamos nos excertos acima. Embora tenha citado tanto na Introdução, quanto na seção de Fundamentação teórica e na Justificativa, estudiosos da tradução para, depois, avaliar de forma lógica a pesquisa e a obra do poeta, o raciocínio criado deixa entrever, como verificamos nas modalizações autonímicas e nas avaliações lógicas, as avaliações da estudante quanto à complexa obra do poeta, que comporta aspectos brasileiros, mas também aborda questões universais.

Como mostramos também nas análises das outras categorias, pode-se notar o valor positivo atribuído aos aspectos da cultura brasileira que são a base da poética de Drummond, mas que permitem também a discussão de assuntos que não tocam somente aos brasileiros, pois são questões com potencial para serem lidas e tratadas por outras culturas, inclusive a francesa. Portanto, definimos uma voz específica que cria o raciocínio no projeto de pesquisa: trata-se da voz do estudante graduando intrigado com algum aspecto percebido na sua experiência enquanto tal. Essa voz organizou, desde a seção de Introdução, um modo de pensamento em que se ressaltou a obra de Carlos Drummond de Andrade com todas as suas peculiaridades. É por meio dessa apreciação dirigida ao poeta que a voz da estudante emerge e pela qual identificamos a sua motivação para a proposição do estudo, sendo a sua experiência enquanto aluna de Letras que a 
motivou a desenvolver a sua primeira pesquisa científica.

A voz da ciência pode ser constatada nas citações diretas e indiretas dos teóricos pertinentes para a pesquisa:

(56) Jauss (1978) propõe a definição de uma "obra como resultado da convergência do texto e de sua recepção, e, portanto, como uma estrutura dinâmica que só pode ser entendida em suas 'concretizações' históricas sucessivas" (JAUSS, 1978, p. 269, tradução nossa). Assim, é importante o modo como os receptores com outras referências culturais reagem à leitura das obras estrangeiras. (PP1)

As aspas marcam a citação direta do teórico Jauss a respeito de um conceito próprio. Após a citação direta, verificamos um comentário tirado pela voz do pesquisador a respeito do conceito citado.

\section{Estudante 2}

No projeto de pesquisa da Estudante 2, do mesmo modo, encontramos a voz da estudante de graduação avaliando e se posicionando quanto às ideias colocadas ao longo do conteúdo temático. Abaixo, mostraremos alguns excertos significativos, a fim de analisarmos os posicionamentos enunciativos:

(57) Mais recentemente, no contexto da didática das línguas a noção de plurilinguismo, a formação pela intercompreensão de línguas românicas têm se mostrado como fundamental no contexto de desenvolvimento de competências de leitura. Partindo do princípio de que num contexto plurilíngue as línguas "se inter-relacionam e interagem", a abordagem pela intercompreensão desenvolve a compreensão escrita de falantes de diferentes línguas, cada um interagindo em sua língua materna. (PP2)

No excerto acima, identificado na introdução do projeto de pesquisa, verificamos uma modalização lógica expressa pela forma "fundamental". Ora, essa avaliação está 
baseada em quais representações lógicas? A nosso ver, trata-se da avaliação lógica advinda da experiência da estudante enquanto estudante da graduação e interessada nas questões relativas à Didáticas da Línguas Estrangeiras, mais especificamente engajada no tema da intercompreensão no ensino de línguas, notadamente a língua francesa. Outro indício textual que corrobora para a nossa análise é a ilha textual, que está entre aspas, "se inter-relacionam e interagem", a qual representa explicitamente a voz do estudante, pois mostra que o projeto de pesquisa é produzido a partir do modo com a Estudante 2 compreende o estudo que empreenderá. Encontramos no projeto de pesquisa uma outra ocorrência de aspas, porém esta contém uma diferença:

(58) Algumas estratégias de leitura, comuns aos dois contextos aqui estudados, partem da exploração de "territórios de transferência em potencial" (DEGACHE, 2012) entre as línguas envolvidas, como na exploração das transparências (palavras cognatas nas línguas vizinhas), no trabalho das analogias e transferências "interlinguísticas" e no acesso aos conhecimentos anteriores de outras línguas. (PP2)

O fragmento acima entre aspas não tem o mesmo valor que o anterior, pois ele mostra a separação entre a voz do estudante e a voz da ciência materializada pelo conceito citado. A Estudante 2 se apóia nessa voz para corroborar a sua afirmação, por isso há justamente a indicação bibliográfica na frente do fragmento.

Na seção dos objetivos da pesquisa, constamos uma modalização apreciativa com alto valor de subjetividade, também esta advinda da voz do estudante e que expressa o seu posicionamento a respeito da temática da pesquisa:

(59) Por meio da análise dos pontos convergentes entre o ensino da leitura em francês nos cursos de Práticas de leitura do CL-USP e as teorias de IC entre línguas românicas e visando contribuir para uma real implantação de políticas de plurilinguismo e intercompreensão no Centro de Línguas $[\ldots](\mathrm{PP} 2)$

O modalizador "real" contém uma apreciativa que não é baseada em estudos científicos, mas sim na voz da estudante, que acredita em uma "real implantação" no Centro de Línguas da FFLCH, após o término da pesquisa. Mais uma vez, trata-se de uma avaliação baseada na experiência da voz da estudante enquanto interessada na temática da pesquisa. 


\section{Estudante 3}

Evidencia-se, durante o projeto de pesquisa, a voz da estudante em Letras, que cursa a habilitação em língua francesa e interessada no ensino dessa língua estrangeira aos brasileiros em nível universitário. Com enunciado no projeto de pesquisa, no início da aprendizagem do francês, os estudantes mostram muita dificuldade na expressão escrita em língua estrangeira, daí o interesse da estudante em realizar um estudo nessa área.

A voz do estudante pode ser identificada por meio das modalizações autonímicas, sobretudo na parte de Fundamentação teórica do projeto, que expressam comentários explicativos cuja função é reformular para adequar a escrita teórica tendo em vista uma melhor compreensão do se diz:

(60) Sob esta perspectiva, a língua não é vista como mero conhecimento passivo de aceitação, mas como ocorrência ativa e real, ou seja, não se insere como informações a serem acumuladas, mas sim como savoir-faire a ser desenvolvido. (PP3)

Assim, se ressaltamos a definição de Bakhtin para os gêneros discursivos, temos que estes são realizações comunicativas através de formas mais ou menos estáveis de enunciados, ou seja, fundados por convenções sociais. (PP3)

O texto, por sua vez, corresponderia a uma unidade comunicativa ou interativa global e pode ser entendido como uma unidade de agir linguageiro, situado em determinado tempo e espaço, contentor de uma mensagem organizada de maneira a produzir efeito de sentido, ou seja, coerência, no destinatário. (PP3)

De acordo com Authier-Revuz (1999), a modalização autonímica cria, no próprio dizer, um outro dizer sobreposto, logo um discurso Y no interior do discurso X. A forma "ou seja" é uma modalização autonímica que evidencia a voz da estudante ao comentar e re-explicar a sua própria escrita teórica, gerando um discurso $\mathrm{Y}$ dentro do discurso $\mathrm{X}$ (AUTHIER-REVUZ, 1999). Assim, constatamos que a estudante está adentrando na esfera científica, já que ela busca adequar e compreender, ela própria, os conceitos que ela utilizará na pesquisa. No segundo excerto, verificamos a voz da ciência por meio da referência ao conceito de gêneros do discurso de Bakhtin.

A partir da voz da estudante que encontramos no projeto de pesquisa, identificamos modalizações apreciativas advindas dessa voz, pela qual ela externa a sua 
avaliação acerca da urgência e importância da pesquisa que no projeto. Na introdução do texto, encontramos:

(61) O presente projeto tem por objetivo o estudo da produção escrita de alunos universitários implicados no aprendizado do francês como língua estrangeira, tendo em vista o lugar privilegiado da escrita como instrumento de desenvolvimento das capacidades de linguagem e, portanto, da comunicação em si mesma. (PP3)

No excerto acima, a estudante avalia o contexto no qual a pesquisa seria desenvolvida, quer dizer, o contexto universitário onde a língua francesa deve ser aprendida tanto na sua modalidade oral, como também na modalidade escrita. O contexto universitário, assim, passa a ser um espaço propício para a investigação da pesquisa, pois nele são cobrados vários gêneros textuais dos quais os estudantes devem se apropriar e compreender os usos linguageiros dos textos. Advinda também da voz da estudante, verificamos a seguinte passagem:

(62) Logo, podemos considerar os gêneros um instrumento importante no processo de ensino da língua, em que a apropriação das capacidades de linguagem passa, forçosamente, pela comunicação. (PP3)

Ao avaliar os gêneros textuais como "importantes" instrumentos para o ensino de uma língua, fica evidenciada a voz do estudante, que passou pela experiência de aprendido a língua francesa por meio da perspectiva que foi adotada na pesquisa. Logo, ela avalia essa o ensino de línguas via gêneros textuais como "importantes" nesse contexto.

No tocante às modalizações lógicas, elas aparecem no momento da síntese teórica relevante para a pesquisa, no início do projeto de pesquisa. Nesse momento, sobressai-se a voz do estudante que está se apropriando de conceitos científicos importantes para o desenvolvimento da sua pesquisa e, por isso, relaciona as ideias dos teóricos de forma a construir um raciocínio lógico:

(63) Os gêneros textuais têm vasta aplicação na didática das línguas e, portanto, têm sido amplamente abordados. (PP3)

Para ambos, todo gênero é constituído de diversos elementos que representam os objetos de 
ensino gradativo que devem ser aplicados pelo professor [...] Assim, no processo de aprendizagem, faz-se necessário compreender quais conteúdos são dizíveis em determinado gênero [...] (PP3)

As modalizações lógicas são encontradas dentro do raciocínio lógico criado pelo tipo de discurso teórico. Elas evidenciam avaliações que possuem um alto grau de probabilidade e necessidade, logo, elas têm um estatuto lógico, cuja relevância é dada pela voz do estudante.

\subsection{Quadro sintético das análises dos projetos de pesquisa}

A seguir, elaboramos um quadro com os principais resultados encontrados no projeto de pesquisa por meio dos índices textuais o que os evidenciam.

\begin{tabular}{|c|c|c|}
\hline & Índices textuais & O que mostram? \\
\hline $\begin{array}{c}\text { Plano global } \\
\text { do conteúdo } \\
\text { temático }\end{array}$ & $\begin{array}{l}\text { Presença de uma ideia central: } \\
\text { Estudante 1: a ideia central se refere ao fato } \\
\text { de Carlos Drummond de Andrade abordar } \\
\text { temas brasileiros, que tocam à cultura } \\
\text { brasileira, mas que, por suas abrangências, } \\
\text { podem ser discutidos e pensados em outras } \\
\text { culturas. } \\
\text { Estudante 2:A ideia central que guia o } \\
\text { projeto de pesquisa da Estudante } 2 \text { se refere } \\
\text { ao fato de que não há dentro da didática das } \\
\text { línguas uma reflexão a respeito do } \\
\text { desenvolvimento da competência de leitura } \\
\text { em contextos plurilíngues. } \\
\text { Estudante 3: A ideia central que } \\
\text { encontramos no projeto de RA se refere ao } \\
\text { papel da produção escrita no } \\
\text { desenvolvimento das capacidades de } \\
\text { linguagem, a fim de possibilitar ao } \\
\text { estudante a expansão do seu "savoir-faire" } \\
\text { e, assim, ser capaz de participar de diversas } \\
\text { realizações comunicativas. }\end{array}$ & $\begin{array}{l}\text { Por meio das análises, percebemos que } \\
\text { essa ideia central revela a relação que há } \\
\text { entre a esfera universitária e a esfera } \\
\text { científica no início de uma primeira } \\
\text { pesquisa, ou seja, é a experiência em meio } \\
\text { universitário que propiciará a motivação } \\
\text { para a formulação de um projeto de } \\
\text { pesquisa. }\end{array}$ \\
\hline
\end{tabular}




\begin{tabular}{|c|c|c|}
\hline $\begin{array}{l}\text { Tipos de } \\
\text { discurso }\end{array}$ & $\begin{array}{l}\text { Predominância do tipo de discurso teórico: } \\
\text { Estudante 1: "A busca inicial é, portanto, } \\
\text { mais física, ou seja, exige pesquisa em } \\
\text { bibliotecas e } \\
\text { livrarias nacionais e francesas, além de } \\
\text { editoras que tenham publicado as traduções } \\
\text { de Carlos Drummond de Andrade" } \\
\text { Estudante 2: "Mais recentemente, no } \\
\text { contexto da didática das línguas a noção de } \\
\text { plurilinguismo, a formação pela } \\
\text { intercompreensão de línguas românicas têm } \\
\text { se mostrado como fundamental no contexto } \\
\text { de desenvolvimento de competências de } \\
\text { leitura." } \\
\text { Estudante } 3: \underline{\text { Para ambos, todo gênero é }} \\
\text { constituído de diversos elementos que } \\
\text { representam os objetos de ensino gradativo } \\
\text { que devem ser aplicados pelo professor a } \\
\text { fim de que }\end{array}$ & $\begin{array}{l}\text { O tipo de discurso teórico, construído } \\
\text { com um menor grau de autonomia, } \\
\text { evidencia a construção de uma ideia } \\
\text { central nos projetos, a qual organiza toda } \\
\text { a pesquisa. Essa ideia central revela que a } \\
\text { motivação para a pesquisa advém da } \\
\text { experiência em meio universitário. }\end{array}$ \\
\hline $\begin{array}{c}\text { Coesão } \\
\text { nominal }\end{array}$ & $\begin{array}{l}\text { Cadeias de retomadas nominais: } \\
\text { Estudante 1: poeta } \neq \text { poeta brasileiro. } \\
\text { Estudante 2: expressões nominais "uma } \\
\text { reformulação", "uma desconstrução", "uma } \\
\text { construção" e "uma implementação. } \\
\text { Estudante 3: retomadas nominais do } \\
\text { referente gêneros textuais". }\end{array}$ & $\begin{array}{l}\text { As retomadas nominais estabelecem } \\
\text { relações que permitem o desenvolvimento } \\
\text { da ideia central e sua compreensão na } \\
\text { micro-estrutura textual. Elas mostram os } \\
\text { posionamentos subjetivos da estudantes. }\end{array}$ \\
\hline Conectores & $\begin{array}{l}\begin{array}{l}\text { Estudante 1: conectores de oposição } \\
\text { (contudo, entretanto, porém) e adição (além } \\
\text { disso). }\end{array} \\
\begin{array}{l}\text { Estudante 2: conectores de marcação } \\
\text { temporal; adição e sequenciação. }\end{array} \\
\begin{array}{l}\text { Estudante 3: conectores adversativos; } \\
\text { adição; finalidade e explicação }\end{array}\end{array}$ & $\begin{array}{l}\text { Mostram como a ideia central é } \\
\text { construída ao longo das principais partes } \\
\text { do projeto de pesquisa. }\end{array}$ \\
\hline Vozes & $\begin{array}{l}\text { Modalizações autonímicas: } \\
\text { Estudante 1: de modo que; desse modo. } \\
\text { Estudante 3: ou seja } \\
\text { Ilha textual: } \\
\text { Estudante 2: "se inter-relacionam e }\end{array}$ & $\begin{array}{l}\text { Mesmo que o discurso teórico seja } \\
\text { predominante nos projetos de pesquisa, } \\
\text { criando uma autonomia do agente } \\
\text { produtor do texto, encontramos } \\
\text { comentários na superfície textual que } \\
\text { revelam a voz do estudante, que se } \\
\text { coloca no texto, concedendo-lhe autoria. }\end{array}$ \\
\hline
\end{tabular}




\begin{tabular}{|c|c|c|}
\hline & intera & \\
\hline Modalizações & $\begin{array}{l}\text { Lógicas: } \\
\text { Estudante 1: evidentemente; } \\
\text { essencialmente; naturalmente; certamente. } \\
\text { Estudante 2: fundamental. } \\
\text { Estudante 3: construções com o verbo TER } \\
\text { (os gêneros textuais têm vasta...têm sido...) } \\
\text { Apreciativas com valor de asserção: } \\
\text { Estudante 1: grande valor; maiores poetas } \\
\text { que o Brasil já teve. } \\
\text { Estudante 2: real implantação. } \\
\text { Estudante 3: lugar privilegiado; importante. }\end{array}$ & $\begin{array}{l}\text { As modalizações lógicas com alto grau de } \\
\text { certeza nos certificam que pode ser a voz } \\
\text { do estudante quem julga e aprecia o } \\
\text { conteúdo temático, estando baseada na } \\
\text { sua experiência pessoal em meio } \\
\text { universitário. Os modalizadores com } \\
\text { função de apreciação mostram uma } \\
\text { avaliação subjetiva das estudantes quanto } \\
\text { à relevância do estudo que empreenderão. }\end{array}$ \\
\hline
\end{tabular}

\section{Resumos para apresentação oral de pesquisa}

Como apresentado no capítulo anterior, iniciaremos nossas análises dos resumos das apresentações orais de pesquisa por meio do contexto de produção textual e, em seguida, do plano global do conteúdo temático e dos tipos de discurso associados à coesão verbal. Depois, analisaremos os mecanismos de textualização por meio das conexões encontradas e da coesão nominal criada nos textos. Por último, mostraremos nossos resultados quanto às análises das vozes e das modalizações.

\subsection{Contexto de produção dos resumos}

A escrita do gênero textual resumo foi uma condição necessária para a participação no V Encontro de Pesquisa do Francês. Segundo consta na chamada do evento, o resumo deveria conter entre 150 e 300 palavras (Estudante 1: 168 palavras; Estudante 2: 136 palavras; Estudante 3: 288 palavras), sendo esta a única informação relacionada à escrita desse gênero textual. 
As produtoras dos resumos estão no término de sua pesquisa de Iniciação Científica e, devido às prescrições estabelecidas pelo Programa de Iniciação Científica da USP, necessitaram redigi-lo para poderem apresentar oralmente o estudo realizado em um evento científico. Os resumos das comunicações foram divulgados nos canais de divulgação de eventos da FFLCH e também na página da Monitoria do Francês da rede social Facebook por meio da disponibilização do caderno de resumo do evento.

Os leitores do resumo foram, sobretudo, os discentes da Área de ELLTF da FFLCH que, por meio dos seus orientadores, são incentivados a submeterem seus resumos para o V Encontro de Pesquisas do Francês e que compuseram o público do evento. No momento da escrita do resumo para a comunicação, as estudantes já tinham redigido outros dois resumos, um para o projeto de pesquisa e outro no relatório parcial de pesquisa.

\subsection{Plano global dos conteúdos temáticos}

Através do plano global do conteúdo temático do resumo verificamos uma retomada da ideia central da pesquisa, tal qual já tínhamos identificado em nossas análises do projeto de pesquisa. Por exemplo, os objetivos expressos nos resumos são idênticos àqueles dos projetos, como podemos ler no início dos resumos. Além disso, pudemos perceber algumas inadequações quanto à estrutura composicional nesse gênero textual.

\section{Estudante 1}

O resumo é introduzido pela mesma ideia geral que serviu para o desenvolvimento do projeto de pesquisa, da Fundamentação teórica e da justificativa do estudo:

(64) A obra literária de Carlos Drummond de Andrade é uma das mais reconhecidas da história da Literatura Brasileira. Apesar de bastante ligada às raízes do poeta, transparecendo sua brasilidade e sua origem interiorana, a poesia drummondiana vai além do regional, atingindo patamares, por assim dizer, universais.

Dada essa característica universal, a obra de Drummond foi traduzida para outras línguas, como 
o inglês, o holandês e também o francês. (R1) ${ }^{28}$

Por essa característica, chama-nos a atenção que a apresentação oral de pesquisa também será exposta segundo essa ideia geral, já que o gênero textual resumo tem a função de sumarizar as principais informações da comunicação que foi apresentada no $\mathrm{V}$ Encontro de Pesquisas do francês.

Em seguida, apresenta-se o objetivo da comunicação oral que, na verdade, foi o objetivo da pesquisa realizada:

(65) Essa pesquisa de Iniciação Científica teve como principal objetivo realizar o levantamento da recepção da poesia do escritor mineiro traduzida para o francês e difundida na França, especificamente. (R1)

Embora o objetivo da pesquisa tenha sido explicitado no resumo, a estudante não aponta para os resultados da pesquisa, pois não faz menção aos comentários críticos que ela realizou após o levantamento dos dados coletados. Assim, o leitor do resumo provavelmente não saberá qual o objetivo do levantamento.

Posteriormente, são sintetizados os pressupostos teóricos os quais a estudante utilizou para o desenvolvimento da pesquisa:

(66) Esse levantamento teve como base as teorias sobre recepção estética e sobre as influências de elementos culturais na tradução e na difusão de obras estrangeiras. (R1)

Finalizando o resumo da apresentação, foram apresentados os métodos utilizados na pesquisa:

(67) Para o desenvolvimento desse trabalho, os recursos eletrônicos como o computador e a internet foram elementos fundamentais, já que possibilitaram o acesso a bibliotecas, lojas virtuais e também a sites e blogs, que podem ser fonte de traduções não publicadas e, portanto, menos difundidas no meio acadêmico. (R1)

${ }^{28} \mathrm{R} 1$ : Resumo 1

R2:Resumo 2

R3: Resumo 3 
Nessa parte, a estudante não mencionou o método de análise dos dados, apenas o local de coleta dos dados, que no caso da pesquisa foi a internet. Desse modo, o leitor do resumo não soube de antemão, nem de modo geral, os resultados encontrados durante a pesquisa.

\section{Estudante 2}

Ao iniciar o resumo, a Estudante 2 resgatou a ideia central da sua pesquisa, assim como identificado no projeto:

(68) A presente pesquisa busca, por meio da análise da convergência entre as teorias do ensino da leitura já existentes e aquelas trazidas pela abordagem plural da intercompreensão de línguas românicas, surgidas a partir dos anos 80 , refletir sobre como o desenvolvimento de competências leitoras pode ultrapassar os limites de uma única língua-alvo e contribuir para o surgimento de um leitor autônomo plurilíngue. (R2)

Posteriormente, são explicitadas as informações da metodologia, no que tange ao contexto mais específico da pesquisa, a saber, o Centro de Línguas da FFLCH-USP:

(69) Para tanto apresenta-se a experiência de leitura de textos em outras línguas românicas feita em uma turma do curso de Práticas de Leitura em Francês do Centro de Línguas da FFLCH-USP. (R2)

Contudo, o método de análise não foi explicado no resumo, sendo que um dos objetivos da estudante foi construir uma sequência de atividades, baseadas no conceito de intercompreensão, para serem aplicadas na turma do curso.

\section{Estudante 3}

O resumo da Estudante 3 é o mais canônico dentre os anteriores, pois é iniciado pelo objetivo, depois pela fundamentação teórico-metodológica (sobretudo o método de análise) e os resultados obtidos com a pesquisa. No objetivo, retoma-se a ideia central da pesquisa: 
(70) Esta comunicação tem por objetivo apresentar um estudo sobre a produção escrita de alunos universitários, aprendizes do francês como língua estrangeira, observando, para tanto, o desenvolvimento de suas capacidades de linguagem ao longo do processo de aprendizagem. (R3)

Nesse resumo há tanto um arcabouço teórico quanto um método advindo dos conceitos que foram utilizados. Isso pode ser comprovado, pois a Fundamentação teórica ocupa grande parte do texto, sendo muito maior do que a metodologia. Os resultados obtidos mostram a qual conclusão a pesquisa chegou, de que houve um desenvolvimento geral dos alunos por meio dos textos produzidos, porém se notou uma dificuldade dos estudantes na compreensão dos aspectos linguísticos e discursivos.

Para visualizarmos de forma mais clara nossas análises do Plano global do conteúdo temático do resumo, criamos o quadro sintético abaixo:

\begin{tabular}{|c|c|c|c|}
\hline & Estudante 1 & Estudante 2 & Estudante 3 \\
\hline Situar a pesquisa & $\bar{X}$ & - & - \\
\hline Apresentar a pesquisa & $\mathrm{X}$ & $\mathrm{X}$ & $\mathrm{X}$ \\
\hline Descrever a metodologia & $\begin{array}{l}\text { Somente da coleta } \\
\text { de forma implícita }\end{array}$ & - & $\mathrm{X}$ \\
\hline Sumarizar os resultados & $\begin{array}{c}\text { Só trata do } \\
\text { levantamento de } \\
\text { forma geral }\end{array}$ & - & $\mathrm{X}$ \\
\hline Discutir a pesquisa & - & $\begin{array}{l}\text { A partir dos objetivos } \\
\text { gerais da pesquisa }\end{array}$ & - \\
\hline
\end{tabular}

Quadro 13: síntese das análises dos Planos globais do conteúdo temático dos resumos ("X"= possui; "“." = não possui; "escrito" = possui em partes)

Voltaremos a discutir essa análise de forma comparativa em nossas análises do Plano global do conteúdo temático das apresentações orais de pesquisa para as quais os resumos foram produzidos.

\subsection{Tipos de discurso e coesão verbal}

Os tipos de discurso evidenciam que as Estudantes 1 e 3 compreenderam a situação do resumo, logo encontramos o tipo de discurso misto narrativo-teórico, que 
recupera temporalmente as etapas da pesquisa quanto às escolhas teóricas e metodológicas, bem como explicitam os resultados obtidos. A coesão verbal nos permite visualizar essa situação.

\section{Estudante 1}

No tocante aos tipos de discurso, nota-se que somente no primeiro parágrafo do resumo encontramos o tipo de discurso teórico, já que o tempo verbal predominante é o presente do indicativo (verbo "é") e há conectores textuais lógicos expressos por sintagmas nominais (“Apesar de" e "por assim dizer"):

(71) A obra literária de Carlos Drummond de Andrade é uma das mais reconhecidas da história da Literatura Brasileira. Apesar de bastante ligada às raízes do poeta, transparecendo sua brasilidade e sua origem interiorana, a poesia drummondiana vai além do regional, atingindo patamares, por assim dizer, universais. (R1)

Ainda com relação aos tempos verbais, encontramos a utilização do gerúndio em dois verbos, no "transparecer" e "atingir", cujo aspecto verbal exprime uma ação em curso ou uma ação simultânea a outra, bem como uma ideia de progressão indefinida. Nesse sentido, notamos que, no excerto acima em discurso teórico, o valor gerado pelo uso do gerúndio é a expressão de uma ação em curso, mas não simultânea a outra pois, no excerto em questão, a poesia de Drummond, antes de conter discussões universais, deixa transparecer os referenciais nacionais e regionais ligados ao escritor. Assim, primeiramente a poesia do autor contém questões nacionais e, somente depois, "atinge" questões que podem ser abordadas por outros leitores que não brasileiro.

Nos outros excertos do resumo, é possível identificarmos o tipo de discurso narração, visto que o resumo foi produzido no final da pesquisa e, tanto as leituras teóricas já tinham sido lidas quanto a metodologia aplicada, logo nesse momento a estudante já tinha realizado o levantamento da pesquisa e feito os comentários dos dados da pesquisa. A narração pode ser encontrada em alguns excertos por meio do uso do pretérito perfeito: 
(72) Dada essa característica universal, a obra de Drummond foi traduzida para outras línguas, como o inglês, o holandês e também o francês. (R1)

(73) Essa pesquisa de Iniciação Científica teve como principal objetivo [...] (R1)

(74) Esse levantamento teve como base as teorias sobre recepção estética [...] (R1)

Para o desenvolvimento desse trabalho, os recursos eletrônicos como o computador e a internet foram elementos fundamentais [...] (R1)

No final do resumo, a narração é fusionada com o discurso teórico, como podemos perceber no uso dos conectores lógicos encontrados nessa parte do texto.

(75) Para o desenvolvimento desse trabalho, os recursos eletrônicos como o computador e a internet foram elementos fundamentais, já que possibilitaram o acesso a bibliotecas, lojas virtuais e também a sites e blogs, que podem ser fonte de traduções não publicadas e, portanto, menos difundidas no meio acadêmico.(R1)

\section{Estudante 2}

O resumo foi produzido por meio do discurso teórico, através dos verbos no presente do indicativo, que evidenciam uma conjunção e autonomia com relação aos parâmetros contextuais:

(76) A presente pesquisa busca [...] Para tanto apresenta-se a experiência [...] (R2)

No último excerto, o verbo "levar" no gerúndio é indicativo da importância dos dois conceitos, intercompreensão e plurilinguismo para o desenvolvimento da pesquisa, pois foi por meio deles que a sequência de atividades da pesquisa, ou seja, o método de análise pode ser construído:

(77) Além da análise dos processos cognitivos e metacognitivos envolvidos no processo de leitura, visa-se também contribuir para a reformulação do programa do curso de Práticas de Leitura em Francês, levando em consideração as novas possibilidades trazidas pelo plurilinguismo e pelas teorias de intercompreensão. (R2) 


\section{Estudante 3}

O resumo é construído sobremaneira por meio do tipo de discurso misto narrativo-teórico, pois encontramos somente verbos no presente do indicativo (propõe, retomam, operam) e conectores lógicos (igualmente, segundo, então, assim), bem como verbos no pretérito perfeito (apoiou, remetemos). Essa coesão verbal acontece, sobretudo na exposição dos pressupostos teórico, onde encontramos um raciocínio lógico:

(78) A pesquisa se apoiou no quadro teórico-metodológico do interacionismo sociodiscursivo, conforme os estudos de Bronckart (1999, 2006, 2008) [...] Apoiamo-nos igualmente na noção bakhtiniana de gêneros do discurso, retomada por Bronckart (1997), que propõe o termo gêneros textuais. Segundo essa perspectiva [...] Remetemos, então, às proposições de Schneuwly \& Dolz (2004) que retomam as ideias de Vigotsky sobre a noção de instrumento [...] Assim, os gêneros operam concomitantemente $[\ldots](\mathrm{R} 3)$

Igualmente ao excerto anterior, este contém o tipo de discurso misto narrativo-teórico (BRONCKART, p.209), porém a narração tem uma relevância na seção de metodologia da pesquisa:

(79) As análises do corpus foram feitas conforme o folhado textual proposto por Bronckart (1997), composto por infraestrutura geral do texto, pelos mecanismos de textualização e de responsabilização enunciativa. Tais aspectos foram observados através dos eixos relatar e expor, a partir dos quais se organizam os tipos discursivos, isto é, os elementos estruturais que determinariam as distinções formais entre os gêneros. (R3)

Como aponta Bronckart (1999, p. 289), atrelado aos verbos no pretérito perfeito, encontramos conectores lógicos como: conforme, a partir de, isto, os quais evidenciam um raciocínio lógico associado à narração.

\subsection{Mecanismos de textualização: conectores textuais}

Os conectores textuais foram importantes para identificarmos o tipo de discurso misto narrativo-teórico e para avaliarmos se as alunas se adequaram ou não à situação de 
produção do texto, tal como determinada pelo dispositivo de formação da Iniciação Científica.

\section{Estudante 1}

Os conectores lógicos que encontramos definem o tipo de discurso teórico encontrado somente no primeiro parágrafo do resumo da apresentação oral da pesquisa. Nos excertos em narração, não encontramos conectores temporais que marcassem uma continuidade das ações da pesquisa, que foram elencadas separadamente na seguinte ordem: objetivos da pesquisa, Fundamentação teórica e metodologia. No final do resumo, na sumarização da metodologia da pesquisa, é possível nos depararmos com conectores lógicos, como "já que" e "portanto", atrelados à narração:

(80) Para o desenvolvimento desse trabalho, os recursos eletrônicos como o computador e a internet foram elementos fundamentais, já que possibilitaram o acesso a bibliotecas, lojas virtuais e também a sites e blogs, que podem ser fonte de traduções não publicadas e, portanto, menos difundidas no meio acadêmico. (R1)

\section{Estudante 2}

No que concerne ao uso dos conectores, duas ocorrências chamaram a nossa atenção:

(81) Para tanto apresenta-se a experiência de leitura de textos em outras línguas românicas feita em uma turma do curso de Práticas de Leitura em Francês do Centro de Línguas da FFLCH-USP $[\ldots](\mathrm{R} 2)$

No excerto acima, o conector "Para tanto" tem a função de explicar resumidamente no resumo qual é o contexto da pesquisa e quem são os participantes dela. Assim, ele introduz o espaço social no qual LM está inserida, pois ela é monitora do Centro de Línguas da FFLCH e estudante da graduação em Letras. É por meio dessa experiência enquanto aluna universitária que a estudante desejou realizar a pesquisa sintetizada no resumo. O outro conector com um uso particular é o "além de", em: 
(82) Além da análise dos processos cognitivos e metacognitivos envolvidos no processo de leitura, visa-se também contribuir para a reformulação do programa do curso de Práticas de Leitura em Francês [...] (R2)

O conector "Além de" introduz um objetivo de pesquisa que é revelador da ideia de novidade trazida pelo trabalho de LM, pois há como intenção reformular um programa de curso do Centro de Línguas, ou seja, no âmbito mais local da pesquisa, considera-se que o Centro de Línguas (e a USP enquanto espaço onde ele funciona) não realiza pesquisas a respeito da intercompreensão e da formação do leitor plurilíngue.

\section{Estudante 3}

Dado que a exposição da teoria contem maiores detalhes, encontramos alguns conectores que têm a função de desenvolver essa explicação:

(83) Sob tal perspectiva, a aprendizagem estabelece-se [...]

Apoiamo-nos igualmente na noção bakhtiniana [...]

Segundo essa perspectiva, as atividades humanas exigem [...]

Remetemos, então, às proposições de Schneuwly \& Dolz (2004) [...]

Assim, os gêneros operam concomitantemente como unidade de ensino e como instrumento [...] (R3)

\subsection{Mecanismos de textualização: coesão nominal}

A coesão nominal permite criar cadeias nominais que nos confirmaram as nossas análises do plano global do conteúdo temático, já que essas retomadas nominais são parecidas com as estabelecidas nos projetos de pesquisa e deixam entrever a ideia central da pesquisa. 


\section{Estudante 1}

$\mathrm{Na}$ coesão nominal, encontramos algumas nominalizações que nos permitem identificarmos os posicionamentos da estudante frente à(s):

a) Poesia de Carlos Drummond de Andrade: "uma das mais reconhecidas da história da Literatura Brasileira".

b) Características dessa poesia: "sua brasilidade" e "patamares, por assim dizer, universais".

A respeito da série coesiva criada no resumo, encontramos a seguinte sequência:

(84) \{Carlos Drummond de Andrade, poeta, Drummond, escritor mineiro\} (R1)

Essa sequência nos mostra um valor específico de uso das retomadas anafóricas, sobretudo o termo "escritor mineiro", que marca a característica de "brasilidade" da sua poesia e também os aspectos "universais" abarcados por ela. Diferentemente da análise que realizamos no projeto de pesquisa, na qual há várias retomadas com o termo "poeta brasileiro", no resumo esse tipo não foi encontrado, no entanto é a nominalização "sua brasilidade" que criou o valor específico à poesia de Drummond, sendo este o mesmo valor gerado com o uso do termo "brasileiro" atrelado ao poeta.

\section{Estudante 2}

A coesão nominal nos revela o ineditismo do projeto de pesquisa da Estudante 2, segundo o ponto de vista da pesquisadora, uma vez que não existem muitos estudos que abordem a questão de pesquisa a qual ela buscou desenvolver. Por meio da cadeia coesiva em que ela expressa os objetivos da pesquisa, isso pode ser constatado:

(85) \{refletir sobre como o desenvolvimento de competências leitoras [...] contribuir para o surgimento de um leitor autônomo plurilíngue [...] contribuir para a reformulação do programa do curso de Práticas de Leitura em Francês [...]\} (R2) 
Os dois usos do verbo "contribuir" sinalizam que LM compreende que há poucas pesquisas na Didática do Francês Língua Estrangeira, as quais tratam do assunto da formação do leitor plurilíngue. O primeiro verbo "contribuir" está atrelado ao substantivo "surgimento", que traz para a pesquisa uma responsabilidade de mostrar, de forma inédita, a formação desse tipo de leitor. Já o segundo verbo "contribuir" está relacionado ao substantivo "reformulação", o qual evidencia um objetivo de pesquisa de LM relacionado ao seu contexto enquanto estudante universitária, monitora do Centro de Línguas da FFLCH.

\section{Estudante 3}

Igualmente ao que constatamos no projeto de pesquisa, a maior cadeia coesiva se refere à ideia dos gêneros textuais e suas potencialidades para o ensino/aprendizagem de línguas estrangeiras. Vejamos a cadeia coesiva encontrada no resumo:

(86) \{instrumento mediador; gêneros do discurso; gêneros textuais; formas mais ou menos estáveis de enunciados; instrumento; gêneros; unidade de ensino; instrumento\} (R3)

A exposição teórica ocupou grande parte do resumo da apresentação, pois, como já havíamos analisado no projeto pesquisa, a RA tem como ideia central da sua pesquisa que a escrita por meio dos gêneros textuais propicia o desenvolvimento das capacidades de linguagem, assim é necessário explicar em que medida isso é possível. Essa ideia central da pesquisa é identificada novamente no resumo da apresentação oral ao final do processo da IC.

\subsection{Mecanismos enunciativos: vozes e modalizações}

Conforme já apresentamos, nas análises do projeto de pesquisa, identificamos uma voz a qual nomeamos de "voz da estudante", que é responsável pelo desenvolvimento da ideia central nos projetos de pesquisa. Apesar do resumo ter sido produzido no final do processo de IC, é ainda a voz da estudante que enuncia ao retomar a 
ideia central da pesquisa. Como realçamos nas análises dos planos globais dos conteúdos temáticos do resumo, as estudantes não tratam dos resultados da pesquisa ou tratam de forma rápida (Estudante 3), sendo essa parte do resumo essencial na situação de produção desse gênero textual, como apontam Motta-Roth e Hendges (2010); por outro lado, os objetivos aparecem no resumo conforme foram apresentados no projeto de pesquisa, ou seja, não foram alterados como consequência do desenvolvimento da IC. Assim, constata-se que os objetivos que deram origem à ideia central da pesquisa, baseados nas motivações oriundas da experiência da graduação (VIGOTSKI, 2001), não se modificam frente aos resultados encontrados.

Além da voz da estudante, encontramos também a voz do pesquisador, sobretudo nas passagens de disjunção, seja na exposição da metodologia, seja no tratamento dos resultados. Ambas as vozes foram identificadas em ocorrências de modalizações autonímicas (AUTHIER-REVUZ, 1999; MAINGUENEAU, 2005). A respeito das modalizações, encontramos as lógicas que contêm um valor de asserção e apreciativas, como veremos a seguir.

\section{Estudante 1}

A modalização autonímica aparece do resumo da Estudante 1, no seguinte excerto:

(87) Apesar de bastante ligada às raízes do poeta, transparecendo sua brasilidade e sua origem interiorana, a poesia drummondiana vai além do regional, atingindo patamares, por assim dizer, universais. (R1)

A modalização autonímica, expressa pelo termo "por assim dizer", mostra como, do ponto de vista interpretativo da voz do pesquisador, a poesia de Drummond pode ser entendida. A palavra "universais", que vem a seguir do termo "por assim dizer", adjetiva o substantivo "patamares" indicando, a primeira vista, uma não coincidência imediata com o termo "patamares" sozinho; porém, a pesquisadora estabelece a coincidência entre esses dois termos, a fim de marcar sua apreciação sobre a abrangência da poesia de Drummond. Essa afirmação não foi enunciada de forma não tão assertiva, pois a Estudante 1 procurou resguardar-se de críticas, como costumam fazer os pesquisadores. 
Por meio da voz da estudante, nós encontramos uma avaliação no seguinte excerto:

(88) A obra literária de Carlos Drummond de Andrade é uma das mais reconhecidas da história da Literatura Brasileira. (R1)

A oração acima destacada indica a apreciação da voz da estudante, mostrando a mesma avaliação que identificamos no projeto de pesquisa, pois, ao contrário do excerto 87, nesse a Estudante 1 não toma precaução ao fazer uma afirmação geral. Por outro lado, no final do resumo, encontramos, mais uma vez, indícios da voz do pesquisador em duas modalizações apreciativas e um modalizador lógico: "que podem ser". As modalizações "fundamentais" e "menos difundidas" são baseadas na experiência da Estudante 1 no papel de pesquisadora durante da IC. Já a modalização lógica "que podem ser "atribui à afirmação um sentido de possibilidade e não de certeza absoluta. Portanto, as três modalizações evidenciam a voz do pesquisador na escrita do resumo, pois demonstram uma avaliação da estudante em relação à própria pesquisa, como os resultados foram obtidos e, também, indicam certa precaução, característica da voz do pesquisador.

(89) os recursos eletrônicos como o computador e a internet foram elementos fundamentais, já que possibilitaram o acesso a bibliotecas, lojas virtuais e também a sites e blogs, que podem ser fonte de traduções não publicadas e, portanto, menos difundidas no meio acadêmico. (R1)

\section{Estudante 2}

A voz do estudante aparece no resumo por meio das ideias produzidas no texto, que foram retomadas da ideia central, pautada na experiência da Estudante 2. Primeiramente, encontramos a ideia de ineditismo da pesquisa evidenciada nos objetivos expressos no resumo por meio dos verbos "refletir" e, sobretudo, por meio do verbo “contribuir". Este último traz uma responsabilidade para a pesquisa, pois se considera que o surgimento do leitor plurilíngue por meio das teorias da intercompreensão não recebeu atenção em pesquisas científicas: 
(90) A presente pesquisa busca [...] refletir sobre como o desenvolvimento de competências leitoras pode ultrapassar os limites de uma única língua-alvo e contribuir para o surgimento de um leitor autônomo plurilíngue. (R2)

Como constatamos no projeto de pesquisa, não há um estado da arte dos estudos já realizados sobre o assunto e nem a citação deles, o que mostra a voz do estudante adentrando a esfera científica e tendo somente como motivação para a realização do trabalho a sua experiência enquanto aluna da graduação. Nesse sentido, podemos estabelecer uma ligação com o que afirma Vigotski (2009) e Friedrich (2013, p.100) sobre o fato de que os conceitos científicos, para eles, sempre se apoiam em conceitos cotidianos, que são construídos nas práticas cotidianas. Também no papel de graduanda, a Estudante 2 ocupa a posição de monitora do Centro de Línguas da FFLCH e, por isso, busca com a pesquisa reformular o programa do curso de Práticas de Leitura em Francês, o que mostra indícios da voz do estudante, já que é do posicionamento de graduanda que parte a pesquisa.

Esses indícios de voz do estudante podem ser verficiados por meio das modalizações lógicas que encontramos:

(91) A presente pesquisa busca, por meio da análise da convergência entre as teorias do ensino da leitura já existentes e aquelas trazidas pela abordagem plural da intercompreensão de línguas românicas, surgidas a partir dos anos $80[\ldots]$ (R2)

Ao avaliar de forma lógica que existem pesquisas sobre ensino da leitura, por meio da modalização "já existentes”, a Estudante 2 faz uma comparação entre os estudos a respeito do ensino de leitura, inclusive em língua estrangeira, e as poucas pesquisas que têm a intercompreensão de línguas românicas como foco de análise, mesmo elas tendo surgido há mais de duas décadas. Assim, evidenciamos, mais uma vez, a voz do estudante que avalia o seu trabalho como contendo um caráter de ineditismo, porém esse caráter não é comprovado com um estado da arte (como mostramos nas análises dos projetos de pesquisa), o que mostra outra vez a voz do estudante. Logo, a apreciação do trabalho enquanto não é em relação a outras pesquisas, o que se contrapõe ao que estudiosos dos resumos de pesquisa dizem sobre eles (MOTTA-ROTH, HENDGES, 2010).

Ainda advinda da voz do estudante, encontramos uma modalização apreciativa: 
(92) visa-se também contribuir para a reformulação do programa do curso de Práticas de Leitura em Francês, levando em consideração as novas possibilidades trazidas pelo plurilinguismo e pelas teorias de intercompreensão [...] (R2)

Ao utilizar o modalizador "novas", LM avalia o seu objetivo de pesquisa do seu ponto de vista enquanto estudante universitária, pois não realizou um levantamento das pesquisas já existentes para verificar o quão novo é o seu projeto (Cf. análise do projeto de pesquisa).

\section{Estudante 3}

No resumo, identificamos a voz do estudante no seguinte excerto:

(93) Esta comunicação tem por objetivo apresentar um estudo sobre a produção escrita de alunos universitários, aprendizes do francês como língua estrangeira, observando, para tanto, o desenvolvimento de suas capacidades de linguagem ao longo do processo de aprendizagem. (R3)

No excerto acima, podemos constatar que a estudante explicitou o objetivo geral da pesquisa sem mencionar a sua especificidade, isto é, ela estudaria a produção de escrita de alunos universitários por meio dos gêneros textuais da ordem do expor e relatar. Segundo afirmam Motta-Roth, Hendges (2010, p.155), deve-se explicitar no resumo tanto os objetivos gerais quanto específicos da pesquisa. Desse modo, constatamos que a ideia central, desenvolvida pela voz do estudante em nossas análises dos planos globais dos conteúdos temáticos do projeto de pesquisa e baseada na sua experiência enquanto graduanda, reaparece no final do processo da IC. Sendo assim, a motivação para a pesquisa, baseada na experiência da aluna, pode ser verificada também no resumo.

Ao mesmo tempo, encontramos também a voz do pesquisador nos resumos, pois a última parte do texto abordou sinteticamente os resultados. Isso fica claro no seguinte excerto:

(94) Tais aspectos foram observados através dos eixos relatar e expor, a partir dos quais se organizam os tipos discursivos, isto é, os elementos estruturais que determinariam as distinções formais entre os gêneros. (R3) 
O modalizador autonímico "isto é", tal como definido por Maingueneau (2005, p. 159), produz um plano discursivo que se sobrepõe a outro, pois, ao explicar o método dos dados, a estudante reformula o seu próprio dizer buscando uma coincidência entre o dito e o explicado, mostrando uma consciência do método utilizado na pesquisa, evidenciada pela tentativa de explicação com suas próprias palavras. Ao nosso ver, trata-se de uma ocorrência da voz do pesquisador, já que mostra que a aluna busca compreender a teoria da pesquisa, reformulando-a com suas próprias palavras.

As modalizações lógicas também nos permitem identificar a voz da pesquisadora já no resumo:

(95) Os resultados apontam para o desenvolvimento em geral dos alunos por meio dos textos produzidos, no entanto demonstram que alguns aspectos linguísticos e discursivos são mais dificilmente apropriados do que outros. (R3)

O excerto acima nos mostra, por meio de três modalizadores lógicos sublinhados, a avaliação realizada não mais pela voz do estudante, mas pela voz do pesquisador que retoma o processo da pesquisa, evidenciando de forma sintética os principais resultados obtidos, porém fazendo-o com uma precaução e distância características da voz do pesquisador, que evita se comprometer fazendo afirmações categóricas.

\subsection{Quadro sintético das análises}

A seguir, elaboramos um quadro com os principais resultados encontrados nos resumos para apresentação oral por meio dos índices textuais o que os evidenciam. 


\begin{tabular}{|c|c|c|}
\hline & Índices textuais & O que mostram? \\
\hline $\begin{array}{c}\text { Plano global do } \\
\text { conteúdo } \\
\text { temático }\end{array}$ & $\begin{array}{l}\text { Plano global do conteúdo temático: } \\
\text { Estudante 1: Apesar de bastante } \\
\text { ligada às raízes do poeta, } \\
\text { transparecendo sua brasilidade e sua } \\
\text { origem interiorana, a poesia } \\
\text { drummondiana vai além do regional, } \\
\text { atingindo patamares, por assim dizer, } \\
\text { universais. } \\
\text { Estudante 2: refletir sobre como o } \\
\text { desenvolvimento de competências } \\
\text { leitoras pode ultrapassar os limites de } \\
\text { uma única língua-alvo e contribuir } \\
\text { para o surgimento de um leitor } \\
\text { autônomo plurilíngue. } \\
\text { Estudante 3: Esta comunicação tem } \\
\text { por objetivo apresentar um estudo } \\
\text { sobre a produção escrita de alunos } \\
\text { universitários, aprendizes do francês } \\
\text { como língua estrangeira, observando, } \\
\text { para tanto, o desenvolvimento de } \\
\text { suas capacidades de linguagem ao } \\
\text { longo do processo de aprendizagem. }\end{array}$ & $\begin{array}{l}\text { Através do plano global do conteúdo } \\
\text { temático do resumo, verificamos } \\
\text { uma retomada da ideia central da } \\
\text { pesquisa, tal qual já tínhamos } \\
\text { identificado em nossas análises do } \\
\text { projeto de pesquisa. Por exemplo, os } \\
\text { objetivos expressos nos resumos são } \\
\text { próximos àqueles dos projetos, como } \\
\text { podemos ler no início dos resumos. }\end{array}$ \\
\hline $\begin{array}{l}\text { Tipos de } \\
\text { discurso }\end{array}$ & 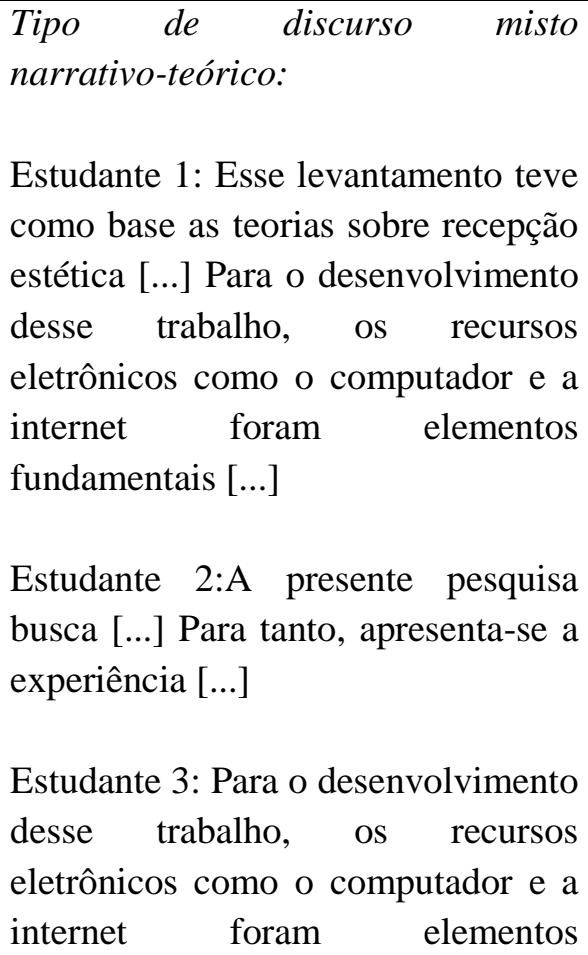 & $\begin{array}{l}\text { O tipo de discurso misto } \\
\text { narrativo-teórico identifica um } \\
\text { raciocínio de retomada da pesquisa } \\
\text { de forma lógica. Encontramos } \\
\text { também segmentos de discurso } \\
\text { teórico somente, sobretudo no } \\
\text { resumo da Estudante } 2 .\end{array}$ \\
\hline
\end{tabular}




\begin{tabular}{|c|c|c|}
\hline & $\begin{array}{l}\text { fundamentais, já que possibilitaram } \\
{[\ldots]}\end{array}$ & \\
\hline Conectores & $\begin{array}{l}\text { Predominância dos conectores } \\
\text { lógicos: } \\
\text { Estudante 1: já que; portanto; logo. } \\
\text { Estudante 2: para tanto; além de. } \\
\text { Estudante 3: então; assim }\end{array}$ & $\begin{array}{l}\text { Embora tenhamos identificado o tipo } \\
\text { de discurso misto narrativo-teórico, } \\
\text { há o predomínio de conectores } \\
\text { lógicos. Como o resumo é produzido } \\
\text { no final da IC, a narração indica a } \\
\text { retomada de alguns aspectos da } \\
\text { pesquisa. }\end{array}$ \\
\hline $\begin{array}{c}\text { Coesão } \\
\text { nominal }\end{array}$ & $\begin{array}{l}\text { Cadeias nominais: } \\
\text { Estudante } 1 \text { - cadeia que evidencia as } \\
\text { características da poesia de } \\
\text { Drummond: "sua brasilidade", e } \\
\text { "patamares, por assim dizer, } \\
\text { universais". } \\
\text { Estudante } 2 \text { - cadeia que retoma os } \\
\text { objetivos da pesquisa: \{refletir sobre } \\
\text { como o desenvolvimento de } \\
\text { competências leitoras [...] contribuir } \\
\text { para o surgimento de um leitor } \\
\text { autônomo plurilíngue [...] contribuir } \\
\text { para a reformulação do programa do } \\
\text { curso de Práticas de Leitura em } \\
\text { Francês [...]\} } \\
\text { Estudante } 3 \text { - cadeia que mostra a } \\
\text { importância dos gêneros textuais } \\
\text { para o ensino da escrita: \{refletir } \\
\text { sobre como o desenvolvimento de } \\
\text { competências leitoras [...] contribuir } \\
\text { para o surgimento de um leitor } \\
\text { autônomo plurilíngue [...] contribuir } \\
\text { para a reformulação do programa do } \\
\text { curso de Práticas de Leitura em } \\
\text { Francês [...]\} }\end{array}$ & $\begin{array}{l}\text { A coesão nominal permite criar } \\
\text { cadeias nominais que nos } \\
\text { confirmaram as nossas análises do } \\
\text { plano global do conteúdo temático, já } \\
\text { que essas retomadas nominais são } \\
\text { parecidas com as estabelecidas nos } \\
\text { projetos de pesquisa e deixar entrever } \\
\text { a ideia central da pesquisa. }\end{array}$ \\
\hline Vozes & $\begin{array}{l}\text { Modalizações autonímicas: } \\
\text { Estudante 1: por assim dizer } \\
\text { Estudante 3: isto é }\end{array}$ & $\begin{array}{l}\text { As modalizações autonímicas } \\
\text { permitem a identificação da voz do } \\
\text { pesquisador }\end{array}$ \\
\hline
\end{tabular}




\begin{tabular}{|c|c|c|}
\hline Modalizações & $\begin{array}{l}\text { Modalizações apreciativas: } \\
\text { Estudante1: fundamentais; menos } \\
\text { Estudante 2: novas } \\
\text { Estudante 3: dificilmente } \\
\text { Modalizações lógicas: } \\
\text { Estudante 1: que podem ser } \\
\text { Estudante 2: já existentes } \\
\text { Estudante 3: em geral; alguns }\end{array}$ & $\begin{array}{l}\text { As modalizações lógicas com alto } \\
\text { grau de certeza expressam } \\
\text { geralmente a voz do estudante. } \\
\text { Outros modalizadores lógicos } \\
\text { possuem baixo grau de asserção, } \\
\text { possibilitando a identificação da voz } \\
\text { do pesquisador. Já as modalizações } \\
\text { apreciativas podem evidenciar tanto } \\
\text { a voz do pesquisador, caso estejam } \\
\text { baseadas na experiência enquanto } \\
\text { pesquisador, quanto a voz do } \\
\text { estudante, caso estejam muito } \\
\text { próximas às modalizações } \\
\text { encontradas nos projetos de pesquisa. }\end{array}$ \\
\hline
\end{tabular}

\section{Apresentação oral de pesquisa ${ }^{29}$}

Como apresentado no capítulo anterior, iniciaremos nossas análises das apresentações orais de pesquisa por meio do contexto de produção textual e, em seguida, do plano glabal do conteúdo temático e dos tipos de discurso associados à coesão verbal. Depois, analisaremos os mecanismos de textuzaliação por meio das conexões encontradas e da coesão nominal criada nos textos. Por último, mostraremos nossos resultados quanto às análises das vozes e das modalizações.

\subsection{Contexto de produção das apresentações orais da pesquisa}

As apresentações orais de pesquisa foram realizadas no V Encontro de Pesquisas do Francês, ocorrido no dia 29 de agosto de 2013, nas dependências da Faculdade de Filosofia, Letras e Ciências Humanas da Universidade de São Paulo. O evento é organizado anualmente pelo programa de Pós-graduação em Estudos Linguísticos,

\footnotetext{
${ }^{29}$ Para as transcrições foram utilizadas as normas do Projeto NURC (anexo, p.296).
} 
Literários e Tradutológicos em francês, que forma uma Comissão Organizadora para preparar o Encontro.

A $5^{\circ}$ edição do evento contou com a participação de muitos estudantes graduandos, incluindo as três participantes de nossa pesquisa, que realizam estudos em IC e procuram no evento um espaço para apresentá-los seja no início, para receber sugestões, seja em momentos em que ela esteja mais desenvolvida, a fim de poder discuti-los mais criticamente. De todo modo, são inúmeras as contribuições nesse contexto, dado que cada sessão de comunicação é organizada tematicamente e mediada por um docente pesquisador do Programa de Pós-graduação, incumbido de dialogar com os estudantes a respeito de suas pesquisas, sugerir novos encaminhamentos, fornecer sugestões bibliográficas ou estabelecer relações com outras pesquisas afins.

A comunicação da Estudante 1, intitulada "De Itabira para o mundo: levantamento sobre a poesia de Carlos Drummond de Andrade na França", foi selecionada para compor a mesa redonda "Tradução e intertexto", juntamente com as seguintes seções: "A tradução da novela Orlamonde de Le Clézio", "Aspectos da presença francesa em Castro Alves" e "Primeira tradução interlingual do francês para o português do livro L'enfant multiple, de André Chedid". Ademais, a sessão foi mediada por uma pesquisadora do programa de pós-graduação em ELLTF, especialista em Análise do Discurso francesa nos textos literários e jornalísticos e estudos de gramáticas francesas.

As apresentações orais da Estudante 2 e Estudante 3 ocorreram na mesma mesa de comunicações, intitulada "Fazer saber e saber fazer". As comunicações foram mediadas por uma docente cujo tema de pesquisa é o processo da leitura em geral e, mais especificamente, a leitura em língua francesa. Além das apresentações das duas estudantes participantes da nossa pesquisa, a mesa foi também composta pelas seguintes apresentações: "Diálogo literário em aulas de FLE para alunos de nível iniciante" e "O desenvolvimento da produção oral para alunos da POLI-USP que preparam intercâmbio com Escolas de Engenharia na França”. 


\subsection{Plano global do conteúdo temático}

Ao final da pesquisa de Iniciação Científica, como verificamos no percurso das três estudantes, percebe-se que as alunas estão se apropriando das práticas de linguagem utilizadas na esfera científica, visto que, na apresentação oral, encontramos algumas peculiaridades na hierarquização das informações que são importantes para o estabelecimento da coerência (Dolz et al, 2004, p.221). Evidencia-se, assim, que as estudantes estão no processo de formação enquanto pesquisadoras. No entanto, as inadequações que mostraremos abaixo não somente marcam o momento de formação das estudantes, mas nos permitem depreender quais as etapas das pesquisas foram mais custosas para a realização do trabalho. Ademais, é possível confirmarmos nossas análises do plano global nos projetos de pesquisa, tendo em vista que as estudantes reforçam a importância do lugar ocupado por elas enquanto estudantes para a realização do estudo.

No desempenho da apresentação oral, as estudantes utilizam um tempo considerável dos 20 minutos da comunicação para enfatizar alguma parte da pesquisa, objetivando, com isso, explicar o que não foi bem desenvolvido nos resumos relacionados a essas apresentações. Desse modo, elas demonstram uma consciência do percurso de uma pesquisa científica (conhecimento fundamental no agir do pesquisador), pois sabem a importância de cada parte necessária.

\section{Estudante 1}

O plano global da apresentação da pesquisa é iniciado pela ordem dos tópicos que seriam expostos:

Primeiramente, a estudante retoma o objetivo da sua pesquisa: temática...o objetivo...o material e o método...depois eu passo para as fases da pesquisa de 
fato...e finalmente...e posteriormente para os desdobramentos possíveis... (linhas 4-6) (AO1) ${ }^{30}$

(97) os objetivos é realizar o levantamento da poesia traduzida...de textos teóricos traduzidos...e de textos teóricos escritos em francês diretamente...éh...o material...a internet foi essencial...pois através dela a gente chegou a ferramentas de busca...como o Google...e bibliotecas e livraria online também [...]...bom...o método...primeiro a gente fez leituras sobre teorias da recepção...depois a gente foi pra parte física da pesquisa... (linhas 8-15) (AO1)

Ao enunciar o seu objetivo de pesquisa, a apresentadora expõe também os métodos que foram utilizados, como podemos ler no excerto sublinhado acima. Nele, apresenta-se o método de busca dos dados e também os métodos analíticos: primeiramente o levantamento e depois um comentário crítico sobre o material encontrado. Assim, as seções do objetivo e da metodologia da pesquisa foram fusionadas no início da apresentação. Com isso, é possível notarmos que a exposição da metodologia foi importante para o trabalho da aluna, já que a sua explicação no início da apresentação é essencial para a compreensão dos resultados encontrados.

Como constatamos nas análises do plano global do conteúdo temático dos resumos, as Estudantes não desenvolveram resumos canônicos, pois mostramos algumas lacunas na produção desse gênero textual. Todavia, exatamente essas mesmas lacunas não desenvolvidas foram em certa medida justificadas pelas alunas durante as apresentações. Por exemplo, a maior da parte da exposição da Estudante 1 foi justamente aquela que trata dos resultados da pesquisa, pois das 108 linhas de transcrição, 62 delas foram destinadas à discussão dos resultados.

\section{Estudante 2}

No caso de LM, o objetivo da pesquisa é explicitado após todas as explicações dos conceitos teóricos utilizados e também da explicação do contexto e dos participantes da pesquisa (metodologia). Já no início da apresentação, a expositora inicia a explicação dos conceitos da pesquisa, como o de "plurilinguismo":

30 AO1: Apresentação oral da Estudante 1 AO2: Apresentação oral da Estudante 2 AO3: Apresentação oral da Estudante 3 
(98) antes de falar de intercompreensão é preciso ter em mente a noção do que é plurilinguismo...e o que é ser plurilíngue...não se todos aqui já tiveram contato com o Quadro Comum Europeu de Referência para as Línguas...mas SER plurilíngue é diferente totalmente diferente de ser poliglota....ahn... (linhas 6-9) (AO2)

Depois dessa parte, LM começa a desenvolver a metodologia adotada na pesquisa:

(99) bom ((frase exclamativa))...o curso de leitura em francês...vou falar um pouco do que é um curso de leitura e o que é um curso instrumental...é um curso em que as pessoas procuram porque elas precisam daquela língua não para chegar em um festa e "eu falo francês"...mas para desenvolver a sua pesquisa...para trabalhar...eu vou pra francês mas eu vou trabalhar com isso...então tem alguns objetivos específicos...aqui no Centro de Línguas os alunos são todos universitários...graduação ou pós...ou entre esses dois...graduação especialmente aqui na FFLCH que tem muita bibliografia... (linhas 64-69) (AO2)

O marcador "bom" é indicativo da mudança de tópico entre a seção da Fundamentação teórica e a metodologia, na qual LM explicará o seu contexto de pesquisa (Centro de Línguas da FFLCH) e os participantes (estudantes universitários). Somente após essas explicações, a estudante percebe que não explicitou o seu objetivo na pesquisa realizada:

(100) ahn...o meu objetivo então - - está lá em cima...eu me esqueci de citar - -...é o surgimento de um autor autônomo plurilíngue...o que é um leitor autônomo plurilíngüe? [...] o meu objetivo é fazer com que esse aluno que fez o curso de francês...se amanhã muda a bibliografia dele e ele precisa fazer/precisa ler em italiano...que não necessariamente ele precise fazer um curso de dois semestres para ler em italiano...ou pelo menos começar a consultar essa bibliografia...é esse o leitor autor plurilíngue...ahn...o que eu fiz com o curso?... (linhas 89-98) (AO2)

O público em questão não conhecia a pesquisa realizada pela estudante, fato que é percebido por ela depois das diversas explicações. Após explicitar o objetivo da pesquisa aos ouvintes, LM continua a exposição dos métodos usados por ela para a coletada dos dados, que se deu por meio da elaboração de um curso no Centro de Línguas da FFLCH. O marcador "ahn" mostra a mudança tópica. 
Assim, a seção da Fundamentação teórica foi importante, segundo o ponto de vista da estudante, para a compreensão da pesquisa, já que os conceitos de "plurilinguismo" e "intercompreensão" não são muito difundidos e são importantes para o estudo realizado e serviram para a construção da metodologia que não existia a priori.

No gênero textual apresentação oral, assim como discutimos em nossa Fundamentação teórica, a delimitação do conteúdo referencial (o objetivo) faz parte do início da organização interna desse gênero textual, a fim de que o público possa compreender, no decorrer da exposição, o porquê dos conceitos utilizados e a escolha da metodologia adotada (DOLZ et al., 2004). Todavia, essa sequência, frequente e geralmente desejável nesse gênero textual, não foi seguida na apresentação oral de pesquisa da Estudante 2, já que ela não começa apresentando o objetivo. ${ }^{31}$

Nas nossas análises dos conteúdos temáticos dos resumos, mostramos que a metodologia não foi exposta na escrita desse gênero textual, porém, na apresentação oral, a Estudante 2 dedica a maior parte da sua comunicação ao detalhamento dessa parte da pesquisa. Nossa transcrição teve um total de 160 linhas, sendo que 83 delas foram destinados à explicação da metodologia da pesquisa, sobretudo ao método.

\section{Estudante 3}

A estudante inicia a sua apresentação informando ao público que a sua pesquisa deu continuidade ao trabalho de outra aluna, que desenvolveu a IC sob orientação da mesma professora. Em seguida, ela destaca a proximidade que teve com os materiais da pesquisa, pois, por um lado, a estudante analisou os textos dos seus colegas de sala e, por outro, já conhecia a plataforma de coleta desses textos, o Moodle, pois enquanto aluna ela já havia utilizado:

(101) a pesquisa dá continuidade a:::...ao que já tinha sido estudado pela colega aqui na área do francês...a ((nome da colega))...que estudou a produção escrita de alunos da habilitação de

\footnotetext{
${ }^{31}$ Sabemos que, em outras tradições de pesquisa, o objetivo não necessariamente precisa ser exposto no início da apresentação oral, porém, em nossa pesquisa, consideramos que sim, já que as estudantes produziram outros textos em que começavam pelos objetivos, e iniciar a apresentação com o objetivo seria a estrutura geralmente esperada. Outro fator que nos faz esperar o anúncio do objetivo no início, é o fato de que a própria estudante retoma suas palavras e indica que ela havia "esquecido" de mencionar inicialmente o objetivo, o que mostra que ela tem consciência da estrutura esperada.
} 
francês...Bom (frase exclamativa)...eu também sou aluna da habilitação de francês...claro (frase exclamativa) (risos)...isso foi importante para a pesquisa uma vez que eu já tinha contato com a plataforma de entrega dos exercícios...o moodle...tinha contato com a estrutura dos exercícios e com os gêneros textuais que foram trabalhados durante o semestre...no final das contas o que eu fiz foi analisar as produções escritas dos meus colegas de sala... (linhas 4-11) (AO3)

Igualmente ao que mostramos acima, nos dados de BT, RA também destaca o fato dela, no papel de pesquisadora, estar próxima ao contexto da pesquisa e aos participantes do trabalho. Mais uma vez, portanto, notamos que essa fase da pesquisa foi relevante do ponto de vista das estudantes para o desenvolvimento do trabalho.

Posteriormente, RA destaca a justificativa para a realização da sua pesquisa, defendendo que desde a publicação dos PCNs a perspectiva dos gêneros textuais ganhou considerável aceitação e sua aplicação ocorre em grande escala nos estudos da língua materna e inglesa, porém pouco aplicada nos estudos sobre a didática do francês. Após essa ressalva, a estudante expõe o seu objetivo de pesquisa:

(102) o objetivo da pesquisa portanto foi fazer um estudo do desenvolvimento das capacidades de linguagem implicados na aprendizagem do francês língua estrangeira e fazer isso por meio dos eixos discursivos do relatar e expor... (linhas 20 a 23) (AO3)

Entre os conteúdos temáticos faltantes nas nossas análises do conteúdo temático do resumo da apresentação oral da Estudante 3, verificamos que a pesquisa não foi situada em relação às outras pesquisas e nem foi discutida por meio de conclusões e recomendações futuras, assim como esperado nesse gênero textual, como mostradas em nossa Fundamentação teórica, de acordo com os estudos Motta-Roth, Hendges (2010). Entretanto, essas duas partes foram contempladas na apresentação, pois entre as linhas 15-24, a aluna discorreu sobre as lacunas da pesquisa sobre gêneros textuais em língua francesa frente aos vastos estudos em português e inglês; já entre as linhas 129-139, a aluna traz conclusões da pesquisa e levanta hipóteses. 


\subsection{Tipos de discurso e coesão verbal}

Nas apresentações orais de pesquisa, encontramos uma dinâmica peculiar entre os tipos de discurso interativo e o relato interativo. Como apontamos na Fundamentação teórica, o conceito de tipos de discurso, proposto por Bronckart (1999), é oriundo dos estudos de Benveniste, sobre discurso e história e de Weinrich, sobre mundo comentado e mundo narrado. De acordo com Weinrich (1973), o mundo comentado se caracteriza pela ocorrência de uma tensão, sobretudo nas situações em que o enunciador e o enunciatário estão engajados no processo comunicacional. Assim, o discurso interativo, presente nas apresentações orais, condiciona a ação de linguagem a essa tensão devido à necessidade de rapidez no fluxo das ideias, pelas quais as estudantes devem apresentar a pesquisa realizada para a compreensão dos espectadores. Justamente pelo fato de a apresentação oral ser construída localmente, passo a passo, na co-presença dos participantes da comunicação, é produzida uma tensão, ou seja, uma dificuldade ao pensamento, nos dizeres de Vigotski (2001). Essas tensões, dificuldades, podem ser percebidas nos textos orais, pelas hesitações e as reformulações que evidenciam que o discurso interativo cria um mundo discursivo conjunto, no qual há presença dos interlocutores no qual os enunciadores constroem suas falas passo a passo e de forma não planejada (BRONCKART, 1999, p. 158). Ou, como aponta Rodrigues (2003, p. 23), toda situação de comunicação oral tem uma tendência ao não planejado.

Tendo essas reflexões em mente, observamos que, em nossos dados, sobretudo no momento da apresentação das análises da pesquisa, instante em que o raciocínio temporal aparece por meio do relato interativo, houve a ocorrência de generalizações que expressam o modo pelo qual as estudantes interpretaram e aproximaram os resultados obtidos, conferindo-lhes um termo generalizador. Esse raciocínio é gerado na apresentação oral justamente pela situação comunicativa conjunto e implicada por ele criada, na qual o expositor (aluno da graduação), investido de "especialista" (Dolz et al., 2004), deve encontrar uma coerência entre os resultados diante do auditório (composto por um pesquisador experiente). Justamente, o termo generalizador surge de forma não prevista pelas estudantes, tanto que elas próprias declaram não saber se podem o "chamar assim". Logo, os trechos de relato interativo marcam a autoria da pesquisa, pois representam o ponto de vista interpretativo das estudantes frente à pesquisa. 


\section{Estudante 1}

Na apresentação oral de pesquisa, há predominância do discurso interativo, pois há uma conjunção com relação aos parâmetros de produção, sobretudo com a presença face a face dos participantes da interação. No excerto abaixo, a expressão "Tem pouca gente" indica a conjunção da ação de linguagem, já que a apresentadora nota que não havia muitas pessoas assistindo a sua comunicação:

(103) Tem pouca gente...a minha orientadora é uma das cinco (frase exclamativa)...NÃO...uma das quatro...éh....cinco. (linhas 1 a 2) (AO1)

O discurso interativo, além de ser conjunto com os elementos contextuais de produção, também é implicado. Durante a apresentação oral de pesquisa, encontramos várias marcações de implicação:

(104) a gente realizou um comentário do que a gente levantou....agora eu passo para as fases da pesquisa ((tossiu)) e a leitura teórica...fizemos um estudo breve sobre a estética da recepção de Jauss e Iser...éh:.:....foi um pouco difícil de ler isso e de entender essa leitura... (linhas 18 a 21) $(\mathrm{AO} 1)$

[...] DAS reuniões...nós encontramos três...a primeira de mil novecentos e oitenta e três Réunion que foi escrito por Jean-Michel Massa...a segunda de noventa La machinedu monde et autrespoèmes...é a mais extensa...e a última que foi traduzida pela Ariane Witkowski Mort dans l'avions \& autres poèmes..é bem mais curta mas éh melhor eh bilingui... (linhas 41 a 44) (AO1) [...] acho que ficou um pouco clara...mas enfim...éh::.....depois as antologias....a gente conseguiu oito ou nove antologias...mas eu destaquei três que me chamaram mais atenção...primeiro a do Tavares-Bastos de mil novecentos e quarenta e sete...a mais antiga... (linhas 42 a 45)

[...] eu acho que mostra bem essa ideia de tropical né?...éh::.....na capa já tem essa ideia de páis tropical...pra ilustrar a relação com a literatura portuguesa...eu citei uma das críticas que a gente conseguiu... (AO1)

[...] acho que pra gente que estuda Literatura brasileira dentro do Brasil...não é uma relação que a gente vê fazer...mas::....tá dado isso...e não éh só nessa citação que essa relação acontece... (linhas 91 a 93) (AO1) 
No mais, identificamos outros aspectos definidores do discurso interativo, como as hesitações a as reformulações:

(105) [...] e a última do ano passado que foi lançada...que é muito extensa...assim...é uma BÍblia mesmo (frase exclamativa)...bem interessante...éh::....eh Anthologie bilíngüe du XVIe au XXe siècle... (linhas 43 a 44) (AO1)

[...] as pu/publicações não foram feitas porque foram feitas...tinha uma razão por fora pra isso...como por exemplo o Ano do Brasil na França em dois mil e cinco... (linhas 76 a 77) (AO1)

Em suma, também encontramos as hesitações, como o "éh" e os marcadores conversacionais, como o "né?", ambos marcados em excertos acima mostrados.

Embora o discurso interativo seja predominante, podemos verificar também alguns conectores lógicos indicadores da fusão entre este tipo de discurso e o discurso teórico, como verificamos abaixo:

(106) A obra literária se caracteriza portanto por uma tensão entre dois horizontes de espera...aquele da obra...aquele o público...que coincidem mais ou menos"...então na verdade...na SíNtese eles têm a mesma direção né?...se direcionam para a mesma ideia. (linhas 33 a 35) (AO1)

Esse excerto contém tanto um mundo conjunto e implicado com relação ao contexto de produção, expresso pelo marcador conversacional "né?", indicador da presença de interlocutores, como também uma conjunção que tende a uma autonomia, justamente pela razão de que no excerto em questão a apresentadora faz uma síntese dos conceitos teóricos que ela usou na pesquisa sem considerar tanto os espectadores. Assim, é claro neste excerto a construção de um raciocínio lógico, ou seja, é perceptível a ocorrência de uma atividade mental tendendo à autonomia. O conector lógico "portanto" é indicador da fusão dos dois tipos de discurso (BRONCKART, 1999, p.192).

A atividade mental a qual nos referimos é também observada em pequenos momentos de relato interativo, os quais têm a função de retomar uma generalização já feita em um outro momento da pesquisa que não aquele da apresentação: 
(107) na verdade eu vou comentar o comentário...apresentar partes dos comentários que foram feitos...ahn::.....primeiro que as traduções e recepções são escassas ainda (recepção e tradução da poesia de Drummond na França)...e não realmente bem difundidas...depois o contexto de publicação dessas traduções tem uma relação que eu chamei de EXtra literária...então assim...né?...as pu/publicações não foram feitas porque foram feitas...tinha uma razão por fora pra isso...como por exemplo o Ano do Brasil na França em dois mil e cinco... (linhas 72 a 77) (AO1)

[...] eu percebi duas coisas...primeiro que existe uma mística com relação ao país tropical...o Brasil... (linhas 81 a 82) (AO1)

Por meio do relato interativo, temos acesso às generalizações das relações efetuadas pela apresentadora no período de análise dos seus dados de pesquisa. Ao utilizar o relato, ela constrói um raciocínio causal através do qual é possível identificarmos os resultados das análises efetuadas, sendo que a primeira generalização por meio da palavra "extraliterária - a própria apresentadora afirma que nomeou (uso do verbo "chamar") dessa forma, ou seja, é possível afirmarmos que se trata de uma noção criada com índices maiores de generalização em comparação a segunda, expressa pelo termo "uma mística", do qual a estudante somente "percebeu" que existe um traço em comum em alguns dados analisados. ${ }^{32}$

\section{Estudante 2}

Do mesmo modo que nas outras duas apresentações orais, encontramos nesta muitas marcas de discurso interativo, as quais marcam a conjunção da ação de linguagem e a implicação da apresentadora:

(108) antes de falar de intercompreensão é preciso ter em mente noção do que é plurilinguismo...e o que é ser plurilíngue...não se todos aqui já tiveram contato com o Quadro

\footnotetext{
${ }^{32}$ Podemos notar também indícios de generalização na discussão que seguiu a apresentação oral, no seguinte trecho: "Da teoria da Estética da recepção...éh...existe essa diferença temporal...mas...eu acho que dentro da pesquisa o que mais chamou atenção...eu não sei eu posso chamar assim...mas a diferença espacial...então como o ponto de vista faz muita diferença... (linhas 177-179) (AO1)". A expressão sublinhada "diferença espacial", construída pela estudante parte do conceito científico "diferença temporal" para caracterizar a distância geográfica entre a cultura local da cidade do poeta estudado e de todos os locais em que foi difundida. No entanto, como as discussões das apresentações orais não são dados da nossa pesquisa, optamos por não analisar esse excerto detalhadamente.
} 
Comum Europeu de Referência para as Línguas (linhas 7-9) (AO2)

O termo "aqui" nos indica que a ação de linguagem é conjunta com o conteúdo apresentado, posto que há um público ouvinte, composto por estudantes de graduação que realizam pesquisa de IC e também por uma pesquisadora experiente, que trabalha com questões parecidas àquelas abordadas pela expositora. No mais, encontramos outras marcas do discurso interativo, como a interjeição (bom) e os marcadores conversacionais de hesitação (éh):

(109) meu contexto na Didáticas da Línguas é o ensino e aprendizagem da leitura...o que é a leitura?...bom ((frase exclamativa))...não é só uma atividade...pegar o livro e codificar o que está escrito...é uma constante formulação de hipóteses como a colega já disse...éh...o tempo todo...a gente só pode construir sentido daquilo que a gente conseguiu...éh...formular hipótese...a gente faz a nossa e confirma no texto...isso é constante...éh...(linhas 50-54) (AO2)

Como já mostramos nas análises anteriores, os tipos de discurso que textualizam uma disjunção da ação de linguagem também foram encontrados nesta apresentação, igualmente na seção das análises e resultados das pesquisas de IC em término. Tendo em vista que os resultados das análises foram obtidos durante um curso montado pela estudante, o relato interativo aparece neste momento, ora para apresentar o que os alunos produziam e como correspondiam às expectativas, ora para relatar as decisões e os resultados percebidos por LM:

(110) eu acredito aqui que todos saibam o que é o sumário...e batem o olho vai saber que é...em seguida eu apresento a eles o sumário de uma revista em francês...que é uma revista de uma outra área...que tem um layout totalmente diferente...mas que nem por isso deixa de ser um sumário...ahn...e eles percebem... (linhas 123-127) (AO2)

[...] eu apresento pra eles primeiro um conjunto de resumos todos cortados...eu separo os títulos...o resumo e as palavras chaves... (linhas 131-132) (AO2)

Nessa seção, os relatos interativos são mais frequentes do que a narração, pois a estudante está construindo um raciocínio causal-temporal, retomando as ações da pesquisa pelas quais os resultados foram percebidos: 
(111) então eu recorto isso...recortei e coloquei em envelopes...e eles deveriam - - o tema de todos os resumos eram inter-compreensão...não era a área deles...então eles deveriam encontrar o título referente...e as palavras chaves de cada resumo...COMO?...com a referência do francês que estava no título...o francês eles já dominavam...essa era a ÂNcora deles nesse momento...ahn....apesar de aqui...esse esse...é em italiano esse resumo...eles não tinham a base do conhecimento de mundo da área...ahn:.....nem da língua do resumo...mas tinham a referência do título em francês...e eles fazem isso...deu SUper certo...eles conseguiram na aula seguinte...eu peço pra eles escolherem um artigo...que...numa língua que eles não dominam e que provavelmente eles não leriam...aí ta em romeno não consigo ler então eu não vou ler...ahn...então que eles procurassem esse artigo e trouxessem pra mim o resumo...trouxessem na aula para que nós lêssemos o resumo...que é a porta de entrada...é nele que você vai...ahn::....saber o que aquele artigo está falando...esse resumo é de um aula ((a apresentadora aponta para a tela do Power point)) que estudava medicina...e ela era boliviana...mora no Brasil...e estava fazendo curso de francês...e já tinha estudado italiano...então pra ela só sobrou o romeno e ela escolheu esse resumo...qual que era a âncora nesse caso? (linhas 133-146) (AO2)

Durante o momento do relato interativo, notamos que a estudante, a partir dos comandos das suas ações em sala de aula, faz algumas generalizações das reações dos estudantes do curso e do que ela interpreta disso por meio da inserção de segmentos de relato interativo. As expressões "âncora" e "porta de entrada" evidenciam a generalização, pois, por meio do termo "âncora", a estudante expressa que os alunos sempre recorrerão a algum conhecimento prévio, que será a "porta de entrada" para a leitura em uma língua não dominada por eles.

\section{Estudante 3}

Por se tratar do gênero textual apresentação oral de pesquisa, encontramos diversas marcas de discurso interativo, como tempos verbais no presente, que indicam a conjunção da ação de linguagem bem como marcadores conversacionais, interjeições e hesitações:

(112) Bom (frase exclamativa)...eu também sou aluna da habilitação de francês...claro (frase exclamativa) (risos) (linhas 6-7) (AO3) 
[...] e as produções escritas foram entregues via a plataforma moodle para favorecer a aprendizagem e autonomia...todos conhecem o moodle?(a aluna faz uma pergunta para o público ouvinte) (linhas 56-57) (AO3)

[...] bem...ah:.....primeiramente nós tivemos...ah:....que analisar os gêneros que eram trabalhados....ah:.....saber o conteúdo que nós esperávamos que os alunos se apropriassem em cada gênero...ah:.....para isso nós utilizamos o modelo de análise do ISD (linhas 71-74) (AO3)

Entretanto, também podemos observar excertos de disjunção, de relato interativo, na introdução da apresentação, na exposição da metodologia e também nas análises dos dados:

(113) isso foi importante para a pesquisa uma vez que eu já tinha contato com a plataforma de entrega dos exercícios...o moodle....tinhacontato com a estrutura dos exercícios e com os gêneros textuais que foram trabalhados durante o semestre...no final das contas o que eu fiz foi analisar as produções escritas dos meus colegas de sala (linhas 7-10) (AO3)

[...] para poder analisar o desenvolvimento das capacidades de linguagem nós usamos o modelo de análise do ISD... (linhas 47 a 48) (AO3)

Durante a apresentação encontramos, na mesma parte, tanto a narração quanto o relato interativo. Todavia, notamos uma predominância do relato interativo na exposição das análises dos dados, como podemos verificar pelos excertos a seguir:

(114) nós notamos algumas dificuldades na intensificação do suspense que é fundamental para poder seduzir o leitor a assistir o filme...isso denota problemas com relação à projeção de um interlocutor...ou seja...problemas na capacidade de ação de acabam também diminuindo as capacidades discursivas... (linhas 77 a 80) (AO3)

[...] passando para o segundo gênero trabalhado...o fait divers...nós notamos que não houve grandes problemas com as capacidades de ação e as capacidades discursivas...mas sobretudo com capacidades linguístico-discursivas... (linhas 101 a 104) (AO3)

[...] o terceiro gênero trabalhado foi relato de viagem em blog...de discurso implicado...portanto havia subjetivação...o emprego de modalizações apreciativas foi frequente...e nós verificamos uma melhora na coesão verbal...ah:: [...] exceção foi o aluno GS...que parecei ter se apropriado das capacidades linguístico-discursivas principalmente coesão verbal (linhas 116 a 119) (AO3)

[...] o último gênero trabalhado foi o relato curto literário...nós verificamos que os alunos tiveram uma apropriação satisfatória das capacidades esperadas... (linhas 123 a 125) (AO3)

[...] nós levantamos uma hipótese de que as capacidades e as capacidades discursivas são mais 
facilmente transferíveis da língua materna para a língua alvo...já as capacidades linguístico-discursivas que tiveram uma apropriação mais custosa...elas mais dificilmente podem ser passadas para a língua alvo uma vez que elas requerem uma sistematização mais específica...(linhas 129 a 134) (AO3)

Nos excertos acima, podemos notar que a estudante, no momento da apresentação oral, desloca a ação de linguagem para o momento da sua pesquisa no qual ela estava analisando os dados e estabelecendo relações entre eles.

No término da apresentação, encontramos um excerto em discurso teórico, expressamente marcado textualmente:

(115) portanto estudar o percurso de aprendizagem tornou possível adequar as estratégias de ensino às suas necessidades...nesse sentido o uso de gêneros textuais no processo de aprendizagem permite o estreitamento as ferramentas de ensino e as práticas de linguagem permitindo a apropriação de verdadeiros savoirs-faire e com isso aluno amplia as suas formas de atuação no mundo por meio da linguagem... (linhas 134 a 139) (AO3)

O fragmento acima encerra o raciocínio lógico da apresentadora, pois conclui as relações estabelecidas por ela durante a análise dos dados.

\subsection{Mecanismos de textualização: conectores textuais}

$\mathrm{Na}$ apresentação das análises dos dados das três pesquisas de IC, constatamos que os conectores criam links entre as ideias, permitindo uma segmentação das macro partes da apresentação oral. Essa função pode ser verificar pelo uso de macro-organizadores textuais: conectores de coordenação e subordinação; marcadores conversacionais (“então", “éh", “ahn”, "bom”, "bem” e "agora”), sendo eles importantes, pois nos permitem verificar a conjunção e implicação da linguagem na apresentação (especialmente o conector "agora"); sintagmas nominais e preposicionais; escolhas lexicais.

Na micro-estrutura textual, analisaremos somente os conectores que dividem as partes dos resultados, pois são nelas que encontraremos elementos para verificar o 
desenvolvimento do pesquisador. Nesse caso, alguns conectores aparecem de forma mais sistemática nas três apresentações, como o conector "então", "mas", o conector "que" indicando uma oração subordinada adjetiva explicativa. Além de segmentar, esses conectores têm a função de destacar algumas estruturas sintáticas nas quais encontramos modalizadores apreciativos, sobre os quais discorreremos a frente.

\section{Estudante 1}

Com relação aos conectores da apresentação, eles marcam primeiramente, na macro-estrutura textual, a mudança das partes do plano global do conteúdo temático comuns ao gênero textual apresentação oral de pesquisa. Entre esses conectores encontramos:

\begin{tabular}{|c|c|}
\hline Conectores & $\begin{array}{l}\text { Partes da apresentação } \\
\text { oral de pesquisa }\end{array}$ \\
\hline É...vou começar então assim...o plano da minha apresentação. & Plano geral da apresentação \\
\hline $\begin{array}{l}\text {...os objetivos é realizar o levantamento da poesia traduzida...de } \\
\text { textos teóricos traduzidos...e de textos teóricos escritos em francês } \\
\text { diretamente. }\end{array}$ & Objetivos da pesquisa \\
\hline $\begin{array}{l}\text {...éh...o material .... internet foi essencial...pois... através dela a } \\
\text { gente chegou a ferramentas de busca...como o Google...e } \\
\text { bibliotecas e livraria online também. }\end{array}$ & Material da pesquisa \\
\hline $\begin{array}{l}\text {...bom...o método...primeiro a gente fez leituras sobre teorias da } \\
\text { recepção...depois a gente foi pra parte física da pesquisa...o } \\
\text { levantamento das traduções francesas da poesia de } \\
\text { Drummond...depois um levantamento da crítica brasileira } \\
\text { traduzida para o francês...e depois levantamento da crítica sobre } \\
\text { Drummond escrita em francês...depois de TUdo isso...a gente } \\
\text { realizou um comentário do que a gente levantou. }\end{array}$ & Método da pesquisa \\
\hline $\begin{array}{l}\text { Agora eu passo para as fases da pesquisa ((tossiu)) e a leitura } \\
\text { teórica. }\end{array}$ & Fundamentação teórica \\
\hline
\end{tabular}




\begin{tabular}{|l|l|}
\hline $\begin{array}{l}\text {...agora falando do levantamento propriamente dito...éh...acho que } \\
\text { já ficou claro que foram três partes de levantamento...da poesia de } \\
\text { fato...do textos crítica traduzidos...e dos textos críticos escritos em } \\
\text { francês...ahn. }\end{array}$ & Resultados da pesquisa \\
\hline $\begin{array}{l}\text { pois é....agora eu já parto para o final da apresentação...ih::....na } \\
\text { verdade eu vou comentar o comentário....apresentar partes dos } \\
\text { comentários que foram feitos. }\end{array}$ & Análise dos resultados \\
\hline ...como desdobramento da pesquisa...primeiro éh:.:. & Considerações finais \\
\hline$\underline{\text { éh isso...as referências bibliográficas (os slides com as referências }}$ & Agradecimento \\
\hline é mostrado pela apresentadora)...e um monte de agradecimento. & \\
\hline
\end{tabular}

Quadro 14: Tipos de conexões entre as partes da apresentação oral (Estudante 1)

As mudanças entre as partes da pesquisa foram marcadas das seguintes formas: pelo conector "então", pelos marcadores "éh", por palavras que marcar diretamente a mudança entre as partes, como "objetivo" e "desdobramento da pesquisa", pelo termo "bom" e sobretudo pelo conector "agora". Este articulador textual é indicativo da criação de um mundo discursivo conjunto entre os participantes da interação, que estão acompanhando o raciocínio construído na apresentação oral da pesquisa.

Como grande parte da apresentação foi destinada à discussão dos resultados da pesquisa, encontramos também conectores que marcam a passagem do desenvolvimento temático dessa parte. A exposição dos resultados, iniciada pelo conector "agora", foi dividida em três partes: levantamento da poesia de Carlos Drummond de Andrade traduzida para o francês; as antologias poéticas encontradas; os textos críticos. Na tabela a seguir, poderemos verificar o modo como ass ubfases apareceram na apresentação oral da pesquisa:

\begin{tabular}{|c|c|c|}
\hline Excertos & Conectores & Subpartes \\
\hline 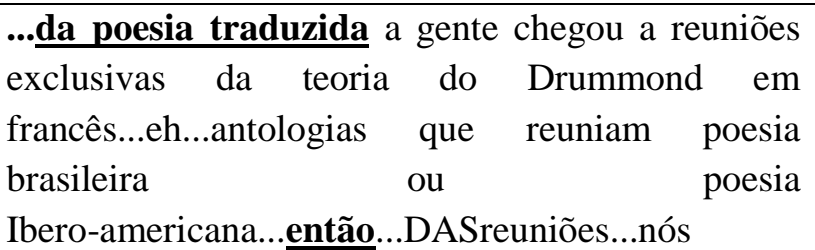 & da poesia traduzida & $\begin{array}{l}\text { Levantamento } \\
\text { da poesia de } \\
\text { Carlos }\end{array}$ \\
\hline
\end{tabular}


encontramos três...a primeira de mil novecentos e oitenta e três Réunion que foi escrito por Jean-Michel Massa...a segunda de noventa $L a$ machine du monde et autres poèmes...é a mais extensa...e a última que foi traduzida pela Ariane WitkowskiMortdansl'avions \& autres poèmes.é bem mais curta mas éh melhor eh bilingui...e a do Jean-Michel Massa também eh do Lamaison não...então...aí estão os três em ordem né?...esse é do Massa...esse é do Lamaison...e esse da Witkowski -

...depois as antologias...a gente conseguiu oito ou nove antologias...mas eu destaquei três que me chamaram mais atenção...primeiro a do Tavares-Bastos de mil novecentos e quarenta e sete...a mais antiga...tem o Poèmes $d u$ Brésil...ahn:....de oitenta e cinco...traduzida por Bernard Lorraine...e a última do ano passado que foi lançada...que é muito extensa...assim...é uma BÍblia mesmo(frase exclamativa)...bem interessante...éh::....eh Anthologiebilíngue du XVIeau XXe siècle...que pega um período de literatura bem extenso...de poesia....aqui os dois...o primeiro de mil novecentos e quarenta e sete do Tavares-Bastos...e essa de dois mil e doze...essa daqui ((a antologia de Tavares-Bastos))((risos))...ela está disponível na biblioteca por incrível que pareça nesse estado (danificada)...eu mostrei a foto só para ilustrar mesmo...ela está cortada por dentro...

...enfim...dos textos traduzidos ((a apresentadora olha para o slide no computador a sua frente com um semblante de houve algum problema))...nós encontramos dois só...primeiro um livro que reúne alguns textos críticos...La Rose du peuple: la poésie de Carlos Drummond de Andrade...que traz textos...assim...BEM_canônicos...Antonio Candido...são textos BEM interessantes...foi publicado em dois mil e cinco...ih::....e outro é um artigo publicado numa revista na França...escrito pelo Jaime Ginzburg...professor aqui da casa ((professor de Literatura brasileira da USP))...éh::...Poésie lyrique et politique au Brèsil: la vie minimale chez Carlos Drummond de Andrade...e foram esses dois que a gente

Levantamento

que

das antologias

poéticas

encontradas 
encontrou...e nada mais...dos textos escritos em francês...éh::....a gente chegou a dez textos críticos....MAS...sobre a poesia mesmo...éh.:.....um só...que é na verdade a tese da Witkowski...aquela autora que publicou a última reunião...Naître et mourir au Minas Gerais: Études de sept récits d'enfance autobiographiques brésiliens du XXe siècle...então...assim...nem é dedicada somente ao Drummond...ela...com diz...ela faz o estudo de...uhn::.....comment je peux traduire ça? ((O título da tese))...são escritas autobiográficas...brasileiras...e o Drummond tá lá pois a poesia dele é autobiográfica...esse assim...é o único texto quente...é uma tese...o resto dos textos que a gente encontrou que falam sobre Drummond...na realidade estão criticando as traduções...então não éh uma crítica da poesia...é uma crítica da tradução...ahn::.....

Quadro 15: Tipos de conexões entre as análises dos dados da pesquisa (Estudante 1)

Pela divisão proposta pela apresentadora na sua comunicação, evidenciada por meio dos marcadores "da poesia traduzida", "depois" e "enfim", notamos que os conteúdos das respectivas partes estão desenvolvidos por meio de conectores textuais, os quais possuem um valor particular em cada caso de uso.

No tocante à poesia traduzida para o francês, foram encontrados três livros de reuniões de poesia tanto brasileiros, que contêm a poesia de Drummond e também poesias ibero-americanas. Dentre essas três reuniões de poemas, a apresentadora fornece informações a respeito de cada uma. Nesse excerto (mas eu destaquei três que me chamaram mais atenção), o conector "mas" indica uma análise realizada pela estudante, já que ela avalia as reuniões indicando quais ela considera mais importante.

Com relação às antologias poéticas, foram encontradas inúmeras que continham também a poesia de Drummond. Entretanto, a apresentadora escolheu somente três dentre essas reuniões para mostrar na apresentação oral, como explicitado pelo conector "mas", que restringe os resultados dessa parte dos dados. Durante o desenvolvimento temático dessa parte, a apresentadora faz uma análise quanto a essas três antologias selecionadas para a apresentação como evidenciado pelo conector "que", introdutor de da oração subordinada adjetiva explicativa, “que é muito extensa...assim...é uma BÍblia mesmo 
(frase exclamativa)...bem interessante...éh::.....eh Anthologie bilíngue du XVIe au XXe siècle...que pega um período de literatura bem extenso...", cuja função é singularizar a antologia encontrada, visto que ela tem uma característica particular.

Dos textos críticos sobre a poesia de Drummond que estão traduzidos para o francês, dois foram encontrados. Sobre o primeiro, que se trata de um livro com vários conteúdos sobre a poesia do escritor mineiro, também é possível encontrar uma análise da estudante quanto a este livro por meio do conector "que", introdutor de uma característica particular que, no caso, trata-se do fato de textos críticos literários assinados por renomados professores de literatura e críticos literários, como Antonio Candido e Jaime Ginzburg, por exemplo. Além desses dois dados encontrados sobre a crítica da poesia, um outro também foi levantado, mas foi escrito diretamente em francês, pois se trata de uma tese de doutorado escrita na França e que tinha como temática a poesia autobiográfica.

\section{Estudante 2}

Por meio dos conectores que marcam a divisão entre as partes da apresentação oral, podemos também notar a criação de um mundo discursivo conjunto, através do lapso de memória da Estudante 2, que esqueceu de expor o seu objetivo de pesquisa ao público ouvinte da apresentação; a implicação dos parâmetros da situação de ação de linguagem é verificada por meio do pronome pessoal "eu" que aparece sobremaneira na transcrição.

\begin{tabular}{|c|c|}
\hline Conectores & $\begin{array}{l}\text { Partes da apresentação } \\
\text { oral de pesquisa }\end{array}$ \\
\hline $\begin{array}{l}\text { esse é o título da minha pesquisa }[. . .] \text { eu vou fazer uma breve } \\
\text { introdução sobre a intercompreensão que não é um termo ainda } \\
\text { muito difundido. }\end{array}$ & $\begin{array}{l}\text { Plano geral da } \\
\text { apresentação }\end{array}$ \\
\hline$\underline{\text { ok }}$ ((frase exclamativa))...o que é a intercompreensão?... & Fundamentação teórica \\
\hline$\underline{\text { bom }}(($ frase exclamativa $))$...o curso de leitura em francês & Contexto da pesquisa \\
\hline $\begin{array}{l}\text { ahn...esse trabalho com as outras língua ele já era de praxe nas } \\
\text { primeiras aulas aqui do francês instrumental. }\end{array}$ & Método da pesquisa \\
\hline ahn...o meu objetivo então - -está lá em cima...eu me esqueci de citar & Objetivo da pesquisa \\
\hline
\end{tabular}




\begin{tabular}{|l|l|}
\hline- -...é o surgimento de um autor autônomo plurilíngue. & \\
\hline ahn...o que eu fiz com o curso? & Análise dos resultados \\
\hline $\begin{array}{l}\text { no módulo quatro, o que eu faço? Ahn...o que eu fiz, né? Não sei se } \\
\text { deu pra ver nos slides anteriores...mas eu fiz essa experiência agora } \\
\text { no primeiro semestre com uma turma do Centro de Língua...o último } \\
\text { módulo eu faço em duas fases... }\end{array}$ & Resultados das análises \\
\hline $\begin{array}{l}\text { ahn:.....consideração final...os dez alunos que fizeram essa última } \\
\text { experiência todos conseguiram fazer... }\end{array}$ & Considerações finais \\
\hline obrigado...tem a bibliografia. & Agradecimento \\
\hline
\end{tabular}

Quadro 16: Tipos de conexões entre as partes da apresentação oral (Estudante 2)

Na seção dos resultados da pesquisa, a expositora discorre sobre as suas análises e resultados por meio da sequência do curso montado por ela no Centro de Línguas da FFLCH. O curso foi dividido quatro módulos, porém a estudante somente expôs a suas análises e resultados de dois deles, do primeiro e último módulos.

\begin{tabular}{|c|c|c|}
\hline Excertos & Conectores & Subpartes \\
\hline $\begin{array}{l}\text { ahn:....bom ((frase exclamativa))...por que eu concentro as } \\
\text { atividades no primeiro e no último módulo?....no primeiro } \\
\text { para mostrar que a língua não depende apenas da matéria } \\
\text { escrita...da língua em que o texto está....ahn....desde que ele } \\
\text { mobilize as estratégias cabíveis...ainda que ele não saiba } \\
\text { ainda quais são...a gente vai nomeando isso ao longo do } \\
\text { curso...o que eu devo fazer em cada gênero?...o que eu vou } \\
\text { fazer para cada tema?...tem relação com esse tema ou não } \\
\text { tem?.....tem imagem no texto ou não tem?...o que isso me } \\
\text { ajuda?...são as primeiras bases que a gente coloca no } \\
\text { primeiro módulo...no último módulo.... ão as três últimas } \\
\text { aulas do curso...eles já fizeram prova...já estão } \\
\text { super-craques...né?...já estão querendo até falar } \\
\text { ((risos))...então eu fiz a experiência de voltar com as } \\
\text { línguas românicas só que com um gênero mais complicado } \\
\text { que é o gênero acadêmico...porque ao longo do curso a } \\
\text { gente trabalha vários pequeno gêneros...não tão articulados } \\
\text { e não tão complexos quanto ao gênero acadêmico...mas } \\
\text { como o nível dois do curso de práticas é específico de } \\
\text { textos acadêmicos...a gente faz essa ponte...e eu aproveito } \\
\text { para voltar com as outras línguas...para eles verem que eles }\end{array}$ & mas & $\begin{array}{l}\text { Primeiro } \\
\text { (Módulo 1) }\end{array}$ \\
\hline
\end{tabular}


podem transferir tudo o que eles aprenderam e já aplicam no francês...aqui tem um pequeno quadro só para demonstrar a carga horária de cada módulo...e os tipos de texto eu que uso...tem chat...tem receita...tem sumário...um pequeno texto de um manual didático...e o último que é o resumo acadêmico...aqui é um exemplo de como eu faço isso no primeiro módulo [...] eu/na segunda aula eu apresento para eles um sumário de uma revista italiana...não necessariamente italiana mas de uma revista estrangeira...de uma língua românica...e peço para eles extraírem informações como o tema da publicação...a língua...qual pode ser o público-alvo...são hipóteses que vão sendo formuladas para construir esse horizonte de expectativa da revista...por que o sumário?...eles podem nunca terem aberto uma revista estrangeira...mas nem por isso eles não conhecem o gênero sumário...é uma estrutura fixa...é um estrutura altamente conhecida...eu acredito aqui que todos saibam o que é o sumário...e batem o olho vai saber que é [...] em seguida eu apresento a eles o sumário de uma revista em francês...que é uma revista de uma outra área...que tem um layout totalmente diferente...mas que nem por isso deixa de ser um sumário...ahn...e eles percebem...são levados a perceber todas essas diferenças mas que nem por isso deixa de ser um sumário....ahn::...e eles são levados a perceber todas essas diferenças mas que dentro do gênero se mantêm...são diferentes mas ainda é um sumário...e claro a gente trabalhou alguns ponto de gramática da língua francesa...

...no módulo quatro, o que eu faço? Ahn...o que eu fiz, né? Não sei se deu pra ver nos slides anteriores...mas eu fiz essa experiência agora no primeiro semestre com uma turma do Centro de Língua...o último módulo eu faço em duas fases...eu apresento pra eles primeiro um conjunto de resumos todos cortados...eu separo os títulos...o resumo e as palavras chaves...sendo que o título está sempre em francês...o resumo está em outra língua românica...e as palavras chaves na mesma língua do resumo...então eu recorto isso...recortei e coloquei em envelopes...e eles deveria - - o tema de todos os resumos eram inter-compreensão...não era a área deles...então eles deveriam encontrar o título referente...e as palavras chaves de cada resumo...COMO?...com a referência do francês que estava no título...o francês eles já dominavam...essa era a ÂNcora deles nesse momento...ahn...apesar de aqui...esse esse...é em italiano esse resumo...eles não do curso de

leitura

mas

mas

mas

então

então

Último

(Módulo 4)

do curso de 
tinham a base do conhecimento de mundo da área...ahn::...nem da língua do resumo...mas tinham a referência do título em francês...e eles fazem isso...deu SUper certo...eles conseguiram...ok...na aula seguinte...eu peço pra eles escolherem um artigo...que...numa língua que eles não dominam e que provavelmente eles não leriam...aí ta em romeno não consigo ler então eu não vou ler...ahn...então que eles procurassem esse artigo e trouxessem pra mim o resumo...trouxesse na aula para que nós lêssemos o resumo...que é a porte de entrada...é nele que você vai...ahn:......saber o que aquele artigo está falando...esse resumo é de um aula ((a apresentadora aponta para a tela do Power point)) que estudava medicina...e ela era boliviano...mora no Brasil...e estava fazendo curso de francês...e já tinha estudado italiano...então pra ela só sobrou o romeno e ela escolheu esse resumo...qual que era a âncora nesse caso? Eu não tenho mais o francês...o romeno eu não domino...era justamente o conhecimento de mundo da sua área de pesquisa...era isso que iria te dar o conhecimento leitura...ahn:.....consideração final... necessário para você avançar na

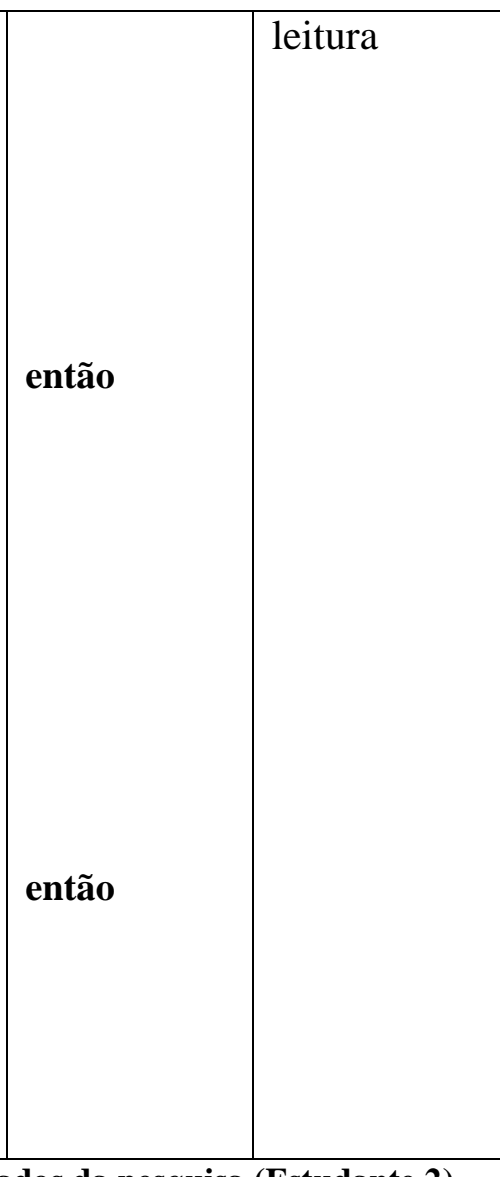

Quadro 17: Tipos de conexões entre as análises dos dados da pesquisa (Estudante 2)

Ao expor os resultado da pesquisa, a Estudante 2 inicia a sua exposição por meio das atividades produzidas por ela para o primeiro módulo do curso de leitura em francês. Em seguida, ela começa a expor os resultados da aplicação das atividades do quarto e último módulo do curso. No exposto do primeiro módulo, verifica-se que a estudante se vale sobremaneira do conector "mas", diferentemente da sua fala ao expor o quarto módulo, na qual ela se vale mais do conector "então". Ambos os elementos de conexão têm uma função particular na apresentação oral da pesquisa.

O conector "mas" tem a função de justificar os procedimentos usados pela Estudante 2 na preparação das atividades do módulo inicial do curso por meio de orações adversativas. Assim, esse conector nos mostra os resultados da pesquisa no que tange aos procedimentos construção da fase inicial do curso de leitura:

(116) então eu fiz a experiência de voltar com as línguas românicas só que com um gênero mais complicado que é o gênero acadêmico...porque ao longo do curso a gente trabalha vários pequeno gêneros...não tão articulados e não tão complexos quanto ao gênero acadêmico.... mas como o nível dois do curso de práticas é específico de textos acadêmicos...a gente faz essa ponte. 
(linhas 110 a 114) (AO2)

O conector "mas" acima tem a função de justificar a ideia da Estudante 2 de se escolher um gênero textual acadêmico para compor as atividade do primeiro módulo do curso. Ela argumenta que no segundo nível do curso, que é oferecido em outro semestre, os alunos trabalham com muitos gêneros acadêmicos e, por isso, ela fez a ponte e já iniciou esse trabalho no primeiro módulo do nível 1.

O segundo "mas" encontrado tem a função a mesma função de apresentação de uma justificativa:

(117) eu/na segunda aula eu apresento para eles um sumário de uma revista italiana...não necessariamente italiana mas de uma revista estrangeira...de uma língua românica (linhas 118 a 119) (AO2)

No excerto acima, a Estudante 2 justifica a importância de se propor atividades de intercompreensão já nas primeiras aulas do curso, por meio de revista de línguas românicas não dominadas pelos alunos do curso.

Os três usos do conector "mas", abaixo, também mostram as justificativas da estudante, pois, segundo ela, mesmo que os alunos não dominam a língua do texto apresentado na revista estrangeira, o fato do sumário estar dentro da estrutura desse gênero textual possibilita que os estudantes o percebam e possam iniciar a compreensão do conteúdo:

(118) em seguida eu apresento a eles o sumário de uma revista em francês...que é uma revista de uma outra área...que tem um layout totalmente diferente...mas que nem por isso deixa de ser um sumário...ahn...e eles percebem...são levados a perceber todas essas diferenças mas que nem por isso deixa de ser um sumário...ahn:....e eles são levados a perceber todas essas diferenças mas que dentro do gênero se mantêm [...] (linhas 124 a 127) (AO2)

Na exposição do quarto módulo do curso, há muitas ocorrências do conector "então", os quais têm a função de apresentar algumas conclusões das últimas atividades de intercompreensão do curso, que foram aplicadas no último módulo e as quais tiveram a participação direta dos estudantes na execução: 
(119) então eles deveriam encontrar o título referente...e as palavras chaves de cada resumo...COMO?...com a referência do francês que estava no título...o francês eles já dominavam [...] (linhas 135 a 137) (AO2)

No excerto acima, o conector "então" tem a função de concluir as reações dos alunos do curso frente às atividades, a fim de justificar o porquê da sua elaboração para o módulo. O mesmo ocorre abaixo:

(120) eu peço pra eles escolherem um artigo...que...numa língua que eles não dominam e que provavelmente eles não leriam...aí ta em romeno não consigo ler então eu não vou ler...ahn...então que eles procurassem esse artigo e trouxessem pra mim o resumo...trouxesse na aula para que nós lêssemos o resumo...que é a porte de entrada [...] (linhas 139 a 143) (AO2)

Aqui, a Estudante 2 parece antecipar as reações dos estudantes ao terem que fazer a atividade proposta, pois ela prevê que os alunos não conseguiriam ler o resumo do artigo escrito em uma língua românica não dominada por eles. A preparação da atividade se deu baseada nessa percepção da estudante, que realmente se concretizou. No último excerto a seguir, o conector "então" tem a função de concluir a reação dos estudantes, que deveriam ler o resumo de um artigo sem a ajuda de nenhuma outra língua. A atividade foi preparada justamente para que ocorresse como aconteceu no caso da aluna boliviana, citado abaixo:

(121) esse resumo é de uma aula ((a apresentadora aponta para a tela do Power point)) que estudava medicina...e ela era boliviana...mora no Brasil...e estava fazendo curso de francês...e já tinha estudado italiano...então pra ela só sobrou o romeno e ela escolheu esse resumo [...] (linhas 143 a 145) (AO2)

\section{Estudante 3}

Os marcadores conversacionais que marcam a divisão da macro-estrutura da apresentação oral não são distintos daqueles que encontramos nas outras duas apresentações. Igualmente a elas, notamos que a implicação da linguagem é verificável por meio pronome "eu”. Após a abertura da exposição oral, a Estudante 3 reforça o seu 
papel enquanto próxima do contexto da pesquisa, onde os dados foram coletados, pois ela também era aluna da graduação.

\begin{tabular}{|c|c|}
\hline Conectores & $\begin{array}{c}\text { Partes da } \\
\text { apresentação oral de } \\
\text { pesquisa }\end{array}$ \\
\hline $\begin{array}{l}\text {.produção escrita do FLE em foco: Um estudo sobre os } \\
\text { lvolvimento da capacidades de linguagem por meio das atividades } \\
\text { ageiras do relator e expor }\end{array}$ & $\begin{array}{ll}\text { Abertura } & \text { da } \\
\text { apresentação } & \end{array}$ \\
\hline $\begin{array}{l}\text { Bom (frase exclamativa)...eu também sou aluna da habilitação de } \\
\text { francês...claro (frase exclamativa) (risos). }\end{array}$ & Contexto da pesquisa \\
\hline $\begin{array}{l}\text { bem (frase exclamativa)...por que estudar os gêneros textuais para o } \\
\text { ensino e por que fazê-lo na didática do francês. }\end{array}$ & Justificativa da pesquisa \\
\hline $\begin{array}{l}\text { Bem } \quad \text { frase exclamativa)...para realizar a } \\
\text { foram.... ah.:.....usados alguns conceitos teóricos. }\end{array}$ & Fundamentação teórica \\
\hline $\begin{array}{l}\text { ah::...para poder analisar o desenvolvimento das capacidades de } \\
\text { linguagem nós usamos o modelo de análise do ISD...composto de duas } \\
\text { partes. }\end{array}$ & Método de análise \\
\hline $\begin{array}{l}\text { o contexto da pesquisa foi formado por exercícios de produção escrita } \\
\text { produzidos por alunos do segundo ano da habilitação de francês aqui } \\
\text { da FFLCH }\end{array}$ & Contexto da pesquisa \\
\hline ah::...para compor o corpus...ah::....selecionamos sete alunos & $\begin{array}{l}\text { Metodologia } \\
\text { pesquisa }\end{array}$ \\
\hline $\begin{array}{l}\text { ah:...pra começar... gênero sinopse...foi a primeira produção escrita } \\
\text { proposta para eles }\end{array}$ & Resultados das análises \\
\hline $\begin{array}{l}\text { ah::...portanto estudar o percurso de aprendizagem tornou possível } \\
\text { adequar as estratégias de ensino às suas necessidades... }\end{array}$ & Considerações finais \\
\hline e obrigada (frase exclamativa). & Agradecimento \\
\hline
\end{tabular}

Quadro 18: Tipos de conexões entre as partes da apresentação oral (Estudante 3)

A seção de apresentação das análises foi dividida pela expositora tendo em vista osquatrogêneros textuais trabalhados na pesquisa: sinopse de filme, fait divers, relato de 
viagem, e relato curto literário.Abaixo, elaboramos uma tabela para melhor visualizarmos os conectores utilizamos na exposição das análises e resultados da pesquisa.

\begin{tabular}{|c|c|c|}
\hline Excertos & Conectores & Subpartes \\
\hline $\begin{array}{l}\text { ah:.....gênero sinopse...foi a primeira produção } \\
\text { escrita proposta para eles...ah:.....nós notamos } \\
\text { algumas dificuldades na intensificação do } \\
\text { suspense que é fundamental para poder seduzir } \\
\text { o leitor a assistir o filme...isso denota problemas } \\
\text { com relação à projeção de um interlocutor...ou } \\
\text { seja....problemas na capacidade de ação de } \\
\text { acabam também diminuindo as capacidades } \\
\text { discursivas...uma vez que a organização do texto } \\
\text { acaba sendo prejudicada....aqui nós temos um } \\
\text { exemplo...do aluno LF...é uma parte de uma } \\
\text { primeira produção escrita que ele fez no } \\
\text { semestre...nessa altura ele não incluiu uma } \\
\text { complicação dentro da sua sinopse....a tensão } \\
\text { central do filme que é fundamental para a } \\
\text { construção da sinopse...e ele terminou a } \\
\text { produção escrita dele como uma generalização } \\
\text { que não é comum ao gênero...ah:.....a parte } \\
\text { sublinhada ele diz...Cette personne enseigne à } \\
\text { Alexander beaucoup de chose sur la vie et il } \\
\text { enseigne beaucoup à cette personne aussi...esse } \\
\text { tipo de generalização estava presente na maior } \\
\text { parte das produções dos alunos...não é o que a } \\
\text { gente identifica no gênero sinopse...aqui tem um } \\
\text { exemplo de uma sinopse disponível no site } \\
\text { allóciné do filme Ratatouille....ao invés de fazer } \\
\text { esse tipo de generalização...é preferível fazer } \\
\text { uma enumeração que acaba convencendo o leitor } \\
\text { de que ele vai ter acesso a uma série de valores se } \\
\text { ele assistir o filme...então a sinopse diz...Remy } \\
\text { va découvrir le vrai sense de l'aventure...de } \\
\text { l'amitié...de la famille...e assim por } \\
\text { diante...interessante notar que esse mesmo aluno } \\
\text { que teve problemas na construção do suspense na } \\
\text { primeira produção escrita...na última produção } \\
\text { escrita ele mostra que não tem mais problemas } \\
\text { com esse tipo de capacidade de ação e } \\
\text { discursivas e na construção do suspense... }\end{array}$ & $\begin{array}{l}\text { isso denota } \\
\text { ou seja }\end{array}$ & $\begin{array}{l}\text { Primeiro } \\
\text { gênero } \\
\text { textual: } \\
\text { sinopse }\end{array}$ \\
\hline
\end{tabular}


ah:....passando para o segundo gênero trabalhado...o fait divers...nós notamos que não houve grandes problemas com as capacidades de ação e as capacidades discursivas... sobretudo com capacidades linguístico-discursivas...uma hipótese levantada no trabalho de Cinthia Bezerra na pesquisa dela...que::....as::...as::....as capacidades de linguagem da língua materna...conforme as meninas já expuseram aqui (a aluna se refere as outras comunicadoras que apresentaram trabalhos de pesquisa na mesma sessão)...elas podem ser transferidas para a língua alvo...de modo que...grosso modo nós não temos fait divers no Brasil...mas nós temos o gênero notícia que acaba guardando várias semelhanças com o fait divers...então nós tivemos problemas nas capacidades

linguísticos-discursivas...principalmente coesão verbal...e aí é interessante...é interessante...mostrar o que aconteceu...nas perguntas introdutórias para a produção desse gênero e sobre a utilização dos tempos verbais...alguns alunos não responderam corretamente à pergunta...mas aplicaram todos os tempos verbais corretamente nas suas produções escritas...e o contrário também aconteceu...eles respondia corretamente a pergunta...mas não aplicavam nas suas produções escritas...

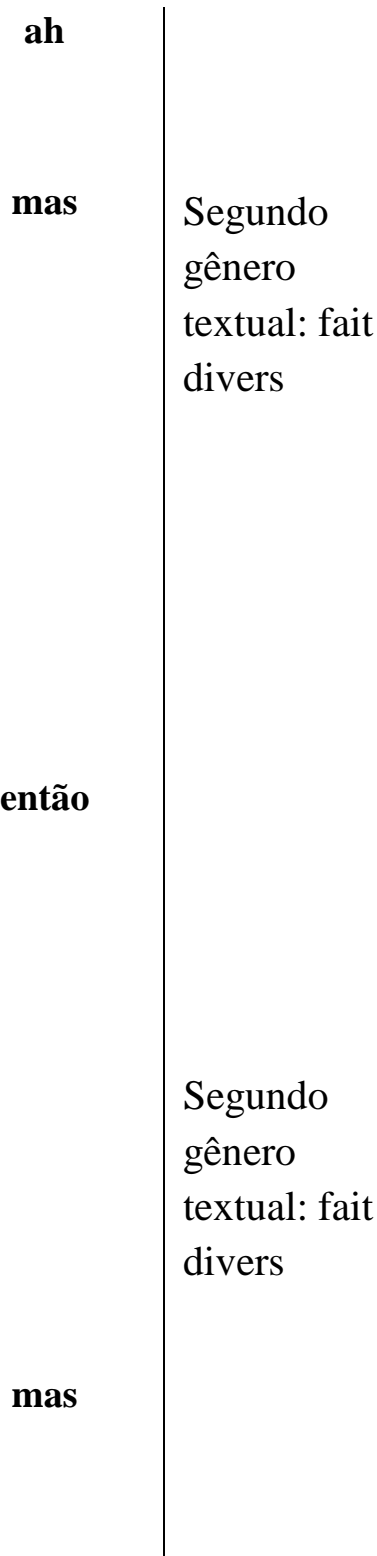


ah:...o terceiro gênero trabalhado foi relato de viagem em blog...de discurso implicado...portanto havia subjetivação...o emprego de modalizações apreciativas foi frequente...e nós verificamos uma melhora na coesão verbal...ah:....nesse gênero é possível construir tanto no presente quanto utilizando tempos pretéritos...eles preferem a utilização de tempos pretéritos e conseguem aplicar isso de maneira satisfatória...uma exceção foi o aluno GS...que parecei ter se apropriado das capacidades linguístico-discursivas principalmente coesão verbal... momento ele acaba cometendo erros relacionados ao uso de passé composé e no uso do imparfait ah

\section{Terceiro}

gênero

textual:

relato de

viagem

mas

o último gênero trabalhado foi o relato curto literário...nós verificamos que os alunos tiveram um apropriação satisfatória das capacidades esperadas...persistiram alguns problemas isolados relacionados às capacidades linguístico-discursivas..ah:...relacionados à coesão verbal e a coesão nominal...nas produções dos alunos GS e RG...então nós verificamos que a maioria iniciou o semestre co problemas nas capacidades de ação e discursiva...mas a maioria supera isso a partir da segunda produção escrita...nós levantamos uma hipótese de que as capacidades e as capacidades discursivas são mais facilmente transferíveis da língua materna para a língua alvo...já as capacidades linguístico-discursivas que tiveram uma apropriação mais custosa...elas mais dificilmente podem ser passadas para a língua alvo uma vez que elas requerem uma sistematização mais específica...

\section{Quadro 19: Tipos de conexões entre as análises dos dados da pesquisa (Estudante 3)}

A seção dos resultados da pesquisa é iniciada pelo marcador conversacional“ah", utilizada mais duas vezes para marcar a mudança da exposição de um gênero textual para outro, e pelo conector "pra começar". Nesse momento da apresentação, a expositora iniciou a exposição das análises e resultados por meio do gênero textual relato de viagem, 
mostrando as relações estabelecidas durante a análise dos dados da pesquisa. Ao longo dessa seção, notamos que os conectores nos permitem enxergar essas relações:

(122) isso denota problemas com relação à projeção de um interlocutor...ou seja...problemas na capacidade de ação de acabam também diminuindo as capacidades discursivas (linhas 78-79) $(\mathrm{AO} 3)$

Aqui, o conector "isso" retoma uma constatação feita pela estudante a respeito do desempenho dos alunos da escrita do gênero textual sinopse. Em seguida, por meio do conector de reformulação "ou seja”, a apresentadora ressalta que os estudantes tiveram dificuldades na apropriação da capacidade de ação referente ao gênero textual sinopse de filme quando da escrita da produção inicial. No entanto, constatou-se que na produção final os estudantes não mostravam mais esses problemas de projeção do interlocutor do texto. Para isso, RA usa o exemplo de um aluno que apresentou muitos problemas na capacidade de ação:

(123) na última produção escrita ele mostra que não tem mais problemas com esse tipo de capacidade de ação e discursivas e na construção do suspense... (linhas 95 a 96) (AO3)

[...] passando para o segundo gênero trabalhado...o fait divers...nós notamos que não houve grandes problemas com as capacidades de ação e as capacidades discursivas... mas sobretudo com capacidades linguístico-discursivas [...] então nós tivemos problemas nas capacidades linguísticos-discursivas...principalmente coesão verbal (linhas 101 a 110) (AO3)

Ao tratar dos resultados do segundo gênero textual trabalhado, identificamos que os conectores "mas" e "então" introduzem uma oração coordenada adversativa seguida de uma conclusiva, pelas quais constatamos a mesma ideia de que os textos apresentavam problemas nas capacidades de ação e nas capacidades discursivas, mas também nas capacidades linguístico-discursivas.

Ao passar para o terceiro gênero textual trabalhado na pesquisa, por meio do conector "ah", a expositora faz as seguintes considerações:

(124) ah:...o terceiro gênero trabalhado foi relato de viagem em blog...de discurso implicado...portanto havia subjetivação...o emprego de modalizações apreciativas foi frequente...e nós verificamos uma melhora na coesão verbal...ah:.... [...] uma exceção foi o aluno GS...que parecei ter se apropriado das capacidades linguístico-discursivas principalmente coesão 
verbal... mas aí nesse momento ele acaba cometendo erros relacionados ao uso de passé composé e no uso do imparfait... (linhas 116 a 123) (AO3)

Mais uma vez, a expositora apresenta um dado da pesquisa que evidencia a dificuldade dos estudantes no que tange às capacidades linguístico-discursivas. $O$ conector "mas" expressa essa análise de RA. Essa mesma ideia será afirmada quando a expositora aborda as análises do último gênero textual trabalhado:

(125) o último gênero trabalhado foi o relato curto literário...nós verificamos que os alunos tiveram um apropriação satisfatória das capacidades esperadas...persistiram alguns problemas isolados relacionados às capacidades linguístico-discursivas..ah::..relacionados à coesão verbal e a coesão nominal...nas produções dos alunos GS e RG...então nós verificamos que a maioria iniciou o semestre co problemas nas capacidades de ação e discursiva...mas a maioria supera isso a partir da segunda produção escrita. (linhas 123 a 129) (AO3)

Mais uma vez, encontramos um movimento particular entre os conectores "então" e "mas". Eles ressaltam que, embora os estudantes tenham mostrado em um primeiro momento uma dificuldade com a capacidade de ação, eles as superaram na segunda produção. Todavia, as capacidades linguístico-discursivas se mostraram-mais difíceis de compreensão por parte dos estudantes, como se constatou na análise dos seus textos.

\subsection{Mecanismos de textualização: coesão nominal}

Não há muitas séries coesivas nas apresentações orais de pesquisa e, sim, generalizações. Isso é bastante diferente dos outros gêneros textuais produzidos, em que havia séries coesivas. Como mostramos, os projetos de pesquisa contêm muitas retomadas nominais, pois elas buscam contruir a ideia central da pesquisa e também clarificar o posionamento subjetivo das estudantes. Acreditamos que essa diferença se dá pelo fato de que os outros gêneros foram escritos, portanto há maior necessidade de referenciação interna no texto. Assim, em relação aos textos orais das apresentações, levantamos a hipótese de que as generalizações podem indicar, de acordo com Vigotski (2009, p.226), uma síntese, por meio da palavra, das relações comparativas entre os dados 
das pesquisas. Nesse sentido, segundo (FRIEDRICH, 2012), as generalizações funcionariam como um instrumento psicológico, pois auxiliamas estudantes na atividade psíquica de comparar os dados e expor essa relação para o auditório.

\section{Estudante 1}

No excerto abaixo, destacamos as duas generalizações encontradas na apresentação da estudante, que são expressas pelas palavras "Extra literária" e "mística". As generalizações encontradas foram:

(126) pois é....agora eu já parto para o final da apresentação...ih:.:....na verdade eu vou comentar o comentário...apresentar partes dos comentários que foram feitos...ahn::.....primeiro que as traduções e recepções são escassas ainda (recepção e tradução da poesia de Drummond na França)...e não realmente bem difundida...depois o contexto de publicação dessas traduções tem uma relação que eu chamei de EXtra literária...então assim...né?...(linhas 75-80) (AO1)

[...] do leitor francês sobre a literatura brasileira...éh...eu percebi duas coisas...primeiro que existe uma mística com relação ao país tropical...o Brasil......e depois que/ existe uma relação muito direta feita constantemente com a Literatura portuguesa...por causa da relação da língua mesmo...entre outras razões...aí eu coloquei a capa de uma das antologias (Poème) du Brésil...que eu acho que mostra bem essa ideia de tropical né? (linhas 85-89) (AO1)

Essas duas generalizações não podem ser compreendidas pela cadeia nominal que tenha como referente os resultados da pesquisa, pois evidenciam generalizações dos resultados gerais do estudo realizado, que não foram mostrados na apresentação oral. Por exemplo, a palavra "Extra literária" não pertence a uma cadeia nominal pela qual pudéssemos recuperar o referente, bem como a palavra "mística", que estabelece uma relação catafórica somente com a seguinte explicação: “pra ilustrar a relação com a literatura portuguesa...eu citei uma das críticas que a gente conseguiu..”Drummond de Andrade n'est un hétéronyme oublié par Pessoa de l'autre côté de l' Atlantique" ((a continuação da citação é "il naquit dans la province du Minas Gerais en 1902 et mourut à Rio de Janeiro en 1987”))...eu vou ler só isso...que na verdade é o que interessa". É somente por meio dessa informação que podemos compreender a generalização, porém não é possível criarmos uma cadeia nominal que a justifique. 


\section{Estudante $2^{33}$}

A seguir, mostraremos as duas generalizações feitas pela estudante 2, ambas realizadas pelo uso da mesma palavra, "âncora":

(127) o último módulo eu faço em duas fases...eu apresento pra eles primeiro um conjunto de resumos todos cortados...eu separo os títulos...o resumo e as palavras chaves...sendo que o título está sempre em francês...o resumo está em outra língua românica...e as palavras chaves na mesma língua do resumo...então eu recorto isso...recortei e coloquei em envelopes...e eles deveria - - o tema de todos os resumos eram intercompreensão...não era a área deles...então eles deveriam encontrar o título referente...e as palavras chaves de cada resumo...COMO?...com a referência do francês que estava no título...o francês eles já dominavam...essa era a Âncora (linhas 144-145) (AO2)

[...] ok...na aula seguinte...eu peço pra eles escolherem um artigo...que...numa língua que eles não dominam e que provavelmente eles não leriam...aí ta em romeno não consigo ler então eu não vou ler...ahn...então que eles procurassem esse artigo e trouxessem pra mim o resumo...trouxesse na aula para que nós lêssemos o resumo...que é a porte de entrada...é nele que você vai...ahn:......saber o que aquele artigo está falando...esse resumo é de uma aluna ((a apresentadora aponta para a tela do Power point)) que estudava medicina...e ela era boliviano...mora no Brasil...e estava fazendo curso de francês...e já tinha estudado italiano...então pra ela só sobrou o romeno e ela escolheu esse resumo...qual que era a âncora nesse caso? Eu não tenho mais o francês...o romeno eu não domino...era justamente o conhecimento de mundo da sua área de pesquisa [...] (AO2)

As duas generalizações encontradas têm como referente os procedimentos de execução das atividades do último módulo do curso de leitura em francês.

\footnotetext{
${ }^{33}$ No caso das Estudantes 2 e 3, que estavam na mesma mesa de apresentação, no V Encontro de Pesquisas do Francês, a própria mediadora, uma pesquisadora experiente, comentou a respeito das generalizações feitas pela Estudante 2. Ressalta-se que a pesquisadora em questão é especialista na área de leitura em língua estrangeira, ou seja, trabalha com o tema de pesquisa da Estudante 2:

"bom (frase exclamativa)...o que eu achei MUIto bom...né...a passagem desse leitor monolíngue...se torna bílingue...depois plurilíngue...e a estratégia de nomear as próprias estratégias...né?.... nomeação dos processos...dos objetos...as fases...é algo importantíssimo em qualquer aprendizagem...e algo importantíssimo na vida das pessoas...a pessoa que está tremendo...não sabe o que está tendo...vai ao médico ou ao psiquiatra...e fala...eu estou sentindo isso isso isso...o médico fala...olha (frase exclamativa)...isso é DEpressão...ah:......então isso é depressão? (resposta do hipotético paciente)...bom...a partir do momento em que há uma nomeação...de algo é nomeado...ele passa a ser tangível...quando uma criança aprende a falar...a gente não fala vamos brincar com aquele objeto redondo que é usado....se você disser BOLA....aquilo vai catalisar uma série de informações é representações e passa a ser adotado...e portanto disponível para a criança [...]e a noção de âncora eu nunca tinha ouvido...a gente tem ancrage ((palavra francesa))...mas eu não tinha lido em nenhum texto em português a noção de ancora...você falou...a âncora nesse caso é os conhecimento do mundo...a âncora nesse outro caso...se você puder desenvolver mais.

Não daremos mais destaque a esse fato, pois as discussões que seguem as apresentações não são dados de nossa pesquisa.
} 
Como podemos verificar no primeiro excerto acima, a palavra "âncora" é resultado de todos os procedimentos seguidos pela estudante para a construção da atividade do quarto módulo do curso de leitura em francês. A palavra "âncora", a primeira vista, poderia ter como referente o termo "o francês", no entanto esse termo só tem sentido uma vez que o resumo e as palavras-chaves estavam em outra língua românica, diferente do francês, tal como a Estudante 2 planejou.

No segundo excerto, podemos verificar que a Estudante 2 continua a análise da execução das atividades do quarto módulo do curso, expondo as reações dos alunos. Notemos, mais uma vez, a ocorrência da palavra "âncora", a qual estabelece uma relação catafórica com a expressão "o conhecimento de mundo da sua área de pesquisa". Contudo, verifica-se que cada aluno do curso poderia escolher um artigo escrito em uma língua desconhecida por ele, logo cada um deles poderia utilizar certo conjunto de saberes para a leitura o texto. Assim, o termo generalizador "âncora" tem como referente os procedimentos de execução da atividade, isto é, é necessária a criação de uma dificuldade maior de leitura para os alunos, retirando-lhes qualquer “ajuda” da língua francesa.

\section{Estudante 3}

No excerto abaixo, a generalização ocorre por meio da palavra "apropriação" identificada em duas ocorrências ${ }^{34}$ :

(128) o último gênero trabalhado foi o relato curto literário...nós verificamos que os alunos tiveram uma apropriação satisfatória das capacidades esperadas...persistiram alguns problemas isolados relacionados às capacidades linguístico-discursivas..ah::..relacionados à coesão verbal e a coesão nominal (linhas 111 a 115) (AO3)

[...] nós levantamos uma hipótese de que as capacidades e as capacidades discursivas são mais facilmente transferíveis da língua materna para a língua alvo...já as capacidades

\footnotetext{
${ }^{34}$ Encontramos também na exposição dos resultados das análises e resultados uma forma verbal que se refere também à generalização "uma apropriação", trata-se do termo "se apropriado": "o terceiro gênero trabalhado foi relato de viagem em blog...de discurso implicado...portanto havia subjetivação...o emprego de modalizações apreciativas foi frequente...e nós verificamos uma melhora na coesão verbal...ah:.....nesse gênero é possível construir tanto no presente quanto utilizando tempos pretéritos...eles preferem a utilização de tempos pretéritos e conseguem aplicar isso de maneira satisfatória...uma exceção foi $o$ aluno GS...que parecei ter se apropriado das capacidades linguístico-discursivas principalmente coesão verbal...mas aí nesse momento ele acaba cometendo erros relacionados ao uso de passé composé e no uso do imparfait (linhas 104-111).
} 
linguístico-discursivas que tiveram uma apropriação mais custosa...elas mais dificilmente podem ser passadas para a língua alvo uma vez que elas requerem uma sistematização mais específica (linhas 129 a 133) (AO3)

Como já explicamos ao longo da pesquisa, a Estudante 3 objetivou verificar o desenvolvimento das capacidades de linguagem por meio da escrita de cinco gêneros textuais. Na exposição da suas análises e resultados, na apresentação oral, ela estabeleceu uma comparação entre o primeiro texto de cada gênero textual produzido pelos alunos e as características encontradas na produção final de cada um desses gêneros. Assim, o referente da palavra "apropriação" não é identificável dentro de uma cadeia nominal, mas é o resultado das análises comparativas feitas pela estudante.

\subsection{Mecanismos enunciativos: vozes e modalizações}

Como expusemos em nossos procedimentos de análise, encontramos, do projeto de pesquisa ao relatório final, duas categorias de vozes: a voz do estudante e a voz do pesquisador. Como vimos, a voz do estudante (presente no projeto de pesquisa) permite evocar um conteúdo que emerge da experiência da própria aluna. Por outro lado, a voz do pesquisador não é mais baseada na experiência da estudante enquanto aluna de Letras, mas emerge quando observamos um modo pessoal de pensar científico, ou seja, as estudantes estabelecem relações entre os dados da pesquisa, buscando similaridades entre eles. Para expor essas relações, elas utilizam-se dos pronomes "eu" e nós", no momento da generalização. Além disso, as palavras (ou seja, as generalizações) utilizadas pelas estudantes para sintetizar as relações por elas feitas a respeito de suas pesquisas revelam a voz do pesquisador no final do processo da Iniciação Científica.

Nesse momento, podemos inferir que, assim como constatado por Vigotski (2009, p.226), a palavra utilizada, ou a generalização, parece guiar o pensamento das estudantes no momento da apresentação dos resultados, permitindo expressar um sentido atribuído pelas estudantes. Em outros termos, podemos dizer que a essas palavras (ou generalizações) é atribuído um sentido, isto é, um emprego autonímico, que, segundo Maingueneau (2008, p.157), se opõe ao uso corrente ao qual a palavra se refere na sua 
realidade externa. Podemos dizer, assim como Saussure (2002), que a palavra ganha uma valoração dentro do sistema da língua. Desse modo, o valor das generalizações só pode ser compreendido no emprego que as estudantes fazem dele no interior das pesquisas. Por isso, para nós, trata-se de um modo pessoal de pensar científico.

Como explicamos em nossa Fundamentação teórica e retomamos nas análises dos tipos de discurso, o mundo discursivo conjunto, de acordo com Weinrich (1973), cria uma situação de tensão e conflito que, a nossa entender, propricia a criação de uma situação favorável à generalização. Nesse sentido, à guisa de Vigotski (2009), podemos perceber que o pensamento generalizante surge diante de uma dificuldade criada pela situação de comunicação.

As modalizações lógicas encontradas contêm uma perspectiva avaliativa das estudantes frente aos dados a que chegaram e, por meio delas, é possível compreendermos a leitura realizada pela estudante nas análises. Assim, as modalizações lógicas são mais frequentes ao final da pesquisa e são reveladoras da voz da pesquisadora, que emerge no término do processo da IC.

\section{Estudante 1}

O sentido autonímico expresso pelas palavras "uma mística" e "Extraliterário" é o resultado da interpretação da voz do pesquisador, que estabelece relações entre os dados da pesquisa, buscando compará-los. Assim, os dois termos generalizadores acima têm um emprego específico no interior da pesquisa desenvolvida pela Estudante 1, e oposto ao seu uso corrente. A palavra "Extraliterário" expressa que, de acordo com a comparação entre os dados da pesquisa, pode-se afirmar que há sempre um motivo não literário para que a poesia de Drummond seja traduzida para o francês como, por exemplo, o ano do Brasil na França, em 2005. Já a palavra "mística” têm como finalidade expressar a ideia de que os franceses associm a sempre a literatura brasileira à portuguesa, além de ter um ponto de vista sobre a poesia de Drummond associando-a ao estereótipo de Brasil tropical. 
(129) depois o contexto de publicação dessas traduções tem uma relação que eu chamei de EXtra literária...então assim...né?... (linhas 75 a 80) (AO1)

[...] do leitor francês sobre a literatura brasileira...éh...eu percebi duas coisas...primeiro que existe uma mística com relação ao país tropical...o Brasil... (linhas 81 a 82)

Nas nossas análises da conexão na apresentação oral de pesquisa, afirmamos que por meio do seu uso é possível identificarmos as posições avaliativas da estudante quanto ao conteúdo exposto na apresentação. Encontramos avaliações lógicas e apreciativas em vários momentos da apresentação como:

Na exposição da metodologia:

(130) o material ...a internet foi essencial...pois através dela a gente chegou a ferramentas de busca...como o Google...e bibliotecas e livraria online também...foi por aí que a gente encontrou tudo o que a gente queria conseguir... (linhas 10 a 12) (AO1)

Na exposição da Fundamentação teórica, na qual encontramos a avaliação da voz do pesquisador sobre a voz da ciência, registrada nas referências teóricas utilizadas para a pesquisa:

(131) e a leitura teórica...fizemos um estudo breve sobre a estética da recepção de Jauss e Iser...éh::.....foi um pouco difícil de ler isso e de entender essa leitura...ih:::....aí a gente usou duas vias pra principalmente conseguir...conseguir entender a Estética da recepção...entender um pouco melhor essa discussão...éh:....lemos o Paul Zumthor...Desempenho, recepção e leitura...Regina Zilberman...Estética da recepção e história da literatura...que foi essencial para a compreensão dessa teoria da Estética da recepção de entender essa leitura.. (linhas 19 a 24) $(\mathrm{AO} 1)$

Entretanto, foi no momento da exposição dos resultados da pesquisa que encontramos vários modalizadores que mostram a avaliação da estudante com relação ao seu modo de pensar quanto aos dados coletados. Retomando alguns excertos dos quais analisamos os conectores textuais, podemos perceber os vários posicionamentos avaliativos. 
$\mathrm{Na}$ apresentação da poesia traduzida, em que foram analisadas as reuniões de poesias encontradas:

(132) a primeira de mil novecentos e oitenta e três Réunion que foi escrito por Jean-Michel Massa...a segunda de noventa La machine du monde et autres poèmes...é a mais extensa...e a última que foi traduzida pela Ariane Witkowski Mort dans l'avions \& autres poèmes..é bem mais curta mas éh melhor eh bilingui... (linhas 41 a 44) (AO1)

Mesmo avaliando a segunda reunião de poemas de Drummond encontrada como a mais extensa por trazer mais poesias do escritor, a estudante considera a última reunião melhor, pois contém uma característica que as outras não possuem, ou seja, ela é bilíngue. Assim, o fato de possuir a poesia tanto em língua francesa quanto em língua portuguesa é motivo suficiente para a última reunião com poesias de Drummond seja a melhor avaliada com relação às outras três.

\section{Estudante 2}

Na seção de análises e resultados da apresentação da Estudante 2, a voz do pesquisador pode ser identificada por meio das duas ocorrências da palavra "âncora" que, na pesquisa, possuem um mesmo emprego autonímico. A primeira ocorrência da palavra refere-se à análise de que os alunos do curso, diante de um texto escrito em uma língua românica desconhecida, recorrem primeiramente a alguma informação que esteja em uma língua conhecida por eles para efetuarem a leitura. O segundo emprego autonímico da palavra refere-se à constatação de que os alunos, não tendo mais o apoio de uma língua conhecida para compreenderam o texto, utilizando-se de algum conhecimento de mundo para ler o texto escrito uma língua desconhecida. Esses empregos autonímicos atribuídos pela Estudante 2 evidenciam a voz do pesquisador.

(133) com a referência do francês que estava no título...o francês eles já dominavam...essa era $\underline{a}$ ÂNcora deles nesse momento...ahn... (linhas 144-145) (AO2)

[...] então pra ela só sobrou o romeno e ela escolheu esse resumo...qual que era a âncora nesse caso? Eu não tenho mais o francês...o romeno eu não domino...era justamente o conhecimento de 
mundo da sua área de pesquisa... (linhas 154-156) (AO2)

Abaixo, destacaremos duas modalizações apreciativas com valor de lógicas. Pela primeira podemos perceber que o advérbio “já" denota uma avaliação lógica das impressões da estudante frente aos dados da pesquisa. Esse advérbio é atrelado à expressão "super-craques", que expressa a perspectiva avaliativa da estudante.

No segundo excerto, o prefixo "super" retorna na expressão "super certo" que, igualmente a anterior, tem a função de mostrar a avaliação da estudante frente aos dados da pesquisa:

(134) no último módulo...são as três últimas aulas do curso...eles já fizeram prova...já estão super-craques...né?...já estão querendo até falar ((risos))... (116 a 118) (AO2)

[...] eles não tinham a base do conhecimento de mundo da área...ahn:.....nem da língua do resumo...mas tinham a referência do título em francês...e eles fazem isso... deu SUper certo...eles conseguiram... (linhas 146 a 148) (AO2)

\section{Estudante 3}

Na pesquisa da Estudante 3, a voz do pesquisador pode ser verificada no emprego autonímico atribuído à palavra "apropriação". Ela expressa as relações comparativas feitas pela Estudante 3 entre as produções iniciais e as finais dos cinco gêneros textuais escolhidos para a pesquisa, buscando mostrar o desenvolvimento das capacidades de linguagem dos estudantes envolvidos na pesquisa. Verifica-se, assim, que o sentido atribuído à palavra "apropriação" somente pode ser depreendido no interior da pesquisa da realizada pela Estudante 3.

(135) o último gênero trabalhado foi o relato curto literário...nós verificamos que os alunos tiveram uma apropriação satisfatória das capacidades esperadas...persistiram alguns problemas isolados relacionados às capacidades linguístico-discursivas..ah::..relacionados à coesão verbal e a coesão nominal (linhas 123 a 128) (AO3)

[...] nós levantamos uma hipótese de que as capacidades e as capacidades discursivas são mais facilmente transferíveis da língua materna para a língua alvo...já as capacidades linguístico-discursivas que tiveram uma apropriação mais custosa....elas mais dificilmente 
podem ser passadas para a língua alvo uma vez que elas requerem uma sistematização mais específica (linhas 129 a 134) (AO3)

Atrelado às palavras com valor autonímico, identificamos duas modalizações apreciativas expressas por "satisfatória" e "mais custosa". Encontramos algumas modalizações lógicas que marcam a voz do pesquisador, no momento da análise em que a ação de linguagem acontecia em relato interativo:

(136) interessante notar que esse mesmo aluno que teve problemas na construção do suspense na primeira produção escrita. (linhas 93-95)(AO3)

[...] e aí é interessante...é interessante...mostrar o que aconteceu....nas perguntas introdutórias para a produção desse gênero e sobre a utilização dos tempos verbais... (linhas 110-113)(AO3)

[...] já as capacidades linguístico-discursivas que tiveram uma apropriação mais custosa...elas mais dificilmente podem ser passadas para a língua alvo uma vez que elas requerem uma sistematização mais específica (linhas 131-134)(AO3)

As modalizações acima, "interessante notar que" e "é interessante mostrar o que aconteceu" ocorreram, pois a expositora estava fazendo uma relação entre os resultados das análises e, assim, comenta a sua própria escrita, momento em que podemos identificar a voz do pesquisador.

\subsection{Quandro sintético das análises}

A seguir, elaboramos um quadro com os principais resultados encontrados na apresentação oral de pesquisa por meio dos índices textuais o que os evidenciam. 


\begin{tabular}{|c|c|c|}
\hline & Alguns índices textuais & O que mostram? \\
\hline $\begin{array}{c}\text { Plano global } \\
\text { do conteúdo } \\
\text { temático }\end{array}$ & $\begin{array}{l}\text { Plano global do conteúdo temático - } \\
\text { inadequação ao gênero textual } \\
\text { apresentação oral de pesquisa. } \\
\text { Estudante 1: A seção de metodologia foi } \\
\text { desenvolvida após a exposição dos } \\
\text { objetivos. } \\
\text { - Parte mais desenvolvida: seção das } \\
\text { análises e seus resultados (62 linhas de } \\
\text { transcrição). } \\
\text { Estudante 2: A exposição é iniciada pela } \\
\text { fundamentação, que ocupa a grande parte } \\
\text { da apresentação (83 linhas de transcrição) } \\
\text { - Parte mais desenvolvida: exposição da } \\
\text { metodologia da pesquisa, sobretudo o } \\
\text { método. }\end{array}$ & $\begin{array}{l}\text { Ao final da pesquisa de Iniciação } \\
\text { Científica, percebe-se que as estudantes } \\
\text { estão se apropriando das práticas de } \\
\text { linguagem da ciência. As lacunas } \\
\text { apresentadas nos resumos das } \\
\text { apresentações foram as mais } \\
\text { desenvolvidas durante as apresentações } \\
\text { orais, de acordo com os números de linhas } \\
\text { transcritas. }\end{array}$ \\
\hline $\begin{array}{l}\text { Tipos de } \\
\text { discurso }\end{array}$ & 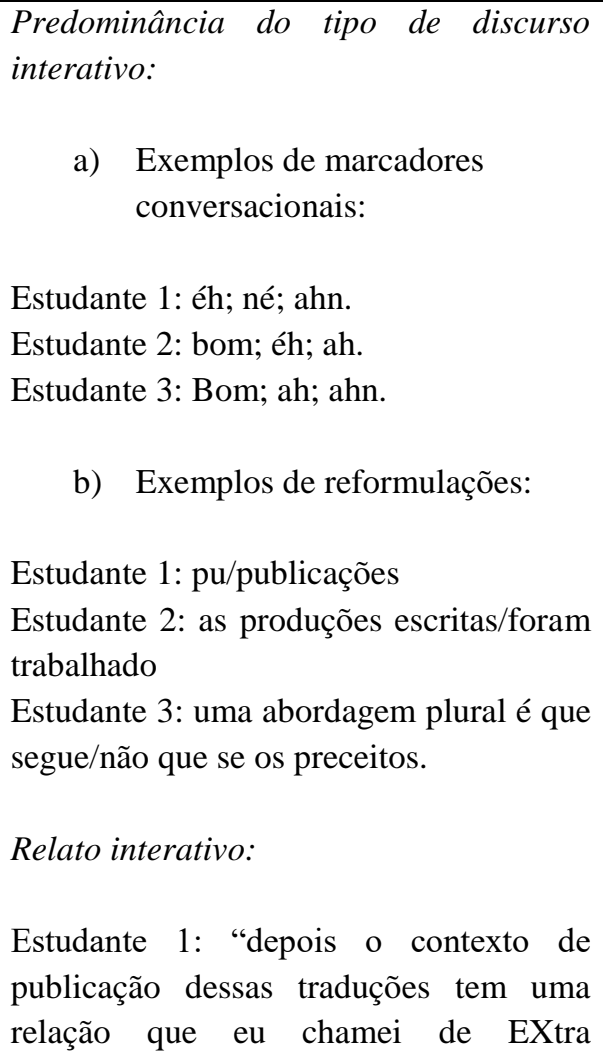 & $\begin{array}{l}\text { O discurso interativo produz uma situação } \\
\text { de comunicação na qual os interlocutores } \\
\text { estão implicados, sendo o conteúdo } \\
\text { temático desenvolvido em face dos } \\
\text { destinatários, entre eles um docente } \\
\text { pesquisador experiente. } \\
\text { O relato interativo produz um efeito de } \\
\text { implicação pelo qual as estudantes fazem } \\
\text { uma disjunção da ação de linguagem, } \\
\text { retomando e presentificando o momento } \\
\text { das análises dos dados e as relações que } \\
\text { entre eles foram estabelecidas. }\end{array}$ \\
\hline
\end{tabular}




\begin{tabular}{|c|c|c|}
\hline & 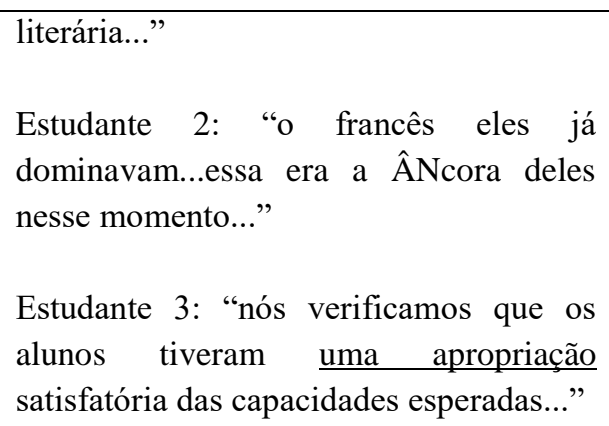 & \\
\hline $\begin{array}{c}\text { Coesão } \\
\text { nominal }\end{array}$ & $\begin{array}{l}\text { Estudante 1: Extra-literária; uma mística. } \\
\text { Estudante 2: a âncora; porta de entrada. } \\
\text { Estudante 3: uma apropriação. }\end{array}$ & $\begin{array}{l}\text { Levantamos a hipótese de que as } \\
\text { generalizações podem indicar uma } \\
\text { síntese, por meio da palavra, das relações } \\
\text { comparativas entre os dados das } \\
\text { pesquisas. }\end{array}$ \\
\hline Conectores & $\begin{array}{l}\text { Conectores que constroem períodos } \\
\text { compostos: } \\
\text { Estudante 1: mas; porém; que (subordinas } \\
\text { adjetivas explicativas). } \\
\text { Estudante 2: repetições com o pronome } \\
\text { interrogativo "O que"; com "para" e } \\
\text { estruturas fixas que fazem o raciocínio } \\
\text { avançar. } \\
\text { Estudante 3: mas; então. }\end{array}$ & $\begin{array}{l}\text { Os conectores textuais localizados na } \\
\text { seção de apresentação de análises e } \\
\text { resultados mostram as relações feitas } \\
\text { pelas alunas entre os dados das suas } \\
\text { pesquisas e modo com elas os qualifica } \\
\text { frente aos outros. }\end{array}$ \\
\hline Vozes & $\begin{array}{l}\text { Valor autonímico de algumas palavras e } \\
\text { expressões: } \\
\text { Estudante 1: Extra-literária; uma mística. } \\
\text { Estudante 2: a âncora. } \\
\text { Estudante 3: uma apropriação. }\end{array}$ & $\begin{array}{l}\text { O valor autonímico das palavras não } \\
\text { coincide com o seu valor corrente, sendo } \\
\text { ele resultado de uma interpretação que é } \\
\text { feita pelas estudantes ao término da } \\
\text { pesquisa. Por isso levantamos a hipótese } \\
\text { de que se trata da voz do pesquisador. }\end{array}$ \\
\hline Modalizações & 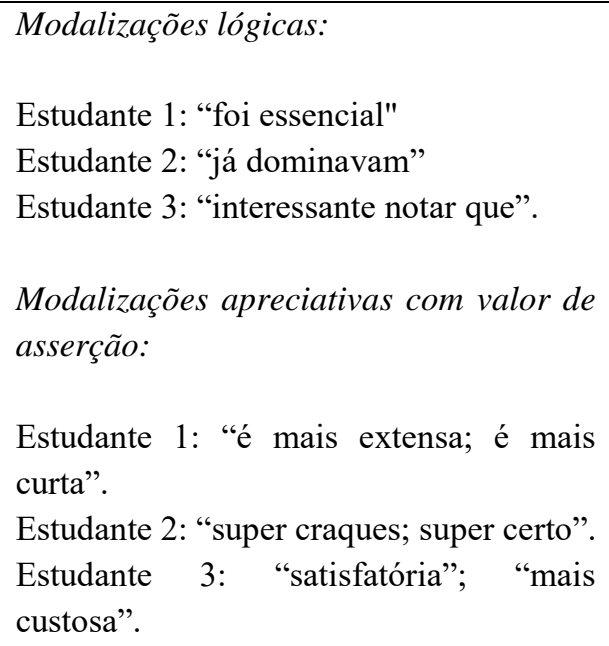 & $\begin{array}{l}\text { As modalizações lógicas e apreciativas } \\
\text { criam um efeito e um grau de certeza } \\
\text { baseados nas experiências das estudantes } \\
\text { ao término da experiência da pesquisa. Já } \\
\text { as modalizações apreciativas mostram a } \\
\text { subjetividade do pesquisador ao analisar } \\
\text { os dados da pesquisa. }\end{array}$ \\
\hline
\end{tabular}




\section{Relatório final de pesquisa}

Como apresentado no capítulo anterior, iniciaremos nossas análises do relatório final de pesquisa por meio do contexto de produção textual e, em seguida, do plano glabal do conteúdo temático e dos tipos de discurso associados à coesão verbal. Depois, analisaremos os mecanismos de textuzaliação por meio das conexões encontradas e da coesão nominal criada nos textos. Por último, mostraremos nossos resultados quanto às análises das vozes e das modalizações.

\subsection{Contexto de produção dos relatórios finais de pesquisa}

Os relatórios finais de pesquisa tiveram dois lugares sociais: a Faculdade de Filosofia, Letras e Ciências Humanas e a Fundação de Amparo à Pesquisa do Estado de São Paulo (FAPESP) (Estudante 2). No primeiro, os relatórios de pesquisa foram produzidos como exigência do Programa de Iniciação Científica (IC), gerido pela Comissão de Pesquisa da faculdade (Cpq/FFLCH). O segundo lugar social é uma renomada agência de fomento à pesquisa científica desde a graduação até o pós-doutorado, sediada no estado de São Paulo, e que tem um importante papel no financiamento de pesquisas científicas de elevada importância no cenário nacional e internacional.

Em ambos os lugares, os estudantes não têm modelos de relatórios de pesquisa que eles possam seguir. Fornece-se somente a estrutura de um relatório de pesquisa, sem outras informações específicas sobre esse gênero textual. No caso da FFLCH, o relatório final de pesquisa deve conter 20 páginas. A FAPESP, por sua vez, não fornece uma numeração específica.

O destinatário primeiro dos relatórios analisados foram as orientadoras, professoras doutoras. Depois de prontos, os relatórios foram submetidos à avaliação pela Cpq/FFLCH ou pelo sistema de envio de documentos da FAPESP, no site da instituição. 
Os relatórios finais pesquisa são pré-requisitos para a finalização oficial da pesquisa de Iniciação Científica, logo contêm um valor de certificação do processo realizado.

\subsection{Plano Global do conteúdo temático}

Os planos globais dos relatórios finais de pesquisa são importantes para compreendermos as análises feitas quanto aos tipos de discurso, à coesão verbal, aos mecanismos de textualização e enunciativos. Embora iremos analisar os fragmentos dos relatórios, abaixo selecionados, acreditamos que os planos globais tenham um importante papel para termos uma visão de conjunto das pesquisas realizadas.

\section{Estudante 1}

Para a análise do plano global do conteúdo temático do relatório final de pesquisa, mostraremos abaixo o modo pelo qual a estudante organizou o conteúdo do último gênero textual necessário para o cumprimento da sua pesquisa de Iniciação Científica. As seções do relatório foram:

\begin{tabular}{|l|l|}
\hline \multicolumn{1}{|c|}{ Nome das seções } & \multicolumn{1}{|c|}{ Principais ideias da seção } \\
\hline 1. Resumo do plano inicial & $\begin{array}{l}\text { Síntese do objetivo, dos textos teóricos } \\
\text { utilizados e da metodologia. }\end{array}$ \\
\hline $\begin{array}{l}\text { 1. Resumo do que foi realizado no período a que se } \\
\text { refere o relatório }\end{array}$ & $\begin{array}{l}\text { Retomada do cronograma da pesquisa e das } \\
\text { etapancluídas. }\end{array}$ \\
\hline $\begin{array}{l}\text { 1.1. Etapas e cronograma } \\
\text { 1.2. Resumo das etapas concluídas pesalhamento dos progressos realizados, dos } \\
\text { resultados obtidos no período, justificando } \\
\text { eventuais alterações no projeto ou em sua } \\
\text { execução e discutindo dificuldades surgidas ou } \\
\text { esperadas na realização do projeto }\end{array}$ & $\begin{array}{l}\text { Considerações acerca das alterações } \\
\text { realizadas e das dificuldades encontradas. }\end{array}$ \\
\hline
\end{tabular}




\begin{tabular}{|c|c|}
\hline $\begin{array}{l}\text { 2.1. Etapa } 1-\text { Levantamento da poesia de } \\
\text { Drummond traduzida na França }\end{array}$ & Início da descrição do levantamento. \\
\hline 2.1.1. Etapa 1 - resultados obtidos & $\begin{array}{l}\text { Resultados obtidos no levantamento da } \\
\text { poesia de Drummond traduzida na França. }\end{array}$ \\
\hline $\begin{array}{l}\text { 2.1.2. Etapa } 1-\text { eventuais alterações } \mathrm{e} \\
\text { dificuldades surgidas }\end{array}$ & $\begin{array}{lll}\text { Considerações } & \text { finais } & \text { acerca do } \\
\text { levantamento da poesia de } & \text { Drummond } \\
\text { traduzida na França. } & \end{array}$ \\
\hline $\begin{array}{l}\text { 2.2. Etapa } 2 \text { - Levantamento de textos teóricos } \\
\text { traduzidos }\end{array}$ & Início da descrição do levantamento. \\
\hline 2.2.1. Etapa 2-Resultados obtidos & $\begin{array}{l}\text { Resultados obtidos no levantamento de } \\
\text { textos teóricos traduzidos. }\end{array}$ \\
\hline $\begin{array}{l}\text { 2.2.2. Etapa } 2 \text { - eventuais alterações e dificuldades } \\
\text { surgidas }\end{array}$ & $\begin{array}{l}\text { Considerações finais acerca do } \\
\text { levantamento de textos teóricos traduzidos. }\end{array}$ \\
\hline $\begin{array}{l}\text { 3. Etapa } 3 \text { - Levantamento de textos críticos } \\
\text { escritos diretamente em francês }\end{array}$ & Início da descrição do levantamento. \\
\hline 3.1. Etapa 3 - Resultados obtidos & $\begin{array}{l}\text { Resultados obtidos no levantamento de } \\
\text { textos críticos escritos diretamente em } \\
\text { francês. }\end{array}$ \\
\hline $\begin{array}{l}\text { 3.1.2. Etapa } 3 \text { - eventuais alterações e dificuldades } \\
\text { surgidas }\end{array}$ & $\begin{array}{lcc}\text { Considerações finais } & \text { acerca do } \\
\text { levantamento de textos } & \text { críticos escritos } \\
\text { diretamente em francês. } & \end{array}$ \\
\hline $\begin{array}{l}\text { 3.2. Etapa } 4 \text { - Comentário sobre a recepção da } \\
\text { obra de Carlos Drummond de Andrade na França }\end{array}$ & $\begin{array}{l}\text { Comentários gerais acerca das análises } \\
\text { sobre os levantamentos realizados. }\end{array}$ \\
\hline $\begin{array}{l}\text { 3.2.1. Comentários sobre os textos críticos } \\
\text { encontrados durante a pesquisa }\end{array}$ & $\begin{array}{l}\text { Apresentação das análises de textos teóricos } \\
\text { traduzidos. }\end{array}$ \\
\hline $\begin{array}{l}\text { 3.2.2. Comentários sobre as antologias poéticas } \\
\text { que contêm poemas de Carlos Drummond de } \\
\text { Andrade }\end{array}$ & $\begin{array}{l}\text { Apresentação das análises de textos críticos } \\
\text { escritos diretamente em francês. }\end{array}$ \\
\hline $\begin{array}{l}\text { 3.2.3. Comentários sobre as reuniões de poemas } \\
\text { dedicadas à Carlos Drummond de Andrade }\end{array}$ & $\begin{array}{l}\text { Apresentação das análises da poesia de } \\
\text { Drummond traduzida na França. }\end{array}$ \\
\hline 4. Considerações Finais & Considerações finais.. \\
\hline 5. Bibliografia & Referências bibliográficas \\
\hline
\end{tabular}

Quadro 20: Plano global do relatório final de pesquisa (Estudante 1) 
Nas seções 1 e 2, há informações que situam o leitor quanto aos passos gerais da pesquisa por meio de um resumo e também são mostrados os avanços obtidos durante a segunda metade do trabalho, sobretudo quanto aos resultados encontrados e as análises realizadas durante esse período. Em seguida, na seção 3, a produtora do texto primeiramente expõe os resultados encontrados na sua busca e, depois, tece comentários quanto a esse mesmo levantamento. Assim, a cada grupo de textos levantados a estudante elabora um comentário crítico.

Como explicitado pelo título da seção 3 , a produtora do relatório de pesquisa discorreu sobre o levantamento realizado durante o período em que os dados foram coletados, logo a organização do conteúdo visará abordar os resultados encontrados em um eixo temporal. Já no que concerne aos comentários, espera-se que contenham uma organização temática em que não seja construído um raciocínio causal-temporal, mas um modo de pensar lógico.

Na seção de abertura dos comentários do material encontrado na pesquisa, a estudante novamente enfatiza a ideia da complexidade das poesias de Carlos Drummond de Andrade, pois tratam de questões de caráter universal:

(137) Certamente, como se explicitou em diversos momentos dessa pesquisa, a poesia de Carlos Drummond de Andrade tem características que a definem como uma obra "digna do mundo", pronta a se fazer entender em línguas e olhares culturais diversos, como mostra a afirmação sobre os poemas de Drummond destacada em uma das antologias levantadas: "Esses [poemas] poderiam ser escritos em qualquer língua: eles teriam a mesma densidade que encontramos na versão original" (BASTOS, 1947, p. 333) (RP1) $)^{35}$

A própria estudante enfatiza que a ideia do parágrafo já foi explicitada em vários momentos da pesquisa, isto é, de que a poesia de Drummond contém um aspecto de universalidade, como já havíamos mostrado nas nossas análises do projeto de pesquisa. Por meio desse parágrafo, a estudante já estabelece os critérios de análise que guirão os seus comentários, tendo como pano de fundo as características particulares da poesia de Drummond, assim como já explicadas por ela mesma nas seções do projeto de pesquisa.

\footnotetext{
35 RP 1: Relatório de Pesquisa 1

RP 2: Relatório de Pesquisa 2

RP 3: Relatório de Pesquisa 3
} 


\section{Estudante 2}

O relatório final de pesquisa segue a sequência temática deste gênero textual, com introdução, justificativa, objetivos, pressupostos teóricos, metodologia, análises e conclusão. Ressalta-se que a seção das análises foi fusionada com os resultados, uma vez que a estudante nomeou a seção de "análises dos resultados". Para visualizarmos de forma mais clara o modo como a estudante organizou o relatório, observemos abaixo um quadro descritivo:

\begin{tabular}{|c|c|}
\hline Nome das seções & Principais ideias da seção \\
\hline 1. Introdução & $\begin{array}{l}\text { 1. Contextualização da pesquisa nos estudos sobre leitura em língua } \\
\text { estrangeira, mais especificamente no francês, com a abordagem da } \\
\text { intercompreensão das línguas românicas. A pesquisa busca refletir sobre o } \\
\text { desenvolvimento das competências de leitura. } \\
\text { 2. Dados sobre o contexto da pesquisa. }\end{array}$ \\
\hline 2. Justi & $\begin{array}{l}\text { 1. A divisão no âmbito da USP e no Centro de Línguas dessa universidade das } \\
\text { línguas românicas, não permitindo um intercâmbio entre elas para o trabalho } \\
\text { da intercompreensão. } \\
\text { 2. Os incentivos da USP para que seus estudantes de graduação e } \\
\text { pós-graduação tenham uma experiência em outros países. }\end{array}$ \\
\hline 3. Objetivos & $\begin{array}{l}\text { Diante desse contexto plurilíngue real, pergunta-se: como o desenvolvimento da } \\
\text { competência de compreensão escrita em língua francesa poderia favorizar a } \\
\text { compreensão escrita nas outras línguas vizinhas (espanhol, italiano e romeno)? }\end{array}$ \\
\hline $\begin{array}{l}\text { 4. Referencial } \\
\text { teórico } \\
4.1 \text { A leitura } \\
\text { como } \\
\text { processo }\end{array}$ & $\begin{array}{l}\text { A leitura não é mera codificação, mas um processo. A construção de sentido } \\
\text { acontece por meio de } 5 \text { processos durante a leitura: neurofisiológico, cognitivo, } \\
\text { afetivo, argumentativo, simbólico. }\end{array}$ \\
\hline $\begin{array}{l}\text { 4.1.2 Modelos } \\
\text { de leitura }\end{array}$ & $\begin{array}{l}\text { O processo de construção do sentido depende também do modelo de leitura: } \\
\text { ascendente, descendente, interativa. O modelo a ser escolhido depende do agir do } \\
\text { leitor para atingir seu objetivo, ou seja, depende da sua competência leitora. }\end{array}$ \\
\hline 4.1 .3 & É a competência dos leitores em saber ativar seus conhecimentos acerca do código \\
\hline
\end{tabular}




\begin{tabular}{|c|c|c|}
\hline & $\begin{array}{l}\text { Competências } \\
\text { leitoras }\end{array}$ & $\begin{array}{l}\text { linguístico, das regras de co-referência, detectar as seleções contextuais, interpretar o } \\
\text { código retórico e estilístico, das relações intertextuais. }\end{array}$ \\
\hline & $\begin{array}{l}4.1 .4 \\
\text { Estratégias de } \\
\text { leitura }\end{array}$ & $\begin{array}{l}\text { Estratégia para antes, durante e depois da leitura. Em um contexto plurilíngüe, as } \\
\text { estratégias são: transferência dos conhecimentos já usados em língua materna; } \\
\text { associação de conhecimentos de diversas ordens, inferência, dedução e indução. }\end{array}$ \\
\hline & $\begin{array}{l}4.2 \\
\text { Ensino/Apren } \\
\text { dizagem da } \\
\text { leitura em } \\
\text { língua } \\
\text { estrangeira }\end{array}$ & $\begin{array}{l}\text { Os cursos de leitura, em geral, dão primazia para a recepção em detrimento da } \\
\text { produção (do escrito sobre o oral); dão destaque aos textos "informativos"; buscam } \\
\text { ensinar a língua científica, mais próxima da gramática. Entretanto, no curso que } \\
\text { serviu de base a pesquisa, a produção oral foi valorizada; houve uma escolha de } \\
\text { textos tanto informativos, quanto literários e científicos; a língua francesa foi } \\
\text { analisada assim como estava nos textos autênticos. }\end{array}$ \\
\hline & $\begin{array}{l}\text { A.3 A } \\
\text { intercompreen } \\
\text { são de línguas } \\
\text { românicas } \\
\text { 4.3.1 Origens }\end{array}$ & $\begin{array}{l}\text { Contexto político em que essa noção surgiu: no época do nascimento da União } \\
\text { Européia. }\end{array}$ \\
\hline & $\begin{array}{l}4.3 .2 \\
\text { Definições }\end{array}$ & $\begin{array}{l}\text { É uma abordagem metodológica para o ensino/aprendizagem de línguas estrangeiras } \\
\text { em que se utiliza o apoio e reconhecimento entre línguas de uma mesma raiz. No } \\
\text { caso das línguas românicas, englobam-se o português, francês, espanhol, italiano, } \\
\text { romeno, catalão e alguns outros dialetos. }\end{array}$ \\
\hline & $\begin{array}{l}4.3 .3 \\
\text { Objetivos e } \\
\text { competências }\end{array}$ & $\begin{array}{l}\text { Objetivo da abordagem da intercompreensão é facilitar a interação entre falantes de } \\
\text { línguas diferentes e vizinhas sem a necessidade de recorrerem a uma língua franca, } \\
\text { papel hoje ocupado pelo inglês. Ela supõe a dissociação das quatro competências } \\
\text { (ler, escrever, falar, ouvir), pois nem todos serão trabalhadas ao mesmo tempo, mas } \\
\text { na medida em que desenvolverem as capacidades de compreensão do aluno. }\end{array}$ \\
\hline 5. & $\begin{array}{l}\text { Contexto da } \\
\text { pesquisa }\end{array}$ & $\begin{array}{l}\text { Descrição do contexto da pesquisa: foi realizada no curso Práticas de Leitura em } \\
\text { francês do Centro de Línguas da USP. O objetivo curso é oferecer uma variedade de } \\
\text { gêneros textuais para o desenvolvimento da leitura em francês. }\end{array}$ \\
\hline 6. & $\begin{array}{l}\text { Metodologia } \\
\text { da pesquisa }\end{array}$ & $\begin{array}{l}\text { O semestre do curso foi dividido em quatro módulos, sendo que o trabalho com a } \\
\text { intercompreensão se deu em duas fases: no módulo } 1 \text { e módulo } 4\end{array}$ \\
\hline & 6.1 Corpus & $\begin{array}{l}\text { O corpus foi composto pela análise das reações dos alunos às atividades em } \\
\text { intercompreensão propostas. }\end{array}$ \\
\hline & 6.2 Módulo 1 & $\begin{array}{l}\text { O módulo } 1 \text { teve o objetivo de sensibilizar os alunos na perspectiva da } \\
\text { intercompreensão, por isso as primeiras atividades visaram a mostrar aspectos da } \\
\text { compressão escrita, independentemente da língua. Para isso, foram utilizados textos } \\
\text { em português, romeno, francês, espanhol e francês. }\end{array}$ \\
\hline & 6.3 Módulo 4 & No módulo 4 , as atividades de intercompreensão retornam ao programa do curso \\
\hline
\end{tabular}




\begin{tabular}{|c|c|}
\hline & $\begin{array}{l}\text { para mostrar aos alunos que os conhecimentos de leitura em português, que eles já } \\
\text { têm, e aqueles aprendidos em língua francesa nos módulos em ( } 2 \text { e } 3) \text {, poderão ser } \\
\text { transferidos para a leitura em outras línguas. O módulo foi dividido em duas etapas. }\end{array}$ \\
\hline 6.3.1 Etapa 1 & $\begin{array}{l}\text { Foram escolhidos } 5 \text { resumos de } 5 \text { artigos sobre intercompreensão,tendo em vista dois } \\
\text { critérios: 1- o título e o resumo do artigo deveriam estar escritos em línguas } \\
\text { diferentes, mas um dos dois deveria estar em francês; } 2 \text { - o tema dos artigos não } \\
\text { deveria ser da área de estudos dos alunos. }\end{array}$ \\
\hline 6.3.2 Etapa 2 & $\begin{array}{l}\text { Nesta segunda etapa, os alunos quem escolheriam um texto acadêmico (artigo, } \\
\text { capítulo de livro ou resenha), seguindo as orientações: } 1 \text { - a língua do artigo não } \\
\text { podia ser uma das línguas do repertório do aluno (logo, o português e o francês } \\
\text { estavam descartados); } 2 \text { - o assunto do artigo deveria estar ligado à área de estudos } \\
\text { de cada um. }\end{array}$ \\
\hline \multirow{4}{*}{$\begin{array}{l}\text { 7. Análise dos } \\
\text { resultados }\end{array}$} & Foram divididas em três questões: \\
\hline & $\begin{array}{l}\text { i) O primeiro módulo contribuiu para a tomada de consciência do processe } \\
\text { de leitura }\end{array}$ \\
\hline & $\begin{array}{l}\text { ii) No módulo quatro os estudantes conseguiram transferir as estratégias e } \\
\text { procedimentos estudados para a construção dos sentidos dos textos } \\
\text { escolhidos }\end{array}$ \\
\hline & $\begin{array}{l}\text { iii) curso na sua totalidade contribuiu para a formação de leitores } \\
\text { autônomos e plurilíngües. }\end{array}$ \\
\hline 8. Conclusões & $\begin{array}{l}\text { Confirma-se a validade da aplicação das atividades em intercompreensão para o } \\
\text { desenvolvimento das competências leitoras. Melhora o reconhecimento dos } \\
\text { estudantes para perceberam semelhanças no léxico. Propicia a transferência dos } \\
\text { conhecimentos de uma língua para outra. }\end{array}$ \\
\hline $\begin{array}{ll}\text { 9. } & \text { Referências } \\
\text { Bibliográficas }\end{array}$ & Indicações bibliográficas das citações diretas e indiretas feitas durante o relatório \\
\hline
\end{tabular}

Quadro 21: Plano global do relatório final de pesquisa (Estudante 2)

Como é possível verificarmos acima, a seção 7 vem após a metodologia da pesquisa (seção 6), o que nos mostra que o estudo objetivou construir uma metodologia para a sua execução, já que, como afirma a estudante na introdução: 
(138) Para responder essas questões, a presente pesquisa apresenta a experiência feita em uma turma do curso de Práticas de Leitura em Francês - Nível I, organizado em quatro módulos (doravante, PLF), do Centro de Línguas da Faculdade de Filosofia, Letras e Ciências Humanas da USP (doravante, CL-USP), por meio da aplicação de atividades concebidas a partir dos conceitos trazidos pela abordagem da intercompreensão de línguas românicas, envolvendo outras línguas desta família além do francês. (RP2)

Baseados no excerto acima, é possível levantarmos a hipótese de que não havia previamente uma metodologia do curso a ser dado já pronta para ser analisada na pesquisa, mas que seria criada pela pesquisadora e, durante o trabalho, seria aplicada por ela. Também na seção da justificativa, é possível verificarmos que a própria estudante quem elaboraria a metodologia da pesquisa:

(139) Dessa forma, uma metodologia que visa "quebrar o tabu" do ensino compartimentado, segmentada, língua por língua, tem muito a contribuir com a formação desse estudante universitário atual [...] (RP2)

Bem como na seção dos objetivos:

(140) Para tanto, é necessária a reflexão sobre quais atividades e exercícios facilitam a evolução dos processos de leitura desenvolvidos pelos alunos e, sobretudo, de que forma essas atividades impactam no surgimento dos leitores autônomos. Na fase de elaboração das atividades [...] (RP2)

Para a construção da metodologia, a estudante partiu dos conceitos de teóricos que abordam a leitura, ensino/aprendizagem da leitura e a intercompreensão. Foram essas leituras que a basearam na elaboração dos módulos da metodologia e suas etapas. 


\section{Estudante 3}

Este relatório final de pesquisa, diferentemente do anterior, contém na seção de análise dos dados a maior parte da sua extensão. Verifiquemos no quadro abaixo o método de análise dos dados, que deriva da Fundamentação teórica.

Abaixo, mostraremos uma tabela com os conteúdos temáticos do relatório final de pesquisa:

\begin{tabular}{|c|c|}
\hline Nome das seções & Principais ideias da seção \\
\hline 1. Introdução & $\begin{array}{l}\text { Exposição dos objetivos da pesquisa e da relevância do estudo (justificativa): A } \\
\text { perguntas de pesquisa são: } \\
\text { 1. Quais capacidades de linguagem os alunos desenvolveram (ou não) durante } \\
\text { as atividades de produção escrita? } \\
\text { 2. Em quais aspectos da produção escrita, observada a partir da ótica dos } \\
\text { gêneros textuais, os alunos encontram maior dificuldade? }\end{array}$ \\
\hline $\begin{array}{l}\text { 2. Fundamentaçã } \\
\text { o teórica }\end{array}$ & $\begin{array}{l}\text { A Fundamentação teórica tem a seguinte ordem de explicação dos conceitos usados } \\
\text { no estudo: Interação verbal para Vygotski e Bakhtin, gêneros textuais para o ISD, } \\
\text { tipos de discurso, folhado textual, sequências textuais, mecanismo de textualização e } \\
\text { enunciativos, capacidades de linguagem, sequência didática e modelo didático. }\end{array}$ \\
\hline 3. Metodologia & $\begin{array}{l}\text { Os participantes da pesquisa são estudantes do segundo semestre do curso de Língua } \\
\text { Francesa da habilitação em francês da Universidade de São Paulo }\left(2^{\circ} \text { ano de }\right. \\
\text { faculdade). } \\
\text { Como suporte, foi utilizada a plataforma moodle, onde a docente responsável pela } \\
\text { disciplina postava as atividades de escrita, que foram } 5 \text { no total. } \\
\text { Os corpus da pesquisa foi composto pelos textos redigidos por } 7 \text { estudantes do curso, } \\
\text { dentre os quais tinham muito, pouco ou algumas dificuldades. }\end{array}$ \\
\hline $\begin{array}{l}\text { 4. Análise dos } \\
\text { resultados }\end{array}$ & $\begin{array}{l}\text { Os resultados foram apresentados segundo as análises dos textos dos } 7 \text { graduandos e } \\
\text { os resultados encontrados pela pesquisadora. }\end{array}$ \\
\hline 5. Conclusão & $\begin{array}{l}\text { O estudo mostrou a necessidade de mais investigações na área de língua estrangeira, } \\
\text { do francês, principalmente, a respeito do uso de gêneros textuais para o } \\
\text { desenvolvimento das capacidades de linguagem em meio universitário. }\end{array}$ \\
\hline $\begin{array}{l}\text { 6. } \text { Referências } \\
\text { Bibliográficas }\end{array}$ & Referência dos textos teóricos utilizados. \\
\hline
\end{tabular}

Quadro 22: Plano global do relatório final de pesquisa (Estudante 3) 


\subsection{Tipos de discurso e coesão verbal}

$\mathrm{Na}$ análise dos tipos de discurso e da coesão verbal, constatamos uma dinâmica específica entre a disjunção e a conjunção da linguagem, mais especificamente entre a narração e o discurso teórico. Nos fragmentos que mostraremos abaixo, especificamente na seção de análises dos dados, a narração tem a função de criar um raciocínio temporal da análise dos dados, assim como as pesquisadoras a realizaram. Durante a organização das análises, surge o tipo de discurso teórico, que visa a fornecer uma explicação lógica para constatações levantadas nos excertos de narração. Assim, há muitos excertos de misto narrativo-teórico nos relatórios finais de pesquisa.

\section{Estudante 1}

Na seção 3.1., a estudante inicia a exposição do material levantado na pesquisa, iniciando-a pelos livros encontrados que contêm a poesia de Drummond na França. Nesse excerto, notamos características de três tipos de discurso: o relato interativo (mundo disjunto e implicado pelo uso do pretérito perfeito, imperfeito e do pronome "nosso"), narração (mundo disjunto e autônomo no uso também do pretérito perfeito, imperfeito da terceira pessoa do singular ou plural) e o discurso teórico (conectores lógicos e construção de um mundo conjunto e autônomo no uso dos verbos no presente). Essa afirmação pode ser demonstrada no excerto abaixo:

(141) A Etapa 1 de nossa pesquisa compreendia um longo período (de Novembro de 2012 a Março de 2013), já que também seria uma fase intensa de busca em sites de livrarias, bibliotecas nacionais e internacionais, além de blogs e sites relacionados à literatura. Para tanto, como já foi dito no Projeto inicial e no Relatório Parcial, a internet foi elemento essencial sem o qual não conseguiríamos colher os dados necessários ao levantamento proposto. (RP1)

Nos parágrafos seguintes da mesma seção, encontramos mais marcas que nos remetem aos três tipos de discurso.

Ora, entre os tipos de discurso e suas variações, Bronckart (1999) não aponta a fusão do relato interativo com o discurso teórico, senão deste com a narração. Como 
constatado por Bronckart (1999, p. 195), o que há nos parágrafos do excerto acima é uma variação do tipo de discurso narração.

Segundo o autor, a narração é caracterizada pela disjunção/autonomia da ação de linguagem que é marcada principalmente pela ausência de pronomes e adjetivos de primeira e de segunda pessoa do singular e do plural, que remetem diretamente ou ao agente-produtor, ou a seus destinatários. Contudo, Bronckart (1999) também analisou segmentos de narração que comportam marcas de implicação. Nesse caso, há um gerenciamento narrativo diferente do que ocorre habitualmente, pois o narrador, ao invés de ficar externo às instâncias de agentividade (personagens e vozes sociais) postas na narração, ele se investe dessas mesmas instâncias que são verbalizadas pela implicação.

Assim, cria-se uma identidade entre o narrador e o personagem da história, pois não podemos afirmar que a implicação remete diretamente ao autor da ação de linguagem, mas a uma representação desse autor tal como é encenado como autor empírico, ou seja, a implicação não remete à Estudante 1, mas à voz do pesquisador. Permeando a narração, encontramos os conectores lógicos típicos do discurso teórico (Assim, primeiramente, em segundo lugar, já que), muitas vezes mais do que organizadores temporais explícitos. Logo, encontramos nesses excertos em que há a variação do tipo de discurso narração marcas do discurso teórico, que geram assim segmentos mistos desses dois tipos de discursos. A seguir, mostraremos mais um exemplo sobre isso:

(142) Como já dito, foram encontrados apenas um livro e um artigo escritos em português e traduzidos para o francês sobre a poesia de Drummond. Também chegamos, através de uma intensa investigação, a textos críticos escritos diretamente em francês relacionados à obra do poeta itabirano. No primeiro caso, deve-se destacar a qualidade dos textos traduzidos: artigos e ensaios renomados no meio acadêmico brasileiro, escritos por profissionais da literatura, da poesia e, o mais importante, especialistas na leitura de Carlos Drummond de Andrade. Ressalta-se novamente a importância dessas traduções, que garantem ao leitor francófono uma qualidade crítica e, por que não, uma leitura feita a partir do olhar brasileiro sobre essa poesia ao mesmo tempo nacional e universal. (RP1)

Neste excerto, podemos encontrar o tipo de discurso misto narrativo-teórico por meio da utilização do pretérito perfeito e do presente, bem como uma alta densidade nominal: profissionais da literatura; especialista na leitura de Carlos Drummond de 
Andrade; o mais importante; a importância. Novamente, não encontramos o relato interativo, porém a variante da narração em que há implicação.

Após "relatar" as ações quanto ao levantamento da poesia de Drummond traduzida na França, a estudante enumera os livros encontrados sobre esse assunto. Nessa seção, a disjunção desaparece dando lugar ao mundo conjunto (verbo no presente) e também pela implicação da pesquisadora por meio do pronome "nossa". Verifica-se também o conector "além de", logo há nesse excerto um discurso misto interativo e teórico:

(143) Os resultados obtidos na Etapa 1 de nossa pesquisa são dez livros, entre antologias e reuniões, localizados e adquiridos pela internet, além detraduções encontradastambém na internet, verificáveis na lista a seguir. Os poemas e suas respectivas traduções onlineestão registrados no Relatório Parcial dessa pesquisa. (RP1)

Sobre o efeito dessa passagem da disjunção para a conjunção, a pesquisadora poderia ter escrito "Os resultados obtidos na Etapa 1 de nossa pesquisa foram dez livros...", no entanto ela construiu um mundo discursivo conjunto que, a nosso ver, enfatiza a seriedade do levantamento realizado, pois ela relata que essa etapa da pesquisa foi intensa, logo, possivelmente, segundo o seu ponto de vista, não há mais o que ser procurado a respeito dos livros de poesia de Carlos Drummond de Andrade traduzidos na França e nem há expectativas de novos trabalhos nesse sentido.

No final da abordagem desse primeiro conjunto de informações, notamos que ela é construída pela variante de narração em primeira pessoa e pelo discurso teórico, logo pelo misto entre esses dois tipos de discurso. O tipo de discurso misto também tem a função de elencar as dificuldades encontradas durante a pesquisa. A própria estudante usou a palavra "garimpar" ao se referir à busca que fez, assim percebemos sua apreciação sobre a dificuldade a qual ela se deparou nesta etapa da pesquisa. Aqui, contamos somente três marcas de implicação com uso da primeira pessoa do plural: nosso ("nosso trabalho consistia..."), entramos ("entramos em contato por e-mail com a biblioteca de Université de Rennes 2, na França...”), recorremos ("O recurso que recorremos para adquirir o livro foi o site de venda AbeBooks). Por meio da narração do discurso misto, registram-se as dificuldades do levantamento do material como: 
(144) A primeira dificuldade enfrentada nessa Etapa 1, de levantamento da poesia traduzida, foi o reconhecimento dos tradutores de blogs que, livres das burocracias editoriais, não são facilmente identificáveis. (RP1)

(145) Outra dificuldade encontrada durante o período de busca dessa pesquisa foi a localização do livro Réunion (1973), traduzido por Jean-Michel Massa. (RP1)

Nesses dois excertos, há o uso dos verbos no pretérito perfeito no verbo "foi”. No segundo excerto, anotamos o uso do verbo no presente "são" caracterizando o discurso teórico, pois se trata de um discurso misto, em que o mundo discursivo conjunto nos fornece explicações da situação de busca dos dados, enquanto a narração registra o problema encontrado no período em que essa ação foi realizada.

Nos comentários sobre os textos críticos levantados na pesquisa, encontramos somente uma recorrência de implicação no uso do verbo no pretérito perfeito "chegamos" e, mais uma vez, o verbo “foi” mostra que a implicação na verdade é uma característica da variante de narração. O parágrafo é predominantemente construído pelo discurso teórico por meio do conector ("No primeiro caso") e anáforas textuais ("profissionais da literatura", "especialistas de Carlos Drummond Andrade"):

(146) No primeiro caso, deve-se destacar a qualidade dos textos traduzidos: artigos e ensaios renomados no meio acadêmico brasileiro, escritos por profissionais da literatura, da poesia e, o mais importante, especialistas na leitura de Carlos Drummond de Andrade. (RP1)

Como já dissemos, o discurso teórico foi usado na discussão dos resultados da pesquisa, a fim de mostrar os posicionamentos da estudante quanto aos dados encontrados e o modo como ela os relacionou de forma a construir um modo de pensar lógico entre eles. O mesmo posicionamento em discurso teórico pode ser encontrado na continuidade do excerto anterior:

(147) Ressalta-se novamente a importância dessas traduções, que garantem ao leitor francófono uma qualidade crítica e, por que não, uma leitura feita a partir do olhar brasileiro sobre essa poesia ao mesmo tempo nacional e universal. (RP1) 
Nos próximos parágrafos, a estudante comenta outros dados levantados, apontando que os muitos textos críticos encontrados carregam uma visão literária em língua francesa da poesia de Drummond. Depois dessa exposição, do $4^{\circ}$ ao $7^{\circ}$ parágrafos, o discurso teórico reaparece.

(148) De todo modo, é notável o prestígio do poeta mineiro para o público francês, ainda que sob um "desconhecimento velado" de sua obra. Averíguam-se, vinculados a seu nome, termos como "um dos grandes nomes da poesia brasileira", "poeta excepcional" ou "o maior poeta brasileiro do século XX". (RP1)

Esse parágrafo, assim como a maioria dos outros desta seção, foi construído em discurso teórico (presença dos conectores "De todo modo" e "ainda que", verbos no presente do indicativo), logo é possível entrever a posição da estudante quanto aos textos críticos encontrados em francês a respeito da poesia de Drummond.

No último parágrafo, iniciado pelo conector "Finalmente", ocorre a disjunção da ação de linguagem e não há implicação. Logo, a estudante vai, mais uma vez, registrar algum detalhe da análise dos dados.

(149) Finalmente, um detalhe chamou atenção dentre as críticas levantadas. (RP1)

Após o ponto final, o discurso teórico retorna para dar detalhes do conteúdo expresso pela narração. Por meio dele, a pesquisadora mostra uma comparação encontrada em um dos textos críticos que chamou a sua atenção: "Drummond de Andrade não é um heterônimo perdido de Fernando Pessoa no outro lado do Atlântico”. Diante dessa afirmação, a estudante se posiciona da seguinte forma:

(150) Ou seja: as leituras de uma obra, como a poesia de Drummond, variam conforme a visão cultural e os valores dirigidos a ela. Pelo que indica essa comparação, a poesia de Drummond é, para os franceses, um exemplo de expressão da língua portuguesa, como o é Fernando Pessoa. (RP1)

No que concerne aos comentários sobre as antologias poéticas que contêm poemas de Carlos Drummond de Andrade, encontramos no início do parágrafo a primeira e única implicação desta seção em: "No total, obtivemos acesso a sete antologias em francês contendo poemas traduzidos de Carlos Drummond de Andrade"; e, no mesmo 
parágrafo, identificamos a narração quando a voz da pesquisadora narra que dentre as antologias "Três delas foram publicadas entre as décadas de 1940 e 1950; outras três tiveram publicação de 1980 1990" e ainda uma outra “teve publicação no final de 2012".

Os parágrafos seguintes, no entanto, são predominantemente construídos pelo discurso teórico, como verificamos no excerto abaixo (p.19):

(151) Dentre as publicações, duas contém poemas ibero-americanos e as outras abordam a poesia brasileira de maneiras variadas: uma antologia que reúne poemas diversos em uma espécie de "viagem" pelo Brasil; outra que desenvolve um panorama geral da poesia brasileira, outra ainda que se propõe a apresentar a "nova poesia brasileira". Sobre essa última, nota-se uma contradição: intitulado Anthologie de la nouvelle poésie brésilienne (1988), o livro contém poemas de Carlos Drummond de Andrade. Ora, um leitor atento às datas percebe, sem esforço, que o ano de publicação do livro não corresponde ao período em que viveu Drummond (1902 1987). (RP1)

Em meio ao discurso teórico que predomina nesta seção, encontramos um excerto que, embora pequeno, é suficiente para revelar novamente um posicionamento da estudante:

(152) O caso de Anthologie de la poésie brésilienne (1998) é ainda mais específico: o livro foi publicado por meio de um concurso organizado pelo Centre Culturel Calouste Gulbenkian (Paris), pela Fundação Biblioteca Nacional (Rio de Janeiro) e pelo Centre Nationaldu Livre. (RP1)

Neste excerto, a narração do discurso misto-teórico tem a função de encadear as ações em um raciocínio temporal do caso mais específico da antologia de poemas encontrada, referente ao seu processo de publicação que envolveu tanto dois centros franceses e a Fundação Biblioteca Nacional. Assim, a estudante afirma que:

(153) Com isso, quer-se dizer que, em muitos casos, a publicação dessas antologias não se dá simplesmente por interesses estéticos e literários, mas por ocasiões culturais ou mesmo políticas, como é o caso da coleção promovida pela UNESCO. Percebe-se, assim, que o interesse em relação à literatura brasileira como um todo é, normalmente, ligado a contextos extrínsecos, como já afirmado neste relatório. (RP1) 
O discurso teórico é retomado para afirmar e dar certeza (por meio do uso do presente do indicativo) aos comentários efetuados quanto às antologias encontradas e, também, para reafirmar a posição que a estudante vem construindo discursivamente no relatório final, ou seja, a depender do "olhar" sobre a literatura brasileira e, mais especificamente, sobre a poesia de Drummond, obtém-se uma análise singular. Ademais, ao dar detalhes de uma das antologias por meio da narração, a estudante também se posiciona frente ao "olhar da cultura francesa" muitas vezes "mística" sobre a literatura brasileira.

Como já apontamos em outros excertos, identificamos a variação da narração que marca a implicação, evidenciada no excerto acima pelo pronome "nosso". Em seguida, a narração é usada para fornecer o detalhe de que foram encontrados três livros “exclusivamente dedicados à poesia de Carlos Drummond de Andrade traduzidos para o francês". Após esse parágrafo, há uma retomada do discurso teórico que tem a função de explicar aspectos dos três livros encontrados.

\section{Estudante 2}

Igualmente ao que encontramos no relatório final de pesquisa da Estudante 1, observamos o movimento particular que ocorre entre os tipos de discurso narração e discurso teórico, pelo qual o primeiro tem a função de criar um raciocínio temporal e o segundo de construir o raciocínio lógico a partir dos conteúdos temáticos destacados pela narração:

(154) Sendo assim, é possível afirmar com certeza que o trabalho feito neste início de curso se estendeu ao longo de todo semestre. A partir dos textos em italiano, espanhol e romeno, os alunos tornavam-se pouco a pouco mais à vontade para sempre construir e expor suas próprias associações ao longo da leitura, mesmo quando o trabalho se deteve à língua francesa. Os comentários e justificativas apresentados a cada texto estudado não raro apresentavam as reflexões sobre o percurso de leitura até a construção de sentido, além de considerações relacionadas às inferências e associações lexicais, feitas com palavras transparentes. (RP2) 
O excerto acima, da seção de análise, indica o misto narrativo-teórico, pois encontramos o uso do pretérito perfeito (se estendeu) e pretérito imperfeito (tornavam-se, apresentavam), o uso do presente do indicativo (é possível) e conectores lógicos (Sendo assim, além de). Notemos que o pretérito imperfeito tem a função de criar uma continuidade das ações dos estudantes do curso no tempo passado; já o tempo presente tem a função de criar um modo de pensar lógico quanto a essa temporalidade, pelo uso dos conectores lógicos.

No fragmento abaixo, é possível compreendermos melhor o uso deste tipo de discurso no relatório final de pesquisa:

(155) a maior parte dos alunos se considerou surpresa de ter lido os textos em outras línguas jamais estudadas, afinal, eles se imaginavam capazes ler apenas nas línguas em que tinham conhecimentos mais "sólidos". Entretanto, vários citaram a experiência feita no Módulo 1 com o texto em romeno (Poftiţi la masă!) como exemplo de confiança para avançar na leitura. (RP2)

Nesse excerto, é o conector "Entretanto" que nos indica a organização lógica do raciocínio expresso pela narração (“eles se imaginavam”, “vários citaram”), constituindo o tipo de discurso misto narrativo-teórico. A partir das percepções da pesquisadora acerca da reação dos alunos e daquilo que imaginavam ou citavam, cria-se um raciocínio lógico das análises realizadas. Outros fragmentos da seção de análises indicam o tipo de discurso misto:

(156) Em relação às competências de leitura em língua francesa, objetivo inicial dos alunos e do programa de curso, pelas avaliações feitas, podemos afirmar que "o dever foi cumprido": todos os alunos foram aprovados, e entre as dez médias individuais finais, apenas uma foi inferior a 8,5. (RP2)

Embora o excerto seja curto, já é possível identificarmos o tipo de discurso misto, por meio do presente do indicativo (podemos) e dos verbos no pretérito (foram aprovados, foi inferior a 8,5). O organizador textual "Em relação à" cria o raciocínio lógico da pesquisadora dentro do modo de pensar que ela construiu na seção das análises. Abaixo, outro excerto em que a narração aparece: 
logo, ao português também), pela análise dos resultados dos exercícios do Módulo 4, podemos dizer que os alunos desenvolveram a consciência do processo de leitura como uma competência complexa na qual a língua (ou as línguas) não é o único fator envolvido. Se por um lado, eles desenvolveram as estratégias necessárias para o trabalho de compreensão escrita em língua francesa, pode-se dizer também que eles estão conscientes da possibilidade de transferir essas mesmas estratégias para as outras línguas românicas. (RP2)

Ao passar do eixo da disjunção para a conjunção, a pesquisadora interpreta os dados da pesquisa segundo as regularidades encontradas por meio das formas "podemos dizer que" e "pode-se dizer também que". Aqui, mais uma vez, encontramos a mistura dos tipos de discurso, narração e discurso teórico, interligados por conectores lógicos, como o "Se por um lado".

\section{Estudante 3}

Como já analisado no plano global do conteúdo temático do relatório final de pesquisa da Estudante 3, a seção de análises e resultados da pesquisa ocupa a maior parte do texto. Essa seção foi dividida pela pesquisadora de acordo com os 5 gêneros textuais trabalhados durante o curso e as análises por ela realizadas. Seguindo a organização textual-discursiva dos outros dois relatórios finais, neste também encontramos a relação que identificamos entre os tipos de discurso narração e discurso teórico, como explicitaremos nos excertos a seguir, iniciando pela análise dos textos pertencentes ao gênero sinopse de filme:

(158) A construção do suspense, no entanto, ficou prejudicada em decorrência de dois aspectos presentes nas produções dos alunos: supressão de dados importantes através de subjetivações e revelação abrupta da complicação, sem instaurar intensificação suficiente. A supressão acima referida ocorreu de duas maneiras. A primeiradá-se quando o aluno omite ações que poderiam intensificar o suspense com subjetivações genéricas [...] A outra maneira de apresentara supressão de dados importantes não omite ações, mas, sendo também espécie de caracterização aplicável a qualquer filme, parece configurar-se como a inserção da opinião do autor, a semelhança do gênero resenha. (RP3) 
No fragmento acima, notamos características dos dois tipos de discurso em questão. Primeiramente, os verbos "ficar" e "ocorrer" no pretérito perfeito atrelado ao conector "no entanto" já nos indica que o raciocínio lógico do discurso teórico (verbos no presente do indicativo e conectores "A primeira", "A outra maneira de", "mas") tem a função de organizar o raciocínio temporal da narração, ressaltando aspectos importantes que os dados mostraram e a estudante interpretou. No caso acima, trata-se das duas maneiras de supressão. Após destacar esse dado importante, a pesquisadora se vale do discurso teórico para explicar esses resultados de forma lógica, buscando compreendê-los.

Nas análises dos resultados dos textos pertencentes ao gênero textual fait divers, encontramos os seguintes excertos:

(159) Os alunos S.C. e R.F. não situaram seu leitor utilizando um título. Aqui, o fato importante não é apenas a não utilização do título, mas a não apreensão de uma estratégia importante do gênero: se o fait divers deve ser rápido e chamar a atenção por seu conteúdo insólito, é necessário chocar o leitor desde o primeiro contato com o texto. (RP3)

(160) Os outros alunos responderam bem às perguntas do gênero, cumprindo o objetivo de chocar o leitor. A.S. e G.S., entretanto, não inseriram as informações sobre local e data nem no título, nem no cabeçalho. Todos os estudantes compreenderam que era necessário construir um discurso disjunto e sem a utilização da primeira pessoa. (RP3)

O primeiro excerto segue o mesmo raciocínio dos anteriores. Já o segundo, além de conter mais características específicas da narração (verbos no pretérito perfeito) do que do discurso teórico (ocorrência do conector "entretanto"), aponta-nos para o fato de que a pesquisadora não necessitou criar um raciocínio lógico a partir desses dados, pois as inadequações produzidas pelos estudantes na escrita do gênero textual fait divers não foram graves, já que eles conseguiram cumprir o objetivo de chocar o leitor. Assim, confirma-se a função do discurso teórico no relatório final de pesquisa, a saber, criar um encadeamento lógico na narração e buscar a essência lógica dos dados.

A seguir, um fragmento das análises do relato de viagem:

(161) Por último, quanto à coesão verbal, todos os alunos preferiram fazer seus relatos usando o passé composé e o imparfait, talvez por estarem mais familiarizados com o uso de tempos verbais 
pretéritos para abordar eventos passados. Alguns problemas com a formação do passé composé, no entanto, são identificados na produção de R.F. ("Nous avons arrivé”). Já no texto de G.S., os três momentos em que o aluno opta pelo imparfait são inadequados, requerendo, na verdade, $\mathrm{o}$ uso do passé composé. (RP3)

Aqui, mais uma vez, podemos identificar características dos dois tipos de discurso, a narração (verbos "preferir" e "estar" no pretérito) e o discurso teórico (verbos no presente do indicativo, como "são" e "opta", e conectores lógicos "Por último" e "no entanto"). Nesse excerto, a pesquisadora nota uma dificuldade dos alunos na construção e distinção de dois tempos verbais da língua francesa, o passé composé e o imparfait. Essas constatações são realizadas pela narração, mas certificadas por meio do discurso teórico.

Excerto das análises do gênero textual e-mail informal:

(162) Quanto ao restante dos alunos, todos obtiveram rendimento satisfatório no que diz respeito ao emprego de dêiticos e à coesão verbal. $\mathrm{O}$ imperativo foi usado corretamente pelos sete estudantes, com alguns erros na ortografia dos irregulares. Vale também ressaltar que cinco deles incluíram verbos no condicional em suas produções, demonstrando facilidade em modalizar suas falas. Expressões como "Je amarais savoir ces choses pour me preparer" (R.F.), “J'ai entendu parler" (C.S.), "J'ai écouté" (V.C.), "Tu pourrais m'informer" (A.S.) e "Je voudrais sauvoir" (S.C.) mostram que os alunos entreviram as reações de seu interlocutor e, portanto, amenizaram suas falas para parecerem polidos ou para não se mostrarem demasiadamente taxativos. Também é válido apontar que as modalizações não desequilibraram as produções, ainda deixando-as no registro informal requerido pelo gênero. (RP3)

O excerto acima mistura de forma clara a narração e o discurso teórico, evidenciando as suas funções específicas no relatório final de pesquisa. A narração tem a função de criar uma sequência temporal dos resultados obtidos com as análises e o discurso teórico busca dar lógica aos dados apresentados nos textos dos alunos de forma muito ou pouco detalhada, explicar as causas das inadequações explicadas. Notemos que os verbos da narração somente registram aspectos das análises, porém os verbos do discurso teórico (verbos "valer" e "mostrar") são usados para fornecer explicações mais sólidas quanto às causas dos resultados encontrados:

(163) Vale também ressaltar que cinco deles incluíram verbos no condicional em suas produções, demonstrando facilidade em modalizar suas falas [...] mostram que os alunos entreviram as 
reações de seu interlocutor e, portanto, amenizaram suas falas para parecerem polidos ou para não se mostrarem demasiadamente taxativos. (RP3)

Excerto das análises do gênero textual relato curto:

(164) No que tange às capacidades linguístico-discursivas, ainda persistem alguns erros quanto às preposições. No entanto, é preciso ressaltar a melhora no uso dos possessivos. $\mathrm{O}$ aluno não precisou usá-los no exercício 4. Em todos os outros, entretanto, apresentou erros na matéria. Todavia, na produção 5, o aluno os emprega sem cometer equívocos. (RP3)

Nesse fragmento, é vista uma predominância das características do discurso teórico sobre a narração. Isso ocorre, pois a pesquisadora, nessa constatação específica, vai fornecer uma explicação mais elaborada desse resultado da pesquisa, buscando a sua causa. Em outros casos, a pesquisadora somente nos fornece a constatação, sem, todavia, fornecer uma explicação:

(165) R.G. e C.S. apresentaram boas produções. R.G. revelou dificuldade com os pronoms personnels e toniques da terceira pessoa. (RP3)

(166) C.S., por sua vez, teve desempenho satisfatório, usando de maneira abundante, mais do que em suas outras produções, os pronomes en e y, de difícil apropriação pelos alunos de francês. (RP3)

Na sequência dessa constatação, não há a passagem da disjunção para a conjunção, a fim de encontrar uma explicação das dificuldades. Não encontramos conectores lógicos que demonstrariam a construção de um raciocínio lógico, explicativo do fato destacado. Isso nos confirma, mais uma vez, a dinâmica que há entre a narração e tipo de discurso teórico no relatório de pesquisa. 


\subsection{Mecanismos de textualização: conectores textuais}

A respeito dos conectores textuais, constatamos que estão ligados aos modos de organização da seção de análises/resultados de acordo com as respectivas metodologias das três pesquisas. Assim, eles têm a função de organizar o raciocínio lógico construído nesta seção, o que facilita a visualização do conjunto dos dados para as análises.

\section{Estudante 1,}

Os conectores encontrados se referem à organização feita pela estudante segundo o levantamento que fizera e o modo com ela o organizou por meio da poesia de Drummond traduzida na França, os teóricos traduzidos e os textos críticos escritos diretamente em francês sobre a poesia de Carlos Drummond de Andrade.

\section{Poesia de Drummond traduzida na França}

(167) No total, obtivemos acesso a sete antologias em francês contendo poemas traduzidos de Carlos Drummond de Andrade. Três delas foram publicadas entre as décadas de 1940 e 1950; outras três tiveram publicação entre as décadas de 1980 e 1990.

Dentre as publicações, duas contém poemas ibero-americanos e as outras abordam a poesia brasileira de maneiras variadas: uma antologia que reúne poemas diversos em uma espécie de "viagem" pelo Brasil.

Outro fator interessante em relação a grande parte das antologias levantadas é o contexto editorial envolvido nas publicações. (RP1)

\section{Textos teóricos levantados}

(168) Como já dito, foram encontrados apenas um livro e um artigo escritos em português e traduzidos para o francês sobre a poesia de Drummond. Também chegamos, através de uma intensa investigação, a textos críticos escritos diretamente em francês relacionados à obra do poeta itabirano. No primeiro caso, deve-se destacar a qualidade dos textos traduzidos: artigos e ensaios renomados no meio acadêmico brasileiro, escritos por profissionais da literatura, da poesia e, o mais importante, especialistas na leitura de Carlos Drummond de Andrade.

Ainda tratando dos textos teóricos traduzidos para a língua francesa, deve-se considerar a ocasião em que foram publicados. La Rose dupeuple: lapoésie de Carlos Drummond de Andrade (2005) 
publicou-se por ocasião do ano do Brasil na França, como afirma a própria edição. (RP1)

\section{Textos críticos escritos diretamente em francês}

(169) No que se refere aos textos críticos escritos diretamente em francês, podem-se destacar características comuns a quase todos: são, em grande maioria, textos lançados há pouco tempo, à época do lançamento de Mortdansl'avion\&autrespoèmes (2005, tradução de Ariane Witkowski), ou da reedição de La machinedu monde et autrespoèmes (2005, tradução de Didier Lamaison). (RP1)

\section{Estudante 2}

As conexões têm a função de organizar o pensamento lógico da estudante quanto ao modo de organização da seção das análises e resultados que, como mostramos das análises do plano global do conteúdo temático, são divididos por meio do primeiro e o quarto módulo do curso de leitura em francês.

(170) Em relação ao primeiro módulo, as atividades em intercompreensão contribuíram para a tomada de consciência do processo de leitura? (RP2)

No que concerne ao módulo 4, os alunos conseguiram transferir as estratégias e procedimentos estudados para a construção do sentido dos textos escolhidos? (RP2)

Quanto à totalidade do curso, é possível dizer que as atividades em intercompreensão contribuíram para a formação de leitores autônomos plurilíngues? (RP2)

Em relação às competências de leitura em língua francesa, objetivo inicial dos alunos e do programa de curso, pelas avaliações feitas, podemos afirmar que "o dever foi cumprido": todos os alunos foram aprovados, e entre as dez médias individuais finais, apenas uma foi inferior a 8,5. (RP2)

Já no que concerne as competências para o trabalho com as línguas vizinhas ao francês (e, logo, ao português também), pela análise dos resultados dos exercícios do Módulo 4, podemos dizer que os alunos $[\ldots](\mathrm{RP} 2)$ 


\section{Estudante 3}

As conexões revelam a organização das análises realizadas, segundo os cinco gêneros textuais trabalhados durante a pesquisa. Em um primeiro momento, a pesquisadora forneceu as principais características desses gêneros textuais e, em seguida, foi construindo o seu modo de pensar a partir das análises das capacidades de linguagem:

(171) A primeira atividade proposta referia-se à produção de uma sinopse de filme [...] (RP3)

Quanto à coesão verbal, embora a narração exija, normalmente, o uso de tempos verbais passados, o gênero sinopse se desenvolve principalmente através do indicatif présent [...]

Quanto às capacidades de ação, todos os alunos compreenderam que na atividade social proposta era necessário cumprir a função de enunciador que instiga o destinatário a assistir o filme $[\ldots]$

Quanto à revelação abrupta da complicação, podemos defini-la como uma falha na etapa de projeção [...]

Quanto às capacidades linguístico-discursivas, é possível observar a instituição da origem espaço-temporal.

Quanto aos mecanismos de coesão nominal, os alunos mobilizaram bem tanto as anáforas nominais quanto as pronominais, havendo uso mais intenso das primeiras.

Passando à segunda atividade proposta, os alunos deveriam produzir um fait divers. (RP3)

Quanto à infraestrutura geral do texto, o gênero, semelhante à notícia, procura responder às questões “O que? Quem? Por quê? Quando? Onde? Como?”.

Quanto ao tipo de discurso utilizado, há variação entre o relato interativo e a narração, e está, portanto, sempre situado no eixo da atividade relatar.

Quanto à coesão verbal, começando por R.F., há um dado interessante a ser notado.

Por último, no que se refere à coesão nominal, observaremos algumas escolhas lexicais. R.F. usa somente la jeune fille, recorrendo no resto do texto a pronomes ou substantivos sem adjetivação.

Passando à terceira produção, era proposto que os alunos fizessem um relato sobre uma viagem pessoal que pudesse ser publicado em um blog.

No que tange à infraestrutura geral do gênero, há sempre um título ou cabeçalho que contêm a data, já que os relatos costumam ser divididos em pequenos períodos de tempo, ou seja, a cada poucos dias de viagem faz-se novo texto para partilhar novas experiências. 
No que diz respeito ao desenvolvimento das capacidades de ação e discursivas dos alunos, é preciso fazer algumas ressalvas.

Chegando à última proposta de produção, os alunos deviam fazer um relato curto, usando como referência o livro de crônicas Enregistrements Pirates [...]

\subsection{Mecanismos de textualização: coesão nominal}

No que tange às análises da coesão nominal, encontramos nominalizações nos três relatórios finais de pesquisa, tendo elas a função de agrupar os resultados similares encontrados ou destacar algum dado importante no conjunto dos textos analisados. Assim, verificamos que há uma orientação de certos aspectos das análises com o objetivo de sintetizá-los por meio da linguagem (VIGOTSKI, 2009, p. 226). Essas nominalizações, típicas do discurso teórico, são encontradas na seção de análises e resultados das pesquisas (BRONCKART, 1999, p.270-271). A cada momento das análises, verificamos algumas expressões nominais que nos mostram, na linguagem, os resultados aos quais a pesquisa chegou. Ademais, encontramos cadeias nominais cujo referente são os participantes da pesquisa e que expressam quantitativamente os resultados obtidos.

\section{Estudante 1}

No tange aos aspectos da coesão nominal encontrados, destacamos muitas expressões nominais nas seções onde os dados foram comentados.

\section{a) Expressões nominais nos comentários sobre os textos críticos encontrados durante a pesquisa:}

(172) No primeiro caso, deve-se destacar a qualidade dos textos traduzidos: artigos e ensaios renomados no meio acadêmico brasileiro, escritos por profissionais da literatura, da poesia e, $\underline{\mathrm{o}}$ mais importante, especialistas na leitura de Carlos Drummond de Andrade. (RP1) 
A expressão nominalizada "o mais importante" evidencia que, do ponto de vista da estudante, os textos traduzidos para o francês que foram escritos por pesquisadores brasileiros, especialistas da poesia de Drummond, contêm um olhar diferente. Sobre esse "olhar diferente", a pesquisadora novamente se posicionará no período seguinte $\left(4^{\circ}\right.$ período):

(173) Ressalta-se novamente a importância dessas traduções, que garantem ao leitor francófono uma qualidade crítica e, por que não, uma leitura feita a partir do olhar brasileiro sobre essa poesia ao mesmo tempo nacional e universal. (RP1)

A expressão nominalizada, "a importância", evidencia a posição da estudante quanto às traduções dos textos críticos encontrados, dado que esses textos têm uma qualidade crítica, pois possuem um "olhar brasileiro" e "nacional e universal" sobre o escritor mineiro. Nos parágrafos seguintes, a estudante comenta outros dados levantados, apontando que os muitos textos críticos encontrados carregam uma visão literária em língua francesa da poesia de Drummond. Depois dessa exposição, do $4^{\circ}$ ao $7^{\circ}$ parágrafos, o discurso teórico reaparece o ponto de vista da estudante na expressão entre aspas "desconhecimento velado":

(174) De todo modo, é notável o prestígio do poeta mineiro para o público francês, ainda que sob um "desconhecimento velado" de sua obra. Averíguam-se, vinculados a seu nome, termos como "um dos grandes nomes da poesia brasileira", "poeta excepcional" ou "o maior poeta brasileiro do século XX". (RP1)

\section{b) Expressões nominais encontradas nos comentários sobre as reuniões de poemas dedicadas à poesia de Carlos Drummond de Andrade:}

No início da seção a estudante faz a seguinte afirmação:

(175) Em Réunion (1973), Massa compõe um prefácio que, diferentemente dos outros dois tradutores, introduz o leitor francófono em uma camada mais profunda da poesia de Drummond: suas origens interioranas, o contexto histórico-social da época, a relação de sua cidade, Itabira, 
com o Estado de Minas Gerais e com o Brasil. (RP1)

Nesse terceiro excerto, também em discurso teórico, a estudante opõe o prefácio desse livro aos demais por meio da expressão nominal "camada mais profunda da poesia de Drummond".

\section{Estudante 2}

A seção destinada à análise dos resultados da pesquisa foi dividida pela pesquisadora em questões, as quais ela respondeu de acordo com as análises que realizou:

(176) Tendo em mente que o objetivo de aplicação das atividades com as línguas românicas ao longo de um curso que, inicialmente, se limitava ao desenvolvimento da leitura em língua francesa era demonstrar como as mesmas estratégias podem ser transferidas também para essas outras "línguas vizinhas", a análise dos resultados deve ser pensada a partir de três questões. (RP2)

Algumas expressões nominais que marcam quantitativamente os resultados da pesquisa de acordo com os participantes do curso no qual as atividades de intercompreensão foram aplicadas. Por meio da cadeia referencial que se refere a eles, é possível constatarmos essa marcação:

(177) Todas as atividades em intercompreensão do Módulo 1 tiveram seus resultados analisados

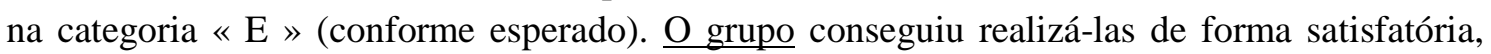
sempre atendendo ao que era pedido e chegando aos objetivos propostos. (RP2)

No excerto acima, a estudante constata que todos os alunos do seu curso de leitura em francês conseguiram tirar a maior nota possível, expressa pela letra "E", nas atividades do módulo 1, ou seja, aquelas pelas quais os alunos foram expostos a textos de diferentes línguas românicas, a fim de serem sensibilizados acerca da intercompreensão. Abaixo, outros referentes de retomada dos participantes da pesquisa:

(178) Na Etapa 2, da mesma forma, todos os alunos conseguiram construir sentido na leitura dos resumos escolhidos, de forma que afirmaram se considerar prontos para avançar na leitura 
mesmo em outras línguas. Cada um apresentou suas impressões [...](RP2)

(179) a maior parte dos alunos se considerou surpresa de ter lido os textos em outras línguas jamais estudadas, afinal, eles se imaginavam capazes ler apenas nas línguas em que tinham conhecimentos mais "sólidos". Entretanto, vários citaram a experiência feita no Módulo 1 com o texto em romeno (Poftiţi la masă!) como exemplo de confiança para avançar na leitura. (RP2)

Já o módulo 4 era composto por duas etapas; na segunda os estudantes tinham que escolher um resumo em uma outra língua românica que não fosse o português e nem o francês, além do assunto do resumo ser da área de estudo dos alunos:

(180) os conhecimentos anteriores acerca dos temas dos textos foi classificada como determinante pela totalidade dos alunos. Segundo eles, a confirmação das hipóteses levantadas ao longo da leitura foi feita, em grande parte, pelos conceitos já conhecidos, fato que facilitou até na superação das dificuldades lexicais. (RP2)

As nominalizações têm a função de nomear alguns resultados similares encontrados segundo uma expressão nominal, como podemos verificar nos excertos abaixo:

(181) [...] pela análise dos resultados dos exercícios do Módulo 4, podemos dizer que os alunos desenvolveram a consciência do processo de leitura como uma competência complexa na qual a língua (ou as línguas) não é o único fator envolvido. (RP2)

Esse excerto evidencia a leitura dos resultados feita pela pesquisadora, que acredita que os estudantes desenvolveram a compreensão de que a atividade de leitura é complexa e não envolve somente a codificação de um sistema linguístico, porém outros fatores igualmente importantes. Essa compreensão é nomeada pela pesquisadora de "consciência do processo de leitura como uma competência complexa". No fragmento abaixo, alguns resultados das análises apontam para uma conscientização dos alunos quanto a mobilizar técnicas de leituras de acordo com objetivo da leitura. Esses resultados foram nomeados de "a ideia de autonomia", expressão na qual o termo "autonomia" recebeu aspas, ou seja, não se trata de uma ideia enquanto conceito teórico, mas de uma nominalização dada pela própria estudante: 
(182) Levando em consideração a ideia de "autonomia" como a característica de um aluno que define por si mesmo seus objetivos, o conteúdo para alcançá-los, assim como os métodos e técnicas que usará e que, sobretudo, se autoavalia ao longo do percurso de aprendizagem [...] a observação das diferentes fases do trabalho [...] demonstra que o grupo é capaz de estabelecer tais elementos para atingir seus objetivos de leitura. (RP2)

Já no excerto abaixo, os resultados encontrados foram agrupados na expressão "o dever foi cumprido", expressão nominal que evidencia o bom rendimento dos estudantes quanto ao desenvolvimento da leitura especificamente em língua francesa:

(183) Em relação às competências de leitura em língua francesa, objetivo inicial dos alunos e do programa de curso, pelas avaliações feitas, podemos afirmar que "o dever foi cumprido": todos os alunos foram aprovados, e entre as dez médias individuais finais, apenas uma foi inferior a 8,5. (RP2)

\section{Estudante 3}

Neste relatório de pesquisa, as nominalizações encontradas estão expressas nos excertos a seguir que, como mostramos nas análises do plano global do conteúdo temático, se organiza em função dos cinco gêneros textuais analisados:

(185) A supressão acima referida ocorreu de duas maneiras. A primeira dá-se quando o aluno omite ações que poderiam intensificar o suspense com subjetivações genéricas, como nas frases [...] A outra maneira de apresentar a supressão de dados importantes não omite ações, mas, sendo também espécie de caracterização aplicável a qualquer filme, parece configurar-se como a inserção da opinião do autor, a semelhança do gênero resenha. (RP3)

Os resultados encontrados nas análises dos textos produzidos pelos estudantes deste primeiro gênero textual mostram que ora eles suprimem dados importantes através de subjetivações e revelação abrupta da complicação, sem instaurar a intensificação suficiente necessária para o gênero, ora inserem informações que serviriam para qualquer filme, além de inserirem uma opinião pessoal. Esses resultados foram nomeados de 
"supressão". Ainda com relação às análises dos dados da sinopse de filme, encontramos as seguintes nominalizações

(186) Quanto à revelação abrupta da complicação, podemos defini-la como uma falha na etapa de projeção, como nos exemplos a seguir, que dizem respeito à última linha de duas produções, quando a complicação de cada uma é instaurada, sem nenhuma outra manifestação que seduza o leitor $[\ldots](\mathrm{RP} 3)$

(187) O segundo desses dois aspectos também pode ser entendido como uma dificuldade nas capacidades discursivas, ou seja, um percalço na organização do texto. (RP3)

As nominalizações referentes ao segundo gênero textual trabalhado na pesquisa aparecem de forma mais abrangente sem uma expressão nominal definida, porém como um aspecto a ser ressaltado nas análises segundo a leitura analítica da pesquisadora:

(188) Os alunos S.C. e R.F. não situaram seu leitor utilizando um título. Aqui, o fato importante não é apenas a não utilização do título, mas a não apreensão de uma estratégia importante do gênero: se o fait divers deve ser rápido e chamar a atenção por seu conteúdo insólito, é necessário chocar o leitor desde o primeiro contato com o texto [...] (RP3)

(189) Quanto à coesão verbal, começando por R.F., há um dado interessante a ser notado. Em pergunta que antecedia as instruções para a produção textual, o aluno não identificou a diferença entre o uso do passe composé e do imparfait, no entanto, ao longo do texto ele os aplica corretamente. (RP3)

Também encontramos nominalizações não definidas nas análises do tex to "relato curto":

(190) A produção da aluna A.S., por sua vez, apresenta alguns pontos interessantes. A estudante decidiu abordar a importância cultural do sofá. Para tanto, usou muitas retomadas com inserção de índices de subjetividade ("Un espace démocratique idéal pour les discussions", por exemplo). (RP3)

No excerto abaixo, vemos uma cadeia nominal que se organiza a partir dos sujeitos da pesquisa: 
(191) Quanto às capacidades de ação, todos os alunos compreenderam que na atividade social proposta era necessário cumprir a função de enunciador que instiga o destinatário a assistir o filme, o que significa não avançar além da fase de complicação. Todos os estudantes identificaram [...] (RP3)

Já o aluno G.S. indicou uma origem espaço-temporal suficiente para o sistema de conexão, mas insatisfatória para a compreensão do filme, já que não aponta qual a guerra ou período em que se passa a história [...]

Ainda cabe apontar que S.C. tem desempenho melhor, por inserir outras marcas do gênero, como data e local no cabeçalho.

A.S apresenta alguns problemas de vocabulário, errando na utilização de alguns verbos (lancer, ao invés de publier, por exemplo) e G.S. comete equívoco quanto à transitividade do verbo tuer, prejudicando a compreensão de todo o texto ("Aujourd-hui deux personnes ont tué[quem?] dans un accident de voiture"). Não passa, no entanto, de erro isolado.

$\mathrm{O}$ aprendiz que apresentou maior dificuldade em adequar seu conteúdo aos propósitos do gênero foi R.F., que em texto muito curto (apenas 64 palavras), não introduziu nenhuma informação que fosse válida a algum viajante leitor.

Tendo analisado o desempenho de cada aluno em cada exercício, notamos que a maioria iniciou o semestre com alguma dificuldade em adequar-se ao contexto do gênero que era pedido. Para a maior parte, o problema foi resolvido logo a partir da segunda produção escrita. R.F. e S.C., no entanto, como alunos com desempenho menor, demoraram mais algum tempo para adequar-se. A coesão verbal e a nominal mostraram ser um problema para parte significativa dos alunos. $\underline{\mathrm{A}}$ maioria, no entanto, conseguiu, até o final do semestre, dominar os mecanismos de textualização. Em relação às modalizações e às vozes, nenhum aluno apresentou problemas significativos, indicando, assim, que, dentro das expectativas quanto ao desenvolvimento no nível básico, esses não são mecanismos que apresentam muitos obstáculos aos aprendizes. (RP3)

\subsection{Mecanismos enunciativos: vozes e modalizações}

A partir do que constatamos das nossas análises dos tipos de discurso, nas quais verificamos a narração atrelada ao discurso teórico, que comporta sempre uma avaliação da estudante com relação aos resultados da pesquisa, podemos perceber o surgimento da voz do estudante enquanto pesquisadora na escrita do relatório final de pesquisa. Essa voz é identificada no momento de recuperar o processo seguido desde o projeto, no início do 
trabalho, até o momento final, inserindo-os em um raciocínio temporal. Ademais, a voz do pesquisador é aquela que nomeia os resultados encontrados e interpreta os dados, dando-lhes uma explicação lógica, e não mais apenas uma explicação temporal. A voz do pesquisador pode ser identificada por meio de alguns recursos linguísticos-discursivos, como as ilhas textuais e as modalizações autonímicas, ambas advindas dos estudos de análise do discurso de Maingueneau (2008) e Authier-Revuz (1999). Esses recursos de identificação das vozes, sobretudo a modalização autonímica, evidenciam uma síntese e uma abstração dos resultados encontrados.

No tocante as modalizações, encontramos apreciativas e lógicas. As primeiras contêm uma diferença em relação àquelas encontradas nos projetos de pesquisa, as quais continham alto grau de subjetividade: elas contêm um baixo grau de subjetividade; já os modalizadores apreciativos identificados no projeto com um valor subjetivo baseadas na comparação entre os dados coletados, isto é, eles contêm um valor de subjetividade menor, pois podem ser "comprovados".

\section{Estudante 1}

Verificamos que a voz da pesquisadora por meio das ilhas textuais e por meio de várias modalizações autonímicas e apreciativas com alto valor de subjetividade, identificadas ao longo das seções dedicadas aos comentários dos dados encontrados durante o levantamento da pesquisa. No excerto abaixo, encontrado na seção dos resultados da pesquisa, podemos identificar uma ilha textual:

(192) De todo modo, é notável o prestígio do poeta mineiro para o público francês, ainda que sob um "desconhecimento velado" de sua obra. Averíguam-se, vinculados a seu nome, termos como "um dos grandes nomes da poesia brasileira", "poeta excepcional" ou "o maior poeta brasileiro do século XX". (RP1)

O excerto entre aspas, "desconhecimento velado", indica-nos a voz do pesquisador que, no excerto em discurso teórico, emite a sua avaliação de forma precavida acerca dos resultados encontrados na pesquisa. Notemos que a ilha se ajusta 
perfeitamente à sintaxe do período, sendo esta uma característica desse recurso textual (MAINGUENEAU, 2008).

Já no excerto abaixo, em discurso indireto, podemos verificar a expressão "o mais importante" que, segundo os estudos de Maingueneau (2008), é uma modalização autonímica, cuja função é mostrar um comentário sobre o conteúdo temático do qual está se tratando. Esse tipo de modalização pode sinalizar a voz do pesquisador que emerge no final da pesquisa de Iniciação Científica, sendo este quem avalia os resultados obtidos ao longo do estudo realizado baseado na sua experiência enquanto pesquisador.

(192) No primeiro caso, deve-se destacar a qualidade dos textos traduzidos: artigos e ensaios renomados no meio acadêmico brasileiro, escritos por profissionais da literatura, da poesia e, $\underline{\mathrm{o}}$ mais importante, especialistas na leitura de Carlos Drummond de Andrade. (RP1)

A modalização autonímica acima, "o mais importante", evidencia que, do ponto de vista da voz do pesquisador, os textos traduzidos para o francês que foram escritos por pesquisadores brasileiros, especialistas em Drummond, contêm um olhar diferente. Sobre esse "olhar diferente", a pesquisadora novamente se posicionará no período seguinte $\left(4^{\circ}\right.$ período):

(193) Ressalta-se novamente a importância dessas traduções, que garantem ao leitor francófono uma qualidade crítica e, por que não, uma leitura feita a partir do olhar brasileiro sobre essa poesia ao mesmo tempo nacional e universal. (RP1)

No excerto acima, também encontramos uma modalização apreciativa e uma modalização autonímica nas expressões "a importância" e "por que não", pelas quais evidencia mais uma vez a voz do pesquisador quanto às traduções dos textos críticos encontrados, uma vez que esses textos têm qualidade, pois possuem um "olhar brasileiro" e "nacional e universal" sobre o escritor mineiro.

Também encontramos as avaliações do pesquisador no excerto abaixo, no qual ele discorre sobre o primeiro livro encontrado de reuniões de poema francês dedicado a Drummond, intitulado "La machine du monde et autres poème". Por meio da 
modalização "interessante", identificamos a apreciação do pesquisador que qualifica o livro:

(194) Dos livros levantados, o primeiro é La machine du monde et autres poèmes (1990), uma extensa reunião de poemas traduzidos por Didier Lamaison. Publicado em 1990 e reeditado em 2005 pela Editora Gallimard, o livro oferece ao leitor francófono um prefácio interessante, que apresenta o poeta mineiro a um público ainda desconhecedorde sua obra. (RP1)

Sobre o segundo livro encontrado, intitulado "Mort dans l'avion \& autres poèmes", encontramos a seguinte apreciação:

(195) O prefácio deste é, em relação ao de Lamaison, bem menos intenso: além de apresentar a tradutora, apresenta-se brevemente a biografia do poeta: "Carlos Drummond de Andrade nasceu em Itabira do Mato Dentro, no Estado de Minas Gerais, no dia 31 de outubro de 1902. (RP1)

O modalizador apreciativo "bem menos intenso" também revela a voz do pesquisador, pois faz aparecer a sua subjetividade na comparação entre os dados da pesquisa.

Continuando a comparação entre os três livros encontrados, a voz do pesquisador fornece o seguinte detalhe em um excerto curto de narração:

(196) Foi Lamaison, aliás, o tradutor que mais se preocupou com notas explicativas ao final do livro: ao todo, La machinedu monde et autrespoèmes (2005) conta com dezesseis páginas dedicadas a notas de esclarecimento ao leitor, enquanto as reuniões de Witkowski e Massa oferecem apenas uma página. Por outro lado, deve-se considerar que Mort dans l'avion \& autres poèmes(2005), bem como Réunion (1973), são edições bilíngues, que possibilitam ao leitor uma comparação direta com o original em português. (RP1)

O início do parágrafo formado pela narração revela que a voz do pesquisador por meio da modalização autonímica expressa por "aliás", que indica um discurso dentro do discurso (AUTHIER-REVUZ, 1999). Nesse excerto, a voz do pesquisador considera importante as notas explicativas nos livros de poemas brasileiros traduzidos para o francês, além de evidenciar sua apreciação por dois dos três livros encontrados, posto que dois deles permitem a comparação com os poemas escritos no original em língua portuguesa. Essas explicações são dadas não mais pela narração que teve um efeito específico, mas pelo discurso teórico. 


\section{Estudante 2}

$\mathrm{Na}$ seção dos resultados das análises, encontramos diversas avaliações da estudante quanto aos resultados encontrados. $\mathrm{Na}$ verdade, as modalizações avaliam o modo pelo qual a pesquisadora interpretou seus dados, segundo a metodologia selecionada para a pesquisa. Como já informamos nas análises dos mecanismos de textualização, a pesquisadora as dividiu em três questões, nas quais ela avalia os resultados obtidos, como mostraremos nos exemplos abaixo:

1)Em relação ao primeiro módulo, as atividades em intercompreensão contribuíram para a tomada de consciência do processo de leitura?

(197) Todas as atividades em intercompreensão do Módulo 1 tiveram seus resultados analisados na categoira « $\mathrm{E} »$ (conforme esperado). $\mathrm{O}$ grupo conseguiu realizá-las de forma satisfatória, sempre atendendo ao que era pedido e chegando aos objetivos propostos. (RP2)

Sendo assim, é possível afirmar com certeza que o trabalho feito neste início de curso se extendeu ao longo de todo semestre. (RP2)

os conhecimentos anteriores acerca dos temas dos textos foi classificada como determinante pela totalidade dos alunos. Segundo eles, a confirmação das hipóteses levantadas ao longo da leitura foi feita, em grande parte, pelos conceitos já conhecidos, fato que facilitou até na superação das dificuldades lexicais. (RP2)

Nos dois primeiros excertos, encontramos três modallizações: A primeira, expressa pelo modalizador apreciativo "de forma satisfatória", pode evidenciar a subjetividade menor da voz do pesquisador por meio da sua apreciação em relação aos resultados da pesquisa. A segunda avaliação, enunciada pela modalização lógica contida em "é possível afirmar com certeza", evidencia que a Estudante 2 está no processo de formação do pesquisador, pois ela faz uma afirmação sem nenhuma precaução, logo encontramos aqui também a voz do estudante no final da pesquisa, como já tínhamos identificado em nossas análises do resumo e da apresentação oral de pesquisa.

2) No que concerne ao módulo 4, os alunos conseguiram transferir as estratégias e procedimentos estudados para a construção do sentido dos textos escolhidos? 
(198) A experiência feita no módulo 4 foi igualmente positiva. Na Etapa 1, todos os alunos conseguiram associar os títulos aos resumos correspondentes, além de construírem sentido também acerca dos temas específicos de cada um. (RP2)

No excerto acima, encontramos sublinhado, mais uma vez, uma modalização apreciativa que contém um baixo valor de subjetividade, pois está baseada nos resultados da pesquisa e não na experiência da estudante em meio universitário.

3) Quanto à totalidade do curso, é possível dizer que as atividades em intercompreensão contribuíram para a formação de leitores autônomos plurilíngues?

(199) Se por um lado, eles desenvolveram as estratégias necessárias para o trabalho de compreensão escrita em língua francesa, pode-se dizer também que eles estão conscientes da possibilidade de transferir essas mesmas estratégias para as outras línguas românicas. (RP2)

a maior parte dos alunos se considerou surpresa de ter lido os textos em outras línguas jamais estudadas, afinal, eles se imaginavam capazes ler apenas nas línguas em que tinham conhecimentos mais "sólidos". (RP2)

Nos dois excertos acima, encontramos a avaliação autonímica "pode-se dizer" e a ilha textual "sólidos". A modalização autonímica mostra uma não-coincidência entre as palavras e as coisas (MAINGUENEAU, 2008), o que evidencia uma precaução da voz do pesquisador em fazer uma afirmação. A ilha textual, sinalizada pelas aspas, pode ser uma constatação da voz do pesquisador, que toma precaução ao afirmar algum resultado da pesquisa.

\section{Estudante 3}

Encontramos algumas modalizações autonímicas no momento de discussão dos resultados da pesquisa: 
(200) Era esperado que os estudantes partilhassem suas perspectivas sobre as situações vividas, fazendo uso de modalizações apreciativas para expressar suas opiniões. É preciso também lembrar que as experiências deveriam ser significativas para uma possível viagem que o leitor pretendesse empreender. (RP3)

Como é improvável que qualquer um dos alunos dispusesse de qualquer uma das duas condições expostas, quase todos preferiram relatar suas viagens como um todo, não se restringindo a pequenos períodos, preferindo contar a perspectiva geral que tiveram dos lugares e dando detalhes somente sobre uma ou duas experiências mais marcantes. (RP3)

C.S., por sua vez, teve desempenho satisfatório, usando de maneira abundante, mais do que em suas outras produções, os pronomes en e y, de difícil apropriação pelos alunos de francês. (RP3)

As três modalizações autonímicas expressam interpretações da voz do pesquisador acerca das produções textuais dos estudantes nos cinco gêneros textuais trabalhados durante o curso. Desse modo, a voz do pesquisador comenta a sua própria escrita.

Além desse tipo de modalização, encontramos as avaliações lógicas com menor grau de certeza e apreciativas com baixo grau de subjetividade. As modalizações lógicas encontradas mostram as avaliações da voz do pesquisador com relação aos resultados da pesquisa:

Nas análises da sinopse de filme, encontramos:

(201) A manutenção do suspense e a crescente inserção de elementos que caracterizem o filme como interessante são, portanto, indispensáveis na produção do gênero. (RP3)

Já nas análises do Fait divers, podemos ver:

(202) Por último, no que se refere à coesão nominal, observaremos algumas escolhas lexicais. R.F. usa somente la jeune fille, recorrendo no resto do texto a pronomes ou substantivos sem adjetivação. É perceptível, no entanto, melhora em seu sistema de coesão. Não mais repetindo excessivamente, o aluno somente apresenta certa dificuldade com pronomes possessivos. (RP3)

Já as modalizações apreciativas com menor grau de subjetividade evidenciam a apreciação da voz do pesquisador que, agora, está baseada na comparação dos dados e não na sua experiência em meio universitário. Nas análises do E-mail informal, identificamos três ocorrências dessa modalização: 
(203) Começando por R.F., o aluno teve desempenho sensivelmente melhor na quarta atividade, adequando-se ao gênero. (RP3)

Quanto ao restante dos alunos, todos obtiveram rendimento satisfatório no que diz respeito ao emprego de dêiticos e à coesão verbal. (RP3)

A primeira produção a ser observada, a de R.F., apresenta sensível melhora nas capacidades de ação e nas discursivas. (RP3)

\subsection{Quadro sintético das análises}

A seguir, elaboramos um quadro com os principais resultados encontrados nos relatórios de pesquisa, destacando os índices textuais e o que eles evidenciam.

\begin{tabular}{|c|c|c|}
\hline & Índices textuais & O que mostram? \\
\hline $\begin{array}{l}\text { Infraestrutura } \\
\text { textual }\end{array}$ & $\begin{array}{l}\text { Predominância do misto } \\
\text { narrativo-teórico, com verbos no presente } \\
\text { do indicativo atrelado a alta densidade } \\
\text { nominai e lógica e, também, com verbos } \\
\text { no pretérito perfeito. }\end{array}$ & $\begin{array}{l}\text { O tipo misto narrativo-teórico cria, em um } \\
\text { mesmo período, um mundo discursivo } \\
\text { disjunto e conjunto, através do qual } \\
\text { notamos que a produtora do texto recria } \\
\text { temporalmente as suas análises para, em } \\
\text { seguida, comentá-las. }\end{array}$ \\
\hline Conectores & $\begin{array}{l}\text { Conectores de organização dos } \\
\text { resultados das análises: } \\
\text { Estudante 1: Outro fator interessante em } \\
\text { relação a grande parte das antologias } \\
\text { levantadas; Ainda tratando dos textos } \\
\text { teóricos traduzidos para a língua francesa. } \\
\text { Estudante 2: Em relação ao primeiro } \\
\text { módulo; no que concerne ao módulo } 4 . \\
\text { Estudante 3: Quanto à coesão verbal; } \\
\text { Quanto ao tipo de discurso utilizado. } \\
\text { Conectores que } \\
\text { quantitativamente os resultados da } \\
\text { pesquisa: } \\
\text { Estudante 1:Um único texto; grande parte } \\
\text { dos textos críticos encontrados; Somente } \\
\text { um de todos os textos encontrados. }\end{array}$ & $\begin{array}{l}\text { Os conectores organizam o conteúdo } \\
\text { temático em discurso teórico referente aos } \\
\text { resultados da pesquisa. Além disso, } \\
\text { percebemos uma quantificação dos } \\
\text { resultados, o que mostra um processo } \\
\text { categorização desses resultados. }\end{array}$ \\
\hline
\end{tabular}




\begin{tabular}{|c|c|c|}
\hline & $\begin{array}{l}\text { Estudante 2: o grupo; todos os alunos; a } \\
\text { maior parte dos alunos; totalidade dos } \\
\text { alunos. } \\
\text { Estudante3: todos os alunos; já o aluno } \\
\text { G.S.; nenhum aluno. }\end{array}$ & \\
\hline $\begin{array}{r}\text { Coesão } \\
\text { nominal }\end{array}$ & $\begin{array}{l}\text { Expressões nominais: } \\
\text { Estudante 1: o mais importante; a } \\
\text { importância; "um desconhecimento } \\
\text { velado"; uma camada mais profunda da } \\
\text { poesia de Drummond. } \\
\text { Estudante 2: a consciência do processo de } \\
\text { leitura como uma competência complexa; } \\
\text { a ideia de "autonomia" como a } \\
\text { característica; "o dever cumprido". } \\
\text { Estudante 3: um percalço; como uma } \\
\text { falha na etapa de projeção; um percalço na } \\
\text { organização do texto }\end{array}$ & $\begin{array}{l}\text { As nominalizações encontradas na seção } \\
\text { de análises e resultados das pesquisas } \\
\text { expressam as regularidades entre as } \\
\text { análises encontradas pelas três estudantes, } \\
\text { que nomeiam essas relações } \\
\text { comparativas. }\end{array}$ \\
\hline Vozes & $\begin{array}{l}\text { Modalizações autonímicas: } \\
\text { Estudante 1: o mais importante; por que } \\
\text { não; aliás. } \\
\text { Estudante 2: em grande parte, pode-se } \\
\text { dizer. } \\
\text { Estudante 3: É preciso também lembrar; É } \\
\text { possível observar. } \\
\text { Ilha textual: } \\
\text { Estudante 1: "desconhecimento velado". } \\
\text { Estudante 2: "sólidos". }\end{array}$ & $\begin{array}{l}\text { As modalizações autonímicas e as ilhas } \\
\text { textuais podem evidenciar a voz do } \\
\text { pesquisador que toma precaução em fazer } \\
\text { certas afirmações com relação aos } \\
\text { resultados da pesquisa. }\end{array}$ \\
\hline Modalizações & $\begin{array}{l}\text { Lógicas: } \\
\text { Estudante 1: interessante; bem menos } \\
\text { intenso. } \\
\begin{array}{l}\text { Estudante 2: é possível afirmar com } \\
\text { certeza }\end{array} \\
\text { Estudante 3: É perceptível. }\end{array}$ & $\begin{array}{l}\text { As modalizações lógicas encontradas } \\
\text { contêm baixo grau de certeza, bem como } \\
\text { as modalizações apreciativas, que } \\
\text { possuem menor grau de subjetividade se } \\
\text { comparadas àquelas dos projetos. Ambas } \\
\text { podem ser avaliação emitidas pela voz do } \\
\text { pesquisador. }\end{array}$ \\
\hline
\end{tabular}




\begin{tabular}{|l|l|l|}
\hline & $\begin{array}{l}\text { Apreciativas com valor de asserção: } \\
\text { Estudante 2: de forma satisfatória; } \\
\text { positiva. }\end{array}$ & \\
$\begin{array}{l}\text { Estudante 3: interessante; rendimento } \\
\text { satisfatório. }\end{array}$ & \\
\hline
\end{tabular}

\section{Síntese e discussão dos resultados}

Para a síntese dos nossos resultados, retomaremos as nossas perguntas de pesquisa de pesquisa, buscando discuti-las à luz do que encontramos em nossas análises. Para facilitar a compreensão desta seção, elaboramos algumas tabelas comparativas dos resultados encontramos nos textos das três estudantes, buscando discutir o desenvolvimento delas enquanto pesquisadoras.

\section{1) Houve desenvolvimento dos alunos participantes da pesquisa durante o processo de IC?}

De acordo com os resultados da nossa pesquisa, podemos dizer que houve desenvolvimento das três estudantes ao longo da IC, no tocante à apropriação de saberes essenciais para o pesquisador, como: organizar a pesquisa de acordo com as etapas principais necessárias de todo estudo científico; ponderar as afirmações com relação aos resultados da pesquisa, para não incorrer no risco de confirmar de forma peremptória algumas relações estabelecidas, dando-lhes um julgamento inquestionável; além de terem estabelecido relações entre os dados e generalizando-os por meio de um termo generalizante, construindo assim um possível saber.

Como expusemos em nossa Fundamentação teórica, de acordo com Friedrich (2012), os instrumentos psicológicos têm por finalidade auxiliar o desempenho dos fenômenos psíquicos necessários para a realização de uma tarefa por meio de uma atividade psíquica do sujeito que o utiliza. Ainda segundo Friedrich (2012), Vigotski entendia que o desenvolvimento ocorre na transformação do sujeito operada pelo instrumento psicológico. Se pensarmos nos dados de nossa pesquisa por esse prisma, podemos dizer que as estudantes utilizaram palavras do cotidiano, isto é, com um sentido 
ou um conhecimento já existente para elas, como instrumentos psicológicos para as auxiliarem na tarefa de comparar e expor os resultados das análises. Por exemplo, quando a Estudante 1 utiliza a palavra "mística", ela se apoia no que ela conhece dessa palavra em seu uso corrente, para dar-lhe um novo significado em relação aos seus dados de pesquisa, criando um conceito que se aplica à sua pesquisa. Dessa forma, a palavra utilizada se torna, para ela, um conceito que lhe permite organizar seu pensamento sobre a pesquisa realizada e, ao mesmo tempo, que construir um novo saber.

Nesse sentido, podemos dizer que o maior desenvolvimento se deu na capacidade das estudantes construírem relações mais complexas entre os dados da pesquisa e dar-lhes uma nomeação, pois o conceito científico, segundo Vigotski (2009), possui um nível de complexidade maior, já que denota uma generalização e abstração maior da realidade, logo uma relação mais "sofisticada" entre o pensamento e a linguagem. Assim, constatamos na pesquisa que houve um aprimoramento na formação dos conceitos científicos, ou seja, verificamos uma "sofisticação" dessa função psicológica superior possibilitada, sobretudo, pelo uso da linguagem. Dessa maneira, como encontramos generalizações nos textos produzidos por todas as alunas, chegamos à conclusão de que, possivelmente em graus diferentes, houve desenvolvimento das estudantes durante o processo de Iniciação Científica.

A seguir, mostraremos três tabelas com os resultados das análises dos textos de cada uma das pesquisas de IC, a fim de facilitar a compreensão do desenvolvimento de cada uma das estudantes:

Estudante 1

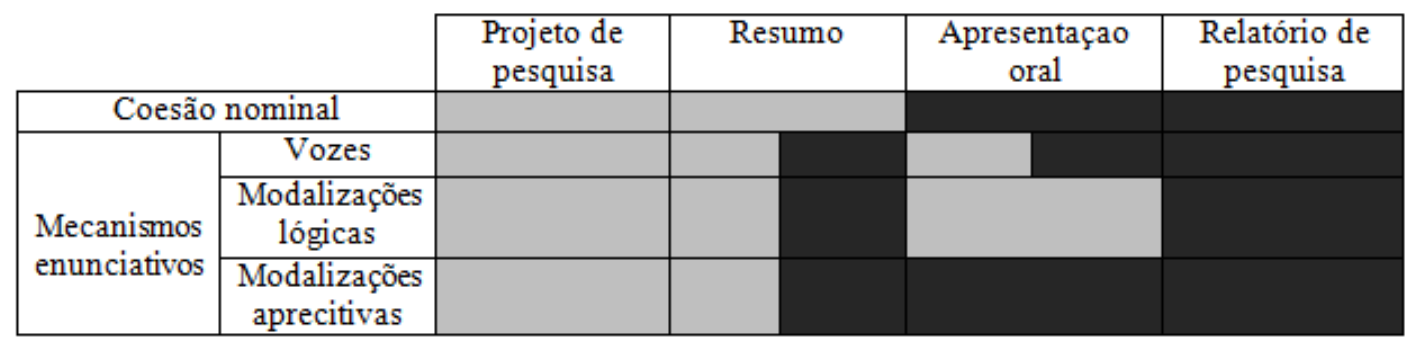

Quadro 23: índices textuais de desenvolvimento (Estudante 1) 
Estudante 2

\begin{tabular}{|c|c|c|c|c|c|}
\hline & & $\begin{array}{l}\text { Projeto de } \\
\text { pesquisa }\end{array}$ & Resumo & $\begin{array}{c}\text { Apresentaçao } \\
\text { oral }\end{array}$ & $\begin{array}{c}\text { Relatório de } \\
\text { pesquisa }\end{array}$ \\
\hline \multicolumn{6}{|c|}{ Coesão nominal } \\
\hline \multirow{3}{*}{$\begin{array}{l}\text { Mecanismos } \\
\text { enunciativos }\end{array}$} & Vozes & & & & \\
\hline & $\begin{array}{c}\text { Modalizações } \\
\text { lógicas }\end{array}$ & & & & \\
\hline & $\begin{array}{c}\text { Modalizações } \\
\text { apreciativas }\end{array}$ & & & & \\
\hline
\end{tabular}

Quadro 24: índices textuais de desenvolvimento (Estudante 2)

\section{Estudante 3}

\begin{tabular}{|c|c|c|c|c|c|}
\hline & $\begin{array}{l}\text { Projeto de } \\
\text { pesquisa }\end{array}$ & Resumo & $\begin{array}{c}\text { Apresentaçao } \\
\text { oral }\end{array}$ & $\begin{array}{c}\text { Relatório de } \\
\text { pesquisa }\end{array}$ \\
\hline \multicolumn{6}{|c|}{ Coesão nominal } \\
\hline \multirow{3}{*}{$\begin{array}{l}\text { Mecanismos } \\
\text { enunciativos }\end{array}$} & Vozes & & & & \\
\hline & $\begin{array}{l}\text { Modalizações } \\
\text { lógicas }\end{array}$ & & & & \\
\hline & $\begin{array}{c}\text { Modalizações } \\
\text { apreciativas }\end{array}$ & & & & \\
\hline
\end{tabular}

Quadro 25: índices textuais de desenvolvimento (Estudante 3)

\begin{tabular}{|c|c|c|c|}
\hline Mecanismos de textualização & \multicolumn{3}{|c|}{ Mecanismos enunciativos } \\
\hline $\begin{array}{c}\text { Coesão relacionada à ideia } \\
\text { central }\end{array}$ & $\begin{array}{c}\text { Voz do } \\
\text { estudante }\end{array}$ & $\begin{array}{c}\text { Modalizações lógicas } \\
\text { com alto grau de } \\
\text { autonomia }\end{array}$ & $\begin{array}{c}\text { Modalizações apreciativas } \\
\text { com maior grau de } \\
\text { subjetividade }\end{array}$ \\
\hline $\begin{array}{c}\text { Coesão nominal que indica } \\
\text { uma generalização }\end{array}$ & $\begin{array}{c}\text { Voz do } \\
\text { pesquisador }\end{array}$ & $\begin{array}{c}\text { Modalizaçóes lógicas } \\
\text { com baixo grau de } \\
\text { autonomia }\end{array}$ & $\begin{array}{c}\text { Modalizações apreciativas } \\
\text { com menor grau de } \\
\text { subjetividade }\end{array}$ \\
& & &
\end{tabular}

Após a discussão sobre a primeira pergunta, retomemos, a seguir, a segunda pergunta de pesquisa: 
2) Quais marcas linguístico-discursivas presentes nos textos produzidos durante o processo de IC (projeto de pesquisa, resumo para apresentação, apresentação oral de pesquisa e relatório final) permitem depreender esse desenvolvimento?

No gênero textual projeto de pesquisa, o primeiro produzido no processo da IC, encontramos, por meio das análises, uma ideia central que guia toda a escrita do projeto e revela a relação que há entre a esfera universitária e a esfera científica no início de uma primeira pesquisa. Constatamos que a experiência em meio universitário propicia a motivação para a formulação de um projeto de pesquisa. A predominância do tipo de discurso teórico evidencia a construção lógica dessa ideia central nos projetos, a qual organiza toda a pesquisa. Os mecanismos de textualização utilizados na escrita do projeto nos revelam a mobilização dessa ideia central, pois as retomadas nominais estabelecem relações que permitem o desenvolvimento da ideia central e a sua compreensão na micro-estrutura textual por meio dos conectores. Eles mostram como a ideia central é construída ao longo das principais partes do projeto de pesquisa. Mesmo que o discurso teórico seja predominante nos projetos, criando uma maior autonomia do agente produtor do texto em relação aos parâmetros de produção, encontramos comentários na superfície textual que revelam a voz do estudante, que se coloca no texto, concedendo-lhe autoria. As modalizações lógicas com alto grau de certeza nos certificam que pode ser a voz do estudante quem julga e aprecia o conteúdo temático, estando baseada na sua experiência pessoal em meio universitário. Os modalizadores com função de apreciação mostram uma avaliação subjetiva das estudantes quanto à relevância do estudo que empreenderão.

Na etapa mais próxima do final da IC, nas análises do gênero textual resumo para apresentação oral, verificamos, por meio do plano global do conteúdo temático, a retomada da ideia central da pesquisa, tal qual já tínhamos identificado em nossas análises do projeto de pesquisa. Por exemplo, os objetivos expressos nos resumos são próximos àqueles dos projetos, como podemos ler no início desses textos. Além disso, constatamos também algumas inadequações referentes às partes essenciais de um resumo, por exemplo, a Estudante 2 que não explicita o método de análise dos seus dados de pesquisa, o que indica que as estudantes ainda estão se apropriando do gênero resumo e, também, da própria maneira de desenvolver a pesquisa. Como vimos, o tipo de discurso misto narrativo-teórico constrói um raciocínio de retomada da pesquisa, que só é possível pelo fato da pesquisa estar em sua fase final. Encontramos também segmentos de discurso 
teórico somente, sobretudo no resumo da Estudante 2, com o predomínio de conectores lógicos, o que indica que a aluna ainda não consegue fazer a retomada dos resultados da pesquisa. Como o resumo é produzido no final da IC, a narração indica a retomada de alguns aspectos da pesquisa. A coesão nominal permite criar cadeias nominais que nos confirmaram as nossas análises do plano global do conteúdo temático, já que essas retomadas nominais são parecidas com as estabelecidas nos projetos de pesquisa e que estão ainda contidas na ideia central, porém elas ainda não demonstram a presença de generalizações que, em nossos dados, apresentam-se como possíveis índices de desenvolvimento. Nos mecanismos enunciativos, constatamos que as modalizações autonímicas permitem a identificação da voz do pesquisador nesse momento da pesquisa. No caso da Estudante 1, por exemplo, podemos perceber que a modalização autonímica expressa por "por assim dizer" mostra uma precaução quanto a afirmação realizada. As modalizações lógicas com alto grau de certeza expressam geralmente a voz do estudante. Outros modalizadores lógicos possuem baixo grau de asserção, possibilitando a identificação da voz do pesquisador. Já as modalizações apreciativas podem evidenciar tanto a voz do pesquisador, caso estejam baseadas na experiência enquanto pesquisador, quanto a voz do estudante, caso estejam muito próximas às modalizações encontradas nos projetos de pesquisa.

Sendo assim, podemos concluir que já houve, nesse estágio do processo de IC, algum desenvolvimento das alunas, o que pode ser depreendido pelas marcas linguísticas que apresentamos.

Já na apresentação oral da pesquisa, percebe-se que as estudantes estão se apropriando das práticas da esfera científica, pois as lacunas apresentadas nos resumos das apresentações, como, por exemplo, a ausência dos resultados da pesquisa no texto da Estudante 1, foram as mais desenvolvidas durante as exposições orais, de acordo com os números de linhas transcritas, em comparação com o número de linhas dedicado a essas partes no resumo. Sendo assim, percebemos que a própria escolha dos conteúdos temáticos já indica um possível desenvolvimento das estudantes.

Em relação aos tipos de discurso, observamos que o discurso interativo produz uma situação de comunicação na qual os interlocutores estão implicados, sendo o conteúdo temático desenvolvido em face dos destinatários, entre eles um docente e pesquisador experiente. $\mathrm{O}$ relato interativo produz um efeito de implicação pelo qual as 
estudantes fazem uma disjunção da ação de linguagem, retomando e presentificando o momento das análises dos dados para estabelecer as relações entre eles. Então, a mobilização de ambos os tipos de discurso parece ser um dos índices indicadores do desenvolvimento das estudantes, pois permite que, ao mesmo tempo, que a pesquisa seja relatada, nos excertos em relato interativo e, também, que haja reflexão sobre ela, nos excertos em discurso interativo, já que se trata, segundo Weinrich (1973, p.30), de momentos de maior tensão, ou seja, momentos em que surgem ideias e generalizações ${ }^{36}$. Na mesma linha de pensamento, podemos refletir sobre o que diz Vigotski (2001) sobre o papel do conflito no desenvolvimento, já que é justamente nos momentos de maior tensão, em discurso interativo, que aparecem generalizações sobre a pesquisa.

Dessa forma, levantamos a hipótese de que as generalizações podem indicar uma síntese, por meio da palavra, das relações comparativas entre os dados das pesquisas. Nesse sentido, podemos aproximar as generalizações encontradas ao que diz Vigotski (2009) quando ele afirma que o "significado da palavra só é um fenômeno de pensamento na medida em que o pensamento está relacionado à palavra e nela materializado, e vice-versa: é um fenômeno de discurso apenas na medida em que o discurso está vinculado ao pensamento e focalizado por sua luz". À luz dessa afirmação, podemos compreender a presença de generalizações sobre os resultados da pesquisa como índices que podem indicar o desenvolvimento das estudantes, não apenas pelo domínio dos gêneros, mas, sobretudo, pela aprendizagem do "pensar científico".

No âmbito dos mecanismos de textualização, os conectores textuais localizados na seção de apresentação de análises e resultados mostram as relações de igualmente ou diferença feitas pelas alunas entre os dados das suas pesquisas.

Por meio dos mecanismos enunciativos, verificamos que o valor autonímico das generalizações não coincide com o seu sentido no uso corrente, sendo ele resultado de uma interpretação que é feita pelas estudantes ao término da pesquisa. Em outras palavras, entedemos que as estudantes escolhem termos para descrever e qualificar suas pesquisas. Por isso, levantamos a hipótese de que se trata da voz do pesquisador que emerge nesse momento. As modalizações lógicas com grau de certeza estão baseadas nas experiências das estudantes ao término da prática da pesquisa, sendo essas avaliações

\footnotetext{
${ }^{36}$ Nesse sentido, embora com dados essencialmente diferentes, encontramos resultados semelhantes aos encontrados por Lousada (2006) sobre o papel do discurso interativo e do relato interativo para relatar uma experiência vivida (nem nosso caso a pesquisa) e, ao mesmo tempo, refletir sobre ela.
} 
emitidas pela voz do estudante. Já as modalizações lógicas com menor grau de certeza e a apreciativas mostram a subjetividade do pesquisador ao analisar os dados.

No último gênero produzido no âmbito da IC, o relatório final de pesquisa, o tipo misto narrativo-teórico cria um mundo discursivo disjunto e conjunto, através do qual notamos que a produtora do texto recria temporalmente as suas análises para, em seguida, comentá-las. Pelos mecanismos de textualização, verificamos que os conectores organizam o conteúdo temático em discurso teórico referente aos resultados da pesquisa. Além disso, percebemos uma quantificação dos resultados, o que mostra um processo de categorização. As nominalizações encontradas na seção de análises e resultados das pesquisas expressam as regularidades entre as análises encontradas pelas três estudantes, que nomeiam essas relações comparativas. Nos mecanismos enunciativos, os termos que configuram as modalizações autonímicas criam um comentário encaixado na exposição dos resultados da pesquisa. As modalizações autonímicas e as ilhas textuais podem evidenciar a voz do pesquisador que toma precaução em fazer certas afirmações com relação aos resultados da pesquisa. As modalizações lógicas encontradas contêm baixo grau de certeza, bem como as modalizações apreciativas, que possuem menor grau de subjetividade se comparadas àquelas dos projetos. Ambas podem ser avaliação emitidas pela voz do pesquisador.

A partir do que expusemos, podemos concluir que as marcas linguístico-discursivas que apresentamos revelam não apenas uma apropriação das estudantes em relação aos gêneros textuais próprios da IC, mas, sobretudo, um desenvolvimento do pensar científico possível pelo fato de que os índices linguístico-discursivos mobilizados permitem, ao mesmo tempo, organizar o pensamento sobre a pesquisa realizada.

Tendo respondido à segunda pergunta de pesquisa, vejamos, agora, a discussão da última pergunta. 
3) Qual o papel dos gêneros textuais produzidos durante o processo da IC nesse desenvolvimento?

Para compreendermos o papel dos gêneros textuais ao longo da Iniciação Científica, buscaremos discutir o papel dos tipos de discurso mobilizados por esses gêneros no decorrer da pesquisa. Para organizar essa discussão, retomaremos, assim como exposto na Fundamentação teórica, a reorganização do método de análise do ISD (BRONCKART, 1999) por meio das categorias de restrição da linguagem (BRONCKART, 2008), sendo essas retomadas e nomeadas por Bota (2011) como sistemas da linguagem. Essa última reorganização é interessante para discutir o nosso trabalho, já que ela visa mostrar como as restrições da linguagem atuam em um único processo em que várias ações linguageiras são efetuadas, de maneira semelhante ao que ocorre na Iniciação Científica. Abaixo, mostraremos essa reorganização, que contempla todos os aspectos analisados nos textos de nossa pesquisa:

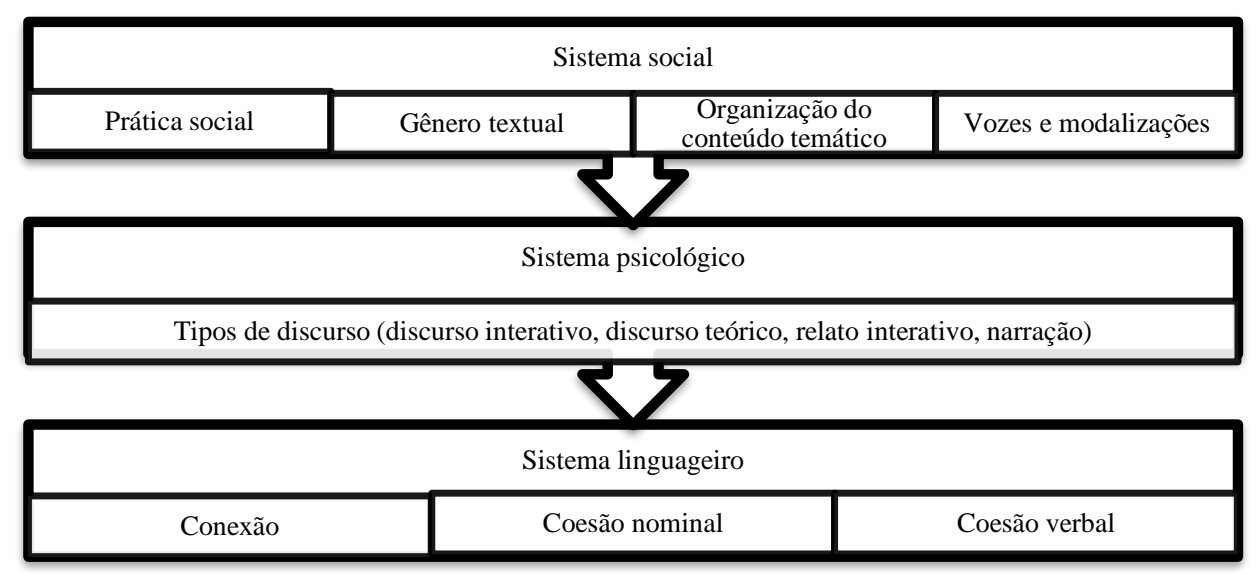

Figura 15 - Os três sistemas que exercem restrições em qualquer ação de linguagem (BRONCKART, 2008b; BOTA, 2011)

Para discutirmos os nossos resultados, a noção de sistemas da linguagem nos permite compreender o papel da linguagem verbal, materializada nos textos dos quatro gêneros textuais produzidos pelas estudantes ao longo da IC.

No momento inicial da pesquisa, a produção do gênero textual projeto de pesquisa exerce uma restrição social, pois as estudantes nunca outrora tinham redigido um projeto. 
Como vimos, no caso da Estudante 2, que teve um desempenho parcial na escrita do projeto de pesquisa ao não justificá-lo por meio do estado da arte dos estudos realizados.

A produção do gênero textual projeto de pesquisa também exerce uma restrição ao texto de modo a influenciar o sistema psicológico na construção de um raciocínio lógico por meio do discurso teórico, dando forma à pesquisa dentro dos limites desse gênero textual. Em nossas análises, constatamos que o discurso teórico permite que identifiquemos uma ideia central, que é motivadora da pesquisa. Nas seções que compõem o gênero textual projeto de pesquisa, foram encontradas essas ideias centrais conjugadas com a finalidade de cada uma das seções do gênero textual. Assim, até mesmo a metodologia do projeto foi pensada tendo em vista o desenvolvimento da ideia central.

Como discutimos na nossa segunda pergunta, nomeamos a voz presente no projeto de voz do estudante, pois é ela quem organiza a investigação de acordo com a motivação individual baseada na experiência universitária inicial que a levou efetuá-la; e vinda dessa voz a emissão de avaliações lógicas com grau de certeza sobre o seu objeto de pesquisa. A voz do estudante faz transparecer no discurso teórico as modalizações lógicas, que expressam um valor de certeza e de probabilidade altos. Baseados nos graus de autonomia constatados por Bronckart (1999, p.191) na análise de textos do gênero textual monografia científica, levantamos a hipótese de que o valor de certeza das afirmações presentes nos projetos não é característico do discurso científico, já que este valoriza a presença de modalizações que atenuam o valor de verdade das afirmações, pois procura trazer uma certa precaução ao pesquisador, evitando afirmações fortes que possam ser facilmente contrariadas. De acordo com Bronckart (1999, p. 191), é possível encontrarmos a voz do autor empírico do texto no discurso teórico por meio da forma como são apresentadas as suas posições e interpretações acerca do conteúdo temático mobilizado. Sendo assim, entendemos as afirmações com grau de certeza não como advindos da voz da ciência (nem poderiam, pois as pesquisas estavam no início de desenvolvimento), porém oriundas da própria experiência das estudantes no meio universitário.

Portanto, verificamos que a prática científica da IC, desenvolvida na esfera universitária, impõe primeiramente a escrita do gênero textual projeto de pesquisa, logo, 
encontramos características próprias dessa relação nos textos produzidos pelas estudantes, como, por exemplo, a presença da ideia central, a voz do estudante, que influenciam no menor grau de autonomia do discurso teórico.

Até mesmo a mobilização do sistema linguístico nos mostra essa situação. Em trabalho anterior (LOUSADA; SANTOS, 2014), constatamos que as primeiras versões dos projetos contêm segmentos de discurso teórico com poucas conexões lógicas entre eles, por exemplo, observamos a falta de um tipo específico de conexão entre os conceitos selecionados para a pesquisa, indicando causa/consequência, oposição etc. Nesse sentido, o sistema linguístico busca trazer lógica ao texto por meio dos conectores lógicos, típicos do discurso teórico. O sistema linguístico também atua de modo a revelar, através da cadeia coesiva, a ideia central da pesquisa.

No momento que se aproxima ao final da Iniciação Científica, três gêneros textuais são produzidos: o resumo da apresentação oral, a apresentação propriamente, e o relatório final de pesquisa.

No gênero textual resumo da apresentação oral, encontramos novamente a voz do estudante, posto que a ideia central é retomada no texto, ou seja, não houve alteração dessa ideia durante o processo da Iniciação Científica. O sistema psicológico atua por meio do discurso teórico e também pela narração, ao se retomar os resultados encontrados na pesquisa. No caso da Estudante 2, as restrições foram maiores, pois ela não utilizou a narração para a escrita do resumo, senão o discurso teórico, o que mostra uma inadequação quanto à prática de linguagem determinada nesse momento final da pesquisa. O sistema linguístico, por seu turno, age, principalmente, por meio da coesão nominal, pela qual pudemos estabelecer uma cadeia coesiva que remete à ideia central, sendo as retomadas nominais semelhantes àquelas que encontramos nos projetos de pesquisa. Assim, tanto a voz do estudante quanto a do pesquisador aparecem, mostrando que, até o momento da escrita do resumo, podemos verificar que o processo de formação do pesquisador não está ainda concluído, já que há um misto das duas vozes. Assim, constatamos que o sistema social, por meio da voz do estudante, influencia na escrita do resumo para apresentação oral, revelando uma etapa intermediária, de apropriação de alguns índices linguístico-discursivos, mas não de outros. Advinda também do sistema social foram as restrições exercidas pelo gênero textual resumo, pois as três estudantes 
omitiram algumas partes necessários nesse gênero textual, como a Estudante 3, por exemplo, que não explicitou o objetivo específica da sua pesquisa.

Também a apresentação oral de pesquisa, possibilitou-nos compreender que o processo de formação do pesquisador não é finalizado na Iniciação Científica por conta da restrição do sistema social exercida pelo gênero, posto que encontramos algumas inadequações nos desempenhos das apresentações no que tange à estrutura do plano global desse gênero, como no caso da Estudante 2, que apresenta o objetivo da sua apresentação após todas as explicações teóricas. No entanto, as partes mais desenvolvidas, segundo o número de linhas da nossa transcrição, foram justamente aquelas não desenvolvidas no resumo da apresentação, portanto identificamos que o sistema social, por meio da restrição exercida pelo gênero textual, influencia a produção do texto no final da pesquisa. Por outro lado, podemos constatar também uma apropriação pelas estudantes das principais etapas de uma pesquisa científica.

A atuação do sistema psicológico ocorre por meio da utilização do discurso interativo, no qual as estudantes estão implicadas na ação de linguagem e esta ocorre concomitantemente ao tempo de produção, gerando uma "tensão" e um "conflito" na fala das alunas, pois o enunciador se encontra comprometido com a situação comunicativa (WEINRICH, 1973, p.30). Nessa situação, há presença de um público que acompanha o desenrolar da apresentação oral.

Além do tipo de discurso interativo, encontramos, no momento das discussões dos dados e resultados das pesquisas, o tipo de discurso relato interativo, que demonstra uma retomada e uma "nova vivência" da situação de análise, na qual as estudantes estabeleciam relações de semelhança e diferença entre os dados encontrados. Essas relações, dentro da situação de tensão criada pelo discurso interativo, foram nomeadas pelas estudantes durante a apresentação oral de pesquisa, sendo que as palavras e expressões nominais criadas funcionaram como instrumentos psicológicos para a síntese comparativa dos dados, possibilitando as suas análises.

Segundo Friedrich (2012), os instrumentos psicológicos têm por finalidade auxiliar o desempenho dos fenômenos psíquicos necessários para a realização de uma tarefa, sendo o objeto de sua ação não o meio natural, mas a atividade psíquica do sujeito que o utiliza. Ao utilizar palavras já conhecidas e atribuindo-lhes um sentido próprio dentro de cada pesquisa de IC, notamos a influência exercida pelo sistema linguístico 
neste momento da Iniciação Científica. De acordo com Vigotski, (2009), os conceitos cotidianos são aqueles que utilizamos nas nossas atividades práticas e nas interações sociais imediatas, nas quais não há um pensamento com grau elevado de generalização. $\mathrm{O}$ valor autonímico dado às palavras e expressões pelas estudantes não condiz com o seu valor enquanto conceitos cotidianos, mas somente podem ser interpretados dentro das relações estabelecidas pelas estudantes, pois se trata de saberes com maior grau de abstração construídos ao longo das pesquisas. A produção de saberes é própria da esfera científica, sendo que é a voz do pesquisador quem atribui significado a essas palavras. Nesse sentido, recuperamos o princípio e) proposta por Bota (2011) e explicado por nós na Fundamentação teórica de que os conceitos não podem ser produzidos de forma independente das unidades de uma língua natural.

A utilização do relato interativo só é possível na apresentação oral, uma vez que a prática da Iniciação Científica, tal como é ordenada no nosso contexto de pesquisa, demanda uma exposição oral ao final do processo, o que possibilita uma retomada dos resultados e a sua generalização pela palavra. Desse modo, constatamos que o sistema social atua por meio do gênero apresentação oral de pesquisa.

Por meio da atuação do sistema linguístico, podemos verificar que as conexões estabelecidas na exposição das análises e resultados têm a função de evidenciar, na microestrutura textual, as relações que as estudantes estabeleceram entre os dados coletados, formando, assim, a parte de análise de dados na apresentação oral. Sendo assim, a apresentação oral parece ter uma importância fundamental no processo de IC, já que ela permite a mobilização do discurso interativo e do relato interativo e, assim, permitindo que a generalização apareça. Com isso, retomamos o princípio c) de Bota (2011), exposto em nossa Fundamentação teórica, e no qual se afirma que é no nível tipos de discurso que pode ocorrer o processo de generalização e de abstração.

A produção do gênero textual relatório final de pesquisa, ao término dos estudos empreendidos, impõe uma retomada da pesquisa e a construção de relações entre os dados coletados. Desse modo, a produção do gênero relatório influencia o sistema psicológico de modo a criar um raciocínio temporal para registrar algum detalhe importante dos dados de forma a dar-lhe uma lógica científica, por isso encontramos nos relatórios o tipo de discurso misto narrativo-teórico. O sistema linguístico confirma essa nossa hipótese, uma vez que encontramos conectores temporais próprios da narração 
atrelados aos conectores do tipo de discurso teórico. Portanto, podemos concluir que o gênero relatório é essencial no processo de IC, já que ele permite uma emergência mais concreta da voz do pesquisador, por meio dos índices que já descrevemos.

Justamente por meio da mobilização do discurso misto narrativo é que podemos identificar uma transformação maior da voz do estudante para a voz do pesquisador. Nesse momento, verifica-se uma apropriação maior das estudantes das práticas da esfera científica. Isso pode ser constatado, pois a voz do pesquisador constrói nominalizações que ocorrem, sobretudo, no momento de recuperar e sistematizar as análises e os resultados encontrados, e também por meio de algumas ilhas textuais que, com aspas, demonstram uma precaução na tomada de alguns posicionamentos. Essa voz é emissora de algumas modalizações lógicas que, distintamente daquelas encontradas no projeto de pesquisa, contêm um grau de certeza e assertividade menores, pois não são confirmadas peremptoriamente, porém consideradas dentro dos limites dos dados analisados e das relações estabelecidas entre eles. Retomando os graus de autonomia de Bronckart (1999, p.191), levantamos a hipótese de que os posicionamentos e as interpretações são atenuados no momento da escrita do relatório final de pesquisa, o que demonstra uma maior precaução nas afirmações, atitude própria do pesquisador.

Portanto, a mobilização do discurso misto narrativo-teórico imposta pelo dispositivo de formação possibilita que as estudantes recuperem os dados das pesquisas, relacionando-os e, assim, diminuindo a restrição da voz do estudante e possibilitando o desenvolvimento da voz do pesquisador.

Podemos concluir, assim, que os quatro gêneros produzidos dentro do processo determinado pelo dispositivo de formação são importantes para verificar o desenvolvimento do pesquisador. A prática da IC tal como praticada no âmbito da FFLCH delimita que, a cada momento da pesquisa, um gênero textual seja produzido e, por conseguinte, determina também quais tipos de discurso serão mobilizados ao longo do processo de formação. Desse modo, como constatado, os raciocínios criados pelos tipos de discurso atrelados à especificidade de cada etapa do processo permitem a compreensão do desenvolvimento propiciado pelo dispositivo de formação. De acordo com as restrições exercidas pelo sistema social por meio da prática da IC no que diz respeito aos textos produzidos, podemos delinear o seguinte esquema de desenvolvimento propiciado pelos gêneros textuais: 


\begin{tabular}{|c|c|c|c|c|}
\hline & $\begin{array}{c}\text { Projeto de } \\
\text { pesquisa }\end{array}$ & $\begin{array}{c}\text { Resumo da } \\
\text { apresentação } \\
\text { oral }\end{array}$ & $\begin{array}{c}\text { Apresentaçao } \\
\text { oral de pesquisa }\end{array}$ & $\begin{array}{c}\text { Relatório final } \\
\text { de pesquisa }\end{array}$ \\
\hline Estudante 1 & $\mathrm{E}$ & $\mathrm{P}$ & $\mathrm{P}$ & $\mathrm{E}$ \\
\hline Estudante 2 & $\mathrm{P}$ & $\mathrm{P}$ & $\mathrm{P}$ & $\mathrm{P}$ \\
\hline Estudante 3 & $\mathrm{E}$ & $\mathrm{P}$ & $\mathrm{P}$ & $\mathrm{E}$ \\
\hline
\end{tabular}

\begin{tabular}{|c|c|c|}
\hline Não houve desenvolvimento & Houve desenvolvimento parcial & Houve desenvolvimento \\
\hline $\begin{array}{r}\mathrm{E}=\text { Excelente desempenh } \\
\text { text }\end{array}$ & $\mathbf{P}=$ & $\begin{array}{l}\text { nho pa } \\
\text { gêner }\end{array}$ \\
\hline
\end{tabular}

Quadro 26: Papel dos gêneros textuais no desenvolvimento. 


\section{Considerações Finais}

Como indicamos em nossa Introdução, nossa pesquisa faz parte de um conjunto de estudos desenvolvidos no âmbito do grupo ALTER e ALTER-AGE (CNPq).As pesquisas realizadas por esses grupos têm como objetivo geral estudar o papel da linguagem no desenvolvimento humano e, mais especificamente: - a) no trabalho do professor e nos dispositivos de formação de professores; - b) no desenvolvimento dos alunos, por meio dos gêneros textuais e visando ao desenvolvimento de capacidades de linguagem, seja no ensino/aprendizagem de línguas, seja no letramento acadêmico. Nesse âmbito, embora dialogando estreitamente com essas pesquisas, pois compartilha o mesmo quadro teórico-metodológico, nossa pesquisa tem uma particularidade, pois ela não utiliza as vertentes da Clínica da Atividade (CLOT, 1999, 2001) e da Ergonomia da Atividade (FAÏTA, 2004; AMIGUES, 2004; SAUJAT, 2004), e nem a metodologia das sequências didáticas (SCHNEUWLY; DOLZ, 2004), todas elas amplamente utilizadas por nosso grupo de pesquisa.

Sendo assim, a pesquisa que realizamos contém uma semelhança e uma diferença com relação àquelas desenvolvidas pelo grupo. A semelhança diz respeito a nossa preocupação com a formação, por isso selecionamos o processo da Iniciação Científica. Nossa diferença está no fato de buscarmos desenvolver uma reflexão acerca da formação e do desenvolvimento do pesquisador especificamente, e não do professor ou do aluno que aprende uma língua. Para isso, valemo-nos dos textos que os próprios estudantes produzem durante aIC. Assim, nossos dados foram obtidos no decurso em que o dispositivo de formação estava operando, e os estudantes tendo que seguir esse processo de acordo com o que é determinado pela Comissão de Pesquisa.

Posto que buscamos compreender a Iniciação Científica desde o momento inicial, da redação do projeto de pesquisa, até o momento final, na escrita do relatório final de pesquisa, acumulamos um grande volume de dados os quais tivemos que selecionar para a viabilidade da pesquisa. Alguns dos textos que não pudemos selecionar foram as diferentes versões de cada gênero textual exigido que, embora de grande interesse para a compreensão do processo de formação, inviabilizaria a realização da pesquisa no âmbito do mestrado. Consideramos essa uma primeira limitação do nosso trabalho, pois, mesmo que nós já tivéssemos realizado uma análise de versões de projetos de pesquisa e escrito 
um artigo científico a respeito, entendemos que uma análise dos textos pertencentes aos quatro gêneros textuais poderia também nos fornecer análises interessantes para a compreensão do processo de formação.

Também não coletamos para a nossa pesquisa entrevistas com as orientadoras, anotações de reuniões, entre outros textos que, embora não sejam determinados pelo dispositivo de formação, são produtos dessa prática. Se o fizéssemos acumularíamos, mais uma vez, um grande conjunto dados, o que também inviabilizaria a pesquisa de mestrado. Ademais, consideramos como limitação da nossa pesquisa o fato de termos trabalhado com textos de graduandos somente de três estudantes e todas de Letras e não de outros cursos. Mais uma vez, a opção foi feita para poder restringir a quantidade de dados, além de facilitar a coleta. No entanto, embora tenhamos trabalhado somente no campo das Humanidades e, dentro dele, com estudantes de Letras, ressaltamos que encontramos resultados similares entre os textos analisados e que, já que o mesmo dispositivo de formação da IC é oferecido para toda a Faculdade de Filosofia, Letras e Ciências Humanas da USP, podemos levantar a hipótese de que, como os mesmos procedimentos para a realização da Iniciação Científicasão seguidos, seria possível, também, encontrar resultados semelhantes em textos de alunos de outras Faculdades. De qualquer forma, nos parece importante salientar a pertinência da realização de uma pesquisa com mais estudantes e de outras faculdades também, procurando validar os resultados que já encontramos.

Por ser uma corrente de estudos na esteira dos pressupostos desenvolvidos por Vigotski (2007, 2009), a teoria do Interacionismo Sociodiscursivo tem como objetivo validar o papel da linguagem na construção do pensamento e dos saberes. Para isso, um passo importante dado pela ISD foi a construção de um método de análise textual e discursiva. Nesse sentido, o ISD formula a questão das restrições de linguagem: sociais, psicológicas e linguísticas (BRONCKART, 2008), que atuariam em toda produção textual. Assim, a pergunta que se colocou foi a seguinte: Como as restrições da linguagem atuam em um processo formativo no qual vários textos são produzidos em sequência?

Essa questão foi problematizada por Bota (2011), que reformulou a noção de restrições de linguagem e a nomeou de sistemas da linguagem: o social, o psicológico e o linguístico. Ambas as noções, seja de restrições de linguagem, seja de sistemas de linguagem não são muito utilizadas em pesquisas do ISD no Brasil, por isso destacamos a 
nossa reflexão enquanto uma pesquisa contendo um elemento novo, mesmo tendo o processo da Iniciação Científica recebido atenção em algumas dissertações e teses, como mostramos em nossa Introdução.

Justamente, as análises que fizemos e os resultados aos quais chegamos propiciam uma reflexão acerca da atuação dos sistemas da linguagem, proposta por Bota (2011) em dispositivos de formação, buscando compreender o papel dos textos durante esses processos formativos. Assim, os resultados de nossa pesquisa impõem uma primeira pergunta para reflexão: em outros dispositivos de formação do pesquisador na graduação, como seria a dinâmica dos sistemas da linguagem?

No contexto da FFLCH, é oferecida por alguns departamentos uma outra modalidade de pesquisa, sobre a qual já discutimos na Introdução da dissertação, trata-se do Trabalho de Graduação Individual (TGI). Esse dispositivo, que possibilita o desenvolvimento de uma pesquisa na graduação, contém uma organização diferente da Iniciação Científica, pois não há produção de relatório, mas uma banca composta por pesquisadores experientes que debatem os resultados finais da pesquisa. Nesse caso, como atuariam os sistemas da linguagem nesse processo? Essa reflexão poderia ser expandida fora dos limites da graduação e realizada nos processos formativos da pós-graduação, como o Mestrado, por exemplo. Nesse processo de formação do pesquisador, há a produção de um projeto de pesquisa, de um relatório de qualificação, de uma banca de qualificação, de uma dissertação e de uma defesa oral da pesquisa. Ou seja, temos no processo do Mestrado três produções escritas e duas produções orais. Ambos os processos formativos poderiam ser objetivo de uma continuação de nossa pesquisa.

Na dinâmica dos sistemas que encontramos em nossa pesquisa, verificamos uma generalização, proposta pelas estudantes-pesquisadoras, pela qual podemos compreender como elas pensaram e propuseram conceitos sobre as pesquisas que desenvolveram; assim, ensejamos uma problematização de uma das teses do ISD, a qual defende que o uso linguagem permite a construção dos saberes humanos. Levantamos a hipótese de que as generalizações são resultados de abstrações maiores, próximas de um conceito científico tal como entendido nos estudos vigotskianos. A discussão do valor dessas genralizações dentro de determinada área de pesquisa pode ser levada adiante, seja pelas respectivas orientadoras, seja por pesquisadores experientes próximos às pesquisas 
realizadas. Portanto, uma segunda pergunta se faz necessária? Qual a importância das generalizações para as áreas de estudo em que as três pesquisas foram realizadas?

As generalizações encontradas tanto nos relatórios finais de pesquisa quanto nas apresentações orais ocorrem em momento de disjunção, o qual cria um mundo narrado, no qual se recupera a situação de análise dos dados da pesquisa. Assim, ao se criar uma disjunção pela linguagem, as estudantes revivem essa etapa da pesquisa, que lhes permite uma consciência desse momento, possibilitando, por conseguinte, que as generalizações apareçam. Nossa pesquisa, então, aponta para a importância da análise dos tipos de discurso dentro dos dispositivos de formação, a fim de verificar quais raciocínios são criados e o modo com eles podem nos fornecer pistas para a compreenssão dos dispositivos. Desse modo, consideramos de grande importância que outras pesquisas analisem os tipos de discurso do ponto de vista dos raciocínios criados por eles, não somente descrevendo-os por suas características textuais, porém buscando explicações sobre os seus usos.

Além disso, nossa pesquisa mostra que os tipos de discurso têm relação com os mecanismos enunciativos que, segundo Bronckart (2008) e Bota (2011), fazem parte do sistema social. Detectamos a voz do estudante no início do processo da IC, pois percebemos que o tipo de discurso teórico é predominante justamente para a criação de um raciocínio que dê lógica à ideia central. Já no final do percurso, identificamos a voz do pesquisador, que emerge tanto no relatório de pesquisa quanto nas apresentações orais, sobretudo em momentos de relato interativo, isto é, de disjunção da linguagem. Portanto, há uma relação entre a construção textual por meio dos tipos de discurso e a definição de uma voz no texto.

Podemos também inferir que as generalizações podem ser um meio de discutirmos o processo da Iniciação Científica, pois elas advêm das escolhas realizadas desde o início da pesquisa, inclusive elas têm relação com a ideia central que encontramos nos projetos e que perduram até o final da IC, como constatamos nos resumos das apresentações orais de pesquisa. A importância do gênero textual apresentação oral de pesquisa, na criação de um mundo discursivo conjunto e implicado, possibilitando a emergência de generalizações, é um aspecto do dispositivo de formação para o qual a pesquisa chamou atenção. Ademais, destacamos que o gênero textual apresentação oral carece de um trabalho mais sistematizado, uma vez que as três estudantes tiveram 
problemas na sua execução. O trabalho com os gêneros textuais predominantemente escritos é orientado em várias versões e com o auxílio direto das orientadoras, no entanto, muitas vezes, isso não acontece nas apresentações. Nesse sentido, Lousada, Rocha e Guimarães-Santos (2015) apontam que os gêneros textuais orais são muitas vezes negligenciados em meio universitário, carecendo, portanto, de uma atenção maior. Além do mais, dado que a apresentação oral é um gênero textual determinado no final da Iniciação Científica, seria necessária uma sistematização maior desse gênero seja em disciplinas, seja com um trabalho orientado. Nesse sentido, apontamos a pertinência do trabalho que está sendo desenvolvido por alguns pesquisadores do Grupo ALTER-AGE, dentre eles Zani e Bueno (2015). Igualmente, percebemos em nossa pesquisa que, diferentemente dos gêneros projeto e relatório de pesquisa, dos quais são fornecidas informações acerca da sua escrita no edital de IC, nada se diz sobre a apresentação oral, nem mesmo sua estrutura composicional.

As apresentações orais de pesquisa não são registradas dentro do dispositivo de formação da Iniciação Científica da FFLCH, sendo somente os relatórios finais de pesquisa entregues à Comissão de Pesquisa da faculdade. O registro em vídeo para a posterior transcrição das apresentações seria um importante recurso para orientadores e grupos de pesquisa poderem discutir resultados obtidos à luz das generalizações encontradas, além de poderem validá-las e difundi-las de forma mais consistente enquanto um conceito.

A respeito dos relatórios de pesquisa, eles não são disponibilizados nem para a comunidade interna da USP, nem para a comunidade externa, pois não há na universidade uma biblioteca de relatórios finais de pesquisas de Iniciação Científica, o que indica que importantes pesquisas, ainda que de escopo reduzido, estão fora de circulação para a comunidade científica. Também não há na biblioteca da FFLCH um espaço físico de consulta dos trabalhos de IC. Nesse sentido, advogamos a favor da criação de um espaço no qual as pesquisas de IC possam ser disponibilizadas, pois poderiam ajudar na reflexão de outras pesquisas na graduação ou de novas pesquisas de mestrado a partir dos resultados obtidos na IC.

De tudo posto, ressaltamos a importância de se considerar a Iniciação Científica com um espaço efetivamente de formação, no qual é iniciado o desenvolvimento do pesquisador. Como mostramos, os próprios textos escritos pelos estudantes durante a 
pesquisa podem nos revelar aspectos que mostram como eles se apropriam dos gêneros, mas, sobretudo, desenvolvem um pensar científico que é próprio do pesquisador.É comum encontrarmos a IC sendo descrita como um dispositivo de construção do conhecimento em relação aos conteúdos desenvolvidos na pesquisa, porém, apenas mais raramente encontramos uma reflexão sobre a IC como um processo de desenvolvimento do "pensar científico". Portanto, salientamos que esses saberes construídos nesse momento de formação do pesquisador devem de fato ser levados a sério, tanto ao identificá-los, discuti-los e validá-los para uma futura divulgação dos resultados das pesquisas produzidas nesse contexto, pois, ao nosso ver, não se trata de um trabalho de um estudante que não merece destaque, mas, ao contrário, já se trata de um momento inicial do"pensar científico" que começa a ser desenvolvido. 


\section{Referências Bibliográficas}

ADAM, J.M. Les textes: types et prototypes. Paris: Nathan, 1992.296 p.

AGUIAR, L. C. C. O. Perfil da iniciação científica no Instituto de Biofísica Carlos Chagas Filho e no Departamento de Bioquímica Médica da Universidade Federal do Rio de Janeiro. 1997. 119f. Dissertação (Mestrado em Química Biológica) - Centro de Ciências da Saúde/Instituto de Ciências Biomédicas, Universidade Federal do Rio de Janeiro, Rio de Janeiro. 1997.

AUTHIER-REVUZ, J. Algumas considerações sobre modalização autonímica e discurso outro. 2 ed.Rio Grande do Sul: Letras de Hoje, 1999, v. 116.

BAKHTIN, M. M.(VOLOSHÍNOV). Marxismo e filosofia da linguagem: problemas fundamentais do método sociológico da linguagem. 12 ed. Trad. Sob a direção de Michel Lahud e Yara Frateschi Vieira. São Paulo: Hucitec, 2006.

MUNIZ-OLIVEIRA, S. Entrevista com Professor Jean-Paul Bronckart em colaboração com EcaterinaBulea. Revista L@elem (Dis)Curso, São Paulo, v. 3, p. 3-12. 2011.

BAZIN, M. J. O que é a iniciação científica. Revista de Ensino de Física, São Paulo, v.5, n.1, p.81-88, jun.1983.

BENVENISTE, E. Problemas de lingüística geral. São Paulo: Companhia Editora Nacional/ Editora da Universidade de São Paulo, 1976.387 p.

BOTA, C. Savoirs, textes et apprentissages en milieu universitaire: pour une analyse sociodiscursive de travaux de validation pour les cours. 2011. 340 f.Tese (Sciences de l'Éducation) - Universidade de Genebra, Genebra. 2011.

BREGLIA, V.L.A. Graduação, formação e pesquisa: entre os discursos e as práticas. Trivium (Online), Rio de Janeiro,v. 5, p. 1. 2013.

BRIDI, J.C.A. A iniciação científica na formação do universitário. 2004. 135f. Dissertação (Mestrado em Educação) - Faculdade de Educação, Universidade Estadual de Campinas, Campinas. 2004. 
BRONCKART, J.P. Atividade de linguagem, textos e discursos: por um interacionismo sociodiscursivo. 1ed. Trad. Sob a direção de Anna Rachel Machado e Péricles Cunha. São Paulo: Educ, 1999.

.Gêneros textuais, tipos de discursos, e operações psicolinguísticas. Revista de Estudos da Linguagem, Belo Horizonte, v.11, p. 49-69. 2003.

Atividade de linguagem, discurso e desenvolvimento humano. 1 ed. Trad. Sob a direção deAnna Rachel Machado e Maria Lucia Meirelles Matêncio. Campinas: Mercado de Letras, 2006.

.Une science du langage pour une science de l'humain. In:Actes du $1^{\circ}$ Congrès mondial de linguistique française, 2008a, Berlim. CD-ROM.

.Genres de textes, types de discours, et degrés de langue. Revue Texto!: Dialogues et débats, Genève, v. XIII, n. 1, jan. 2008 b.

O agir nos discursos: das concepções teóricas às concepções dos trabalhadores. 1 ed. Trad. Sob a direção deAnna Rachel Machado e Maria Lucia Meirelles Matêncio. Campinas: Mercado de letras, 2008c.

.Le rôle de la maîtrise du langage dans le développement psychologique humain. Revista Nonada, Porto Alegre, v.2, n. 17. 2011.

BOTA, C. Bakhtine démasqué: histoire d'un menteur, d'une escroquerie et d'un délire collectif. Genève: Droz, 2011.629p.

BULEA, E.; BOTA, C.; BRONCKART, J.P. L'épistémologie nébuleuse de l'autoformation. Education permanente, Paris, v. 9, n. 168, p. 31-57. 2006.

CHAVES, M.H.R.O Gênero seminário escolar como objeto de ensino:instrumentos didáticos nas formas do trabalho docente. 2008. Dissertação (Programa de Pós-Graduação em Letras) - Instituto de Letras e Comunicação, Universidade Federal do Pará, Belém, Pará. 2008.

DOLZ, J.; GAGNON, R.; TOULOU, S. Production écrite et difficultés d'apprentissage. Carnets des Sciences de l'éducation, Diptyque,Genève,v. 1, n 13. 2008. 
DOLZ, J. et al. A exposição oral. In: Gêneros orais e escritos na escola. Trad. Sob a direção deRoxane H. R. Rojo e Glaís S. Cordeiro. Campinas: Mercado de Letras, 2004.

EUFRÁSIO, D.A. Traços das formações discursivas do dogma e da investigação em relatórios de pesquisa e de estágio: reflexão sobre o papel da pesquisa na formação docente. 2007.196 f. Mestrado (Programa em Educação) - Universidade de São Paulo, São Paulo. 2007.

FIOR, C.A. Contribuições das atividades não obrigatórias na formação universitária. 2003. 122f. Dissertação (Mestrado em Educação) - Faculdade de Educação, Universidade Estadual de Campinas, Campinas.2003.

FRIEDRICH, J. Lev Vigotski: Mediação, Aprendizagem e Desenvolvimento. Campinas: Mercado de Letras, 2012. 128 p.

FRISTALON, I.; Meuwly-Bonte, M. Conceptions de l'être humain et de son développement dans la recherche et la formation. In: Bota, C.; Cifali, M.; Durand, M. Recherche, Intervention, Formation, Travail. (Orgs).Genève: Cahiers de la Section des Sciences de l'éducation, 2006.

GENETTE, G. Introduction à l'architexte. Paris: Seuil, 1979. 236 p.

KIRSCH, D.B. A. Iniciação Científica na formação inicial de professores: repercussões no processo formativo de egressas do curso de Pedagogia. 2007. $111 \mathrm{f}$. Dissertação (Mestrado em Educação) - Universidade Federal de Santa Maria, Rio Grande do Sul. 2007.

LEITÃO, P.D.V. A apreensão do projeto de pesquisa por alunos do curso de Licenciatura em Letras. 2012. 204 f. Dissertação de Mestrado (Mestrado em Estudos Linguísticos) - Universidade Federal de Pernambuco, João Pessoa.2012.

LEONTIEV, A. Os princípios do Desenvolvimento Psico-intelectual da Criança em Idade Escolar. In: VIGOTSKI, L.S.et al. (Orgs).Psicologia e Pedagogia. São Paulo: Centauro Editora, 2005.

Uma contribuição à teoria do desenvolvimento da psique infantil. In: VIGOTSKII, L. S.; LURIA, A. R.; LEONTIEV, A. N. (Orgs).Linguagem, desenvolvimento e aprendizagem. Trad. Sob a direção de Maria da Pena Villalobos. 11 
ed. São Paulo: Ícone, 2012.p.59-84.

LOUSADA, E. G. Entre o trabalho prescrito e o realizado: um espaço para a emergência do trabalho real do professor. 2006. 333f. Tese (Doutorado em Linguística Aplicada e Estudos da Linguagem) - Pontifícia Universidade Católica de São Paulo, São Paulo. 2006.

A abordagem do interacionismo sociodiscursivo para a análise de textos. In: CARLOS, J.T.; CUNHA, C.; PIRIS, E.L. (Org.). Abordagens metodológicas em estudos discursivos - II EPED. São Paulo: Paulistana, 2010, v. 1.

OLIVEIRA, S.M.; BARRICELLI, E. Gêneros textuais em foco: instrumentos para o desenvolvimento de alunos e professores. Estudos Linguísticos, São Paulo, v. 40, n. 2,p. 627-640, maio-ago. 2011.

ROCHA, S.M. Coerções e liberdades textuais: o relato de viagem na aprendizagem do FLE. Eutomia, Recife, v. 1, p. 581-603. 2014.

SANTOS, T.J.F. La construction du raisonnement dans le texte scientifique. SHS Web of Conferences,v. 8, p. 1063-1080. 2014.

ROCHA, S.M.; GUIMARÃES-SANTOS, L. Gêneros orais, projetos didáticos de gêneros e mobilidade estudantil: perspectivas para ensinar a agir em francês como língua estrangeira. In: BUENO, L.; COSTA-HÜBES, T. C. (Orgs). Gêneros orais e sua transposição didática. Campinas: Mercado de Letras, 2015.

LURIA, A.R. Linguagem e Pensamento. 2 ed. Rio de Janeiro: Civilização Brasileira, 1994.

MAINGUENEAU, D. Análise de textos de comunicação. São Paulo: Cortez Editora, 2008. $240 \mathrm{p}$.

MACHADO, A.R. A Perspectiva interacionista sociodiscursiva de Bronckart. In: MEURER, J.L.; BONINI, A.; MOTTA-ROTH, D. (Orgs). Gêneros: teorias, métodos, debates. São Paulo: Parábola, 2005. p.237-259.

LOUSADA, E.G.; ABREU-TARDELLI, L.S. Planejar gêneros acadêmicos. São Paulo: Parábola, 2005.120 p. 
MASSI, L. Contribuição da iniciação científica na apropriação da linguagem científica por alunos de graduação em Química. 2008. 227 f.Dissertação (Mestrado em Ciências) - Universidade de São Paulo, São Carlos. 2008.

QUEIROZ, S.L. Estudos sobre iniciação científica no Brasil: uma revisão. Cadernos de Pesquisa (Fundação Carlos Chagas. Impresso),Brasília,v. 40, p. 173-197, 2010.

MOTTA-ROTH, D.; HENDGES, G.R. Produção textual na universidade. 1 ed. São Paulo: Parábola Editorial, 2010.165 p.

MUNIZ-OLIVEIRA, S. O trabalho representado do professor de pós-graduação de uma universidade pública. 2011. 220f.Tese (Doutorado em Linguística Aplicada e Estudos da Linguagem) - Pontifícia Universidade Católica de São Paulo, São Paulo. 2011.

OLIVEIRA, K.G. A leitura do outro e a modalidade linguística: impactos no percurso de formação de um jovem pesquisador. 2013. $166 \mathrm{f}$. Dissertação (Mestrado em Educação) - Universidade de São Paulo, São Paulo.2013.

OLIVEIRA, M.K. Linguagem e cognição: questões sobre a natureza da construção do conhecimento. Temas em Psicologia, São Paulo, v. 2, p. 1-9, 1995.

Vigotski e o processo de formação dos conceitos. In: OLIVEIRA, M.K.; DE LA TAILLE, Y.; DANTAS, H.P.;VIGOTSKI, W.(Orgs).Teorias psicogenéticas em discussão. São Paulo: Summus, 1992.

PIRES, R.C.M. A formação inicial do professor pesquisador universitário no Programa Institucional de Bolsas de Iniciação Científica - PIBIC/CNPq e a prática profissional de seus egressos: um estudo de caso na Universidade do Estado da Bahia. 2008. 355 f.Tese (Doutorado em educação) - Universidade Federal do Rio Grande do Sul. 2008.

RIBEIRO, M.A.O. O discurso universitário materializado: aprendendo a escrever o texto acadêmico. 2010. 106 f.Dissertação (Mestrado em Educação) - Universidade de São Paulo, São Paulo.2010.

RODRIGUES, F.S. Análise crítica de gênero de relato de pesquisa sobre escrita. 2008. 139 f.Dissertação (Mestrado em Letras) - Centro de Artes e Letras, Universidade Federal de Santa Maria, Santa Maria.2008. 
SANTOS, S.A. Mudanças na graduação na universidade pública: a nova prática da iniciação científica. 2013. 124f.Tese (Doutorado em Educação) - Universidade Federal de São Carlos, São Carlos. 2013.

SAUSSURE, F. Escritos de Linguística Geral. Trad. Sob a direção de Carlos Augusto Leuba Salum e Ana Lúcia Franco. 12 Ed. São Paulo: Cultrix, 2002. 296 p.

SCHNEUWLY, B. Le 7ème chapitre de "Pensée et langage" de Vigotski: esquisse d'un modèle psychologique de production langagière. Enfance, França,v. 42, p. 23-30. 1989.

SILVA, W.R.; SILVA, L.H.O. Como fazer relatórios de pesquisa: investigações sobre ensino e formação de professor de língua materna. São Paulo: Mercado de Letras, 2010.104 p.

SMOLKA, A.L.B. A Concepção de linguagem como instrumento: um questionamento sobre as práticas discursivas e educação formal. Temas em Psicologia, São Paulo, v. 2, p. 11-21, 1995.

SOUZA, M.B. A influência dos conteúdos e atividades de iniciação científica para o estímulo ao desenvolvimento do pensamento crítico em Ciências Contábeis: pesquisa com coordenadores de curso na cidade de São Paulo. 2005. 131 f.Dissertação (Mestrado em Controladoria e Contabilidade Estratégica) - Centro Universitário Álvares Penteado, São Paulo.2005.

SWALES, J.M. Genre Analyses: English in Academic and Research Settings. Cambridge: CUP, 1990.274 p.

TULESKI, S.C. Vigotski e a construção de uma psicologia marxista. 2 ed. Maringá: EDUEM, 2008.207 p.

VERSIANI, F.; SUZIGAN, W. O processo brasileiro de industrialização: uma visão geral. Série Textos Didáticos, Brasília, n. 10. 1990.

VOLOCHINOV, V. A construção da enunciação e outros ensaios. Trad. Sob a direção de João Wanderley Geraldi. São Carlos: Pedro \& João Editores, 2013.273 p. 
VIGOTSKII, L.S. Aprendizagem e desenvolvimento intelectual na idade escolar. In: VIGOTSKII, L. S.; LURIA, A. R.; LEONTIEV, A. N. (Orgs).Linguagem, desenvolvimento e aprendizagem. 7 ed. São Paulo: Ícone, 2001. p. 103-119.

Psicologia Pedagógica. Trad. Sob a direção de Paulo Bezerra. São Paulo: Martins Fontes, 2004.576 p.

A formação social da mente. São Paulo: Martins Fontes, 2007.224 p.

A Construção do pensamento e da linguagem. Trad. Sob a direção de Paulo Bezerra. São Paulo: Martins Fontes, 2009.159 p.

WEINRICH, H. Le temps. Paris: Seuil, 1973.256 p.

ZAKON, A. Qualidades desejáveis na iniciação científica. Ciência e Cultura, Campinas, v. 41, n.9, p.868-877.1989.

ZANI, J.B.; BUENO, L. Os gêneros orais no programa ler e escrever do Estado de São Paulo. Revista Intercâmbio, São Paulo, v. XXVI, p. 114-128. 2012. 


\title{
Anexos
}

\section{PROJETOS DE PESQUISA}

\author{
ESTUDANTE 1
}

Projeto de Iniciação Científica:

\section{De Itabira para o mundo: levantamento sobre a recepção da poesia de Carlos Drummond de Andrade na França}

\section{Resumo}

Carlos Drummond de Andrade, poeta mineiro nascido em 1902, produziu grande obra literária que passou pela prosa e pela poesia. Seus textos e poemas, que geralmente abordam questões cotidianas e são compostos de vocabulário simples, ganharam grande repercussão no Brasil, e, ao mesmo tempo, possuem dimensão universal, já que englobam pensamentos filosóficos que definem a existência humana.

É importante, portanto, que uma obra tal qual a de Drummond seja difundida em outras línguas, conhecida em outras culturas, expandida a mais olhares. Para isso, a tradução mostra-se elemento essencial, já que permite o acesso de um maior número de leitores aos textos - mais especificamente, nesse trabalho proposto, aos poemas de Carlos Drummond de Andrade.

Assim, buscaremos fazer um levantamento da obra do poeta brasileiro traduzida na França, país que muito influenciou Drummond em diversos aspectos, como a cultura e a literatura. Para tanto, deverão ser utilizados textos teóricos a respeito da recepção cultural da tradução, além de críticas sobre a obra drummondiana, tanto em francês quanto em português.

O objetivo da pesquisa que aqui se propõe é reunir material que possa formar uma crítica da obra de Carlos Drummond de Andrade na França, conhecer o modo como o poeta foi recebido em língua francesa, como é lida sua poesia através de outra perspectiva além da brasileira.

\section{Introdução}

Muitas são as linhas e entrelinhas que compõem a obra de Carlos Drummond de Andrade, escritor brasileiro nascido em 1902 no interior do Estado de Minas Gerais. É a partir de uma pacata cidade interiorana, chamada Itabira, que surge uma das grandes obras poéticas da história do país: entre 1930 e 1987, Drummond publicou diversos livros de poemas e contos, 
deixando ainda algumas obras inéditas, inclusive traduções publicadas somente após sua morte (cf. GUIMARÃES, 2011, p. 7).

A grande repercussão de sua obra no contexto brasileiro explica-se por aspectos linguísticos, históricos (cf. LUCCHESI, 2009) e também estéticos e sociais. No que se refere à Linguística, segundo Lucchesi (2009, p. 12), está presente na poesia de Drummond "um Brasil linguístico, com suas novas regências, neologismos oportunos, conjugações inesperadas". Em seguida, a extrema agitação do contexto histórico em que se deu a escrita da obra drummondiana é evidente em diversos poemas: em proporções mundiais, as Grandes Guerras, sua iminência e suas consequências provocam no poeta uma grande perturbação literária, o que inspirou publicações como "Sentimento do Mundo" (DRUMMOND, 1940); no que se refere ao Brasil, a ditadura que se inicia em 1964 também é fator importante em sua poesia. Quanto às características estéticas do poeta, a grande influência modernista oriunda do Movimento de 1922 faz-se notar nos versos escritos por Drummond - em sua grande maioria, não são compostos em métrica pré-definida, sendo alguns poemas definidos como "poemas em prosa", ou "prosa poética", típicos do movimento que rompeu com as regras clássicas da literatura. Além disso, são evidentes as suas preocupações sociais, sobretudo em relação a seu próprio país. Essas preocupações, que parecem ser um dos grandes motores de sua escrita, podem ser reconhecidas na leitura de diversos poemas, dentre os quais "Morte do Leiteiro" (DRUMMOND, 2009, 178) e "A flor e a náusea" (DRUMMOND, 2009, p. 36).

Com tais informações, pode-se pressupor um caráter concreto nos versos do poeta mineiro, já que fatos verídicos e acontecimentos de proporções nacionais e mundiais permeiam sua obra. Contudo, não é possível cristalizá-la dessa maneira, porque a matéria de que trata a poesia de Drummond é demasiado profunda e vai além das sólidas questões históricas e sociais, percorrendo, além do universo material propriamente dito, o difuso e instável universo humano. De modo que uma das maiores preocupações em torno da obra de Drummond relaciona-se aos aspectos coletivos e individuais que constituem seus poemas. Dessa forma, sua leitura proporciona a exploração de vieses diversos, permite a visita concomitante ao modesto e ao sublime, em uma composição entremeada de vocabulário simples e regional, questões intelectuais e filosóficas, temas cotidianos e questionamentos universais.

É justificável, portanto, a grande difusão da obra de Carlos Drummond de Andrade, considerado por muitos um dos maiores poetas que o Brasil já teve (CF ?????). Sua poesia está presente, sob forma de exemplo poético, tanto na escola quanto na universidade, além de compor o que se chama de sabedoria popular. Segundo Lucchesi (2009, p. 12), "boa parte de nossa forma de sofrer o mundo já se tornou drummondiana".

Naturalmente, tamanha recepção nacional à obra de um artista repercute internacionalmente, atingindo e interessando leitores em outros lugares, de culturas diferentes. Na pesquisa que aqui se apresenta, o objetivo é levantar e compreender a recepção dos poemas de Drummond em língua francesa, mais particularmente na França.

\section{Fundamentação teórica}

A tradução de uma poesia composta de tão notáveis e complexos elementos tal como a de Drummond torna-se um processo delicado e exige critérios outros que a simples relação direta entre palavras, porque tange não só à linguística das línguas em questão, mas aos componentes culturais de cada uma delas. Segundo Azenha Jr. (1999, p. 28), "a linguagem deve ser vista aqui como elemento integrante de uma cultura, como uma de suas formas de manifestação mais poderosas". Além disso, sabe-se que é grande a discussão acerca da dificuldade da tradução poética, que exige do tradutor muito além do conhecimento linguístico, já que "a mensagem de um poema é muitas vezes implícita e conotativa ao invés de explícita e 
denotativa, originando diferentes leituras e múltiplas interpretações" ${ }^{1}$ (cf. CONNOLLY, 1998, 170, tradução nossa).

Todos esses aspectos ganham, portanto, ainda mais complexidade quando se trata dos poemas de Carlos Drummond de Andrade, pelas diversas razões já expostas acima (cf. Introdução). Podem tornar-se ilusoriamente dubitáveis, desse modo, as possibilidades da tradução de um poeta que, ao mesmo tempo em que se questiona filosoficamente sobre o mundo em que vive, utiliza um vocabulário regional, imagens de seu cotidiano e referências à sua origem interiorana. É tarefa árdua a representação de tal obra em outra língua que não o português brasileiro, porque impõe ao tradutor um percurso que atravessa a língua original e a língua alvo, os contextos históricos dos quais surge e nos quais se pretende disseminá-la e, sobretudo, as referências culturais de cada um desses espaços.

Tais referências culturais transformam a tradução da obra de Drummond em trabalho merecedor de aguda atenção, já que estenderá a obra a outros horizontes, e atingirá outros leitores, aqueles que receberão a versão traduzida. A pesquisa que aqui se propõe buscará justamente compreender o modo como leitores específicos - os franceses - têm acesso à obra do poeta brasileiro, e como se deu a expansão de sua obra literária no país que o influenciou e inspirou. Para isso, deve-se realizar o levantamento dos poemas traduzidos para a língua francesa, baseando-se em textos teóricos sobre a recepção cultural da tradução e em textos propagados pela crítica literária, além de se estudar o contexto em que foram traduzidos os poemas em questão.

Para auxiliar os estudos em relação à recepção cultural da tradução, serão referidos durante a pesquisa nomes encontrados num primeiro levantamento bibliográfico sobre o tema, como Mona Baker (1998), organizadora da Routledge Encyclopedia of translation studies (1998), em que termos relacionados à tradução podem ser esclarecidos; Jean-Louis Cordonnier (1995), que trabalha as relações de linguagem, cultura e tradução em Traduction et Culture (1995); e Hans Robert Jauss, sobre recepção da literatura em Pour une esthétique de la réception (1978). Além desses, serão importantes aos estudos propostos neste projeto as ideias de Henri Meschonnic (2010) e de Mário Laranjeira (2003) para a tradução de poesia e também as críticas (tanto brasileiras quanto francesas) da poesia de Carlos Drummond de Andrade. Quanto às últimas, muitos são os textos críticos a respeito da obra drummondiana em português brasileiro. Já em busca inicial, críticos como Pilati (2009) e Lucchesi (2011) auxiliaram a compreensão da linha literária e do estilo de Drummond. Quanto à crítica em francês sobre o poeta brasileiro, uma primeira busca detectou uma reunião de textos brasileiros traduzidos para a língua francesa: $L a$ Rose du Peuple: la poésie de Carlos Drummond de Andrade (2005), livro organizado por Toledo, Miranda e Libânio e que contém textos de grandes críticos literários do Brasil. Além desse, os prefácios das duas antologias de Carlos Drummond de Andrade em francês localizadas até o presente momento promoveram um primeiro contato com a recepção crítica do poeta brasileiro na França. Evidentemente, outros críticos literários da obra do poeta e outros teóricos que trabalham a questão da recepção cultural de tradução deverão se reunir aos autores aqui apresentados, de modo a acrescentar à pesquisa um embasamento teórico que possibilitará o levantamento proposto neste projeto.

No mais, destacam-se como principais tradutores da poesia de Carlos Drummond de Andrade para o francês Didier Lamaison, que publicou uma coletânea de poemas em Poésie (1990), e Ariane Witkowski, que também traduziu alguns poemas de Drummond publicados em Mort dans l'avion \& autres poèmes (2005). Para a pesquisa, o entorno dessas traduções será investigado, levando-se em consideração o contexto cultural em que foram produzidas, as marcas culturais que nelas se afirmam e os aspectos das línguas (original e alvo) que influenciam tais traduções.

Além de Lamaison e Witkowski, outros nomes isolados de tradutores da poesia drummondiana foram encontrados em uma primeira busca online ${ }^{2}$, mas ainda faz-se necessário

\footnotetext{
1 "the message of a poem is often implicit and connotative rather than explicit and denotative, giving rise to different readings and multiple interpretations" (cf. CONNOLLY, 1998, 170).
} 
uma pesquisa mais detalhada a respeito. Assim sendo, e uma vez que atualmente não é possível desprezar a força da Internet, pode ser importante para o levantamento proposto considerar também comentários online, blogs, sites relacionados ao autor e à tradução de poesia, que podem ser fonte de traduções não publicadas e, portanto, menos difundidas no meio acadêmico.

\section{Objetivos}

O objetivo geral da pesquisa que aqui se propõe é o levantamento sobre a recepção da tradução de poemas de Carlos Drummond de Andrade na França.

\section{Objetivos específicos}

- levantamento de publicações impressas ou eletrônicas de obras completas, coletâneas ou textos isolados do autor traduzidos na França, com especial atenção aos textos - prefácios, posfácios, críticas, artigos, entre outros - que nelas constam;

- levantamento de textos brasileiros sobre Drummond traduzidos na França;

- levantamento de pesquisas acadêmicas sobre Drummond realizadas na França;

- levantamento de textos que envolvem o autor e sua obra em jornais e revistas especializadas.

Justificativa

A obra de Carlos Drummond de Andrade tem suas raízes, evidentemente, fincadas em solo brasileiro. Sua poesia, entretanto, retrata grande parte do século XX (cf. LUCCHESI, 2009, p. 12), percorre importantes eventos em dimensão mundial e aborda aspectos relativos à realidade humana - ao percorrer os poemas de Drummond, nota-se um crescendo de matéria, que se inicia nos elementos mais humildes e que se abre a grandes reflexões. É, portanto, de grande proveito o estudo de sua obra pura, daquilo que, deixado pelo poeta, perpetua-se ao longo da história literária. Ainda mais proveitoso, porém, pode ser o aprofundamento daquilo que se propaga e se multiplica a partir de tal obra - o impacto que ela causa, o modo como atinge o público em outra época, em outra sociedade, em outra cultura e, mais especificamente no caso do presente projeto, o modo como é lida a tradução da poesia drummondiana, essencialmente brasileira, no contexto sociocultural francês.

Há, aliás, uma relação intensa do poeta brasileiro em relação à França e à língua francesa. Segundo Lamaison (1990, p. XIV), Drummond “[...] demonstrou com frequência o desejo de ser traduzido e reconhecido na França. Também nossa cultura [a cultura francesa] não devia pouco a ele ${ }^{3 \text { ". }}$. A dívida à qual se refere Lamaison deve-se ao fato de que Drummond também se voltou à tradução de maneira geral, de modo que se podem encontrar algumas traduções assinadas por ele, sobretudo do francês para o português brasileiro - entre elas, notam-se Les fourberies de Scapin, de Molière, Les liaisons dangereuses, de Laclos, Les Paysans, de Balzac, e Albertine Disparue, de Proust, entre outros poemas e textos em prosa (cf. LAMAISON, 1990, p. XV). Por isso, mostra-se de grande valor o levantamento sobre a recepção da poesia de Drummond em um país que difere em diversos aspectos da nação em que foi escrita sua obra. Esta, cujos valores possuem grandes proporções, merece atenção não só dos falantes do português, mas de leitores interessados em uma literatura de alta qualidade, que

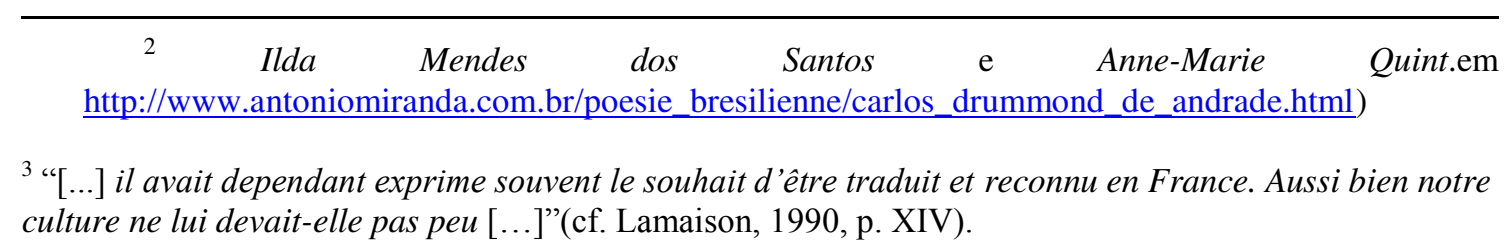


expressa algo além dos sentimentos do poeta, atingindo patamares filosóficos e existenciais. Seguindo, assim, as proporções de sua essência, a poesia drummondiana deve ser expandida, irradiada, vista por mais olhos e, para tanto, a tradução mostra-se elemento essencial.

Jauss (1978) propõe a definição de uma "obra como resultado da convergência do texto e de sua recepção, e, portanto, como uma estrutura dinâmica que só pode ser entendida em suas 'concretizações' históricas sucessivas"4 (JAUSS, 1978, p. 269, tradução nossa). Assim, é importante o modo como os receptores com outras referências culturais reagem à leitura das obras estrangeiras. Por isso, o levantamento sobre a recepção da poesia de Drummond na França $^{5}$ pode ajudar os estudos da recepção de obras literárias em outras línguas que não a original, e, sobretudo, os estudos da própria obra de Carlos Drummond de Andrade, já que suas extensões, suas expansões para a língua francesa serão levantadas durante a pesquisa que aqui se propõe.

O levantamento acerca da recepção dos poemas de Carlos Drummond de Andrade na França pode trazer grandes benefícios no que se refere aos estudos relacionados à cultura, porque estabelece um paralelo entre dois diferentes universos culturais, possibilitando assim o confronto comparativo entre ambos. Tal confronto representa muito, já que um objeto pode ser mais bem analisado e reconhecido quando, para isso, for posicionado ao lado de outro e a ele relacionado. É válido lembrar que são fortes as relações de Drummond com a cultura e a literatura francesas, que muito influenciaram e inspiraram sua poesia. Sendo assim, certamente pode-se conhecer mais profundamente a cultura brasileira - tanto do século XX quanto do século XXI, séculos que englobam a existência da poesia drummondiana -, em seus mais variados aspectos, quando se confronta com ela a cultura francesa, ou seja, pelo modo como esta última lê o poeta brasileiro. Também pode ser útil a tais estudos o cotejo de diversas culturas através de prismas literários e linguísticos, já que estes colaboram com a diversificação de pontos de vista, funcionando como um outro ângulo à investigação cultural.

Além disso, a pesquisa pode acrescentar muito às investigações tradutológicas. O estudo da recepção de uma obra por outra cultura proporciona a observação a fundo dos aspectos que compõem as difíceis e variadas linhas de raciocínio do ato tradutório, podendo conduzir muito além de uma análise contrastiva do original e sua tradução, sem, no entanto, excluir este viés. Por isso, e considerando a cultura como um conjunto de propriedades linguísticas, sociais, comportamentais e etc., é produtivo para a área dos Estudos de Tradução o investimento em tal enfoque, que se ampara em diversos pontos de vista, e por ser também abrangente, não exclui nenhuma direção de estudos.

No que tange às áreas de estudos da Faculdade de Letras, a pesquisa científica que se desenvolverá a partir deste projeto funciona como limiar que une os Estudos Literários, Linguísticos e Tradutológicos em francês, Área do Departamento ao qual estão vinculadas a candidata e a orientadora - trata-se de um triângulo que abrange a poesia como estilo literário, digno de grande estética, imagens, rimas e ritmo; funciona também como um verdadeiro painel de aspectos linguísticos que revelam, por exemplo, o vasto vocabulário drummondiano e o modo como o poeta trata sons e signos; e, sobretudo, serve à área de Tradução, que ligará todos estes elementos afim de identificar e reconhecer os inúmeros processos que envolvem a tradução e a recepção de poemas como os de Carlos Drummond de Andrade em francês.

Do mesmo modo, a pesquisa proporcionará à sua proponente um crescimento acadêmico significativo, já que a introduzirá no universo da pesquisa científica, trará aperfeiçoamento às suas noções da língua e da cultura francesas, além de oferecer material para ampliar seus conhecimentos em literatura e cultura brasileiras.

\footnotetext{
4 "l'oeuvre comme résultant de la convergence du texte et de sa réception, et donc comme une structure dynamique qui ne peut être saisie que dans ses 'concrétisations' historiques successives " (Jauss, 1978, p. 269).

${ }^{5}$ Até o momento, foram encontrados somente um artigo sobre a recepção de Carlos Drummond de Andrade na Holanda (cf. POS, 2009) e duas introduções de livros que reúnem alguns poemas traduzidos para a língua francesa.
} 


\section{Material e métodos}

O material inicial utilizado para a pesquisa envolve diversos suportes, que dão versatilidade à busca. São eles a própria obra de Carlos Drummond de Andrade, textos teóricos - tanto em português quanto em francês, ou em outras línguas - que envolvem a obra do poeta, prefácios escritos por estudiosos brasileiros e franceses, textos teóricos que introduzem o universo da recepção e da tradução cultural e os poemas de Drummond traduzidos em francês.

Além disso, a internet é um ambiente valioso para uma pesquisa inicial, sendo um mecanismo de busca ágil e vasto que pode proporcionar descobertas inacessíveis em outros suportes. Para tanto, será essencial o uso de mecanismos de busca online como bibliotecas virtuais, blogs e sites voltados à literatura e à tradução, nos quais a possibilidade de expansão de textos traduzidos é muito grande.

A busca inicial é, portanto, mais física, ou seja, exige pesquisa em bibliotecas e livrarias nacionais e francesas, além de editoras que tenham publicado as traduções de Carlos Drummond de Andrade. A esse material inicial, serão acrescidos os materiais resultantes do levantamento, já que, de fato, o material da pesquisa é a própria busca e os mecanismos nela implicados.

A pesquisa proposta neste projeto deve se apoiar em teóricos da recepção cultural da tradução, como os já citados (Cf. Fundamentação teórica) Cordonnier (1995), Jauss (1978) e Azenha Junior (1999) para formar base teórica ao estudo da recepção da poesia de Carlos Drummond de Andrade na França. Também servirão de apoio os prefácios de antologias publicadas tanto em português brasileiro quanto em francês, além de textos críticos sobre a obra do poeta brasileiro e sua recepção em outras culturas.

A realização do levantamento da obra drummondiana na França dependerá - além da já explicitada busca física - dos materiais de informática localizados no Centre de Documentation da Área de Língua Francesa da Faculdade de Letras da Universidade de São Paulo, ou seja, computadores, impressoras, scanners e etc. Tais materiais já auxiliaram uma busca inicial que permitiu a localização dos sites contendo traduções isoladas de poemas de Drummond (referidos na Fundamentação teórica) e também proporcionaram buscas em bibliotecas online, a fim de investigar a propagação de livros que concernem à poesia do poeta brasileiro.

Também em busca onlline através do Dedalus da Universidade de São Paulo, foi encontrada uma tese de doutoramento que poderá servir de ajuda à pesquisa que aqui se propõe: Lúcia Peixoto Cherem, em Um olhar estrangeiro sobre a obra de Clarice Lispector: Leitura e recepção da autora na França e no Canadá (Québec) (2003), realizou um levantamento da recepção da obra de Clarice Lispector em língua francesa. Nesse trabalho, Cherem localiza as traduções e as críticas relacionadas à obra de Lispector, e analisa o contexto em que se realizou a recepção da obra clariciana.

Do mesmo modo, a pesquisa que aqui se propõe buscará, com o auxílio de todos os materiais enumerados acima, encontrar e reunir materiais que possibilitem o levantamento da recepção da obra de um poeta importante à literatura e à cultura brasileiras como Carlos Drummond de Andrade, que, aliás, como já referido (cf. Justificativa), muito se interessava pela França, buscando por muito tempo inspiração em sua cultura e em sua língua.

\section{Metodologia}

Etapa 0 - Levantamento bibliográfico sobre recepção. Textos teóricos para suporte dos estudos da recepção. 
Etapa 1 - Levantamento das traduções francesas da poesia de Carlos Drummond de Andrade. Etapa 2 - Levantamento dos textos teóricos brasileiros sobre o poeta traduzidos para o francês. Etapa 3 - Levantamento de textos impressos ou eletrônicos que possam constituir uma crítica da obra traduzida.

Etapa 4 - Comentários analíticos sobre alguns aspectos do levantamento efetuado sobre a recepção da obra na França baseados nas leituras teóricas efetuadas.

Etapa 5 - Publicação dos resultados.

\section{Específicação de métodos}

Etapa 0 - Buscaremos textos teóricos sobre a recepção em geral da literatura em países estrangeiros, para obter base teórica que auxilie o levantamento da recepção poética de Carlos Drummond de Andrade no contexto francês. Após entendimento do que vem a ser recepção e a forma pela qual ela se expressa (críticas, estudos acadêmicos, textos publicados em revistas etc.), será possível traçar uma estratégia de busca sobre a recepção de Drummond na França.

Etapa 1 - A partir da base teórica sobre recepção de literatura em língua estrangeira adquirida na Etapa 0, poderemos dar início ao levantamento da poesia de Carlos Drummond de Andrade traduzida na França. Nessa etapa, o trabalho será mais prático, ou seja, faremos uma busca em bibliotecas virtuais e físicas, em suportes eletrônicos como sites e blogs para adquirir material que possa constituir uma obra traduzida do poeta.

Etapa 2 - A Etapa 2 dará início à organização de uma crítica da poesia de Carlos Drummond de Andrade na França. Para tanto, buscaremos textos críticos brasileiros, que analisem a obra do poeta, traduzidos para o francês.

Etapa 3 - Na Etapa 3 também buscaremos a organização da crítica entorno da poesia de Drummond. Nessa fase, porém, levantaremos textos críticos escritos diretamente em francês, afim de formar uma possível crítica da obra traduzida do escritor.

Etapa 4 - Os estudos e levantamentos realizados em todas as Etapas anteriores permitirão na Etapa 4 a realização de uma análise sobre a obra de Carlos Drummond de Andrade traduzida para o francês e sobre a crítica realizada a partir dessa tradução. Nessa fase, serão explorados os conhecimentos e as informações adquiridas ao longo da pesquisa.

Etapa 5 - Após a realização de todas as etapas que constituirão a pesquisa proposta, serão publicados os resultados dela provenientes...(Como? Onde?)

\section{Cronograma}




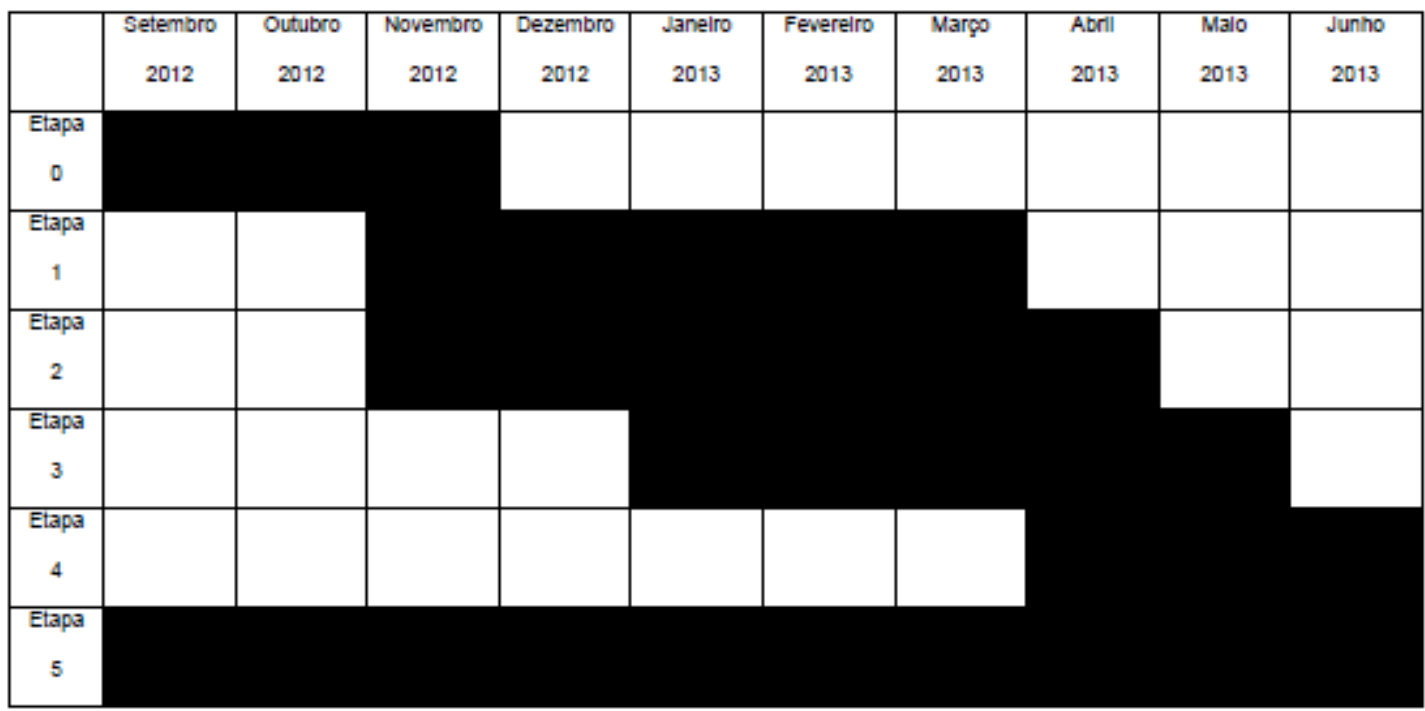

Bibliografia

ANDRADE, Carlos Drummond de. Antologia Poética. 64ª ed. Rio de Janeiro: Record, 2009.

ANDRADE, Carlos Drummond de. Mort dans l'avion \& autres poèmes. Tradução de Ariane Witkowski. Paris: Éditions Chandeigne, 2005.

ANDRADE, Carlos Drummond de. Poesia Traduzida. Org: Augusto Massi e Júlio Castañon Guimarães. São Paulo: Cosac Naify, 2011.

ANDRADE, Carlos Drummond de. Poésie. Tradução de Didier Lamaison. Editions Gallimard, 1990.

AZENHA JUNIOR, J. Tradução técnica e condicionantes culturais: primeiros passos para um estudo integrado. São Paulo: Humanitas; FFLCH-USP, 1999.

CHEREM, Lúcia Peixoto. Um olhar estrangeiro sobre a obra de Clarice Lispector: Leitura e recepção da autora na França e no Canadá (Québec). São Paulo, 2003. Tese (doutoramento) USP.

CORDONNIER, Jean-Louis. Traduction et culture. Editions Didier, 1995.

JAUSS, H.R. Pour une esthétique de la réception. Tradução do alemão de Claude Maillard. Paris: Editions Gallimard, 1978.

LARANJEIRA, Mário. Poética da tradução: Do sentido à significância. São Paulo, Editora da Universidade de São Paulo, 2003.

MAROTE, J. T. D’Olim. (org.). Minidicionário francês-português/português-francês. $6^{\mathrm{a}} \mathrm{ed}$. São Paulo: Ática, 1999.

MESCHONNIC, Henri. Poética do Traduzir. Tradução de Jerusa Pires Ferreira e Suely Fenerich. São Paulo: Perspectiva, 2010. 
PILATI, Alexandre. A nação drummondiana: quatro estudos sobre a presença do Brasil na poesia de Carlos Drummond de Andrade. Rio de Janeiro: 7Letras, 2009.

POS, Arie. Drummond em holandês: O cachimbo do poeta e o tabaco do tradutor. Em: Tradução em Revista, nº 6, 2009.

TOLEDO, D.; MIRANDA, W. M.; LIBÂNIO, C (coord.). La Rose du Peuple: la poésie de Carlos Drummond de Andrade. Belo Horizonte: Edições Margens/ Márgenes, Editora UFMG, 2005.

(http://www.antoniomiranda.com.br/poesie bresilienne/carlos_drummond de andrade.html)

(http://www.caligrafias-iberes.com/article-23652917.html)

ESTUDANTE 2

UNIVERSIDADE DE SÃO PAULO

FACULDADE DE FILOSOFIA, LETRAS E CIÊNCIAS HUMANAS

DEPARTAMENTO DE LETRAS MODERNAS - ÁREA DE FRANCÊS

\section{PROJETO DE INICIAÇÃO CIENTÍFICA}




\title{
Desenvolvimento de competências leitoras em francês pela abordagem da intercompreensão nos cursos de Práticas de Leitura do Centro de Línguas da FFLCH
}

\author{
Aluna: Estudante 2 \\ $\mathbf{N}^{\circ}$ Usp: $\operatorname{xxxxxx}$
}

OUTUBRO 2012

\section{Resumo do Projeto:}

O objetivo desta pesquisa é discutir os pressupostos metodológicos que orientam as atividades propostas para os módulos iniciais do Curso Práticas de Leitura em Francês e a articulação com os conceitos de intercompreensão (daqui em diante, IC), por meio da aplicação de atividades de leitura em diferentes línguas românicas. Como a metodologia da IC pode contribuir para o desenvolvimento de competências leitoras em francês? Quais atividades proporcionam esse desenvolvimento? A concepção, aplicação, análise dos resultados e avaliação de atividades em IC no contexto citado permitirá a reformulação conceitual e metodológica dos cursos de leitura em língua estrangeira do Centro de Línguas, numa perspectiva de construção de uma política linguística de IC na Universidade de São Paulo, principalmente no que se refere aos programas de cursos, metodologia utilizada, níveis de progressão em leitura e formação de professores.

\section{Introdução}

O ensino instrumental de línguas estrangeiras surgiu e se desenvolveu na América Latina, a partir de 1970, em resposta a uma demanda de candidatos a cursos de pós-graduação que 
deveriam prestar exames de proficiência em língua estrangeira ou de alunos de cursos de línguas que tinham como objetivo aperfeiçoar suas competências leitoras para compreensão de bibliografia específica relacionada a pesquisas em desenvolvimento ou, ainda, para aqueles que visavam elaborar apresentações orais em congressos e colóquios em língua estrangeira (Pietraróia, 1997, Albuquerque-Costa, 1999, Mourlhon-Dallies, 2008). Pesquisas na área do ensino de leitura em língua estrangeira permitiram a reflexão sobre as competências e estratégias a serem desenvolvidas para a compreensão de textos, visando a formação progressiva do leitor na língua alvo (Giasson, 1990; Jouve, 1993; Pietraróia, 1997; Chartier, 1998). Mais recentemente, no contexto da didática das línguas a noção de plurilinguismo, a formação pela intercompreensão de línguas românicas têm se mostrado como fundamental no contexto de desenvolvimento de competências de leitura. Partindo do princípio de que num contexto plurilíngue as línguas "se inter-relacionam e interagem", a abordagem pela intercompreensão desenvolve a compreensão escrita de falantes de diferentes línguas, cada um interagindo em sua língua materna. No contexto aqui trabalhado, a intercompreensão se dá entre línguas românicas - espanhol, francês, italiano, português e romeno - valendo-se sempre das proximidades linguísticas trazidas pela "raiz latina" comum a todas elas. Baseando-nos nesses estudos, na qualidade de professora dos Cursos de Práticas de Leitura em Francês do Centro de Línguas da FFLCH e na experiência como aluna participante de uma sessão Galanet - equipe De Loin, da sessão "Verba Volant Societatis de set-dez 2011 (dossier de presse "Os Clichés")" - projeto europeu que tem por objetivo uma pedagogia de intercompreensão entre línguas românicas, por meio de uma plataforma na internet, em que participantes de várias nacionalidades interagem por meio de fóruns e chats (Manual Galanet, 2001) - foi possível estabelecer comparações entre o ensino da leitura e os novos caminhos metodológicos trazidos pelas políticas de plurilinguismo e intercompreensão. Algumas estratégias de leitura, comuns aos dois contextos aqui estudados, partem da exploração de "territórios de transferência em potencial" (DEGACHE, 2012) entre as línguas envolvidas, como na exploração das transparências (palavras cognatas nas línguas vizinhas), no trabalho das analogias e transferências "interlinguísticas" e no acesso aos conhecimentos anteriores de outras línguas. Por meio das atividades de leitura pela intercompreensão no Curso de Práticas de Leitura em francês pretendemos propiciar uma reflexão sobre a "desconstrução" do horizonte de expectativa inicial (com foco na língua francesa), para uma "reconstrução" de competências de leitura em contextos plurilíngues.

\section{Objetivos}

Por meio da análise dos pontos convergentes entre o ensino da leitura em francês nos cursos de Práticas de leitura do CL-USP e as teorias de IC entre línguas românicas e visando contribuir para uma real implantação de políticas de plurilinguismo e intercompreensão no Centro de Línguas, esta pesquisa tem por objetivos:

a) Analisar em que medida as estratégias de leitura trabalhadas nos cursos do CL são equivalentes às utilizadas nos contextos de intercompreensão, como o Galanet.

b) Identificar os procedimentos cognitivos e metacognitivos ativados nos processos de construção de sentido dos textos durante as aulas de PLF.

c) Aplicar, analisar e avaliar a realização das atividades pela intercompreensão no contexto do ensino da leitura em língua francesa dos cursos do CL

d) Contribuir para a reformulação dos programas de PLF e para a formação de professores do Centro de Línguas pela intercompreensão de línguas românicas.

\section{Metodologia}


A primeira parte da pesquisa partirá de um levantamento teórico dos pressupostos que orientam as atividades de leitura em francês realizadas nos cursos de Práticas de Leitura em Francês da USP (PLF-USP). Somado a isso, o estudo da noção de plurilinguismo e das teorias e projetos sobre intercompreensão entre línguas românicas (CHAVAGNE, 2006; DEGACHE, 2006), fundamentando a análise comparativa dos dois contextos em questão: cursos de Práticas de Leitura em Francês (situação bilíngue) e Galanet (situação plurilingue). A segunda parte do projeto consiste na concepção, aplicação e avaliação de atividades envolvendo as línguas românicas em uma turma de Práticas de Leitura em Francês, durante o módulo inicial do curso. Desta forma, serão coletados dados a partir da observação do desempenho da turma em cada uma das atividades propostas. A aplicação de tais atividades se justifica como parte da conscientização do processo de leitura rumo à construção de sentido, dado que este não depende apenas do conhecimento linguístico, mas envolve outros elementos, como a interação de experiências de linguagem do leitor e seus conhecimentos de mundo (PIETRAROIA ,1997), entre outros aspectos.

\section{Cronograma}

\begin{tabular}{|c|c|c|c|}
\hline Out/nov/dez 2012 & Jan/fev/mar 2013 & Abril/mai/jun 2013 & $\begin{array}{c}\text { Jul/ago/set } \\
2013\end{array}$ \\
\hline $\begin{array}{l}\text { - Embasamento teórico: } \\
\text { ensino e aprendizagem } \\
\text { da leitura em língua } \\
\text { estrangeira e } \\
\text { Plurilinguismo/ } \\
\text { intercompreensão; } \\
\text { fichamento de textos e } \\
\text { reuniões de orientação } \\
\text { - análise dos pontos } \\
\text { convergentes e } \\
\text { divergentes entre as } \\
\text { metodologias }\end{array}$ & $\begin{array}{l}\text { - Levantamento e análise } \\
\text { das atividades iniciais de } \\
\text { um curso de leitura em } \\
\text { francês do CL } \\
\text { - elaboração das } \\
\text { atividades a serem } \\
\text { aplicadas para uma } \\
\text { turma de PLF com base } \\
\text { nas teorias de IC - } \\
\text { critérios e categorias de } \\
\text { análise dos pressupostos } \\
\text { teóricos das atividades }\end{array}$ & $\begin{array}{l}\text { - Aplicação das } \\
\text { atividades e início da } \\
\text { análise dos resultados } \\
\text { obtidos ; } \\
\text { - Elaboração de texto } \\
\text { teórico acerca dos } \\
\text { resultados obtidos - A } \\
\text { contribuição da } \\
\text { Intercompreensão aos } \\
\text { cursos de leitura em } \\
\text { língua estrangeira. } \\
\text { - Relatório parcial }\end{array}$ & $\begin{array}{l}\text { - Continuidade } \\
\text { da análise dos } \\
\text { dados } \\
\text { - Redação do } \\
\text { relatório final }\end{array}$ \\
\hline
\end{tabular}

\section{Referências bibliográficas}

ALBUQUERQUE-COSTA, H. "Um ensino específico da leitura: o ensino instrumental". In: Caderno do Centro de Línguas FFLCH-USP, n. 1 (1997). São Paulo: Humanitas/FFLCH/USP, 1997.

CANDIDO, A. et al. O Francês Instrumental: a experiência da Universidade de São Paulo. São Paulo: Hemus, 1977.

CICUREL, F. Lectures interactives en langues étrangère. Paris: Hachette, 1991.

CHARTIER, R. A aventura do livro - do leitor ao navegador. São Paulo, Editora da UNESP, 1998. 
CHARDENET, P. "Approches multilingues et francophonie : intercompréhension et interlinguisme". In V. Conti \& F. Grin (Ed.), S'entendre entre langues voisines : vers l'intercompréhension. Genève : Georg (151-167), 2008

DEGACHE, C. "Recherches praxéologiques: méthodologie d'enseignement de l'intercompréhension, ingénierie pédagogique". In : Didática das Línguas e didática do plurilinguismo: o lugar da intercompreensão, Capítulo 4. (Material do curso de Pós-Gradução, Universidade de São Paulo, abril 2012)

Didactique du plurilinguisme. Travaux sur l'intercompréhension et l'utilisation des technologies pour l'apprentissage des langues. Habilitation à Diriger des Recherches en Sciences du langage-didactique des langues. Grenoble : Lidilem-Université Stendhal, 2006

GIASSON, J. La Compréhension en Lecture. Québec: Ed. G. Morin, 1990.

JOUVE, V. La Lecture. Paris: Hachette, 1993.

JOVER-FALEIROS, R. A experiência da leitura literária em um curso de francês instrumental. Dissertação de Mestrado defendida junto ao programa de Pós-Graduação em Francês - DLM USP, 2006

PIETRAROIA, C.M.C. Percursos de Leitura - Léxico e Construção do Sentido na Leitura em Lingua Estrangeira, Col. Parcours. São Paulo: Ed. Anablume, 1997.

QUADRO EUROPEU COMUM DE REFERÊNCIA PARA AS LÍNGUAS - Aprendizagem, ensino, avaliação. Coleção: Perspectivas Actuais/Educação. Direção De: José Matias Alves. Edições Asa, 2001 (Edição Portuguesa)

\section{ESTUDANTE 3}

UNIVERSIDADE DE SÃO PAULO

FACULDADE DE FILOSOFIA, LETRAS E CIÊNCIAS HUMANAS

DEPARTAMENTO DE LETRAS MODERNAS - ÁREA DE FRANCÊS 
PROJETO DE INICIAÇÃO CIENTÍFICA

\author{
Produção escrita de FLE em foco : um estudo sobre o desenvolvimento das \\ capacidades de linguagem por meio das atividades linguageiras relatar expor
}

Aluna: Estudante 3

Data: $29 / 08 / 2012$

RESUMO

O presente projeto tem por objetivo o estudo da produção escrita de alunos universitários implicados no aprendizado do francês como língua estrangeira, tendo em vista o lugar privilegiado da escrita como instrumento de desenvolvimento das capacidades de linguagem e, portanto, da comunicação em si mesma. Para tanto, a pesquisa estará inscrita no quadro teóricometodológico do interacionismo sociodiscursivo, conforme os estudos de Bronckart (1999, 2006, 2008), principalmente no tocante à utilização dos gêneros textuais como meio de aceder ao ensino-aprendizagem das línguas (Schneuwly \& Dolz, 2004; Machado, 2009; Machado, Lousada \& Abreu-Tardelli, 2004a, 2004b, 2005, 2007; Lousada, 2002, 2009; Motta-Roth, D. \& Hendges, G. R, 2010; Cristovão, 2002; entre outros). O percurso do estudo visará a reflexão sobre atividades de produção escrita que contribuam para o desenvolvimento dos alunos. Para 
sua elaboração, numa primeira etapa, faz-se necessária a análise das produções textuais dos alunos, a fim de identificar os percalços e êxitos alcançados no processo de aprendizagem, seja nos aspectos linguísticos, seja nos âmbitos discursivo e contextual. Posteriormente, parte-se para o processo de autocorreção, através de legendas que incentivem o próprio estudante a reconhecer os pontos que necessitem ser modificados em seus textos. Num último momento, são desenvolvidas atividades e sequências didáticas a partir dos dados coletados durante a correção, a fim de modular o processo de ensino conforme o percurso e as necessidades do aluno. Acreditamos, assim, cooperar com os esforços para a adequação entre o ensino e a aprendizagem da expressão escrita, facilitando o trajeto rumo à comunicação plena do aluno de FLE (francês como língua estrangeira).

Palavras chave: capacidades de linguagem; produção escrita; atividade linguageira; gênero textual

\section{Introdução}

O presente projeto tem por objetivo o estudo da produção escrita de alunos universitários implicados no aprendizado do francês como língua estrangeira, tendo em vista o lugar privilegiado da escrita como instrumento de desenvolvimento das capacidades de linguagem e, portanto, da comunicação em si mesma. Tal proposta baseia-se nos estudos construídos por Bronckart (1999, 2006), Schneuwly \& Dolz (2004), que, por sua vez, se inserem no quadro do interacionismo sociodiscursivo e pautam-se na noção bakhtiniana de gênero. Sob esta perspectiva, a língua não é vista como mero conhecimento passivo de aceitação, mas como ocorrência ativa e real, ou seja, não se insere como informações a serem acumuladas, mas sim como savoir-faire a ser desenvolvido. Assim, se ressaltamos a definição de Bakhtin para os gêneros discursivos, temos que estes são realizações comunicativas através de formas mais ou menos estáveis de enunciados, ou seja, fundados por convenções sociais. Logo, podemos considerar os gêneros um instrumento importante no processo de ensino da língua, em que a apropriação das capacidades de linguagem passa, forçosamente, pela comunicação.

Se Bakhtin (1953/1997) propôs a noção de gêneros discursivos, Bronckart (1999), estando inscrito na vertente teórica do interacionismo sociodiscursivo, propõe a adequação do termo para gêneros textuais, instituindo a diferenciação em relação aos tipos de discurso, que nomeariam outra categoria, englobante dos diferentes mundos discursivos que o produtor do texto pode criar. O texto, por sua vez, corresponderia a uma unidade comunicativa ou interativa global e pode ser entendido como uma unidade de agir linguageiro, situado em determinado tempo e espaço, contentor de uma mensagem organizada de maneira a produzir efeito de sentido, ou seja, coerência, no destinatário (Bronckart, 2006). Assim, todo texto insere-se em determinado quadro situacional, que lhe ditará as especificidades, conforme as condições de interação a que estará submetido. Dessa maneira, conclui-se que todo texto está vinculado a algum gênero, ou seja, a algum formato historicamente convencionado, que, no entanto, não exclui seu caráter permanentemente passível de mudanças. A apreensão e aplicação dos gêneros ocorrem pelo contato constante que com eles mantemos ao longo de nossa história, permitindo, de maneira intuitiva e, muitas vezes, inconsciente, a compreensão de seu funcionamento.

Os gêneros textuais têm vasta aplicação na didática das línguas e, portanto, têm sido amplamente abordados. Dentre os trabalhos desenvolvidos na área, destacam-se os de Schneuwly \& Dolz (2004). Para ambos, todo gênero é constituído de diversos elementos que representam os objetos de ensino gradativo que devem ser aplicados pelo professor a fim de que o aprendiz desenvolva suas capacidades de linguagem e, mais que apreender uma modalidade de texto, possa expandir os novos savoir-faire para diversas realizações comunicativas que 
partilhem elementos constitutivos em comum. Assim, no processo de aprendizagem, faz-se necessário compreender quais conteúdos são dizíveis em determinado gênero, assim como entender qual é sua estrutura comunicativa particular, formada por um conjunto de unidades linguísticas, de sequências textuais e pelos tipos de discurso que constroem o texto.

Ainda nos estudos de Schneuwly \& Dolz (2004), os autores remetem à noção vigotskiniana de ferramenta, que seria o meio pelo qual o homem pode operar modificações desejadas no objeto em seu processo de trabalho. Tais ferramentas seriam intermediações indispensáveis na relação do homem e objeto, bem como no contato entre o homem e os outros. É a ferramenta que guia o comportamento do indivíduo, adequando-o aos diversos contextos cotidianos. E é, portanto, aqui que reside o cerne da utilização dos gêneros textuais no ensino das línguas. Se entendemos os gêneros como ferramentas, trabalhamos, então, com a construção e transformação das relações entre sujeito-objeto e sujeito-sujeito, ultrapassando o ensino-aprendizagem e promovendo o desenvolvimento do aprendiz enquanto sujeito no mundo.

Para planejar e desenvolver o processo de aprendizagem de um gênero, nos são caros dois conceitos básicos: o de modelo didático e o de sequência didática (SD). Antes de tudo, é necessário conhecer o gênero trabalhado e identificar suas principais características, ou, seja, é preciso construir um modelo didático. Assim, faz-se indispensável delinear o que os alunos deverão alcançar como novas capacidades de linguagem. Tal especificação só é possível se debruçarmo-nos sobre o gênero-alvo, identificando seus elementos constitutivos. Para aceder à apreensão por parte do aprendiz dos diferentes gêneros textuais, Bronckart $(1999,2006)$ propõe um modelo de análise textual que compreende a reflexão relativa ao contexto de enunciação e ainda mais três níveis: o da infraestrutura geral do texto, o dos mecanismos de textualização e, por último, o da responsabilidade enunciativa.

As SD, por sua vez, propostas por Schneuwly \& Dolz (2004), são a sistematização de atividades didáticas organizadas em torno do gênero trabalhado. Quatro etapas se distinguem: a apresentação do gênero; uma produção inicial para identificação das dificuldades; atividades (módulos) que possam reparar os problemas detectados; produção final. Toda sequência didática deve ser apropriada aos objetivos, capacidades e dificuldade dos aprendizes. Identificá-los através de análise e estudo e trabalhá-los posteriormente em SD caracteriza o alvo da presente pesquisa. Neste projeto, trabalharemos, sobretudo, com atividades de produção escrita, ainda que desvinculadas de uma SD.

\section{Objetivos}

Com este projeto, visamos a estudar o desenvolvimento da expressão escrita dos alunos, através de produções escritas organizadas a partir de gêneros textuais e que têm como eixo condutor as atividades linguageiras relatar e expor.

Esse objetivo de pesquisa está atrelado a uma reflexão de âmbito educacional, pois pretendemos contribuir para a reflexão sobre instrumentos de aprendizagem da produção escrita que promovam o deslocamento do aprendiz da posição passiva de receptor de conhecimento para actante da própria compreensão e realização dos diferentes gêneros textuais. Sendo assim, pretendemos analisar o percurso do aluno em direção ao domínio do francês, refletindo sobre o papel das atividades didáticas no desenvolvimento do estudante, pensando inclusive na contribuição da autocorreção, por meio de legendas construídas para esse fim, como maneira de promover a reflexão e, portanto, a melhor aprendizagem da língua. Para tanto, a pesquisa pretende responder às seguintes questões:

A. Quais capacidades de linguagem os alunos desenvolveram (ou não) durante as atividades de produção escrita? 
B. Em quais aspectos da produção escrita, observada a partir da ótica dos gêneros textuais, os alunos encontram maior dificuldade?

\section{Metodologia}

Para responder à primeira questão, coletaremos vários textos pertencentes aos gêneros que serão estudados pelos alunos do segundo semestre do bacharelado de Francês/Português do DLMUSP. Estando ainda no início da aprendizagem, deverão produzir gêneros textuais que têm em comum as atividades linguageiras narrar e expor. A partir do corpus coletado, será possível traçar uma série de características em comum nos textos. Para organizar os dados e melhor compreendermos o funcionamento dos gêneros, desenvolveremos um modelo didático a partir das proposições de Bronckart (1999, 2006). Para isso, devemos analisar:

- os aspectos contextuais: quem escreveu, para quem, por que, quando e onde;

- a infraestrutura geral do texto: plano global, tipos de discurso e sequências;

- mecanismos de textualização: coerência e coesão nominal e verbal;

- responsabilidade enunciativa: modalizações e vozes.

Baseando-nos no modelo desenvolvido, analisaremos as produções dos alunos, procurando compreender suas dificuldades ao produzi-las. Partindo das observações feitas e do modelo didático construído, poderemos, então responder à segunda pergunta, enquanto moldamos as atividades às necessidades dos aprendizes.

3. Plano de Trabalho e Cronograma

2012

\begin{tabular}{|l|l|l|}
\hline Setembro & Outubro & Novembro/Dezembro \\
\hline Leitura Bibliográfica & Elaboração do modelo & Análise do corpus \\
Coleta de corpus & didático & Redação do relatório \\
& Coleta de corpus & \\
\hline
\end{tabular}

4. Referências Bibliográficas e Bibliografia

BAKHTIN, Mikhail. Estética da criação verbal. 2a edição. São Paulo, Martins Fontes. 1953/1997.

BRONCKART, Jean-Paul. Atividade de linguagem, textos e discursos : por um interacionismo sociodiscursivo. São Paulo, Educ, 1999.

BRONCKART, Jean-Paul. Atividade de linguagem, discurso e desenvolvimento humano. Campinas, Mercado de letras, 2006.

BRONCKART, Jean-Paul. $O$ agir nos discursos : das concepções teóricas às concepções dos trabalhadores. Campinas, Mercado de letras, 2008.

CRISTOVÃO, Vera Lúcia. O gênero quarta capa no ensino do inglês. In: DIONISIO, A. P.; MACHADO, A. R.; BEZERRA, M. A. Gêneros textuais e ensino. Rio de Janeiro, Lucerna, 2002. 
LOUSADA, Eliane Gouvêa. Elaboração de material didático para o ensino de francês. In: DIONISIO, A. P.; MACHADO, A. R.; BEZERRA, M. A. Gêneros textuais e ensino. Rio de Janeiro, Lucerna, 2002. p. 73-86.

LOUSADA, Eliane Gouvêa. Produção escrita em francês como segunda língua: uma experiência baseada em gêneros textuais. Revista do GEL, São Paulo, v.6, n. 2, p. 160-174, 2009

MACHADO, Anna Rachel. Colaboração e crítica: possíveis ações do LinguISTA na atividade educacional. In: Abreu-Tardelli, L. A. Cristovão, V. L. L. (orgs). O ensino e a aprendizagem de gêneros textuais. Campinas, Mercado de Letras, 2009.

MACHADO, Anna Rachel.; ABREU-TARDELLI, Lília Santos; LOUSADA, Eliane Gouvêa. Resumo. São Paulo, Parábola, 2004a.

MACHADO, Anna Rachel.; ABREU-TARDELLI, Lília Santos; LOUSADA, Eliane Gouvêa. Resenha. São Paulo, Parábola, 2004b.

MACHADO, Anna Rachel.; ABREU-TARDELLI, Lília Santos; LOUSADA, Eliane Gouvêa. Planejar gêneros acadêmicos. São Paulo, Parábola, 2005.

MACHADO, Anna Rachel.; ABREU-TARDELLI, Lília Santos; LOUSADA, Eliane Gouvêa. Trabalhos de pesquisa: diários de leitura para a revisão bibliográfica. São Paulo, Parábola, 2007.

SCHNEUWLY, Bernard; DOLZ, Joaquim. Gêneros orais e escritos na escola. Campinas, Mercado de letras, 2004. 


\section{ESTUDANTE 1}

\section{DE ITABIRA PARA O MUNDO: LEVANTAMENTO SOBRE A RECEPÇÃO DA POESIA DE CARLOS DRUMMOND DE ANDRADE NA FRANÇA}

A obra literária de Carlos Drummond de Andrade é uma das mais reconhecidas da história da Literatura Brasileira. Apesar de bastante ligada às raízes do poeta, transparecendo sua brasilidade e sua origem interiorana, a poesia drummondiana vai além do regional, atingindo patamares, por assim dizer, universais.

Dada essa característica universal, a obra de Drummond foi traduzida para outras línguas, como o inglês, o holandês e também o francês. Essa pesquisa de Iniciação Científica teve como principal objetivo realizar o levantamento da recepção da poesia do escritor mineiro traduzida para o francês e difundida na França, especificamente.

Esse levantamento teve como base as teorias sobre recepção estética e sobre as influências de elementos culturais na tradução e na difusão de obras estrangeiras. Para o desenvolvimento desse trabalho, os recursos eletrônicos como o computador e a internet foram elementos fundamentais, já que possibilitaram o acesso a bibliotecas, lojas virtuais e também a sites e blogs, que podem ser fonte de traduções não publicadas e, portanto, menos difundidas no meio acadêmico. 


\title{
DESENVOLVIMENTO DE COMPETÊNCIAS LEITORAS EM FRANCÊS PELA ABORDAGEM DA INTERCOMPREENSÃO NOS CURSOS DE PRÁTICAS DE LEITURA DO CENTRO DE LÍNGUAS DA FFLCH
}

\begin{abstract}
A presente pesquisa busca, por meio da análise da convergência entre as teorias do ensino da leitura já existentes e aquelas trazidas pela abordagem plural da intercompreensão de línguas românicas, surgidas a partir dos anos 80 , refletir sobre como o desenvolvimento de competências leitoras pode ultrapassar os limites de uma única língua-alvo e contribuir para o surgimento de um leitor autônomo plurilíngue. Para tanto apresenta-se a experiência de leitura de textos em outras línguas românicas feita em uma turma do curso de Práticas de Leitura em Francês do Centro de Línguas da FFLCH-USP. Além da análise dos processos cognitivos e metacognitivos envolvidos no processo de leitura, visa-se também contribuir para a reformulação do programa do curso de Práticas de Leitura em Francês, levando em consideração as novas possibilidades trazidas pelo plurilinguismo e pelas teorias de intercompreensão.
\end{abstract}




\title{
ESTUDANTE 3
}

\section{PRODUÇÃO ESCRITA DE FLE EM FOCO: UM ESTUDO SOBRE O DESENVOLVIMENTO DAS CAPACIDADES DE LINGUAGEM POR MEIO DAS ATIVIDADES LINGUAGEIRAS RELATAR E EXPOR}

\begin{abstract}
Esta comunicação tem por objetivo apresentar um estudo sobre a produção escrita de alunos universitários, aprendizes do francês como língua estrangeira, observando, para tanto, o desenvolvimento de suas capacidades de linguagem ao longo do processo de aprendizagem. A pesquisa se apoiou no quadro teórico-metodológico do interacionismo sociodiscursivo, conforme os estudos de Bronckart $(1999,2006,2008)$. Sob tal perspectiva, a aprendizagem estabelece-se como processo dependente das interações do indivíduo com o mundo, cujo instrumento mediador será a língua. Apoiamo-nos igualmente na noção bakhtiniana de gêneros do discurso, retomada por Bronckart (1997), que propõe o termo gêneros textuais. Segundo essa perspectiva, as atividades humanas exigem formas mais ou menos estáveis de enunciados fundados por convenções sociais sem os quais seria impossível a comunicação (Bakhtin, 1986). Remetemos, então, às proposições de Schneuwly \& Dolz (2004) que retomam as ideias de Vigotsky sobre a noção de instrumento, meio pelo qual o homem pode operar modificações no objeto em seu processo de trabalho. Assim, os gêneros operam concomitantemente como unidade de ensino e como instrumento, o que possibilita utilizá-lo para o desenvolvimento dos três tipos de capacidades de linguagem, isto é, as de ação, as discursivas e as linguístico-discursivas (Schneuwly; Dolz, 2004). As análises do corpus foram feitas conforme o folhado textual proposto por Bronckart (1997), composto por infraestrutura geral do texto, pelos mecanismos de textualização e de responsabilização enunciativa. Tais aspectos foram observados através dos eixos relatar e expor, a partir dos quais se organizam os tipos discursivos, isto é, os elementos estruturais que determinariam as distinções formais entre os gêneros. Os resultados apontam para o desenvolvimento em geral dos alunos por meio dos textos produzidos, no entanto demonstram que alguns aspectos linguísticos e discursivos são mais dificilmente apropriados do que outros.
\end{abstract}




\section{APRESENTAÇÕES ORAIS DE PESQUISA}

\section{ESTUDANTE 1}

1 Apresentadora: Tem pouca gente...a minha orientadora é uma das cinco (frase

2 exclamativa)...NÃ̃....uma das quatro...éh....cinco.

3 Orientadora: (e também tem ela que está filmando).

4 Apresentadora: É...vou começar então assim...o plano da minha apresentação...eu vou apresentar 5 a temática...o objetivo...o material e o método...depois eu passo para as fases da pesquisa de

6 fato...e finalmente...e posteriormente para os desdobramentos possíveis...bom...a temática...o

7 título da minha pesquisa já É BEM...bem explicativo ...éh...a gente fez um levantamento da

8 tradução da poesia de Carlos Drummond de Andrade...em francês...na França...uhn::.....os

9 objetivos é realizar o levantamento da poesia traduzida...de textos teóricos traduzidos...e de textos 10 teóricos escritos em francês diretamente...éh...o material ....a internet foi essencial...pois através 11 dela a gente chegou a ferramentas de busca...como o Google...e bibliotecas e livraria online 12 também...foi por aí que a gente encontrou tudo o que a gente queria conseguir...no final de contas 13 a própria pesquisa consistia na busca desse material...o que a gente encontrou também se constitui material da pesquisa...bom...o método...primeiro a gente fez leituras sobre teorias da recepção...depois a gente foi pra parte física da pesquisa...o levantamento das traduções francesas da poesia de Drummond...depois um levantamento da crítica brasileira traduzida para o francês...e depois levantamento da crítica sobre Drummond escrita em francês...depois de TUdo isso...a gente realizou um comentário do que a gente levantou....agora eu passo para as fases da pesquisa ((tossiu)) e a leitura teórica...fizemos um estudo breve sobre a estética da recepção de Jauss e Iser...éh:......foi um pouco difícil de ler isso e de entender essa leitura...ih:......aí a gente usou duas vias pra principalmente conseguir...conseguir entender a Estética da recepção...entender um pouco melhor essa discussão...éh:.....lemos o Paul Zumthor...Performance, recepção e leitura...Regina Zilberman...Estética da recepção e história da literatura...que foi essencial para a compreensão dessa teoria da Estética da recepção...éh::.....isso acho que foi um dos guias né?...o outro guia muito importante foi o Chevrel...sobretudo esse texto Le texte étranger: la littérature 
traduite ...que foi também...éh...uma outra via de TEoria...embasamento teórico...aí eu trouxe duas referências só pra localizar um pouco...acho que não vai precisar localizar tanto assim...mas...éh...éh...uma definição de obra de Jauss...”a obra é resultado da convergência do texto e de sua recepção portanto de uma dinâmica que só pode ser entendida em suas concretizações históricas sucessivas"...então com essa compreensão de obra a gente consegue embasar aquilo que a gente levantou...ih...o Chevrel que introduz um conceito que até então eu não conhecia de horizonte de espera...éh...”o público é condicionado por um horizonte de espera que serve como verdadeiro filtro ou como crivo para as novas obras...A obra literária se caracteriza portanto por uma tensão entre dois horizontes de espera...aquele da obra...aquele o público...que coincidem mais ou menos"...então na verdade...na SíNtese eles têm a mesma direção né?....se direcionam para a mesma ideia...ih.:.....enfim...esses dois conceitos foram super importantes para a gente entender aquilo pra entender aquilo que a gente levantou...agora falando do levantamento propriamente dito...éh...acho que já ficou claro que foram três partes de levantamento...da poesia de fato...do textos crítica traduzidos...e dos textos críticos escritos em francês....ahn... da poesia traduzida a gente chegou a reuniões exclusivas da teoria do Drummond em francês...eh...antologias que reuniam poesia brasileira ou poesia Iberoamericana...então...DAS reuniões...nós encontramos três...a primeira de mil novecentos e oitenta e três Réunion que foi escrito por Jean-Michel Massa...a segunda de noventa La machine du monde et autres poèmes...é a mais extensa...e a última que foi traduzida pela Ariane Witkowski Mort dans l'avions \& autres poèmes..é bem mais curta mas éh melhor eh bilingui...e a do JeanMichel Massa também eh do Lamaison não...então...aí estão os três em ordem né?...esse é do Massa...esse é do Lamaison...e esse da Witkowski ----acho que ficou um pouco clara...mas enfim...éh::....depois as antologias...a gente conseguiu oito ou nove antologias...mas eu destaquei três que me chamaram mais atenção...primeiro a do Tavares-Bastos de mil novecentos e quarenta e sete...a mais antiga...tem o Poèmes $d u$ Brésil...ahn:.....de oitenta e cinco...traduzida por Bernard Lorraine...e a última do ano passado que foi lançada...que é muito extensa...assim...é uma Bíblia mesmo (frase exclamativa)...bem interessante...éh:.....eh Anthologie bilíngüe du XVIe au XXe siècle...que pega um período de literatura bem extenso...de poesia...aqui os dois...o primeiro de mil novecentos e quarenta e sete do Tavares-Bastos...e essa de dois mil e doze...essa daqui ((a antologia de Tavares-Bastos))((risos))...ela está disponível na biblioteca por incrível que pareça nesse estado (danificada)...eu mostrei a foto só para ilustrar mesmo...ela está cortada por dentro...enfim...dos textos traduzidos ((a apresentadora olha para o slide no computador a sua frente com um semblante de houve algum problema))...nós encontramos dois só...primeiro um livro que reúne alguns textos críticos...La Rose du peuple: la poésie de Carlos Drummond de Andrade...que traz textos...assim...BEM canônicos...Antonio Candido...são textos BEM 
interessantes...foi publicado em dois mil e cinco...ih:.:...e outro é um artigo publicado numa revista na França...escrito pelo Jaime Ginzburg...professor aqui da casa (professor de Literatura brasileira da USP)...éh::...Poésie lyrique et politique au Brèsil: la vie mini male chez Carlos Drummond de Andrade...e foram esses dois que a gente encontrou...e nada mais...dos textos escritos em francês...éh.:.....a gente chegou a dez textos críticos...MAS...sobre a poesia mesmo...éh::....um só...que é na verdade a tese da Witkowski...aquela autora que publicou a última reunião...Naître et mourir au Minas Gerais: Études de sept récits d'enfance autobiographiques brésiliens du XXe siècle...então...assim...nem é dedicada somente ao Drummond...ela...com diz...ela faz o estudo de...uhn::.....comment je peux traduire ça? ((O título da tese))...são escritas autobiográficas...brasileiras...e o Drummond tá lá pois a poesia dele é autobiográfica...esse assim...é o único texto quente...é uma tese...o resto dos textos que a gente encontrou que falam sobre Drummond...na realidade estão criticando as traduções...então não éh uma crítica da poesia...é uma crítica da tradução...ahn:......pois é...agora eu já parto para o final da apresentação...ih:......na verdade eu vou comentar o comentário...apresentar partes dos comentários que foram feitos....ahn::.....primeiro que as traduções e recepções são escassas ainda (recepção e tradução da poesia de Drummond na França)...e não realmente bem difundida...depois o contexto de publicação dessas traduções tem uma relação que eu chamei de EXtra literária...então assim...né?....as pu/publicações não foram feitas porque foram feitas...tinha uma razão por fora pra isso...como por exemplo o Ano do Brasil na França em dois mil e cinco...foi a tradução do livro da Witkowski...em dois mil e cinco foi publicado uma nova versão do Lamaison...e aquele texto de poemas traduzidas também foi publicado em dois mil e cinco...éh::....e finalmente...éh uma observação geral e não propriamente da poesia do Drummond...a visão né?...do leitor francês sobre a literatura brasileira...éh...eu percebi duas coisas...primeiro que existe um mística com relação ao país tropical...o Brasil...e depois que/ existe uma relação muito direta feita constantemente com a Literatura portuguesa...por causa da relação da língua mesmo...entre outras razões...aí eu coloquei a capa de uma das antologias (Poème) du Brésil...que eu acho que mostra bem essa ideia de tropical né?...éh::....na capa já tem essa ideia de páis tropical...pra ilustrar a relação com a literatura portuguesa...eu citei uma das críticas que a gente conseguiu..."Drummond de Andrade n'est un hétéronyme oublié par Pessoa de l'autre cote de l' Atlantique" ((a continuação da citação é "il naquit dans la province du Minas Gerais en 1902 et mourut à Rio de Janeiro en 1987”))...eu vou ler só isso...que na verdade é o que interessa...então assim...eu não sei se alguém já pensou no Drummond como um heterônimo do Fernando Pessoa...acho que pra gente que estuda Literatura brasileira dentro do Brasil...não é uma relação que a gente vê fazer...mas::....tá dado isso...e não éh só nessa citação que essa relação acontece...eles associam muito a Literatura brasileira no geral com a Literatura portuguesa...como 
desdobramento da pesquisa...primeiro éh:.:...tem poemas que podem ser retraduzidos...que precisam de outras propostas...éh::...eu também pensei...éh::.....bom...além traduções inéditas de poemas...pensei que tem mais textos teórico que podem ser traduzidos como forma de difundir...ah:.:....poesia do Drummond...tem muito texto teórico traduzido...e tem muito texto bom ...e tem muito texto bom brasileiro que pode ser útil também...e éh isso...as referências bibliográficas (os slides com as referências é mostrado pela apresentadora)...e um monte de agradecimento...FAPESP...a Área((Área de Estudos Linguísticos, Literários e Tradutológicos em francês da FFLCH-USP))...professores Álvaro e João Azenha...que ajudaram muito...o Álvaro inclusive ajudou muito no último encontro ((IV Encontro de Pesquisa do Francês, em 2012, onde a aluna havia apresentado pela primeira vez a pesquisa, que estava no início))...agradecendo um pouco ((a apresentadora faz gestos com as mãos demonstrando que é um agradecimento a alguém que está longe fisicamente))...ao Michel Chandeigne...que enviou a tese da Witkowski...e a minha professora...orientadora Adriana Zavaglia...Obrigada (frase exclamativa). 


\section{ESTUDANTE 2}

Eu vou falar...falar...falar...falar...depois seu der tempo eu aprofundo em alguma coisa ((risos))...esse é o título da minha pesquisa...Desenvolvimento de competências leitoras em francês no curso de intercompreensão no Centro de Línguas da FFLCH...eu vou fazer uma breve introdução sobre a intercompreensão que não é um termo ainda muito difundido...fala um pouco sobre a leitura em língua estrangeira no contexto do curso...um panorama rápido da minha proposta...ahn...também essa atividade final que dá esse salto do leitor bilíngue para o leitor plurilíngue...e as considerações finais...ok ((frase exclamativa))...o que é a intercompreensão?...antes de falar de intercompreensão é preciso ter em mente noção do que é plurilinguismo...e o que é ser plurilíngue...não se todos aqui já tiveram contato com o Quadro Comum Europeu de Referência para as Línguas...mas SER plurilíngue é diferente totalmente diferente de ser poliglota....ahn...tem esse citação aqui ((a aluna aponta para a tele do projetor))...não significa que você vai falar várias línguas num alto grau...significa que você usa os seus conhecimentos em uma, duas, três, quatro línguas de acordo com a sua necessidade...e de acordo com a situação em que você tá inserido...então demanda conhecimento linguístico sim...mas cultural e social também...então quando a gente fala em plurilíngue é bom não confundir com poliglota...não alguém fluente em várias línguas...essa é uma noção importante - - o que é a intercompreensão? - -...a Claire Benveniste nos anos oitenta...ela teve esse insight que na verdade não é um insight...já estavam nos registros do Umberto Eco...nos registros europeus de comércio que não existia curso de língua mas mesmo assim os comerciantes dos diferentes países se entendiam..."Se as línguas românicas de assemelham entre em si em maior ou menor grau, também as pessoas que falam uma delas como língua materna deverão ser capazes de compreender em maior ou menos grau as outras línguas da famílias apoiando-se precisamente nas semelhanças" ((citação de Claire Benveniste lida pela aluna))...todo mundo sabe que todo brasileiro fala espanhol, né?...mas os espanhóis não falam português $(($ risos $))$...é mais ou menos isso...isso não é convencimento nosso...essa passagem...essa transparência existe entre as línguas de uma mesma família...ahn::...a intercompreensão então ela...ela começa a surgir como abordagem didática...na didática das línguas...ih:....ela tem alguns pontos...pontos...ahn...específicos que diferem de tudo o que a gente já viu nos cursos regulares de línguas...uma nessas coisas é a dissociação de competências...quando a gente entra em um curso de língua...a gente esperar ouvi...a aprender a compreender oralmente...compreender a escrita...conseguir escrever e conseguir falar...em um curso de inglês você quer tudo ao mesmo tempo...geralmente você só sai falando e entendendo...escrevendo e lendo fica um pouco para trás...mas as abordagens plurais especialmente a intercompreensão ela foca nas competências passivas...compreensão escrita e compreensão oral...por que?...segundo teóricos da área essas competências de desenvolvem muita mais rápido do que as 
competências de produção...todo mundo aqui é aluna de língua então acho que isso é fácil de perceber...a gente começa a entender mais fácil do que a gente começa a produzir...ok ((frase exclamativa))...o que é uma abordagem plural?...uma abordagem plural é que segue/ não que se os preceitos...mas que é uma raiz do plurilinguismo...o plurilinguismo é citado no Quadro Europeu de Referência para as Línguas e depois é criado um novo Quadro das abordagens plurais a partir dessas novas definições...sendo assim...o que a colega acabou de falar sobre a língua materna na minha pesquisa isso é primordial...éh::...ela é a primeira porta...não só a língua materna...mas todas as competências que o aluno já tem desenvolvidas...no meu caso como é um curso de leitura...e aqui na USP são todos universitários...todos ele já sabem ler em português...resta transferir...então tem essa citação da Capucho...que é uma portuguesa muito interessante..."Uma metodologia da intercompreensão visa sempre despertar nos alunos aquilo que eles já são capazes de fazer durante o trabalho com duas línguas - - duas ou mais...claro que a gente não vai começar com cinco...mas você com o português começasse a trabalho com o francês e o italiano ao mesma tempo...então essa é a noção...são três línguas envolvidas porque a língua materna tem o seu lugar ((interrupção da citação pela aluna)) - - ...reunindo simplesmente uma linguística popular baseada no senso comum e na experiência das pessoas...numa situação de interação exolíngue...os indivíduos são construídos a co-construir o sentido... - - eles numa interação que leva em consideração a intercompreensão ou os valores do plurilinguismo...éh...tudo constrói sentido não só o sujeito...não só dele que ele nasce - -...visando a utilização pragmática do discurso seja apenas para se orientar e se manter no contexto em que se encontram seja para se comunicarem com os outros"...a situação interação...de trabalho...de aprendizagem também influenciam muito quando a gente fala em intercompreensão...bom ((frase exlclamativa))...meu contexto na Didáticas da Línguas é o ensino e aprendizagem da leitura...o que é a leitura?...bom ((frase exclamativa))...não é só uma atividade...pegar o livro e codificar o que está escrito...é uma constante formulação de hipóteses como a colega já disse...éh...o tempo todo...a gente só pode construir sentido daquilo que a gente conseguiu...éh...formular hipótese...a gente faz a nossa e confirma no texto...isso é constante...éh...esses processos eles são citado em um livro dedica a leitura...ele multidimensional...a leitura é um processo multidimensional cognitivo, afetivo, argumentativo e simbólico...porque ele envolve desde que o autor está querendo falar no texto até as funções do corpo...do cérebro...os movimentos dos olhos...tem muito coisa envolvida...é um construção de sentido e não uma mera decodificação...não é de propósito ((risos)) ((a aluna mostra no projetor uma citação de um livro sobre leitura escrito pela moderadora da sessão de comunicação))...mas eu sempre digo isso para os meus alunos...essa citação está em todos os meus trabalhos...((risos))...“construir sentido é fazer interagir as experiências do leitor e seus conhecimentos de mundo com a matéria-prima escrita que ele possui diante dos olhos por meio dos dados formais e contextuais desta última"...é tudo isso que está envolvido na leitura...a construção do sentido só dá se interage a experiência do leitor...do texto...do paratexto...do peratexto...hipertexto ((risos))...bom ((frase exclamativa))...o curso de leitura em francês...vou falar um pouco do que é um curso de leitura e o que é um 
curso instrumental...é um curso em que as pessoas procuram porque elas precisam daquela língua não para chegar em um festa e "eu falo francês"...mas para desenvolver a sua pesquisa...para trabalhar...eu vou pra francês mas eu vou trabalhar com isso...então tem alguns objetivos específicos...aqui no Centro de Línguas os alunos são todos universitários...graduação ou pós...ou entre esses dois...graduação especialmente aqui na FFLCH que tem muita bibliografia - - engraçado que alunos de Letras não aparecem no curso...eu nunca tive alunos de Letras-francês que precisassem de ajuda para ler os textos de literatura...mas os de Filosofia ((alunos do curso de Filosofia da FFLCH)) cuja bibliografia é oitenta por cento em francês...eles dominam o curso...ou no caso dos alunos que querem ingressar no mestrado...que precisa fazer exame de proficiência vêm fazer o curso também...o que a gente ensina para esses alunos?...a gente já parte do pressuposto de que eles já são leitores...eles já sabem ler...eles precisam transferir o que eles sabem em português...o que sabem inconscientemente desde pequenos e não sabem que fazer...para o francês...essa transferência é o que a gente chama de estratégias de leitura...que são muitos detalhes que eu não vou ter como entrar aqui...o papel da língua materna é primordial...sendo as duas línguas parentes...éh:....da mesma raiz...o primeiro contato vai ser sempre valorizando o que a gente chama de transparentes...que são as analogias...as palavras que são parecidas em português e em francês pelo menos no escrito...na hora que fala aí os alunos desistem...eles fazem bonitinho...mas:....ok ((frase exclamativa))...qual era a minha proposta?...ahn...demonstrar que com a estrutura do curso de leitura...e se tratando de língua românicas...ahn...esse processo de ensinar língua estrangeira não precisa se limitar a uma língua só...já que a gente tem teorias como a intercompreensão...ahn...esse trabalho com as outras língua ele já era de praxe nas primeiras aulas aqui do francês instrumental...a maioria dos professores começam dando o curso em romeno para mostrar aos alunos que eles poderiam formular hipóteses...e chegar numa leitura global...mesmo no romeno que é muito mais distante do que o francês...mesmo sem saber que o nome disso era intercompreensão...então já era praxe...então isso desperta sim no aluno a confiança...e a necessidade que ele tem de avançar na língua que ele não domina e não conhece...a metodologia é simples...eu mexi no programa o máximo que eu pude...e apliquei as atividades com outras línguas em dois momentos do curso...ahn...o meu objetivo então - -está lá em cima...eu me esqueci de citar - -...é o surgimento de um autor autônomo plurilíngue...o que é um leitor autônomo plurilíngue?..."é aquele capaz de articular seus conhecimentos adquiridos durante o curso para facilitar sua leitura em outras línguas românicas ainda que ele não as tenha estudado a fundo...sempre levando em consideração seus objetivos e necessidades"...o rapaz ((convidado do evento para a conferência)) lá na conferência disse que ele lia em italiano...então ele pegou lá o livro do Perec em italiano...o meu objetivo é fazer com que esse aluno que fez o curso de francês...se amanhã muda a bibliografia dele e ele precisa fazer/precisa ler em italiano...que não necessariamente ele precise fazer um curso de dois semestres para ler em italiano...ou pelo menos começar a consultar essa bibliografia...é esse o leitor autor plurilíngue...ahn...o que eu fiz com o curso?...a gente tem um curso de sessenta horas...eu dividi em quatro módulos...o primeiro sensibilização e conscientização do processo de leitura...o segundo...desenvolvimento e 
aplicação das estratégias vistas no módulo um...o módulo três...consolidação das competências em um trabalho específico sobre o francês...afinal eles estão ali para aprender $\mathrm{O}$ francês....apesar de um querer fazer um monte de coisa ((risos))...e no último módulo a gente volta...com a conscientização da possibilidade de transferência dos procedimento adquiridos para outras línguas românicas....ahn::...bom ((frase exclamativa))...por que eu concentro as atividades no primeiro e no último módulo?...no primeira para mostrar que a língua não depende apenas da matéria escrita...da língua em que o texto está...ahn...desde que ele mobilize as estratégias cabíveis...ainda que ele não saiba ainda quais são...a gente vai nomeando isso ao longo do curso...o que eu devo fazer em cada gênero?...o que eu fazer para cada tema?...tem relação com esse tema ou não tem?....tem imagem no texto ou não tem?...o que eu isso me ajuda?...são as primeiras bases que a gente coloca no primeiro módulo...no último módulo...são as três últimas aulas do curso...eles já fizeram prova...já estão super-craques...né?...já estão querendo até falar ((risos))...então eu fiz a experiência de voltar com as línguas românicas só que com um gênero mais complicado que é o gênero acadêmico...porque ao longo do curso a gente trabalha vários pequeno gêneros...não tão articulados e não tão complexos quanto ao gênero acadêmico...mas como o nível dois do curso de práticas é específico de textos acadêmicos...a gente faz essa ponte...e eu aproveito para voltar com as outras línguas...para eles verem que eles podem transferir tudo o que eles aprenderam e já aplicam no francês...aqui tem um pequeno quadro só para demonstrar a carga horária de cada módulo...e os tipos de texto eu que uso...tem chat...tem receita...tem sumário...um pequeno texto de um manual didático...e o último que é o resumo acadêmico...aqui é um exemplo de como eu faço isso no primeiro módulo...eu/na segunda aula eu apresento para eles um sumário de uma revista italiana...não necessariamente italiana mas de uma revista estrangeira...de uma língua românica...e peço para eles extraírem informações como o tema da publicação...a língua...qual pode ser o público-alvo...são hipóteses que vão sendo formuladas para construir esse horizonte de expectativa da revista...por que o sumário?...eles podem nunca terem aberto uma revista estrangeira...mas nem por isso eles não conhecem o gênero sumário...é uma estrutura fixa...é um estrutura altamente conhecida...eu acredito aqui que todos saibam o que é o sumário...e batem o olho vai saber que é...em seguida eu apresento a eles o sumário de uma revista em francês...que é uma revista de uma outra área...que tem um layout totalmente diferente...mas que nem por isso deixa de ser um sumário...ahn...e eles percebem...são levados a perceber todas essas diferenças mas que nem por isso deixa de ser um sumário...ahn:....e eles são levados a perceber todas essas diferenças mas que dentro do gênero se mantêm...são diferentes mas ainda é um sumário...e claro a gente trabalhou alguns ponto de gramática da língua francesa...no módulo quatro, o que eu faço? Ahn...o que eu fiz, né? Não sei se deu pra ver nos slides anteriores...mas eu fiz essa experiência agora no primeiro semestre com uma turma do Centro de Língua...o último módulo eu faço em duas fases...eu apresento pra eles primeiro um conjunto de resumos todos cortados...eu separo os títulos...o resumo e as palavras chaves...sendo que o título está sempre em francês...o resumo está em outra língua românica...e as palavras chaves na mesma língua do resumo...então eu recorto isso...recortei e coloquei em envelopes...e eles deveria 
- - o tema de todos os resumos eram inter-compreensão...não era a área deles...então eles deveriam encontrar o título referente...e as palavras chaves de cada resumo...COMO?...com a referência do francês que estava no título...o francês eles já dominavam...essa era a ÂNcora deles nesse momento...ahn...apesar de aqui...esse esse...é em italiano esse resumo...eles não tinham a base do conhecimento de mundo da área...ahn::...nem da língua do resumo...mas tinham a referência do título em francês...e eles fazem isso...deu SUper certo...eles conseguiram...ok...na aula seguinte...eu peço pra eles escolherem um artigo...que...numa língua que eles não dominam e que provavelmente eles não leriam...aí ta em romeno não consigo ler então eu não vou ler...ahn...então que eles procurassem esse artigo e trouxessem pra mim o resumo...trouxesse na aula para que nós lêssemos o resumo...que é a porte de entrada...é nele que você vai...ahn:.:...saber o que aquele artigo está falando...esse resumo é de um aula ((a apresentadora aponta para a tela do Power point)) que estudava medicina...e ela era boliviano...mora no Brasil...e estava fazendo curso de francês...e já tinha estudado italiano...então pra ela só sobrou o romeno e ela escolheu esse resumo...qual que era a âncora nesse caso? Eu não tenho mais o francês...o romeno eu não domino...era justamente o conhecimento de mundo da sua área de pesquisa...era isso que iria te dar o conhecimento necessário para você avançar na leitura....ahn::...consideração final...os dez alunos que fizeram essa última experiência todos conseguiram fazer...inclusive um saiu fluente em romeno...ele disse que se saiu melhor em romeno do que em francês...ahn...ahn...os fatores facilitadores que eles citaram além do nível de relação com o tema...eles já sabiam os procedimentos e as dicas que eles tinham que buscar em cada um dos textos...ahn...bom...a possibilidade de utilizar os conhecimento linguísticos...seja em língua materna seja em língua estrangeira já que muitas vezes os alunos já vêm com conhecimento de língua...a gente entrega um questionário no começo do curso....a maioria fala inglês...outros falam espanhol...então o conhecimento em outra língua já têm...isso se coloca como um elementos essencial para o trabalho em questão...pois demonstra que a transferência das competências leitoras independem das línguas envolvidas...italiano ou francês...o primeiro passo é buscar o que há de transparente...o que tece alguma relação com o que é conhecido...a partir disso construir hipóteses para depois buscar as confirmações numa leitura mais profunda... e uma última reflexão que eu queria fazer...uma didática da intercompreensão só será possível se se passar de uma didática centrada na especificidade de uma dada língua a uma didática de línguas que visa desenvolver uma competência comunicativa que se deseja plurilíngue ((leitura feita pela Estudante 2 do escrito de um teórico))...é difícil pensar isso mas a gente pode discutir depois...obrigado...tem a bibliografia. 


\section{ESTUDANTE 3}

Ah::...produção escrita do FLE em foco: Um estudo sobre os desenvolvimento da capacidades de linguagem por meio das atividades linguageiras do relator e expor...foi uma pesquisa de Iniciação Científica desenvolvida no prazo de seis meses por se tratar de uma bolsa FFLCH já iniciada...a pesquisa dá continuidade a::....ao que já tinha sido estudado pela colega aqui na área do francês...a Cinthia Bezerra...que estudou a produção escrita de alunos da habilitação de francês...Bom (frase exclamativa)...eu também sou aluna da habilitação de francês...claro (frase exclamativa) (risos)...isso foi importante para a pesquisa uma vez que eu já tinha contato com a plataforma de entrega dos exercícios...o moodle...tinha contato com a estrutura dos exercícios e com os gêneros textuais que foram trabalhados durante o semestre...no final das contas o que eu fiz foi analisar as produções escritas dos meus colegas de sala...também é importante ressaltar os estudos do grupo ALTER (trata-se do grupo de pesquisa liderada pela orientadora da aluna)...onde eu tive os primeiros contatos com as teorias do Interacionismo sociodiscursivo...que é a teoria metodológica a qual se vincula essa pesquisa...bem (frase exclamativa)...por que estudar os gêneros textuais para o ensino e por que fazê-lo na didática do francês...a questão dos gêneros textuais tomou muito vulto no Brasil depois da publicação dos PCNs...dos Parâmetros Curriculares Nacionais...e além disso por que fazê-lo em francês? Por que se comparado a produção teórica relacionado à língua inglesa e à língua materna...a publicação do francês é menor e por isso carece...ah::...de pesquisas na área...bem (frase exclamativa)...o objetivo da pesquisa portanto foi fazer um estudo do desenvolvimento das capacidades de linguagem implicados na aprendizagem do francês língua estrangeira e fazer isso por meio dos eixos discursivos do relatar e expor...devido ao tempo limitado a gente não vai tratar do eixo expor só do eixo relatar...Bem (frase exclamativa)...para realizar a pesquisa foram...ah::.....usados alguns conceitos teóricos...sobre os gêneros textuais no ensino...com Scheuwly e Dolz...Bronckart...o modelo de análise usado é do ISD...além disso há os conceitos de capacidades e modelo didático...sobre os gêneros textuais Bronckart vai dizer que a comunicação humana se dá por meio de textos...ela se dá por textos...e os textos por sua vez se organizam em gêneros textuais...ele vai definir portanto gêneros textuais como maneiras de adaptar a linguagem a tipos de atividades humanas...ou seja...os gêneros textuais e as atividades humanas estão intrinsecamente ligados...tendo isso em vista isso Scheuwly e Dolz vão propor a utilização dos gêneros textuais como instrumentos de ensino...ou seja...ao invés de partir de estruturas linguísticas soltas e independentes...partir de gêneros que estão relacionado às atividades humanas...para o desenvolvimento das capacidades de linguagem dos alunos...assim o conceito de instrumento acaba importando...e não sendo instrumento somente para $\mathrm{O}$ professor...mas também para os alunos uma vez que...todas as ferramentas...ah:....todas as capacidades de linguagem apropriadas durante o trabalho 
com determinado gênero podem ser aplicados à utilização de outras gêneros...assim o que temos é o desenvolvimento de um verdadeiro savoir faire...que o aluno possa ser ativo na própria aprendizagem e que possa agir no mundo...capacidades de linguagem propostas do Dolz...Pasquier...e Bronckart...elas são por questões didáticas divididas em três tipos...ah:....mas elas são interdependentes...primeiro tipo são as capacidades de ação...que são as representações que o sujeito constrói sob o contexto de produção e sobre o seu referente....as capacidades discursivas dizem respeito a organização geral do texto...e as capacidades linguístico-discursivas que se referem às unidades linguísticas necessárias para o construção textual...ah:.....para poder analisar o desenvolvimento das capacidades de linguagem nós usamos o modelo de análise do ISD...composto de duas partes...primeiro o contexto de produção...primeiro refletir quem é o enunciador...quem é o enunciatário...qual o objetivo do gênero...em que momento ele foi produzido e em que local social...a segunda parte do modelo de análise do ISD...o folhado textual...que é dividido em três níveis...não vamos discutir profundamente agora...mas se trata da infraestrutura geral do texto...os mecanismos de textualização...e os mecanismo de responsabilidade enunciativa...o contexto da pesquisa foi formado por exercícios de produção escrita produzidos por alunos do segundo ano da habilitação de francês aqui da FFLCH...e as produções escritas foram entregues via a plataforma moodle para favorecer a aprendizagem e autonomia...todos conhecem o moodle?(a aluna faz uma pergunta para o público ouvinte) (risos)...esse é um exemplo de exercício...os exercícios eram elaborados pela professora do curso...os exercícios eram introduzidos por questões e promoviam a reflexão sobre as características do gênero que era trabalhado...em seguida vinha um exemplo autêntico do gênero e por fim tinha a proposta de produção escrita...foram analisadas trinta e uma produções escritas dos alunos...as produções escritas/foram trabalhado cinco gêneros diferentes...da ordem da relatar a sinopse de filme...o fait divers...relato de viagem em blog...e relato curto literário...do eixo do expor foi o e-mail informal...ah:.....para compor o corpus...ah:.....selecionamos sete alunos...a seleção foi gradativa pois no começo do semestre não dá para saber qual aluno vai entregar ou não todas as atividades...foi preciso estipular o mínimo de três atividades entregues para poder participar do corpus...ah::...a semelhança do que Pétrech numa pesquisa de 2008...nós tentamos escolher alguns alunos com muitas dificuldades..outros alunos com pouca dificuldade e outras com algumas dificuldades para poder contemplar os vários níveis de desempenho...bem...ah::...primeiramente nós tivemos...ah::...que analisar os gêneros que eram trabalhados...ah:....saber o conteúdo que nós esperávamos que os alunos se apropriassem em cada gênero...ah::...para isso nós utilizamos o modelo de análise do ISD...analisando o contexto e o folhado textual de cada gênero...a partir daí a gente pode ir nas produções dos alunos e aí seguindo o modelo didático...ah:...pra começar... gênero sinopse...foi a primeira produção escrita proposta para eles...ah:....nós notamos algumas dificuldades na intensificação do suspense que é fundamental para poder seduzir o leitor a assistir o filme...isso denota problemas com relação à projeção de um interlocutor...ou seja...problemas na capacidade de ação de acabam também diminuindo as capacidades discursivas...uma 
vez que a organização do texto acaba sendo prejudicada...aqui nós temos um exemplo...do aluno LF...é uma parte de uma primeira produção escrita que ele fez no semestre...nessa altura ele não incluiu uma complicação dentro da sua sinopse...a tensão central do filme que é fundamental para a construção da sinopse...e ele terminou a produção escrita dele como uma generalização que não é comum ao gênero...ah:....a parte sublinhada ele diz...Cette personne enseigne à Alexander beaucoup de chose sur la vie et il enseigne beaucoup à cette personne aussi...esse tipo de generalização estava presente na maior parte das produções dos alunos...não é o que a gente identifica no gênero sinopse...aqui tem um exemplo de uma sinopse disponível no site allóciné do filme Ratatouille...ao invés de fazer esse tipo de generalização...é preferível fazer uma enumeração que acaba convencendo o leitor de que ele vai ter acesso a uma série de valores se ele assistir o filme...então a sinopse diz...Remy va découvrir le vrai sense de l'aventure...de l'amitié...de la famille...e assim por diante...interessante notar que esse mesmo aluno que teve problemas na construção do suspense na primeira produção escrita...na última produção escrita ele mostra que não tem mais problemas com esse tipo de capacidade de ação e discursivas e na construção do suspense...o último gênero trabalhado...se tratava do relato curto literário e aí eu vou ler o que ele escreveu...alors il commence à penser qu'est ce bruit...c'est une personne?...c'est un animal?...une voiture qui est dans la rue?...et beaucoup a commencé passer à sa tête...il n'y a pas d'autres personnes à la maison...il se souvient que la porte était ouverte...et il commence à marcher très rapidement...ah:....passando para o segundo gênero trabalhado...o fait divers...nós notamos que não houve grandes problemas com as capacidades de ação e as capacidades discursivas...mas sobretudo com capacidades linguístico-discursivas...uma hipótese levantada no trabalho de Cinthia Bezerra na pesquisa dela...que::...as:....as:....as capacidades de linguagem da língua materna...conforme as meninas já expuseram aqui (a aluna se refere as outras comunicadoras que apresentaram trabalhos de pesquisa na mesma sessão)...elas podem ser transferidas para a língua alvo...de modo que...grosso modo nós não temos fait divers no Brasil...mas nós temos o gênero notícia que acaba guardando várias semelhanças com o fait divers...então nós tivemos problemas nas capacidades linguísticos-discursivas...principalmente coesão verbal...e aí é interessante...é interessante...mostrar o que aconteceu...nas perguntas introdutórias para a produção desse gênero e sobre a utilização dos tempos verbais...alguns alunos não responderam corretamente à pergunta...mas aplicaram todos os tempos verbais corretamente nas suas produções escritas...e o contrário também aconteceu...eles respondia corretamente a pergunta...mas não aplicavam nas suas produções escritas...ah::..o terceiro gênero trabalhado foi relato de viagem em blog...de discurso implicado...portanto havia subjetivação...o emprego de modalizações apreciativas foi frequente...e nós verificamos uma melhora na coesão verbal...ah::....nesse gênero é possível construir tanto no presente quanto utilizando tempos pretéritos...eles preferem a utilização de tempos pretéritos e conseguem aplicar isso de maneira satisfatória...uma exceção foi o aluno GS...que parecei ter se apropriado das capacidades linguísticodiscursivas principalmente coesão verbal...mas aí nesse momento ele acaba cometendo 
123 erros relacionados ao uso de passé composé e no uso do imparfait...o último gênero

124 trabalhado foi o relato curto literário...nós verificamos que os alunos tiveram um 125 apropriação satisfatória das capacidades esperadas...persistiram alguns problemas 126 isolados relacionados às capacidades linguístico-discursivas..ah::..relacionados à coesão 127 verbal e a coesão nominal...nas produções dos alunos GS e RG...então nós verificamos 128 que a maioria iniciou o semestre com problemas nas capacidades de ação e 129 discursiva...mas a maioria supera isso a partir da segunda produção escrita.......nós 130 levantamos uma hipótese de que as capacidades e as capacidades discursivas são mais 131 facilmente transferíveis da língua materna para a língua alvo...já as capacidades 132 linguístico-discursivas que tiveram uma apropriação mais custosa...elas mais 133 dificilmente podem ser passadas para a língua alvo uma vez que elas requerem uma 134 sistematização mais específica...ah:.....portanto estudar o percurso de aprendizagem 135 tornou possível adequar as estratégias de ensino às suas necessidades...nesse sentido o 136 uso de gêneros textuais no processo de aprendizagem permite o estreitamento as 137 ferramentas de ensino e as práticas de linguagem permitindo a apropriação de 138 verdadeiros savoirs-faire e com isso aluno amplia as suas formas de atuação no mundo 139 por meio da linguagem...as referências bibliográficas...e obrigada (frase exclamativa). 
Normas usadas nas transcrições acima:

\begin{tabular}{|c|c|c|}
\hline Ocorrências & Sinais & Exemplificação \\
\hline $\begin{array}{l}\text { Incompreensão de palavras ou } \\
\text { segmentos }\end{array}$ & () & $\begin{array}{l}\text { Do nives de rensa ( ) nivel de renda } \\
\text { nominal }\end{array}$ \\
\hline Hipótese do que se ouviu & (hipótese) & $\begin{array}{l}\text { (estou) meio preocupado (com o } \\
\text { gravador) }\end{array}$ \\
\hline $\begin{array}{l}\text { Truncamento (havendo } \\
\text { homografia, usa-se acento } \\
\text { indicativo da tônica e/ou timbre) }\end{array}$ & I & E comé/e reinicia \\
\hline Entonação enfätica & Maiúscula & Porque as pessoas reTÊM moeda \\
\hline $\begin{array}{l}\text { Prolongamento de voga e } \\
\text { consoante (como s, r) }\end{array}$ & $\begin{array}{c}:: \text { podendo } \\
\text { aumentar para :.:.:.: } \\
\text { ou mais } \\
\end{array}$ & Ao emprestarmos éh::: ... dinheiro \\
\hline Silabação & - & Por motivo tran-sa-ção \\
\hline Interrogação & $?$ & E o Banco... Central... certo? \\
\hline Qualquer pausa & $\ldots$ & $\begin{array}{l}\text { São três motivos... ou três razoes ... } \\
\text { que fazem com que se retenha moeda } \\
\text {... existe uma ... retençăo }\end{array}$ \\
\hline $\begin{array}{l}\text { Comentários descritivos do } \\
\text { trancritor }\end{array}$ & ((minúscula)) & $(($ tossiu $))$ \\
\hline $\begin{array}{l}\text { Comentários que quebram a } \\
\text { sequência temática da } \\
\text { exposição: desvio temático }\end{array}$ & $\cdots \cdots$ & $\begin{array}{l}\text {... a demanda de moeda - . vamos dar } \\
\text { casa essa notaçăo -. - demanda de } \\
\text { moeda por motivo ... }\end{array}$ \\
\hline $\begin{array}{l}\text { Superposição, simultaneidade de } \\
\text { vozes }\end{array}$ & Ligando as linhas & $\begin{array}{l}\text { a. na casa de sua irmã } \\
\text { b. [sexta-feira? } \\
\text { a. fazem LÁ } \\
\text { b. } \quad \text { [cozinham lả } \\
\end{array}$ \\
\hline $\begin{array}{l}\text { Indicação de que a fala foi } \\
\text { tomada ou interrompida em } \\
\text { determinado ponto. Não no seu } \\
\text { inicio, por exemplo. }\end{array}$ & $(\ldots)$ & (...) nós vimos que existem... \\
\hline $\begin{array}{l}\text { Citaçôes literais de textos, } \\
\text { durante a gravação }\end{array}$ & "entre aspas" & $\begin{array}{l}\text { Pedro Lima ... ah escreve na ocasião.. } \\
\text { “ O cinema falado em lingua } \\
\text { estrangeira não precisa de nenhuma } \\
\text { baRREIra entre nós”... }\end{array}$ \\
\hline \multicolumn{3}{|c|}{$\begin{array}{l}\text { 1. Iniciais maiúsculas : só para nomes próprios ou para siglas (USP etc) } \\
\text { 2. Fáticos: ah, èh, ahn, ehn, uhn, tá (não por está: tá? Você está brava?) } \\
\text { 3. Nomes de obras ou nomes comuns estrangeiros são grifados. } \\
\text { 4. Números por extenso. } \\
\text { 5. Não se indica o ponto de exclamação (frase exclamativa) } \\
\text { 6. Não se anota o cadenciamento da frase. } \\
\text { 7. Podem-se combinar sinais. Por exemplo: oh::.... (alongamento e pausa) } \\
\text { 8. Não se utilizam sinais de pausa, típicas da lingua escrita, como ponto e virgula, ponto } \\
\text { final, dois pontos, virgula. As reticências marcam qualquer tipo de pausa. }\end{array}$} \\
\hline
\end{tabular}

Figura 16 - Normas para transcrição (NURC) 


\section{RELATÓRIOS FINAIS DE PESQUISA}

\section{ESTUDANTE 1}

Relatório Final - Iniciação Científica

De Itabira para o mundo: levantamento sobre a recepção da poesia de Carlos Drummond de Andrade na França

Número do processo: $\operatorname{xxx} \operatorname{xxx} x \times x x$

Bolsista de IC: Estudante 1

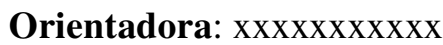




\section{Resumo do plano inicial}

É indubitável a importância da obra de Carlos Drummond de Andrade para a Literatura Brasileira. Sua personalidade, a técnica que empregou em sua poesia e seu olhar crítico e agudo sobre as coisas garantiram a Drummond o título de um dos maiores e mais importantes poetas da história da Literatura no Brasil. Tamanho reconhecimento extravasou o contexto nacional e atingiu outros países, como a Holanda, a Espanha, o Canadá e também a França.

Essa pesquisa de Iniciação Científica tinha como principal objetivo realizar o levantamento sobre a recepção da poesia de Carlos Drummond de Andrade traduzida para o francês, especificamente na França. Levando em consideração o caráter universal que os versos drummondianos podem alcançar, ainda que reconhecendo suas particularidades regionais, realizamos uma busca de toda essa poesia traduzida na França até o presente momento e procuramosentender como tal obra poética foi recebida em outro contexto cultural e em outra língua, no caso, a língua francesa.

Para tanto, baseamo-nos em teóricos que fundamentaram os elementos envolvidos na recepção de textos. Assim, a leitura de Hans Robert Jauss e Wolfgang Iser foi essencial à introdução do tema, já que ambos são responsáveis pela noção de "estética da recepção". Além desses, incorporaram-se à nossa base teórica: Regina Zilberman e Paul Zumthor, que ajudaram na compreensão da teoria defendida por Jauss e Iser; John Milton, que garantiu a compreensão do funcionamento do mercado editorial envolvendo a tradução; e Yves Chevrel, que adicionou à teoria da recepção a ideia de "horizonte de espera".

Além do embasamento teórico, o uso da internet foi uma ferramenta indispensável para que a pesquisa fosse realizada. Com ela, pudemos alcançar a grande maioria dos resultados obtidos, por meio de sites de livrarias, bibliotecas brasileiras e francesas e sebos online. No mais, foi através da internet que chegamos à comunicação com instituições francesas (uma editora e uma biblioteca) que colaboraram para a finalização desse estudo.

Finalmente, a união dos componentes destacados acima possibilitou a escrita de um comentário crítico sobre a poesia de Drummond traduzida para o francês, durante os dez meses dedicados a essa pesquisa de Iniciação Científica.

\section{Resumo do que foi realizado no período a que se refere o relatório}

\subsection{Etapas e cronograma}

Seguem abaixo, para um melhor acompanhamento das etapas descritas neste relatório, o plano de trabalho e o cronograma apresentados no projeto inicial da pesquisa:

Etapa 0 - Buscaremos textos teóricos sobre a recepção em geral da literatura em países estrangeiros, para obter base teórica que auxilie o levantamento da recepção poética de Carlos Drummond de Andrade no contexto francês. Após entendimento do que vem a ser recepção e a forma pela qual ela se expressa (críticas, estudos acadêmicos, textos publicados em revistas etc.), será possível traçar uma estratégia de busca sobre a recepção de Drummond na França. Cherem (2003), que localiza as traduções e as críticas relacionadas à obra de Lispector e analisa o contexto em que se realizou a recepção da obra clariciana, poderá servir como um apoio metodológico inicial.

\footnotetext{
6 “l'horizond'attente" (CHEVREL, 1989, p. 68)
} 
Etapa 1 - A partir da base teórica sobre recepção de literatura em língua estrangeira adquirida na Etapa 0, poderemos dar início ao levantamento da poesia de Carlos Drummond de Andrade traduzida na França. Nessa etapa, o trabalho será mais prático, ou seja, faremos uma busca em bibliotecas virtuais e físicas, em suportes eletrônicos como sites e blogs para adquirir material que possa constituir uma obra traduzida do poeta.

Etapa 2 - A Etapa 2 dará início à pesquisa da crítica em língua portuguesa da poesia de Carlos Drummond de Andrade traduzida na França.

Etapa 3 - Na Etapa 3, buscaremos textos críticos da poesia de Drummond escritos diretamente em francês.

Etapa 4 - Os estudos e levantamentos realizados em todas as Etapas anteriores permitirão na Etapa 4 a redação de comentários sobre a recepção da obra de Carlos Drummond de Andrade traduzida em francês (sobretudo da França). Nessa fase, serão explorados os conhecimentos e as informações adquiridas ao longo da pesquisa.

Etapa 5 - Durante e após a realização de todas as etapas que constituirão a pesquisa proposta, serão submetidos a publicação os resultados dela provenientes em eventos ou veículos científicos.

Cronograma:

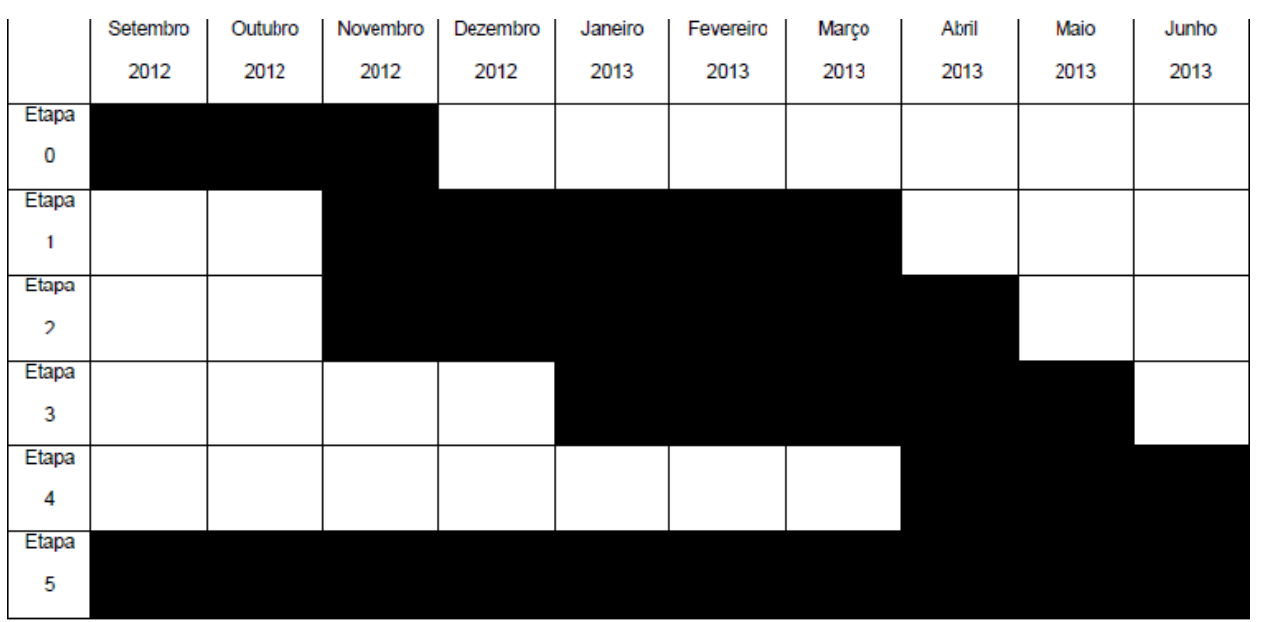

Tendo em vista que este relatório refere-se à segunda metade de nosso trabalho, estarão aqui relatadas as etapas previstas para esse período, ou seja, as etapas de número 1, 2, 3, 4 e 5.

\subsection{Resumo das etapas concluídas}

Como referido acima, este Relatório Final refere-se aos cinco últimos meses (de Janeiro de 2013 a Junho de 2013) de nossa pesquisa de Iniciação Científica. Durante esse período pudemos aproveitar o trabalho realizado na Etapa 0, em que a leitura de textos teóricos garantiram embasamento para a realização do levantamento da obra poética de Carlos Drummond de Andrade traduzida na França. Assim, demos continuidade à parte prática da pesquisa, de modo que conseguimos um avanço na Etapa 1, em que se previa o levantamento dos poemas de Drummond traduzidos para a língua francesa.

Também na etapa 2, que previa o levantamento de uma crítica traduzida sobre os poemas drummondianos, fizemos um pequeno progresso em relação ao que se registrou no 
Relatório Parcial, entregue em Janeiro de 2013. É importante destacar aqui que, apesar de não serem abundantes, os avanços alcançados nessas etapas são bastante significativos.

Dando continuidade ao cronograma, durante a Etapa 3, em que se planejou buscar textos críticos escritos diretamente em francês, a busca online permitiu encontrar alguns textos que podem compor uma concisa crítica da obra de Drummond traduzida para a língua francesa.

A busca física realizada durante as etapas posteriores reuniu antologias, reuniões de poemas e textos críticos, que serão brevemente comentados neste relatório, como previa a Etapa 4 do Projeto inicial. Por fim, a realização da Etapa 5, que compreendia todo o período da pesquisa, deu-se no mês de novembro de 2012, durante o "IV Encontro de Pesquisas do Francês" promovido pelo Departamento de Letras Modernas da Universidade de São Paulo. A mesma etapa deverá ter continuidade após a data de entrega deste relatório, também em apresentação ao "V Encontro de Pesquisas do Francês" do ano de 2013.

\section{Detalhamento dos progressos realizados, dos resultados obtidos no período, justificando eventuais alterações do projeto ou em sua execução e discutindo eventuais dificuldades surgidas ou esperadas na realização do projeto.}

\subsection{Etapa 1 - Levantamento da poesia de Drummond traduzida na França}

A Etapa 1 de nossa pesquisa compreendia um longo período (de Novembro de 2012 a Março de 2013), já que também seria uma fase intensa de busca em sites de livrarias, bibliotecas nacionais e internacionais, além de blogs e sites relacionados à literatura. Para tanto, como já foi dito no Projeto inicial e no Relatório Parcial, a internet foi elemento essencial sem o qual não conseguiríamos colher os dados necessários ao levantamento proposto.

Assim, uma busca no Google francês ${ }^{7}$ com as palavras-chave "Carlos Drummond de Andrade" / "poème" / "traduction" levou-nos a resultados já apresentados no Relatório Parcial dessa pesquisa. Essa procura ajudou-nos a compreender que, primeiramente, os suportes online facilitam a propagação da literatura mundial, já que dispensam os trâmites e burocracias editoriais; em segundo lugar, permitiu observar que a maioria dessas traduções informais online parte de tradutores (leitores e apreciadores da poesia drummondiana) brasileiros, dispostos a difundir a literatura brasileira na França. Dentre os poemas traduzidos encontrados nessa busca, "Poema de sete faces" e "No meio do caminho" são os mais recorrentes, já que também muito reconhecidos nacionalmente.

Para além dessa busca abrangente em blogs e sites, as buscas pelo sistema Dedalus ${ }^{8}$ da Universidade de São Paulo, bem como pelo sistema da Bibliothèque Nationale de France ${ }^{9}$, permitiram o mapeamento inicial que indicou a existência de livros importantes à recepção da poesia de Drummond em francês. Primeiramente, no sistema Dedalus, encontramos o livro La machinedu monde et autres poèmes(1990), uma reunião relativamente volumosa de poemas drummondianos, traduzidos por Didier Lamaison e publicados pela Editora Gallimard.

Já pelo site da livraria FNAC francesa ${ }^{10}$ adquirimos o Mort dans l'avion \& autres poèmes (2005) que, assim como a tradução de Lamaison, já foi apresentado no Relatório Parcial. Bilíngue, o livro é uma curta reunião de poemas traduzidos por Ariane Witkowski e publicado pela Éditions Chandeigne.

A intensa procura através de endereços eletrônicos conduziu-nos ao site da Librairie Compagnie $^{11}$, em que tivemos acesso a uma lista de antologias contendo poemas de Carlos Drummond de Andrade. Se, nessa página, boa parte dos livros catalogados é dada como esgotada, alguns exemplares foram encontrados no acervo da Biblioteca Florestan Fernandes, da

\footnotetext{
7http://www.google.fr

${ }^{8}$ http://dedalus.usp.br

${ }^{9}$ http://www.bnf.fr

${ }^{10} \mathrm{http}: / /$ www.fnac.com

${ }^{11}$ http://www.librairie-compagnie.fr
} 
Faculdade de Filosofia, Letras e Ciências Humanas da Universidade de São Paulo. Das antologias obtidas, algumas abordam a literatura ibero-americana, outras a poesia brasileira como um todo, outras ainda a poesia brasileira "contemporânea" - publicadas, portanto, até os anos 1980, quando o poeta itabirano era ainda vivo.

Outra livraria que nos permitiu acesso a traduções da poesia de Drummond foi a Librairie Portugaise ${ }^{12}$, em cujo site pudemos adquirir (com uso da Reserva Técnica fornecida pela FAPESP) a recém-publicada antologia bilíngue La poésie du Brésil: anthologie du XVIe au XXe siècle (2012), um intenso trabalho de Max de Carvalho publicado pela Éditions Chandeigne.

A última aquisição da pesquisa, também feita com o uso da Reserva Técnica, é o importante Réunion (1973), publicado pela Aubier Montaigne. Esgotado, o livro reúne poemas de Carlos Drummond de Andrade traduzidos para a língua francesa por Jean-Michel Massa, que também compôs um denso prefácio para essa reunião bilíngue. Esse livro, bem como todo o material citado acima, será comentado posteriormente neste relatório.

\subsubsection{Etapa 1 - resultados obtidos}

Os resultados obtidos na Etapa 1 de nossa pesquisa são dez livros, entre antologias e reuniões, localizados e adquiridos pela internet, além detraduções encontradastambém na internet, verificáveis na lista a seguir. Os poemas e suas respectivas traduções onlineestão registrados no Relatório Parcial dessa pesquisa.

La machine du monde et autres poèmes (1990) - Éditions Gallimard - Tradução: Didier Lamaison

Mort dans l'avion \& autres poèmes (2005) - Chandeigne - Tradução: ArianeWitkowski

Réunion (1973) - Aubier Montaigne - Tradução: Jean-Michel Massa

La poésie du Brésil: Anthologie bilingue du XVIe au XXe siècle - Chandeigne - Tradução: Max de Carvalho, Isabel Meyelles e Ariane Witkowski

Introduction à la poésie ibéro-américaine (1947) - Le livre dujour - Tradução: A. D. Tavares-Bastos

Anthologie de la poésie brésilienne contemporaine (1954) - Éditions Pierre Tisné Tradução: A. D. Tavares-Bastos

Anthologie de la poésie ibéro-américaine (1956) - Nagel - Tradução: Armand Guibert

Poèmes du Brésil (1985) - Éditions Ouvrières Dessain et Tolra - Tradução: Bernard Lorraine

Anthologie de la nouvelle poésie brésilienne(1988) - ÉditionsL'Harmattan - Tradução: Serge Bourjea e Benjamin Pinto-Bull

Anthologie de la poésie brésilienne (1998) - ÉditionsChandeigne - Tradução: Isabel Meyrelles

http://www.caligrafias-iberes.com - Rosario Duarte da Costa

http://myriam.rubis.wenig.over-blog.com/article-poeme-a-sept-faces-carlos-drummond-deandrade-107759055.html - Myriam Rubis

\footnotetext{
${ }^{12}$ http://www.librairie-portugaise.com/
} 
http://linguairma.blogspot.com.br/2009/02/poeme-de-sept-faces.html- Fernando de Oliveira

http://alainconny.blogspot.com.br/2011/09/hommage-carlos-drummond-de-andrade.html Alain Conny

http://www.4c.com.br/poemes_drummond_sept_faces_f.htm - tradutor desconhecido

\subsubsection{Etapa 1 - eventuais alterações e dificuldades surgidas}

Conforme mencionado no Relatório Parcial dessa pesquisa, nosso trabalho consistia em, mais do que simplesmente mapear a recepção da poesia de Drummond em francês, "garimpar" as traduçõespara o francês do poetamineiro para, somente então, identificar a recepção de sua obrana França.

A primeira dificuldade enfrentada nessa Etapa 1, de levantamento da poesia traduzida, foi o reconhecimento dos tradutores de blogs que, livres das burocracias editoriais, não são facilmente identificáveis. Em algumas das páginas, por exemplo, reconhece-se o autor do blog em questão, mas não necessariamente o tradutor que, de fato, trabalhou na versão ou tradução do poema em francês.

Outra dificuldade encontrada durante o período de busca dessa pesquisa foi a localização do livro Réunion (1973), traduzido por Jean-Michel Massa. Desde a pesquisa inicial, realizada para a composição do projeto dessa Iniciação Científica, o nome de Massa apareceu nas buscas pelo Google associado, sobretudo, à obra de Machado de Assis, mas também estava diretamente relacionado ao de Carlos Drummond de Andrade. No entanto, somente em pesquisa online pela Bibliothèque Nationale de France tomamos conhecimento da existência da reunião de poemas drummondianos traduzidos por Jean-Michel Massa.

Na tentativa de adquirir um exemplar de Réunion (1973), entramos em contato por email com a biblioteca da Université de Rennes 2, na França, instituição em que o tradutor trabalhou como professor. Informou-se que havia disponibilidade de exemplares do livro em Rennes e que a aquisição de um exemplar deveria ser negociada entre as bibliotecas de Rennes 2 e da Universidade de São Paulo. Muito provavelmente, porém, o tempo para essa negociação extrapolaria o período previsto para a realização da pesquisa.

$\mathrm{O}$ recurso a que recorremos para adquirir o livro foi o sitede vendas AbeBooks ${ }^{13}$, que reúne sebos e lojas do mundo inteiro e onde se podem encontrar livros raros. Recomendado por Júlio Castañon Guimarães ${ }^{14}$, o site dispunha de um exemplar do livro procurado, que foi adquirido, como já dito, com a Reserva Técnica da FAPESP. Desse modo, a realização da Etapa 1 terminou com a identificação de três reuniões dedicadas exclusivamente aos poemas de Carlos Drummond de Andrade em língua francesa.

\subsection{Etapa 2 - Levantamento de textos teóricos traduzidos}

A Etapa 2 da nossa pesquisa de Iniciação Científica pretendia colher possíveis textos teóricos sobre a poesia de Carlos Drummond de Andrade traduzidos para o francês. Até a data de entrega do Relatório Parcial, em Janeiro de 2013, havíamos como resultado um único livro: La Rose dupeuple: lapoésie de Carlos Drummond de Andrade (2005), publicado por ocasião do ano do Brasil na França, reunindo textos críticos de célebres teóricos brasileiros, como Antonio Candido.Na introdução, escrita pelos coordenadores, afirma-se:

\footnotetext{
${ }^{13}$ http://www.abebooks.com/

14 Em palestra, realizada na Casa Guilherme de Almeida (SP), sobre as traduções feitas por Carlos Drummond de Andrade, reunidas no livro Poesia traduzida (2011), organizado e anotado por Júlio Castañon Guimarães e Augusto Massi.
} 
Esta reunião foi preparada com o intuito de oferecer ao público francês certo número de ensaios críticos sobre a obra de um dos maiores poetas brasileiros de todos os tempos, Carlos Drummond de Andrade (TOLEDO, MIRANDA e LIBÂNIO, 2005, p. 11, tradução nossa) ${ }^{15}$.

Já o segundo e último texto teórico encontrado durante a pesquisa é « Poésie lyrique et politique au Brésil: 'la vie minimale' chez Carlos Drummond de Andrade », de Jaime Ginzburg $^{16}$. O artigo, traduzido do português para o francês por Michael A. Soubbotnik, foi publicado em 2007 na Revue Française d'Histoire des Idées Politiques e trata da relação entre a lírica e a política na poesia de Drummond.

Interessante notar que, no decorrer do texto, Ginzburg faz menção a outros textos teóricos sobre o poeta, publicados por estudiosos brasileiros. Assim, pode-se ler em nota nomes como os de Iumna Maria Simon e Vagner Camilo ${ }^{17}$. Além disso, enquanto trata da poesia do escritor mineiro, o autor entrelaça dados importantes da História Brasileira, construindo um olhar crítico sobre a constituição da literatura no país:

O Brasil da época de A Rosa do Povo é, nesse sentido, um país que não constituiu sujeitos na totalidade do termo, que não operou sínteses coletivas harmoniosas em seu processo de modernização e, ao contrário, cuja vida política reforça constantemente a desumanidade e a reificação ${ }^{18}$ (GINZBURG, 2007, p. 362-363, tradução nossa).

Enfim, é necessário destacar a importância literária das duas publicações encontradas durante essa fase de nossa pesquisa. Primeiramente porque difundem a obra do poeta mineiro e garantem ao leitor francês uma leitura especializada sobre a poesia drummondiana. Depois porque, além de posicionar os leitores francófonos nos contextos histórico e literário do Brasil, propagam nomes de críticos brasileiros, não só na França, mas em outros países de expressão francesa.

\subsubsection{Etapa 2 - Resultados obtidos}

Os resultados do levantamento da crítica sobre Drummond traduzida para o francês foram, durante o período da pesquisa:

La Rose du Peuple: la poésie de Carlos Drummond de Andrade (2005) -Editora UFMG TOLEDO, D.; MIRANDA, W. M.; LIBÂNIO, C (coord.).

\footnotetext{
${ }^{15}$ Cerecueil a étépréparédanslebut d'offriraupublicfrançaisuncertainnombre d'essais critiques surl'oeuvre de l'undesplusgrandspoètesbrésiliens de touslestemps, Carlos Drummond de Andrade (TOLEDO, MIRANDA e LIBÂNIO, 2005, p. 11).

${ }^{16}$ Jaime Ginzburg é professor de Literatura Brasileira na Faculdade de Filosofia, Letras e Ciências Humanas da Universidade de São Paulo.

${ }^{17}$ Ambos professores da Faculdade de Filosofia, Letras e Ciências Humanas da Universidade de São Paulo.

${ }^{18}$ Le Brésil de l'époque de A Rosa do Povo est, encesens, unpaysqui n'a pasconstitué de sujetsaupleinsensduterme, qui n'a pasopéré de synthèsescollectivesharmonieusesdanssonprocessus de modernisation e dont, aucontraire, lavie politique renforceconstammentl'inhumanité et laréification(GINZBURG, 2007, p. 362-363).
} 
«Poésie lyrique et politique au Brésil: 'la vie minimale' chez Carlos Drummond de Andrade » (2007) - Revue Française d'Histoire des Idées Politiques - GINZBURG, J.

\subsubsection{Etapa 2 - eventuais alterações e dificuldades surgidas}

A principal dificuldade dessa etapa deu-se, na realidade, pela falta de material produzido. Com isso quer-se dizer que ainda há muito a ser feito em relação à tradução de textos teóricos que deem suporte aos estudos da poesia de Carlos Drummond de Andrade em francês.

Como se sabe, há uma vasta crítica literária da obra poética de Drummond em português. Tais textos, no entanto, somente alcançam aqueles que por ventura conhecem o idioma. Espera-se, portanto, que os ricos textos produzidos por estudiosos brasileiros ainda não traduzidos possam ter expressão em língua francesa, para que, desse modo, a poesia drummondiana tenha maior difusão na França.

\section{Etapa 3 - Levantamento de textos críticos escritos diretamente em francês}

Na Etapa 3 de nosso trabalho, propunha-se levantar textos críticos sobre a poesia de Drummond escritos diretamente em francês. Nessa, como na maioria das outras fases da pesquisa, a internet teve papel fundamental. Buscamos no sitemaDedalus e no site da Bibliothèque Nationale de France os possíveis textos com a palavra-chave "Carlos Drummond de Andrade". Nessa fase, no entanto, esse tipo de busca não gerou nenhum resultado.

Um único texto, em particular, foi localizado através de e-mail: sabendo da existência de uma tese escrita por Ariane Witkowski, uma das tradutoras de Drummond, entramos em contato com a editora que publicou suas traduções para tentar obter esse documento, que nos foi enviado prontamente por Michel Chandeigne.

Grande parte dos textos críticos encontrados, então, foi detectada através do Google, com o uso da mesma palavra-chave. Dessa busca, resultaram oito textosenvolvendo o nome de Drummond e sua poesia. Somente um de todos os textos encontrados estava indisponível para o público em geral. Para acessá-lo, portanto, realizamos o pagamento de 2,50€ à revista eletrônica Magazine Littéraire ${ }^{19}$.

Vale aqui ressaltar que a maioria das críticas localizadas nessa fase da pesquisa trata das traduções lançadas, as divulga e considera o processo de tradução em si. Isso quer dizer que, apesar de abordarem a obra de Drummond traduzida para o francês, esses textos não necessariamente analisam literariamente as poesias traduzidas. Sobre esse assunto, retornaremos mais tarde neste relatório.

\subsubsection{Etapa 3 - Resultados obtidos}

Seguem abaixo listados os títulos de textos críticos escritos diretamente em francês sobre a poesia de Carlos Drummond de Andrade, levantados durante nossa pesquisa:

Naître et mourir au Minas Gerais. Étude de septrécits d'enfance autobiographiques brésiliens du XXe siècle - Ariane Witkowski (Tese. Paris III-Sorbonne, 1995).

Andrade, Carlos Drummond de. Poésie - Michel Riaudel (InfosBrésil n 56 Février 1991).

Anthologie permanente: Carlos Drummond de Andrade - Florence Trocmé (http://www.librairie-portugaise.com/ShowArticle.aspx?ID=345).

Mortdansl'avion\&autrespoèmes, de Carlos Drummond de Andrade - Richard Blin (http://www.lmda.net/din/tit_lmda.php?Id=21938).

Mort dansl'avion (ô drummond, ô sombra) - Patrice Beray (http://blogs.mediapart.fr/blog/patrice-beray/100911/mort-dans-lavion-o-drummond-osombra)

Luxuriance brésilienne - Jean-Yves Masson - (Magazine Littéraire: http://www.magazinelitteraire.com/mensuel/525/luxuriance-bresilienne-25-10-2012-57488)

\footnotetext{
${ }^{19} \mathrm{http} / / /$ www.magazine-litteraire.com/
} 
Le Brésil, terre de vers - Louise de Crisnay - (Libération: http://www.liberation.fr/livres/2012/12/05/le-bresil-terre-de-vers_865365)

Brésil, poésie d'uncontinentoublié - Alain Nicolas - (L'Humanité: http://www.humanite.fr/culture/bresil-poesie-d-un-continent-oublie-509210)

Du modernismeetdesanthologies - O Pau-Brasileiro (http://www.boisbresilcie.com/2012/10/du-modernisme-et-des-anthologies.html)

\subsubsection{Etapa 3 - eventuais alterações e dificuldades surgidas}

Apesar da precariedade de material em francês sobre a poesia traduzida de Carlos Drummond de Andrade, essa etapa foi concluída de acordo com o planejado, sem alterações em relação ao Projeto Inicial e sem maiores dificuldades.

\subsection{Etapa 4 - Comentário sobre a recepção da obra de Carlos Drummond de Andrade na França}

No Relatório Parcial dessa pesquisa, destacamos a importância do trabalho de Yves Chevrel (1989) para o entendimento do processo de recepção de um texto traduzido, sobretudo na França. Em "Le texteétranger: lalittératuretraduite" (1989), Chevrel questiona, sobre essa recepção:

[...] quais são os textos traduzidos? como são apresentados ao leitor? de que forma são difundidos, tanto no plano quantitativo - quantos exemplares por edição? quantas edições? - como no plano qualitativo: que tipo de público é visado? Não é certo que a resposta a essas questões seja fácil (CHEVREL, 1989 , p. 60, tradução nossa) ${ }^{20}$.

Certamente, como se explicitou em diversos momentos dessa pesquisa, a poesia de Carlos Drummond de Andrade tem características que a definem como uma obra "digna do mundo", pronta a se fazer entender em línguas e olhares culturais diversos, como mostra a afirmação sobre os poemas de Drummond destacada em uma das antologias levantadas: "Esses [poemas] poderiam ser escritos em qualquer língua: eles teriam a mesma densidade que encontramos na versão original" (BASTOS, 1947, p. 333) ${ }^{21}$.

Também já foi dito que, de fato, não é fácil entender a recepção de um texto traduzido, ou seja, o modo como é divulgado, lido e interpretado em uma língua estrangeira. Para tentar entender a recepção da poesia de Carlos Drummond de Andrade na França, e com base nas perguntas enunciadas por Chevrel, realizaremos a seguir um comentário crítico sobre todo o material que foi levantado durante os dez meses dedicados a essa pesquisa de Iniciação Científica.

\subsubsection{Comentários sobre os textos críticos encontrados durante a pesquisa}

Como já dito, foram encontrados apenas um livro e um artigo escritos em português e traduzidos para o francês sobre a poesia de Drummond. Também chegamos, através de uma

\footnotetext{
${ }^{20}[\ldots .$.$] quelssont les textestraduits?commentsont-ilsprésentés aux lecteurs? quelle diffusion connaissent-ils,$ tant au plan quantitatif - combiend'exemplaires par édition? combiend'éditions? - qu'au plan qualitatif: quel type de public estvisé? Il n'est passûr que laréponse à cesquestionssoitaisée (CHEVREL, 1989, p. $60)$.

21"Dans n'importe quelle langue ceux-cipourraientêtreécrits: ilsauraientlamêmedensitépoétique que l'ontrouvedansleurversionoriginale" (BASTOS, 1947, p. 333).
} 
intensa investigação, a textos críticos escritos diretamente em francês relacionados à obra do poeta itabirano. No primeiro caso, deve-se destacar a qualidade dos textos traduzidos: artigos e ensaios renomados no meio acadêmico brasileiro, escritos por profissionais da literatura, da poesia e, o mais importante, especialistas na leitura de Carlos Drummond de Andrade. Ressaltase novamente a importância dessas traduções, que garantem ao leitor francófono uma qualidade crítica e, por que não, uma leitura feita a partir do olhar brasileiro sobre essa poesia ao mesmo tempo nacional e universal.

Ainda tratando dos textos teóricos traduzidos para a língua francesa, deve-se considerar a ocasião em que foram publicados. La Rose dupeuple: lapoésie de Carlos Drummond de Andrade (2005) publicou-se por ocasião do ano do Brasil na França, como afirma a própria edição:

Esta publicação de ensaios sobre a notável poesia de Carlos Drummond de Andrade representa uma dupla homenagem prestada pelo Ministério da Educação aos artistas brasileiros que tanto contribuíram e contribuem para o diálogo cultural entre nosso país e a Europa e também aos leitores franceses nesse ano de 2005, em que se comemora o Ano do Brasil na França (MACULAN, 2005, p. 9, tradução nossa) ${ }^{22}$.

Já« Poésie lyrique et politique au Brésil: 'la vie minimale' chez Carlos Drummond de Andrade », por outro lado, teve publicação no ano de 2007 e tinha um conteúdo bastante particular que, efetivamente, encaixava-se no tema específico proposto pela revista em que se encontra: "poésie et politique".Assim, se o livro traduzido teve publicação justificada por um fator extrínseco à literatura em si, o artigo de Ginzburg foi traduzido em um contexto coerente aos estudos literários. Certamente, vê-se entre o livro e o artigo uma significativa diferença circunstancial de publicação.

No que se refere aos textos críticos escritos diretamente em francês, podem-se destacar características comuns a quase todos: são, em grande maioria, textos lançados há pouco tempo, à época do lançamento de Mort dans l'avion \& autres poèmes (2005, tradução de Ariane Witkowski), ou da reedição de La machine du monde et autres poèmes (2005, tradução de Didier Lamaison). Não por coincidência, observa-se novamente que em 2005 comemorou-se o ano do Brasil na França.

Nos textos ainda mais recentes, de 2012, nota-se a atenção voltada ao lançamento da antologia La poésie Du Brésil: anthologie Du XVIe au XXe siècle (2012, organização de Max de Carvalho). Nesses, não há especificamente uma crítica dos poemas de Drummond, mas da antologia como um todo.

Essa é, aliás, outra característica observada nesses textos críticos levantados: não são, exatamente, artigos voltados à análise literária. São, na verdade, críticas das traduções lançadas.Assim, por exemplo, lê-se na crítica publicada em $1991 \mathrm{em}$ InfosBrésil ${ }^{23}$, sobre a coletânea traduzida por Lamaison:

Infelizmente, a satisfação que suscita esse lançamento está impregnada de decepção: parece ter faltado um "anjo torto" para vigiar o tradutor e the

\footnotetext{
${ }^{22}$ Cette publication d'essais sur la remarquable poésie de Carlos Drummond de Andrade représente un double hommage rendu par leMinistère de l'Education d'une par taux artistes brésiliens qui ont tant contribué et contribuent au dialogue culturel entre notre pays et l'Europe et de l'autre aux lecteurs français en cette année 2005 où l'on comémore l'Année du Brésilen France (MACULAN, 2005, p. 9). ${ }^{23}$ Infos Brésil, no 56 Février 1991.
} 
sussurrar 'Didier, você será gauche ao traduzir Drummond'” (RIAUDEL, 1991, tradução nossa $)^{24}$.

Enfim, destaca-se um trabalho, em especial, em que se estudam alguns versos de Carlos Drummond de Andrade: Ariane Witkowski, em sua tese ${ }^{25}$ intitulada Naître et mourir au Minas Gerais. Étude de sept récits d'enfance autobiographiques brésiliens du XX esiècle (Paris IIISorbonne, 1995), propõe-se a analisar textos autobiográficos de escritores brasileiros do século $\mathrm{XX}$. Assim, consequentemente, tem-se uma análise mais literária, em língua francesa, dos versos drummondianos.

De todo modo, é notável o prestígio do poeta mineiro para o público francês, ainda que sob um "desconhecimento velado" de sua obra. Averíguam-se, vinculados a seu nome, termos como "um dos grandes nomes da poesia brasileira", "poeta excepcional" ou "o maior poeta brasileiro do século XX".

Finalmente, um detalhe chamou atenção dentre as críticas levantadas. Em meio aos termos elogiosos à figura do poeta itabirano, surge uma comparação entre Carlos Drummond de Andrade e Fernando Pessoa: "Drummond de Andrade não é um heterônimo esquecido por Pessoa no outro lado do Atlântico" (BÉRAY, 2011) ${ }^{26}$. Tal comparação, que parece óbvia ao autor do texto, evoca justamente o que afirma Regina Zilberman (2009), em Estética da recepção e história da literatura:

A obra literária é comunicativa desde sua estrutura; logo, depende do leitor para a constituição de seu sentido. Este não corresponde a nenhum conteúdo universal, perene e imutável a ser extraído por um leitor competente; pelo contrário, pode mudar, se o público, a sociedade e a época forem outros (ZILBERMAN, 2009, p. 64).

Ou seja: as leituras de uma obra, como a poesia de Drummond, variam conforme a visão cultural e os valores dirigidos a ela. Pelo que indica essa comparação, a poesia de Drummond é, para os franceses, um exemplo de expressão da língua portuguesa, como o é Fernando Pessoa. Tal constatação se confirma com a leitura de outra crítica, sobre a antologia organizada por Max de Carvalho:

Mas o português não é somente a língua de Portugal: oito países, dos quais cinco africanos, o têm como língua oficial, o que faz dele (aproximadamente) a oitava língua mais falada do mundo - classificação obtida, sobretudo, graças ao Brasil e seus 192 milhões de lusófonos. Do ponto de vista literário, o Brasil ainda é para os franceses, largamente, um continente a ser explorado (MASSON, 2012) ${ }^{27}$.

\footnotetext{
${ }^{24}$ Malheureusement, la satisfaction que suscite sa parution est empreinte de décéption: il aura manquéun 'angetortu' pour mettre engardele traducteur et luis ouffler 'Didier, tu seras gauche entraduisant Drummond' (RIAUDEL, 1991).

${ }^{25}$ Tese gentilmente cedida por Michel Chandeigne para compor nosso levantamento.

26 "Drummond de Andrade n'est pasunhétéronymeoublié par Pessoa de l'autre côté de l'Atlantique" (BÉRAY, 2011).

${ }^{27}$ Mais le portugais n'est pass eu le mentla langue du Portugal: huit pays, dont cinqen Afrique, l'ont pour langue officielle, ce quien fait (environ) la huitième langue la plus par léeau monde - un rang qu'elle do it sur tout au Brésil et à ses 192 millions de lusophones. Du point de vue littéraire, le Brésil reste pour les Français, très largement, un continent à explorer (MASSON, 2012).
} 
Como Masson não deixa de afirmar, e felizmente, os franceses ainda têm muito a explorar sobre a vasta literatura brasileira - incluindo aí, obviamente, a vasta obra poética de Drummond.

\subsubsection{Comentários sobre as antologias poéticas que contêm poemas de Carlos Drummond de Andrade}

No total, obtivemos acesso a sete antologias em francês contendo poemas traduzidos de Carlos Drummond de Andrade. Três delas foram publicadas entre as décadas de 1940 e 1950; outras três tiveram publicação entre as décadas de 1980 e 1990; e, finalmente, a já citada $L a$ poésie du Brésil: anthologie du XVIe au XXe siècle teve publicação no final de 2012.

Dentre as publicações, duas contém poemas ibero-americanos e as outras abordam a poesia brasileira de maneiras variadas: uma antologia que reúne poemas diversos em uma espécie de "viagem" pelo Brasil; outra que desenvolve um panorama geral da poesia brasileira, outra ainda que se propõe a apresentar a "nova poesia brasileira". Sobre essa última, nota-se uma contradição: intitulado Anthologie de la nouvelle poésie brésilienne (1988), o livro contém poemas de Carlos Drummond de Andrade. Ora, um leitor atento às datas percebe, sem esforço, que o ano de publicação do livro não corresponde ao período em que viveu Drummond (1902 1987). O organizador, no entanto, explica:

Poderia parecer surpreendente encontrar, nesta reunião sobre a nova poesia brasileira, o nome de Carlos Drummond de Andrade, que faleceu em agosto de 1987 no Rio de Janeiro, e é característico para muitos de uma poesia modernista cuja elaboração teve sua contribuição [...]. Isso seria esquecer que Drummond, seguramente um dos maiores poetas mundiais contemporâneos, desenvolveu até o fim de sua vida uma obra complexa, e que o mesmo é invariavelmente reconhecido como mestre por todos os poetas brasileiros atuais (BOURJEA, 1988, p. 189, tradução nossa) ${ }^{28}$.

Outro fator interessante em relação a grande parte das antologias levantadas é o contexto editorial envolvido nas publicações. Anthologie de la poésie Ibéro-américaine (1956), por exemplo, é parte de uma coleção chamada "Collection UNESCO d'oeuvresreprésentatives", que, como se pode concluir, propõe-se a apresentar obras significativas da literatura mundial. $\mathrm{O}$ caso de Anthologie de la poésie brésilienne (1998) é ainda mais específico: o livro foi publicado por meio de um concurso organizado pelo Centre Culturel CalousteGulbenkian (Paris), pela Fundação Biblioteca Nacional (Rio de Janeiro) e pelo Centre Nationaldu Livre. No mais, notase uma constante ligação afetiva dos tradutores e organizadores com brasileiros: Serge Bourjea, por exemplo, dedica sua antologia, in memoriam, a Maria Arminda de Souza Aguiar.

Com isso, quer-se dizer que, em muitos casos, a publicação dessas antologias não se dá simplesmente por interesses estéticos e literários, mas por ocasiões culturais ou mesmo políticas, como é o caso da coleção promovida pela UNESCO. Percebe-se, assim, que o interesse em relação à literatura brasileira como um todo é, normalmente, ligado a contextos extrínsecos, como já afirmado neste relatório.

\footnotetext{
${ }^{28}$ Il pourrait paraître surprenant de trouver au terme de ce recueil surla nouvelle poésie brésilienne le nom de Carlos Drummond de Andrade, décédéen août 1987 à Rio de Janeiro, et caractéristique pour beaucoup d'une poésie moderniste qu'il contribua à élaborer[...]. Ce serait oublier que Drummond, assurément l'un des plus grands poètes mondiaux contemporains, a développé jusqu'à la fin de savie une oeuvre complexe et qu'il est invariablement reconnu comme maître à écrire par tous les poètes brésiliens actuels(BOURJEA, 1988, p. 189).
} 
Também as diferenças culturais são notáveis nas antologias levantadas: um bom exemplo disso é Poèmes du Brésil (1985), que propõe uma "viagem didática" ao país tropical: "Dê-me sua mão, siga-me, estamos indo ao Brasil" 29" (LORRAINE, 1985, p. 7, tradução nossa). O livro parece, na verdade, voltado para o público infantil e disposto a esclarecer malentendidos criados pela diversidade cultural entre Brasil e França. Não é sua principal intenção, portanto, apresentar o trabalho poético brasileiro, mas as características do país em forma de versos.

Por fim, é interessante atentar às diferenças de visão literária transparentes em certas passagens: em Anthologie de la poésie brésilienne contemporaine (1954), A. D. Tavares Bastos começa a apresentação de Carlos Drummond de Andrade com a seguinte frase: "Assim como Murilo Mendes, Carlos Drummond de Andrade fez-se notar inicialmente por umaveia sarcástica que evocava um lirismo muito puro ${ }^{30 "}$ (BASTOS, 1954, p. 173, tradução nossa). No entanto, aqueles que, na escola ou na universidade brasileiras, estudam o Modernismo brasileiro, raramente são apresentados a Drummond por meio de uma comparação com Mendes. Por razões histórico-literárias diversas - que não cabem a este relatório -, a obra desse último é menos reconhecida nacionalmente. Muito provavelmente, em um texto brasileiro, o contrário aconteceria: Murilo Mendes seria apresentado ao público a partir de uma comparação com Drummond. Esse pequeno detalhe, observado de perto, confirma o que explica Chevrel (1989) sobre os "horizontes de espera":

[...] o público é condicionado por um horizonte de espera que serve como verdadeiro filtro, ou como crivo, para as novas obras. A obra literária se caracteriza, portanto, por uma tensão entre dois horizontes de espera - aquele da obra, aquele do público - que coincidem mais ou menos (CHEVREL, 1989, p. 68 , tradução nossa) ${ }^{31}$.

Assim, a condição do público atingido pela tradução (e com disso entende-se, aqui, sua visão cultural, seus conhecimentos prévios e os valores que atribui a cada objeto) modifica sua leitura e, por consequência, transforma a obra lida.

\subsubsection{Comentários sobre as reuniões de poemas dedicadas à poesia de Carlos Drummond de Andrade}

Durante a Etapa 1 de nossa pesquisa, foram levantados três livros dedicados exclusivamente à poesia de Carlos Drummond de Andrade traduzida para o francês. Tendo em vista o que afirma John Milton, em $O$ Clube do Livro e a Tradução (2002):

A literatura traduzida pode ter um papel importante na visão de mundo ao dar aos cidadãos a sensação de familiaridade com coisas estrangeiras, resultando na crescente sofisticação dos membros da comunidade "imaginada" $e$ tornando-os participantes de uma comunidade "imaginada" internacional (MILTON, 2002, p. 133).

\footnotetext{
29 "Donne-moi lamain, suis-moi, nouspartonspourleBrésil” (LORRAINE, 1985, p. 7)

30 “Tout comme Murilo Mendes, Carlos Drummond de Andrade se fitremarquer à sesdébuts par une verve sarcastique d'où se dégageaitunlyrismetrèspur" (BASTOS, 1954, p. 173).

${ }^{31}[. .$.$] le public est conditionné par un horizon d'attente qui sert de véritable filtre, ou de crible, pour les$ oeuvres nouvelles, L'oeuvre littéraire se caractérise donc par une tension entre deux horizons d'attentecelui de l'oeuvre, celui du public - qui coincident plus ou moins (CHEVREL, 1989, p. 68).
} 
Certamente, essas três coletâneas encontradas podem colaborar - e já colaboram - para a familiarização do público francês com a poesia brasileira.

Dos livros levantados, o primeiro é La machine du monde et autres poèmes (1990), uma extensa reunião de poemas traduzidos por Didier Lamaison. Publicado em 1990 e reeditado em 2005 pela Editora Gallimard, o livro oferece ao leitor francófono um prefácio interessante, que apresenta o poeta mineiro a um público ainda desconhecedorde sua obra:

É, então, um poeta fenomenológico que apresentamos hoje ao público francês? Aparentemente, ninguém se preocupou menos com a filosofia e, mais certamente, com a fenomenologia, que esse filho de proprietário da terra, de uma região montanhosa do Brasil, nascido em 1902 e destinado pelo pai, com o qual nunca teve boas relações, a se tornar auxiliar farmacêutico(LAMAISON, 2005 , p. 8 , tradução nossa) ${ }^{32}$.

Além disso, também trata de questões literárias, ao analisar brevemente o poema "Mort et avion":

É claro que o estranhamento desse dispositivo poético simplesmente reproduz, aumentando-o, o próprio estranhamento da condição humana dessa condição mortal que lhe cabe, face à morte que lhe é destinada, de estar em condição de indubitável saber e de ignorância absoluta (LAMAISON, 2005 , p. 7 , tradução nossa) ${ }^{33}$.

Coincidência ou não, esse mesmo poema brevemente analisado por Lamaison intitula a segunda reunião levantada durante nosso trabalho: Mort dans l'avion \&autres poèmes (2005) é uma pequena coletânea bilíngue de poemas traduzidos por Ariane Witkowski e publicados pela Éditions Chandeigne. O prefácio deste é, em relação ao de Lamaison, bem menos intenso: além de apresentar a tradutora, apresenta-se brevemente a biografia do poeta: "Carlos Drummond de Andrade nasceu em Itabira do Mato Dentro, no Estado de Minas Gerais, no dia 31 de outubro de 1902. Casou-se muito novo e se tornou professor de colégio, ainda que sua formação fosse de farmacêutico" (WITKOWSKI, 2005, p. 7, tradução nossa) ${ }^{34}$.

Não há nesse livro, portanto, nenhuma análise literária que aprofunde as características líricas de Carlos Drummond de Andrade. Isso não significa, porém, que não haja por parte da editora e da tradutora uma preocupação estética com a poesia de Drummond. Essa preocupação, nota-se, pode ser verificada na já citada tese de Witkowski sobre a literatura brasileira autobiográfica do século XX.

32 Est-ce donc un poète phénoménologue que nous présentons aujourd'huiau public français?

Apparamment, nulnes'est moins soucié de philosophie, et, à plus forte raison, de phénoménologie, que ce fils de propriétaire terrien d'une région montagneuse du Brésil, né en 1902, et destiné par son père, avec leque lil n'avait cessé d'avoir des relations difficiles, à devenir laborantin en pharmacie (LAMAISON, 2005, p. 8).

${ }^{33}$ Il est clair que l'étrangeté de ce dispositif poétique ne fait que reproduire, en la grossissant, l'étrangeté même da la condition humaine - de cette condition mortelle à laquelle il échoit, face à la mort qui lui est destinée, d'être ensituation d'indubitables avoir et dignorance absolue (LAMAISON, 2005, p. 7).

${ }^{34}$ “Carlos Drummond de Andrade naquit à Itabira do Mato Dentro, dans la province du Minas Gerais, le 31 octobre 1902. Il se maria très jeune et devint professeur de lycée, quoiqu'il fût pharmacien de formation" (WITKOWSKI, 2005, p. 7) 
São também notáveis as preocupações estética e histórico-literária no terceiro livro levantado durante a pesquisa: Réunion (1973) é uma reunião também bilíngue de poemas drummondianos traduzidos para o francês por Jean-Michel Massa. Curiosamente, quando da publicação desse livro pela Editora Aubier Montaigne, o poeta itabirano ainda era vivo.

Em Réunion (1973), Massa compõe um prefácio que, diferentemente dos outros dois tradutores, introduz o leitor francófono em uma camada mais profunda da poesia de Drummond: suas origens interioranas, o contexto histórico-social da época, a relação de sua cidade, Itabira, com o Estado de Minas Gerais e com o Brasil:

Não há necessidade de desenvolver aqui o que poderia constituir uma teoria da literatura brasileira, mas somente de reter um traço que faz com que o itinerário seguido por nosso poeta não seja um caso único. O que lhe é próprio são as variações individuais que seu destino literário conhecerá através de suas peregrinações (MASSA, 1973, p. 14, tradução nossa) ${ }^{35}$.

Para além das diferenças significativas observadas nos prefácios das três reuniões, algumas características são constantes em todos os livros: primeiramente, nota-se que a escolha dos poemas traduzidos não é aleatória. Os três tradutores incluíram em suas coletâneas poemas representativos da poesia drummondiana, como "Poema de sete faces" e "No meio do caminho" (Alguma Poesia, 1930). No entanto, também consideraram a obra poética como um todo, demonstrando discernimento e consciência sobre a importância da obra de Carlos Drummond de Andrade em sua totalidade.

Também é importante notar que, nos três casos, os tradutores apresentaram preocupação quanto à organização dos poemas, que estão classificados de acordo com a publicação original brasileira. Sobre isso, em nota, Didier Lamaison afirma: "Nós respeitamos o texto e a ordem quase cronológica adotada pelo próprio Drummond para os dois volumes de Nova Reunião" [...] (LAMAISON, 2005, p. 16)

Foi Lamaison, aliás, o tradutor que mais se preocupou com notas explicativas ao final do livro: ao todo, La machine du monde et autres poèmes (2005) conta com dezesseis páginas dedicadas a notas de esclarecimento ao leitor, enquanto as reuniões de Witkowski e Massa oferecem apenas uma página. Por outro lado, deve-se considerar que Mort dans l'avion \& autres poèmes (2005), bem como Réunion (1973), são edições bilíngues, que possibilitam ao leitor uma comparação direta com o original em português.

Finalmente, é importante compreender como se deu a recepção desses três livros, bem como de todo o material levantado durante essa pesquisa de Iniciação Científica: como já observado neste relatório, 2005 foi data marcante para as relações entre França e Brasil, porque foi quando se comemorou o ano do Brasil na França. Nesse período, como já dito, reeditou-se a reunião de Didier Lamaison, publicado pela primeira vez em 1990, e foi lançada a coletânea traduzida por Ariane Witkowski.

Sobre esta última, faz-se necessário atentar à editora que publicou os poemas traduzidos: trata-se das Éditions Chandeigne, que conta com uma série denominada Série Lusitane. Nela, estão também publicados autores como Camões, Fernando Pessoa e Machado de Assis, além da antologia La poésie du Brésil: anthologie du XVIe au XXe siècle (2012), referida em nosso trabalho. Essa série, cabe dizer, é coerente com a linha editorial descrita por Chevrel (1989):

\footnotetext{
${ }^{35}$ Il n'est pas utile de développer ici ce qui pourrait constituer une théorie de la littérature brésilienne, mais seulement de retenir untraitqui fait que l'itinéraire suivi par notre poète n'est pas un cas unique. Ce qui lui est propre ces ont les variations individuelles que son destin littéraire va connâitre à travers ses périgrinations (MASSA, 1973, p. 14).

${ }^{36}$ "Nous avons respecté le texte et l'ordre quasi chronologiquea dopté par Drummond lui-même pour les deux volumes de Nova Reunião" [...] (LAMAISON, 2005, p. 16).
} 
[...] alguns editores jogam com o estrangeirismo, assim como com a excentricidade do texto traduzido: as Publicações orientalistas da França escolheram apresentar suas traduções fazendo aparecer claramente, na capa, a expressão “D”Etranges pays”...(CHEVREL, 1989, p. 66, tradução nossa) ${ }^{37}$.

A visão "estrangeirizada" da poesia de Carlos Drummond de Andrade, percebida durante essa pesquisa, está associada, primeiramente, à visão mística do público francês sobre um país tropical como o Brasil. Depois, observou-se que há, para o leitor francófono, uma ligação direta entre a literatura portuguesa e a brasileira, que resultou, por exemplo, na Série Lusitane das Éditions Chandeigne.

Desse modo, a conclusão geral dessa pesquisa é que, apesar das reuniões traduzidas e da presença do poeta mineiro em algumas antologias em francês, a poesia de Carlos Drummond de Andrade na França é ainda um tema a ser vastamente explorado e estudado.

\subsection{Etapa 5 - Publicação dos resultados da pesquisa}

A realização da Etapa 5, que previa a publicação dos resultados obtidos durante todo o período da pesquisa de Iniciação Científica, deu-se primeiramente no mês de novembro de 2012, durante o "IV Encontro de Pesquisas do Francês" promovido pelo Departamento de Letras Modernas da Universidade de São Paulo.

Essa mesma etapa deverá ter continuidade após a data de entrega deste relatório, também em apresentação ao "V Encontro de Pesquisas do Francês" do segundo semestre de 2013. Além disso, está submetido um resumo de nosso trabalho para apresentação de pôster no XI Congresso Internacional da ABRAPT a ocorrer em Setembro de 2013 e um artigo em coautoria com a orientadora está em preparação.

\section{Considerações Finais}

Durante os dez meses consagrados à nossa pesquisa de Iniciação Científica, cujos resultados estão descritos neste relatório, pudemos melhor compreender como uma obra estrangeira é recebida em outro país. O estudo da recepção da poesia de Carlos Drummond de Andrade na França permitiu-nos observar o modo como é lido um poeta tão representativo de nosso país e de nossa literatura em um contexto extranacional. Com isso, pôde-se traçar um panorama do olhar francês dirigido à literatura - especificamente à poesia de Drummond - e à cultura brasileiras.

Com odesenvolvimento desse trabalho, chegou-se à conclusão de que, muito mais do que o processo tradutório, o estudo da recepção de uma obra estrangeira envolve questões culturais, políticas e editoriais que marcam a chegada de um texto literário em outro país. Além disso, observou-se a importância da internet para a difusão da literatura estrangeira: livres de processos burocráticos, tradutores (profissionais ou não) publicam livremente aquilo que produzem, em blogs e sites direcionados à literatura. Com isso, a difusão literária torna-se maior e mais rica, atingindo um público também maior e mais abrangente. Obviamente, essa maior difusão dificulta o mapeamento da recepção de uma obra e, assim, algumas orientações foram essenciais para o desenvolvimento de nossa pesquisa.

Desse modo, gostaria de agradecer especialmente o Prof. Dr. João Azenha Junior pelas referências indicadas sobre recepção literária; Michel Chandeigne, das Éditions Chandeigne,

\footnotetext{
${ }^{37}[. .$.$] certains éditeurs jouent sur l'étrangeté, autant que sur l'extranéité du texte traduit: les Publications$ orientalistes de France ont choisi de présenter leurs traductions en faisant figurer bien nettement, sur la page de couverture, l'expression «D'Etranges pays »...(CHEVREL, 1989, p. 66).
} 
pela atenção em nos enviar a tese de Ariane Witkowski que compõe a crítica de Carlos Drummond de Andrade em francês; e, finalmente, o Prof. Dr. Álvaro Faleiros pelos comentários realizados durante o Encontro em que apresentei a pesquisa, além das indicações bibliográficas sobre recepção literária, tradução e, especificamente, as traduções de Drummond para o francês.

Com a pesquisa desenvolvida em nível de Iniciação Científica, consegui entender um pouco melhor os procedimentos referentes ao desenvolvimento de um projeto, com todas as suas consequências (redação de relatório, apresentação da pesquisa em eventos científicos, por exemplo) e, mais especificamente, entender como parte da literatura brasileira é vista e recebida em outro país, no caso a França. Além disso, os resultados dessa pesquisa de IC serão a base para a elaboração de um projeto de mestrado, em preparação, sobre o mesmo tema, porém acrescido de nossa tradução comentada de poemas de Drummond para o francês, como mostra o exemplo abaixo: 


\section{"Destruição" (Lição de Coisas, 1962) - Carlos Drummond de Andrade}

Os amantes se amam cruelmente e com se amarem tanto não se vêem. Um se beija no outro, refletido.

Dois amantes que são? Dois inimigos.

Amantes são meninos estragados pelo mimo de amar: e não percebem quanto se pulverizam no enlaçar-se, e como o que era mundo volve a nada.

Nada, ninguém. Amor, puro fantasma que os passeia de leve, assim a cobra se imprime na lembrança de seu trilho.

E eles quedam mordidos para sempre. Deixaram de existir mas o existido continua a doer eternamente.

\section{"Destruction" (tradução: Ana Beatriz Coutinho Takematsu)}

Les amants, ilss'aimentcruellement etcommeilss'aimenttant, ils ne voientrien.

L'uns'embrassedansl'autre, reflété

Que sontlesdeuxamants? Deuxcombattants.

Les amants, cespetits gamins gâtés

Par le câlind'aimer, ils ne voient pas quel'on se pulvérise à s'enlacer

etquece monde pleindevient le rien.

Rien.Personne.L'amour, cepurfantasme cepromenneurléger, êtreondulant qui reste à lamémoire de leurschemins.

Et puis ils se trouventpris à jamais. Eux, ils n'existentplus, mais l'existé persiste et fait mal, éternellement.

A tradução acima foi realizada em 2013 e já discutida com a orientadora, podendo ser ainda melhorada durante o desenvolvimento da continuação da presente pesquisa em nível de mestrado. 
Bibliografia

ANDRADE, C. D. de. Mort dans l'avion \& autres poèmes. Tradução de Ariane Witkowski. Paris: Éditions Chandeigne, 2005.

1990. . La machine du monde et autres poèmes. Tradução de Didier Lamaison. Editions Gallimard, . Réunion. Tradução de Jean-Michel Massa. Aubier Montaigne, 1973.

BOURJEA, S . (org.). Anthologie de la nouvelle poésie brésilienne. Paris : Editions L’Harmattan, 1988.

CHEREM, L. P. Um olhar estrangeiro sobre a obra de Clarice Lispector: Leitura e recepção da autora na França e no Canadá (Québec). São Paulo, 2003. Tese (doutoramento) - USP.

CHEVREL, Y. "Le texte étranger: la littérature traduite". Em : Précis de littérature comparée. BRUNEL, P. CHEVREL, Y (dir.). Presses Universitaires de France, 1989.

GINZBURG, J. « Poésielyriqueet politique auBrésil: 'lavieminimale' chez Carlos Drummond de Andrade ». Tradução de Michael A. Soubbotnik. In: RevueFrançaised'HistoiredesIdées Politiques, 2007.

ISER, W. “A interação do texto com o leitor". Em: A literatura e o leitor: textos de estética da recepção (org. e trad.: Luiz Costa Lima). Rio de Janeito: Paz e Terra, 1979.

JAUSS, H.R. Pour une esthétique de la réception. Tradução do alemão de Claude Maillard. Paris: Editions Gallimard, 1978.

LORRAINE, B. (org.). Poémes du Brésil. Paris : Les Editions Ouvrières Dessain et Tolra, 1985.

MILTON, J. O clube do livro e a tradução. Bauru : EDUSC, 2002.

OSNIS, F. (org.). Anthologie de la poésie ibéro-américaine. Paris : Nagel, 1956.

PALlOTTINI, R. (org.). Anthologie de la poésie brésilienne. Paris : Éditions Chandeigne, 1998.

TAVARES-BASTOS, A. D. DARMANGEAT, P (org.). Introduction à lapoésieibéro-américaine. Paris: Le livre dujour, 1947.

TAVARES-BASTOS, A. D. (org.). Anthologie de lapoésiebrésiliennecontemporaine. Paris: Éditions Pierre Tisné, 1954.

ZILBERMAN, R. Estética da recepção e história da literatura. São Paulo: Ática, 2009.

ZUMTHOR, P. Performance, recepção, leitura. Tradução de Jerusa Pires Ferreira e Suely Fenerich.São Paulo: COSACNAIFY, 2007. 


\section{ESTUDANTE 2}

\section{Introdução}

A presente pesquisa insere-se contexto do ensino/aprendizagem da leitura em língua estrangeira, mais especificamente, em língua francesa, e busca, por meio da análise da convergência entre as teorias do ensino da leitura já existentes e aquelas trazidas pela abordagem plural da intercompreensão de línguas românicas, surgidas a partir dos anos 80, refletir sobre como o desenvolvimento de competências leitoras pode ultrapassar os limites de uma única língua-alvo e contribuir para o surgimento de um leitor autônomo plurilíngue.

Tal discussão apresenta-se há muito tempo como indispensável no contexto acadêmico, dada a necessidade comum dos estudantes de consultar bibliografias de pesquisa que nem sempre se encontram traduzidas, ou mesmo no que diz respeito aos exames de proficiência em língua estrangeira - pré-requisito para o ingresso nos programas de Pós-Graduação da Universidade de São Paulo (doravante, USP) - que avaliam justamente a competência de compreensão escrita na língua-alvo. Será mesmo necessário ingressar em um curso de língua estrangeira a cada vez que surgir a necessidade de ler em outra língua? Como mostrar aos alunos que a compreensão escrita não se dá apenas por meio da "decifração" dos elementos linguísticos de um texto? E mais, como fazer para que os alunos ativem e transfiram para outras línguas as competências já desenvolvidas em língua materna?

Para responder essas questões, a presente pesquisa apresenta a experiência feita em uma turma do curso de Práticas de Leitura em Francês - Nível I, organizado em quatro módulos (doravante, PLF), do Centro de Línguas da Faculdade de Filosofia, Letras e Ciências Humanas da USP (doravante, CL-USP), por meio da aplicação de atividades concebidas a partir dos conceitos trazidos pela abordagem da intercompreensão de línguas românicas, envolvendo outras línguas desta família além do francês. Essas atividades foram aplicadas em dois momentos do curso: no chamado "Módulo 1", como forma de sensibilizar os alunos para o processo da compreensão escrita; e no "Módulo 4", o último do curso, cujo objetivo era demonstrar para os alunos que, ao final do percurso proposto, eles estão capacitados a ler não só em português e/ou francês, mas também em outras línguas românicas, desde que mobilizando as estratégias e recursos corretos.

\section{Justificativas}

2.

Inicialmente, se faz importante destacar alguns aspectos institucionais atuais. A atual organização dos cursos de leitura oferecidos pelo CL-USP segue a organização "por língua" do Departamento de Letras Modernas, no qual cada língua - francês, espanhol, inglês e italiano - é responsabilidade dos professores/pesquisadores de cada área. Nesse contexto, são raros os projetos de colaboração numa perspectiva "transversal", como seria a intercompreensão em línguas românicas. Do ponto de vista institucional, arrisca-se dizer que a USP, e mais particularmente, o CL-USP, não têm intenção concreta de mudar essa situação.

Entretanto, mesmo que as estruturas não mudem, é preciso levar em consideração as mudanças no que concerne as políticas de internacionalização que a USP tem privilegiado já há alguns anos. A crescente mobilidade de alunos das mais diversas universidades para a Europa, possibilitada pelos programas de intercâmbio e de formação de duplo-diploma, nos faz analisar com mais atenção o perfil e as necessidades dos alunos. 
A questão do plurilínguismo tornou-se uma das mais mais centrais de nossos dias, no que concerne os projetos de internacionalização e as políticas de ensino/aprendizagem de línguas, na medida em que o perfil linguístico adquire uma dimensão maior, principalmente em relação às competências a serem desenvolvidas, pois, a partir de agora, produção e recepção podem ser consideradas em diferentes níveis. Não se trata de não desenvolver as quatro competências tradicionais (ler, escrever, falar e compreender), mas sobretudo de apontar uma abertura para um novo perfil que leva em conta uma certa dissociação entre recepção e produção nas línguas que os alunos já dominam ou estão estudando.

Dessa forma, uma metodologia que visa "quebrar o tabu" do ensino compartimentado, segmentada, língua por língua, tem muito a contribuir com a formação desse estudante universitário atual, que têm sua necessidade de pesquisar e ler textos ainda não traduzidos nas diversas línguas, que precisa ser aprovado no exame de proficiência para ingresso nos programas de pós-graduação e/ou planeja fazer parte de seus estudos no exterior.

\section{Objetivos}

Diante desse contexto plurilíngue real, pergunta-se: como o desenvolvimento da competência de compreensão escrita em língua francesa poderia favorizar a compreensão escrita nas outras línguas vizinhas (espanhol, italiano e romeno)?

Por meio das citadas atividades envolvendo outras línguas românicas, a presente pesquisa tem por objetivo principal analisar em que medida as teorias de intercompreensão contribuem para o desenvolvimento de competências leitoras em línguas estrangeiras (no plural), por meio da identificação dos procedimentos cognitivos e metacognitivos ativados nos processos de construção de sentido durante a leitura dos textos e das aulas de PLF.

Para tanto, é necessária a reflexão sobre quais atividades e exercícios facilitam a evolução dos processos de leitura desenvolvidos pelos alunos e, sobretudo, de que forma essas atividades impactam no surgimento dos leitores autônomos. Na fase de elaboração das atividades, está implicada a análise de alguns elementos, como as estratégias que cada gênero textual possibilita trabalhar, a observação de como reagem os alunos diante dos textos em outras línguas e como essas atividades contribuem, especificamente, para um melhor desempenho da compreensão escrita em francês.

Por fim, a experiência aqui apresentada visa contribuir também para a reformulação do programa do curso de PLF, levando em consideração as novas possibilidades trazidas pelo plurilinguismo e pelas teorias de intercompreensão. Nesse ponto, considera-se, ainda, possibilitar uma maior abertura do CL-USP para essas novas políticas linguísticas dentro da Universidade, principalmente no que concerne à formação de professores de línguas estrangeiras.

\section{Referencial teórico}

\subsection{A leitura como processo}

A leitura é objeto de estudo de vários estudiosos (GIASSON, 2008; JOUVE, 1993; PIETRAROIA, 1997; entre outros) e se apresenta como um tema complexo, cuja análise pode se dar em diversos aspecto. Parece mais fácil dizer o que a leitura não é: mera decodificação. Pelo contrário, é uma competência (e não só uma "atividade", segundo PIETRAROIA, 1997) "complexa, plural e que se desenvolve 6 em várias direções" (JOUVE, 1993, p. 9, tradução nossa)1, cujo objetivo maior é a construção do sentido contido na matéria textual com que se trabalha.

Para que essa construção de sentido aconteça, podemos destacar pelo menos cinco processos que são desencadeados durante a leitura: (THÉRIEN apud JOUVE, 1993) 
$\square$ processo neurofisiológico, no que concerne ao cérebro, aos olhos e a seus movimentos;

processo cognitivo, relativo à memória, à construção de sentido, à conversão das palavras e dos "grupos de palavras" em elementos carregados de significação;

$\square$ processo afetivo, já que a leitura suscita emoções que estão na base do princípio de identificação com o texto;

$\square$ processo argumentativo, o texto é tomado como um discurso, em que a fala do autor é carregada de intenções que devem ser percebidas pelo leitor; e, enfim

$\square$ processo simbólico, em que elementos como o contexto histórico-cultural do momento da leitura têm lugar central na construção de sentido, é a influência da "bagagem" pessoal de cada leitor sobre a compreensão escrita.

Por esses cinco processos, podemos concluir que o domínio da matéria escrita, ou seja, o nível de conhecimento da língua em que o texto está escrito, não é o único fator responsável para que a leitura aconteça de fato: o nível de relação com o tema do texto, sua forma, o motivo e o projeto envolvidos na leitura em questão e até o momento histórico em que vive o leitor têm influência no processo de construção de sentido. Podemos dizer, então:

Construir sentido em leitura é fazer interagir as experiências de linguagem do leitor e seus conhecimentos de mundo com a matéria-prima escrita que possui diante dos olhos, por meio dos dados formais e contextuais desta última. (PIETRAROIA, C., 1997)

Sobre a construção de sentido, Cuq \& Gruca (2002) também afirmam que ela se dá a partir da soma de fatores de esferas diferentes:

a hipótese de partida indica que o "sentido" do texto será percebido por meio de sua organização linguística e de seus articuladores, as palavras-chave, as relações anafóricas são, assim, igualmente orientadores para o leitor, orientadores que surgem do contexto linguístico, mas que irão clarear os saberes anteriores do leitor e seus conhecimentos extra-linguísticos. (p. 167, tradução nossa)

Tendo em vista que os "conhecimentos de mundo" de cada leitor também são colocados em jogo durante a leitura, assim como suas "experiências de linguagem", por mais que a "matéria-prima escrita" seja a mesma, não é possível dizer que o produto dessa leitura seja igual entre leitores diferentes: cada leitura é um "novo percurso, individual e subjetivo" e cada concretização é "única e peculiar" (PIETRAROIA, 1997). Como afirma ECO (1987, apud JOUVE, 1993), o universo textual é sempre inacabado e gerador de um número infinito de leitores, a partir da mesma matéria escrita, afinal, cada leitor, com sua "bagagem" de conhecimentos anteriores única completará de maneira diferente os "não ditos" e os "espaços em branco" deixados intencionalmente, pelo autor, no texto.

Dentro desse "número infinito de leitores" nem todos agem da mesma forma diante do texto a ser lido. São os chamados "tipos de leitores" (CORNAIRE; GERMAIN, 1999), desde os "inexperientes", de leitura lenta, linear e fragmentada (fatores que inibem o reconhecimento da relação entre as palavras), que não sabem como solucionar suas dificuldades por conta de seu repertório limitado de estratégias; até os "bons leitores", que são hábeis em prever as informações que estarão no texto, pois conseguem estabelecer relações entre os elementos textuais e seus conhecimentos anteriores, além de usarem com 
frequência estratégias como inferência e uso do contexto. Nesse sentido, podemos citar a definição de Kleiman (1996) para os chamados "leitores experientes":

O leitor experiente tem duas características básicas que tornam a sua leitura uma atividade consciente, reflexiva e intencional: primeiro, ele lê porque tem algum objetivo em mente, isto é, sua leitura é realizada sabendo para que está lendo, e, segundo, ele compreende o que lê, o que seus olhos percebem seletivamente é interpretado, recorrendo a diversos procedimentos para tornar o texto inteligível quando não consegue compreender. (KLEIMAN, 1996, p. 51)

\subsubsection{Modelos de leitura}

No caminho para a concretização da leitura, ou seja, para o total aproveitamento do texto rumo à construção de sentido, além de diferentes tipos de leitores, é possível identificar diferentes procedimentos para que a construção de sentido aconteça, são os chamados "modelos de leitura", entre os quais podemos destacar três, segundo Cornaire \& Germain (1999):

$\square$ Leitura ascendente: é caminho linear e unidirecional percorrido pelo leitor iniciante, inexperiente, ou mesmo por um bom leitor diante de um texto difícil. Aqui a significação se constrói a partir da decodificação das unidades de base, ou seja, do signo para o sentido, "de baixo para cima".

Leitura descendente: sendo a compreensão um processo de elaboração e verificação contínua de hipóteses, nesse tipo de leitura o leitor "elabora" um sentido a partir de seus conhecimentos pessoais e vai verificando sua pertinência por meio de indícios presentes no texto, ao mesmo tempo que formula novas hipóteses que permitirão acessar o sentido do texto. Assim, este é um percurso que se dá do sentido para o signo, "de cima para baixo".

$\llcorner$ Leitura interativa: é a junção dos dois modelos anteriores, em que o sentido do texto se constrói pela correspondência das estruturas, de conhecimentos do leitor com os dados que ele extrai do texto. É considerado o modelo "ideal", dado que não se prende apenas a dados formais, ao mesmo tempo que não parte apenas de uma hipótese global.

O modelo de leitura a ser seguido não é "pré-determinado", o importante é que o leitor saiba como agir para atingir seu objetivo de leitura. Essa noção de como agir é resultado do desenvolvimento da consciência do processo de leitura, assim como das competências leitoras.

\subsubsection{Competências leitoras}

Antes de falar em "competências leitoras", devemos definir o conceito de "competência". Em um primeiro momento, no contexto da didática das línguas, chamamos "competências" as quatro habilidades trabalhadas no ensino/aprendizagem das línguas, sendo elas divididas em dois "grupos": competências passivas ou de recepção (ler e ouvir/compreensão escrita e oral) e competências ativas ou de produção (escrever e falar/produção escrita e oral). Mas o que entendemos por "competência"? Vários autores teorizam sobre esse tema (LÉVY-LEBOYER, JOBERT, ECO, entre outros), cada um com sua visão particular sobre o que separa uma simples atividade ou mesmo uma "habilidade" de uma competência. Entre as principais definições, temos a de Guillevic (1991 apud BULEA; BRONCKART): 
A competência dos operadores será considerada como o conjunto dos recursos disponíveis para fazer frente a uma situação nova no trabalho. Esses recursos são constituídos por conhecimentos estocados em memória e por meios de ativação e de coordenação desses conhecimentos.

Em outras palavras, as competências são os recursos acumulados ao longo de experiências anteriores e são colocadas em prática em situações de desafio, as quais demandam, por parte do indivíduo, a articulação de todos os saberes já aprendidos. Como afirma Toupin (1995, apud BULEA; BRONCKART):

a competência se apresenta, assim, como uma reconstrução formal da procedimentos de objetivação presentes no centro de esquemas de ação, ou seja, capacidades que consistem em selecionar, reunir e aplicar a uma situação, conhecimentos de habilidades e de comportamentos.

Considerando, então, que a situação citada seja o momento da leitura, espera-se do leitor uma série de atitudes diante do texto que facilitem a construção de sentido, as quais formam as "competências leitoras" do individuo.

ECO (apud JOUVE, 1993) traz que a competência do leitor compreende: o conhecimento de um dicionário de base (domínio mínimo do código linguístico) e regras de co-referência (entender expressões dêiticas e anafóricas, por exemplo); capacidade de detectar as seleções contextuais e circuntanciais (permite interpretar as expressões em razão do contexto que se encontram); capacidade de interpretar o hipercódigo retórico e estilístico (compreensão de formas estereotipadas, como "Era uma vez..."); familiaridade com os cenários comuns e intertextuais (saber geral a respeito do mundo, roteiros comuns, sequências de acontecimentos da vida cotidiana, quer dizer, o leitor espera encontrar sequências e ações estereotipadas); visão ideológica (o leitor aborda o texto com seus próprios valores).

Todos esses conhecimentos e capacidades são adquiridos ao longo da formação do sujeito leitor, de forma a construir a sua "competência de leitura", característica de um bom leitor. O papel dos cursos de leitura é justamente "ativar" essa competência e, mais, tornar o aluno consciente de que todas as leituras feitas ao longo de sua vida contribuem para as leituras futuras, em língua materna ou na língua-alvo.

\subsubsection{Estratégias de leitura}

Mesmo diante de um texto escrito em língua materna, durante o processo de compreensão escrita, o leitor lança mão de vários tipos de procedimentos e conhecimentos que o ajudam a construir sentido - estes procedimentos, ainda que inconscientes e/ou "automáticos", são chamados estratégias de leitura. Segundo Cantalice (2009, p. 105): "são planos flexíveis adaptados às diferentes situações que variam de acordo com o texto a ser lido e a abordagem elaborada previamente pelo leitor para facilitar a sua compreensão".

Solé (1998) separa as estratégias por "fase" da leitura, ou seja, estratégias para antes, durante e depois da leitura. Alguns exemplos:

a) Antes da leitura: formulação de hipóteses acerca do tema a partir de elementos paratextuais (título, subtítulo, imagens, gráficos etc.); levantamento de conhecimento prévio sobre o assunto; expectativas ligadas ao meio de publicação, à formatação do gênero e ao autor; 
b) Durante a leitura: confirmação, rejeição ou retificação das hipóteses levantadas; localização/contrução do tema ou da ideia principal do texto; inferência de palavras desconhecidas; identificação de palavraschave; construção do sentido global do texto;

c) Após a leitura: síntese semântica do texto; troca de impressões; avaliação crítica do texto.

As estratégias de leitura tem um papel central no trabalho de desenvolvimento da competência de compreensão escrita - seja em contexto bilíngue ou em contexto plurilíngue, como sugere Dégache (2012). Segundo o autor, temos quatro estratégias principais para o trabalho da competência plurilíngue um dos objetos de estudo dessa pesquisa - são elas:

I) a transferência dos conhecimentos e procedimentos já utilizados em língua materna;

II) a associação entre conhecimentos de diversas ordens durante o processo de construção de sentido;

III) a inferência, como instrumento de superação das dificuldades lexicais, sem necessariamente recorrer à ajuda do professor ou do dicionário;

IV) a dedução e a indução por meio de elementos de paratexto e contexto.

Todos esses procedimentos são indispensáveis no início do trabalho com a leitura em língua estrangeira. Dessa forma, o início do trabalho é todo baseado em fazer com que os alunos tomem consciência de todos os procedimentos aos quais eles podem recorrer ao longo da leitura.

\subsection{Ensino/aprendizagem da leitura em língua estrangeira}

O curso de Práticas de Leitura em Francês do Centro de Línguas da USP é concebido segundo os parâmetros do ensino instrumental de línguas estrangeiras, ou seja, contexto em que a língua-alvo é vista como um "instrumento" que visa facilitar a compreensão de textos escritos de áreas específicas e, $\operatorname{logo}$, em que a competência de compreensão escrita tem lugar central.

Tendo isso em mente, é possível apontar algumas diferenças em relação aos cursos ditos "regulares", a saber, aqueles em que as quatro competências (ouvir, falar, ler e escrever) têm o mesmo status. São elas: (AUPECLE; ALVAREZ, 1977 apud JOVER-FALEIROS, 2006)

$\square$ primazia da recepção em detrimento da produção, assim como do escrito sobre o oral;

$\square$ destaque para textos “informativos”, sem lugar para o prazer estético;

$\square$ necessidade de orientação científica, cujo objetivo último é atingir a "língua de especialidade";

$\square$ o objetivo do curso é que o aluno saiba extrair informações de um texto, identificar e compreender seu conteúdo e não necessariamente "traduzi-lo".

Em relação a este último ponto, é importante destacar o lugar que a língua materna, no caso, o português, ocupa nesse tipo de curso - e que será um dos fatores que determinam o contexto desta pesquisa: as aulas são ministradas em língua portuguesa e toda interação com o texto escrito em língua francesa, assim como a formulação e confirmação de hipóteses, comentários etc., são também feitos em português. Assim, podemos dizer que mais do que "traduzir" o texto lido para o português, durante as aulas, o que se pede dos alunos é que eles forneçam "uma interpretação com um equivalente em sua língua materna" 3 (BLANCHE-BENVENISTE, 2005 tradução nossa). 
Nesse sentido, podemos dizer que a língua materna tem papel central quando trabalhamos a leitura em línguas vizinhas, como o português e o francês. A língua materna age como "porta de entrada" nos textos na língua-alvo, isso porque os alunos são levados a explorar as chamadas "transparências", em outras palavras, as "zonas de transferência em potencial" (DÉGACHE, 2012), que são as semelhanças existentes entre duas línguas de mesma raiz (nesse caso, o latim).

A leitura do texto se faz, então, a partir do que é "reconhecível", ou seja, a identificação de palavras ou unidades semânticas que, em um determinado contexto, são transparentes de uma língua à outra. Para o leitor, a utilização de tal procedimento é uma possibilidade de construção de hipóteses sobre o sentido geral do texto, um processo de descoberta de significados. (ALBUQUERQUE-COSTA, 2000, p. 67)

Dessa forma, o "foco" no início da conscientização do processo de leitura nos cursos de PLF - ou seja, fase em que os alunos são levados a reconhecer os movimentos e procedimentos colocados em prática ao longo da leitura - é exatamente a percepção dessas semelhanças e a criação, no aluno, da confiança de que ele pode sim se guiar por elas.

No que se refere a "transferências", a língua materna não é o único elemento favorável no ensino/aprendizagem da leitura em francês língua estrangeira. Tomando o contexto dos cursos do CLUSP, em que o principal público-alvo é de universitários (de graduação ou pós) que, como citado, buscam melhorar seu desempenho na leitura em língua estrangeira para a realização de pesquisas e/ou aprovação nos exames de proficiência, podemos afirmar, então, que esses alunos já são leitores em língua materna, quer dizer, já têm procedimentos e estratégias necessários desenvolvidos para a leitura de textos em língua portuguesa; em outras palavras, já desenvolveram a competência de leitura, em diferentes contextos, desde a escola até a universidade. Ora, será toda essa bagagem descartada quando se inicia um curso de leitura em língua estrangeira? Não, pelo contrário, ela também será "transferida".

Faz parte do trabalho do professor lembrar o aluno de que ele já é um leitor, ou seja, que ele recorre, ainda que de maneira inconsciente, a uma série de recursos (as chamadas estratégias) durante a leitura em português. CUQ \& GRUCA (2002) nomeiam essa transferência de "leitura global", a qual visa a transferir à língua estrangeira "hábitos e estratégias que o leitor possui em língua materna: percepção global de palavras e frases, construção de sentido graças à percepção da estrutura do texto etc." (p. 167, tradução nossa)4. POULET (1996) reforça o papel do professor nessa fase:

O professor reativa ao máximo as competências dos alunos no que se refere à passagem da língua materna à língua estrangeira retomando todos os conhecimentos anteriores, com o objetivo de fornecer-lhes os instrumentos necessários para uma construção de sentido coerente, a partir das novidades aprendidas na língua estrangeira estudada. (apud ALBUQUERQUE-COSTA, 2000, p. 66, tradução da autora)

A partir dessas considerações, já é possível identificar, pelo menos, dois pontos em que o ensino/aprendizagem da leitura em francês se aproxima dos preceitos básicos da intercompreensão: a valorização da língua materna e dos conhecimentos anteriores dos alunos. A intercompreensão, nova abordagem da didática de ensino/aprendizagem de línguas estrangeiras nascida das teorias do plurilinguismo, é um dos conceitos caros a essa pesquisa, pois entra como ferramenta metodológica para 
o desenvolvimento das competências leitoras em francês. A seguir, tratamos de suas origens, definições e análise de seus objetivos e competências.

\subsection{A intercompreensão de línguas românicas}

\subsubsection{Origens}

Comentar a origem de abordagens didáticas é sempre um desafio, pois estas podem ter sua razão em diversas naturezas, por motivos diferentes, em épocas distintas. Blank, por exemplo, destaca o caráter político do interesse pela intercompreensão na Europa, como um reflexo do nascimento da União Europeia, no fim dos anos 1980. Entretanto, a autora aponta também para a existência de "documentos indicando que, desde as feiras medievais de Troyes en Champagne, os clientes e negociantes que vinham de toda a Europa sempre interagiam cada um na sua língua materna, entendendo-se sem maiores dificuldades". No clássico "O nome da Rosa", Umberto Eco também descreve situações de compreensão plurilíngue. A partir da publicação do Quadro Comum Europeu de Referências (2001), que aborda, entre outras, a questão do desenvolvimento das competências plurilíngue e pluricultural em contexto europeu, as abordagens plurais, contexto no qual se insere a Intercompreensão, ganham novo fôlego. Elas responderiam ao enorme desafio da Europa de integração e coesão social, com preservação da diversidade linguística e cultural.

\subsubsection{Definições}

O conceito Intercompreensão é heterogêneo (Araújo e Sá et ali, 2009), fluído e fecundo (Séré, 2009), podendo ser interpretado de diversas formas por diferentes autores. A noção cara para a didática das línguas tal qual conhecemos hoje surgiu em meados da década de 80, tendo por base a hipótese de Claire Blanche Benveniste:

se as línguas românicas se assemelham entre si em maior ou menor grau, também as pessoas que falam uma delas como língua materna deverão ser capazes de compreender, em maior ou menor grau, as outras línguas da família, apoiando-se precisamente nas semelhanças. (BONVINO et ali, 2011, p. 2)

A definição mais comum que se tem de Intercompreensão é a trazida pelo método EuRom 5 (Bonvino $e t$ ali, 2011, p. 2), consagrado a esta abordagem: “(...) fenômeno que se verifica quando duas pessoas comunicam entre si com sucesso falando cada uma na sua própria língua". Tem-se, então, um "processo de compreensão recíproca entre falantes de línguas diferentes". Diferentes, mas vizinhas, como as que nascem de uma mesma raiz linguística, como o latim.

Neste caso, fala-se em "intercompreensão entre línguas românicas", as quais englobam o português, o francês, o espanhol, o italiano, o romeno, o catalão e alguns outros dialetos menores, totalizando nove línguas. Esta abordagem metodológica para o ensino/aprendizagem de línguas estrangeiras parte do reconhecimento e apoio nas paridades entre línguas de uma mesma raiz, sendo esta uma de suas principais características.

Além de uma interessante e inovadora abordagem plurilíngue, a intercompreensão surge como uma importante ferramenta de desenvolvimento da consciência linguística por parte dos estudantes, já que há uma integração de todas as línguas no percurso de aprendizagem, rompendo com a tradição do ensino/aprendizagem "compartimentado”, ou seja, limitado a uma língua por vez.

\subsubsection{Objetivos e competências}


A intercompreensão é, antes de tudo, um princípio de comunicação. Logo, os objetivos estão sempre ligados à necessidade de facilitar a interação entre falantes de línguas diferentes e vizinhas sem a necessidade de recorrerem a uma língua franca, papel hoje ocupado pelo inglês.

Sendo assim, a Intercompreensão é uma das quatro abordagens para o ensino de línguas e culturas chamadas "plurais", ou seja, aquelas que colocam em jogo atividades de ensino/aprendizagem que utilizam, ao mesmo tempo várias (ou mais de uma) variadades linguísticas e culturais. Em outras palavras, é como se, ao entrar na aula de francês, os alunos pudessem fazer uso de conhecimentos já adquiridos em língua materna e também em outras línguas que tenha aprendido. Por essa característica, as abordagens plurais e, logo, a abordagem da intercompreensão, rompem com muitas das práticas "tradicionais" na didática das línguas, como a visão compartimentada das competências dos alunos rompimento que está consonante com as orientações do Quadro Europeu Comum de Referência para Línguas (QECR):

O objetivo do ensino de línguas se encontra profundamente modificado. Não se trata mais simplesmente de adquirir o "domínio" de uma, duas, ou mesmo três línguas, cada uma em seu lugar, com o "locutor nativo ideal", como modelo último. O objetivo é desenvolver um repertório linguístico no qual todas as capacidades linguísticas encontram seu lugar. (p. 11, tradução nossa)

Dessa forma, a intercompreensão visa, sobretudo, formar sujeitos capazes de agir em situações de interação plurilíngue e pluricultural por meio do desenvolvimento das competências plurilíngues e pluriculturais.

[a intercompreensãp] propõe aumentar o campo da compreensão a um número muito maior de línguas/culturas, endereçando-se a públicos diversificados por meio de procedimentos abertos, visando ao desenvolvimento de capacidades variadas que mobilizam estratégias complexas. (CASTELOTTI, 2007 apud GUEIDÃO; MELOPFEIFER; PINHO, 2009, p. 61, tradução nossa)7

Importante definirmos o que se entende por "plurilíngue" e "pluricultural". O Quadro Europeu Comum de Referência para as Línguas (CECR) traz que a competência plurilíngue e pluricultural não é o conjunto de competências de comunicação distintas e isoladas de acordo com as línguas, mas, pelo contrário, é uma única competência que engloba o todo do repertório linguístico que o sujeito tem à sua disposição. Retomando, então, as definições de competência vistas anteriormente, a competência plurilíngue e pluricultural corresponde à gestão de todo esse repertório, e essa gestão implica que as variedades e que o compõem não sejam abordadas de maneira isolada, mas que, ainda que distantes entre elas, que tais variedades sejam tratadas como uma competência única, disponível para o aluno/ator social em questão (Guia Europeu para a elaboração de políticas linguísticas educativas, 2007)

A prática da intercompreensão supõe uma dissociação de competências, em outras palavras, nem todas as quatro (ler, escrever, falar e ouvir) serão trabalhadas ao mesmo tempo, além de uma hierarquização de objetivos que têm como prioridade o desenvolvimento das capacidades de compreensão do aluno (DÉGACHE, 2012), ou seja, das quatro competências clássicas, o trabalho se restringe à recepção e à compreensão - aqui, mais uma semelhança com os cursos voltados para a leitura. A justificativa para o trabalho dissociado das competências, segundo BONVINO et ali, é o fato de que as competências "passivas", ou seja, ligadas à compreensão e recepção (oral ou escrita) se desenvolvem muito mais rapidamente nos alunos do que aquelas ligadas à produção (competências "ativas") 
É importante frisar que a formação desse aluno/ator social plurilíngue parte de competências e potencialidades já desenvolvidas em sua língua materna. Um leitor brasileiro, por exemplo, já é capaz de selecionar informações de um texto em português, interpretar imagens e dados, estabelecer um campo lexical, identificar temas, enfim, é capaz de ler um texto. Logo, o que ele tem a fazer é mobilizar esses conhecimentos e procedimentos utilizados em português durante a leitura em outra língua, como o francês.

Uma metodologia da intercompreensão visa, assim, despertar nos alunos aquilo que eles já são capazes de fazer durante o trabalho com duas línguas, reunindo, simplesmente, uma linguística popular baseada no senso comum e na experiência das pessoas. Numa situação de interação exolingue, os indivíduos são chamados a co-construir o sentido com seus interlocutores, sempre visando a utilização pragmática do discurso, seja para se orientar e se manter no contexto em que se encontram, seja para se comunicarem com os outros.(CAPUCHO, 2009, p. 242, tradução nossa)

Essa particularidade da IC, a transferibilidade de competências, faz com que o aluno desenvolva sua consciência linguística e metalinguística, tanto em relação à língua materna quanto às línguas aprendidas ou em processo de aprendizagem. No aluno, desenvolve-se um processo de valorização da língua materna, bem como a consciência da diversidade de estratégias existentes chegar à compreensão. Além disso, é interessante ressaltar que a relação de parentesco entre as línguas pode levar também à relativização da percepção de dificuldades de aprendizagem de línguas na medida em que os objetivos de compreensão oral ou escrita em situações plurilíngues podem ser apoiados no reconhecimento e aplicação de diferentes estratégias que levam ao alcance do objetivo - no caso dos cursos de leitura, à construção do sentido de um texto - e, segundo PISHVA \& THAMIN (2012), isso provoca um impacto direto sobre a motivação do aluno.

\section{Contexto de pesquisa}

O curso de Práticas de Leitura em Francês do Centro de Línguas da USP é dividido em dois níveis: o primeiro, responsável por oferecer aos alunos uma gama variada de gêneros textuais, com 60 horas; e o segundo, focado nas produções do gênero acadêmico, com 30 horas. Como já citado, os cursos são dados em português, enquanto os textos trabalhados são em francês - característica que, em um primeiro momento, já configura uma situação de intercompreensão.

Direcionado para universitários, o curso tem por objetivo geral:

desenvolver a habilidade de leitura em língua francesa, levando o aluno à compreensão de textos de sua área acadêmica e/ou profissional e à seleção de informações de acordo com o objetivo de leitura estabelecido, além de noções gramaticais e lexicais fundamentais da língua francesa que possam subsidiar o processo de compreensão escrita e construção de sentido. (Programa do curso)

Para isso, antes mesmo das "noções gramaticais", visa-se enfatizar a conscientização do processo de leitura por meio da exposição das estratégias de aprendizagem e da transferência dos procedimentos já praticados na leitura em língua materna. Além disso, a percepção da estrutura particular de cada gênero e 
a análise de textos levando em consideração a sua estrutura formal também fazem parte do trabalho com o futuro leitor em língua francesa.

O trabalho com variados gêneros textuais justifica-se tanto pelo perfil do público em questão (em sua maioria, universitários, cujas experiências como leitores em língua materna se dão em vários gêneros) quanto do ponto de vista pedagógico, conforme afirmam Schneuwly e Dolz (2004):

[...] de um ponto de vista didático, a diversificação dos gêneros trabalhados, regulada pelos agrupamentos, oferece a possibilidade de definirmos especificidades de funcionamento dos diferentes gêneros e tipos, para um trabalho de comparação de textos. Trata-se de um princípio elementar de construção por confronto com o mesmo e o diferente. (SCHNEUWLY; DOLZ, 2004, p.62)

O contexto de aplicação da pesquisa é de uma turma do curso do citado curso, durante o primeiro semestre de 2013 (março a junho). A turma final era formada por dez alunos, de idades entre 19 e 43 anos, em sua maioria, estudantes universitários de graduação. Entre os objetivos citados, os mais comuns foram a necessidade de obter autonomia na leitura de textos em língua francesa referentes às respectivas áreas acadêmicas e a aprovação em exames de proficiência, visando o ingresso no mestrado.

Em um questionário aplicado no início do curso, os alunos preencheram um pequeno «perfil linguístico » segundo o qual:

7 alunos disseram serem capazes de ler em inglês ;

$\square 6$ declararam serem capazes de ler em espanhol ;

1 se declarou leitor em italiano;

1 se declarou leitor em árabe ;

1 declarou ler apenas em português.

\section{Metodologia de pesquisa}

Pensando na realização da experiência com a intercompreensão, o semestre foi dividido em quatro módulos, conforme exposto a seguir. Como é possível observar, o trabalho com a intercompreensão se deu em duas fases, estando concentrado no primeiro e último módulos, com objetivos diferentes, mas que se completam entre si. 


\begin{tabular}{|c|c|}
\hline \multirow{4}{*}{$\begin{array}{c}\text { Módulo } 1 \text { - Sensibilização e conscientização } \\
\text { do processo de leitura }\end{array}$} & Aula 1 - Atividade em Intercompreensão \\
\hline & Aula 2 - Atividade em Intercompreensão \\
\hline & Aula 3 - Atividade em Intercompreensão \\
\hline & Aula 4-Atividade em Intercompreensão \\
\hline \multirow{3}{*}{$\begin{array}{l}\text { Módulo } 2 \text { - Desenvolvimento e aplicação } \\
\text { das estratégias do Módulo } 1\end{array}$} & Aula 5 \\
\hline & Aula 6 \\
\hline & Aula 7 - Avaliação 1 \\
\hline \multirow{4}{*}{$\begin{array}{c}\text { Módulo } 3 \text { - Consolidação das } \\
\text { competências/trabalho específico sobre o } \\
\text { francês }\end{array}$} & Aula 8 \\
\hline & Aula 9 \\
\hline & Aula 10 \\
\hline & Aula 11 \\
\hline \multirow{4}{*}{$\begin{array}{c}\text { Módulo } 4-\text { Conscientização da } \\
\text { possibilidade de transferência dos } \\
\text { procedimentos adquiridos para outras } \\
\text { línguas românicas }\end{array}$} & Aula 12 - Atividade em Intercompreensão \\
\hline & Aula 13 - Atividade em Intercompreensão \\
\hline & Aula 14 - Avaliação 2 \\
\hline & Aula 15 - Entrega de notas/recuperação| \\
\hline
\end{tabular}

No módulo 1, o objetivo com tais atividades é mostrar aos alunos que a leitura é possível ainda que não se domine a língua-alvo, desde que sabendo mobilizar as estratégias cabíveis para cada gênero textual e objetivo de leitura - neste momento, o foco é criar neles a confiança necessária ao início do trabalho com a compreensão escrita em língua francesa.

Já no módulo 4, o último do curso, após a consolidação das competências de leitura em língua francesa, as atividades com outras línguas voltam para mostrar ao grupo que todos os procedimentos estudados podem ser reaproveitados, ou melhor, "transferidos", para as demais línguas românicas. Para além desse aspecto "cognitivo", do ponto de vista prático, as últimas atividades em intercompreensão avançam também na questão do gênero textual, pois são feitas com resumos de artigos acadêmicos.

Assim, o objetivo é que o grupo conclua o Nível I com as devidas competências de um leitor autônomo em língua francesa, sem dúvida, mas também com todas as possibilidades de tornar-se um leitor autônomo "plurilíngue", ou seja, capaz de acessar seus conhecimentos adquiridos no presente curso para facilitar sua leitura em outras línguas românicas, ainda que ele não as tenha estudado, sempre levando em consideração seus objetivos e necessidades.

\subsection{Corpus}

O corpus da presente pesquisa é composto pela análise das reações dos alunos às atividades em intercompreensão propostas. As reações foram registradas aula a aula pela professora e autora dessa pesquisa em um diário de bordo. Os propósitos das atividades com outras línguas foram apresentados aos alunos no primeiro dia de aula, como parte da metodologia de ensino da leitura em francês.

As citadas atividades foram concebidas e analisadas segundo algumas categorias de análise. São elas:

\footnotetext{
$\square$ tipo/gênero do texto;

$\square$ fonte/origem;
}

$\square$ línguas envolvidas; 
$\square$ estratégias desenvolvidas;

$\llcorner$ grau de relevância do tema (amplamente divulgado/área específica/referência cultural etc.);

"portas de entrada" (forma/tema/imagem/transparência etc.);

$\square$ tempo de realização;

$\square$ resultados ("E" - conforme o esperado; "S" - satisfatório, mas com observações; "I" - insatisfatório, demanda reformulação)

Conforme adiantado, as atividades foram concebidas de acordo com os preceitos trazidos pelas teorias de intercompreensão, principalmente, o fato de destacar para os alunos a importância e a validade de conhecimentos de duas ordens durante o processo de leitura em francês: os conhecimentos linguísticos (da língua materna principalmente, mas também de outras línguas que o aluno já tenha estudado), assim como os conhecimentos "práticos" de um leitor experiente (ou seja, sua experiência com diversos gêneros textuais).

\subsection{Módulo 1}

As atividades referentes ao Módulo 1 foram aplicadas entre os meses de março e abril, somando oito horas de intercompreensão num total de dezesseis horas deste primeiro bloco. Neste início de trabalho, busca-se sensibilizar os estudantes para o trabalho da conscientização acerca do processo de leitura pelo fio da intercompreensão, ou seja, antes de praticar especificamente a leitura em língua francesa, é necessário conhecer os vários aspectos que fazem parte da competência de compreensão escrita, independentemente da língua do texto. Para isso, a Aula 1 tem papel central - o quadro a seguir apresenta os textos utilizados nessa aula 1, suas características principais e os objetivos didáticos da aplicação de cada um.

\begin{tabular}{|c|c|c|c|}
\hline Texto & Língua & Características & Objectifs didactiques \\
\hline $\begin{array}{l}\text { Trecho de O } \\
\text { Ser e o Nada } \\
\text { (Sartre, J. P., } \\
\text { 1943) }\end{array}$ & Português & $\begin{array}{l}\text { Por ser um tratado filosófico em } \\
\text { torno da teoria do existencialismo, } \\
\text { não é um tipo de texto nem um tema } \\
\text { ao qual qualquer leitor está } \\
\text { habituado. Assim, é necessário ter } \\
\text { conhecimentos anteriores sobre a } \\
\text { obra e a filosofia de Sartre para } \\
\text { melhor compreender suas ideias. }\end{array}$ & $\begin{array}{l}\text { Ainda que o texto esteja escrito } \\
\text { em português, a construção de } \\
\text { sentido não se dá facilmente. } \\
\text { Dessa forma, destaca-se o papel } \\
\text { do repertório de leituras e de } \\
\text { conhecimento de mundo dos } \\
\text { leitores ao longo do trabalho de } \\
\text { compreensão de um texto. }\end{array}$ \\
\hline Flor Legal $^{9}$ & Português & $\begin{array}{l}\text { O texto, composto por algumas } \\
\text { palavras estranhas ao vocabulário do } \\
\text { português, apresenta informações e } \\
\text { dicas que podem ser aplicadas ao } \\
\text { contexto da leitura em língua } \\
\text { estrangeira, no que concerne às } \\
\text { reações diante de palavras } \\
\text { desconhecidas de um texto. }\end{array}$ & $\begin{array}{l}\text { Mobilizar novas estratégias de } \\
\text { leitura, destacando que o trabalho } \\
\text { de compreensão escrita não se } \\
\text { faz de forma linear (palavra a } \\
\text { palavra), mas pela relação entre } \\
\text { diferentes elementos linguísticos, } \\
\text { lexicais e discursivos, inclusive a } \\
\text { ajuda do contexto. }\end{array}$ \\
\hline
\end{tabular}




\begin{tabular}{|c|c|c|c|}
\hline $\begin{array}{l}\text { Poftiţi } \\
\text { masă! }\end{array}$ & $\begin{array}{l}\text { Romeno/ } \\
\text { Português }\end{array}$ & $\begin{array}{l}\text { O texto faz parte de um manual para } \\
\text { o ensino do romeno e trata de regras } \\
\text { de boas maneiras durante uma visita } \\
\text { à casa de uma família romena. Pelas } \\
\text { palavras transparentes pode-se } \\
\text { iniciar um trabalho de formulação de } \\
\text { hipóteses acerca do tema do texto. }\end{array}$ & $\begin{array}{l}\text { Sensibilizar para a importância } \\
\text { da formulação de hipóteses, } \\
\text { exploração de transparências e } \\
\text { apreensão do sentido global de } \\
\text { um texto. Após o trabalho com o } \\
\text { texto em romeno, a confirmação } \\
\text { das hipóteses levantada foi feita } \\
\text { com a leitura de uma tradução do } \\
\text { texto em português. }\end{array}$ \\
\hline $\begin{array}{l}\text { Trecho de } \\
\text { histórico do } \\
\text { Chat Galanet }{ }^{10} \\
\text { [Sala de } \\
\text { discussão } \\
\text { vermelha, } \\
22 / 09 / 2011 \text {, } \\
\text { Sessão Verba } \\
\text { Voltant } \\
\text { Societatis] }\end{array}$ & $\begin{array}{l}\text { Espanhol, } \\
\text { francês, } \\
\text { português, } \\
\text { romeno }\end{array}$ & $\begin{array}{l}\text { Este trecho de conversa retirada do } \\
\text { chat plurilíngue da plataforma } \\
\text { Galanet apresenta um discussão } \\
\text { sobre a língua portuguesa, na qual } \\
\text { falantes de outras línguas românicas } \\
\text { expõem suas impressões sobre ela. }\end{array}$ & $\begin{array}{l}\text { Apresentar a plataforma Galanet } \\
\mathrm{e} \text { os projetos de } \\
\text { intercompreensão como meio de } \\
\text { aprendizagem de línguas a partir } \\
\text { do desenvolvimento da } \\
\text { compreensão escrita em uma } \\
\text { interação plurilíngue. }\end{array}$ \\
\hline $\begin{array}{l}\text { Títulos e olho- } \\
\text { do-texto de } \\
\text { notícias }\end{array}$ & Francês & $\begin{array}{l}\text { Manchetes jornalísticas curtos sobre } \\
\text { temas da atualidade }\end{array}$ & $\begin{array}{l}\text { Colocar em prática as estratégias } \\
\text { vistas ao longo dos textos } \\
\text { anteriores para fazer o exercício } \\
\text { de associação entre o título e o } \\
\text { olho-de-texto correspondente. }\end{array}$ \\
\hline
\end{tabular}

Durante as aulas seguintes do módulo 1, as atividades com as línguas românicas tinha sempre o objetivo de introduzir um novo gênero textual que seria trabalhado, em seguida, em língua francesa. Por exemplo, na segunda aula, para trabalhar o gênero "sumário" - facilmente identificável pelos alunos - o trabalho foi feito em duas etapas: primeiramente, com o sumário de uma revista italiana sobre decoração e designer11e, em seguida, o sumário de uma publicação francesa sobre história geral.

Kleiman (2013) desta o "conhecimento textual", parte dos "conhecimentos de mundo" do aluno, como um dos fatores determinante para a construção de sentido ao longo da leitura: “(...) o conhecimento adquirido determina, durante a leitura, as inferências que o leitor fará com base nas marcas formais do texto" (p. 30).

Assim, a identificação da estrutura e da função do gênero "sumário" foi feita imediatamente pelo alunos: apesar das diferenças entre as duas publicações, eles foram capazes de identificar os elementos principais - tipo de publicação, tema da edição, principais matérias etc. Nesse momento, o objetivo era demonstrar ao grupo como a experiência anterior com sumários facilitou a entrada nesse gênero: qualquer que seja a língua da publicação, o tema ou mesmo a organização visual das informações, a função do sumário é sempre a mesma.

Apresentamos a seguir traz o conjunto de textos trabalhados no restante do primeiro módulo. 


\begin{tabular}{|c|c|c|c|}
\hline Aula & Textos & Gênero & Língua \\
\hline \multirow[t]{4}{*}{2} & $\begin{array}{l}\text { - Sommario Casa Facile } \\
\text { (dez 2012, p. 5) }\end{array}$ & \begin{tabular}{|l|} 
Sumário de revista \\
italiana sobre decoração
\end{tabular} & Italiano \\
\hline & $\begin{array}{l}\text { - Sommaire Ça m'interesse } \\
\text { - Histoire (jan-fev 2012, p. } \\
\text { 3) }\end{array}$ & $\begin{array}{l}\text { Sumário de revista } \\
\text { francesa sobre História }\end{array}$ & Francês \\
\hline & $\begin{array}{l}\text { - "D'Amazonie à Zumbi" } \\
\text { (L'Histoire, jul-ago 2011, } \\
\text { p. 112-113) }\end{array}$ & $\begin{array}{l}\text { Glossário de revista } \\
\text { francesa dedicada à } \\
\text { história do Brasil }\end{array}$ & Francês \\
\hline & $\begin{array}{l}\text { - Saint-Paul (CENDRARS, } \\
\text { B.) }\end{array}$ & $\begin{array}{l}\text { Poema de autor francês } \\
\text { sobre a cidade de São } \\
\text { Paulo }\end{array}$ & Francês \\
\hline \multirow[t]{5}{*}{3} & $\begin{array}{l}\text { - La langue comme vision } \\
\text { du monde: un stéréotype? }\end{array}$ & - Resenha teórica & Francês \\
\hline & $\begin{array}{l}\text { - La lingua come "visione } \\
\text { del mondo": uno } \\
\text { stereotipo? }\end{array}$ & - Resenha teórica & Italiano \\
\hline & \begin{tabular}{|ll} 
- Publicidade da TAM \\
publicada na França
\end{tabular} & - Anúncio publicitário & Francês \\
\hline & $\begin{array}{l}\text { - Sujet oublié: } 8 \text { millions de } \\
\text { pauvres en France (Plantu, } \\
\text { mar 2012) }\end{array}$ & - Charge & - Francês \\
\hline & $\begin{array}{l}\text { - Le RAID reçu à l'Élysée } \\
\text { (Plantu, mar 2012) }\end{array}$ & - Charge & Francês \\
\hline \multirow[t]{4}{*}{4} & $\begin{array}{l}\text { - Pesce d'aprile/Pescado de } \\
\text { abril }\end{array}$ & - Enciclopédico & $\begin{array}{l}\text { Italiano } \\
\text { espanhol }\end{array}$ \\
\hline & - Poisson d'avril & - Enciclipédico & Francês \\
\hline & $\begin{array}{l}\text { - Déclaration des droits de } \\
\text { l'homme et du citoyen de } \\
1789\end{array}$ & - Jurídico & Francês \\
\hline & - Rencontres africaines & - Entrevista & Francês \\
\hline
\end{tabular}

Como já citado, os módulos seguintes ( 2 e 3 ) foram consagrados ao trabalho específico dos textos em francês - objetivo inicial do curso. A cada aula, foram usados textos de gêneros diferentes, sempre numa progressão de "complexidade" (no que concerne às estruturas textuais, o número de palavras e os temas). Entretanto, o princípio do trabalho a cada texto retomava a todo tempo as estratégias e procedimentos estudados nas primeiras aulas: sempre era necessário reconhecer o gênero do texto, o campo lexical, assim como formular hipóteses a partir dos elementos transparentes.

\subsection{Módulo 4}

No último módulo do curso, após a consolidação das estratégias de compreensão escrita em língua francesa, a intercompreensão retorna ao programa para demonstrar aos alunos que todos os procedimentos estudados podem ser reutilizados, ou melhor, transferidos, para a leitura de textos escritos em outras línguas românicas, o que poderia confirmar a formação de leitores plurilíngues (e não apenas bilíngues - português e francês).

Tendo em mente a progressão dos gêneros textuais, assim como as necessidades e expectativas dos alunos no contexto universitário, as atividades propostas no Módulo 4 foram feitas com resumos de artigos acadêmicos. O trabalho foi feito em duas etapas: a primeira com textos selecionados pela professora; e a segunda com resumos escolhidos pelos próprios alunos.

\subsubsection{Etapa 1}


Os resumos da primeira etapa foram selecionados por dois critérios:

o título e o resumo do artigo deveriam estar escritos em línguas diferentes, mas um dos dois deveria estar em francês;

o tema dos artigos não deveria ser da área de estudos dos alunos.

Tais critérios se justificam pelo objetivo que de o que os alunos tenham sempre uma espécie de "âncora" que possa facilitar o trabalho de compreensão escrita. Nessa etapa, esse papel será feito pela língua francesa presente em uma das duas partes dos textos.

Sendo assim, a partir desses dois pontos, foram escolhidos cinco artigos da publicação "Intercompreensão em línguas românicas: com conceitos, práticas, formações (2009)13, os quais tinham os títulos escritos em uma língua e o resumo em outra, e cujo tema geral, como sugere o título do livro, era a intercompreensão - assunto que o grupo conhecia apenas pelas considerações feitas ao longo do curso.

O exercício consistia em associar cada título a seu resumo correspondente. A sala foi dividida em duplas, sendo que cada um recebeu um envelope com as três partes dos cinco artigos (título, resumo e conjunto de palavras-chave) e ficou responsável pela montagem de um (delegado pela professora). Como já citado, apesar do fato de não ter conhecimentos anteriores sobre o tema dos resumos, os grupos tinham sempre a ajuda das experiências de leitura em língua francesa feitas durante todo o curso.

\subsubsection{Etapa 2}

Após a primeira parte do trabalho, foi pedido aos alunos que cada um pesquisasse um texto do gênero acadêmico (artigo, capítulo de um livro, resenha etc.), seguindo as seguintes orientações:

$\square$ a língua do artigo não podia ser uma das línguas do repertório do aluno (logo, pelo menos português e francês estavam descartadas);

$\square$ o assunto do artigo deveria estar ligado à área de estudos de cada um;

Nessa etapa, o papel de âncora, citado anteriormente, seria feito, não pela língua dos textos, mas pelos conhecimentos anteriores dos estudantes para com o texto escolhido. De qualquer forma, as estratégias de leitura utilizadas durante todo curso deveriam ser colocadas em jogo.

Os alunos tiveram uma semana para procurar os artigos e enviar os respectivos resumos à professora para a preparação do exercício. A variedade e a qualidade dos textos selecionados foi grande: desde um artigo de medicina em romeno (enviado por uma aluna em mestrado na área) até um artigo em italiano sobre a obra do cineasta Fellini, passando por dissertação em espanhol sobre a relação entre ficção e realidade no romance Dom Quixote.

Em sala, o foco do trabalho foi com os resumos dos textos escolhidos. Os alunos foram novamente divididos em grupos, dessa vez, sob o critério da língua do texto escolhido - assim, o objetivo era estimular uma ajuda mutual entre os leitores para superar os problemas concernentes à identificação dos elementos lexicais.

Cada aluno recebeu um "roteiro de compreensão escrita" cujo objetivo era fazer uma retomada das etapas de leitura aprendidas ao longo do curso. As fases do roteiro, que deveria ser preenchido e entregue ao final da atividade, estão descritas a seguir: 
$\square$ identificação dos elementos de paratexto: título, subtítulo, língua, gênero, fonte, se havia imagens e a que elas remetiam, entre outras;

observação do texto e sua estrutura: área à qual o texto pertence e assunto. Aqui, os alunos foram chamados a identificar, nos textos, frases referentes à apresentação do objeto de estudo, os objetivos/pontos estudados no texto, organização do texto e quaisquer outras informações que julgassem importantes para a leitura.

Depois deste trabalho e da leitura do texto, os alunos refletiram sobre seus próprios processos de construção de sentido, a partir das últimas questões do roteiro, que eram:

Quais procedimentos você usou com mais frequência ao longo da leitura?

Como define o fato de ter trabalhado com uma língua que você não domina? No início do curso, você sabia que era capaz de realizar tarefas como essas?

Como você analisa o papel das línguas românicas que você já domina (português e francês, pelo menos) durante a realização da leitura? Acredita que isso tenha ajudado ?

E o conhecimento que você já tinha sobre esse tema, também contribuiu para a leitura? Em que sentido?

\section{Análise dos resultados}

Tendo em mente que o objetivo de aplicação das atividades com as línguas românicas ao longo de um curso que, inicialmente, se limitava ao desenvolvimento da leitura em língua francesa era demonstrar como as mesmas estratégias podem ser transferidas também para essas outras "línguas vizinhas", a análise dos resultados deve ser pensada a partir de três questões:

i) Em relação ao primeiro módulo, as atividades em intercompreensão contribuíram para a tomada de consciência do processo de leitura?

Todas as atividades em intercompreensão do Módulo 1 tiveram seus resultados analisados na categoira « $\mathrm{E} »$ (conforme esperado). O grupo conseguiu realizá-las de forma satisfatória, sempre atendendo ao que era pedido e chegando aos objetivos propostos.

Sendo assim, é possível afirmar com certeza que o trabalho feito neste início de curso se extendeu ao longo de todo semestre. A partir dos textos em italiano, espanhol e romeno, os alunos tornavam-se pouco a pouco mais à vontade para sempre construir e expor suas próprias associações ao longo da leitura, mesmo quando o trabalho se deteve à língua francesa. Os comentários e justificativas apresentados a cada texto estudado não raro apresentavam as reflexões sobre o percurso de leitura até a construção de sentido, além de considerações relacionadas às inferências e associações lexicais, feitas com palavras transparentes.

ii) No que concerne ao módulo 4, os alunos conseguiram transferir as estratégias e procedimentos estudados para a construção do sentido dos textos escolhidos? 
A experiência feita no módulo 4 foi igualmente positiva. Na Etapa 1, todos os alunos conseguiram associar os títulos aos resumos correspondentes, além de construírem sentido também acerca dos temas específicos de cada um.

Na Etapa 2, da mesma forma, todos os alunos conseguiram construir sentido na leitura dos resumos escolhidos, de forma que afirmaram se considerar prontos para avançar na leitura mesmo em outras línguas. Cada um apresentou suas impressões a partir do roteiro de compreensão preenchido, cujas reações da terceira parte apresentamos a seguir:

$\square$ entre os procedimentos mais utilizados, os alunos citaram: identificação do tema a partir do título e das palavras-chave, a presença de palavras transparentes e o exercício de ler o texto mais de uma vez;

a maior parte dos alunos se considerou surpresa de ter lido os textos em outras línguas jamais estudadas, afinal, eles se imaginavam capazes ler apenas nas línguas em que tinham conhecimentos mais "sólidos". Entretanto, vários citaram a experiência feita no Módulo 1 com o texto em romeno (Poftiţi la masă!') como exemplo de confiança para avançar na leitura.

A propósito do papel das línguas românicas já estudadas (pelo menos, português e francês), o comentário de uma aluna merece ser citado :

No começo do curso, usamos apenas os conhecimentos em portugês para compreender que éramos capazes de ler em francês. Agora, nós fizemos algo muito melhor, porque vimos que a partir dos conhecimentos em português e francês, somos capazes de ler em outras línguas. (A.L.)

os conhecimentos anteriores acerca dos temas dos textos foi classificada como determinante pela totalidade dos alunos. Segundo eles, a confirmação das hipóteses levantadas ao longo da leitura foi feita, em grande parte, pelos conceitos já conhecidos, fato que facilitou até na superação das dificuldades lexicais.

iii) Quanto à totalidade do curso, é possível dizer que as atividades em intercompreensão contribuíram para a formação de leitores autônomos plurilíngues?

Em relação às competências de leitura em língua francesa, objetivo inicial dos alunos e do programa de curso, pelas avaliações feitas, podemos afirmar que "o dever foi cumprido": todos os alunos foram aprovados, e entre as dez médias individuais finais, apenas uma foi inferior a 8,5.14

Já no que concerne as competências para o trabalho com as línguas vizinhas ao francês (e, $\operatorname{logo}$, ao português também), pela análise dos resultados dos exercícios do Módulo 4, podemos dizer que os alunos desenvolveram a consciência do processo de leitura como uma competência complexa na qual a língua (ou as línguas) não é o único fator envolvido. Se por um lado, eles desenvolveram as estratégias necessárias para o trabalho de compreensão escrita em língua francesa, pode-se dizer também que eles estão conscientes da possibilidade de transferir essas mesmas estratégias para as outras línguas românicas.

Levando em consideração a ideia de "autonomia" como a característica de um aluno que define por si mesmo seus objetivos, o conteúdo para alcançá-los, assim como os métodos e técnicas que usará e que, sobretudo, se autoavalia ao longo do percurso de aprendizagem (BAISNÉE, 2008), a observação dos resultados nas diferentes fases do trabalho (na etapa 2 feita no Módulo 4, por exemplo, os alunos procuraram seus textos de interesse e garimparam as estratégias consideradas aplicáveis sem a interferência da professora, ou seja, de forma autônoma), demonstra que o grupo é capaz de estabelecer 
tais elementos para atingir seus objetivos de leitura. Dessa maneira, confirma-se que as atividades em intercompreensão contribuíram em grande parte para a formação desses estudantes em direção ao desenvolvimento de sua autonomia em relação ao trabalho da compreensão escrita não só em francês e/ou português, mas nas demais línguas românicas.

\section{Conclusões}

Os resultados iniciais da citada experiência confirmam a validade da aplicação das atividades em intercompreensão ao curso de Práticas de Leitura em Francês, como parte do processo de desenvolvimento das competências leitoras em língua estrangeira. Depois das primeiras aulas, quando o trabalho volta-se unicamente para o francês, as situações em que os alunos justificam suas respostas baseando-se em conhecimentos tirados de outras línguas ou mesmo de leituras anteriores tornaram-se comuns. As respostas dos alunos no questionário de avaliação parcial do curso (aplicado em abril) corroboram essa constatação: boa parte da turma citou, entre os pontos positivos do curso, o trabalho da intercompreensão na fase de sensibilização à leitura em língua estrangeira.

Constatou-se que trabalho com outras línguas românicas favorece a tomada de consciência do processo de leitura e da metarreflexão linguística dos alunos, as quais se manifestam por meio da mobilização de funções cognitivas, como a identificação de palavras semelhantes entre as diferentes línguas, na construção de campos lexicais ligados a determinado tema e, ainda, o reconhecimento do gênero do texto estudado (publicidade, charge, artigo acadêmico etc.).

A possibilidade de utilizar todos seus conhecimentos linguísticos, seja em língua materna, seja em uma língua estrangeira - já que, muitas vezes, os alunos já possuem conhecimento em alguma outra língua além do português -, coloca-se como um elemento essencial para o trabalho em questão, pois demonstra que o amadurecimento e a transferência das competências leitoras independe das línguas envolvidas: em italiano ou em francês, o primeiro passo é buscar explorar o que é transparente, o que tece alguma relação com algo já conhecido, e a partir disso, construir hipóteses; para, depois, buscar as confirmações numa leitura mais profunda.

No que concerne à proposta de mudança dos programas de curso em direção a uma política que considere mais amplamente as possibilidades trazidas pelo plurilinguismo, consideramos que novas práticas nessa direção seriam de imensa valia para uma formação mais completa e dinâmica daqueles que buscam os cursos de leitura do Centro de Línguas da USP. Nesse sentido, concluímos a presente pesquisa com a seguinte reflexão:

Uma didática da intercompreensão só será possível se se "passar de uma didática centrada sobre a especificidade de uma dada língua a uma didática de línguas que visa o desenvolvimento de uma competência comunicativa que se deseja plurilíngue". (ANDRADE, ARAÚJO SÁ, 2001, apud GUEIDÃO, 2010, p. 253)

\section{Referências bibliográficas}

ALBUQUERQUE-COSTA, H. B. Um ensino específico da leitura: o ensino instrumental. In: Caderno do Centro de Línguas FFLCH-USP n.1 (1997). São Paulo: Humanitas/FFLCH/USP, 2000.

BAISNEE, V. " Autonomie et langue de spécialité : enjeux et perspectives », Cahiers de l'APLIUT [online], Vol. XXVII $\mathrm{N}^{\circ} 2$ | 2008, Publicado em 15 octobre 2012. Disponível em: http://apliut.revues.org/1406 ; DOI : 10.4000/apliut.1406

BLANCHE-BENVENISTE, C. Aspect lexical de la confrontation entre langues romanes: Existe-t-il un lexique européen ?, 2005.2 Disponível em: http://www.eurom5.com/Media/Default/Bibliografia/article\%20SienneBLANCHE-BENVENISTE.pdf BLANK, C. A. "A Intercompreensão em línguas romanas ». Revista Hispeci\&Lema. Faculdades Integradas Fafibe.

Disponível em 
http://www.unifafibe.com.br/revistasonline/arquivos/hispecielemaonline/sumario/12/19042010150157.pd $\mathrm{f}$

BONVINO, E et ali. EuRom 5. Sgel; La Maison du dictionnaire; Editore Ulrico Hoepli Milano. 2011.

BULEA, E., \& BRONCKART, J.-P. Coda : pour une approche dynamique des compétences (langagières). In J.-P. Bronckart, E. Bulea et M. Pouliot (Ed.), Repenserl'enseignement des langues : comment identifier et exploiter les compétences. Villeneuve d'Ascq : Presses Universitaires du Septentrion, 2005.

CANTALICE, L. M. "Ensino de estratégias de leitura", 2009. Disponível em: http://www.scielo.br/scielo.php?pid=S1413-85572004000100014\&script=sci_arttext

CAPUCHO, F. “L'intercompréhension est-elle une mode?”. In Pratiques, 139/140, 2009 p.238-250. Disponível em: http://www.pratiquescresef. com/p139_ca1.pdf

CORNAIRE, C; GERMAIN, C. Le Point sur la Lecture. Paris: Clé International, 1999.

CUQ, J.-P., GRUCA, I. Cours de didactique du français langue étrangère et seconde. Grenoble: Presses Universitaires de Grenoble, 2002, p. 166-175

DEGACHE C. Didática das línguas e didática do plurilinguismo: o lugar da Intercompreensão. Cap. 3: "L'analogie lexicale". Curso de Pós-Graduaçaão, FFLCH-USP, 2012.

GUEIDÃ̃O, A. "L'intercompréhension. Ça se pratique! Mais est-ce que ça s'enseigne?". In: ARAUJO SÁ, M. H. MELO-PFEIFER, S. (org) Formação de formadores para a intercompreensão: princípios, práticas, reptos, 2010, p. 245-260.

JOUVE, V. La Lecture. Paris: Hachette, 1993.

JOVER-FALEIROS, R. A experiência da leitura literária em um curso de Francês Instrumental. Dissertação de Mestrado. Faculdade de Filosofia, Letras e Ciências Humanas, Universidade de São Paulo, São Paulo 2006.

KLEIMAN, A. Oficina de Leitura: teoria e prática. 4 ed. Campinas, SP: Pontes: Editora da Universidade Estadual de Campinas, 1996.

2013.

Texto e Leitor: aspectos cognitivos da leitura. 15 ed. Campinas, SP: Pontes Editores,

PIETRAROIA, C.C.M. Percursos de leitura: léxico e construção de sentido na leitura em língua estrangeira. São Paulo: Annablume, 1997.

PISHVA, Y; THAMIN, N. Pratiques de formation aux approches plurielles : approche réflexive et intercompréhension. In Redinter-Intercompreensão. Investigação sobre metodologia de ensino de intercompreensão. 2012, p. 249-267

Quadro Europeu Comum de Referência para as Línguas - Aprendizagem, ensino, avaliação. Porto, Edições ASA, 2001.

SERE, A. «Une Approche Pragmatique du Concept d'Intercomprehension ». In ARAÚJO SÁ, M.H.; DOWNING, R. H.; MELO-PFEIFER, S.; SÉRÉ, A.; VELA-DELFA, C. (org) A Intercompreensão em Linguas Românicas: conceitos, práticas, formação. 2009, p. 33-44

SOLÉ, I. Estratégias de leitura. Porto Alegre: Artes Médicas, 1998

SCHNEUWLY, B.; DOLZ, J. Gêneros e Progressão em Expressão Oral e Escrita - Elementos para Reflexão sobre uma Experiência Suíça in: Gêneros orais e escritos na escola - Campinas, SP: Mercado de Letras, 2004. 
ESTUDANTE 3

UNIVERSIDADE DE SÃO PAULO

FACULDADE DE FILOSOFIA, LETRAS E CIÊNCIAS HUMANAS

DEPARTAMENTO DE LETRAS MODERNAS - ÁREA DE FRANCÊS

\section{Produção escrita de FLE em foco: um estudo sobre o desenvolvimento das capacidades de linguagem por meio das atividades linguageiras relatar e expor}

Bolsista: Estudante 3

Departamento de Letras Modernas - DLM

Relatório final, referente a projeto de iniciação científica desenvolvido entre setembro e janeiro de 2012, apresentado à Universidade de São Paulo, como parte das exigências da bolsa FFLCH. 


\section{SÃO PAULO \\ SÃO PAULO - BRASIL \\ JANEIRO/2012}

\section{Introdução}

Nesta pesquisa objetivamos acompanhar o desenvolvimento da produção escrita de alunos do segundo semestre de aprendizado de língua francesa, a fim de avaliar a evolução de suas capacidades de linguagem por meio das atividades linguageiras relatar e expor (BRONCKART, 1997; SCHNEWLY \& DOLZ, 2004),isto é, nos propomos a observar a apropriaçãopor parte dos estudantes das características dos textos produzidos em diferentes situações de ação de linguagem(DOLZ, GAGNON \& TOULOU, 2009). A presente pesquisa enquadra-se, portanto, nos estudos vinculados à noção de gênero textual, baseando-se nos trabalhos desenvolvidos por Bronckart (1997, 2006), Schneuwly \& Dolz (2004), que, por sua vez, se inserem no quadro do interacionismo sociodiscursivo.

Assim, observando a importância e o caráter transversal da produção escrita, é necessário lembrar seu lugar de crescente destaque, sobretudo após a popularização das mídias eletrônicas e da Internet, tendo em vista o aumento da gama de atividades cotidianas desenvolvidas virtualmente, cujo veículo de interação social configura-se principalmente através da escrita. Logo, o ensino de línguas, que, de maneira intrínseca, inclui o aprendizado da produção escrita, assume o papel de promover o desenvolvimento dos aprendizes, de modo que disponham dos savoir-faire necessários para integrar-se às diferentes atividades sociais que os cercam (DOLZ, GAGNON \& TOULOU, 2009)

Concomitantemente, a pesquisa aponta para a importância da sistematização do ensino da produção escrita, contrapondo-se às ideias - e práticas daí subsequentes - comuns em sala de aula que pregam o não ensino da escrita por acreditá-lo impossível ou por considerar seu aprendizado como processo automático, muitas vezes condicionado à simples prática de leitura (SCHNEUWLY \& DOLZ, 2004; BUNZEN, 2007).Dolz, Gagnon e Toulou (2009) apontam que

\footnotetext{
L'analyse des capacités langagières des apprenants et l'identification de leurs problèmes d'écriture sont donc des conditions pour adapter l'enseignement à leurs besoins. A cellesci s'ajoute l'analyse des dimensions de l'écriture et des composantes du texte à produire.
}

Assim, o ensino da escrita implica na sistematização das práticas de aula, que requer o reconhecimento das dificuldades dos aprendizes, podendo ser identificadas somente com o delineamento das diferentes práticas que emergem através da língua, isto é, com a identificação das características principais de cada gênero textual explorado em sala de aula(DOLZ, GAGNON, TOULOU, 2009).

O ensino de línguas através de gêneros textuais é bastante difundido no Brasil (BEATO-CANATO, 2008; BRONCKART, 2008a), desde a publicação dos Parâmetros Nacionais Curriculares entre os anos de 1998 e 2002 (BUNZEN, 2007). No entanto, a maior parte das investigações concentram-se no ensino da língua materna, como vemos emMachado (2009).No caso das línguas estrangeiras, grande parte dos estudos 
se volta para o idioma inglês(BEATO-CANATO, 2008)

Tendo em vista a necessidade de exploração do gênero textual noensino do francês como língua estrangeira, e ainda considerando a importância em identificar os problemas enfrentados pelos alunos em seu desenvolvimento, a fim de promover a sistematização do aprendizado da produção escrita através dos gêneros textuais, procuraremos responder às seguintes perguntas:

A. Quais capacidades de linguagem os alunos desenvolveram (ou não) durante as atividades de produção escrita?

B. Em quais aspectos da produção escrita, observada a partir da ótica dos gêneros textuais, os alunos encontram maior dificuldade?

Ao responder a essas questões, procuramos contribuir para o enriquecimento do ensino do francês, uma vez que, identificadas as dificuldades e êxitos dos estudantes em seu percurso de aquisição da língua, fica-se mais próximo da aprendizagem que proporciona ao estudante, mais que conhecimentos estáticos, verdadeiros instrumentos de interação.

\section{Fundamentação teórica}

Das inúmeras abordagens que se propõem a analisar o papel e o funcionamento da linguagem, as teorias vygotskianas (2010)priorizamo caráter interacional da linguagem, isto é, focando a importância do outrona aprendizagem e no desenvolvimento. Sob tal perspectiva, a construção do sujeito está associada às suas interações, nas quais os elementos alheios que o rodeiam tornam-se indispensáveis ao seu desenvolvimento. Nesse processo, a linguagem tem, portanto, primazia, sendo o instrumento central das interações humanas (VYGOTSKI, 2010;CRISTÓVÃO, 2007). Das proposições de Vygotski, deriva, então, o Interacionismo Sociodiscursivo ${ }^{38}$, que investiga a função determinante da linguagem no que concerne às atividades humanas.

À perspectiva de Vygostski sobre a linguagem vem juntar-sea noção bakhtiniana de gênero do discurso, precedida da observação de que a verdadeira substância da língua se constitui pelo fenômeno social da interação verbal (BAKHTIN, 1986). Assim, a linguagem, mais que um sistema baseado em sua forma linguística, é ocorrência ativa que emana das interrelações desenvolvidas através dela. Tais relações manifestam-se na forma de atividades que são, por fim, as verdadeiras restrições que dominam as diferentes manifestações e formatos que a linguagem pode assumir. Bakhtin (1986), então, aponta para o fato de que estando toda atividade humana atrelada à linguagem, é aquela que regrará o uso desta. De cada atividade diferente emanará, portanto, um gênero do discurso com um conjunto de características distintas, ditadas pelas condições de enunciação. Assim, se ressaltamos a definição de Bakhtin para os gêneros discursivos, temos que estes são realizações comunicativas através de formas mais ou menos estáveis de enunciados, ou seja, fundados por convenções sociais (2003). O autor ainda tocará a questão da heterogeneidade dos gêneros, observando que as diferenças darão orgirem ao estilo e serão constituídas pelas unidades dependentes do gênero (2010).

Bronckart (1997), por sua vez, chamará atenção para as dificuldades terminológicas presentes nos postulados de Bakhtin, apontando como causas,em parte alguns problemas de tradução, em parte a própria evolução dos estudos desenvolvidos ao longo da obra bakhtiniana, que teria promovido adequações graduais dos termos utilizados. Assim, Bronckart proporá o emprego dos termos gêneros textuais, para substituir gêneros do discurso e nomeará de tipos discursivos os elementos estruturais que determinariam as distinções formais entre os gêneros e que Bakhtin havia chamado de unidades dependentes.

Com a diferenciação entre gêneros textuais e tipos de discurso, ficam melhor delineadas as margens entre forma linguística e a dimensão social do gênero, intrinsecamente ligado às atividades humanas. Assim, se a função de determinada atividade de linguagem é definidora de seu gênero, este somente se manifesta reunindo determinadas características fomais, das quais os tipos de discurso são um dos

\footnotetext{
${ }^{38}$ Doravante ISD.
} 
protagonistas.Bronckart (1997), então,os definirá como formas linguísticas que se traduzem na criação de mundos discursivos.

Os mundos propostos por Bronckart (1997) se organizam a partir das operações que efetuam. A primeira divisão sugerida expressa a relação entre as coordenadas de um mundo ordinário e as coodenadas do conteúdo temático de um texto. O segundo põe em contato diferentes instâncias agentivas, seu espaço, seu tempo e os parâmetros concretos da enunciação. Pode-se, assim, considerá-los como dois mundos em que, no primeiro, há distância entre a ação de linguagem e o mundo ordinário, e que chamamos, então de disjunto. Já no segundo, o conteúdo da ação de linguagem e a situação de produção são conjuntos.

O mundo disjunto, em especial, possui a característica de ancorar-se a uma origem espaço-temporal. Em outras palavras, é como se os fatos organizados textualmente fossem relatados e, portanto, distantes do espaço-tempo da enunciação. Já o mundo conjunto não teria nenhuma origem a qual remeter, já que se organiza de maneira mais ou menos direta com as coordenadas da atividade de linguagem, representando, portanto, uma exposição. Bronckart (1997) propõe, então, a divisão dos tipos de discurso em dois eixos: relatar (disjunto) e expor (conjunto).

O pesquisador distingue ainda outro aspecto a ser considerado em sua classificação, propondo uma segunda oposição binária, finalizando, portanto, quatro tipos diferentes de discurso. Essa última dicotomia se baseia na explicitação das relações entre as instâncias agentivas e os parâmetros materiais de linguagem, o que define a implicação ou autonomia de um texto. Em outras palavras, um discurso é implicado se o conteúdo narrado ou exposto compartilhar o mesmo espaço, tempo, agente produtor e interlocutor que o ato de enunciação. Se tais elementos não coincidirem, o discurso será considerado autônomo.(BRONCKART, 1997;LOUSADA, 2010)

As observações de Bronckart (1997) resultam, portanto, nos seguintes quatro mundos discursivos: expor (conjunto) implicado, expor (conjunto) autônomo, relatar (disjunto) implicado e relatar (disjunto) autônomo. Tendo-os já delineados, o autor volta-se à noção de tipos psicológicos, que derivariam da proposição segundo a qual é possível delimitar propriedades gerais da linguagem a partir da generalização das formas pelas quais se manifesta uma língua natural. Assim, a cada tipo psicológico corresponderia respectivamente um tipo dicursivo: discurso interativo, discurso teórico, relato interativo e narração.

A caracterização dos componentes de cada tipo de discurso repousará sobre o modelo de análise textual do ISD. Bronckart (1997, 2006, 2008b) proporá que, a partir da arquitetura geral do texto, seja observado o folhado textual, composto pela sua infraestrutura geral, pelos mecanismos de textualização e pelos mecanismos de responsabilização enunciativa (Lousada, 2010).

O primeiro dos aspectos citados, isto é, a infraestrutura geral, é composto por três outros aspectos: o plano global dos conteúdos temáticos, os tipos de discurso e as sequências. O primeiro deles diz respeito aos assuntos abordados no texto, ou seja, assemelha-se a um resumo. Tendo os tipos de discurso sido longamente abordados, passemos às sequências.

Retomando as ideias de Adam (1992),Bronckart (1997) propõe a consideração de unidades estruturais mais ou menos independentes do texto que se organizam para formar as ideias nele contidas. Tais unidades seriam chamadas de sequências e poderiam ser divididas conforme suas diferentes características. A primeira sequência, a narrativa, é condicionada à existência de uma intrigae é composta minimamente por três fases, ou seja, situação inicial, transformação e situação final. Está presente em gêneros textuais como o fait divers e o romance.

A segunda sequência, a descritiva, não diz respeito a ações, mas a objetos e contém três fases que se ordenam de maneira mais ou menos aleatória. São elas a ancoragem, quando o tema da descrição é anunciado, a aspectualização, quando os aspectos do objeto são listados e o relacionamento, momento em que há comparações com outros objetos que não o escolhido. A sequência argumentativa, por sua vez, seria organizada em premissas, argumentos, contra-argumentos e conclusão, forçosamente nessa ordem. Já a sequência explicativa se diferencia por partir de uma constatação irrefutável, se organizando em constatação inicial, problematização, resolução e conclusão-avaliação. A sequência injuntiva, por sua vez, caracteriza-se por impelir à ação. A última sequência, a dialogal, requer uma conversa entre interlocutores, em que os enunciados se determinem mutualmente, formando um todo coerente. Bronckart (1997) ainda postula a existência de sequências narrativas desprovidas de tensão, que seriam chamadas de script, e sequências 
argumentativas e explicativas em que não é necessário explicar ou argumentar, em parte porque apresentam evoluções lógicas de fácil compreensão e seriam, portanto, chamadas de esquematização.

Tendo explanado os componentes da infraestrutura geral do texto, passamos à descrição dos mecanismos de textualização, compostos pela coerência e pela coesão, que garantem a progressão temática através de recursos linguísticos (Lousada, 2010). O primeiro mecanismo, o da coerência, garante a conexão entre as ideias desenvolvidas no texto, a fim de formar um plano global sólido. Sua manifestação ocorre através dos organizadores textuais. Já a coesão, que pode ser dividida em verbal e nominal, exprime-se através de tempos e modos verbais e também de catáforas e anáforas, utilizando para tanto, pronomes e substantivos.

Nos resta, portanto, abordar os mecanismos de responsabilização enunciativa, através dos quais vem à tona o caráter dialógico da linguagem. Isso quer dizer que toda atividade linguageira implica na presença indireta de outras instâncias e indivíduos. Tais mecanismos manifestam-se pelas modalizações e pelas vozes. A primeira permite que os julgamentos do enunciador possam emergir do texto. Além disso, também podem ocorrer, promovendo a amenização ou intensificação de declarações, a fim de adequar-se às perspectivas do destinatário. Quanto às vozes, Bronckart (1997) aconselha o uso de referências de outros autores. Lousada (2010), recorrendo a pesquisadores como Maingueneau (1989, 1991, 2001), Authier-Revuz (2001) e Brait (2008), aponta que suas ocorrências se dão por diversos meios, sejam formais, como os discursos direto ou indireto ou as aspas, seja de maneira mais abstrata, como o posicionamento político, o registro ou mesmo a ironia.

Bronckart (1997) ainda ressalta que, antes de avaliar os três níveis do folhado textual, é necessário refletir sobre o contexto de produção do texto, o que se traduz em observar as representações dos interlocutores sobre o local e o momento da produção, além do papel social de cada agente em suas ações de linguagem, assim como considerá-los sob o ponto de vista físico. Também é necessário refletir sobre a instituição social da situação, bem como o que pretendem, tanto enunciador quanto enunciatário, na interação que estiver sendo analisada(Machado, 2009). Assim, é necessário avaliar a situação de maneira ampla, do mesmo modo como torna-se imprescindível considerar a ação de linguagem que o origina, já que toda atividade linguageira emerge de uma situação concreta e tem motivações reais pautadas nas interrelações humanas, o que dá origem aos gêneros textuais.

Assim, todo indivíduo convive, é exposto e produz textos que são organizados em diferentes gêneros. A maneira como os indivíduos dependem deles para arranjar suas relações sociais faz com que de modo mais ou menos intuitivo cada um consiga produzi-los, acessando o arquitexto de sua comunidade verbal (Lousada, 2010).A existência de tal intuição não é garantia, no entanto, de que todos indivíduos serão capazes, em completa autonomia, de produzir todos os gêneros existentes(MACHADO, LOUSADA \& ABREUTARDELLI, 2008; SHNEUWLY \& DOLZ, 2004). É nesse aspecto, portanto, que reside uma das justificativas do uso dos gêneros como unidade de ensino, não se restringindo, no entanto, a um fim em si mesmo.

Schneuwly \& Dolz (2004)remetem à noção vigotskiana de instrumento, que seria o meio pelo qual o homem pode operar modificações desejadas no objeto em seu processo de trabalho. Tais instrumentos seriam intermediações indispensáveis na relação do homem e objeto, bem como no contato entre o homem e os outros. É o instrumento que guia o comportamento do indivíduo, adequando-o aos diversos contextos cotidianos. Ao entender os gêneros como instrumentos, trabalha-se, então, com a construção de savoir-faire que, passíveis de ser aplicados em diferentes atividades linguageiras, possibilitam a ação do aprendiz, que reafirma, portanto, seu papel de sujeito nas diferentes interações sociais. Assim, enxergando os gêneros concomitantemente como unidade de ensino e como instrumento, é possível utilizá-lo para o desenvolvimento dos três tipos de capacidades de linguagem, isto é, as de ação, as discursivas e as linguístico-discursivas (LOUSADA, MUNIZ-OLIVEIRA \& BARRICELLI, 2011).

A primeira delas diz respeito às representações que o sujeito faz sobre a situação de comunicação e sobre seu referente. A segunda remete às atividades necessárias à organização geral do texto. Já a terceira refere-se às operações psicolinguísticas e às unidades linguísticas necessárias à construção textual (LOUSADA, MUNIZ-OLIVEIRA \& BARRICELLI, 2011; BEATO-CANATO, 2008). É preciso ressaltar, no entanto, que os diferentes tipo de capacidades de linguagem são interdependentes e que o desenvolvimento de uma delas muitas vezes implica na progressão das outras. 
Para o desenvolvimento das capacidades de linguagem, Schneuwly e Dolz (2004) propõem que o ensino-aprendizagem, tanto da escrita como da expressão oral, seja sistematizado, baseando-se, para tanto, na noção bakhtiniana de gênero, aprimorada por Bronckart. $\mathrm{O}$ modelo por eles proposto consiste em sequênciasdidáticas. $\mathrm{O}$ processo da SD compreende a apresentação da situação, sucedida por uma produção inicial, seguida por módulos de atividades, finalizadas por uma última produção (LOUSADA, 2007;LOPESROSSI, 2008; BEATO-CANATO, 2008).

Fazendo a apresentação da siuação de produção textual, deve ficar claro para o aluno o contexto que dá origem ao texto que será proposto. Já o intuito da produção inicial é de que o professor identifique as dificuldades dos alunos na criação de algum texto pertencente a determinado gênero. Propondo aos estudantes uma produção sem preparação alguma, o professor passa a contar com material que permite a identificação dequais pontos devem ser trabalhados para promover o real desenvolvimento das capacidades do aprendiz. Baseado nas características do texto expressas no folhado textual, é possível montar Nmódulos de atividades que levem o aluno ao reconhecimento das características do gênero, o que, portanto, permitiria ao estudante não somente produzir algum gênero específico, mas aplicar as capacidades desenvolvidas durante a SD a outras situações e atividades de linguagem. A sequência termina com uma produção final que, se comparada a inicial, torna-se importante registro da progressão dos aprendizes (SCHNEUWLY \& DOLZ, 2004). É importante ressaltar que tal proposta de ensino não se baseia em uma visão linear da aprendizagem, mas no conceito de espiral, em que periodicamente volta-se a algum conteúdo já estudado, momento em que outras capacidades são aprimoradas.

Para a efetuação da sequência didática, no entanto, é necessário ainda ter outro conceito em vista, também desenvolvido por Schneuwly e Dolz (2004), isto é, a noção de modelo didático. Segundo os pesquisadores, é necessário identificar quais características do gênero trabalhado podem se tornar objeto de ensino-aprendizagem. Para tal identificação, é necessário recorrer a documentos oficiais que já indiquem as dificuldades e êxitos comuns que os alunos encontram em suas trajetórias de aprendizagem, além de consultar as pesquisas já desenvolvidas a respeito do gênero escolhido. Além disso, é preciso levar em consideração as capacidades de linguagem que os alunos já desenvolveram (Crsitóvão, 2007). Levando todos os aspectos listados em conta, resta somente analisar textos empíricos em que se possa, a partir do folhado textual, traçar as características principais que identificam o gênero.

\section{Metodologia}

A presente pesquisa foi desenvolvida entre alunos do segundo semestre do curso de Língua Francesa da habilitação em francês da Universidade de São Paulo. Os estudantes que chegam a esse estágio estão cursando, normalmente, o segundo ano do curso de Letras e a maioria também segue concomitantemente a habilitação em português. As idades dos estudantes podem variar muito, se diversificando entre indivíduos que finalizaram recentemente o Ensino Médio, alguns que cursam a segunda faculdade e outros, ainda, que após anos distantes da universidade, decidem cursar Letras, nesse caso muitas vezes sem ter exigências profissionais que os impilam a isso. Parte deles cursou o primeiro semestre de francês com a mesma professora, outros decidiram mudar na metade de 2012.

A professora desenvolveu suas aulas usando atividades didáticas (SCHNEUWLY \& DOLZ, 2004),nem sempre inseridas em uma sequência didática clássica e propôs, periodicamente, tarefas de produção escrita que devem ser desenvolvidas em casa, tendo em vista o escasso tempo disponível em sala. Para a entrega dos exercícios feitos, foi usada a plataforma onlineMoodle, onde é possível dispor atividades, apresentar suas correções, fazer comentários e enviar mensagens, configurando-se, portanto, em canal de comunicação extra-classe entre professora, monitoras e alunos, além de ser um facilitador que poupa o tempo que comumente se separaria durante a aula para entregar as propostas de produção escrita, assim como os textos prontos dos estudantes. Ao longo do semestre foram propostos cinco exercícios.

Quanto à coleta do corpus, alguns pontos tiveram que ser levados em conta. A presente pesquisa configura-se como continuação dos estudos iniciados por Bezerra\& Lousada (2012), cuja proposta muito se assemelha à nossa, situando-se, no entanto, em momento diverso do desenvolvimento dos alunos. O curso de que, tanto nós, quanto as pesquisadoras, coletaram produções escritas conta com cerca de 50 alunos se somados os períodos matutino e noturno Conforme apontado por Bezerra\& Lousada, embora a observação de 
todas as produções escritas tenha trazido dados importantes ao estudo, a grande quantidade de aprendizes dificultou o trabalho de análise. Assim, sentimos a necessidade de restringir a cerca de seis os estudantes cujas produções fariam parte de nossas análises.Para a escolha dos alunos, optou-se, a semelhança do que fez Petreche (2008), escolher alguns alunos de ótimo rendimento, alguns com desempenho um pouco inferior e ainda outros que apresentassem diversas dificuldades em seus processos de aprendizagem. A escolha dos estudantes, no entanto, foi progressiva, visto que não era possível desde o começo ter certeza de quais alunos entregariam um número suficiente de exercícios feitos para acompanhar seu desenvolvimento. Assim, diversos aprendizes escolhidos durante a pesquisa tiveram que ser descartados, por efetuarem poucas produções escritas. Outros, que não estavam originalmente no corpus, foram adicionados por apresentarem um número satisfatório de atividades. A tabela a seguir mostra o desempenho dos alunos no início da pesquisa, a quantidade de exercícios feitos por cada um e a que período (matutino ou noturno) pertencem.

$\begin{array}{llll}\text { Aluno } & \text { Desempenho } & \begin{array}{l}\text { Exercícios } \\ \text { entregues }\end{array} & \text { Período } \\ \text { R.F. } & \text { Muita dificuldade } & 5 & \text { Noturno } \\ \text { C.S. } & \text { Pouca dificuldade } & 4 & \text { Noturno } \\ \text { V.C. } & \text { Pouca dificuldade } & 4 & \text { Noturno } \\ \text { R.G. } & \text { Pouca dificuldade } & 5 & \text { Noturno } \\ \text { A.S. } & \begin{array}{l}\text { Algumas } \\ \text { dificuldades }\end{array} & 5 & \text { Matutino } \\ \text { G.S. } & \begin{array}{l}\text { Algumas } \\ \text { dificuldades }\end{array} & 5 & \text { Matutino } \\ \text { S.C. } & \text { Muita dificuldade } & 3 & \text { Matutino }\end{array}$

Tabela 1: características dos alunos escolhidos

Outra dificuldade enfrentada refere-se à classificação dos alunos como tendo melhor ou pior rendimento. Num primeiro momento foi considerada a possibilidade de aváliá-los apenas pelas notas obtidas em provas escritas. Verificou-se, no entanto, que os dados eram objetivos demais e não transpareciam necessariamente o desempenho real dos estudantes. Tendo em vista que no começo da pesquisa os alunos haviam feito somente uma pequena avaliação que verificava apenas capacidades linguístico-discursivas, foi comum encontrar alunos de bom rendimento com notas iguais a alunos de rendimento menor. Percebemos, então, que as notas obtidas não revelavam necessariamente os dados que procurávamos, sendo necessário dar preferência às experiências de sala de aula, em que a professora, conhecendo seus alunos, podia observar o grau de dificuldade que apresentavam na língua. Associando as considerações da professora aos resultados progressivos que os estudantes obtinham nos exercícios, foi possível chegar a uma classificação aproximada sobre o desempenho dos aprendizes. No entanto, como nem todos fizeram a totalidade das atividades, foi ainda necessário estabelecer um mínimo de três exercícios entregues para que as produções de determinado aluno fossem incluídas no corpus, o que justifica a inclusão de S.C.

Uma última questão, levantada ainda no início da pesquisa foi a de inclusão ou não de faux débutants, isto é, alunos que já tivessem estudado francês antes de fazê-lo na faculdade. Optamos por não excluí-los por dois motivos: a) a quantidade de alunos que começam a estudar a língua com antecedência é grande, mesmo que a maioria não seja formada por falantes independentes; b) como as análises consideram o 
desenvolvimento de cada estudante separadamente, não buscamos fazer um retrato do desenvolvimento da classe, mas, de preferência, delinear a progressão considerando as diferentes faixas de desempenho.

\section{Desenvolvimento de pesquisa e resultados}

A primeira atividade proposta referia-se à produção de uma sinopse de filme, indicado nas instruções do exercício ou escolhido livremente pelos alunos. O gênero em questão tem como suportes mais comuns a contra capa de DVDs e Blu-Ray e sites especializados em filmes. No último caso, destacamos o site allocine.fr, que goza relativa popularidade na comunidade francófona e que contém vasta gama de sinopses disponíveis ao público. O gênero também ocorre em sites de vendas online, embora nestes haja, normalmente, a repetição das informações da capa do produto. Em todo caso, o intuito do texto é sempre de seduzir o leitor a assistir o filme, seja porque assim sua venda será efetuada, seja para manter o status do site como fornecedor de boas sinopses e contentor de bom conteúdo. A manutenção do suspense e a crescente inserção de elementos que caracterizem o filme como interessante são, portanto, indispensáveis na produção do gênero.

O tipo de discurso que constitui a sinopse é a narração, o que implica no uso majoritário de sequências narrativas. Bronckart (1997), retomando Labov \& Waletsky (1967), sugere cinco fases constituintes dessa sequência: situação inicial, complicação, ações, resolução e situação final. A essas podem juntar-se outras duas : avaliação e moral.Na sinopse, dado que é impossível revelar o final da trama, a narração se limitará às duas primeiras fases, finalizando, portanto, num nó que constitui a intriga e que motiva o leitor a assistir ao filme, a fim de descobrir quais ações serão empreendidas para a resolução do problema. É possível, no entanto, identificar neste gênero algumas etapas comuns que constituem as duas primeiras fases:

- apresentação: nomeação e caracterização do(s) protagonista(s) e,frequentemente,instituição da origem espaço-temporal;

- evento: acontecimento de relativa importância que tranforma a situação inicial e que possibilita a complicação;

- construção da complicação: etapa em que elementos diversos (ações, características das personagens ou da situação) constroem as condições necessárias à complicação;

- projeção pós-complicação: denso uso de formas de futuro. Monta hipóteses acerca das ações decorrentes da complicação e sua resolução. É um último esforço para instigar a curiosidade do leitor.

Também é comum introduzir previsões acerca dos benefícios morais que o protagonista descobrirá em sua jornada, configurando-se, portanto, em outra modalidade da etapa final, que simula a própria fase moral. Sua ocorrência na sinopse se justifica como uma maneira de convencer o leitor de que, assistindo ao filme, ele também terá acesso às lições de vida aprendidas pelas personagens.

Quanto à coesão verbal, embora a narração exija, normalmente, o uso de tempos verbais passados, o gênero sinopse se desenvolve principalmente através do indicatif présent, que Bronckart (1997) chamará de présent de narration, quando usado para apresentar progressão de ações no passado. Além disso, o uso de pronomes na terceira pessoa com função anafórica é comum, a fim de evitar repetições. Por último, é necessário apontar a importância das modalizações a fim de aumentar o suspense e o efeito de sedução, normalmente colocando o leitor a favor do protagonista e ajudando-o a enxergar de maneira intensificada a complicação da narrativa. Tendo tais características em vista, é possível abordar as capacidades de linguagem dos alunos.

Quanto às capacidades de ação, todos os alunos compreenderam que na atividade social proposta era necessário cumprir a função de enunciador que instiga o destinatário a assistir o filme, o que significa não avançar além da fase de complicação. Todos os estudantes identificaram satisfatoriamente essa fase, construindo os textos de forma a desembocar na complicação da narrativa. A única exceção foi R.F., que não identificou um nó em sua narração, nem construiu um momento de tensão. 
A construção do suspense, no entanto, ficou prejudicada em decorrência de dois aspectos presentes nas produções dos alunos: supressão de dados importantes através de subjetivações e revelação abrupta da complicação, sem instaurar intensificação suficiente. A supressão acima referida ocorreu de duas maneiras. A primeira dá-se quando o aluno omite ações que poderiam intensificar o suspense com subjetivações genéricas, como nas frases "Mais la guerre n'est pas finis et ils ont affronter divers problèmes et obstacles, jusqu'à qu'ils finalement retrouvent Ryan" (G.S.)e «Ellis devient un vrai ami et l'aide à affronter nombreuses situations dificilles.” (R.G.) A inadequação das frases sublinhadas reside no fato de que são aplicáveis a quase qualquer filme no intento de valorizá-lo, o que, logo, não permite que os filmes sobre os quais se escreve sejam reconhecidos como mais desejáveis que outros.O mesmo ocorre na produção de R.F: «Dans le voyage le garçon connaît beaucoup de personnes differents. Cette personne enseignent Alexander beaucoup choses sur la vie et il enseigne beaucoup choses pour cette personnes aussi. » No exemplo, o aluno também não intensifica nem carateriza satisfatoriamente as experiências do protagonista, fazendo com que o trecho, que deveria ser a etapa de projeções pós-complicação, não cumpra sua função de apresentar ao leitor conhecimentos ou sensações que poderão ser acessados unicamente assistindo ao filme.

Ao invés de tais supressões, seria mais adequado ao gênero inserir dados exclusivos do filme sobre o qual se escreve. Sobre um filme de guerra, por exemplo, ao invés de afirmar que os personagens enfrentarão diversos problemas e obstáculos, é preferível nomear as dificuldades, como fome, exaustão, saudade etc., seguindo o que se encaixa melhor à história.No modelo apresentado aos alunos ${ }^{39}$, é possível observar a nominalização de elementos ao invés de suprimi-los de maneira genérica: "Ecartelé entre son rêve et sa condition, Rémy va découvrir le vrai sens de l'aventure, de l'amitié, de la famille..." Aqui, o autor, no intento de seduzir o leitor, prefere expor-lhe os valores específicos a que terá acesso assistindo ao filme ao invés de dizer vagamente que Rémy vai descobrir muitas coisas sobre a vida.

A outra maneira de apresentara supressão de dados importantes não omite ações, mas, sendo também espécie de caracterização aplicável a qualquer filme, parece configurar-se como a inserção da opinião do autor, a semelhança do gênero resenha. O exemplo a seguir encontra-se próximo ao final da produção de C.S: "C'est un filme très marrante, et on ne sais jamais quoi espérer." A inadequação da frase reside no fato de que no gênero sinopse raramente faz-se adjetivações diretamente ligadas ao filme, usando-se, de preferência, modalizações apreciativas referentes ao elementos constitutivos da história, como personagens, lugares, situações. Assim, no exemplo dado era esperado que o aluno, ao invés de afirmar que o filme é engraçado, expusesse ao leitor tal característica inserindo adjetivações quanto aos personagens, por exemplo, de maneira que deixasse implícito sua comicidade. A supressão das adjetivações a favor de uma subjetivação genérica não se encaixa, portanto, nas expectativas quanto ao gênero. Esse ponto é importante porque é uma das características que diferem resenha e sinopse. Enquanto no primeiro espera-se encontrar a opinião do autor sobre o filme, no segundo procura-se somente um pequeno resumo e a caracterização da história.

Quanto à revelação abrupta da complicação, podemos defini-la como uma falha na etapa de projeção, como nos exemplos a seguir, que dizem respeito à última linha de duas produções, quando a complicação de cada uma é instaurada, sem nenhuma outra manifestação que seduza o leitor: "Maria prend l'affection et le respect des enfants mais elle se tombe amoureuse du capitaine." (V.C.) e «Mais bientôt, des leçons de piano deviennent les rencontres sexuelles et aucun retard pour les deux tombent amoureux »(A.S.). As supressões e a revelação abrupta da complicação podem ser compreendidas como certa dificuldade na representação do destinatário e de suas expectativas quanto ao gênero. $\mathrm{O}$ segundo desses dois aspectos também pode ser entendido como uma dificuldade nas capacidades discursivas, ou seja, um percalço na organização do texto.

Quanto às capacidades linguístico-discursivas, é possível observar a instituição da origem espaçotemporal. Cinco alunos conseguiram instituí-la. R.F., no entanto, apesar de estabelecer uma ação que marca o tempo ("Il termine les etudies sur medicine"), não consegue utilizar uma palavra ou expressão como quand ou le jour où que indique que aquela é uma ação marco para o desenrolar da história: "Alexander est un garçon dans une famille americaine tradicionalle. Il termine les etudies sur medicine et gagne une voiture ses parents, mais Il ne se sent pas complet et heureux. Ensuite Alexander decide quiter son maison... », assim, o

\footnotetext{
${ }^{39}$ Durante as aulas, os alunos foram apresentados ao gênero sinopse de filme através de dois textos do site allocine.fr. Um deles foi a sinopse do longa Le Petit Nicolas (2010). O trecho que trazemos como exemplo logo a seguir, diz respeito ao filme Ratatouille, cuja sinopse encontra-se disponível em http://www.allocine.fr/film/fichefilm_gen_cfilm=46211.html (acessado em jan/2013).
} 
ensuite acaba não fazendo referência clara a nenhum momento específico. Já o aluno G.S. indicou uma origem espaço-temporal suficiente para o sistema de conexão, mas insatisfatória para a compreensão do filme, já que não aponta qual a guerra ou período em que se passa a história: "Quand le capitaine John H. Miller débarque à Normandie au milieu d'une bataille..." Ainda assim, todos os alunos conseguiram organizar temporalmente o corpo do texto, incluindo R.F., que utiliza ensuite para apontar a progressão de ações.

Quanto aos mecanismos de coesão nominal, os alunos mobilizaram bem tanto as anáforas nominais quanto as pronominais, havendo uso mais intenso das primeiras. As modalizações foram poucas vezes acopladas, sem contudo prejudicar os textos. A aluna A.S. é quem adjetiva com mais facilidade, como quando se refere à protagonista de sua sinopse como "jeune femme écossaise". Quanto ao aluno R.F., apesar de tentar construir certa coesão, acaba por repetir muitos elementos, como o nome do protagonista ou a expressão cette persone, como supracitado.

Passando à segunda atividade proposta, os alunos deveriam produzir um fait divers. Também situado no eixo relatar (Bronckart, 1997), o gênero em questão tem como suporte os jornais cotidianos, o que o torna, portanto, também disponível nas versões online da imprensa escrita. Lousada (2010) faz a caracterização do gênero e aponta sua semelhança com a notícia, exceto pelo fato de não ter importância social, cultural, política e econômica e por frequentemente abordar eventos curiosos, inusitados ou acidentes, fazendo uso do humor e da ironia. O público-alvo do gênero, portanto, não procura em sua leitura manter-se informado, mas recorre ao fait divers por prazer, como fonte de entretenimento.

Quanto à infraestrutura geral do texto, o gênero, semelhante à notícia, procura responder às questões "O que? Quem? Por quê? Quando? Onde? Como?". Sendo um texto curto e objetivando sempre chocar o leitor, o fait divers usa a estrutura da pirâmide invertida, ou seja, revela primeiramente as informações mais gerais, passando, posteriormente, às mais específicas(FRANCESCHINI, 2004apud LOUSADA, no prelo). Assim, logo no título é comum responder a todas as perguntas-base, deixando somente o como e por quê para serem esclarecidos ao longo do texto. Após o título encontra-se normalmente um subtítulo, seguido por um lead, parágrafo que responde finalmente a todas as questões colocadas acima. O corpo da notícia, por sua vez, dará os detalhes que não são fundamentais para a compreensão do fato exposto.

Quanto ao tipo de discurso utilizado, há variação entre o relato interativo e a narração, e está, portanto, sempre situado no eixo da atividade relatar. A coesão verbal se dá, no caso do francês, principalmente pelos temposprésent de l'indicatif, passé composé e imparfait.No que tange ao sistema de conexão, o estabelecimento de uma origem espaço-temporal é necessária desde o título e cabeçalho, e organizadores temporais são exigidos ao longo de todo o texto, conforme se relata a progressão das ações. Quanto à inserção de vozes, dado que o gênero guarda muitas semelhanças com a notícia, e tendo em vista que é veiculado por jornais, é esperado que o fait divers seja construído a partir de informações fornecidas por diversos indivíduos e instituições, configurando, assim, um gênero marcadamente polifônico. A escolha dos verbos dicendi utilizados, no entanto, revelam uma das marcas do fait divers, uma vez que o autor pode variar a maneira que insere as diferentes vozes, usando desde um quase neutro expliquer, até um pretenso interroger.

Por último, é necessário apontar a importância das escolhas lexicais na coesão nominal do gênero. Adjetivando os elementos a que o autor remete, o enunciador acaba marcando sua opinião sobre os protagonistas do texto. Lousada (no prelo) ressalta, em exemplo de fait divers, o uso de peu rompue aux subtilités de la langue française e son français hésitant, demonstrando o posicionamento do autor quanto às capacidades, em língua francesa, de algum sujeito do texto. É principalmente pela coesão nominal e pelo índice de subjetividade nelas inserido que se dá a ironia comum nos textos de faits divers.

A partir dessas características, podemos analisar primeiramente as capacidades de ação desenvolvidas pelos alunos. Era necessário que tivessem em vista o objetivo do gênero: chocar através de um fato insólito, guardando, entretanto, características em comum com notícias de jornal. Assim, era esperado que os estudantes mobilizassem o formato do gênero para ressaltar o seu caráter inusitado, respondendo às perguntas de base.

Os alunosS.C. e R.F. não situaram seu leitor utilizando um título. Aqui, o fato importante não é apenas a não utilização do título, mas a não apreensão de uma estratégia importante do gênero: se o fait divers deve ser rápido e chamar a atenção por seu conteúdo insólito, é necessário chocar o leitor desde o primeiro contato com o texto. A leitura do fait divers inteiro só deve, portanto, ocorrer para uma explicação mais detalhada do que aconteceu, onde, quando e por quê. Ao não colocar o título, o caráter instantâneo do gênero fica 
prejudicado. É necessário observar, no entanto, que ambos os alunos procuraram expressar tal instantaneidade através da primeira frase, que logo fornece os dados necessários para causar a sensação de surpresa. Ainda cabe apontar que S.C. tem desempenho melhor, por inserir outras marcas do gênero, como data e local no cabeçalho.

Os outros alunos responderam bem às perguntas do gênero, cumprindo o objetivo de chocar o leitor. A.S. e G.S., entretanto, não inseriram as informações sobre local e data nem no título, nem no cabeçalho. Todos os estudantes compreenderam que era necessário construir um discurso disjunto e sem a utilização da primeira pessoa. A inserção de vozes também não foi um problema para a maioria dos aprendizes. Com exceção de R.F., todos inseriram comentários externos através de discurso indireto. R.F. construiu um texto satisfatório, embora não tenha utilizado declaradamente vozes de personagens.

Quanto à coesão verbal, começando por R.F., há um dado interessante a ser notado. Em pergunta que antecedia as instruções para a produção textual, o aluno não identificou a diferença entre o uso do passécomposé e do imparfait, no entanto, ao longo do texto ele os aplica corretamente.S.C. teve problemas na conjugação de verbos pronominais no passé composé ("une femme s'a tué")e não empregou o imparfait, exceto por uma frase em que seu uso não se fazia necessário, sendo preferível o passé composé ("L'APF recevait d'autres affirmations pareilles.").Quanto aos outros alunos, utilizam bem os tempos necessários ao gênero. A.S apresenta alguns problemas de vocabulário, errando na utilização de alguns verbos (lancer, ao invés de publier, por exemplo) e G.S. comete equívoco quanto à transitividade do verbo tuer, prejudicando a compreensão de todo o texto ("Aujourd-hui deux personnes ont tué[quem?] dans un accident de voiture"). Não passa, no entanto, de erro isolado.

Por último, no que se refere à coesão nominal, observaremos algumas escolhas lexicais. R.F. usa somente la jeune fille, recorrendo no resto do texto a pronomes ou substantivos sem adjetivação. É perceptível, no entanto, melhora em seu sistema de coesão. Não mais repetindo excessivamente, o aluno somente apresenta certa dificuldade com pronomes possessivos.Já a aluna A.S. intensificando ainda mais o que já demonstrava no exercício anterior, insere as expressões le propriétaire du magazine, magnat, l'aînée la vieille femme, focando, através de escolhas lexicais, no dado insólito de seu fait divers, isto é, na idade avançada da protagonista e na posição social do outro personagem ${ }^{40}$. S.C., por sua vez, à semelhança do que fez R.F., somente utilizou l'ecrivain para retomar femme. Quanto aos outros alunos, nenhum utilizou o mecanismo comum ao gênero, de adjetivação através de retomadas. V.C. e R.G., no entanto, constroem boas narrativas, sem prejuízos à compreensão ou mesmo à adequação ao gênero. G.S., entretanto, fez muitas repetições e operou poucas retomadas pronominais e nenhuma nominal com inserção de modalizações apreciativas.

Passando à terceira produção, era proposto que os alunos fizessem um relato sobre uma viagem pessoal que pudesse ser publicado em um blog. A atividade social relatar viagens já era encontrada em livros quando passou a ocupar o espaço em diários online. $\mathrm{O}$ intuito, então, mais que expor experiências próprias, passou a ser de partilhá-las com leitores que possivelmente rumariam para o mesmo destino, guiando-os, assim, nas dificuldades que poderiam encontrar ou dando dicas de atividades interessantes na região escolhida. Exemplo disso é o site francófono e-voyageur.com, que reúne grande quantidade de testemunhos de turistas em diversas regiões do mundo. Tendo em vista as expectativas criadas quanto ao gênero, era necessário que os alunos construíssem um relato interativo, portanto implicado, o que se traduziu no uso intenso da primeira pessoa. Era esperado que os estudantes partilhassem suas perspectivas sobre as situações vividas, fazendo uso de modalizações apreciativas para expressar suas opiniões. É preciso também lembrar que as experiências deveriam ser significativas para uma possível viagem que o leitor pretendesse empreender.

No que tange à infraestrutura geral do gênero, há sempre um título ou cabeçalho que contêm a data, já que os relatos costumam ser divididos em pequenos períodos de tempo, ou seja, a cada poucos dias de viagem faz-se novo texto para partilhar novas experiências. Quando o passeio inclui a visita a diversas regiões também é comum a especificação da localidade que será abordada. O corpo do texto se constitui de maneira bastante livre, apresentando sequências descritivas e principalmente narrativas. Quanto à coesão verbal, o tempo de uso mais comum é oprésent de narration, ou seja, o presente usado para contar eventos passados.

${ }^{40} \mathrm{O}$ título do fait divers da aluna é "Âgée de 80 ans pose pour Playboy". 
No entanto, são também usuais relatos que utilizam o passé composé e o imparfait. Tratando-se, portanto, da progressão de ações no eixo da disjunção, era necessário que os alunos estabelecessem uma origem espaçotemporal e que, a partir dela, usassem organizadores temporais para estruturar seus textos.

No que diz respeito ao desenvolvimento das capacidades de ação e discursivas dos alunos, é preciso fazer algumas ressalvas. Normalmente os relatos são feitos com grande riqueza de detalhes, o que implica grande capacidade de memorização para que o autor consiga lembrar das experiências vividas, ou, no mínimo, é necessário que anotações sobre a viagem sejam feitas pouco tempo depois de sua ocorrência. Como é improvável que qualquer um dos alunos dispusesse de qualquer uma das duas condições expostas, quase todos preferiram relatar suas viagens como um todo, não se restringindo a pequenos períodos, preferindo contar a perspectiva geral que tiveram dos lugares e dando detalhes somente sobre uma ou duas experiências mais marcantes. O único que dividiu seu relato em partes com cabeçalhos foi R.G. Ainda assim, o estudante focou em um período específico de quase 20 dias, dando poucas informações sobre os outros trechos da viagem. Já os alunos V.C. e G.S. aplicaram um cabeçalho com data e destino. G.S. optou por um relato fictício de uma viagem de dois dias somente. V.C.estruturou sua produção com organizadores temporais que faziam referência aos dias que havia passado viajando, até o terceiro dia, depois do qual foi usado um les jours suivantes genérico. A.S. fez o mesmo quanto aos organizadores, usandoquand nous avons arrivés, en le jour suivant, en troisième jour e en le matin de suivant jour, apresentando dificuldade principalmente com preposições, mas facilidade em organizar temporalmente seu texto. Já C.S. relatou de maneira geral sua viagem, não especificando os dias em que cada evento havia ocorrido.

Assim, observamos que dificilmente seriam reproduzidos pelos alunos o nível de detalhamento e o formato de divisão típicos do gênero. A adequação, no entanto, do tema global do texto às expectativas do leitor era um ponto importante a ser desenvolvido ainda sob as capacidades de ação. O aprendiz que apresentou maior dificuldade em adequar seu conteúdo aos propósitos do gênero foi R.F., que em texto muito curto (apenas 64 palavras), não introduziu nenhuma informação que fosse válida a algum viajante leitor. $\mathrm{O}$ aluno, escrevendo sobre uma ida ao litoral no réveillon, não especifica a qual cidade foi, nem relata quais suas impressões sobre o lugar. Por outro lado, a produção que melhor se encaixou aos propósitos do gênero foi a de R.G., que deu mais informações sobre a gastronomia e o modo de vida da região. Já os outros alunos relataram suas experiências de maneira satisfatória, usando diversas modalizações apreciativas, como: [plages] très belles,[rues] propres, plus organisé, une belle vue, la meilleure pizza, l'un des plus beaux paysagese les plus belles et agréables souvenirs. O uso de comparações foi constante e a aluna com mais facilidade para fazê-las foi V.C.

Por último, quanto à coesão verbal, todos os alunos preferiram fazer seus ralatos usando o passé composé e o imparfait, talvez por estarem mais familiarizados com o uso de tempos verbais pretéritos para abordar eventos passados. Alguns problemas com a formação do passé composé, no entanto, são identificados na produção de R.F. ("Nous avons arrivê"). Já no texto de G.S., os três momentos em que o aluno opta pelo imparfait são inadequados, requerendo, na verdade, o uso do passé composé. As falhas do aluno nessa produção, entretanto, não ocorreram no exercício anterior, sendo que ali o estudante utilizou dois tempos verbais de maneira muita satisfatória.

A quarta atividade propunha a produção de um email informal. Os alunos deveriam escrever a algum amigo fictício que tivesse obtido uma bolsa para estudar em algum país francófono, perguntando sobre o percurso necessário para obtenção do subsídio, assim como pedindo informações sobre o curso e sobre o alojamento na cidade de destino. Os alunos também deveriam perguntar o que o amigo vinha fazendo nos últimos meses, assim como relatar as atividades com que eles mesmos tinham se ocupado.

Como o gênero em questão está presente na língua materna dos estudantes e como faz parte do cotidiano de todos eles, as capacidades de ação não se apresentaram como problemáticas para os alunos. A manutenção da informalidade foi operada por todos e nenhum mostrou dificuldade em se apropriar do papel social do enunciador, nem de cumprir as expectativas do leitor quanto ao conteúdo da mensagem. Portanto, o que se esperava dos estudantes é que fossem capazes de desenvolver um discurso interativo, pertencente ao eixo do expor, usando a primeira e a segunda pessoa, empregando frases não declarativas, isto é, interrogativas, imperativas e exclamativas e fazendo uso de alguns dêiticos espaciais e temporais.

Começando por R.F., o aluno teve desempenho sensivelmente melhor na quarta atividade, adequandose ao gênero. Empregou dêiticos estabelecendo o cá e lá, ou seja, o Brasil e o país francófono do amigo. 
Quanto à coesão verbal, não mostrou problemas na escolha dos tempos e teve erros isolados de ortografia (" $t u$ dit" e "tu peau", por exemplo). Quanto à estrutura do passécomposé, o aluno se confundiu unicamente com a complexa montagem de quando se tratava de verbo pronominal na negativa ("tu n'ai m'écrit pas"). Já a aluna S.C. cometeu alguns erros quanto à conjugação de alguns verbos irregulares no presente ("tu vais faire", por exemplo) e deixou de usar o pas de negação por diversas vezes.

Quanto ao restante dos alunos, todos obtiveram rendimento satisfatório no que diz respeito ao emprego de dêiticos e à coesão verbal. O imperativo foi usado corretamente pelos sete estudantes, com alguns erros na ortografia dos irregulares. Vale também ressaltar que cincodeles incluíram verbos no condicional em suas produções, demonstrando facilidade em modalizar suas falas. Expressões como "Je amarais savoir ces choses pour me preparer" (R.F.), "J'ai entendu parler" (C.S.), "J'ai écouté" (V.C.), "Tu pourrais m'informer" (A.S.) e "Je voudrais sauvoir" (S.C.) mostram que os alunos entreviram as reações de seu interlocutor e, portanto, amenizaram suas falas para parecerem polidos ou para não se mostrarem demasiadamente taxativos. Também é válido apontar que as modalizações não desequilibraram as produções, ainda deixando-as no registro informal requerido pelo gênero.

Chegando à última proposta de produção, os alunos deviam fazer um relato curto, usando como referência o livro de crônicas Enregistrements Pirates, de Phillipe Delerm (2004), que fora abordado em sala de aula durante todo o semestre. Todas as produções foram marcadas por sequências de script, e a maioria também por sequências narrativas.

A primeira produção a ser observada, a de R.F., apresenta sensível melhora nas capacidades de ação e nas discursivas. Se o aluno na primeira produção não conseguiu estabelecer a intriga e tampouco foi capaz de construir o suspense em sua sinopse, dessa vez apresenta relato totalmente pautado na angústia do desconhecido, instigando, assim, seu leitor. Em sua produção, uma personagem trabalha em casa, sozinha, quando ouve um barulho intrigante que, ao final, saberá que fora somente seu gato. Durante todo o texto, o estudante adotou a perspectiva da personagem, a fim de passar ao leitor as mesmas sensações por ela experimentadas. No que tange às capacidades linguístico-discursivas, ainda persistem alguns erros quanto às preposições. No entanto, é preciso ressaltar a melhora no uso dos possessivos. O aluno não precisou usá-los no exercício 4. Em todos os outros, entretanto, apresentou erros na matéria. Todavia, na produção 5, o aluno os emprega sem cometer equívocos.

A produção da aluna A.S., por sua vez, apresenta alguns pontos interessantes. A estudante decidiu abordar a importância cultural do sofá. Para tanto, usou muitas retomadas com inserção de índices de subjetividade ("Un espace démocratique idéal pour les discussions", por exemplo). Também é interessante observar o sistema de conexão criado sem inserção de organizadores padrão. Cada início de parágrafo dita o seu tema.Pode-se dizer, por exemplo, que enquanto o segundo parágrafo trata da comodidade do móvel, o terceiro evoca sua função de espaço social na casa.Também cabe notar que o texto começa e acaba com o mesmo tema: "Le temple d'une maison. / Un temple de la procrastination." Quanto à coesão verbal, a quantidade de verbos no infinitivo equipara-se à do presente, acompanhando a imobilidade do objeto e do texto, em que não há progressão de ações.

R.G. e C.S. apresentaram boas produções. R.G. revelou dificuldade com os pronoms personnels e toniques da terceira pessoa. Fora isso, conseguiu aliar suspense à sua narrativa, desenvolvendo-a a partir de imagens surreais que instigam o leitor, que espera entender a situação apresentada antes que o texto acabe. C.S., por sua vez, teve desempenho satisfatório, usando de maneira abundante, mais do que em suas outras produções, os pronomes en e $y$, de difícil apropriação pelos alunos de francês. $\mathrm{O}$ aluno abordou o momento cotidiano do despertar, inserindo discurso indireto livre para adotar a perspectiva do protagonista. C.S., aliás, desenvolveu muito bem os três tipos de capacidades de linguagem, de modo que sua última produção é muito superior à primeira.

Já G.S. evocou a imagem de um cão e sua reação toda vez que via um caminhão de lixo passar, fazendo referência a um momento trivial, assim como a maioria dos alunos que também abordaram cenas da vida cotidiana. G.S., no entanto, apresentou certo retrocesso no uso do passé composé e imparfait. No segundo exercício o aluno não apresentou problemas com nenhum dos dois tempo verbais. No terceiro, entretanto, houve confusão entre os momentos adequados ao uso de um e de outro. No exercício 4, em que usou somente o indicatif présent e o passé composé, não houve maiores problemas. Na última atividade, no 
entanto, em que foi necessário usar os dois tempos, o aluno os confundiu algumas vezes. O uso do présent foi satisfatório e permitiu ao estudante dar a impressão de continuidade indeterminada às reações do cão.

Tendo analisado o desempenho de cada aluno em cada exercício, notamos que a maioria iniciou o semestre com alguma dificuldade em adequar-se ao contexto do gênero que era pedido. Para a maior parte, $o$ problema foi resolvido logo a partir da segunda produção escrita. R.F. e S.C., no entanto, como alunos com desempenho menor, demoraram mais algum tempo para adequar-se. A coesão verbal e a nominal mostraram ser um problema para parte significativa dos alunos. A maioria, no entanto, conseguiu, até o final do semestre, dominar os mecanismos de textualização. Em relação às modalizações e às vozes, nenhum aluno apresentou problemas significativos, indicando, assim, que, dentro das expectativas quanto ao desenvolvimento no nível básico, esses não são mecanismos que apresentam muitos obstáculos aos aprendizes.

A seguir, anotamos a evolução de cada aluno em tabelas conforme as capacidades de linguagem que deveriam ser desenvolvidas. Modalizações e vozes não foram inclusas pela facilidade que os alunos apresentaram quanto ao seu uso. Já nas capacidades discursivas, contemplamos a organização do conteúdo temático, isto é, a adequação da ordem de exposição dos conteúdos em relação ao gênero. Este aspecto foi separado por um "/" da avaliação quanto ao uso de organizadores temporais e conectores lógicos. Decidimos adotar uma marcação objetiva, compreendendo "•" para aspectos apropriados pelos aprendizes conforme o esperado e "x" para aquilo que os estudantes não dominaram idealmente. Reconhecemos que existem níveis diferentes de apreensão de conteúdos, no entanto, uma tabela sumária jamais poderia expressar as nuances do aprendizado de uma língua estrangeira Sendo demasiadamente objetiva para transparecer o detalhamento que foi possível ao longo do estudo, a tabela pretende dar somente um panorama da progressão dos alunos, a fim de entrever o percurso de cada um.

\begin{tabular}{|c|c|c|c|c|c|}
\cline { 2 - 6 } \multicolumn{1}{c|}{} & \multicolumn{5}{c|}{ Capacidades de ação } \\
\hline Alunos & Ex. 1 & Ex. 2 & Ex. 3 & Ex. 4 & Ex. 5 \\
\hline A.S. & $\mathrm{X}$ & $\bullet$ & $\bullet$ & $\bullet$ & $\bullet$ \\
\hline C.S. & $\mathrm{X}$ & & $\bullet$ & $\bullet$ & $\bullet$ \\
\hline G.S. & $\mathrm{X}$ & $\bullet$ & $\bullet$ & $\bullet$ & $\bullet$ \\
\hline R.F. & $\mathrm{X}$ & $\mathrm{X}$ & $\mathrm{X}$ & $\bullet$ & $\bullet$ \\
\hline R.G. & $\mathrm{X}$ & $\bullet$ & $\bullet$ & $\bullet$ & $\bullet$ \\
\hline S.C. & $\bullet$ & $\mathrm{X}$ & & $\bullet$ & \\
\hline V.C. & $\mathrm{X}$ & $\bullet$ & $\bullet$ & $\bullet$ & \\
\hline
\end{tabular}

Tabela 2: Progressão das capacidades de ação dos alunos.

\begin{tabular}{|l|c|c|c|c|c|}
\cline { 2 - 6 } \multicolumn{1}{c|}{} & \multicolumn{5}{c|}{ Capacidades discursivas } \\
\cline { 2 - 6 } \multicolumn{1}{c|}{} & \multicolumn{3}{c|}{$\begin{array}{c}\text { Organização do conteúdo temático/ uso de } \\
\text { organizadores temporais e conectores }\end{array}$} \\
\hline \multirow{2}{*}{ Alunos } & Ex. 1 & Ex. 2 & Ex. 3 & Ex. 4 & Ex. 5 \\
\hline A.S. & $\mathrm{X} / \bullet$ & $\bullet / \bullet$ & $\bullet / \bullet$ & $\bullet / \bullet$ & $\bullet / \bullet$ \\
\hline C.S. & $\bullet / \bullet$ & & $\bullet / \bullet$ & $\bullet / \bullet$ & $\bullet / \bullet$ \\
\hline G.S. & $\bullet / \bullet$ & $\bullet / \bullet$ & $\bullet / \bullet$ & $\bullet / \bullet$ & $\bullet / \bullet$ \\
\hline R.F. & $\mathrm{X} / \mathrm{X}$ & $\mathrm{X} / \bullet$ & $\mathrm{X} / \bullet$ & $\bullet / \bullet$ & $\bullet / \bullet$ \\
\hline R.G. & $\mathrm{X} / \bullet$ & $\bullet / \bullet$ & $\bullet / \bullet$ & $\bullet / \bullet$ & $\bullet / \bullet$ \\
\hline S.C. & $\bullet / \bullet$ & $\mathrm{X} / \bullet$ & & $\bullet / \bullet$ & \\
\hline V.C. & $\mathrm{X} / \bullet$ & $\bullet / \bullet$ & $\bullet / \bullet$ & $\bullet / \bullet$ & \\
\hline
\end{tabular}

Tabela 3: Progressão das capacidades discursivas dos alunos. 


\begin{tabular}{|c|c|c|c|c|c|c|c|c|c|c|}
\hline \multirow[b]{3}{*}{ Alunos } & \multicolumn{10}{|c|}{ Capacidades linguístico-discursivas } \\
\hline & \multicolumn{5}{|c|}{ Coesão verbal } & \multicolumn{5}{|c|}{ Coesão nominal } \\
\hline & Ex. 1 & Ex. 2 & Ex. 3 & Ex. 4 & $\begin{array}{c}\text { Ex. } \\
5\end{array}$ & Ex. 1 & Ex. 2 & Ex. 3 & Ex. 4 & $\begin{array}{c}\text { Ex. } \\
5\end{array}$ \\
\hline A.S. & $\bullet$ & $\bullet$ & - & - & - & $\bullet$ & - & - & - & - \\
\hline C.S. & $\bullet$ & & $\bullet$ & $\bullet$ & • & $\bullet$ & & $\bullet$ & $\bullet$ & - \\
\hline G.S. & $\bullet$ & $\bullet$ & $x$ & $\bullet$ & $x$ & $\bullet$ & $x$ & $\bullet$ & $\bullet$ & $\bullet$ \\
\hline R.F. & $\bullet$ & $\bullet$ & $x$ & $x$ & • & $x$ & $\bullet$ & $x$ & $\bullet$ & $\bullet$ \\
\hline R.G. & $\bullet$ & $\bullet$ & $\bullet$ & $\bullet$ & • & $\bullet$ & - & - & - & $x$ \\
\hline S.C. & • & $x$ & & $x$ & & - & • & & • & \\
\hline V.C. & - & - & - & - & & - & - & - & - & \\
\hline
\end{tabular}

Tabela 4: Progressão das capacidades linguístico-discursivas dos alunos.

\section{Conclusões}

O ensino de línguas estrangeiras através de gêneros textuais mostra-se assunto uma abordagem atual, sobretudo no Brasil, onde as estratégias de ensino daí decorrentes acharam espaço para expandir-se e desenvolver-se (BUNZEN, 2008). O estudo de tais práticas para o ensino do francês, no entanto, é campo que ainda necessita ser mais explorado, uma vez que a maior parte dos estudos produzidos são voltados ao ensino de língua materna ou inglesa (MACHADO, 2009). Nesse sentido, esperamos ter colaborado ao trabalhar em campo com escassa, mas crescente produção teórica, dando pistas ao professor sobre como o aprendiz se relaciona com a apropriação de certos papéis sociais e como isso influencia a sua trajetória de aprendizagem da língua francesa, observando especialmente as atividades linguageiras relatar e expor. Sendo que a vida prática é permeada por ações de linguagem que demandam os dois eixos do discurso, ao observar o desenvolvimento de alunos a partir desse prisma, acreditamos ter contribuído para estratégias de ensino que permitam ao aprendiz o desenvolvimento de ferramentas para agir no mundo. Acreditamos, também, que contribuímos para as pesquisas do Grupo ALTER, ao qual pertence, pois traz uma reflexão sobre o uso de gêneros textuais para a aprendizagem da língua francesa em contexto universitário.

\section{Referências Bibliográficas}

ADAM, J.-M. Les textes: types et prototypes. Paris : Nathan, 1992.

AUTHIER-REVUZ, J. Palavras incertas: as não coincidências do dizer. $2^{\mathrm{a}}$ reimpressão. Trad. C.R.C. Pfeiffer e al. Campinas: editora da Unicamp, 2001. 
BAKHTIN, M.M. Marxismo e filosofia da linguagem. Trad.M. Lahud, Y.F. Vieira. 3. ed. São Paulo: Editora Hucitec, 1986.

BAKHTIN, M.M. Estética da criação verbal. Trad. Paulo Bezerra. 4. ed. São Paulo: Martins Fontes, 2003.

BAKHTIN, M.M. Questões de Literatura e de estética: a teoria do romance. 6. ed. São Paulo: Hucitec/Annablume, 2010.

BEATO-CANATO, A.P.M. Produção escrita em língua estrangeira à luz do Interacionismo Sociodiscursivo. In: CRISTOVÃO, V.L.L. (Org.). Estudos da linguagem à luz do Interacionismo Sociodiscursivo. Londrina: Eduel, 2008.

BEZERRA, C. S. LOUSADA, E.G. Produção escrita em francês por meio de gêneros textuais: desafios da produção textual na universidade. Projeto Ensinar com Pesquisa, apresentado à Universidade de São Paulo em 2012.

BRAIT, B. Ironia em perspectiva polifônica. São Paulo, Martins Fontes, 2008.

BRONCKART, J.-P.Activité langagière, textes et discours : Pour un interactionnisme sociodiscursif.Paris: Delachaux et Niestlé, 1997.

BRONCKART, J.-P. Atividade de linguagem, discurso e desenvolvimento humano. $1^{\text {a }}$ ed. Trad. A.R. Machado; M.L.M. Matêncio. Campinas, Mercado de Letras, 2006.

BRONCKART, J.-P. Sobre linguagem, ação-trabalho e formação: as contribuições da démarche ISD: Entrevista com Jean- Paul Bronckart. Trad. M.C.B.O.Salgado, F. Pinel. In: Educação em Revista (Belo Horizonte), n. 47. p. 273-286, 2008 a.

BRONCKART, J.-P. O agir nos discursos : das concepções teóricas às concepções dos trabalhadores. $1^{\text {a }}$ ed.Trad. A.R. Machado; M.L.M. Matêncio. Campinas, Mercado de letras, 2008 b.

BUNZEN, C. Da era da composição à era dos gêneros: o ensino de produção de texto no ensino médio. In: BUNZEN, C. \& MENDONÇA, M. (Orgs.). Português no ensino médio e formação do professor. 2. ed._São Paulo: Parábola, 2007.

CRISTOVÃO, V.L.L. O gênero quarta-capa no ensino do inglês. In: DIONISIO, A.P; MACHADO, A.R; BEZERRA, M.A. (Orgs.). Gêneros textuais \& Ensino. 5. ed. Rio de Janeiro: Editora Lucerna, 2007.

DELERM, P. Enregistrements pirates. Mônaco: Éditions du Rocher, 2004.

DOLZ, J. GAGNON, R. \& TOULOU, S. Production écrite et difficultés d'apprentissage. Gênova: FAPSE-Unige, 2009.

FRANCESCHINI, F. Notícia e reportagem: sutis diferenças. In: Comum, no. 22, 2004.

LABOV, W. WALETSKY, J. Narrative analysis : oral versions of personal experiences. In: HELM, J. Essays on the verbal and visual arts. Seattle, University of Washington Press, 1967.

LOPES-ROSSI, M.A.G. Gêneros discursivos no ensino de leitura e produção de textos. In: KARWOSKI, A.M. GAYDECZKA, B. BRITO, K.S. Gêneros textuais reflexões e ensino. Rio de Janeiro: Nova Fronteira, 2008.

LOUSADA, E.G. Gêneros textuais e perspectiva acional no ensino do francês como língua estrangeira: prescrições e instrumentos para o agir de alunos e professores. No prelo. 
LOUSADA, E.G. Elaboração de material didático para o ensin de francês. In: DIONISIO, Angela Paiva; MACHADO, Anna Rachel; BEZERRA, Maria Auxiliadora (Orgs.). Gêneros textuais \& Ensino.5. ed. Rio de Janeiro: Editora Lucerna, 2007.

LOUSADA, E. G. A abordagem do interacionismo sociodiscursivo para a análise de textos. In: CUNHA, C.L.; PIRIS, E.L.; CARLOS, J.T. (Orgs.). Abordagens metodológicas em estudos discursivos. São Paulo: Editora Paulistana, 2010.Disponível em:http://www.epedusp.org/IIepedlivro/index.htm.

LOUSADA, E.G. MUNIZ-OLIVEIRA, S. BARRICELLI, E. Gêneros textuais em foco: instrumentos para o desenvolvimento de alunos e professores. (São Paulo. 1978), v. 40, p. 627-640, 2011.

MACHADO, A.R. Linguagem e educação o ensino e a aprendizagem de gêneros textuais. Campinas: Mercado de Letras, 2009.

MACHADO, A.R. LOUSADA, E.G. \& ABREU-TARDELLI, L.S. Planejar gêneros acadêmicos. 3. ed.São Paulo: Parábola Editorial, 2008.

MAINGUENEAU, D. Novas tendências em análise do discurso.Trad. Freda Indursky. Campinas : Pontes Editora, 1989.

MAINGUENEAU, D. L'analyse du discours: introduction aux lectures de l'archive. Paris: Hachette, 1991.

MAINGUENEAU, D. Análise de textos de comunicação. $1^{\text {a }}$ ed. Trad. Cecília P. de Souza-eSilva ; DécioRocha. São Paulo : Cortez Editora, 2001.

PETRECHE, C.R.C.A sequência didática nas aulas de língua inglesa do ensino médio e o desenvolvimento de capacidades de linguagem. In: CRISTOVÃO, V. L. L.. (Org.). Estudos da linguagem à luz do Interacionismo Sociodiscursivo. Londrina: Eduel, 2008.

SCHNEUWLY, B. \& DOLZ, J.Gêneros orais e escritos na escola.Trad. Roxane Rojo, Glaís Sales Cordeiro. Campinas: Mercado das Letras, 2004.

VYGOTSKI, L.S. A construção do pensamento e da linguagem. Trad. Paulo Bezerra. São Paulo: Martins Fontes, 2010. 